\title{
De haast van Albertine: Reizen in de technologische cultuur: naar een theorie van passages.
}

Citation for published version (APA):

Peters, P. F. (2003). De haast van Albertine: Reizen in de technologische cultuur: naar een theorie van passages. [Doctoral Thesis, Maastricht University]. Uitgevrij De Balie.

https://doi.org/10.26481/dis.20030619pp

Document status and date:

Published: 01/01/2003

DOI:

10.26481/dis.20030619pp

Document Version:

Publisher's PDF, also known as Version of record

\section{Please check the document version of this publication:}

- A submitted manuscript is the version of the article upon submission and before peer-review. There can be important differences between the submitted version and the official published version of record.

People interested in the research are advised to contact the author for the final version of the publication, or visit the DOI to the publisher's website.

- The final author version and the galley proof are versions of the publication after peer review.

- The final published version features the final layout of the paper including the volume, issue and page numbers.

Link to publication

\footnotetext{
General rights rights.

- You may freely distribute the URL identifying the publication in the public portal. please follow below link for the End User Agreement:

www.umlib.nl/taverne-license

Take down policy

If you believe that this document breaches copyright please contact us at:

repository@maastrichtuniversity.nl

providing details and we will investigate your claim.
}

Copyright and moral rights for the publications made accessible in the public portal are retained by the authors and/or other copyright owners and it is a condition of accessing publications that users recognise and abide by the legal requirements associated with these

- Users may download and print one copy of any publication from the public portal for the purpose of private study or research.

- You may not further distribute the material or use it for any profit-making activity or commercial gain

If the publication is distributed under the terms of Article $25 \mathrm{fa}$ of the Dutch Copyright Act, indicated by the "Taverne" license above, 
De haast van Albertine 



\title{
De hasi van Albertine
}

Reizen in de technologische culturr:

\section{naar een theorie van passages}

\author{
PROEFSHRIFT
}

ter verkrijging van de graad van doctor aan de Universiteit Maastricht, op gezag van de Rector Magnificus, Prof.dr. A.C. Nieuwenhuijzen Kruseman

volgens het besluit van het College van Decanen, in het openbaar te verdedigen op donderdag r 9 juni 2003 om 14.00 uur

door

Peter Frank Peters

geboren op r 8 juli I 960

te Amsterdam 
Promotor:

Prof.dr. R. de Wilde

Beoordelingscommissie:

Prof.dr.ir. W.E. Bijker (voorzitter)

Prof.dr. H.J. Achterhuis (Universiteit Twente)

Prof. dr. M.A. Hajer (Universiteit van Amsterdam)

Dr. J.P. Koenis

Prof.dr. J.G.A. van Mierlo

(C) 2003, Uitgeverij De Balie/Peter Peters

Uitgeverij De Balie

Kleine-Gartmanplantsoen ro

rol7 RR Amsterdam

www. balie.nl/uitgeverij

Foro onslag: Clock in Pennsyluamia Station. Alfred Eisenstaedt (Time Life Pictures) Vormgeving: Steven Boland, Amsterdam

Druk: Wilco, Amersfoort

ISW 9066172940

NUR $755 / 736$ 


\section{Inhoud}

Woord wooraf

I. Steeds sneller

De roep om snelheid en verte

Op zoek naar de gewonnen tijd $2 \mathrm{I}$

Tussen reistijd en gereisde tijd $\quad 30$

Het ontwerpen van tijd $\quad 36$

2 Gasgeven of afremmen 40

De smalle marges van de mobiliteitspolitiek 43

Mobiliteit als sociaal dilemma 53

De hypothese van de constante reistijd $6 \mathrm{I}$

Conclusie $\quad 69$

3 De passages van Thomas Cook 72

Lijnen in rumte en tijd $\quad 74$

Moderniteit en mobiliteit $\quad 79$

De excursies van Thomas Cook $\quad 89$

Passages $\quad 96$

Conclusie $\quad 100$

4 Met de auto naar het park $\quad 102$

Amerikaanse passages $\quad 104$

Wildernis langs de snelweg $\quad$ Irg

$\begin{array}{lr}\text { Circulatie en representatie } & \text { I } 29\end{array}$

Conclusie $\quad 133$ 
5 Op tijd in de lucht

In de vertrekhal $\quad$ I39

In het Operations Control Center $\quad{ }_{446}$

Gesitueerd handelen en improviseren $\quad$ r62

$\begin{array}{ll}\text { Wisselgeld } & 169\end{array}$

Conclusie $\quad r 75$

6 Het recht van de snelste $\quad$ r79

Denken over het kruispunt $\quad$ I8 I

Tijd, ruimte en risico 192

$\begin{array}{lr}\text { Ontwerpen voor de fiets } & 198\end{array}$

De politick van passages $\quad 209$

Conclusie $\quad 2 \times 6$

7 De kunst van het reizen 2 I9

Naar een theorie van passages 222

Een wijkende horizon $\quad 229$

Passages en innovatie $\quad 232$

Reizen in de technologische cultuur $\quad 244$

Noten $\quad 249$

Literatuur 29 I

Summary 319

Curriculum vitae $33 \mathrm{I}$ 


\section{Woord vooraf}

De eerste ideeën voor dit boek ontstonden rond 1990 toen er fel gedebatteerd werd over de voor- en nadelen van auto's. Het was een periode waarin NRC Handelsblad zonder moeite een hele krantenpagina vulde met brieven waarin lezers zich beklaagden over het gebruik van de term 'straatfascisme' door Henk Hofland. Hij wilde daarmee duidelijk maken dat auto's in een stad als Amsterdam behalve handig vaak ook middelen zijn van ongelegitimeerde machtsuitoefening. In de beleidstaal van die dagen heette het dat automobilisten individuele voordelen afwentelden op de maatschappij. Dit dilemma kon worden opgelost door de groei van het autogebruik te beteugelen, zo veronderstelden velen, en de automobilist moest zich daarom bekeren tot de fiets en de trein. Verkeersdeskundigen konden goed uitleggen waarom deze aanpak maar niet tot succes wilde leiden, maar in hun antwoorden ontbrak de culturele benadering die mij interesseerde.

Dat ik de overstap heb kunnen maken van de journalistiek en het beleidsonderzoek naar de academie dank ik vooral aan mijn promotor Rein de Wilde. We deelden aanvankelijk onze interesse voor het onderzoek naar de toekomst van de technologische cultuur, het thema waarop ik werd aangesteld als assistent in opleiding (aio) aan de Universiteit Maastricht. Van Rein leerde ik om mijn intuities te wantrouwen en het verschil te zien tussen een mooi geschreven verhaal en een overtuigend betoog. Zijn zorgvuldige kritiek ging altijd vergezeld van concrete voorstellen voor veranderingen, waarvan ik soms pas na enige tijd begreep waarom het ook verbeteringen waren. Zonder die talrijke verbeteringen en het vertrouwen dat Rein op beslissende momenten toonde in de goede afloop van het project was dit proefschrift er niet gekomen. Tijdens onze tochten op de racefiets liet hij me zien hoe 
je het best een lastige heuvel beklimt: door niet te snel terug te schakelen.

Mijn leven als aio pendelde tussen momenten van opperste bezieling en diepe onzekerheid. Die momenten heb ik vooral kunnen delen met mijn collega-aio's Anique Hommels en David Hamers. Anique kan goed relativeren, bemoedigen en luisteren tegelijk. Onze onderzoeksreizen, samen met Wiebe Bijker, naar Parijs, Bilbao, Brussel en restaurant De Pionier op de Maasvlakte waren hoogtepunten, al waren de huurauto's aan de kleine kant. in mijn aio-tijd Met David ging ik voor het eerst naar een internationale conferentie, over tijd en cultuur, en zijn enthousiasme en optimisme zijn voor mij een voorbeeld. Ook de andere leden van de 'aio-soep' wisten, vaak beter dan ik, de balans te vinden tussen kritiek en aanmoediging: hartelijk dank aan Guido Goossens, Marco Goud, Stine Jensen, Nel Knols, Eric Lemmens, Ruth Mourik, Jessica Slijkhuis, Cecile aan de Stegge en Manuel Stoffers. De workshops tijdens van de wTMc-opleiding onder leiding van Rob Hagendijk en Gerard de Vries en later Annemiek Nelis en Paul Wouters leerden me mijn weg te vinden in een nieuw onderzoeksveld. De lange dagen resulteerden steeds in een storm van nieuwe ideeen zonder welke dit een ander boek was geweest. Ik denk met veel plezier terug aan de gesprekken met Bram Bos, Ruud van Dael, Jessika van Kammen, en Peter-Paul Verbeek en de anderen.

De Faculteit der Culturrwetenschappen bleek de ideale omgeving voor het interdisciplinaire onderzoek naar reizen in de technologische cultuur dat mij voor ogen stond. De bijeenkomsten van de onderzoeksgroepen BoTs en MARkS vormden een onmisbaar klankbord voor hoofdstukken in wording. Voor hun ideeën, literatuursuggesties, commentaar of hun belangstelling voor mijn onderzoek dank ik met name Jan Baetens, Tannelie Blom, Wiebe Bijker, Karin Bijsterveld, Pieter Caljé, José van Dijck, Maarten Doorman (voor onze gesprekken bij de Vier Moren), Rene Gabriëls, Ernst Homburg, Sjaak Koenis, Marieke Kuipers, Wiel Kusters, Wiebe Nauta, Bernike Pasveer, Jos Perry, Jack Post, Geert Somsen, Ginette Verstraete, Sophie Vanhoonacker, Jo Wachelder, Ger Wackers en Lies Wesseling. Gerard de Vries wil ik bedanken voor wat ik lang geleden van hem leerde over sociologie en filosofie, 
voor zijn even geduldige als strenge kritiek bij mijn probeersels en voor het inzicht dat een boek altijd beter kan. Van de buitenlandse gasten aan de faculteit dank ik met name John Law voor onze gesprekken over orde en heterogeniteit. Margaret Meredith verbeterde mijn Engelse samenvatting, waarvoor ik haar wil bedanken.

In de afgelopen jaren heb ik regelmatig opdrachtonderzoek verricht en sommige resultaten daarvan kregen een plats in mijn proefschrift. Tijdens het uitvoeren van dit onderzoek heb ik veel geleerd over de praktijk van het mobiliteitsbeleid. Voor het delen van hun kennis en het geven van commentaar dank ik Hans Peter Benschop, Jaco Berveling, Boe lie Elzen, Frank van Erkel, Peter Heerema, Mark van den Heuvel, Albert Jansen, Nelly Kalfs, Peter Nijkamp, Jan Prij, Piet Rietveld, Marc Verhagen en Jan van der Waard. Mede dankzij uitnodigingen van Hans Achterhuis, Maarten Hajer en Michiel Schwarz om een bijdrage te leveren aan boeken die zij redigeerden of onderzoek waaraan zij deelnamen, kon ik de basis leggen voor het eerste en tweede hoofdstuk. Bastien Clement ben ik dankbaar voor zijn scherpzinnige assistentie bij het onderzoek naar de hypothese van de constante reistijd. Paul Peeters, die mij leerde hoe je beleidsonderzoek kunt opzetten, dank ik in het bijzonder voor zijn deskundige commentaar op hoofdstuk twee2. Voor hun hulp bij het onderzoek naar de vormgeving van de Nationale Parken in de Verenigde Staten ben ik David Nathanson, Tim Davis en Ethan Carr erkentelijk. Bij de KLM ben ik bijzonder gastvrij ontvangen door de werknemers van de bedrijfsonderdelen Passenger Services en Operations Control Center. Ik dank met name Ben Steeman, Jaap van de Linde, Daan Nijland en Klaas de Waal voor hun tijd en aandacht voor mijn onderzoek.

Het beeld van de eenzame wandelaar die pas door terug te kijken ziet dat hij een weg pad heeft gemaakt datie er nog niet was, heeft mij bij het schrijven van dit boek vaak begeleid. In tegenstelling tot het dit romantische cliché heb ik die weg niet alleen afgelegd. Zonder reisgenoten was het me niet gelukt mijn bestemming te bereiken. Voor hun aandacht voor mijn getob, inhoudelijke suggesties en hun vriendschap dank ik al-lereerst mijn paranimf Ruth Benschop, voor wie meeleven en meelezen op hetzelfde neerkomen, en verder Rolland Bal, Marc Berg, Gerard Bor- 
ren, Elly Borren-van Pagee, Liesbeth Fransen, Emilie Gomart, Linda Heikema, Ruud Hendriks, Paul Herruer, Erik Harteveld, Judith ter Horst, Klasien Horstman, Hans Kiewiet, Hans Koolmees, Marc Lansu, Harro Maas, Jessica Mesman, Andrea Meijer, Marga Ockhuizen, Carolien Oomes, Jacqueline Oskamp, Harjo Pasveer, Gertjan Pasveer, Tineke van der Schoor en Geerte Wachter. Mijn vriend en paranimf Louis Stiller is al sinds de dagen dat we op de fiets naar Parijs gingen ook in letterlijke zin een reisgenoot. Onderweg naar Berlijn, Rome en andere steden leerde ik meer over reizen dan door het schrijven van dit boek.

Het werken aan dit proefschrift wroeg te vaak aandacht die ik niet kon geven aan wie mij lief zijn. Mijn vader en mijn moeder hebben mij steeds gesteund, juist op momenten dat het eind maar niet in zicht wilde komen. Ook mijn broers Hans en Eric Jan en mijn schoonouders Hans en Henni Pasveer volgden mijn vorderingen op de voet. $\mathbb{k}$ ben blij dat Henni een eerdere versie nog heeft kunnen lezen. Bernike weet dat een proefschrift een "verschrikkelijk ding is om te schrijven", zoals ze zelf in de eerste zin van het woorwoord wan haar eigen boek schreef. $Z$ ij kent als geen ander de ogenblikken van verwoestende twijfel aan de waarde van mijn werk; in die zin heeft ze twee proefschriften moeten schrijven. Met haar optimisme, vrolijkheid, en haar fotografisch oog voor de mooie stukken hielp ze me door te zetten. Dat reizen iets is waarin je al heel jong kunt uitblinken heb ik geleerd van mijn dochter Stijn. Terwij] we door het Groningse land trokken, legde ze uit wat het verschil is tussen 'autokilometers' en 'fietskilometers' en waarom de fietskilometers veel leuker zijn. Ze is niet alleen de liefste, maar ook de beste reiziger die er is. 


\section{1 \\ Steeds sneller}

Op de tekentafel van de visionairen is het mobiliteitsprobleem all opgelost. Het is niet moeilijk een auto te maken die geen lawaai maakt, niet of nauwelijks fossiele brandstoffen verbruikt, niet bijdraagt aan het versterkte broeikaseffect, minder ruimte nodig heeft om te kunnen rijden, niet in de file staat en minder verkeersslachtoffers veroorzaakt. Zo'n auto, stelde directeur Leo Jansen van het interdepartementale programma voor Duurzame Technologische Ontwikkeling (DTO) in een interview dat ik ooit met hem had, is gebouwd uit lichte materialen, heeft zonnecellen en een hybride motor. Maar het ontwerp heeft een prijs: snelheid. De auto van de toekomst zou in plaats van honderdtachtig maximaal zestig kilometer per uur kunnen rijden. ${ }^{2}$ Vooruitgang neemt hier de vorm aan van traagheid en dat was ook precies de reden waarom de langzame auto er niet zou komen, meende Jansen. Niet omdat het technisch onmogelijk zou zijn er een te maken, maar omdat niemand er in zou willen rijden. De obstakels voor een langzame auto zijn niet zozeer van technische, maar van maatschappelijke, psychologische, economische en culturele aard. Snelheid, luidde zijn hypothese, is immers een dominante waarde in de westerse cultuur.

Deze terloops geopperde hypothese was het vertrekpunt voor het onderzoek waarvan dit boek verslag doet. ${ }^{2}$ De opmerking van Jansen maakte twee dingen duidelijk. In de eerste plaats vormt de snellheid van auto's, maar ook van andere vervoermiddelen die worden aangedreven door fossiele brandstoffen, een probleem. Meer mensen reizen over grotere afstanden dan ooit en dat heeft in veel opzichten een prijs; er zijn maatschappelijke kosten aan dat reizen verbonden die maar ten dele worden gedragen door de reiziger zelf. In dit sociale dilemma van de moderne mobiliteit staan tegenover voordelen voor het individu na- 
delen woor de samenleving, zoals files, luchtverwuiling, ongevallen, lawaahinder, versnippering van het landschap en ruimtebeslag. In de tweede plaats is de versnelling van het reizen schijnbaar onomkeerbaar. Traagheid is een anathema. Dat werd duidelijk toen we fantaseerden over het opnieuw uitvinden van het luchtschip. ${ }^{3}$ Een transatlantische reis van Amsterdam naar New York zou in plaats van zeven uren enkele dagen duren. De aankomsttijden zouden niet langer in minuten, maar in uren gerekend moeten worden. In een wereld van complexe en precieze tijdsordeningen past de onvoorspelbaarheid van de zeppelin echter niet.

Langzaam en snel zijn relationele begrippen. Ze krijgen betekenis in de relatie die ze leggen, bijvoorbeeld tussen twee manieren van reizen of twee vervoermiddelen. Ze duiken op in alledaagse beschouwingen over moderne mobiliteit als middel om problemen en ervaringen onder woorden te brengen. De vertraagde trein, de racefiets met 2 I versnellingen, de rust van een zondagse wandeling en de dynamiek van een vliegreis zijn moeilijk te begrijpen zonder de snelheid of traagheid van de beweging erin te betrekken. Snel en langzaam zijn woorden waarmee reizigers verleid worden on de trein te nemen; op Franse stations hingen ooit reclameaffiches voor de TGV met daarop een boek dat geen paginanummers telde maar kilometerstanden, een listig spel met de gelijktijdige aantrekkingskracht van rust en waart. Neem de tijd om snel te gaan', luidde het bijschrift. Begrippen als snel en langzaam maken het mogelijk om te redeneren en te rechtvaardigen; in de discussies over de aanleg van de Hoge Snelheids Lijn (HSI) van Amsterdam naar Parijs vormde het bekorten van de reistijd met ruim twee uur de meest gehoorde politieke rechtvaardiging van een miljardeninvestering. Omgekeerd worden debatten over mobiliteitsproblemen op televisie doorgaans gevisualiseerd door beelden van files, hét symbool van traagheid en stagnatie.

In het dagelijks leven gebruiken we woorden als snel en langzaam en stellen er verder geen vragen over. Maar wie zich bezighoudt met de veranderingen in het hedendaagse reizen, de problemen die daarmee verbonden zijn en de voorgestelde vernieuwingen om die problemen op te lossen doet er goed aan om het gebruik van deze op het eerste gezicht 
vanzelfsprekende begrippen nader te onderzoeken. Juist omdat ze dienen om vragen te beantwoorden, om redenen te geven en om verantwoording af te leggen is het nodig ze te problematiseren en te onderzoeken hoe ze de grenzen van ons spreken, denken en handelen bepalen.

Mobiliteitsproblemen kan men verschillend definiëren, bijvoorbeeld als problemen die hun oorsprong vinden in het onvermogen van de overheid om de macht van de auto-industrie a an banden te leggen of zelfs in de eeuwig mobiele menselijke aard. ${ }^{4}$ Dit type probleemdefinities heeft als nadeel dat het nauwelijks perspectief op oplossingen biedt. In dit boek wil ik een probleemformulering onderzoeken die wél aanknopingspunten biedt voor oplossingen of althans aanzetten daartoe biedt. Mijn suggestie is om mobiliteitsproblemen (ook) op te vatten als ontwerpproblemen. De uitdaging is dan te zoeken naar innovatieve ontwerpen, niet slechts voor auto's, maar voor de activiteit van het reizen zelf. De centrale vraag in dit onderzoek is tweeledig: Welke consequenties heeft het gebruik van termen als snel en langzaam in het spreken over innovatie van mobiliteit? Welk nieuw vocabulaire is in staat om zowel het debat over mobiliteit als de analyse van succes en falen van mobiliteitsinnovaties te verrijken met nieuwe inzichten? Om een zo goed mogelijk antwoord op deze vragen te kunnen krijgen, is het nodig eerst de reikwijdte van het bestaande vocabulaire te bepalen.

\section{De roep om snelheid en verte}

Het gebruik van de begrippen snel en langzaam creëert een vergelijkend perspectief. Vanuit dat doorgaans kwantificerende perspectief verschijnen sommige vernieuwingen als mogelijk, wenselijk en zelfs noodzakelijk waar andere al op voorhand als onmogelijk en onwenselijk worden beschouwd. Niet zelden wordt het denken over mobiliteit versmald tot gasgeven of afremmen, meer of minder asfalt. Uitgaande van een vrije markteconomie lijkt dat ook moeilijk anders te kunnen: tijd is immers geld en niemand is graag langer onderweg dan nodig. ${ }^{5}$ De eerste kracht van de woorden snel en langzaam is dat ze zo"n kwantificerende vergelijking mogelijk maken. De tweede kracht is dat deze vergelijkingen ver- 


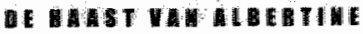

schillende conmotaties kunnen hebben. Vergelijken wordt dan een methode om kennis op te doen, bijwoorbeeld over het handelen van reizende mensen en de keuzes die ze maken tussen manieren van reizen, maar ook over de ontwikkeling van vervoerstechnologie of de wijze waarop reizen in de westerse cultuur betekenis krijgt." Dat wordt duidelijk in drie dominante vertogen die $1 k$ in deze paragraaf kort wil aanstippen: snelheid als onafwendbare technische ontwikkeling, snelheid als tujd uitgedrukt in geld, en snelheid als uitdrukking van vooruitgang en moderniteit. ${ }^{7}$ Redenerend binnen deze vertogen is telkens een ander antwoord mogelijk op de vraag walarom mensen niet graag in langzame auto's rijden.

\section{Snelheid als onafwendbare technische ontwikkeling}

In een technisch-deterministisch vertoog laat de geschiedenis zich schrijven als een onafwendbare opeenvolging van nieuwe verplaatsingstechnologieên, waarbij het tragere vervoermiddel het aflegt tegen het snellere. De historicus Vance bijvoorbeeld, besteedt in zijn standaardwerk Capturing the Horizon. The Historical Geograpby of Transportation since the Sixteenth Century (1986) veel aandacht aan de wisselwerking tussen de 'technologies of movement' (voertuigen) en de 'facilities' (infrastructuur) die deze voertuigen langs geografische liynen leiden. Aan het eind van de Middeleeuwen begon volgens Vance een 'transportrevolutie" die drie eeuwen in beslag nam en die in gang gezet werd door een reeks technologische innovaties variërend van de eerste sluizen in kanalen en de bouw van nieuwe bruggen, tot de ontwikkeling van nieuwe koetsen en wagens. Door deze vernieuwingen, schrijft Vance, groieide het vracht- en personenverkeer, wat weer nieuwe knelpunten creëerde, die op hun beurt weer werden opgeheven door verdere ontwikkeling van zowel infrastructuur als vervoermiddelen. ${ }^{8}$ Aansluitend op de Transportation Revolution ziet Vance tussen I780 en I830 een overgang naar de Era of Technological Advance. Kenmerkend voor deze periode is dat snelheid meer en meer het onderscheid tussen vervoermiddelen gaat bepalen?

Bagwell ( 1986 ) gebruikt in zijn studie over de geschiedenis van transportsystemen in Engeland ook de term transportrevolutie', maar situ- 
eert het begin daarvan rond $x 800$. Tot die tijd waren wegen en verwoermiddelen gebrekkig en hoofdzakelijk lokaal georganiseerd. Verplaatsingen speelden zich over korte afstanden af, wie verder weg gelegen bestemmingen wilde bereiken, moest doorgaans verbindingen improviseren, wat een tijdrovende, kostbare en niet zelden gevaarlijke aangelegenheid was. Een uitzondering vormde het systeem van postkoetsen dat vanaf de zeventiende eeuw in een aantal landen ontstond (in Duitsland reden de snelkoetsen van het familiebedrijf Thum und Taxis vanaf de vijftiende eeuw). Deze koetsdiensten onderhielden vaste lijndiensten, waarbij langs de route werd gewisseld van paarden, koetsiers en soms ook van koets. Dit systeem werd in de loop van de achttiende eeuw zodanig geperfectioneerd dat men de reistijden aanzienlijk wist te bekorten. ${ }^{10}$ Rond $x 800$ werden vernieuwingen in de anleg van wegen toegepast die waren ontwikkeld door Thomas Telford (I757-I 834) en John Loudon McAdam (I756-1836), zoals nieuwe plaveisels die het wegdek versterkten en minder kwetsbaar maakten voor weersinvloeden. " Door betere wegen konden de postkoetsdiensten hun reissnelheid opvoeren. De aanleg van wegen werd meer en meer bowenlokaal georganiseerd, waarbij een land als Frankrijk het voortouw nam. Daar bouwde 'Le corps des Ponts et Chaussées' aan een landelijk netwerk van wegen, de zogenaamde Routes Nationales. Betere wegen, snellere koetsdiensten en lijndiensten, lagere prijzen en een groter comfort leidden, wolgens Bagwell, tot een toename van het aantal reizigers en een toename wan het aantal kilometers dat zij aflegden.

Filarski (I997) constateert op basis van historisch onderzoek naar transportsystemen in de afgelopen twee eeuwen dat de ontwikkeling van vervoerstechnologieën in fasen verloopt. Na de 'pioniersfase", de 'fase van de snelle groei' volgt een 'dominantiefase". "Wanneer een vervoersysteem deze drie fasen heeft doorlopen, voltrekt zich in het algemeen een proces van teruggang, dat soms gepaard gat met verpaupering'. ' $Z 0$ verkeerde de trekschuit in Nederland voor $x 660$ in de fase wan de snelle groei om tussen 1660 en 1870 dominant te zijn. Trein, stoomboot en stoomauto verkeerden tussen 1790 en 1840 in de pioniersfase, ontwikkelden zich daarna snel en verdrongen de trekschuit en de dilligence vanaf 1870 als dominante vervoersmiddelen. Dezelfde 
ontwikkelingsfasen kenden de fiets, de auto en het vliegtuig. Dankzij deze technologische ontwikkeling werd het vervoer voortdurend goedkoper, sneller en comfortabeler, concludeert Filarski. Volgens hem is het mogelijk op grond van historische ontwikkelingen uitspraken te doen over de toekomstige ontwikkeling van vervoersystemen; die zullen "nog sterker dan tegenwoordig afgestemd kunnen worden zijn op individuele mobiliteitswensen, terwijl tegelijkertijd veel beter aan de collectieve verlangens wordt voldaan."

Vervoershistorici als Vance, Bagwell en Filarski vergelijken langzame en snelle technologieën en reconstrueren de geschiedenis als 'transportrevoluties" die het reizen sneller, goedkoper en comfortabeler maakten. De overgang van langzame naar snellere vervoermiddelen wordt vanuit dit technisch-deterministische gezichtspunt verklaard vanuit de onafwendbare ontwikkeling van de techniek zelf. Dat de stoomtrein is vervangen door de dieseltrein en de zeppelin door het vliegtuig is niet meer dan logisch. Niet alleen verloopt de technische ontwikkeling onafhankelijk van andere maatschappelijke ontwikkelingen, techniek vormt tevens de drijvende kracht in de maatschappelijke dynamiek (Smith \& Marx, 1994)." Het idee dat vervoermiddelen letterlijk de oorzaak zijn van vooruitgang komt ook tot uitdrukking in afbeeldingen wan stoomtreinen en stoomboten en later de elektrische tram en de auto. Of zoals kunsthistoricus Taylor ( 1994 ) het formuleert in zijn bespreking van een schilderij waarop een stoomtrein van oost naar west over de Amerikaanse prairie rijdt: "the maiden Progress's movement "brings with it all blessings of technology and settled life in an orderly and rapid passage across space and time." $\times 5$ Wat jaagt deze technologische ontwikkeling nu aan? Daarop geven twee andere vertogen nader antwoord.

\section{Snelheid als tijd uitgedrukt in geld}

Nadat de ontwikkeling van verwoerstechnologie verschillende snelheden creëert (push), bestaat er een economische impuls voor sneller reizen in het gegeven dat reizigers nu kunnen kiezen tussen manieren van reizen (pull). Filarski: 'De consument kiest op basis van snelheid, comfort, de mogelijkheid zich onafhankelijk te verplaatsen en reiskosten, waarbij de eerste drie factoren meestal de doorslag geven. " Vertrek- 
punt in deze redenering is de aanname dat tijd als een schaars goed beschouwd kan worden. Mensen hebben een beperkte levensduur en zullen proberen hun tijd zo goed mogelijk te gebruiken. Omdat maar weinig mensen meer dan een ding tegelijk kunmen doen, zullen ze voortdurend moeten kiezen aan welke activiteit ze hun tijd besteden. Het probleem waarvoor de econoom zich geplatst ziet, is de allocatie van tijd te modelleren en eventueel te verklaren. Dat kan bijvoorbeeld door aan te nemen dat economische subjecten zullen proberen hun nut te maximaliseren en dus ook het nut van elke extra eenheid tijd die aan een activiteit wordt besteed. Hoe minder nut men hecht aan een activiteit, hoe minder men bereid zal zijn er tijd voor uit te trekken.

Economen kunnen nu uitspraken doen over de hoeveelheid tijd die mensen bereid zullen zijn te besteden aan reizen.. ${ }^{{ }^{7}}$ Zoals Sharp (r98 $\mathrm{x}$ ) constateert, is juist op dit terrein veel onderzoek gedaan naar de vraag hoe reistijd wordt besteed en in geld kan worden uitgedrukt. In het simpelst denkbare economische model is de reden dat mensen zich verplaatsen van A naar B het feit dat men op plek B zijn nut kan maximaliseren en niet op plek $A$. Het nut van de reistijd wordt samengesteld uit het intrinsieke nut van de reis zelf (dat afhangt van het reismotief; bij het maken van een vakantiereis wordt niet alleen het bereiken van de bestemming gewaardeerd maar ook het maken van de reis zelf, terwijl dit voor woon-werkverkeer niet of nauwelijks zo is) en het afgeleide nut (het nut dat men op de bestemming hoopt te bereiken). Uit de besteding van tijd aan reizen valt dus op te maken wat de relatieve waarde van tijd is. In de welvaartstheorie gaat men ervan uit dat een individu bij een bepaalde tijdsbesteding een maximaal nut ervaart. Hij of zij is slechts bereid om van het optimale patroon af te wijken wanneer daar een zekere financiële compensatie tegenover staat. Tijd en geld zijn tot op zekere hoogte uitwisselbaar.

Van centraal belang in de berekening van de waarde van reistijd in de welvaartstheorie is de aanname dat het marginale nut van reistijd gewoonlijk negatief is: extra reistijd betekent dat iemand minder tijd overhoudt voor activiteiten die hij of zij liever zou doen. Voor iemand die eerder op moet staan vanwege de ochtendspits is dit een vertrouwde redenering. Hoe meer nut men toekent aan de tijd woor deze andere acti- 
viteiten, hoe meer men bereid is te betalen voor kortere reistijden. Uitgaande wan het disnut van reistijd is volgens Sharp ook te begrijpen waarom de belangrijkste reden voor verbeteringen en vernieuwingen in transportsystemen is gelegen in bekorting van de reistijd. ${ }^{8}$ Door aan tijd een bepaalde waardering toe te kennen, kunnen economen voorspellingen doen over bijvoorbeeld de toekomstige ontwikkeling van de vraag naar mobiliteit of de verhouding in afgelegde kilometers tussen verschillende vervoersystemen. Ze kunnen ook oplossingen aandragen voor mobiliteitsproblemen. Op grond van de economische theorie valt goed te begrijpen waarom bijvoorbeeld beleidsinstrumenten als rekeningrijden en kilometerheffing (het duurder maken van het gebruik van wegen op bepaalde plaatsen en tijdstippen) de vraag zullen verminderen. Voor sommigen is de tijdwaardering te laag om de hogere kosten van het gebruik van de weg te rechtvaardigen; zij zullen op een ander moment reizen. Overigens kunnen economen ook weer uitleggen dat deze redenering alleen opgaat als sprake is van een hoge prijselasticiteit, dat wil zeggen een sterk verband tussen de vraagnaar wegcapaciteit en de hoogte van de prijs. Van Mierlo (2000) heeft betoogd dat dit voor autorijden niet het geval is, waardoor de effectiviteit van het rekeningrijden als beleidsmaatregel om files terug te dringen geringer is dan door de overheid wordt aangenomen. ${ }^{12}$

De verhouding tussen geld en tijd heeft niet alleen een theoretische, maar ook een historische dimensie. Volgens Nowotny (x989) vindt tijdschaarste zijn oorsprong in de grootschalige industrialisatie van de negentiende eeuw. Vanaf de achtiende eeuw makte een overwegend cyclisch, op de natuur georiënteerd tijdsbesef plaats voor een lineair tijdsbeeld, voor de rechte lijn zonder einde. Deze 'grenzeloosheid' van de tijd sloot naadloos aan bij het kapitalistische proces van accumulatie. Tijd werd geld en met tijd kon geld worden verdiend. Eenmaal gereduceerd tot de kwantificeerbare grootheid van het geld kon men tijd gebruiken, besparen en winnen. De temporele normen die waren ingebouwd in de machines van de industriële revolutie weerspiegelden zich in de sociale normen rond tijd en de waarde ervan. Het gevolg was, aldus Nowotny, een versnelling die tot uitdrukking kwam in een toenemende mobiliteit van goederen, mensen, energie, geld en informatie. ${ }^{20}$ 


\section{Snelbeid als teken van vooruitgang en moderniteit}

Ook binnen een cultureel-utopisch vertoog is een antwoord mogelijk op de vraag waarom langzame auto's het afleggen tegen snelle. De Wereldtentoonstelling in 1939-40 in New York is maar een van de voorbeelden die duidelijk maken dat het vergelijkend perspectief dat de begrippen langzaam en snel creëren een utopische dimensie heeft. De bezoekers van de World's Fair zagen de 'wereld van morgen', zoals voorzitter Grover Whalen van het organiserend comité het uitdrukte. ${ }^{2 .}$ In die wereld van morgen zouden mensen sneller en verder kunnen reizen dan ooit. Het verkeer vormde een van de hoofdthema's tijdens de tentoonstelling, die langs twee lijnen was opgezet. Ze gaf een beeld van de geschiedenis en ze keek naar de manier waarop wetenschap en techniek vorm zouden geven aan de toekomst. Aan het eind van de 'streamlined decade' hadden Ford, General Motors en Chrysler, de drie grootste autofabrikanten in de Verenigde Staten, drukbezochte tentoonstellingen gemaakt die het verleden, het heden en de toekomst van het verkeer als onderwerp hadden. ${ }^{2 .}$

In het Chrysler-paviljoen was de geschiedenis van de menselijke voortbeweging geënsceneerd als een enkelvoudige ontwikkeling van de voet tot de raket. De expositie was ontworpen door Raymond Loewy, beroemd om zijn ontwerpen van gestroomlijnde en modern ogende auto's en vliegtuigen. Op een grote kaart met knipperende lampen was te zien hoezeer de snelheid van het reizen was toegenomen sinds de dagen van de Griekse marathonlopers. De rondgang door de geschiedenis eindigde met de lancering van een raket die de reizigers in een uur naar Londen zou brengen. Sirenes waren te horen en een magnetische kraan hees de raket in een kanon. Na een korte stilte volgde een lichtflits, een gedempte explosie en het 'raketschip' verdween in de nacht. Snelheid was hier een afkorting geworden voor vooruitgang, schrijft de techniekhistoricus David Nye. ${ }^{23}$

De raketlancering wees naar een toekomstige wereld die werd verbeeld in de Futurama-tentoonstelling van General Motors dat "Highways and Horizons' was genoemd. Het Futurama-paviljoen werkte als een magneet op de bezoekers van de wereldtentoonstelling. Meer dan vijf miljoen mensen 'zagen de toekomst', zoals de button die ze bij de 
uitgang kregen vermeldde. In een uitgestrekt diorama was een landschap gebouwd dat gedomineerd werd door moderne transportmiddelen. Gezeten in comfortabele stoelen die in zestien minuten over het diorama schoven, keken de bezoekers als vanuit een vliegtuig neer op een pretpark, bergen, een appelboongaard onder glas, bruggen, een enorme stuwdam met waterkrachtcentrale en een stad die door Le Corbusier gebouwd had kunnen zijn. Door het landschap liepen de Magic Motorways' van Norman Bel Geddes, de ontwerper van de expositie. Het waren snelwegen van veertien banen. Technici leidden het verkeer vanuit hoge torens en lieten druppelvormige voertuigen snelheden bereiken van honderdvijftig kilometer per uur. In I960, voorspelde Bel Geddes, zou het mogelijk zijn orn in vierentwintig uur van New York naar Los Angeles te rijden. Het was toekomst gezien in termen van wetenschap, snelheid en het technologisch sublieme (Nye, I993).

Op de tentoonstellingen van Chrysler en General Motors werd de logische lijn van de versnelling van het verkeer uit het verleden doorgetrokken naar de nabije toekomst. Het beeld van die toekomst was optimistisch, zo niet utopistisch. Het snellere reizen vormde de voorwaarde voor een moderne, individualistische wereld waarin mensen zelf zouden kunnen bepalen wanneer ze waar zouden kunnen zijn. De groei van het verkeer werd gezien als voorwaarde voor politieke en maatschappelijke emancipatie en als teken van economische voorspoed. De versnelling van het reizen werd in het New York van 1939 en 1940 niet alleen als feit gepresenteerd, maar ook als waarde en in die zin is de tentoonstelling exemplarisch voor een dominante opvatting van de geschiedenis en de toekomst van het reizen: sneller is beter.

Samenvattend is er, vanuit het vergelijkend perspectief dat de begrippen snel en langzaam creëren, niet één antwoord mogelijk op de vraag waarom het zo lastig is een langzame auto te maken, maar wel drie, athankelijk van het vertoog waarin wordt geredeneerd. Allemaal bieden ze een verklaring voor 'de roep om snelheid en verte". ${ }^{4}$ In het technisch-deterministische vertoog geldt techniek als drijvende kracht in de maatschappij waarbij langzamere vervoersystemen plaatsmaken voor snellere. In het economistisch vertoog vereist nutsmaximalisatie een zo efficiënt mogelijk besteding van de tijd en dus ook van reistijd. 
In het cultureel-utopische vertoog wordt juist de aantrekkingskracht van de snelheidsutopie benadrukt (zie figuur I. I). Snelheid heeft zo een financiele en economische meerwaarde, een techinische meerwaarde en een culturele meerwaarde.

$\begin{array}{lll}\text { Technisch-deterministisch vertoog: } & \text { Stell ons in staat sneller te gaan en dus gaan we sneller } & \text { (pulsh) } \\ \text { Economistisch vertoog: } & \text { Nutsmaxmal isatie vraagt om efficiency, dus sneller } & \text { (punt) } \\ \text { Cultureel-utopisch vertoog: } & \text { De utopie van de snelheid wenkt ons, dus sneiller } & \text { (pull) }\end{array}$

Figuiu 1, 1: Orie vertogen, drie verklaringen voor de 'roep om snelheid en verte'.

\section{Op zoek naar de gewonnen tijd}

Ondanks de vele verschillen is de overeenkomst tussen het technischdeterministische, het economistische en het cultureel-utopische vertoog dat de geschiedenis van het reizen kan worden opgevat als een versnellingsgeschiedenis, zeker wanneer men de drie vertogen combineert. Dit gezamenlijke vergelijkende perspectief heeft voordelen. Het maakt het mogelijk het verplaatsingsgedrag van mensen, hun keuzes tussen vervoermiddelen, de historische ontwikkeling van vervoersystemen en de culturele betekenis die eraan wordt toegekend eenvoudig te verklaren. Bovendien kan men binnen deze vertogen voorspellingen doen over de toekomst van het reizen, bijvoorbeeld door modellen en scenario's op te stellen die de toekomstige vraag naar mobiliteit kunnen berekenen, of door de lijnen uit het verleden door te trekken naar de toekomst en uitspraken te doen over de aard en logica van toekomstige technologische transities, of door te analyseren hoe utopische oerbeelden van versnelling en ontsnapping uit de kluisters van ruimte en tijd vorm geven aan verhalen van vooruitgang. ${ }^{25}$

Maar hoe consistent en maatschappelijk dominant ook, deze vertoogfamilie heeft een winst- en verliesrekening. Het vergelijkend perspectief van de snelheid, creëert in de woorden van techniekfilosoof Ivan Illich, een 'wereld zonder uitgang' waarin we ons de toekomst nog slechts kunnen voorstellen als een voortgaande versnelling. ${ }^{26}$ Het zoe- 
ken nar bevrijding uit de conceptuele dwangbuis van het 'steeds sneller' vormt een dominant thema in kritische beschouwingen waarin tegenover de logica van de snelheid de noodzaak van traagheid wordt gesteld. Centraal in deze kritieken staat de paradox van de tijdschaarste. Journalist Henk Hofland schreef in zijn boek Geen tijd uit 1955: De meeste mensen zijn niet in staat iets te ondernemen dat veel tijd vergt, zijn verslaafd aan de snelle afwisseling van bezigheden, prefereren de krant boven het boek, de foto boven het geschreven bericht, en de telefoon boven de brief. (...) De vakanties zijn langer, de werkweken korter, maar men heeft geen tijd. Een snellere auto, motorfiets, brommer, maar geen tijd. Vrouwen hebben wasmachines, stofzungers, centrifuges, en ondanks deze motorisering van het huishouden geen tijd. Directetaren hebben hun secretaresses, arbeiders hun achturige werkdag, maar niemand heeft tijd. ${ }^{27}$ De utopische belofte van technologie is dat zij tijd bespaart, maar die belofte blijkt vals, zo betogen critici. ${ }^{28}$ Voor "tijdnoodlijders' zoals Hofland ze noemt, blijkt het 'sparen' van tijd nooit een doel op zich maar een manier om meer te doen.

Tijd die wordt gewonnen, bijvoorbeeld door activiteiten uit te besteden aan versnellende apparaten, blijft niet "leeg" maar wordt gebruikt voor andere activiteiten. Prousts roman A la recherche du temps perdu, geschreven tussen I 908 en 1922, biedt een mooie illustratie van dit mechanisme. In het deel 'Sodom en Gomorra u' huurt de verteller als verrassing voor zijn geliefde Albertine een auto om een middagje te gaan toeren naar twee naburige dorpen. Mar volgens haar kon dat niet. $\mathrm{Ze}$ dacht well dat wij onderweg hier en daar zouden kunnen stoppen, maar hield het voor onmogelijk om eerst naar Saint-Jean-de-la-Haise te gaan, dat wil zeggen in een andere richting, én een rit te maken die aan een aparte dag leek voorbehouden. Ze vernam daarentegen van de bestuurder dat niets zo gemakkelijk was als naar Saint-Jean te gaan, waar hij in twintig minuten zou zijm, en dat wij daar een paar uur konden blijven als we wilden, of nog veel verder doorrijden, want dat hij er van Quetteholm naar La Raspelière niet langer dan vijfendertig minuten over zou doen. Wij beseften het toen de auto, wooruitschietend, met éen sprong twintig stappen van een voortreffelijk paard aflegde. Afstanden zijn niets anders dan de verhouding van ruimte tot tijd en variëren naar- 
gelang. De moeite die het ons kost om ons ergens heen te begeven drukken wij uit in een stelsel wan mijlen, van kilometers, dat niet meer klopt zodra die moeite vermindert. De kunst wordt er ook door gewijzigd, want dorpen die in verschillende werelden leken te liggen worden buren in een landschap dat andere dimensies heeft gekregen. ${ }^{329}$ Dorpen als Saint-Jean en La Raspelière waren voor Albertine als 'gevangenen zo hermetisch ingesloten tot dusver in de cel van onderscheiden dagen als vroeger Méséglise en Guermantes, en waarop hetzelfde paar ogen niet in één middag kon rusten, $(\ldots)^{930^{\circ}}$ De autoreizigers doen dat wat hun voertuig mogelijk maakt: ze bezoeken op één middag vrienden in twee verschillende dorpen. Dan gebeurt er iets onverwachts. Albertine, die nog maar enkele uren eerder niet wilde geloven dat je twee dorpen op een enkele dag kunt aandoen en dus een dag gewonnen heeft, krijgt plotseling haast. Op bezoek in het ene dorp werpt ze haar geliefde een blik toe om duidelijk te maken dat ze niet veel langer kunnen blijven; ze moeten immers nog naar het tweede dorp. ${ }^{31}$ De reisgenoten sparen tijd uit door sneller te reizen dan met een koets, maar gebruiken die om een langere reis te maken en meer bestemmingen aan te doen.

Sachs ( 1999 ) stelt de retorische vraag waar de tijd is gebleven die mensen dankzij de auto hebben gewonnen. ' $\mathrm{Zij}$ die een auto kopen slaken geen zucht van verlichting om daarna te genieten van de extra uren vrije tijd. Zij reizen naar verder gelegen bestemmingen. De kracht van snelheid wordt niet omgezet in minder uren op weg maar in meer afgelegde kilometers: De gewonnen tijd wordt besteed aan het afleggen van grotere afstanden. En naarmate de tijd verstrijkt, verandert de ruimtelijke ordening en worden langere afstanden de norm. ${ }^{32}$ Gewonnen tijd verdwijnt in allerlei soorten nieuwe groei, betoogt Sachs. Anders gezegd, een sneller vervoermiddel schept nieuwe mogelijkheden en verwachtingen. De horizon komt niet dichterbij, maar schuift naar achteren ${ }^{33}$ Als snelheid het probleem vormt, is traagheid wellicht de oplossing. Aldus redenerend pleit een aantal auteurs voor een "herontdekking van de langzaamheid".

\section{Traagheid als techniekkritiek}

In deze redenering zou de haast van Albertine kunnen verdwijnen als reizigers bereid waren meer tijd te nemen voor hun reis. Waar haastige 
mobiliteit regeert, schrift Sachs (r999), groeit de voorkeur voor traagheid. Dit betekent dat de ontwikkeling wan verwoersystemen niet langer kan worden begrepen uit het imperatief van de versnelling. Het geloof in de vooruitgang als het voortdurend verminderen van de natuurlijke weerstand van duur en afstand zal verdwijnen, denkt Sachs. "Talloze bruggen, tunnels, snelwegen, kabels en antennes zijn de erfenis van dat geloof Maar het vermoeden ontstaat dat vooruitgang ook wel eens zou kunnen inhouden dat we de weerstand van ruimte en tijd met opzet onveranderd laten of zelfs vergroten. ${ }^{* 4}$ Hoe zou de utopie wan de nieuwe tragheid eruit kunnen zien als het gaat om reizen? Langere reistijden leiden ertoe dat mensen of minder ver weg gaan, of meer tijd uit moeten trekken voor hun reis. In plaats van het verre Europese EuroDisney zullen sommigen weer kiezen voor recreatieve bestemmingen dichter bij huis. Werken en wonen op afstand wordt minder aantrekkelijk, tenzij men gaat telewerken. Winkels en andere voorzieningen zullen zich niet langer kunnen handhaven op grote afstand van woonwijken zoals nu, dankzij de auto, wel het geval is.

Whitelegg (1993) analyseert de, wat hij noemt, "tijdvervuiling' door de auto. On een snelle doorstroming van het autoverkeer mogelijk te maken is veel ruimte nodig in de infrastructuur - ruimte, tijd en snelheid zijn hier als het ware neergeslagen in de inrichting van de infrastructuut: ${ }^{35}$ Het autoverkeer veroorzaakt door de hoge snelheden niet alleen ruimtevervuiling (snelheid vreet ruimte), stelt Whitelegg, maar ook tijdvervuiling omdat langzamere verkeersdeelnemers nu moeten omfietsen of wachten: Verkeersdrempels, voetgangersgebieden, 30-km zones in woonwijken zijn maar enkele voorbeelden van het verlangzamen van het gemotoriseerde verkeer om de leefbaarheid en milieukwaliteit te verbeteren en tijdvervwiling tegen te gaan. Tromp en Van den Bosch (r995) schreven onder de titel 'Langzaam rijden gaat sneller' een "handreiking voor infrastructurele vernieuwing" waarin snelle verplaatsingen niet langer de norm zijn en 'haast hebben beschouwd word als teken van een slecht georganiseerd leven'. ${ }^{6}$ Lichte, langzaan rijdende voertuigen bepalen in deze toekomstvisie het gezicht van stedelijke verkeerssystemen. Met snelheidsbegrenzers wordt het verkeer biji de toegangen tot de stad vertraagd tot $40 \mathrm{~km} / \mathrm{u}$ en bij woonwijken zelfs 
tot $30 \mathrm{~km} / \mathrm{u}$. 'Een smal wegprofiel, in combinatie met lage snelheden, maakt oversteken eenvoudig. Verkeerslichten zijn vrijwel overal overbodig geworden. De tijdwinst die hierdoor ontstaat, compenseert ruimschoots de extra rijtijd als gevolg van de lagere snelherd. Gegarandeerde aankomsttijden, oogcontact met andere verkeersdeelnemers en een aantrekkelijke omgeving maken het reizen in de stad tot een prettige bezigheid." ${ }^{37}$

\section{Traagheid als economiekritiek}

Hoe krijgen we mensen in de 'langzame auto'? Door ze te bevijiden van het juk van de economische groei en de dwang van de klok. Pleidooien voor traagheid nemen waak de vorm aan van een vlucht uit het gedwongen tempo dat economische groei oplegt: Zo stelt Rifkin ( 1987 ) voor 'mechanische tijd' in te wisselen voor 'natuurtijd'. De tijd 'werd losgerukt van zijn biologische ankerplaats in zijn natuurlijke omgeving en opgesloten binnen het raderwerk van een automatische machine die hem nu uitdeelde in regelmatig nietszeggend getilk'. ${ }^{38}$ Rifkin schrijtt dat het huidige hoge tempo niet verenigbaar is met het ritme van de natuur en de tijd die deze nodig heeft om verbruikte grondstoffen te vernieuwen. In plaats van snelheid en haast wordt in een duurzame samenleving traagheid het onderliggende principe van de tijdservaring. Het soms onzichtbaar langzame ontwikkelingstempo van de natuur wordt de leidraad. Dit houdt in, dat tijd niet langer alleen als kwantificeerbare, verhandelbare, economische ruileenheid wordt opgevat, maar ook als het relationele stelsel van "vroeger-later" dat het ooit is geweest. Ecologisch zinvol "tijdhandelen" doet recht aan biologische en naturitijke ritmes en tracht zo het verloren gegane subjectieve tijdsbeleven als Eigenzeit te herstellen. ${ }^{39}$

Hoe we ons een langzame manjer van leven moeten voorstellen is af te leiden uit een Duits onderzoek aan het einde van jaren tachtig onder zogenaamde 'tijdpioniers' (Hörning, Gerhard en Michällow, 1995). Tijdpioniers verzetten zich tegen de snelheidsnorm in de westerse cultuur en nemen afstand van de daarmee verbonden haast, gejaagdheid en nervositeit. Als alternatief ontwikkelen de tijdpioniers een levensstijl die niet langer alleen gebaseerd is op materiele welvaart, maar ook op 
tijdwelvaart. Tijdpioniers - ze komen in het Duitse onderzoek uit alle lagen van de bevolking - ruilen een deel van hun inkomen in om er tijd voor terug te krijgen, echter zonder van tevoren een bestemming voor de nieuwe vrije tijd te hebben. Daarin verschillen ze van mensen die in deeltijd gaan werken om bijvoorbeeld hun partner de gelegenheid te geven te gaan werken. ${ }^{4}$

\section{Traagheid als cultumeritiek}

Behalve in beschouwingen over (verkeers)technologie en economie is het ideaal van traagheid te vinden in cultuurkritieken. ${ }^{4 .}$ De Franse essayist Paul Virilio beschrift een ontwikkeling in de richting van wat hij "razende stilstand' noemt. Dankzij snelle vervoermiddelen en wereldomspannende telecommunicatienetwerken kunnen mensen overal tegelijk zijn en daardoor nergens in het bijzonder. Niet langer is het zo dat wij al reizend bewegen, de beweging voltrekt zich in een steeds hoger tempo aan ons. Gezeten achter de voorruiten van onze auto's of achter de schermen van onze computers en televisies komen wij fysiek volledig tot stillstand, maar zujn we tegelijk machteloos overgeleverd aan de hallucinerende, telkens wisselende gedaantes van de snelheid, meent Virilio. Beweging is woor hem niet langer een vector in de concrete ruimte-tijd, maar een vorm van representatie. De 'kadaver-achtige onbewegelijkheid' waarin dit resulteert is voor hem het meest bedreigende kenmerk van de dystopie van de snelheid. ${ }^{42}$

Ook bij de Duitse filosoof Peter Sloterdijk krijgt moderniteitskritiek de vorm van mobiliteitskritiek. Wat aan het begin van de twintigste eeuw begon als een vrolijke bewegelijkheid, schrijft hij in zijn boek Eurotaoismus ( $\mathrm{t} 989$ ), is verworden tot een onomkeerbaar proces van 'kinetische mobilisatie'. Het proces van modernisering is samen te vatten in een enkele formule, meent Sloterdijk: "Vooruitgang is beweging om de beweging, beweging an meer te kunnen bewegen, beweging on de vaardigheid tot bewegen te kunnen verfijnen. Omdat dit geldt, vloeit in de moderniteit de ethiek rechtstreeks voort uit de kinetiek. Er zijn geen ethische imperatieven meer die niet tegelijk ook kinetische impulsen waren. De categorische impuls van de noderniteit luidt: om zich blijvend als vooruitgangswezen te kunnen doen gelden, moet de mens 
elke toestand overwinnen waarin hij 'een in zijn beweging gehinderd, een in zichzelf besloten, een erbarmenswaardig "vast-gesteld" wezen is." Sloterdijks kritiek van de politieke kinetiek krijgt vervolgens de vorm van een onderzoek naar de ethiek van het nalaten en legt de nadruk op safremmen' als progressieve functie. ${ }^{43}$

\section{De trein van Haw thome}

Hoe verschillend ook, al deze pleidooien voor traagheid delen een omdraaing van de logica van de versnelling. Als sneller reizen nixt leidt tot meer tijd maar tot het afleggen van grotere afstanden, meer bezoeken op een dag en wellicht ook tot haast, zoals Albertine en haar geliefde merkten, dan zou langzamer reizen de weg naar meer rust kunnen zijn. Sachs (1999) constateert dan ook dat mensen alleen meer tijd zullen winnen als ze afzien van de snelheid die tijdwinst mogelijk lijkt te maken. Maar deze redenering berust op een fout die logici de omkering van de antecedens noemen, stelt De Wilde (1997). De traagheidsutopisten redeneren: snelle vervoermiddelen brengen haast, ergo niet-snelle vervoermiddelen brengen niet-haast (rust). Helaas is deze redenering niet waterdicht; ze is alleen sluitend te maken als we op voorhand alle andere factoren uitsluiten. ${ }^{44}$

Deze a-priori inperking is niet toevallig. Beide posities - snelheid als impliciete norm en traagheid als oplossing - spiegelen elkaar. Ze leveren dan ook beide een 'gesloten toekomst' op. In bet ene geval kunnen we slechts over vernieuwing nadenken als versnelling. Het succes van nieuwe vervoersystemen wordt dan afgemeten aan de vraag welke reistijdwinst ze opleveren. Het oplossen van bestaande problemen bestaat hoofdzakelijk uit het wegnemen van 'knelpunten', het verminderen van de verplaatsingsweerstand. De geschiedenis van het reizen wordt geschreven als een ontwikkeling in een bepaalde richting. De koets, de trein, de auto, het vliegtuig: het zijn slechts stadia in een niet in te tomen proces van versnelling. In het andere geval kunnen we de toekomst slechts zien als de omkering van dit standaardbeeld: meer trage auto's, meer fietsen, meer wandelen en de wereld komt tot rust.

Waarom spiegelen beide posities elkaar? Ondat ze, ondanks alle in= 
houdelijke werschillen, op dezelfde basisweronderstellingen zijn gebaseerd. Het verraderlijke karakter van dit gedeelde perspectief wordt duidelijk uit een tweede romanfragment. In Het buis met de zeven zegels uit 185 I beschrijft Nathaniel Hawthorne hoe twee hoofdpersonen, Clifford en Hepzibah, een treinreis in het oosten van Amerika maken. Op het station 'stond net een trein op punt van vertrekken; de locomotief kookte van ongeduld, als een paard dat staat te trappelen om weg te stormen; en de bel liet een haastig gebengel horen dat sterk deed denken aan de korte waarschuwingen die het haastig voortijlende leven ons geeft." 45 Terwijl ze onderweg 'door het raam de wereld langs zien wliegen' merkt Clifford op dat zich in de treincoupe 'het leven zelf" afspeelt. 'Het leek een wonder dat al deze mensen zo rustig op hun plaatsen konden blijwen zitten terwijl er zoveel luidruchtige kracht voor hen aan het werk was. Sommigen; met hun kaartjes in hun hoeden (zij hadden een lange reis van wel honderd mijl voor de boeg), waren verdiept in romannetjes vol taferelen en avonturen die zich in Engeland afspeelden en verkeerden in het gezelschap van hertogen en graven. Anderen, die onvoldoende tijd hadden om zich aan zulke diepzinnige studies te wijden, verdreven de kortstondige verveling onderweg met krantjes. Een groepje meisjes en een jongen die zich aan beide uiteinden van de wagon bevonden, amuseerden zich kostelijk met een bal. Die kaatsten ze heen en weer met een geschater dat men had kunnen meten in mijlen; want de vrolijke spelers schoten, zonder zich ervam bewust te zijn, sneller vooruit dan de vlugge bal kon vliegen, ze lieten hun spoor wan plezier ver achter zich en beëindigden hun spel onder een andere hemel dan die welke getuige was geweest van het begin.' Het wonder van de twee gelijktijdige snelheden, van de gegooide bal en van de voortrazende trein, zet zich voort in de coupé, merkt Clifford op. Het leven gaat er snel; voortdurend stappen nieuwe mensen in en vertrokken er "oude kennissen - want dat werden de mensen hier, waat alles zo snel ging, al heel vlug." Maar verderop zit lemand juist rustig te slapen of leest een boek. De vluchtige stroom van de gebeurtenissen in de trein verleidt hem tot bespiegelingen over de vooruitgang die de spoorwegen zouden brengen. De 'bewonderenswaardige uitvinding' zou afrekenen met "het achterlijke idee van huis en haard, en ze door iets beters vervangen", 
meent hij. "Ze geven ons vleugels, ze besparen ons de vermoejenissen en het stof van de voettocht; ze vergeestelijken het reizen! Wat kan iemand, nu het zo gemakkelijk is je te verplaatsen, nog op een en dezelfde plaats houden? ${ }^{947}$ Het spiritisme, elektriciteit en de telegraaf zijn andere onderwerpen die Clifford ter sprake brengt in een gedreven gesprek met zijn overbuurman. 'Juist toen bereikte de trein een verlaten station. Clifford makte van het korte oponthoud gebruik om de wagon te verlaten, en hij trok Hepzibah mee. Even later gleed de trein met all het leven in zijn binnenste, waar Clifford zich opvallend had gedragen - weg in de verte en werd hij snel kleiner, tot hij een punt was die nog iets later verdween. De wereld was van de twee zwervers weggevlucht. ${ }^{48}$

Wat maakt het romanfragment duidelijk? Dat de beoordeling van snelheid en traagheid niet slechts afhankelijk is van de ervaring van de individuele waarnemer, zoalls in het geval van Albertine die reizend met de auto haast krijgt en haar horizon ziet wijken. De trein van Hawthorne laat meerdere horizonnen corresponderen met meerdere posities van waaruit we de wereld kunnen waarnemen. Snelheid en traagheid verschijnen hier in meervoud en veronderstellen altijd een context. De trein van Hawthorne raast door het landschap, maar mensen liggen rustig te slapen. Gezeten in de coupé denkt en praat Clifford sneller en voelt hij bewondering voor de bijna tastbare vooruitgang die de trein symboliseert. Eenmaal uitgestapt, verkeert hij weer in een trage, achterlijke wereld en voelt hij zich een zwerver De trein - het bruisende leven zelf - verwijdert zich van hem.

Deze contextualiserende benadering van snelheid en traagheid, waarvan het fragment uit Hawthorne's roman als voorbeeld kan worden gellezen, zoekt een oplossing voor de paradox van de tijdschaarste niet in de ervaring van de waarnemer, maar in de combinatie van posities: waar wij terugzien op de jaren vijftig als een 'Holland zonder haast ${ }^{39}$, beschreef Hofland in deze periode zijn tijdgenoten juist als tijd noodlijders. Om het verband tussen reizen en tijd te kunnen analyseren moeten we niet zoveel mogelijk factoren uitsluiten, maar die factoren juist opzoeken. Een zo'n factor betreft de tijd zelf: hoe eenduidig is dit begrip eigenlijk? 


\section{Tussen reistijd en gereisde tiju}

Tijd in enkelvoud bestaat niet, stelt Barbara Adam (r997). Tijd openbaart zich als kloktijd, natuurtijd en kosmische tijd. Als verleden, heden en toekomst. Als duur, snelheid en intensiteit, als eindigheid en eeuwigheid, als veranderlijkheid en continuïteit, als ritme en maat, kwantitatieve grootheid en kwalitatieve ervaring. Als levende wezens zijn mensen doortrokken van een veelvoud aan lichamelijke ritmes en bovendien verweven met een rijk scala aan biologische tijdschalen. Hoe structuur aan te brengen in al deze verschillende tijdsbegrippen?

Om te beginnen kunnen we spreken van 'objectieve tijd'. Dit is tijd die zich buiten mensen om in de wereld voltrekt (Goudsblom, 1997). Tijd bestaat, of er nu mensen zijn om hem waar te nemen of niet. Het opkomen en ondergaan van zon en maan, het draaien van de aarde, maar ook het oplossen van een klontje suiker in een kopje koffie of de halfwaardetijd van atomen zijn gebeurtenissen met een gegeven tijdsverloop. Het is ten tweede gebruikelijk om tijd te beschouwen als een verschijnsel dat slechts bestaat in de individuele waarneming, bijvoorbeeld als innerlijke ervaring of, zoals bij Kant, door tijd te beschouwen als een begrip dat aan de zintuiglijke waarneming vooraf gaat. In deze vorm is tijd tegelijk vertrouwder en heel veel ingewikkelder. Ons leven speelt zich af in steeds wisselende temporele 'horizonnen', die voortdurend veranderen zoals een landschap gezien door het raam van een trein. Mensen ervaren het verstrijken van tijd verschillend en ook ervaart een en dezelfde persoon niet elk uur als het voorgaande. Hartocollis ( 1983 ) benadrukt bijvoorbeeld dat de kwantificeerbare kloktijd waarin het aantal te werken uren is vastgelegd niets zegt over de beleving van die uren, die mede bepaald wordt door de werkdruk.

Het onderscheid tussen objectieve en subjectieve tijd keert terug in het dualistische karakter van veel theorieën over tijd. Bekende voorbeelden zijn het onderscheid tussen temps en durée (Bergson) en Zeit en Dasein (Heidegger) (Adam, r990). ${ }^{50}$ Een minder bekend, maar niettemin verhelderend voorbeeld van zo'n dualistische tijdtheorie is van de Britse hegeliaanse filosoof McTaggart. In het artikel "The Unreality of Time' (1908), waarin hij een logisch argument ontvouwt tegen het be- 
staan van tijd, onderscheidt McTaggart "positions in time" in respectievelijk een A-serie en een B-serie. "In de A-serie is altijd een warmemer (observer) verondersteld die gebeurtenissen categoriseert op grond van het feit dat ze zich in het verleden, heden of de toekomst afspelen. ${ }^{2}$ Elke denkbare gebeurtenis is dan toekomstig totdat zij optreedt, heden op het moment dat zij gebeurt en verleden nadat zij is gebeurd. De relatie tussen gebeurtemissen (of ze behoren tot het verleden, het heden of de toekomst) verandert en dankzij deze veranderingen is het verstrijken wan de tijd waar te nemen. Tijd is hier een dynamisch concept, het verstrijken van tijd zoals mensen die ervaren ligt aan de basis van dit begrip van tijd. Verandering heeft het karakter van 'wording' die wordt ervaren als herinnering en verwachting. In de B-serie daarentegen, vindt het onderscheid tussen gebeurtenissen plaats op grond van het criterium of zij eerder of later hebben plaatsgevonden. Dat Caesar eerder is geboren dan koningin Victoria is een uitspraak waarwan de waarheid niet afhangt van het moment waarop zij wordt gedaan. Anders dan in de A-serie is de temporele relatie tussen gebeurtenissen onveranderlijk en zijn begrippen als verleden, heden en toekomst irrelevant. Tijd is een denkbeeldige lijn waarop gebeurtenissen een onveranderlijke positie hebben.

In zijn essay Die Zeit (I988) beschrijft Norbert Elias een derde tijdsopvatting. Hij beschouwt tijd 'als een sociaal-cultureel gegeven, een constructie met behulp waarvan mensen zich gezamenlijk in de wereld oriënteren en hun handelingen op elkaar afstemmen'.3 Mensen kunnen relaties leggen tussen twee of meer gebeurtenisisen en dit stelt hen in staat een van die gebeurtenissen als gestandaardiseerd referentiekader op te vatten. Op het moment dat men de ene temporele orde met de andere vergelijkt, bijvoorbeeld het opkomen en ondergaan van de zon met de gebeurtenissen op een dag, is sprake van een sociaal geconstrueerd tijdsbegrip. ${ }^{54}$ Tijd is het resultaat van de vaardigheid van mensen om hulpmiddelen te ontwikkelen zoals de klok die hen in staat stellen de talloze processen en gebeurtenissen watmee ze te maken hebben met elkaar te vergelijken.

Elias opvatting dat aan elk tijdsbegrip een proces van sociale constructie ten grondslag ligt, staat in een lange sociologische traditie die teruggaat tot Durkheim en die een breed scala aan onderzoek omvat in 
uiteenlopende disciplines. ${ }^{55}$ Historici hebben zich beziggehouden met de ontwikkeling van het bepalen van de tijd, zoals Goudsblom opmerkt, "niet als het 'bepalen' van een gegeven factor tijd die er al is en die vervolgens wordt bepaald, maar als een activiteit die ertoe leidt dat we met 'tijd' zijn gaan rekenen. ${ }^{56}$ Cultureel-antropologen hebben sinds het baanbrekende werk van Evans-Pritchard, Levi-Strauss en Clifford Geertz tijdrekeningen in niet-westerse culturen bestudeerd. ${ }^{57}$ Sociologen ten slotte, hebben betoogd dat tijdrekening in de vorm van kalenders en roosters niet alleen een middel is om het sociale leven te coördineren en te standaardiseren, maar ook een instrument om te controleren en macht uit te oefenen. ${ }^{58}$ Zo gingen maatschappelijke processen van arbeidsdeling en industrialisatie in de negentiende eeuw hand in hand met een veranderende omgang met tijd. ${ }^{59}$

Uitgaande van het tijdsbegrip van Elias en de traditie waarin hij staat, is de vraag niet langer aan de orde wat tijd is, maar hoe tijd door mensen wordt gebruikt in concrete situaties als middel om zich te oriënteren in hun wereld. Tijd is hier historische, sociale, culturele tijd-niet een objectief gegeven, maar ook meer dan een subjectieve beleving. Historische, sociale, culturele tijd is altijd intersubjectief en higt 'neergeslagen' in artefacten en praktijken. Niet alleen klokken zijn binnen dit begrip dan 'Zeitgeber' (Elias), maar ook auto's, wliegtuigen, magnetrons en mobiele telefoons. Ze veranderen de manier waarop mensen hun leven temporeel kunnen ordenen. Nowotny ( 1989 ) geeft het voorbeeld van de videorecorder, waarmee het tijdstip van uitzending niet langer bepalend is voor het moment waarop men naar een programma kijkt; deze activiteit kunnen tv-kijkers nu verschuiven naar een zelfgekozen tijdstip. 'Sociale tijd' maakt deel uit van manieren waarop groepen mensen hun leven ordenen; verandert die ordening, dan verandert ook de tijd en omgekeerd. Thrift ( 1996 ) geeft daarwan een mooi voorbeeld. De sociale tijd in middeleeuwse kloosters was niet statisch, maar veranderde in relatie tot teksten (zoals de bekende 'urenboeken'), apparaten (zoals de kloosterkerk klok en de eerste uurwerken) en regimes van disciplinering (zoals een strengere omgang met gebedstijden). ${ }^{61}$ Dit tijdsbegrip - waarin tijd als sociale temporele orde wordt opgevat - wil ik, met een knipoog naar McTaggart, de C-serie noemen. 
Het is niet mijn bedoeling om de drie tijdsbegrippen die ik hier heb onderscheiden te reifficeren. Het gaat mij in het vervolg van dit boek niet in de eerste plaats om de vraag of bijvoorbeeld reistijd al dan niet het karakter van A-, B- of C-tijd heeft. Deze categorisering heeft hier yoor alles een heuristische reden: het maakt het mogelijk te onderscheiden tussen stijlen van redeneren over 'snel' en 'langzaam'.

\section{Decontextualiseren en contextualiseren}

In het vergelijkende perspectief dat in de voorgaande paragrafen met de begrippen snel en langzaam werd gecreëerd, is altijd sprake van een tijdsbegrip uit minstens een van de drie series. Als versnelling of vertraging worden opgevat als ervaring, bijvoorbeeld die van Albertine, dan is sprake van A-tijd. Of denk aan de uitspraak dat het leven vroeger langzamer ging, of dat mensen tegenwoordig meer haast hebben. Dit type uitspraken hanteert een kwalitatieve tijdschaal en veronderstelt een waarnemer. Bezien in relatie tot reizen verschijnt tijd hier als 'gereisde tijd', naar analogie van Bergsons 'geleefde tijd'. Het vergelijken van gereisde tijd is voor een buitenstaander strikt genomen onmogelijk omdat een tijdsschaal los van de individuele ervaring ontbreekt. Als versnelling of vertraging worden opgevat als verbouding tussen tijd en afstand, dan is sprake van B-tijd, denk aan uitspraken waarin sneller reizen 'tijd bespaart'. Dit type uitspraken bedient zich van een gekwantificeerde tijdschaal. In relatie tot reizen wordt deze gekwantificeerde tijd gebruikt om te vergelijken tussen gemeten snelheden. Zo leidt ieder tijdsbegrip tot een bepaalde stijl van redeneren over snel en langzaam. De vergelijking tussen een clipper en een stoomboot halverwege de negentiende eeuw kan deze redeneerstijlen verduidelijken. Bij wijze van gedachteexperiment laten we beide schepen dezelfde reis maken.

Beschikten we slechts over A-tijd, dan zou de vergelijking de vorm krijgen van twee verschillende reizen gemaakt door zeereizigers, elk met een plaats van vertrek, een verblijf op zee en een aankomst in de haven van bestemming. Aan boord van een van beide schepen zouden deze reizigers het verstrijken van de tijd ervaren aan de voortgang die het schip boekt; tussengelegen havens liggen letterlijk voor de boeg, worden even later bereikt om vervolgens weer verlaten te worden. Voor een vergelij- 
king van de snellheid van beide reizen kunnen we alleen terugvallen op het tijdsverloop zoals dat werd ervaren door de beide reizigers, maar omdat deze ervaring subjectief is en een gedeelde tijdschaal ontbreekt, is het niet mogelijk vast te stellen of het stoomschip sneller reisde dan de clipper anders dan in de ervaring van beide reizigers. De temporele orde van beide reizen is hier een subjectieve orde en vormt als zodanig een belangrijke dimensie in het moderne levensgevoel. ${ }^{\text {Ga }}$ Maar omdat het mij in dit boek primair gaat om de verneuwing van de politieke taal warin wij spreken over reizen en mobiliteit laat ik deze dimensie verder buiten beschouwing.

Beschikten we slechts over B-tijd, dan leidde dit tot een ander type vergelijking. We zouden dan woor beide schepen twee gebeurtenissen moeten vaststellen: het moment van vertrek en het moment van aankomst. Omdat beide momenten vastliggen in de tijd kunnen we van een 'zelfde moment' spreken en is de duur van de reis te kwantificeren. Een van de manieren om dat te doen is door een klok a an boord te hebben die de reisduur meet. Door de duur van de reis in kloktijd te vergelijken, wordt duidelijk welk van de beide schepen het snelst heeft gevaren, de aanwezigheid van reizigers aan boord is hiervoor irrelevant. De temporele orde van de reis neemt hier de vorm an van een orde die vastligt in uren, dagen, weken en maanden. Met behulp van deze geobjectiveerde tijdschaal is het mogelijk te abstraheren van alle verschillen tussen de clipper en de stoomboot en zo een vergelijking te maken in het aantal kilometers per uur dat beide schepen hebben afgelegd. Vergelijken leidt hier noodzakelijk tot decontextualiseren; alleen zo kunnen we snelheden opvatten als abstracte verhoudingen.

Het vergelijken van de snelheid van beide schepen in $\mathrm{C}$-tijd gaat uit van een andere opvatting van temporele orde, namelijk als een orde die het resultaat is van de activiteit van het reizen. Tijd is hier niet slechts een individuele ervaring of een onafhankelijk raamwerk, maar is het product van de context waarin beide schepen hun reis maken. Een historicus als Vance ( 1986 ) zal er daarbij op wijzen dat stoomschepen in I850 alleen gebruikt werden voor korte afstanden, ondat de stoommachines nog erg veel kolen en water verbruikten. Dat beperkte hun actieradius tot de havens langs de kust. De eigenschappen van de stoom- 
machine zijn hier bepalend voor wat we de spatio-temporele orde van de reis van het stoomschip kunnen noemen. De clipper makte een heel andere "doorgang" door tijd en ruimte mogelijk. Omdat zeilschepen miet zo vaak hoefden te fourageren als stoomschepen, werden ze tot ver in de negentiende eeuw ingezet op de lange afstanden. ${ }^{63}$ Pas toen stoomschepen met minder kolen en water toekonden en daarnaast een regelmatiger temporele orde mogelijk maakten, verdwenen de clippers, maar alleen als handelsvaartuigen en weer niet als opleidingsschepen. In die rol varen ze nog steeds.

Met een stoomschip was de reis nauwkeuriger te plannen, maar dit hield ook in dat schepen 'te laat' konden arriveren waar dit voor een clipper niet zou hebben gegolden, eenvoudig omdat de onvoorspelbaarheid van de reistijd van een zeilschip, een gevolg van de variatie in wind en stroming, een dergelijke punctualiteit in de weg stond. Verschillen als deze tussen stoomschip en clipper worden zichtbaar door tijd niet uit de praktijk te halen, maar door juist te onderzoeken hoe tijd en snelheid tot stand komen binnen praktijken. C-tijd staat dan op de voorgrond en niet $\mathrm{B}$-tijd of $\mathrm{A}$-tijd. Welke tijd we voorop stellen is dus afhankelijk van de interesse en onderzoeksvraag van de onderzoeker. Dat maakt het mogelijk meerdere tijdsordes te vergelijken. Zo creëert Fernand Braudel in zijn beroemde geschiedschrijving van de Middellandse Zee drie tijdsordes, de "welhaast onbewegelijke" geschiedenis van de betrekkingen tussen mens en landschap, de 'langzaam bewegende geschiedenis' van economieën, staten, samenlevingen en beschavingen en de 'geschiedenis van korte, vluchtige en grillige schommelingen' die eigen is aan het dagelijks leven van individuen. ${ }^{64}$ Braudel vraagt niet naar hét tempo van het Middellandse Zeeleven; nee, door als historicus verschillende tijdsordes te construeren weet hij 'de' geschiedenis van het gebied rond de Middellandse Zee op een gelaagde manier te beschrijven. We krijgen daarmee oog voor het belang wan elk van deze drie spatio-temporele ordes voor de geschiedenis. Braudel zet hiermee een belangrijke stap in de richting van het vergelijken in termen van $C-t i j d$, maar gaat nog niet ver genoeg. De drie tijdschalen die Braudel hanteert gaan uit van B-tijd en lijken daardoor onveranderlijk. Maar tijdschalen zijn zelf deel van de geschiedenis: zelfs de 'welhaast onbewegelijke' ge- 


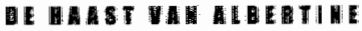

schiedenis van het landschap rond de Middellandse Zee kan opeens in beweging komen, bijvoorbeeld als het Suez-kanaal wordt aangelegd en woorheen onbetekenende steden opeens een strategische rol krigen, wat kan leiden tot nieuwe tijdpraktijken. Met andere woorden, om te kunnen vergelijken tussen praktijken is het nodig meerdere tijdsordes te reconstrueren, maar deze tijdsordes behouden zelf altijd een contextueel karakter.

In de comparatieve studie van de geschiedenis van reizen en mobiliteit zijn drie benaderingen te onderscheiden. Spreken in termen van Btijd verleidt ons tot een decontextualiserende aanpak, een aanpak die er zelf weer toe leidt dat we bij het woord 'tijd' primair denken aan B-tijd. Spreken in termen van A- en C-rijd nodigt daarentegen eerder uit tot een contextualiserende strategie, dat wil zeggen tot het bestuderen van de wijze waarop in historische praktijken tijd en snellheid gestalte krijgen. Spreken in termen van A-tijd geeft aandacht aan individuele reiservaringen zoals vastgelegd in dagboeken en reisverslagen. Spreken in termen van $\mathrm{C}$-tijd daarentegen houdt dan het vergelijken van collectieve praktijken in. Deze drie posities sluiten elkaar niet uit, maar ze leveren andere soorten kennis op over de problemen van het moderne reizen en leiden dus ook tot andere visies op het oplossen van problemen. Omdat het mij in dit boek gaat om de sociale vormgeving van tijdsordes zoals die tot stand komen als mensen reizen stel ik C-tijd voorop. Door dat te doen hoopt dit boek een bijdrage te leveren aan het formuleren van nieuwe lijnen in het onderzoek naar reizen in de technologische cultuur: Maar dit boek wil meer zijn dan een theoretische exercitie. Door het spreken in termen van C-tijd centraal te stellen wil het tevens nieuw licht werpen op hedendaagse mobiliteitsproblemen.

\section{Het ontwerpen van tijd}

De manier warop mensen reizen brengt publieke problemen met zich mee. ${ }^{65}$ In de benadering die Leo Jansen met zijn woorbeeld van de langzame auto typeerde, worden deze problemen veroorzaakt doordat meer mensen steeds sneller en steeds verder reizen. In deze redenering is snel- 
heid de oorzaak van uiteenlopende vormen van schaarste en vormt vertraging wellicht de oplossing. We hebben gezien dat dit denken in termen van snel en langzaam terugkeert in heel uiteenlopende vertogen: technisch-deterministische vertogen over de ontwikkeling van vervoerstechnieken, economistische over het keuzegedrag van mensen, en cultureel-utopische vertogen over snelheid als een dominante waarde in de westerse cultuur. De centrale beleidskwestie die in die boek aan de orde wordt gesteld is hoe we kunnen spreken over innovatie zonder daarbij terug te vallen op een vergelijkend perspectief dat uitgat van Btijd en het oude met het nieuwe vergelijkt in termen van gedecontextualiseerde snelheid of traagheid. Anders gezegd, thoe kunnen we de fixatie op snelheid als leidend principe in de beoordeling van innovaties relativeren zonder dit steeds sneller-vertoog in te ruilen voor een steeds langzamer-vertoog? Omdat het zoeken naar 'nieuwe wegen' in dit boek de vorm aanneemt van conceptuele vernieuwingen, heeft het een filosofisch karakter. Zonder kennis van bestaand historisch en empirisch onderzoek naar de praktijken van reizende mensen kan deze filosofische reflectie het echter niet stellen. Juist het zoeken naar wisselwerking tussen filosofische en empirische studie heeft tot nu toe goeddeels ontbroken in het mobiliteirsonderzoek. ${ }^{66}$ Een aantal vragen is daarbij structurerend geweest voor de opzet van het boek.

De eerste vraag die ik aan de orde stel is wat precies het publieke probleem is waarvoor innovatie van het mobiliteitsvertoog een oplossing moeten bieden. In hoofdstuk 2 maak ik duidelijk dat er niet één enkel mobiliteitsprobleem is, maar een veelheid van publieke problemen die geformuleerd worden in uiteenlopende debatten. De proliferatie van probleemdefinities keert terug in de vele oplossingsrichtingen die in de afgelopen decennia zijn onderscheiden. Al deze oplossingen hebben met elkaar gemeen dat het streven naar kortere reistijden niet ter discussie staat.

De tweede vraag die aan de orde komt is hoe het (gedeeltelijk) falen van het mobiliteitsbeleid te verklaren is. In de beantwoording van deze vraag werk ik het onderscheid verder uit tussen een decomtextualiserend en een contextualiserend vergelijkend perspectief, dat in dit hoofdstukt al aan de orde kwam. In het eerste geval maken tijdsbegrippen in de 
B-serie het mogelijk om het reisgedrag van mensen in modellen te reconstrueren. Deze onderzoeksstrategie, zo laat ik in hoofdstuk 2 zien, wordt gevolgd door verkeerskundigen, verkeerseconomen en planologen. Door gebruik te maken van modellen kunnen zij verklaringen geven voor waargenomen gedrag en voorspellingen doen over de aard van. toekomstig gedrag. In hoofdstuk 3 werk $4 k$ het contextualiserende tijdsbegrip dat C-tijd voorop stelt verder uit. Om dat te kunnen doen is het nodig tijd zelf te historiseren (bijvoorbeeld door te refereren aan de geschiedenis van kloktijd en de totstandkoming van de Wereld Standaard Tijd aan het eind van de negentiende eeuw). De geschiedenis wan de firma Thomas Cook \& Son toont dat nieuwe manieren van relzen resulteerden in nieuwe spatio-temporele ordes.

De vraag naar de eigenschappen van een woordenschat die geschilkt is om te vergelijken tussen reispraktijken zonder daarbij tijd uit die praktijken te halen wordt verder uitgewerkt in de hoofdstukken 4,5 en 6 . Daarin onderzoek ik drie heel verschillende praktijken - het autorijden in de Verenigde Staten, het dagelijks in stand houden van het netwerk van vliegroutes door de KLM en het fietsen en autorijden in Nederlandse steden en dorpen. Tijd heeft in deze praktijken een dubbele betekenis, zo blijkt: enerzijds als probleem in de zin dat elke reis het maken, onderhouden en legitimeren van een temporele orde veronderstelt, maar anderzijds als middel om de problemen waarvoor reizigers zich geplaatst zien op te lossen..

In hoofdstuk 7 komt de vraag aan de orde hoe ik de concepten die ik heb ontwikkeld kan inzetten om enerzijds het mobiliteitsdebat in andere termen te kunnen voeren en anderzijds het spreken over innovatie van mobiliteit te kunnen vernieuwen. Zoals eerder opgemerkt, vat ik mobiliteitsproblemen op als ontwerpproblemen. Deze ontwerpproblemen hebben niet een uitsluitend technisch karakter, maar zijn inherent politiek wan aard. Anders gezegd, ze kennen geen voor de hand liggende oplossingen en hebben doorgaans een dilemmakarakter. In de discussie over deze ontwerpdilemma"s staat het tijdsprobleem vaak niet centraal. Zo ziet de staat het als haar taak om mobiliteitsproblemen op te lossen door een innovatieve ordening van de rumte, bijvoorbeeld door een locatiebeleid te voeren waarin bedrijven worden aangemoe- 
digd nieuw te bouwen op locaties die goed met het openbaar vervoer bereikbaar zijn, of door bij de aanleg van nieuwe woonwijken zorg te dragen voor een goede ontsluiting per sneltram of bus. Niet alleen de overheid, maar ook bedrijven, onderzoeksinstellingen en niet-gouvernementele organisaties als de milieubeweging leggen zich daarnaast toe op het ontwerpen van nieuwe vervoersystemen. Dit resulteert in talloze voorstellen tot vernieuwing, variërend van de herinvoering van de zeppelin tot de bouw van automatisch bestuurde bussen. Wat mijn onderzoek onderscheidt van deze andere aanzetten tot vernieuwing is dat het vertrekt vanuit de vooronderstelling dat niet alleen de ruimtelijke inrichting of de vervoersystemen worden ontworpen, maar dat ook tijd als een ontwerpdimensie beschouwd moet worden. Immers, wie anders reist maakt andere tijd. 


\section{2 \\ Gasgeven of afremmen}

In de centrale hal van het Traffic Information Centre (rIC) in Utrecht is op een metershoge videowall een schematische weergave te zien van de snelwegen in het westen, midden en zuiden van Nederland. Blokjes in verschillende kleuren markeren langzaam rijdend en stilstaand verkeer, van groen via geel en oranje naar rood. De Ar 6 van Breda naar Dordrecht en Rotterdam is vanochtend rood. Er is een tankauto met gevaarlijke stoffen gekanteld waardoor een lange file is ontstaan. Op de radio wordt een filemelding uitgezonden. In de loop van de ochtend komen er meer verkeersopstoppingen, uiteindelijk met een totale lengte van vierhonderd kilometer. De verkeersleider van het Tic ziet de situatie gelaten aan. Vanuit de centrale kan men weliswaar constateren dat een file ontstaat, maar niet ingrijpen om het probleem te verlichten, zegt hij. Over het nut van de file-informatie is hij sceptisch. Mensen willen weten dàt er een file staat, maar kiezen zelden alternatieven. Vaak zijn die er ook niet. Vanochtend staat niet alleen de Ar 6 wast, ook de omleidende routes slibben dicht. De meeste mensen zullen te laat op hun werk komen, maar dat is geaccepteerd. Een file is iets wat je overkomt, daar kun je niets aan doen."

De rode blokjes staan voor stilstand, schaarste en stagnatie. De schermen in het verkeerscentrum verbeelden het probleem van de ongewilde traagheid. De belofte van een wrijvingsloze beweging van $A$ naar B, zo vanzelfsprekend in televisiereclames waarin auto's door lege woestijnlandschappen rijden, wordt zeker in het westen van Nederland vaak niet waargemaakt. Maar het TIC is nog in een ander opzicht een metafoor. De positie van de verkeersieider, die wel kan constateren dát er een file staat maar zich realiseert dat hij de rode blokjes niet kan laten verdwijnen lijkt op die van de beleidsmakers bij de overheid 
en andere maatschappelijke actoren. De groeiende mobiliteit en de problemen die daaruit voortvloeien lijkt even onbeheersbaar als het weer.

Wat zou de overheid kunnen doen? Om te beginnen zou men niets kunnen doen en de files laten aangroeien. Het dwingt hen die het te gek wordt alternatieven te zoeken, bijvoorbeeld door de trein te nemen. Met deze Verelendungstbeorie (NRC-Handelsblad) haalde Margreeth de Boer als nieuwe milieuminister zich in 1994 de boosheid op de hals van autorijdend Nederland en er is sindsdien weinig meer van gehoord. ${ }^{2}$ Een tweede oplossing lijkt meer voor de hand liggend: meer wegen aanleggen 'zodat we er allemaal langs kunnen', zoals een Tweede Kamerlid van de VVD het ooit formuleerde. Dit lost het fileprobleen niet blijvend op omdat mensen die nu een argument hebben om alternatieven te zoeken alsnog de auto zullen nemen. Los van deze "latente vraag' zijn er goede redenen om zuinig te zijn op de schaarse ruimte en de kwaliteit van het milieu. Een derde oplossing ligt in het aanbieden van altermatieven, bijwoorbeeld door in de randstad een systeem van 'light-rail' aan te leggen, een mengvorm tussen trein en metro met een hoge frequentie. Maar deze oplossing is duur en an de effectiviteit ervan wordt door verkeerskundigen getwijfeld omdat auto en openbaar vervoer volgens hen geen 'communicerende vaten' zijn. Een vierde benadering tracht de schaarse wegcapaciteit beter te verdelen door automobilisten te laten betalen in de spits. Sommige economen voorspellen dat dit leidt tot minder lange files, maar opeenvolgende ministers ontdekten dat wie automobilisten meer will laten betalen een open zenuw raakt.

Het probleem dat in het Traffic Information Centre wordt gevisualiseerd is complex. In de afgelopen decennia hebben politici, onderzoekers en beleidsmakers zich beziggehouden met het agenderen ervan, het analyseren van de oorzaken en het ontwikkelen van instrumenten om het althans gedeeltelijk op te lossen. Wie in de zomer van zoor rondliep over de "vernieuwingsmarkt" die het ministerie van Verkeer en Waterstaat ter gelegenheid van het congres 'Kiezen voor vernieuwing" had georganiseerd, zag daar vele wegen naar de toekomst": "een veredelde bakfiets voor maar liefst 225 kilo briefkaarten", de MITKA, een driewieler met overkapping en elektrische motor om de fietser het 
'wind-mee' gevoel te geven, en een simulator om de weggebruiker kennis te laten opdoen met flexibele rijstrookindeling. Gevraagd naar hun favoriete vernieuwing noemden congresgangers zweefbanen, langeafstandswindtunels voor fietsers, samenwerking tussen marktpartijen in het goederenvervoer, verrekening van de milieukosten in de prijs per autokilometer, elektronische rijtaakondersteuning en vernieuwing van her belastinggebouw.

Aan wilde nieuwe ideeën geen gebrek, maar wiè de voortgang op 'de weg naar de toekomst' in de afgelopen dertig jaar in ogenschouw neemt, ziet eerder de stroperigheid van het debat en het ontbreken van effectieve oplossingen. Dit innovatietekort, de stagnatie in het denken die door de file wordt gesymboliseerd, vraagt om een nader onderzoek. Het publieke debat verloopt langs voorspelbare lijnen en het beleid loopt keer op keer vast, maar waarom?

Om deze vraag te kumnen beantwoorden geef ik eerst een beknopt overzicht van het mobiliteitsbeleid sinds de jaren zeventig. In de maatschappelijke discussie rond het Rapport aan de Club van Rome (r972) werd de groei van de mobiliteit meer en meer als een schaarsteprobleem beschouwd: schaarste aan verkeersveiligheid, aan ruimte, aan schone lucht en steeds vaker schaarste aan mobiliteit zelf, althans voor hen die in de file belandden. ${ }^{5}$ Het inzicht won terrein dat deze schaarste niet kon worden opgelost door eenvoudig meer wegen aan te leggen. Vernieuwing kreeg de vorm van wat in het beleidsjargon 'shifts' werden genoemd: van de auto naar het openbaar vervoer en de fiets ("modal shift'), van fysiek vervoer naar elektronisch vervoer (telewerken), van spitskilometers naar dalkilometers, van C-locaties langs de snelweg naar A-locaties die goed bereikbaar zijn per openbaar vervoer, van het ene verplaatsingsgedrag naar het andere. Zowel in het ontwerpen van deze innovatieve 'shifts' als in het verklaren van het succes en falen ervan spelen vergelijkende perspectieven zoals die worden ontwikkeld in verkeerskundige, verwoerseconomische en vervoersplanologische modellen, een centrale rol. Uit het exemplarische voorbeeld van de hypothese van de constante reistijd wordt duidelijk dat deze stijl wan redeneren, waarin B-tijd een sine qua non vormt, een winst- én verliesrekening heeft. 


\section{De smalle marges van de moblititelispolitiek}

Tot 1970 werd de groei van de (auto) mobiliteit niet als een complex, bijna onoplosbaar probleem gezien. Integendeiel, mobiliteit vormde de hoeksteen van een breed gedeelde droom van een samenleving warin de materiële voorspoed zonder grenzen zou zijn. In de jaren vijftig en zestig verruilden steeds meer mensen hun fiets, brommer of scooter voor een auto. Aan de eisen die het snel uitdijende wagenpark stelde aan de infrastructuur werd door de overheid in grote lijnen tegemoet gekomen. Wegen werden verhard, verbreed en verbeterd. In de opeenvolgende Rijkswegenplannen van de overheid werd de lengte van nieuw aan te leggen wegen eenvoudig afgeleid uit de prognoses over de groei van het autoverkeer. Weliswar ontstonden steeds vaker files, maar die waren meestal incidenteel, afgezien van notoire knooppunten als bij Oudenrijn.? Steden werden opengelegd voor het autoverkeer dat tot in het centrum moest kunnen doordringen. Voorbeelden van ingrijpende stedelijke aanpassingen aan het autoverkeer in de jaren zestig zijn de Gatharijnesingel in Utrecht en de verbreding van de Weesperstraat in Amsterdam. In diezelfde tijd werd parkeerruimte gecreëerd op gedempte grachten. Meer en meer ging de auto het straatbeeld beheersen. ${ }^{8}$

In 1970 verscheen de 'toekomstprojectie' TP 2000 van het Ministerie van Verkeer en Waterstaat. ${ }^{9}$ De auteurs van de notitie verwachtten een toename van het aantal auto's tot 7,5 miljoen in 2000 bij een inwonertal van achttien miljoen. Het autobezit zou verdriedubbelen. ${ }^{\text {Io }}$ Voor zover deze groei tot problemen zou leiden, konden die volgens het ministerie langs technologische weg worden opgelost. Toch waren het verkenningen als deze die met name progressieve politici de ogen openden. Zo kwalificeerde Ed van Thijn, destijds $\mathbb{K}$ amerlid voor de PvdA, de toekomstverkenning TP 2000 als een 'gekwantificeerd schrikbeeld'. Van Thijn stond niet alleen in zijn reactie. In de jaren na het verschijnen van TP 2000 kreeg de politiek meer oog voor zaken als luchtvervuling door uitlaatgassen, stijgend brandstofverbruik en verspilling van grondstoffen. Die opstelling werd bij het aantreden van het eerste kabinet Den Uyl in 1973 uitgangspunt van het verkeersbeleid. De mobiliteitsbehoefte 
diende te worden teruggedrongen, de positie van het openbaar vervoer verbeterd en de voorzieningen woor langzamere vervoermiddelen als de fiets uitgebreid. In zijn nieuwjaarstoespraak van 1973 noemde directeurgeneraal van Rijkswaterstaat Van der Kerk als belangrijkste beleidsdoelen 'beperking van de groei van de verplaatsingsbehoefte, selectief autogebruik en stimulering van het gebruik van het openbaar verwoer in stedeligke gebieden?

\section{Reductie van de groel}

In de jaren die volgden werd het beleid wan de rijksoverheid gekenmerkt door een zekere tweeslachtigheid. Enerzijds werd het wegennet verder uitgebreid, groeiden het totale Nederlandse wagenpark en het totaal antal autokilometers en nam het aandeel van het openbaar verwoer in de totale vervoersprestatie geleidelijk af. De kosten van het autorijden namen in reële termen niet toe, waardoor een eigen auto voor een steeds grotere groep mensen binnen bereik kwam. Anderzijds slaagde de overheid erin een deel van de nadelige gevolgen van de groei van het autogebruik te beperken. Het aantal verkeersslachtoffers daalde. Motoren werden minder vervuilend en het brandstofverbruik per kilometer daalde licht. De alomtegerwwoordigheid van de auto in de stad werd verminderd door fysieke beperkingen en hogere parkeertarieven.

De tweede olieboycot in 1979 leidde tot een diepe economische crisis in het begin van de jaren tachtig. Hierdoot steeg de automobiliteit minder snel dan voorheen en werd gemaskeerd dat het beleid gericht op reductie volstrekt ondoelmatig was. Dat bleek des te duidelijker toen de groei van het autoverkeer halverwege de jaren tachtig weer sterk doorzette: In $\mathrm{r} 986$ concludeerde het onderzoeksbureau McKinsey in het rapport Afrekenen met files dat het aantal files drastisch zou moeten verminderen om de concurrentiekracht in het goederenvervoer te kunnen behouden. Maar omdat het wagenpark bleef groeien, verwachtte het bureau dat een vermindering van de files tot een acceptabel niveau niet mogelijk zou zijn. Als oplossing suggereerde het bureau onder meer uitbreiding van het wegennet. Het McKinsey-rapport had in het centrumliberale politieke klimaat tot gevolg dat het accent in de beleidsvorming kwain te liggen op het minimaliseren van de congestie. Reductie van de 
automobiliteit werd wooral vanuit deze doelstelling noodzakelijk geacht. Als instrument werd onder andere gekozen voor variabilisatie van de kosten van het autorijden (verlaging van de Motorijtuigenbelasting, verhoging van de brandstofaccijns). De benodigde verbeteringen in de infrastructuur werden uit de opbrengsten van deze maatregelen bekostigd. Verder werd begonnen met onderzoek naar vormen van 'road pricing" (rekeningrijden).

In november 1988 verscheen het eerste deel van het Tweede Structuurschema Verkeer en Vervoer (svv II), opvolger van het eerste svv uit x 976. De nota behandelde de roll van de auto en het openbaar vervoer; de betekenis van het goederenvervoer en het zakelijk verkeer, de rol van langzaam verkeer zoals de fiets, het recreatieverkeer, de infrastructuur (wegen, waterwegen en spoorlijnen) en de bescherming van het milieu. De door het ministerie van Verkeer en Waterstaat ontwikkelde beleidstrajecten zijn gegroepeerd in vier 'luiken': verbetering van de bereikbaarheid, geleiding van de mobiliteit, verbetering van de leefbaarheid en een reeks ondersteunende maatregelen. Hoewel thet belang van goed openbaar vervoer werd benadrukt, stelde de regering in het regeringsvoornemen van het SVV II meer geld beschikbaar voor wegenaanleg dan voor verbetering van trein, bus, tram en metro. De nota wloeide in dat opzicht voort uit een beleidsvisie waarin de groei van het autoverkeer (weer) werd geaccepteerd. Op het moment dat de regering de nota naar de Tweede Kamer stuurde, werd de publieke opinie sterk beïnvloed door alarmerende rapporten over de gevolgen van de zure regen. Bovendien waren de resultaten uitgelekt van een onderzoek door het Rijksinstituut voor Volksgezondheid en Milieu (RrVM) naar de toestand van het Nederlandse milieu met de titel Zorgen voor Morgen. De Koningin wees in haar traditionele kersttoespraak op de mogelijkheid dat het leven op aarde "langzaam sterft". Uit het niets, zo leek het, was het milieu opnieuw het gesprek van de dag.

De hernieuwde algehele bezorgdheid om het milieu beinvloedde de beleidsdiscussies over verkeer en vervoer. De politieke wil om de uitstoot van verzurende stoffen door het verkeer te verminderen vertaalde zich in zogenaamde 'reductiedoelstellingen". De vvD was de enige par tij die zich niet schaarde achter de noodzaak om maatregelen te nemen 
waarmee de groei van de automobiliteit kon worden teruggedrongen. Toen de partij zich in het voorjaar van 1989 tegen de afschaffing van de fiscale aftrek van reiskosten opstelde, bood het tweede kabinet Lubbers haar ontslag aan. Het was het eerste kabinet in de wereld dat struikelde over een milieumaatregel.. In het derde kabinet Lubbers, een coalitie tussen christen-democraten en sociaal-democraten, werd het svV Ir goeddeels herschreven. Het ideaal van een duurzame samenleving werd, veel sterker dan in het Regeringswoornemen van het svv II uit r988, gezien als maatstaf voor het te voeren beleid. ${ }^{3}$ De overheid zette sterker in op de reductie van autogebruik en verbetering van het openbaar vervoer, ondermeer met plannen als Rail 2 i en ov maal 2 . De verwachtte groei van zeventig procent van het aantal autokilometers ten opzichte van 1986 zou middels een breed scala aan maatregelen teruggedrongen moeten worden tot vijfendertig procent. Het reductiepercentage van vijfendertig procent zou bijna een decennium lang de toetssteen blijven van het mobiliteitsbeleid.

De nieuwe minister van Verkeer en Waterstaat, Hanja Maij-Weggen (CDA), zag zich gesteld voor de taak een beleid te ontwikkelen dat gericht was op reductie van de groei van de automobiliteit. In het parlement werd aan de ene kant aangedrongen op maatregelen, maar aan de andere kant deinsde een meerderheid terug voor de concretisering van die maatregelen. Helemaal onbegrijpelijk was die ambivalentie niet. Het "generieke volumebeleid", zoals het streven de automobiliteit te reduceren in jargon heette, stuitte op grote maatschappelijke weerstand, ondanks het feit dat 'het tij nocit zo gunstig was om de automobiliteit terug te dringen", zoals Maij-Weggen het optimistisch uitdrukte. Maar al snell verliep het getij. Aan het begin van de jaren negentig maakte de apocalyptische grondtoon in het mobiliteitsdebat plaats voor een andere: als voornaamste probleem gold niet langer de verslechtering van het milieu en de leefbaarheid, maar de steeds langer wordende files. Aan de bouw van nieuwe wegen viel niet te ontkomen, meenden sommigen. De auto werd niet langer gezien als een verzuurder en televisiespotjes warin de automobilist werd verteld dat "de auto best een dagje zonder u kan" verdwenen van het scherm. Autorijden werd meer en meer gezien als een onmisbaar onderdeel van een moderne, pseudo-nomadische levensstijl. 
De hernieuwde nadruk op files als grootste probleem bracht het "rekeningrijden" terug op de politieke agenda. Het instrument was van die agenda verdwenen nadat het even een rol had gespeeld in de politieke discussie rond het svv in in $x 989$ en 1990 . Aanvankelijk als een manier om 'stedelijke congestie' in de randstad terug te dringen, later als een middel om de automobiliteit in het hele land te verminderen, was invoering nooit serieus overwogen. Geconfronteerd met verhalen over almaar aangroeiende files, riep een Kamermeerderheid in 1994 minister van Verkeer en Waterstaat Annemarie Jorritsma (VvD) op tot een streng invoeringsschema te komen. Zelf had ze zich als liberaal Kamerlid altijd verzet tegen het rekeningrijden, maar als minister in het eerste Paarse kabinet, waarvan behalve de vvD ook D66 en de PvdA deel uitmaakten, zag ze zich gedwongen het instrument serieus te nemen. Keer op keer benadrukte ze het belang van 'draagvlak' voor het onpopulaire prijsbeleid, dat naast rekeningrijden voorzag in een strenger parkeerbeleid en hogere benzineaccijnzen Op hetzelfde moment werkte ze aan het decentraliseren van bestuurlijke verantwoordelijkheden van de rijksoverheid naar lagere overheden zoals provincies en gemeenten. Het morele appèl aan de burger om de auto minder te gebruiken in het belang van het milieu, zo karakteristiek voor het debat rond 1990 , was zo goed als verdwenen. In een tussentijdse beleidsnota, Samen Werken Aan Bereikbaarheid (SWAB), kondigde ze in 1996 een nieuwe benadering van het mobiliteitsprobleem aan waarin 'marktwerking' centraal zou staan. Het handelen van mensen en bedrijven, zo argumenteerde ze, diende te worden begrepen vanuit een economische rationaliteit en het verkeersen vervoerbeleid zou zich naar deze rationaliteit moeten voegen. ${ }^{14}$

Al voor het SVV II werd veel aandacht gegeven aan technologische oplossingen, zoals de katalysator voor benzineauto's die in $1988 \mathrm{ver}-$ plicht werd. De teleurstellende resultaten van de bewustwordingscampagnes uit het begin van de jaren negentig accentueerde volgens velen nog eens het belang van dit 'technologiespoor'. Als mensen er niet van konden worden overtuigd dat het beter voor het milieu was om minder auto te rijden, dan moest technologie de klus maar klaren. Een ander nieuw accent in de discussie was de aandacht voor de ruimtelijke gevolgen van de groeiende mobiliteit. De koppeling tussen snelle trans- 
portmiddelen en ruimtebeslag $\mathrm{kwam}$ scherp naar voren tijdens de verhitte debatten in 1995 en 1996 rond de keuze van een tracé voor de nieuwe Hogesnelheidslijn van Amsterdam naar Brussel en Parijs door het Groene Hart en de aanleg van een vijfde baan op de luchthaven Schiphol. Ook hier moest technologie politieke meningsverschillen overbruggen. In een aantrekkende economie was het niet moeilik het geld te vinden voor een tunnel onder de weilanden tussen Amsterdam en Rotterdam, een gematerialiseerd compromis dat bijna een miljard gulden zou gaan kosten.

\section{Mobiliteit mag}

In de herfst van 1997 startte het ministerie van Verkeer en Waterstaat met de voorbereidingen voor een nieuwe nota die in 2000 het Tweede Structuurschema moest vervangen. Anders dan in 1990 zag de rijksoverheid zichzelf niet langer als centrale actor; het rijk wilde geen monopolie meer op het 'probleemeigenaarschap'. 'Tijdens een drietal voorbereidende conferenties formuleerde het ministerie een nieuwe rol voor zichzelf: het creèren van 'win-win situaties' voor uiteenlopende actoren (markt, overheid, burgers), sectoren (verkeer en vervoer, economie, ruimtelijke ordening, milieu) en vervoersmiddelen (weg, water, lucht, ondergrond en telematica). 'Interactiviteit' was het toverwoord in de beleidsvoorbereiding. Thema's die in deze fase op de agenda stonden: de relaties tussen verschillende overheidslagen, marktwerking en publiek-private samenwerking, integratie van verkeersbeleid en ruimtelijke ordening, technologische ontwikkelingen, verkeersveiligheid en ketenmobiliteit. ${ }^{5}$ In september 1998 verscheen een Contourennota waarin het accent opnieuw lag op een nieuwe, minder sturende rol van de centrale overheid. Minister van Verkeer en Waterstaat in het tweede Paarse kabinet, de sociaal-democraat Tineke Netelenbos, toonde zich niet tevreden over de Contourennota en herschreef die ingrijpend. In een nieuw document werden de pijlers van wat het nieuwe beleid zou worden omschreven als de 'b-werkwoorden': benutten, beprijzen, bouwen en bestuur op maat. Deze 'kwartetvisie' zou het beleidsvormingsproces in de jaren die volgden blijwen domineren. De grondgedachte was, dat de bouw van nieuwe infrastructuur alleen wenselijk is nadat 


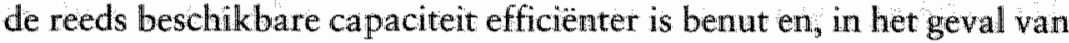
voorturende hoge vraag, is 'beprijsd'.

In februari 1999 ging de Perspectievennota naar het parlement. Aan het rekeningrijden als een manier om de groeiende schaarste op de weg tegen te gaan werd een centrale rol gegeven. De meeste politicke partijen stemden daarmee in - tijdens de formatiebesprekingen in 1998 was daarover een akkoord bereikt -, maar tegelijkertijd bleef de publieke opinie gekant tegen dit beleidsinstrument. De spanning tussen ondersteuning op een theoretisch niveau en kritiek in de praktijk zou blijvend blijken te zijn. Gesteund door de berichtgeving in De Telegraaf begon de ANw $B$ een landelijke protestactie tegen het rekeningrijden die in de zomer van 1999 escaleerde. Netelenbos liet het aanvankelijke plan vallen om tientallen tolpoorten te plaatsen in de randstad. In plaats daarvan stelde ze voor een "proef" te houden om aan te tonen dat rekeningrijden de files inderdaad zou verminderen. Aan de vier grote steden werd gevraagd om deel te nemen aan de proef, maar zij weigerden. Pas na lange onderhandelingen gingen in de lente van 2000 Amsterdam, Rotterdam en Den Haag akkoord met het experiment waarbij ze als tegenprestatie geld van het rijk zouden ontvangen voor uitbreiding van de lokale infrastructuur. Alleen Utrecht weigerde deel te nemen. ${ }^{\text {*6 }}$

In oktober 2000 werd onder de titel 'Van A naar Beter' het eerste Nationaal Verkeers - en Vervoersplan (NVvp) gepresenteerd. De belangrijkste verandering ten opzichte wan het Tweede Structuurschema was dat een min of meer autonome groei van de (auto)mobiliteit nu was geaccepteerd. Tien jaar van beleid om de groei van het autoverkeer af te remmen waren mislukt, concludeerde de vrom-raad al in I999 in 'Mobiliteit met beleid' en die conclusie werd impliciet door de regering overgenomen. ${ }^{17}$ De behoefte aan autokilometers moest worden beschouwd als legitiem en begrijpelijk, maar de automobilist zou well moeten betalen voor de negatieve gevolgen van het autogebruik (congestic, verkeersonveiligheid en milieuschade). Wie meer rijdt, betaalt ook meer, luidde het centralle principe van het nieuwe plan. Om dit te bereiken zou een systeem van "variabele kilometerheffing' ingevoerd moeten worden. In dit systeem zou elke auto een apparaat hebben dat niet alleen het aantal gereden kilometers vastlegt, maar ook plaats en tijdstip. Op tijden 
en plaatsen van verwachte congestie zouden automobilisten hoger aangesllagen kunnen worden, wat tot een afname van de files zou moeten leiden. De vaste wegenbelasting zou op termijn helemaal kunnen worden afgeschaft. Deze variabilisatie mocht het autorijden niet duurder maken voor de gemiddelde automobilist. Voor personenauto's, luidde de verwachting, zou het nog tot zoro duren voor kilometerheffing kon worden ingevoerd.

Een verdere verschuiving van gedragsverandering naar oplossingen langs het 'technologiespoor' was duidelijk in een aantal wan de woorgestelde beleidsontwikkelingen in het NVVP. Maar ook binnen dit technologische perspectief veranderde het accent. Waar toekomstdenkers ooit graag fantaseerden over futuristisch ogende verwoermiddelen, droomt men nu van een efficiëntere besturing en geleiding van het hele verkeers-en vervoersysteem. Omdat mensen meer zullen reizen en het drukker wordt op de weg, het spoor en in de Jucht, zullen individuele verkeersdeelnemers niet langer zelf het stuur in handen hebben, aldus een door velen aangehangen toekomstbeeld. 'Slimme' technologie zal de vervoersbewegingen controleren. ${ }^{18}$ Met Automatische Voertuig Geleiding (AvG) kunnen auto's na het invoegen op de snelweg elektronisch aan elkaar gekoppeld worden. Omdat ze vlak achter elkaar rijden, is minder wegcapaciteit nodig ${ }^{\text {ry }}$ Andere voorbeelden die in het NVvP genoemd worden zijn Dynamische Route Informatie Panelen (zogenaamde okip's) die de weggebruiker informeren over eventuele files en andere verstoringen, Dynamische Parkeerreserveringssystemen en de Intelligente Snelheids Adapter (ISA) die automatisch de rijsnellheid terugbrengen tot het lokaal geldende maximum (bijvoorbeeld vijftig bij her binnenrijden van de bebouwde kom).

Het NVVP stelt innovatie gelijk aan technologische innovatie en technologische innovatie wordt vooral opgevat als "slimme" toepassingen van Informatie en Communicatie Technologie (ICT). Als het reisgedrag van mensen dan nilet makbar is - de ervaring van dertig jaar mobiliteitsbeleid -, valt het misschien bij te sturen. Waar de overheid de burger enerzijds als kritische consument beschouwt die niet langer betutteld dient te worden, worden anderzijds nieuwe instrumenten ontwikkeld 


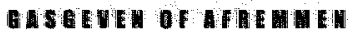

\begin{tabular}{|c|c|c|}
\hline $19 \%$ & Taekomstprojectie TP 2000 & Ministerie van Verkeer en Whaterstalat \\
\hline 1976: & Auttogeboruksbeperking & Socialal en Cultureel Planburau \\
\hline 1977 & Structuurschema Verkeer en Vervoer (SW) & Ministerie van Verkeer en Whaterstat \\
\hline 1986 & Afrekethen met files & Mokinsey \\
\hline 1988 & $\begin{array}{l}\text { Tweede Structuuschema Verkeer en Vervoer (SWW II) } \\
\text { Deet A: Beteidswoornemen }\end{array}$ & Ministerie van Verkeer en Watersitat \\
\hline 1990 & $\begin{array}{l}\text { Tweede Stiructuirschema Verkeer en Verwoer (SW II) } \\
\text { Deel D De regeringsbesilissing }\end{array}$ & Ministerie van Werkeer en Waterstaat \\
\hline 1996 & Samen Werken Alan Bereikbaarheid (SWAB) & Ministerie van Verkeer en Waterstaat \\
\hline 1998 & Contoureninota: & Ministerie van Verkeer en Whaterstgat \\
\hline 1999 & Perspectievennota & Ministerue van Verkeer en Waterstat \\
\hline 1999 & Mobiliteit met beleid & WROM-rat \\
\hline 2001 & $\begin{array}{l}\text { Van A naar Beter. Nationaal Verkeers- en Veroersplan: } \\
\text { Kabinetsstandpunt en Resultaten Inspralak en Adwies (WWP) }\end{array}$ & Ministerie van Verkeer en Waterstat \\
\hline 2001 & Mobihniles & Roel Pleper \\
\hline
\end{tabular}

Figuer 2.1: Een overzicht van de in dit hoofdstuk genoemde nota's en rapporten.

om de ongewilde effecten van die vrijheid te beperken. Het sociaal dilemma, het uit elkaar lopen van individuele belangen op korte termijn en de collectieve nadelen daarvan op zowel korte als langere termijn, kan nu worden opgelost dankzij rcT, zo hoopt het ministerie. ${ }^{21}$ Aan het begin wan de eenentwintigste eeuw worden de wegen naar de toekomst beschreven in een vocabulaire waarin markt en (informatie)technologie centraal staan.

\section{Het plan-Pieper}

Nog een keer kwam het rekeningrijden terug op de politieke agenda en zoals al vaker was de onzekerheid over het moment van invoering de aanleiding. Minister Netelenbos was ervan overtuigd dat het invoeren van een effectief systeem van kilometerheffing pas in 20 ro mogelijk zou zijn. In de tussentijd moesten de "traditionele" tolpoorten het werk doen. ${ }^{22}$ Waarom ze deze positie verliet werd destijds niet helemaal duidelijk. Een mogelijke verklaring is dat ze, geconfronteerd met het vooruitzicht het onpopulaire tolpoorten-dossier te moeten verdedigen tij- 
dens de aanloop naar de verkiezingen voor de Tweede Kamer in 2002, besloot een uitweg te creèren. ${ }^{23}$ In maart 200 x vroeg het ministerie wan Verkeer en Waterstaat aan internetondernemer en deeltijdhoogleraar Roel Pieper (ex-Philips) om de technische haalbaarheid van een systeem van gedifferentieerde kilometerheffing te onderzoeken en te bekijken of een proef met dit systeem al in 2003 kon beginnen.

Na een onderzoek van drie weken presenteerde Pieper het rapport 'MobiMiles'. Hij concludeerde dat de invoering van een landelijk systeem van kilometerheffing mogelijk moest zijn binnen twee tot drie jaar. Elke auto zou cen zogenaamde 'trusted wallet' krïgen, een computerchip die aan de hand van gegevens over de eigen positie kan vaststellen op welk wegvaktype wordt gereden om vervolgens de kosten te berekenen op basis van het tarief voor die tijd en plaats. ${ }^{34}$ Door het wegennet te verdelen in vijf categorieën, variërend van rustig tot druk, zou het niet nodig zijn een koppeling te maken tussen de gebruiker en de feitelijke geografie. Betaling middels een 'elektronische portemonnee', smartcard of siM-card zou plaats moeten vinden op basis van de wegcategorie en het tijdstip. Uit de betalingsgegevens zou niet af te leiden zijn waar de automobilist zich op een bepaald moment bevond, zodat diens privacy was gewaarborgd. Dit uitgangspunt elimineerde een belangrijk sociaal obstakel en politiek tegenargument. De belofte van een ideaal systeem dat op korte termijn beschikbaar zou zijn gaf alle partijen een beslissend argument om het nu 'verouderde' systeem van tolpoorten te verlaten.

Techniek en politiek liepen opnieuw uit de pas. Nu kilometerheffing genoeg zichtbaar was aan de horizon en het draagvlak voor een systeem. wan kilometerheffing duidelijk groter was dan voor rekeningrijden, werd afgezien van het rekeningrijden, ook al omdat het een technologie betrof die na lange jaren van onderhandelingen, experimenten en proeven nog niet helemaal klaar was om geimplementeerd te worden. Piepers inschatting dat de 'trusted wallets' vanaf 2006 op landelijke schaal in werking konden treden, projecteerde de technologie (weer) ver genoeg in de toekomst om het debat zonder al te veel gezichtsverlies op te schorten tot na de verkiezingen van 2002.

Een paar dagen na de presentatie van het rapport van Pieper kwamen de actoren die zich het felst hadden verzet tegen het rekeningrijden 
en zich achter het alternatief van een gedifferentieerde kilometerheffing hadden opgesteld - de ANWB en de liberalen in het parlement-terug op hun standpunt. Een gedifferentieerde kilometerheffing was (nog) niet aan de orde. In plaats daarvan moest een "vlakke heffing', waarbij alle auto's per gereden kilometer zouden betalen, de bestaande vaste lasten vervangen. De sociaal-democraten accepteerden deze wijziging, zelfs als die betekende dat een van de centrale pijlers in het Nvvp - het 'beprijzen' - daardoor in gevaar zou komen.

Hoewel achter de schermen hard gewerkt werd aan de introductie van de kilometerheffing, werd tot aan de verkiezingen in mei 2002 in de pers weinig meer vernomen van het beleidsinstrument. ${ }^{25}$ Tijdens de formatiebesprekingen in de zomer van dat jaar besloten CDA, vvD en de nieuwe partij Lijst Pim Fortuyn (LPF) om tijdens de regeerperiode van dit nieuwe centrum-rechtse kabinet geen voorstellen tot inwoering van kilometerheffing te doen, ook al hadden alle partijen behalve de LPF zich in hun verkiezingsprogramma's voorgenomen de heffing in te voeren. Ook andere dogma's uit het tijdperk van het Tweede Structuurschema Verkeer en Vervoer werden overboord gezet: het 'kwartje van Kok' (in r.99 $\mathrm{x}$ ingevoerd als extra accijns om de mobiliteitsgroei te reduceren) moest volgens de LPF teruggegeven worden aan de automobilist en de uitbreiding van bestaande en bouw van nieuwe wegen werd niet langer als minst wenselijke beleidsoptie gezien. $N$ a de slogans 'De auto kan

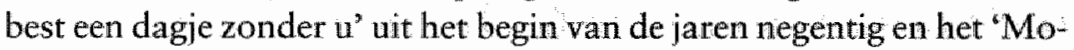
biliteit mag' uit het NVvp stelde LPF-minister Roelf de Boer in een interview vast dat 'je in nota's niet kunt rijden, op asfalt wel'. ${ }^{26}$

\section{Mobiliteit als sociaal dilemma}

In 1976 publiceerde het Sociaal en Cultureel Planbureau (SCP) in opdracht van de regering een onderzoek naar de manieren waarop het autogebruik beperkt zou kunnen worden en de maatschappelijk aanvaarding van een beleid met dat doel. ${ }^{27}$ Het SCP-rapport onderscheidde drie groepen maatregelen die respectievelijk gericht zijn op vermindering van het aantal autokilometers, vermindering van de nadelige effecten van 
het autogebruik en een 'allgemene attitudewijziging". In de eerste groep vielen heffingen, financiële en fiscale maatregelen, stedenbouwkundige maatregelen, steun aan alternatieve vervoersvormen als de fiets en het openbaar vervoer en een ander gebruik van de auto (huurauto en carpooling). Vermindering van nadelige effecten hoopte het $\mathrm{SCP}$ te bereiken door het autovrij of "autoluw' maken van binnensteden, het instellen van autovrije dagen, technische verbeteringen aan de auto en een wijziging wan verkeersregels in het voordeel van langzamere dan well zwakkere verkeersdeelnemers. Tenslotte dacht het SCP aan mentaliteitsbeinvloeding door voorlichting.

In haar conclusies stelde het scP dat het verbeteren van het openbaar vervoer zonder bifzondere belemmeringen voor het autogebruik een geringe invloed heeft op de omvang en plaats van het autogebruik. Beinvloeding van het woon-werkverkeer per auto zall tot effect hebben dat het verkeer gelijkmatiger over de dag verspreid wordt. De verkeersafname zal ertoe leiden dat de infrastructuur beter benut wordt. Het verhogen van de vaste kosten van de auto heeft enig effect, zowel op het autobezit als het autogebruik. Het verhogen van de variabele kosten heeft meer effect, maar de prijsverhoging treft vooral de minst draagkrachtigen. De problemen die het 'autosysteem" als zodanig veroorzaakt, veranderden wolgens het SCP niet door technische verbeteringen aan de auto. En: autovrije (zon)dagen hebben slechts een beperkt effect op de omvang van het autogebruik.

Herlezing van het scp-rapport is interessant. Her laat zien dat er in de kwart eeuw na het verschijnen ervan weinig veranderd is in de opsomming van de problemen die het verkeer veroorzaakt en de gesuggereerde beleidsopties om die problemen aan te pakken. Anders gezegd, het politieke en matschap pelijke debat over mobiliteit kent meer constanten dan vaak wordt aangenomen. Het rapport noemt de groei van het autopark als hoofdoorzaak van het sterk gestegen totaal aantal autokilometers. Deze groei bleef niet zonder consequenties, aldus het SCP. Het toenemend autobezit en -gebruik leidden tot meer files, ruimtebeslag als gevolg van de aanleg van wegen en parkeerruimte, luchtverontreiniging, bodemverontreiniging door lood, geluidshinder, energie- en metaalverbruik, een stijgend aantal verkeersslachtoffers en cen ach- 
terstand in mobiliteit voor mensen die niet over een auto beschikken. Het zijn, met een enkele variatie, de problemen van vandaag. ${ }^{28}$ Deze constatering is ook als vraag te formuleren: waarom ts het sinds 1976 niet gelukt om de problemen op te lossen?

Sociaal-psychologen verklaren de hardnekkigheid van mobiliteitsproblemen uit het feit dat zij het karakter hebben van een sociaal dilemma. ${ }^{29}$ In zo'n dilemma bestaat er een spanning tussen de voordelen die individuen op korte termijn behalen en de nadelen voor de gemeenschap die uit hun handelen voortvloeien. Files rond grote steden vormen een illustratie. Elke afzonderlijke automobilist verwacht sneller thuis te zijn door met auto te gaan, maar samen vormen ze een verkeersopstopping waardoor de reis voor allen juist langer duurt. Tegenover de 'internaliteiten" (voordelen voor de automobilist zoals flexibiliteit, comfort en privacy) staan 'externaliteiten', kosten die niet of maar gedeeltelijk voor rekening van de automobilist komen; dit zijn bijvoorbeell verkeersonveiligheid, de uitstoot van het broeikasgas kooldioxide of de versnippering van de ruimte door wegenaanleg.

Het vinden van een uitweg uit dit soort dilemma's, het zoeken van. een evemwicht tussen individuele en collectieve belangen, behoort traditiegetrouw tot de taken van de owerheid. In het Nederlandse politieke debat rond personenmobiliteit is de omgang met sociale dillemma's dan ook een kernthema. Politici zien zich enerzijds door hun kiezers voor de taak gesteld het autogebruik mogelijk te maken, bijvoorbeeld door wegen en andere infrastructuur aan te leggen. Anderzijds beschouwen zij het als hun verantwoordelijkheid de maatschappelijke nadelen en kosten van het autoverkeer te verminderen. Het mobiliteitsdebat heeft daarom op het eerste gezicht een gefragmenteerd en vaak tegenstrijdig karakter. De krijtlijnen waarbinnen de politieke discussie over mobiliteit zich afspeelt mogen dan vastliggen, de inhoud van het debat blijkt woortdurend te veranderen. Problemen stijgen en clalen op de politieke agenda. Maatschappelijke groeperingen en belangenverenigingen slagen er meer of minder in hun standpunt onder de aandacht van politici te brengen. In de pers worden wooral de wisselende aspecten van een probleem geaccentueerd. De oplossingen die door de politiek worden aangedragen, veranderen met de kleur van elk nieuw kabinet. 


\section{Verbaallinen en vertoogcoalities}

Mobiliteitsproblemen mogen dan vaak de structuur hebben van een sociaal dilemma, daarmee is niet duidelijk waarom het zo lastig is om uit die dilemma's te breken. Een artikel in het weekblad Elsevier geeft een antwoord. Het onvermogen sociale dilemma's rond mobiliteit op te lossen komt voort uit het onvermogen het rekeningrijden in te voeren en dat valt volgens het blad weer te verklaren uit het feit dat "uitsluitend vrouwelijke ministers zich hiervoor uitsloofden". "Het archetype van de filerijder is een man. De heren in het verkeer zagen echter geen heil in de plannen van de opeenvolgende verkeersministers. Hun instinct dicteerde: 'Laat zo'n vrouw zich in vredesnaam niet met ónze file bemoeien, want dan wordt het nóg erger." "3० Wie niet tevreden is met een verklaring die het moet hebben van begrippen als 'instinct' en 'vrouwelijkheid" en een gelaagder antwoord zoekt, kan te rade gaan bij de beleidswetenschap.

Recente sociaal-wetenschappelijke studies hebben beargumenteerd dat wat in de politiek als een probleem wordt beschouwd niet vooraf gegeven is, maat het resultaat van sociale processen. Volgens Gusfield (rg8i) ontwikkeldle rijden onder invloed zich in Amerika pas tot een publiek probleem nadat het machtige 'probleemeigenaars' had gekregen. Deze actoren slaagden erin hun definitie van het probleem op te leggen aan anderen en zo een politiek momentum te creëren. In de definitie van een probleem, zegt Gusfield, worden politieke tegenstellingen gemaskeerd of juist benadrukt. Een keuze voor een probleemdefinitie impliceert dat sommige aspecten van de maatschappelijke werkelijkheid wel en andere niet ter discussie staan. ${ }^{3 x}$ Processen van probleemdefinitie vinden plaats binnen wat wel als een 'vertoog' wordt omschreven. Hajer (1995) vat in navolging van Foucault, Billig en Harré de term vertoog op als een verzameling ideeën, concepten en categoriseringen die gerelateerd zijn aan de sociale en institutionele praktijken waarin ze worden geproduceerd ${ }^{32}$ Personenmobiliteit is, net als de zure regen waarover Hajers boek gaat, een voorbeeld wan een 'interdiscursief' vraagstuk dat alleen kan worden begrepen vanuit een verzameling van vertogen met elk een eigen sociale en wetenschappelijke context. ${ }^{33}$ In de praktijken waarbinnen mobiliteit wordt bediscussieerd, gelden verschillende pers- 
pectieven, kennisclaims en belangenafwegingen. Zo verschilt het vertoog over mobiliteit binnen de milieubeweging sterk van het mobiliteitsvertoog in de wereld van de auto-industrie: bomen en asfalt gaan zelden samen.

Aan de hand van twee begrippen - "verhallinnen' en 'vertoogcoalities" - laat Hajer zien hoe tussen ongelijksoortige en soms zelfs tegengestelde vertogen dwarsverbanden kunnen ontstaan. Verhaallijnen zijn marratieve visies op de sociale werkelijkheid die actoren een symbolisch ijkpunt verschaffen waarmee ze tot een gedeeld begrip komen. Ze reduceren de discursieve complexiteit van een probleem, ze kunnen een welhaast ritueel karakter krijgen en ze verschaffen verschillende actoren de mogelijk heid buiten hun eigen competentie te treden. De "auto als verzuurder' is een voorbeeld van een verhaallijn waarin de negatieve milheueffecten van het autoverkeer voor de leefbaarheid samenkomen; de 'auto als melkkoe' gaat over (te) hoge wegenbelasting en nog altijd onopgeloste knelpunten in het rijkswegennet.

Het begrip vertoogcoalities gebruikt Hajer om aan te geven dat uiteenlopende vertogen verknoopt kunnen raken. Ze worden dan bijeen gehouden door het 'discursieve cement' van de verhaallijnen. Vertoogcoalities moeten volgens Hajer niet verward worden met traditionele politieke coalities. Ze hebben een linguiistische basis, niet een gemeenschappelijke belangenstructuur. Het betreft hier actoren die zich gaan bedienen van het vocabulaire uit elkaars vertogen en zich aangetrokken voelen tot, dan wel verschillende belangen verwoord zien in, gedeelde verhaallijnen. Een vertoogcoalitie kan per thema verschillen en moet dus gemaakt worden. Zo kan een vertoogcoalitie ontstaan tussen de milieubeweging en Veilig Verkeer Nederland (VVN) waarin verlaging van de maximumsnelheden wordt bepleit. De coalitie wordt bijeengehouden door de verhaallijn dat 'auto's te hard rijden', maar de achterliggende vertogen verschillen: het streven naar een lagere uitstoot in het geval van de milieubeweging, minder verkeersslachtoffers voor vVN.

In de ontwikkeling van het mobiliteitsvertoog sinds de jaren zeventig zijn uiteenlopende verhaallijnen en vertoogcoalities te herkennen. Rond het verschijnen van het eerste deel van het SVV 11 , eind 1988 , ontstond een vertoogcoalitie tussen verhaallijnen als 'de auto als verzuur- 
der', 'leefbaarheid' en 'stervende bossen'. Maatschappelijke groeperingen als de milieubeweging en onderdelen van het overheidsapparaat (met name het ministerie van vrom) slaagden erin de maatschappelijke problemen die het autosysteem veroorzaakt te definiëren in termen van uitstoot van schadelijke stoffen en andere negatieve effecten voor de leefbaarheid, zoals lawaai, versnippering en onveiligheid.

In het politieke vertoog kwam het autosysteem naar voren als een bedreiging van de leefbaarheid. Een onbelemmerde groei van de automobiliteit moest worden woorkomen, een groeireductie tot 35 procent ten opzichte van 1986 was nodig om Nederland leefbaar te houden. Deze norm werd vastgelegd in het deel D van het svv II, dat in 1990 in de Tweede Kamer werd aangenomen. ${ }^{34}$ Politici en ambtenaren hadden zich vastgelegd op een concreet en meetbaar beleidsdoel. Het beleid dat werd ontwikkeld om de doelstellingen te halen had vooral een generiek karakter. Prijsbeleid in de vorm van rekeningrijden en accijnsverhogingen moesten het autorijden minder aantrekkelijk maken en de concurrentiepositie van het openbaar vervoer verbeteren.

In 1994 tekende zich met het aantreden van het eerste kabinet Kok een omslag aan. Nu ontstond een vertoogcoalitie tussen verhaallijnen als 'werkgelegenheid', 'economische groei', 'bereikbaarheid', 'infrastructuur', 'marktwerking' en 'technologie'. Deze verhaallijnen vormden het cement van een coalitie waarin mobiliteit niet als een fundamenteel maatschappelijk probleem wordt gezien, maar slechts aanpassingsproblemen veroorzaakt. Van deze aanpassingsproblemen stond de congestie hoog op de politieke agenda vanwege de economische schade door reistijdverlies die files veroorzaken. Dit uitte zich in de politieke pleidooien voor meer infrastructuur en een beleid dat niet langer in het teken staat van het halen van generieke reductienormen, maar het zo goed mogelijk accommoderen van de bestaande vervoersvraag onder zo laag mogelijke maatschappelijke kosten. Zo werd een instrument als rekeningrijden, anders dan in r 990 onder Maij-Weggen, toen het vooral als milieumaatregel werd gepresenteerd, vooral gerechtvaardigd als een middel om de vervoersvraag in tijd en plaats te spreiden.

In de aanloop naar het NVVP verschijnen nieuwe verhaallijnen in het mobiliteitsvertoog: 'interactieve beleidsvorming', "marktwerking' en 
"slimme technologie". In hun onderlinge samenhangen bepalien ze sinds 1998 de discursieve raimte. Een ambtenaar van het ministerie van Verkeer en Waterstaat die nauw betrokken was bij het opstellen van het NVVP omschreef deze verschuiving in het centrale sturingsparadigma $z o$ : 'In dagen van het svv II zagen we mobiliteit als een geintegreerd verkeersen verwoersysteem, als een verzameling buizen en $k$ ranen die open en dicht gedraaid konden worden. Er schuilt een sterk centralistisch element in deze manier van denken, alsof je een zo gecompliceerd verschijnsel als mobiliteit op een zo ingenieurachtige manier zou kunnen sturen. De belangrijkste verandering in het NvPP is het idee dat mobiliteit het resul-

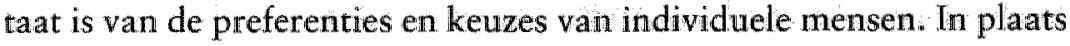
van kranen open en dicht te draaien zouden we de manier waarop mensen keuzes maken moeten beïnvloeden door economische principes te introduceren op de weg: hoge prijzen als er veel vraag is of als de externe kosten hoog zijn. Mobiliteit moeten we zien als een markt." ${ }^{35}$

Om de weg als markt te kunnen laten functioneren is technologie nodig, niet zo maar technologie, maar 'slimme technologie'. De verwachting van de opstellers van het NVve is dat in 2020 dertig procent meer kilometers worden afgelegd en twee keer zoveel goederen worden verwoerd, maar Nederland zal tegen die tijd "het slimste wegennet" van Europa hebben. Dat 'slimme technologie' voor veel beleidsmakers aantrekkelijk is als oplossing van netelige politieke kwesties, illustreert De Wilde (2000) aan woorbeelden als Advanced Cruise Control, Intelligente Snelheidsadaptatie, routenavigatiesystemen, dynamisch verkeersmanagement - allemaal genoemd in het NvvP als beloften voor de nabije toekomst. Ook MobiMiles van Pieper is van die strategie een voorbeeld. In theorie lost deze slimme technologie het sociaal dilemma voorgoed op. Het nieuwe sturingsparadigma van het NVVP, dat de individuele keuzes van mensen wil beïnvloeden door prijsbeleid, komt hier samen met een technologie die in elke individuele auto naar plaats en tijd kan afrekenen. Enerzijds wordt niets de individuele weggebruiker in de weg gelegd; men kan rijden waar en wanneer men maar wil. Anderzijds worden de collectieve kosten van deze keuzes onmiddellijk afgerekend via de 'trusted wallet". Afwenteling van zogenaamde 'externe kosten' op de samenleving behoort tot het verleden. Maar slimme 
technologie is alleen slim als er sociaal vaardig mee wordt omgegaan, stelt De Wilde, als er voldoende aandacht is besteed aan de dagelijks praktijk waarin zo'n technologie zal fumctioneren. ${ }^{36}$ Hoe slim en effectief MobiMiles op papier ook was, tegen de politieke realiteit bleek het systeem niet opgewassen.

\section{Een bewegelijk beleid}

De veranderingen en verschuivingen in het mobiliteitsbeleid van de afgelopen vijftien jaar zijn als volgt samen te vatten. Om te beginnen is de groei van de mobiliteit geaccepteerd. 'Mobiliteit mag. Mobiliteit hoort bij de moderne samenleving. Nog steeds neemt de mobiliteit toe."37 De eerste zinnen van de 'kernboodschap' van het Nvwp markeren een breuk met het beleid van groeireductie dat in het Svv In centraal stond. De groei van de mobiliteit onttrekt zich aan de beinvloeding van politici en beleidsmakers; wat zij kunnen doen is zorgen dat de gevolgen van die groei niet ten koste gaan van 'bereikbaarheid, veiligheid en de kwaliteit van de leefomgeving'. Een tweede verandering betreft de probleemdefinitie. Niet langer ligt daarin het accent op de verslechtering van het milieu, maar op de verslechterende bereik baarheid als gevolg van congestie. Een derde verandering is een 'verzakelijking' wan de benadering van de burger door de overheid. Het morele appèl - 'De auto kan best een dagje zonder u' - dat zijn overtuigingskracht ontleende aan beelden van verzurende bossen en een opwarmende aarde is ingeruild voor het adagium van 'de weg als markt'. Mobiliteit mag, maar heeft wel een prijs. De maatschappelijke kosten dienen voor rekening van de individuele reiziger te komen. Een vierde verandering betreft de rol van de rijksoverheid ten opzichte van andere overheden. Niet langer wenst de rijksoverheid zich als belangrijkste 'probleemeigenaar' te beschouwen. Decentralisering van bestuurlijke macht en verantwoordelijkheden moet ervoor zorgen dat het beleid beter aansluit op de lokale omstandigheden en behoeften. Ten slotte heeft een beleidsstijl die gebaseerd is op kennis van experts plaats gemaakt voor de overlegcultuur van het 'poldermodel'. Zonder "draagvlak" gebeurt er niets en dat maakt het noodzakelijk zoveel mogelijk maatschappelijke actoren te betrekken bij de formulering en uitwerking van het beleid. ${ }^{38}$ 
Een beleidswetenschappelijke analyse van het mobiliteitsprobleem toont de bewegelijkheid en inventiviteit wan politici en beleidsmakers. Het zou onzin zijn te beweren dat dat bewegelijke belleid zonder resultaten is gebleven. Er vallen minder doden in thet verkeer dan in 1970 , motoren zijn minder vervuilend en in binnensteden heeft een streng parkeerbeleid de alomtegenwoordigheid van de auto aan banden gelegd. Maar de scepticus zal opmerken dat veel van de problemen die voortvloeien wit de groei van de mobiliteit nog steeds bestaan, dat de maatschappelijke winst- en verliesrekening niet in balans is. De uitstoot van kooldioxide door het verkeer blijft toenemen, geluidshinder neemt ondanks technische maatregelen als geluidsarm asfalt en geluidsschermen weer toe en doordat auto's tegelijk zuiniger zijn geworden én groter en zwaarder, blijft het brandstofverbruik toenemen. ${ }^{39}$ Het publieke probleem van de uiteenlopende vormen van schaarste die voortvloeien uit de groei van de mobiliteit - denk aan ruimte, veiligheid en leefbaatheid - blijft onopgelost. Ondanks alle beleidsveranderingen zijn de sociale dilemma's die moderne mobiliteit oproept nog dezelfde als vijfentwintig jaar geleden toen het SCP-rapport verscheen.

\section{De hypothese van de constante reistijud}

In de afgelopen decennia heeft de overheid samen met andere maatschappelijke actoren op allerlei manieren beleid geformuleerd waarmee het handelen wan mensen te beïnvleeden zou zijn waar het hun mobiliteit betreft. Dit beleid richtte zich op het bewerkstelligen van 'shifts', verschuivingen in de keuze van vervoermiddel, bestemming of zelfs vestiging. Als mensen andere keuzes maken - bijwoorbeeld door niet met de auto te reizen maar met het openbaar vervoer, orn een beleidsuitgangspunt uit de tijd van het SVV Ir te nemen - kunnen ze zich blijven verplaatsen maar zijn de maatschappelijke kosten van hun verplaatsingen lager. We weten nu boe de opeenvolgende kabinetten en andere maatschappelijke actoren het probleem hebben gedefinieerd en in wisselende vertoogcoalities oplossingen hebben gezocht, maar deze reconstructie toont geen uitweg uit het kernconflict dat in alle sociale dilem- 
ma's ligt besloten: individuele woordelen leiden tot collectieve nadelen. Anders gezegd, een analyse van het mobiliteitsbeleid maakt duidelikk hoe het gebouw in elkaar zit, maar laat in het midden waar we de witgang moeten zoeken.

Om de stagnatie in het debat en het beleid beter te kunnen begrijpen moet de vraag beantwoord worden waarom mensen in het verkeer 20 handelen als ze doen, wat de achtergrond is van de keuzes die ze maken. Waarom wint de auto het zo vaak van het openbaar vervoer als mensen moeten kiezen? Waarom lijken steden woortdurend uit te dijen? Waarom hebben zakenreizigers meer haast dan toeristen? Maken tweever: dieners meer kilometers dan alleenstaanden? En waarom neemt de mobiliteit eigenlijk ieder jaar toe?

Vragen als deze behoren tot het domein van de verkeerskunde en de vervoersplanologie. Om de eerste vraag te kunnen beantwoorden is bijvoorbeeld gekeken naar de verschillen in reistijd tussen openbaar vervoer en auto. Als een reiziger met het openbaar vervoer meer dan anderhalf keer langer onderweg is, geniet de auto doorgaans de voorkeur, zo bleek uit onderzoek. Uitgaande van deze 'verplaatsingstijdfactor', ook well v F-waarde genoemd, kon een eenvoudig beleidsadvies worden gegeven: als de overheid wil dat mensen de overstap maken van auto naar openbaar verwoer moet zij zorgen dat trein, bus en metro in termen van reistijd kunnen concurreren met de auto. ${ }^{\circ}$ De vraag waarom steden voortdurend uitdijen wordt beantwoord door te wijzen naar de relatie tussen de mobiliteit van mensen en de ruimtelijke orde. De 'actieruimte' van mensen wordt bepaald door het aantal bestemmingen dat ze in een bepaalde tijd kunnen aandoen. Hoe sneller men zich kan verplaatsen, hoe meer plaatsen bereikbaar worden in dezelfde tijd. De omvang van steden werd eeuwenlang bepaald door de afstand die mensen lopend konden afleggen. Met de komst van snellere vervoermiddelen nam de 'actieruimte' van mensen toe en groeide ook de omvang van steden. ${ }^{4 \mathrm{x}}$ Dat zakenreizigers meer haast hebben dan toeristen wordt begrijpelijk door er vanuit te gaan dat de tijd van de eersten meer waard is dan van de laatsten; zij hebben een hogere 'reistijdwardering' dan toeristen en zullen daarom bereid zijn meer te betalen om snel van de ene naar de andere plaats te komen. ${ }^{42}$ Of tweeverdieners meer kilome- 
ters maken dan alleenstaanden wordt duidelijk door onderzoek te doen naar de tijdsbesteding van deze groepen, bijvoorbeeld door een groot aantal mensen te vragen een dagboek bij te houden waarin ze nauwkeurig verslag doen van hun reisgedrag. ${ }^{*}$

Deze woorbeelden laten zien dat verkeerskundigen en vervoersplanologen met het begrip 'reistijd' een belangrijk instrument in handen hebben om verklaringen te geven voor het verplaatsingsgedrag van mensen, om het in verkeerskundige termen uit te drukken. Om te analyseren hoe zij redleneren, wil ik uitvoeriger ingaan op de laatste vraag: waarom groeit de mobiliteit? Deze vraag stond centraal in het mobiliteitsdebat van de afgelopen dertig jaar, waarin de groei en de negatieve gevolgen daarvan als een hoofdoorzaak van het probleem zijn aangemerkt. Hoe verkeerskundigen het begrip 'reistijd' inzetten om deze vraag te beantwoorden zet ik uiteen aan de hand van een exemplarisch voorbeeld uit het veld, de hypothese van de constante reistijd die in $\mathrm{Ne}$ derland door Geurt Hupkes ( 1977 ) als eerste is geformuleerd.

\section{De BREVER-wet}

Terug naar de toekomstprojectie TP 2000 uit 1970 . Waar dit onderzoek voor politici als Van Thijn aanleiding vormde de groei van het autoverkeer in het parlement ter discussie te stellen, plaatsten verkeerskundigen kanttekeningen bij de methode van de toekomstprojectic. Vanuit 'kritisch futurologische' hoek kwam kritiek op het lineaire of exponentiële karakter van de extrapolaties. Deze konden volgens de critici slechts leiden tot de uitkomst'dat de matschappij van de toekomst tweemaal die van vandaag zou zijn'. ${ }^{4}$ De prognoses van de nota ontnamen het zicht op een discussie over de wenselijkheid van de geschetste toekomstige situatie, aldus de critici. Immers, de 'verkeersboom kan echt niet tot in de hemel groeien". ${ }^{45}$

Een van de critici van de in TP 2000 gehanteerde methode was de verkeerskundige Geurt Hupkes. In zijn dissertatie Gasgeven of afrewmen. Toekomstscenario's voor ons vervoerssysteem (1977) schrijft hij: 'Blijkbaar staan de transportbehoeften in het jaar 2000 al vast en gaat het er alleen nog maar om, de plannen voor de bijbehorende infrastructuur concreet te maken." 46 Prognoses worden al snel voorspellingen die 
zichzelf waar maken, meent Hupkes. Verwijzend naar De Jouvenel (Futuribles'), de toekomststudies van Herman Kahn en het rapport van de Club van Rome concludeert hij dat het beter is scenario's te ontwikkelen, 'beargumenteerde en logisch samenhangende toekomstbeschrij: vingen, waaraan een uitspraak omtrent de mate van waarschijnlijkheid ontbreekt'. ${ }^{47}$ Scenario's als beargumenteerde toekomstbeelden kunnen helpen bij het maken van keuzes omdat ze de gevolgen van die keuzes inzichtelijk maken. Hupkes ontwikkelt vervolgens twee scenario's voor het 'vervoerssysteem'.

Om zijn scenario's te kunnen maken, moet Hupkes weten wat het mechanisme is achter de groei van de mobiliteit. Dat mechanisme kan hij beschrijven door uit te gaan van de hypothese van de constante reistijd. ${ }^{48}$ Uitgangspunt van Hupkes' redenering is een toenemende schaarste aan tijd die zich uit in de behoefte om meer dingen tegelijk te doen (simultaan tijdgebruik) en het verkorten van de hoeveelheid tijd besteed aan één activiteit (gefragmenteerd tijdgebruik). Een van de manieren om het probleem van de tijdschaarste op te lossen is sneller te reizen. Maar hoewel mensen inderdaad in de afgelopen decennia sneller zijn gaan reizen, blijkt uit onderzoek dat de tijdbesteding aan slapen, werken, persoonlijke verzorging, ontspanning en mobiliteit tamelijk constant is. De mens, concludeert Hupkes, voelde 'blijkbaar geen behoefte aan het bekorten van de reistijd, noch aan het verminderen van het aantal verplaatsingen'. Ook blijkt hij 'geen behoefte te bebben aan bet laten uitdijen van zijn reistijd of het aantal malen dat bij zich verplaatst, betgeen voor een tijdsbesteding waarvan het nut in de regel afgeleid is van dat van andere tijdsbestedingen, ook eigenlijk niet viel te verwachten. (cursivering in het origineel - PP)'. Daarom concludeert Hupkes:

'De mens beschikt kennelijk over een afweegmechanisme waarvan de aard niet bekend is maar dat hem in staat stelt, zijn gemiddelde reistijd en het aantal verplaatsingen op hetzelfde niveau te fixeren. De enige van de drie dimensies van mobiliteit die is toegenomen, is m.a.w. de per hoofd afgelegde afstand, hetgeen werd verwezenlijkt door het opvoeren van het aandeel van de verplaatsingen met relatief snelle vervoersystemen: ${ }^{3} 9$ 
Waarop baseert Hupkes zijn conclusie? Zelf geeft hij aan dat bruikbare onderzoeksgegevens op dit terrein uitermate schaars [zijn]". ${ }^{\circ} \mathrm{Hij}$ citeert een onderzoek van Vidakovic uit 1968 , dat concludeent dat de inwoners van Amsterdam-Zuid in 1968 gemiddeld 68 minuten per dag aan verplaatsingen besteden. Tijdsbudgetonderzoek van Blaas en Heinemeijer vindt een gemiddeld aantal verplaatsingen per dag van ruim vijf met een geringe spreiding. Uit andere bronnen citeert Hupkes zonder de constanten te kwantificeren. ${ }^{5 x}$ Centraal in de onderbouwing van Hupkes' studie staat het omvangrijke tijdbudgetonderzoek The Use of Time van Szalai [et.al.] uit 1972 , dat gebaseerd is op zo'n dertigduizend interviews met bewoners van steden en stedelijke gebieden in vijftien merendeels geïndustrialiseerde landen, variërend van de Verenigde Staten tot Peru. ${ }^{52}$ In het bijlagendeel van zijn dissertatie vat Hupkes vier tabellen uit Szalai samen. Daaronder is een tabel van de tijdbestedingen op een gemiddelde dag in de week. Voor 'mobiliteit' (een categorie die bij Szalai 'travel' heet) resulteert een gemiddelde van 82 minuten met een standaarddeviatie van negen minuten. Hupkes stelt:

'Voor ons was in het vorenstaande vooral van belang dat er geen sprake is van significante verschillen in de per persoon aan mobiliteit bestede tijd bij stijgende welvaart. Het niveau van deze constante reistijd lag in het tijdbudgetonderzoek van Szalai c.s. op gemiddeld $x$ h $\mathrm{I} 3$ minuten per dag of op 444 h per jaar. ${ }^{53}$

Dit verschijnsel duidt Hupkes an als de wet van het Behoud van REistiij en VERplaatsingen: de BREVER-wet.. Volgens Hupkes geldt de wet op het geaggregeerde niveau van 'de gemiddelden per hoofd in alle vervoersystemen over een periode met een bepaalde lengte: een dag, een week of een jaar. Hoe langer de periode, hoe kleiner de spreiding van het gemiddelde per persoon'. Met zijn wet kan Hupkes nu het mechanisme formuleren dat de groei van de mobiliteit verklaart. We kunnen dit mechanisme illustreren aan de paradox van de haast van Albertine. De tiijd die zij bespaart door met de auto te reizen blijft niet 'leeg', maar wordt gebruikt om naar een tweede dorp te gaan. Ze is dus per saldo even lang onderweg als toen ze nog met de koets ging, maar legt een gro- 
tere afstand af. Overigens zou Hupkes opmerken dat de constante reistijd niet hoeft te gelden voor individuen als Albertine.

Hupkes heeft niet zozeer een 'wet' geformuleerd, maar een hypothese over het bestaan van een statistische constante in reistijd en verplaatsingen. ${ }^{34}$ Onder verkeerskundigen heeft deze hypothese steeds opnieuw geleid tot debatten, over de betrouwbalarheid van de gebruikte databestanden, over de beleidsimplicaties - als mensen een vast deel van hun tijd aan reizen besteden heeft het bijvoorbeeld geen zin om fysieke mobiliteit te willen vervangen door voor het milieu minder schadelijke 'virtuele mobiliteit' - en over de verklaring voor de constante. Hupkes zelf heeft woor dat laatste thema de aftrap gegeven. Waarom de gemiddelde reistijdpatronen maar weinig variëren, bijvoorbeeld tussen landen met hoge en lage inkomens of in de tijd, is volgens hem niet duidelijk:

'Die verschillen zouden wel verwacht mogen worden en nu ze ontbreken, dient de oorzaak te worden opgespoord. De geheimzinnige redenen voor de geconstateerde regelmaat in het tijdgebruik blijven echter verborgen in de zwarte doos, gevormd door de mens als biologisch, fysisch en psychologisch wezen. ${ }^{\text {"5 }}$

Wie de verkeerskundige literatuur erop naslaat, ziet dat het vooralsnog niet gelukt is deze 'zwarte doos' te openen. Er zijn hooguit verspreide aanzetten tot verklaringen gedaan. ${ }^{56}$

\section{De verkeerskundige stijl van redeneren}

Het exemplarische voorbeeld van de BREvER-wet makt duidelijk dat het begrip "reistijd" verkeerskundigen in staat stelt verklaringen te geven voor het 'verplaatsinggedrag' van mensen. De wetenschapsfilosoof Hacking ( $\mathrm{x} 85$ ) heeft betoogd dat theoretische begrippen, zoals in dit geval 'reistijd" en "verplaatsingsgedrag', pas betekenis krijgen in een 'style of reasoning', een term die enige werwantschap heeft met de "paradigna's" van Kuhn ( 1 962). Meer dan Kuhn legt Hacking de nadruk op de wijze walarop de warheidsclaim van uitspraken in een bepaalde wetenschappelijke traditie wordt beredeneerd. ${ }^{57}$ In het voorbeeld van de BREVER-wet: de vraag is niet of de hypothese van de constante reistijd 
waar is of niet, maar langs welke weg de hypothese überthaupt een kandidaat kon worden om "waar" of "onwaar' te zijn. Om daarover iets te kunnen zeggen moeten we de vooronderstellingen ten aanzien van centrale begrippen in de redenering nader onderzoeken.

In het geval van de verkeerskunde in het algemeen en de scenarioberekeningen van Hupkes in het bijzonder zijn de vooronderstellingen ten aanzien van het begrip tijd van centraal belang. Gell (r992) betoogt dat de overgrote meerderheid van de economische modellen uitgaat van een tijdsbegrip in de B-serie. "Tijd wordt opgevat als het stabiele raamwerk waarin gebeurtenissen plaatsvinden in een onwrikbare orde, statisch, objectief en onveranderlijk.., Een ander voorbeeld van de wijze waarop deze tijdsopvatting terugkeert in de constructie van Hupkes? scenario's is het onderzoek naar tijdsbudgetten wa armee de socioloog Sorokin in de jaren dertig begon, dat door Szalai in de jaren zestig werd voortgezet en dat de empirische basis vormt van de hypothese van de constante reistijd. ${ }^{59}$ Kenmerkend voor deze stijl van redeneren is vervolgens dat het tijdsbegrip in de B-serie het mogelijk maakt te vergelijken. Bij Hupkes en zijn hypothese van de constante reistijd vormt dit vergelijkend perspectief de kern van de redenering. Immers om überhaupt van een constante te kunnen spreken, bijvoorbeeld tussen verschillende landen zoals in het onderzoek van Szalai of tussen historische periodes, moeten de tijdsbudgetten vergeleken kunnen worden. Onder verkeerskundigen vindt men aanhangers van sterkere en zwakkere varianten van de hypothese van de constante reistijd. Waar de eersten (onder wie Hupkes) uitgaan van een constante met een absolute waarde, namelijk 73 minuten per dag of jaarlijks 444 uur, nemen anderen slechts de stelling voor hun rekening dat de aan reizen besteedde tijd niet afhankelijk is van het vervoersysteem waarover mensen beschikken. ${ }^{60}$ In al deze varianten staat het gekwantificeerde tijdsbegrip zelf echter niet ter discussie.

Welke bijdrage kunnen disciplines als de verkeerskunde en de vervoersplanologie leveren in het doorbreken van de stagnatie in thet denken over mobiliteit? Om te beginnen is het met de hypothese van de constante reistijd mogelijk de groei van mobiliteit te verklaren in termen van één - genetisch verankerd, economisch gemotiveerd dan wel soci- 
aal-gedragsmechanisme. Mensen reizen een constant deel van de tijd. Als ze zich sneller kunnen verplaatsen, dan zullen ze verder reizen en niet korter. Technologische vernieuwingen hebben het mogelijk gemaakt sneller en dus verder te reizen. Als we uitgaan van verdere technologische en economische vooruitgang, dan zal de afgelegde afstand in de toekomst blijven toenemen. ${ }^{61}$ Dit soort 'als-dan'-redeneringen ligt aan de basis wan talloze verkeerskundige en vervoersplanologische mobiliteitsscenario's.

Uitgaande van dit mechanisme kan de verkeerskunde ook aangeven watr we de oplossingen voor de problemen van de groei zouden kunnen zoeken. Ze toont zogezegd de 'knoppen' waaraan we moeten draaien. Opnieuw gebeurt dit in de vorm van hypothetisch-deductieve redeneringen. Als de groel van de mobiliteit het probleem is, dan moeten we de oplossing zoeken in de snelheid waarmee mensen reizen. Immers, sneller reizen leidt tot het afleggen van grotere afstanden en groei van de mobiliteit; door langzamer te reizen leggen we minder grote afstanden af en blijft de groei binnen de perken. Na analyse van een aantal 'subsystemen'(auto, luchtvaart, spoorwegen, lokaal en regionaal openbaar verwoer, taxi en de 'onbeschermde of zachte systemen', dat will zeggen lopen of fietsen) beschrijft Hupkes twee scenario's: SAAL. (Scenario met het Accent op het Autosysteem en de Luchtvaart) en SAzov (Scenario met het Accent op de Zachte vervoersystemen en het Openbaar Vervoer):

'In SAAL correspondeert daarbij een relatief snelle groei van de pkm [personenkilometers - PP] in het autosysteem en de luchtvaart met een snelle inkrimping van het langzaam verkeer per hoofd en een zekere beperking van het openbaar vervoer te land. Omgekeerd treedt in SAZOV een betrekkelijk geringe groei op van de auto (met name van de tweede wagen) en van vliegvakanties naar Bali, Bangkok en Benidorm, gekoppeld aan het behoud van langzaam verkeer op het niveau dat per persoon in $r 972$ bestond en aan enige uitbreiding van dat niveau voor het openbaar vervoer.. ${ }^{362}$

Hupkes kan de beleidsmakers voorhouden wat de gevolgenzijn van hun beslissingen, zelf spreekt hij zich niet uit over 'de waarschijnlijkheid van 
de realisering van een van beide scenario's. (...) Het is de essentie van scenario's, dat zij de keuze voor de huidige generatie t.o.v. de toekomst verhelderen. Het zijn geen prognoses. De toekomst is niet te voorspellen, maar wordt gevormd door het werk van hoofd en hand, geleid door de ingevingen van het hart. Ieder van ons draagt daarbij een eigen verantwoordelifilkheid." "Als persoon en niet als onderzoeker' kiest Hupkes voor het langzame scenario: afremmen is beter dan gasgeven. Of de samenleving hem in die keuze volgt, is in een democratische maatschappijvorm een zaak van de politiek: ${ }^{63}$

\section{Conclusie}

Vanaf het begin van de jaren zeventig wordt de voortgaande groei van de mobiliteit, met name de automobiliteit, in Nederland als een publiek probleem gezien. Tegenover voordelen voor het individu staan nadelen voor de samenleving zoals milieubederf, congestie, een verslechterende leefbaarheid, versnippering van de ruimte en verkeersonveiligheid. Opeenvolgende kabinetten hebben beleid geformuleerd om deze problemen op te lossen, maar zonder dat dat tot blijwende oplossingen leidde. Een beleidswetenschappelijke reconstructie kon de hardnekkigheid van de problemen verklaren vanuit het feit dat ze de structuur hebben van een sociaal dillemma: de spanning tussen voordelen voor individuen op korte termijn en nadelen voor de gemeenschap op kortere én langere termijn.

Het beleid dat werd ontwikkeld om uit dit sociale dilemma te breken is voortdurend in beweging. Probleemdefinities verschuiven, vertoogcoalities en verhaallijmen ontstaan en verdwijnen weer, nieuwe beleidsinstrumenten worden ontwikkeld. Nadere beschouwing leert dat mobiliteitspolitiek in Nederland voor alles wordt opgevat als 'tijdwinstpolitick'. De aanleg van autosnelwegen, rondwegen rond dorpen, nieuwe spoorlijnen en tunnels, de vijfde baan op Schiphol, maar ook de invoering van kilometerheffing hebben immers allemaal tot doel de reisduur te bekorten. In het mobiliteitsdebat staat het primaat van korte reistijden niet ter discussie. Omgekeerd geldt het 'verlies' van tijd, bij- 
voorbeeld in de file of door vertragingen bij het spoor, als een probleem dat ruime aandacht krijgt in politiek en beleid. Gemeten in aantallen pagina's gaat in het NVVP de meeste aandacht uit naar het probleem van de bereikbaarheid. Tijd vormt in politieke zin een hard gegeven, of zoals Goudsblom (1997) het uitdrukt een 'dwingeland waarmee mensen zichzelf en elkaar onder druk zetten', een regime. ${ }^{64}$ Deze tijdwinstpolitiek stoelt op twee veronderstellingen. De eerste is dat binnen dit regime tijd 'gewonnen' kan worden door vervoersystemen te versnellem. De tweede is dat de maatschappelijke verliezen die dit oplevert - in termen van ruimte, leefbaarheid, milieukwaliteit of veiligheid - opgevangen kunnen worden, bijvoorbeeld door ze te internaliseren door gebruik te maken van nieuwe technologieen als kilometerheffing.

Verkeerskundigen als Hupkes bedienen zich van de hypothese van de constante reistijd om te tonen dat deze winst-en verliesrekening niet klopt. Achter de groei van de mobiliteit gaat een mechanisme schuil waardoor in het verkeer geen tijd gewonnen kan worden. Uit de hypothese van de constante tijdsbesteding volgt dat de tijd die mensen denken te winmen door sneller te reizen weer verloren gaat in de groei van het aantal kilometers dat zij afleggen. Redenerend vanuit dit mechanisme kan het politieke streven om mensen meer reissnelheid te bieden alleen maar falen. Ergo, wie aan de negatieve gevolgen van de groei wil ontkomen rest maar een alternatief: hij moet kiezen voor een langzamer scenario. Anders dan de redenering van de traagheidsutopisten die in het vorige hoofdstuk aan de orde kwam, is de redenering van Hupkes - als snellere vervoermiddelen leiden tot groei van de mobiliteit, dan leiden langzamere vervoermiddelen tot vermindering van de groei - wel geldig, maar alleen dan als de hypothese van de constante reistijd geldig is. Het vaststellen van de geldigheid van de hypothese veronderstelt echter een vergelijkend perspectief dat gebaseerd is op een tijdsbegrip uit de B-serie. Dit vergelijkend perspectief abstraheert van concrete manieren van reizen en precies deze decontextualiserende beweging zorgt erwoor dat de verkeerskundigen voor de geldigheid van hun redeneringen een prijs betalen: zij verlaten het politiek-utopisch discours. Hun scenario's verschillen nog maar op een punt, namelijk sneller of langzamer. Juist door het wegvallen van de context komt het B-tijds- 
begrip nog centraler te staan, maar zonder zelf ter discussie gesteld te worden.

Daarmee zijn we terug bij het 'innovatietekort' in het mobiliteitsdebat waarmee ik dit hoofdstuk begon. De historische terugblik op het beleid maakte duidelijk dat de wenselijkheid van verhoging van de reissnelheid niet betwist wordt; de ongewilde traagheid van de file is een anathema, en ook in discussies over maatregelen om de leefbaarheid en de verkeersveiligheid te vergroten biedt tijdverlies een krachtig tegenargument. De gangbare verkeerskundige analyse van 'verplaatsingsgedrag' verschaft het beleid weliswaar de mogelijkheid oplossingen te formuleren, bijvoorbeeld door te kiezen voor Hupkes' langzame SAzovscenario, maar binnen de verkeerskundige redeneerstijl kan niet worden uitgelegd waarom mensen voor dit scenario zouden kiezen. Snelle vervoermiddelen bieden immers de mogelijkheid in dezelfde tijd meer activiteiten te ondernemen en de "opportunity costs ${ }^{3}$ - het feit dat het maken van een reis betekent dat men afziet van andere activiteiten - van het reizen te verlagen. De kracht van de verkeerskundige redeneerstijl is tegelijk de zwakte ervan; sprekend over innovatie hebben we uiteindelijk slechts termen als langzaam en snel tot onze beschikking. Een manier om uit deze impasse te geraken is het ontwikkelen van een contextualiserend vergelijkend perspectief waarin de vraag centraal staat boe mensen reizen en niet slechts hoe lang zij er over doen. Het is dan eerst modig om de relatie tussen tijd en reizen zelf te historiseren. 


\section{3 \\ De passages van Thomas Cook}

Op 7 oktober 1852 verliet het Russische fregat Pallas de haven van Kronstadt voor een reis naar Japan, waar een diplomatieke delegatie nieuwe handels betrekkingen wilde aanknopen. Aan boord was de veertigjarige vrijgezel Ivan Gontsjarov, auteur van verhalen en de roman Een alledagge geschiedenis en later vooral bekend als schepper van Oblomov. Gontsjarov zou als secretaris van de admiraal een officieel verslag bijhouden van de reis om de wereld. Daarnaast schreef hij brieven aan zijn vrienden in Rusland en maakte hij aantekeningen en kleine opstellen die hij na zijn terugkeer in Rusland publiceerde.

In een van zijn brieven schrijft Gontsjarov nog 'geen vat [te] krijgen op de poëzie van de zee en zeelieden, en ik begrijp niet waar ze die zien':

'Het navigeren van een zeilschip lijkt me het droeve bewijs van de zwakte van het menselijk verstand. Ik zie slechts langs welke kwellingen het de mensheid is gelukt een matig resultaat te boeken: bij gunstige wind een eindje over de zee te varen; het hijsen of strijken van het zeil, het wenden van de boot en elke enigszins ingewikkelde manoeuvre is duidelijk zo'n krachtsinspanning dat je in een oogopslag de hele geschiedenis van het gemartel doorziet dat nodig is om de zeeën te kunnen bevaren. Voor de komst van de stoomschepen konden we misschien zo niet trors dan wel verheugd zijn te weten dat we het zover gebracht hadden dat we konden varen, maar sinds die er zijn is de a anblik van een zeilschip wat pijnlijk. Het is net een oude kokette vrouw die rouge opdoet en blanketsel, die een tiental rokken aantrekt en zich in een korset wringt om een man te behagen, en soms heeft ze wel eventjes succes, maar zodra jeugd en frisheid hun entree maken is al haar werk voor niets geweest. Zo door- 
klieft een zeilschip met volle, opgestoken zeilen, helemaal opgetuigd, krakend en zuchtend de golven, en bij een beetje tegenwind moet het bakzeil halen; daarnaast glijdt, zonder zich ergens iets van aan te trekken, de stoomboot voorbij, en de mens zit met de armen over elkaar en de machine doet het werk."'

Dit fragment is een mooi voorbeeld van negentiende-eeuws enthousiasme over de vooruitgang die de zeereiziger in staat stelt zich te ontworstelen aan het toeval van de natuur. De stoommachine maakte een eind aan de afhankelijkheid van wind en stromingen. Reizen ging als vanzelf. Zoals het stoomschip door de golven sneed, zo raasde de stoomtrein door het land met een snelheid die nog maar enkele decennia eerder ondenkbaar was. De machine die ongehinderd zijn eigen weg gaat is de metafoor bij uitstek voor de moderniteit.

Het begrip 'moderniteit' is op talloze manieren gedefinieerd, schrijft de socioloog Bauman (2000), maar het bepalende kenmerk van het moderne leven, het 'verschil dat het verschil maakt', waaruit alle andere verschillen volgen, is de veranderende relatie tussen ruimte en tijd. De moderniteit begint wanneer ruimte en tijd gescheiden raken van de levende praktijk en afzonderlijk van elkaar opgevat worden als categorieën van strategie en handeling. Wie sneller kon reizen kon een groter gebied bestrijken, het in kaart brengen en vervolgens beheersen. De kracht die ruimte en tijd uit elkaar dreef, die het mogelijk maakte om grotere afstanden in minder tijd te overbruggen, betoogt Bauman, was de technologie van voertuigen die sneller konden voortbewegen dan de benen van mensen of paarden ooit zouden kunnen. "De moderniteit werd geboren onder de sterren van de versnelling en de verovering van het land en deze sterren vormen een constellatie die alle informatie bevat over het karakter, de werking en het lot van de moderniteit. Er is slechts een goed opgeleide socioloog nodig, niet een fantasierijke astroloog, om het sterrenbeeld te lezen." 3

Sociologen als Bauman stellen andere vragen over tijd dan beleidswetenschappers en verkeerskundigen. Wie 'reistijd' niet als een gegeven wil opvatten, niet als een verklarende variabele, maar als een begrip dat zelf problematisch is, zo is Bauman te parafraseren, doet er goed aan te 
rade te gaan bij sociologisch onderzoek naar moderniteit, ruimte en tijd. Dit hoofdstuk volgt dit advies op, maar doet meer dan dat: het zet ook een aantal stappen verder. Naast het werk van de socioloog Giddens bespreek ik enkele sociaal-geografische benaderingen van de relatie tussen modernitert, ruimte en tijd. Ze kennen allen een fundamenteel bezwaar $z$ zo zal blijken, doordat ze aan de praktijken van reizende mensen te weinig a andacht besteden.

\section{Lijnen in ruimte en tijd}

Een reiziger als Gontsjarov beschrijft lijnen door ruimte én tijd. Voor het onderzoek naar 'reistijd' heeft dat consequenties. In het vorige hoofdstuk bleek dat verkeerskundigen en economen het begrip reistijd als kloktijd opvatten, maar daarbij werd nog geen onderscheid gemakt tussen reistijd als de tijd die mensen besteden aan reizem en reistijd als de duur van een verplaatsing. In zijn verklaring van de groei van de mobiliteit beschouwt Hupkes de door mensen besteedde reistijd als constante en de duur van een verplaatsing als variabele. Niet de tijdbesteding aan reizen valt te beinvloeden, stelt Hupkes, maar de reisduur. Over tijdsbesteding aan reizen kunnen we spreken zonder het daarbij over ruimte te hebben; we kunnen immers vaststellen hoe lang mensen onderweg zijn zonder te weten waar ze heen gaan. Dit is de manier waarop reistijd verschijnt in de modellen van economen en verkeerskundigen die zich bezighouden met het 'keuzegedrag' van mensen. Reistijd is hier een gekwantificeerde variabele en de allocatie wan tijd aan reizen moet worden afgewogen tegen andere tijdbestedingen; ruimte speelt in deze modellen geen rol, wel reismotieven en de aard van de bestemming. ${ }^{4}$ Over reistijd als de duur van een verplaatsing kunnen we alleen iets te zeggen als we tijd relateren aan afstand. In het voorbeeld van Gontsjarov: hij deed er twee jaar over om rond de wereld te reizen. Reistijd als duur van een verplaatsing, als de verhouding tussen ruimte en tijd behoort tot het domein van geografen en is voor het eerst onderzocht door Torsten Hägerstrand en Donald Janelle. 


\section{De tijd-ruintegeografie van Hägerstrand}

In een presentatie voor het Europese congres van de Regional Science Association in Kopenhagen in 1969 betoogde Hägerstrand dat geografen zich niet alleen met ruimte bezig dienden te houden, mar ook met tijd. "Hij stelde een ruimte-tijd model voor waarin de "levenspaden' van individuen weergegeven konden worden. Tegenover twee ruimtelijke assen (een plat vlak) plaatste hij een derde as, de tijd, om zo de bewegingen van mensen door de ruimte en de tijd weer te geven.

Hägerstrand betoogde dat menselijke activiteit onderworpen is an een aantal beperkingen ("constraints") die voortvloeien uit het feit dat iemand niet op twee plaatsen tegelijk kan zijn, dat de tijd van mensen eindig is, dat de meeste mensen niet meer dan een taak tegelijk kunnen uitwoeren, dat beweging door de ruimte ook altijd beweging door de tijd inhoudt en dat twee mensen niet op hetzelfde moment op exact dezelfde plaats kunnen zijn. ${ }^{6}$ Interacties tussen bewegende individuen wormen tijd-ruimtelijke 'bundells' (ontmoetingen) die samenvallen met "stations', concrete plaatsen, zoals huizen, straten, steden en staten. De tijd-ruimtelijke paden van twee individuen die bijwoorbeeld een afspraak hebben in een café komen daar samen om na enige tijd weer uit elkaar te gaan (zie figuwr 3.I).

Vanwege de genoemde 'constraints' bewegen mensen niet vrij in de ruimte en tijd, maar in zogenaamde 'prisma's", tijd-ruimtelijke muren die zich laten vergelijken met de 'cellen van een enkele dag' die we bij Proust tegenkwamen. Zoals Albertine ervoer dat wie met de auto reist meer dorpen kan aandoen, zo betoogt Hägerstrand dat snellere vervoermiddelen de tijd-ruimtelijke prisma's van mensen hebben vergroot. Anders gezegd, een wandelaar beweegt in een ander prisma dan een automobilist (zie figuur 3.2). Een prisma geeft de som van alle denkbare paden van een persoon gegeven de transportmiddelen die hem of thaar ter beschikking staan.

De tijd-ruimtegeografische grafieken van Hägerstrand zijn wan een werleidelijke eenvoud. Ze verbeelden de lijnen door ruimte en tijd die elk mens volgt en laten bovendien zien dat mensen binnen harde grenzen bewegen. Maar net als de economen en verkeerskundigen uit het worige hoofdstuk kan Hägerstrand zijn grafieken alleen samenstellen als 
(a)

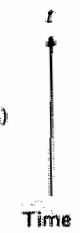

(b)

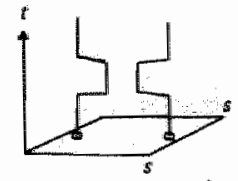

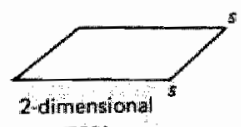

space
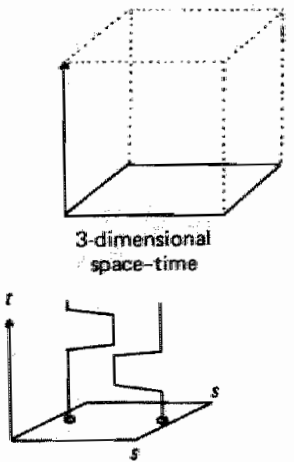

Conocation in space

(c)

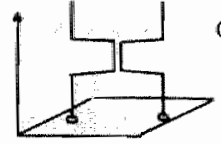

Colowation in time and space in thrme

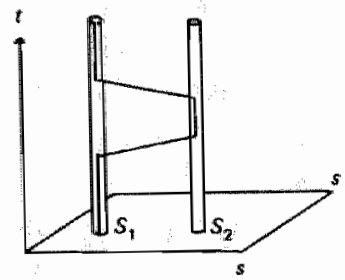

Figutr 3.1: Enkele elementen van de thijd-geografische dynamische kaart. (a) De tijdsdimensie en de tweedimerisionale nimte; gecombineerd als driedimensionale ruimte-tijut. (b) De paden van twee undividuen meft: hun ruimte-tijd relaties. (c) Een individu dat beweegt van het ene naar het andere 'station' en weer terug, $S_{1}$ naar $S_{2}$ maar $S_{1}$. (Bron: Parkes \& Thrift 1980,245 ).

hij uitgaat van een gekwantificeerde opvatting van tijd. Dat wordt duidelijk in grafiek 3.2, waar de reistijd van de wandelaar en de automo* bilist constant worden gehouden. Alleen door dat te doen, door kloktijd als neutrale noemer te beschouwen, kan Hägerstrand betogen dat een automobilist een groter tijd-ruimteprisma ter beschikking staat dan een wandelaar. Anders gezegd, we kunnen alleen dán zeggen dat de automobilist sneller reist dan de wandelaar wanneer we de door hen afgelegde afstanden in een constante tijdspanne vergelijken. ${ }^{7}$ 


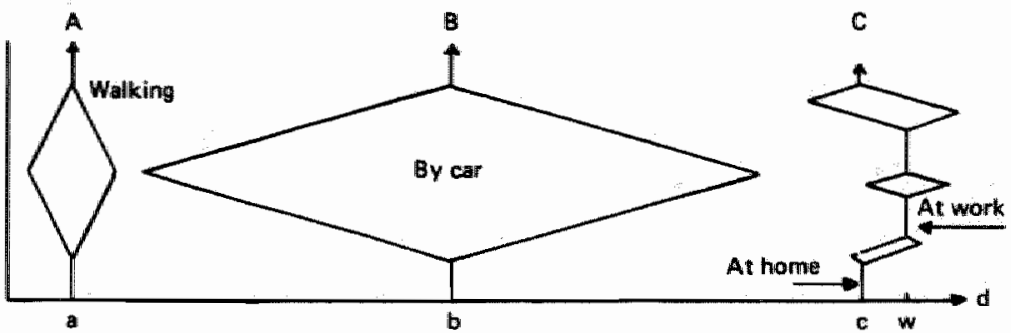

Figur 3.2: Dwarsdoorsnedes van prisma's. (a) Lopent de hoveelheid tijd die men nodig heeft om een bepaalde afstand af te leggen is groot en thet ruimteli hereik beperkt. (b) Autorijden: in een auto kan men in dezelffde tujd ees groter gebied bestrijken. (c) Thjd die men doorbrengt op een 'station' vermindert de oppervilakte van de overblijvende prisma's die in het originele prisma passen. Een snelle reis nalar het werk londerste prisma c w) laat meer rumte om te manceuvreren in ruimte-tijd. Vanwege de beperkingen ('constraints') kan geen wan de taken in de subprisma's de grenzen van het grote prisma overschrijden. (Bron: Parkes \& Thrift, 1980:249).

\section{Janelle en de convergentie van tijd en rwinte}

Een andere manier om de duur van een verplaatsing te relateren aan afstand werd bepleit door Donald Janelle. In I 968 muntte hij het begrip "time-space convergence'. Twee plaatsen zijn gescheiden door een afstand in ruimte en tijd, in kilometers en minuten, betoogde hij. Als de tijd die het kost om van de ene plaats naar de andere te komen afneemt, spreken we van tijd-ruimte convergentie, als die tijd toeneemt van tijdruimte divergentie. Janelle beschouwt de technologische verbeteringen van transport-en communicatietechnologie als de voonaamste oorzalk van het feit dat de afgelopen twee eeuwen zich kenmerken door een proces van geleidelijke tijd-ruimte convergentie. ${ }^{9}$ Janelle illustreert dat proces aan de reis van Londen naar Edinburgh. De gemiddelde tijd-ruimte convergentie tussen deze steden tussen $\times 776$ en 1966 bedraagt volgens Janelle 28,84 minuten per jaar, een getal dat hij berekent door de reistijd in 1776 (5760 minuten) te verminderen met de reistijd in $1966(280$ minuten) en te delen door het aantal verstreken jaren (190). In een grafiek vergelijkt Janelle de reistijden tussen London en Edinburgh voor de postkoets, de trein, de auto en het vliegtuig (zie figuur 3.3 ).

Als gezegd heeft het begrip tijd-ruimte convergentie betrekking op de ontwikkeling in de reistijd tussen elk willekeurig tweetal plaatsen. 


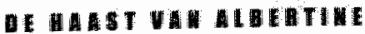

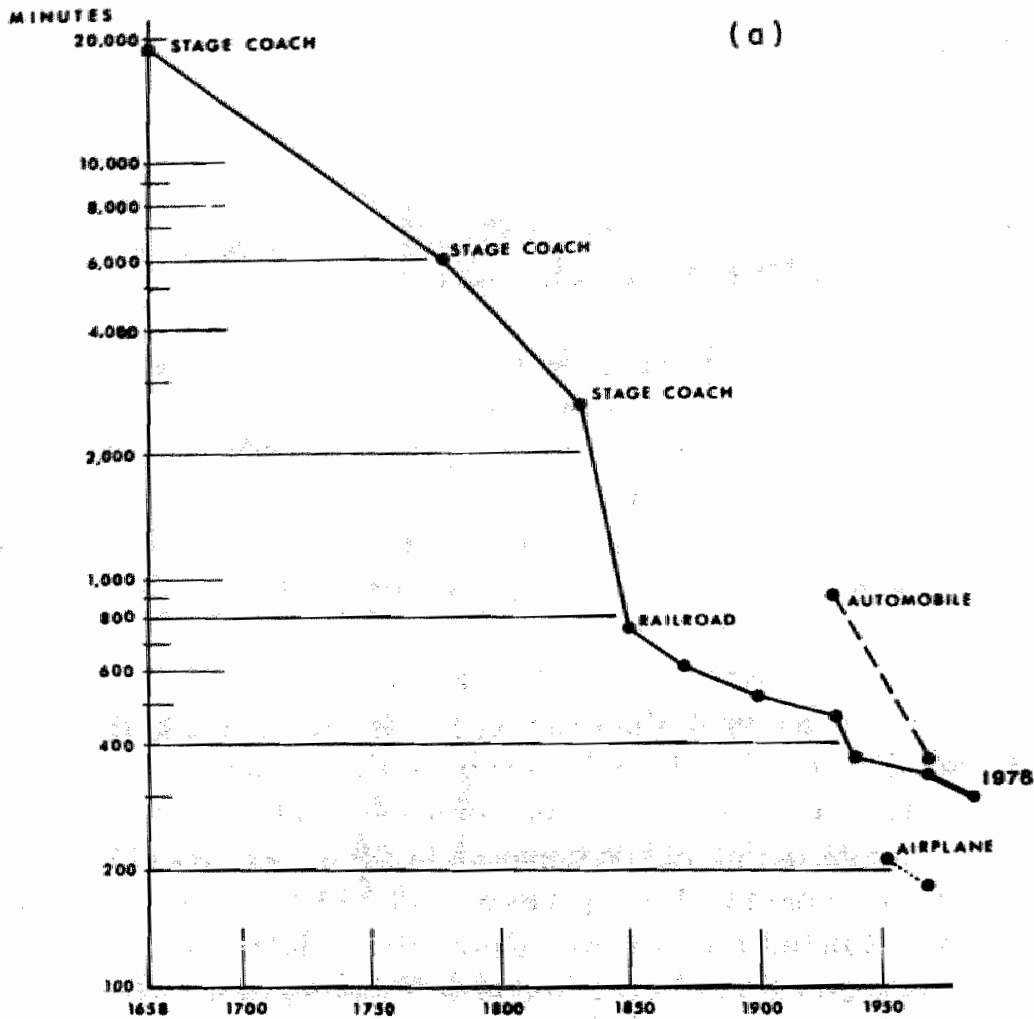

Figuur 3:3: Een woorbeed van tijd-rumte convergentie wolgens Janelle: in 1658 had de posthots bijna twintigduizend munten nodig on de afstand tussen London en Edinburgh te overbruggen. In 1850 deed de trein er achthonderd minuten over. Vanaf de jarenzestig van de vorigg teeww was cen auto minder dan wienonderd ininuten ondenweg. Het whegtuig tenstotte, heefit de reistijd sinds 1958 met een factor honderd bekort. KBron: Parkas \& Thtift, 1980: 292).

Convergentie kan omslaan in divergentie, bijyoorbeeld als de reistijd tussen twee steden toeneemt als gevolg van files. Convergentie hoeft niet in beide richtingen even groot te zijn; de reis van Astrakhan naar Gor$\mathrm{ki}$ aan de Wolga duurt twee keer zo lang als omgekeerd omdat men naar Gorki stroomopwaarts vaart. ${ }^{\text {ro }}$ In een gebouw kan sprake zijn van tijd- 
ruimte convergentie als de bovenste etage na de aanleg van een lift sneller bereikbaar is.

Zoals Hägerstrand de prisma's van een wandelaar en een automobilist kan vergelijken door de tijd constant te houden, kan Janelle slechts spreken van convergentie en divergentie door een ander element in de vergelijking constant te houden, namelijk de afstand tussen twee plaatsen. Hägerstrand en Janelle bieden een systematisch kader om de relatie tussen ruimte en tijd zoals die ontstaat als mensen op reis gaan te kunmen conceptualliseren. Door ofwel tijd (Hägerstrand) ofwel ruimte (Janelle) constant te houden, wordt het mogelijk te vergelijken tussen verschillende manieren van reizen. Deze vergelijkingen hebben echter een enkelvoudige dimensie: sneller of langzamer. Hägerstrands automobilist is sneller dan de wandelaar omdat hij of zij in dezelfde tijd meer kilometers kan afleggen, Janelle's reiziger tussen London en Edinburgh is sneller omdat hij of zij deze afstand in minder tijd kan overbruggen.

Bij de systematiek van Hägerstrand en Janelle zijn twee kanttekeningen te plaatsen. Om te kunnen vergelijken moeten tijd of ruimte constant gehouden worden en dit veronderstelt weer dat we tijd en ruimte niet alleen als relatie, maar ook als afzonderlijke dimensies moeten kunnen opvatten. Tijd kan zo alleen verschijnen als B-tijd. De tweede is dat we met deze systematiek de ontwikkeling van de mobiliteit wel eendimensionaal moeten typeren. Zodra de tijd-ruimte convergentie leidt tot een 'krimpende wereld' waarin mensen al maar grotere tijd-ruimte prisma's ter beschikking hebben, kent dit proces ook maar één richting, namelijk "steeds sneller" (in B-termen). Dat deze typering weinig kritiek ontmoet duidt niet alleen op de dominantie van de drie 'steeds sneller'vertogen die in hoofdstuk $\mathrm{I}$ zijn besproken. Ze sluit ook aan bij een karakteristieke moderne ervaring.

\section{Moderniteit en mobiliteit}

Vanaf het moment dat de stoomboten voeren en de stoomtreinen reden, gaven tijdgenoten van Gontsjarov uitdrukking aan hun verbazing en bewondering door erop te wijzen dat de 'vernietiging van de ruimte en tijd" 
door nieuwe, snellere vervoermiddelen de wereld kleiner zou maken. In 1836 , dus nog voor in Nederland de eerste stoomtrein had gereden, schreef C.E. d'Hanens in een opstel over de invloed van de ijzeren spoorwegen op de beschaving: "Maar ofschoon de ijzeren weg tijd en afstand kunnen vernietigen, zal deze verbetering niet het werk zijn van een dag; $(\ldots)^{\text {". }}$ Ruskin schreef in 1840 dat "no change of pace at a hundred miles an hour will make us one whit stronger, happier or wiser. The railways are nothing but a device to make the world smaller. " Heine vergelijkt de uitvinding van de stoomtrein met die van het buskruit en de boekdrukkunst en schrijft na de opening van de spoorlijn tussen Parijs en Orléans in 1843

"Welke veranderingen zullen er nu optreden in onze waarneming en onze voorstellingen! Zelfs de elementaire begrippen van de tijd en de ruimte zijn in beweging gekomen. Door de spoorlijnen wordt de ruimte gedood en blijft nog slechts de tijd over... In twee uur reist men tegenwoordig naar Orléans, in evenveel uren naar Rouen. Wat zal dat niet betekenen als de lijnen naar Belgiè en Duitsland aangelegd zijn en daar verbonden worden met de spoorlijnen die er al liggen! Het komt mij voor alsof de bergen en wouden van alle landen naar Parijs oprukken. Ik ruik al de geur van de Duitse lindebomen; voor mijn deur rolt de branding van de Noordzee." 3

Uitdrukkingen als "de vernietiging van de ruimte en/door de tijd" en 'de kleiner wordende wereld' waren negentiende-eeuwse karakteriseringen van de ervaring van het machinale reizen. Reizen die vroeger dagen in beslag hadden genomen, duurden nu slechts uren. De grenzen var ruimte en tijd die ooit absoluut waren, leken geslecht en de triomf daarover komt bijvoorbeeld tot uitdrukking in het opschrift op een van de muren van Grand Central Station in New York: The Devourer of Space and Time." 4

Bij Karl Marx krijgt de uitdrukking een plaats in de context van zijn analyse van het belang van snel goederentransport in de kapitalistische economie. In zijn Grundrisse reflecteert hij op de rol van transport en communicatie in de circulatie van het kapitaal. ${ }^{15}$ In haar streven de 
marken van de hele wereld te veroveren tracht het kapitaal 'naar haar natuur' de ruimte te vernietigen door de tijd, dat wil zeggen de tijd die het kost om van de ene naar de andere plaats te bewegen, tot een minimum te beperken. Hoe meer ontwikkeld het kapital, hoe uitgebreider de markt waar het circuleert en hoe meer het streeft naar een nog grotere uitbreiding van de markt, een nog sterkere vernietiging van de ruimte door de tijd.

Voor sociologen en sociaal-geografen die zich bezighouden met onderzoek naar de moderniteit blijken de negentiende-eeuwse metaforen van de 'krimpende wereld" en "de vernietiging van de ruimte door/en de tijd' nog steeds bruikbare vertrekpunten om begrippen als tijd en ruimte te historiseren en te verklaren waarom modernisering niet denkbaar is zonder versnelling. Het werk van de socioloog Giddens en de sociaalgeograaf Harvey illustreert dit.

\section{Giddens en de scheiding van ruimte en tijd}

Giddens heeft de begrippen tijd en ruimte in het hart van de sociale theorievorming geplaatst. Nadenken over menselijk handelen is zinloos zonder daarbij na te gaan hoe dit handelen in tijd en ruimte is georganiseerd, luidt een centrale these in The Constitution of Society ( 1984 ), waarin hij zijn structuratie-theorie ontwikkelt. Veel sociologen, zegt Giddens, beschouwen tijd en ruimte slechts als 'omgevingen van handelen' en hanteren daarmee zonder het zich te realiseren een tijdsbegrip dat stoelt op de meetbare kloktijd die karakteristiek is voor de moderne westerse cultuur. Tijd en ruimte zijn echter niet vooraf gegeven, betoogt Giddens, maar vormen tege $i j k$ voorwaarde voor en uitkomst van menselijk handelen. Handelen krijgt betekenis in de interactie tussen mensen en die interactie is gesitueerd in een tijd-ruimtelijke context. De tijd-ruimtegeografie van Hägerstrand biedt volgens Giddens weliswaar de mogelijkheid de topografie van die tijd-ruimtelijke context te verbeelden, mar gaat daarbij ten onrechte uit van kloktijd als een onproblematische dimensie. ${ }^{16}$ Hoe tijd het socialie leven structureert en tegelijk zelf uitkomst is van dat sociale leven wordt niet duidelijk in de tijdruintegeografie.

In The Consequences of Modernity (1990) analyseert Giddens de 
begrippen tijd en ruimte vanuit het historische perspectief van een nieuwe moderniseringstheorie. Volgens hem schieten de klassieke sociologische theorieên van Marx, Durk heim en Weber tekort omdat ze de mo derniteit reduceren tot een enkele ontwikkeling. De dynamiek van de modernisering is echter niet terug te brengen tot kapitalistische produktieverhoudingen (Marx), noch tot de opkomst van een industriele orde (Durkheim), noch tot processen wan rationalisering en bureaucratisering (Weber). ${ }^{77}$ Elk van deze perspectieven geeft slechts een gedeeltelijke verklaring voor wat Giddens 'de extreme dynamiek en het wereldomspannende bereik van moderne instituties' noemt. ${ }^{\text {I }}$ Zelf verklaart Giddens deze eigenschappen van de moderniteit in drie stappen: de scheiding van tijd en ruimte waarna het opnieuw samenbrengen van beide dimensies een nauwkeurige afstemming wan het sociale leven mogelijk maakt; het 'opheffen' van sociale systemen uit lokale contexten van interactie en herstructureren ervan over grote afstanden in ruimte en tijd; en tenslotte de reflexieve ordening en herordening van sociale relaties in het licht van een voortdurende kennisontwikkeling die het handelen van individuen en groepen beinwloedt. ${ }^{19}$

In premoderne samenlevingen leefden mensen in elkaars nabijheid; informatie reisde net $z o$ snel als de snelste vorm van fysieke verplaatsing. In Giddens' termen: er was een hoge presence-availability. ${ }^{20}$ Interactie veronderstelde dat iemand lijfelijk aanwezig was. Plaats en tijd waren een, "wanneer' was vrijwel overal verbonden met 'waar". ${ }^{2}$. De sleutelgebeurtenis die het begin vormde van de scheiding van ruimte en tijd was de uitvinding van de mechanische klok en de geleidelijke diffusie ervan naar alle geledingen van de samenleving. De opkomst van de kloktijd en de standaardisering van de tijd over grote gebieden en uiteindelijk in de hele wereld leidde tot een uniformering van de sociale organisatie. ${ }^{22}$ In eerder werk gaat Giddens uitvoerig in op wat hij de 'commodificering van de tijd' noemt (Giddens, $198 \mathrm{r}$ ). Met de expansie van het kapitalisme lijkt tijd, net als geld, een uniforme standaard te worden woor de waarde van alle dingen. Tijd als geleefde tijd, als drager van de geleefde ervaring van durée (Bergson) of Dasein (Heidegger), verschijnt nog sleches als gekwantificeerde en verhandelbare duur. ${ }^{23}$ Dit "leegworden" van de tijd vormt de voorwaarde voor het "leegworden van 
de ruimte', het uit elkaar treden van plaats en ruimte. De opkomst wan de moderniteit creeert een nieuwe rumte waarin interacties mogelijk zijn met afwexige anderen. Dit uit elkaar treden van ruimte en tijd, het feir dat het handelen yanmensen uit de concrete context wordt geheven om over grotere afstanden ('distances') in ruimte en tijd te worden geherorganiseerd noemt Giddens time-space distanciation. Hij benadrukt dat juist de scheiding van tijd en ruimte het mogelijk maakt ze opnieuw te combineren. De dienstregeling van een spoorwegmaatschappij is een instrument om tijd en ruimte zodanig te herordenen dat de coördinatie van treinen, passagiers en vracht mogelijk is. ${ }^{24}$

De historische ontwikkeling van de moderniteit die Giddens verklaart uit het 'leegworden van de tijd' heeft een epistemologische consequentie. In de systematiek van Hägerstrand en Janelle is het mogelijk te vergelijken in termen van snel en langzaam, maar dan wordt óf tijd óf ruimte constant gehouden. Giddens beargumenteert dat dit pas mogelijk is nadat beide dimensies in het proces van modernisering zijn ontkoppeld. Met andere woorden, dát het mogelijk is te spreken over snelheid of traagheid in de betekenis van een abstracte relatie tussen ruimte en tijd is volgens Giddens te verklaren uit dezelfde oorzaak als die welke de dynamiek van de moderniteit verklaart, namelijk de witvinding en diffusie van de mechanische klok.

\section{Haney en de compressie van ruimte en tijd}

Ook bij Harvey (1989) vormt het uit elkaar treden van tijd en ruinate een kenmerk van de moderniteit. In premoderne beschavingen was de ervaring van tijd en ruimte sterk gebonden aan de traditionele agrarische, culturele en religieuze ordeningen, stelt Harvey. De Wetenschappelijke Revolutie in de zeventiende eeuw en de Verlichtingsfilosofie van de achttiende eeuw veranderden het denken over tijd en ruimte. Moderne filosofen als Descartes plaatsten de mens in een lege tijd en ruimte. De natuurkunde van Newton versterkte deze notie van tijd en ruimte als abstracte categorieèn, als 'containers' van de gebeurtenissen. Plaatsen werden meer en meer opgevat als delen van een in essentie homogene ruimte. Onder invloed wan uiteenlopende ontwikkelingen als de ontdekkingsreizen (die duidelijk maakten dat de aarde eindig was en 
dus in principe in zijn getieel kenbaar) en de ontdekking van het per spectief in de kunst (waardoor gebroken kon worden met de Middel. eeuwse kunstpraktijken en architectuur), ontstonden nieuwe vormen: van cartografie die het wereldbeeld ingrijpend veranderden. Zeventiende-euwse kaartenmakers tekenden niet langer kaarten waarop de fysieke kenmerken wan het landschap te zien $z i \| n$, maar construeerden netwerken van coördinaten. Deze nieuwe kaarten stimuleerden mensen op hun beurt om op reis te gaan en de 'lege plekken' in te vullen. Iets soortgelijks deed zich voor in de temporele dimensie. De uitvinding van het uurwerk en de geleidelijke maatschappelijke diffusie ervan creëerden een sociale tijd die een universele meetlat ging vormen 'langs' de gebeurtenissen. ${ }^{25}$

Waar Giddens in zijn verklaring van de dynamiek van de moderniteit het primaat geeft aan de opkomst van de kloktijd, stelt Harvey dat we daarmee nog niet hebben begrepen waarom die dynamiek het karakter heeft van een versnelling. ${ }^{26} \mathrm{Hij}$ zoekt daarvoor een verklaring door aan te sluiten bij Marx" dictum van de "Vernichtung des Raums durch die Zeit" als een kenmerk van en voorwaarde voor de kapitalistische produktiewijze. In haar streven de markten van de hele wereld te veroveren tracht het kapitaal "naar haar natuur" de ruimte te vernietigen door de tijd, dat wil zeggen de tijd die het kost om van de ene naar de andere plaats te bewegen, tor een minimum te beperken. Hoe meer ontwikkeld het kapitaal, hoe uitgebreider de markt waar het circuleert en hoe meer het streeft naar een nog grotere uitbreiding van de markt, een nog sterkere vernietiging van de ruinte door de tijd. Expansie van de kapitalistische modernisering leidt tot versnelling.

In The Condition of Postmodernity (1989) betoogt Harvey dat de dynamiek van de kapitalistische expansie verklaard kan worden uit technische ontwikkelingen op het terrein van transport en communicatie. Zo was de economische ineenstorting in Europa na I 848 volgens hem een gevolg van de speculatie in de aanleg van spoorwegen en werd deze crisis opgelost doordat vanaf $x 850$ innovaties de circulatie van het kapitaal opnieuw versnelden. ${ }^{27}$ Deze innovaties en de versnelling van produktie en consumptie die ze veroorzaakten, veranderden ook de ervaring van ruimte en tijd, stelt Harvey. $\mathrm{Hij}_{\mathrm{j}}$ vat deze veranderende erva- 


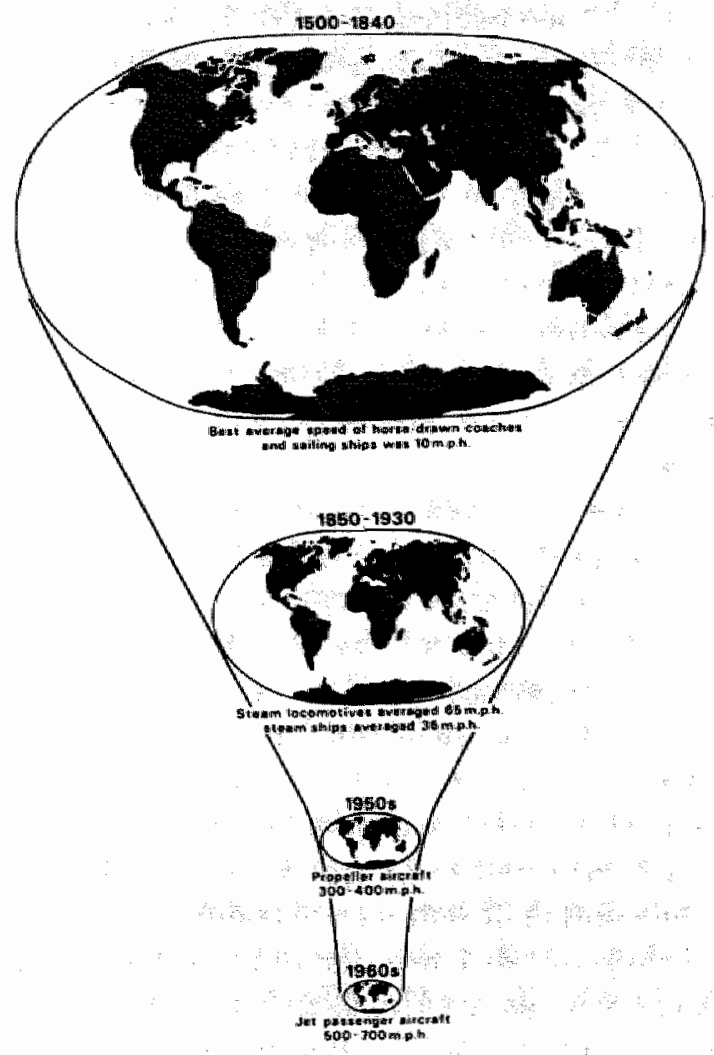

Figuur 3.4: Harvey illustreert aan deze krimpende wereld haart de tijd-ruimte compressie die het gevolg is van transportinnovaties die "de ruimte vernietigen door de tijd". (Bron: Harvey, 1989: 241)

ring samen als 'tijd-ruimte compressie'. Een voorbeeld van tijd-ruimte compressie is de indruk dat de wereld steeds kleiner lijkt te worden (zie figuur 3.4): 'De tijd die het kost om de ruimte te doorkruisen en de manier waarop we ons dat gewoonlijk voorstellen zijn bruikbare aanwij- 
zingen voor het soort verschijnselen dat ik voor ogen heb" ${ }^{28}$ Het zijn volgens hem vooral innovaties in transport-en communicatietechnologie die de wereld kleiner hebben gemaakt. Tussen I 500 en I 840 was de hoogste gemiddelde snelheid die koetsen en zeilschepen konden haler zo"n 5 kilometer per uur. De komst van de stoomlocomotief verkleinde de wereldbol met de helft; stoomlocomotieven halden snelheden van 90 kilometer per uur en stoomboten van wijftig. In de jaren dertig is de wereld weer kleiner dankzij de propellervliegtuigen en in de jaren zestig is zij nog slechts een fractie van de wereld in $x$ soo door de snelheid van het straalvliegtuig. De geschiedenis van het kapitalisme kan geschreven worden als éen grote lange-termijn investering in de verovering van de ruimte door de ontwikkeling van transport- en communicatietechnologie. ${ }^{29}$

Verwijzend naar Kern ( 1.983 ) benadrukt Harvey dat de fasen van crisis en versnelling van de circulatie van het kapitaal als effect hebben dat crises ontstaan in de ervaring en representatie van ruimte en tijd. De toepassing van de lopende band door Ford in zijn autofabriek in River Rouge in 1913 fragmenteerde de taken van de werknemers en leidde tot een herverdeling van het werk in ruimte en tijd om de productie zo vloejend mogelijk te organiseren. Tijd werd versneld door het herorganiseren van de ruimtelijke orde van de produktie. In hetzelfde jaar werd vanaf de Eiffeltoren het eerste radiosignaal uitgezonden dat op hetzelfde moment (simultaan) in de hele wereld te ontwangen was. Modernistische ontwikkelingen in de kunst - de romans wan James Joyce, de atonale muziek van Schönberg en anderen waarin het tonale centrum was verdwenen en de kubistische schilderijen van Picasso en Braque - vormen volgens Harvey de uitdrukking van het feit dat de fordistische economie ruimte en tijd versnelde, comprimeerde en fragmenteerde. ${ }^{30}$

Harvey heeft nu historische processen van tijd-ruimte convergentie zoals ze in Janelle's termen beschreven kunnen worden - het afnemen van de hoevelheid tijd die het kost om een afstand te overbruggen verklaard uit de kapitalistische circulatie. Hij spreekt van 'compressie' en niet van 'convergentie', ondat London en Edinburgh niet alleen in gemeten reistijd maar ook in de ervaring van mensen dichter bij elkaar komente liggen. 
Een toeschouwersperspectief op innovatie

We hebben gezien dat 'reistijd' als duur van de verplaatsing betrekking heeft op de relatie tussen ruimte en tijd. Geografen als Hägerstrand en Janelle hebben een systematiek ontwikkeld om ontwikkelingen in deze relatie te beschrijven. Door ofwel ruimte te herleiden tot tijd (Hägerstrand) ofwel tijd te herleiden tot ruimte (Janelle) creëren zij het vergelijkend perspectief waarin twee manieren van reizen vergeleken kunnen worden op het abstracte niveau van twee snelheden. Maar als we groei van de mobiliteit willen verklaren, dan voegt deze systematiek geen nieuwe elementen toe aan het type verklaringen dat Hupkes kan geven door uit te gaan van de hypothese van de constante reistijd.

Voor verklaringen die het begrip reistijd contextualiseren en historiseren moeten we volgens Bauman te rade gaan bij een goed opgeleide socioloog om 'het sterrenbeeld van de versnelling en de verovering van het land' te lezen. Inderdaad, Giddens en Harvey (al is die dan sociaalgeograaf) komen een heel eind. Redenerend in de lijn van Giddens begrijpen we nu dat verkeerskundigen als Hupkes en sociaal-geografen als Hägerstrand en Janelle een kwantitatief begrip van tijd in de B-serie kunnen gebruiken omdat dit tijdsbegrip in het proces van modernisering is 'leeggemaakt', dat wil zeggen losgemaakt uit premoderne, reëel bestaande contexten. Opgevat als kloktijd krijgt 'reistijd' pas weer betekenis in de samenvoeging met ruimte in een concrete situatie, bijvoorbeeld in de dienstregeling van een spoorwegmaatschappij. Harvey maakt duidelijk dat het streven naar verkorting van de reistijd goed te verklaren is uit de versnelling die het gevolg is van kapitalistische expansie.

Bij nadere beschouwing zijn deze redeneringen problematisch. Zowell Giddens als Harvey zoeken de oorzaak voor de veranderingen steeds in een quasi autonome technische ontwikkeling. Bij Giddens is dit de uitvinding van het uurwerk, de cartografie en het kadaster, Harvey voegt daaraan innovaties op het terrein van de transport- en communicatietechnologie toe. Wegen en kanalen, spoorlijnen, stoomschepen, de telegraaf, de radio en de auto, de containerisatie, het vliegverkeer, televisie en andere vormen van telecommunicatie hebben niet alleen de verhoudingen tussen tijd en ruimte veranderd, maar ook geleid tot nieuwe re- 
presentaties van de ruimte. Het vermogen tijd te meten en te verdelen sterk vergroot waardoor het mogelijk werd de snelheid van de produktie op te voeren (automatisering, robotisering), maar ook de bewtgingssnelheid van goederen, mensen en informatie. ${ }^{31}$

Hoewel de uiterlijke oorzaak voor de dynamiek van de moderniteit bij Giddens en Harvey verschilt (respectievelijk de mechanische klok en vervoers- en communicatietechnologie) vallen beiden terug op technologie als laatste verklarende instantie. Deze technisch-deterministische manier van redeneren is karakteristiek voor veel sociologische en socaal-geografische beschouwingen over ruimte en tijd. De versnelling van de maatschappij - en daarmee de veranderingen in ruimte en tijd - zijn hierin een gevolg van technische ontwikkelingen. Nu zou het onzin zijn te ontkennen dat straalvliegtuigen de reistijd naar de Verenigde Staten hebben bekort ten opzichte van de transatlantische stoomschepen uit de negentiende eeww, of dat deze ontwikkeling ons besef van tijd en afstand heeft veranderd. Maar het is de wereld zoals die er door de ogen van Gontsjarov uitziet. Voor Gontsjarov is het zeilschip Pallas een pijnlijke illustratie van menselijk onvermogen en verbeeldt het stoomschip de voortuitgang van wetenschap en techniek. Met Gontsjarov delen Giddens en Harvey het idee dat het stoomschip de bron is van innovatie in moderne samenlevingen en niet het produkt ervan. ${ }^{3.2}$

Tegenover het toeschouwersperspectief van Gontsjarov zouden we het perspectief van de kapitein van de Pallas kunnen plaatsen. Gontsja rov vervolgt het citaat waarmee dit hoofdstuk opende zo:

'Vergeefs heeft de kapitein me laten zien hoe mooi de zeilen in de wind bollen, of hoe het fregat op zijn zij gaat en met twalf knopen (een knoop is eenendriekwart verst) per uur over de golven scheert. "Zo, dat haalt zelfs een stoomboot niet," zegt hij tegen me. "Maar een stoomboot vaart altijd, terwijl wij twee etmalen twee knopen gaan en dan tien etmalen heen en weer dobberen op de Noordzee, en bij tegenwind Het Kanaal niet kunnen bezeilen." "Die verduivelde stoomboten kunnen me gestolen worden!" zegt de kapitein, wiens hele verstand, kennis en vernuft, en ook trots, eerzucht en alle overige sentimenten gericht zijn op takelages. Intussen laat men alle fre- 
gatten en schepen met stoommachines uitrusten: u kunt zich zijn toestand voorstellen en die van de rest van de heren zoals hij, die zo'n twintig jaar wan hun leven hebben gegeven om de namen van al die duizenden touwtjes van buiten te leren. ${ }^{3 / 3}$

De kapitein beschouwt de voortbeweging van zowel het zeilschip als het stoomschip vanuit een actorperspectief. Hij realiseert zich dat om een boot, om het even of het een zeil- of een stoomschip is, in beweging te krijgen er veel werk verzet moet worden.

Anders dan Bauman veronderstelt, hebben we niet genoeg aan een socioloog om de moderne constellatie van 'de versnelling en de verovering van het land' te kunnen lezen. De technische artefacten die bezien vanuit het perspectief van de toeschouwer kunnen gelden als een stabiele verklaring voor veranderingen in ruimte en tijd, verschijnen vanwit een actorperspectief als de resultaten van een complexe verwevenheid van sociale en technische ontwikkelingen. Technologie vloeit niet als vanzelf voort uit een neutrale bron van innowatie. Ze wordt gevormd uit sociale, economische en technische relaties die reeds bestaan. $\mathrm{Om}-$ gekeerd, als produkt van de bestaande structuor van mogelikheden en beperkingen, verandert, vormt en reproduceert technologie die structuur op een manier die min of meer onvoorspelbaar is. ${ }^{34}$

Het stoomschip vaart niet op eigen kracht de wereld van Gontsjarov binnen.

\section{De excursies van Thomas Cook}

Stoomtreinen werden aanvankelijk gebruikt om goederen te vervoeren. $\mathrm{Al}$ in de zestiende eeuw werden lorries op houten rails gebruikt in de mijnbouw om de steenkool aan de oppervlakte te verplaatsen. Deze toepassing bleef de belangrijkste tot aan het begin van de negentiende ceuw, toen George Stephenson de lorries woorzag van een stoomlocomotief. De eerste spoorlijn ter wereld, de Stoekton and Darlington Railway die in $\mathrm{r} 825$ werd geopend, liep van het grote Auckland kolenveld naar Stockton, van waar de kolen per boot verder vervoerd konden wor- 
den. ${ }^{35}$ De exploitanten van de lijn hadden weliswaar de bedoeling ook passagiers te vervoeren, maar hoge verwachtingen daarvan had men niet. Stephenson kreeg toestemming om in Newcastle een passagiersrijtuig te maken dat de toepasselijke naam Experiment $\mathrm{kreeg}{ }^{36} \mathrm{Het}$ rijtuig had aan beide zijden een rij zitplaatsen en in het midden en lange tafel. De ingang was aan het achtereinde. Het geheel leek op een door paarden getrokken omnibus.

Geheel tegen de werwachting in werd de treinrit van Darlington naar Stockton een succes. Spoorwegmaatschappijen begrepen al snel dat passagierstreinen naast goederentreinen nodig zouden zijn om spoorlinnen winstgevend te kunnen exploiteren. Overigens zagen de passagiers de stoomtrein in de eerste plats als een kermisattractie. Dat was niet zo vreend, want in sommige gevallen stonden de passagiers rechtop in open badkuipen, en werden bedekt met as en vonken uit de schoorsteen van de machine. ${ }^{37}$ Het treinreizen won snel aan populariteit. De spoorlijnen boden ontspanning aan mensen die niet gewend waren zich verder te verplaatsen dan naar de dichtst bijzijnde markt, of andere bestemmingen die binnen loopafstand lagen; de prijzen van de postkoets waren immers veel te hoog. Maar voordat de trein deze positie had bereikt moest et veel werk verzet worden en dat gebeurde voor een niet onbelangrijk deel door Thomas Cook.

\section{Een excurstie voor gebeelontbouders}

Op 9 juni 184 was de 33 -jarige Cook te voet onderweg van zijn huis in Market Harborough naar een bijeenkomst van geheelonthouders in Leicester, toen hij een idee kreeg dat volgens zijn biograaf Brendon ( $199 \mathrm{I}$ ) de wereld zou veranderen. ${ }^{38} \mathrm{Hij}$ bedacht dat het organiseren van excursies per trein een uitstekende manier zou zijn om mensen van de drank te houden. De afleiding die de spoorwegen verschaften, vormde in zijn ogen een middel om 'vooruitstrevende en democratische" krachten te versterken. $Z$ ijn voorstel werd tijdens de vergadering enthousiast ontvangen door zijn mede-geheelonthouders. Speciale tickets werden gedrukt en verkocht, en zo vertrok op 5 juni i 84 I een volle trein uit Leicester op weg naar het nabijgelegen Loughborough en terug. ${ }^{39}$ De excursie was vooral een demonstratie van geheelonthouders; langs elke 
brug stonden toeschouwers en toen de trein in Loughborough arriveerde werd ze begroet door een enthousiaste groep medestanders. Na drie uren van speeches kon Cook ter afsluiting uitroepen: 'One cheer more for 'Teetotalism and Railwayism!!'.4\%

De excursie was de eerste in een lange reeks die Thomas Cook zou organiseren. Volgens Brendon lag zijn kracht in het feit dat hij niet alleen de mogelijkheden voor recreatie per trein onderkende, maar er ook in slaagde om ze voor grote groepen mensen toegankelijk te maken. Want hoezeer de trein ook tot de verbeelding sprak, de meeste mensen vonden reizen per trein duur en moeilijk. Treinreizen moest je leren en Cook hielp daarbij. In 1842 was weliswar het Railway Clearing House opgericht met de bedoeling om orde te scheppen in de chaos van kleine, elkaar fell beconcurrerende spoorwegmaatschappijtjes, het viel voor de gewone man niet mee om uit de veelheid kaartjes en lijnen de goedkoopste te kiezen. Aan het begin van de jaren veertig van de negentiende eeuw was er een specialist nodig om reizen te organiseren over de lijnen wan de verschillende spoorwegmaatschappijen en daarbij zo gunstig mogelijke tarieven in de wacht te slepen. Cook werd zo'n specialisit. Hij onderhandelde met de verschillende spoorwegmaatschappijen langs de trajecten die hij wilde afleggen om de goedkoopste kaartjes te realiseren. ${ }^{41}$

Om mensen aan het reizen te krijgen, was het niet genoeg om ze goedkope treinkaartjes te verkopen, realiseerde Cook zich. Ze moesten een reden hebben om ergens heen te gaan en ze moesten bovendien iets te doen hebben op hun bestemming. De reizen die Cook in 1846 organiseerde naar Schotland, sloten daarom aan bij het beeld van de woeste hooglanden dat was gecreëerd in de romans en gedichten van Sir Walter $S$ cott. Op grond van deze literaire teksten creëerde Cook wat Shields (199r) en Lash \& Urry (r.994) 'plaatsmythen' hebben genoemd. Deze plaatsmythen zijn verhalen en beelden rond plekken - van het romantische Schotland tot de tragedie van Pompei - die mensen een aanleiding gaven om zo'n plaats te willen bezoeken. Urry geeft het voorbeeld van Stratford-upon-Avon dat al twee eeuwen lang op de kaart staat als een verbazend succesvolle toeristische trekpleister. ${ }^{42}$

In de jaren vijftig waren de tours naar Schotland zo'n succes gewor- 
den, dat de toeristen van Cook door de Schotten als een eigen 'clan' werden gezien. In 1860 had Cook ruim vijftigduizend toeristen naar Schotland vervoerd en daarmee, zoals de Schotse historicus Harvie het uitdrukte, "het werk van Scott voltooid'. ${ }^{43}$ Passagiers van Cook kregen voorrang in Schotse rijtuigen. Schotse hotelliers probeerden de goedkeuring van Cook te krijgen en gaven zijn gasten de beste plaatsen.

De Great Exhibition in I 85 , de wereldtentoonstelling in London, is een ander voorbeeld van een gecreëerde besternming. Niet minder dan zes miljoen bezoeken werden afgelegd aan de tentoonstelling in Crystal Palace, op een bevolking van destijds achttien miljoen. Cook verzorgde de reis van $x 65.000$ bezoekers - en dat alles nog maar een kwart eeuw nadat de eerste treinen in Engeland waren gaan rijden. Drie dagen na de opening van de tentoonstelling verscheen het eerste nummer van Cook's Exbibition Herald and Excursion Advertiser, te koop voor een penny. Het blad zou, als Cook's Excursionist tot aan het uitbreken van de Tweede Wereldoorlog bestaan. Zoals Cook in het eerste nummer schreef, wilde de Excursionist vooral 'een praktische werker zijn eerder dan een sentimentele reiziger'. Hij gebruikte het blad om zijn arrangementen te adverteren, om nieuwe excursies aan te bevelen, om de opening van nieuwe routes bekend te maken en in het algemeen om iets als een 'reisgewoonte' aan te kweken. Er stonden de meest uiteenlopende advertenties in, van geheelonthoudershotels tot stoombootmaatschappijen, maar ook voor handige reisattributen als Bailey's Air Cushion ('vermindert de effecten van trillingen op het zenuwstelsel') en Walter's Railway Convenience ('kan onzichtbaar gedragen worden met het grootste comfort en zekerheid'). ${ }^{44}$

Toen vier jaar later een Wereldtentoonstelling in Parijs werd georganiseerd, regelde Cook opnieuw de hele reis: de aansluitingen tussen de verschillende spoorweg-en scheepvaartmaatschappijen, de boekingen in hotels en restaurants die de reizigers onderweg bezochten, de verscheping van de bagage en de informatievoorziening aan de reizigers. Behalve naar Parijs, organiseerde Cook reizen naar steden als Brussel en Keulen en, vanaf i 860, ook naar de Alpen en Italië. Ook hier borduurde hij voort op de mythen die rond deze plaatsen waren geschapen door romantische auteurs als John Ruskin. Overigens veroorzaakten de 
georganiseerde reizen van Cook veel onrust onder het Londense establishment, dat de toeristen van Cook beschouwde als vandalen, "mental patients' of ook wel de 'horden van Cook'.

Cook zocht zorgvuldig uit wanneer en waar zijn reizigers moesten overstappen zodat geen tijd verloren ging met wachten op aansluitingen. Hij sloot overeenkomsten met hotels en restaurants onderweg en liet soms maaltijden langs de trein serveren om sneller weer te kunmen vertrekken. Brendon ( 1991 ) noemt het bijna ongeloofwardige voorbeeld van een diner van negen gangen dat werd geserveerd op het perron aan de reizigers in een wachtende trein in de tien minuten dat de trein er stopte. ${ }^{45}$ Naar Amerikaans voorbeeld regelde Cook dat de bagage van de reizigers onafhankelijk van hen werd vervoerd, zodat zijn toeristen niet zelf hoefden te zeulen met hun zware koffers. ${ }^{6} 6$

Zeer succesvol waren de reizen die Cook vanaf de jaren zestig organiseerde naar Egypte en andere bestemmingen in het Midden-Oosten. Aan het eind van de negentiende eeuw had het bedrijf, dat inmiddels door zijn zoon John Mason werd geleid, een vloot van twintig Nijlschepen. Het varen op deze schepen stond overigens model voor de relatie tussen de toeristen van Cook en de lokale bevolking; leunend over reling, een Egyprische sigaret in de hand, keken de Engelse reizigers over het water naar de lokale bevolking die op de oevers an het werk was. Cook zag het als zijn taak zijn reizigers zoveel mogelijk af te schermen voor de minder aangename aspecten a an het leven in de landen die hij aandeed.

Vanaf 1865 bood het Londense kantoor van Thomas Cook and Son reizigers de gelegenheid om treinkaartjes te kopen tot aan hun bestemming voor de verschillende spoorwegmaatschappijen in Europa. Zijn plaatselijke medewerkers zorgden op alle tussengelegen stations voor de betrouwbaarheid van de verschillende schakels in het keten. Het netwerk van het Britse reisbedrijf strekte zich na 1870 uit over het hele Britse imperium en daarbuiten. Uit deze periode tijd dateren ook de zogenaamde Circular Notes, een soort kredietbrieven die bij banken binnen de netwerken van Cook waren in te wisselen, de voorlopers van de befaamde 'travelers cheques'. Een andere vinding van Cook waren de zogenaande Hotel Coupons die voor het vertrek konden worden aangeschaft en de reizigers de mogelijkheid gaven te overnachten in een hotel onderweg. 


\section{Een reis om de wereld}

In 1872 verwezenlijkte Cook een droom: een excursie om de wereld. Deze reis werd onder meer mogelijk door de opening van het Suez Kanaal, de oprichting van lijndiensten van de westkust van de Verenigde Staten naar Japan en China en de opening van de eerste transcontinentale spoorweg in de Verenigde Staten. Benieuwd naar de Verenigde Staten, India en het Verre Oosten maakte Cook - inmiddels 64 jaar oud - eerst zelf de reis, om vast te kunnen stellen dat het allemaal een stuk eenvoudiger was dan hij gedacht had. De brieven die hij naar de redacties van The Times en Leicester Papers schreef, geven een tamelijk laconieke indruk van de onderneming. Anders dan Phileas Fogg in Verne's Reis om de wereld in tachtig dagen reisde Cook van oost naar west. ${ }^{47}$ Afgezien van "hard gales and strong head winds" tijdens de Atlantische overtocht verliep de reis rimpelloos. In New York bleef hij vijf dagen, 'sufficient for the general purposes of sighseeing'. Per trein trok hij van New York naar San Francisco, via de Niagara Falls, Detroit, Chicago en Salt Lake City. ${ }^{48}$

In een aparte brief schrijft Cook lovend over het reizen in de Verenigde Staten. De rijtuigen zijn comfortabeler dan de Engelse ook het bagagesysteem is handiger. De Baggage Express Company haalt de koffers en kisten op wit het hotel en op het station voorzien van een 'strap and brass indicator being attached to it, a corresponding brass check being given to its owner'. Bij het naderen van de bestemming loopt een employee van de Baggage Express Company door de trein en verzamelt de koperen plaatjes en geeft en ontvangstbewijs, waarna de koffers naar het hotel worden gebracht. Tevreden is Cook ook over het zogenaamde 'lie-over ticket', een kaartje tot de eindbestemming waarmee de reis op elk gewenst station kan worden onderbroken. Ook de rijtuigen zijn comfortabel, ook al is 'the admixture of strangers and sexes very repulsive to the English traveller'.

Van San Francisco reist Cooks gezelschap per stoomboot naar Yokohama. Onderweg heeft hij alle tijd on zijn brieven te schrijven, die op volle zee aan cen passerend schip worden meegegeven en via de Verenigde Staten naar Londen worden verzonden. 
Binnen een week tot tien dagen verwachten we de honderdtachtigste lengtegraad te bereiken, wanneer Londen onder onze voeten zall liggen en er op geheimzinnge wijze een dag van de kalender zal werdwijnen. Maar dit reizen rond de wereld is een erg gemakkelijk, nauwelijks opgemerkte bezigheid; er is geen enkele moeilijkheid aan (...) $)^{\text {49 }}$

Bij het passeren van de meridiaan gaat het gezelschap naar bed op vrijdag 17 movember en staat op zondag de $19^{\mathrm{e}}$ november op, een puzzel waraan Cook veel aandacht besteed. ${ }^{\text {*0 }}$

Zo positief als Cook schrijt over de Japanse havensteden Yokohama, Osaka en Nagasaki - waar het gezelschap porseleinen vazen koopt -, zo laatdunkend luidt het oordeel over Shanghai. 'Narrow, fillthy, and offensive streets, choked and almost choking bazaars, pestering and festering beggars in every shape and hideous deformity. (...) I do not think that the coolies who wheel residents about in barrows got many 'cash' from our party.' Na vierentwintig uur houdt het gezelschap Shanghai voor gezien en gaat aan bood van een kuststomer naar Hong Kong. Daar bleek te weinig tijd om de stad en Canton goed te bekijken, de reis ging verder aan boord van de Mirzapore naar Singapore en van daar naar India. Uitwoerig beschrijft Cook de kwaliteit van de treinen en de hotels in de belangrijkste steden langs de route: Calcutta, Serampore, Agra (waar het gezelschap de Taj Mahal bewondert), Cawnpore, Lucknow, Delhi, Allahabad, Jubbulpore en Bombay.

Van Bombay voer het reisgezelschap op een mooi stoomschip van de Peninsular and Oriental line, de Hydaspes, naar de Rode Zee en van daar naar het Suez kanaal. Cook heeft zijn doel bereikt; hij kent de route rond de wereld, weet hoe de treintickets verkregen moeten worden en heeft overnacht in de beste hotels. De reis van Egypte terug naar Londen is voor zijn frma al jaren routine.

'Tk heb het gevoel dat $\mathrm{k}$ de te verwachten moeilijkheden op de route heb opgelost; ik weet nu welke adviezen ik moet geven aangaande tijdstippen, uitgaven en allerlei soorten onderkomens; en de details over deze zaken zal ik ter beschikking stellen aan het publiek om hen die na mij komen te gidsen, want zelf overweeg ik niet een 
tweede reis rond de wereld. Na tweeëndertig jaar onophoudelijkge reisd te hebben met het oogmerk reizen gemakkelijk, goedkoop en veilig te maken voor anderen moet ik nu gaan "uitrusten en tevre. den zijn" dat mil geen onheil is overkomen." 5 .

\section{Passages}

Het lijdt geen twijfel dat de wereld voor Cook in 1872 en 1873 kleiner was dan voor Gontsjarov die haar twintig jaar eerder omcirkelde. Zoats eerder bleek, nemen Giddens en Harvey ervaringen als die van Cook als vertrekpunt voor beschouwingen over het uit elkaar treden van ruimte en tijd en de versnelling die aan de basis ligt van de ervaring van tijd-ruimte compressie die kenmerkend is voor de kapitalistische moderniteit. Precies de ontwikkeling die Cook in ruim dertig jaar mee in gang zette - van een plaatselijke excursie tot een reis om de wereld - zou kunnen gélden als onderbouwing voor deze thesen. Hoe is het bezwaar van technisch determinisme te ondervangen? Door een actorperspectief in te nemen en te zien welke innovaties Cook tot stand moest brengen om de wereld kleiner te kunnen maken : $^{52}$

De onderneming van Cook is niet denkbaar zonder spoorwegen en stoomboten, maar laat tegelijk zien dat deze vervoermiddelen of de aanleg van de transcontinentale spoorlijn in de VS en het Suezkanaal op zichzelf genomen niet afdoende verklaren waarom zoveel mensen op reis gingen. Cook verkocht reizen ('excursions') en om dat te kunnen doen, om de snelle verplaatsing als een produkt aan te kumen bieden, moest hij passages maken. ${ }^{53}$ Hij moest als 'heterogene ingenieur' uiteenlopende elementen in een netwerk aan elkaar verbinden om zijn klanten snel van de ene naar de andere plaats kunnen brengen. ${ }^{54}$ In de spreektaal heeft her begrip 'passage' meerdere betekenissen en die hel. pen om de heterogeniteit van Cook's excursies uit te werken.

De passage als heterogene orde

Het maken van een reis veronderstelt de aanwezigheid van een ruimtelijke én een temporele orde. Het woord 'passage' drukt deze beide as- 
pecten uit: het heeft tegelijk betrekking op een tijdsverloop, op het passeren $\mathrm{c} . \mathrm{q}$. het verstrijken van de tijd, maar ook op de ruimte die men doorkruist. Een passage is tegelijk een tijdsspanne en een doorgangsruimte. Waar geografen als Hägerstrand ruimte en tijd als 'dragers' van de beweging opvatten - een reiziger beschrijft dan lijnen door een lege, Euclidische ruimte en tijd -, wil het begrip passage duidelijk maken dat een verplaatsing een spatio-temporele orde impliceert waarin ruimte en tijd niet los van elkaar te zien zijn. ${ }^{55}$

In zijn boek over de ruimtelijke orde van Nederland tussen $1798 \mathrm{en}$ 1848 omschrijft Van der Woud $(1987)$ het begrip orde als 'een abstract begrip met analogieën als kosmische orde, sociale orde, economische orde, juridische orde".

'Het veronderstelt een innerlijke samenhang, een zekere bouw - of die nu bewust door de mens veroorzaakt is of niet. Deze orde kan zo complex van aard zijn dat ze paradoxaal of zelfs chaotisch van aard schijnt. De ruimtelijke inrichting kan aldus een onderdeel zijn van de ruimtelijke orde - een materieel, stoffelijk onderdeel. De orde zelf is echter meer dan alleen materieel en omvat naast de door de mens vervaardigde elementen zoals bruggen, het polderpeil, de steden, de zeeweringen, ook het ongevormde, het gegroeide, naast het opgebouwde ook het verval, naast het meet-en weegbare ook de relatieve betrekking tussen ruimte en tijd, snelheid en traagheid, mobiliteit en stagnatie"s6

Naar analogie van Van der Wouds ruimtelijke orde veronderstellen de passages die Cook malkte een spatio-temporele orde die heterogeen en complex is, en niet alleen bestaat uit materiële elementen als treinen, seinen, stations, hotels, stoomboten en hotelcoupons, maar ook uit immateriële zoals geheelonthoudersidealen, plaatsmythen en koloniale vooroordelen.

\section{Een regelmatige en contingente orde}

De spatio-temporele orde van de passage is enerzijds regelmatig, gepland en voorspelbaar, maar ook onvoorspelbaar en toevallig. Er is de passa- 
ge die vooraf gemaakt kan worden, in het voorbeeld van Cook de ress. die door de firma in de brochure kan worden aangeboden dankzij het samenhangend geheel van infrastructuur, dienstregelingen, maar ook de plaatsmythen en reeds bestaande verwachtingen over de bestemming bij reizigers dat samen de "reis naar Schotland' vormt. Maar de passage wordt ook voortdurend herbevestigd of juist veranderd door de activiteit van het reizen. In de reisgids van Cook waren alle reizen eender, maai elke Schotland-reiziger maakte een andere reis. Beide betekenissen keren terug in de uitdrukking 'passage nemen' zoals die gebruikelijk was voor reizen per pakketboot. Men kocht een overtocht, maar begon die pas op het moment dat men daadwerkelijk aan boord ging.

De spatio-temporele orde van de passage moet voortdurend onderhouden worden. Een van de manieren waarop Cook mensen aan reizen kreeg was het reduceren van de onzekerheid en toevalligheid onderweg. lemand die met Cook op reis ging, hoefde zich nooit verloren te voelen in een vreemde wereld. Overal had Cook onderweg zijn plaatselijke agenten en werknemers gestationeerd. The Man from Cooks, een bescheiden beambte met een firmapet op zijn hoofd die reizigers assisteerde bij het instappen in de trein en hen met raad en daad terzijde stond, werd legendarisch. Innowaties als de hotelcoupon, het bagagesysteem, de traveler cheques waren niet slechts een manier om de reis sneller te laten verlopen, maar reduceerden ook de onzekerheid voor de Britse reiziger in den vreemde. Al vanaf zijn eerste excursies realiseerde Cook zich het belang van reisgidsen en handboeken. Hierin vonden reizigers praktische informatie over lokale omstandigheden, voorzieningen en gewoonten. Door de bestemming zo uitvoerig te beschrijven, werd de onzekerheid weggenomen bij de reiziger.

Meer en snellere treinen zorgden voor nieuwe contingenties. Waar het voorheen geen probleem was een paar minuten te laat te arriveren bij de postkoets, was dat bij de trein wel een probleem. Het historische standaardbeeld luidt dat naarmate de spoorwegnetwerken complexer werden en het aantal reizigers toenam, de noodzaak groeide het reizen in de tijd zo exact mogelijk te organiseren. ${ }^{57}$ Om de spoorboekjes te laten kloppen, moesten vertrek-en aankomsttijden tot op de minuut worden berekend. Deze noodzaak vertaalde zich in een praktijk van 
temporele precisie en een groeiende vraag maar goede horloges. Beschouwingen over de opkomst van het horloge in het dagelijks leven van de negentiende eeuw laten deze wisselwerking mooi zien: het uurwerk schiep de voorwaarden voor zijn eigen verspreiding ${ }^{58}$ - naarmate het reizen strakker in de tijd werd georganiseerd zou iemand zonder goed horloge onverbiddelijk de trein missen.

\section{Binnen en buiten de passage}

Het begrip passage veronderstelt een binnen- en een buitenkant. Het maakt duidelijk dat in de spatio-temporele orde van de passage mensen, plaatsen en tijdstippen al dan niet zijn in- of uitgesloten. De passages van Cook maakten de wereld kleiner maar niet voor iedereen. Voor de meeste Egyptenaren die gadegeslagen werden door de Britse toeristen wanaf hun Nijlboot was zij nog even groot als in de dagen van de farao's. Ook in Groot-Brittannië zelf bleef het reizen rond de wereld een zaak wan enkelingen; de snelheid die binnen Cooks passages mogelijk was, was voor weinigen weggelegd. Toen Thomas Cook in 1892 overleed, hadden zo'n twintig reisgezelschappen de reis rond de wereld gemaakt - minder dan duizend mensen, volgens de (waarschijnlijk overtrokken) schatting van Cooks zoon John. ${ }^{59}$ Het reizen rond de wereld mag dan een zaak van elite zijn geweest, Cooks andere excursies maakten het reizen voor de opkomende Victoriaanse middenklasse bereikbaarder dan ooit. Dat gold in het bijzonder voor vrouwen en talrijk zijn dan ook de reisverslagen van welgestelde dames uit die tijd ${ }^{60}$

De spatio-temporele orde van de passage garandeert een snelle verplaatsing, maar niet overal en altijd. Dit wordt duidelijk aan de hand van de reisroute die Cook en na hem de wereldreizigers die bij hem te klant waren volgden. Zoals Withey ( 1997 ) aangeeft, bleef de route die zowel Fogg als Cook aflegden - Londen, New York, San Francisco, Yokohama, Shanghai, Hong Kong, Singapore, Calcutta, Bombay, Suez, Londen - gedurende decennia de enige. Dat juist deze route werd gevolgd komt volgens Withey omdat de diensten van de grote stoombooten spoorwegmaatschappijen een directe uitdrukking waren van de wes terse unvloed in het Midden-Oosten en Azië. ${ }^{61}$ De snelheid die Cook zijn klanten kon bieden was het resultaat van een spatio-temporele orde die 
niet alleen vorm kreeg dankzij snelle treinen en schepen, maar evenzeer de politieke topografie van het kolonialisme weerspiegelde. ${ }^{62}$ Zodra men van de standaardroute afweek, veranderde de rumtelike en temporele orde van de verplaatsing ingripend; wie in de negentiende ceuw vanuit de vs naar Australiè of Nieuw Zeeland wilde, moest naar Honolulu varen en daar wachten op het eerste schip dat naar het zuiden voer, en dat kon weken duren. Van een éénduidig krimpende wereld, zoals figurur 3.4 suggereert, was geen sprake.

\section{Conclusie}

We kunnen nu op een andere manier over 'reistijd' spreken dan als B-tijd, als de duur gemeten in kloktijd van een reis of de abstracte verhouding tussen ruimte en tijd zoals geografen als Hägerstrand en Janelle die voorstellen. Het tijdsbegrip dat aan deze opvattingen ten grondslag ligt, is zelf het resultaat van een historische ontwikkeling die door sociologen als Giddens en sociaal-geografen als Harvey is beschreven als 'time-space distantiation" en 'time-space compression'. Ik heb betoogd dat deze begrippen, die teruggaan op de negentiende-eeuwse topos van de 'annihilation of space through time', een belangrijk bezwaar hebben. De relatie tussen tijd en rumte in een verplaatsing wordt weliswaar gecontextualiseerd en gehistoriseend, en er wordt zo cen eerste stap gezet naar een tijdsbegrip in de C-serie, maar daarbij wordt de uiteindelijke verklaring voor de historische ontwikkeling gezocht in de uitvinding en diffusie van de mechanische klok (Giddens) of in de ontwikkeling van transport-en communicatiemiddelen (Harvey).

Om an deze reductie te ontkomen heb $\mathrm{k}$ aan het voorbeeld van de excursies van Thomas Cook laten zien dat de innovaties die Giddens en Harvey als de verklaring voor de scheiding van ruimte en tijd opvatten - bijwoorbeeld de stoomboten en -treinen die de wereld kleiner maakten - zelf uitgevonden moesten worden. Cook makte als heterogene ingenieur passages. Nieuwe vervoermiddelen zoals de stoomboot en de stoomtrein waren geen voldoende voorwaarde om het Cooks toeristen mogelijk te maken zoveel sneller te reizen dan hun voorouders hadden 
gedaan. Er moesten voldoende reizigers worden gemobiliseerd om de prijs zo laag mogelijk te houden; er moest onderhandeld worden over tarieven met verschillende spoorwegmaatschappijen, met hoteleigenaars en restauranthouders; er moesten "plaatsmythen" in stelling worden gebracht om mensen een argument te geven om te reizen en er moesten reisgidsen komen waarin de bestemming werd toegelicht; er moesten bagagesystemen komen; er waren onderweg werknemers van de firma aanwezig om problemen op te lossen, waardoor het mogelijk was snel weer verder te reizen.

De passages van Cook impliceerden een spatio-temporele orde die zowel materiële als immateriële elementen omvatte. Cooks onderneming trachtte de onvoorspelbaarheid en onzekerheid van het reizen te reduceren, maar de exacte afstemming van de onderdelen van de passage veroorzaakte ook nieuwe contingenties. De reistijd in de dagen van Thomas Cook werd steeds preciezer gemeten en liet minder ruimte voor traagheid en toeval, op straffe van het afbrokkelen van de passage. De passages van Cook maakten het mogelijk sneller te reizen, maar niet voor iedereen en niet naar elke denkbare plaats of op elk gewenst moment.

Waar het B-tijdsbegrip van 'reistijd' zoals verkeerskundigen dat gebruiken abstraheert van de spatio-temporele orde die snelheid mogelijk makt en er daardoor aan vooraf gaat, maakt het concept 'passage' het mogelijk om reistijd (in termen van C-tijd) te beschouwen als uitkomst van verplaatsingspraktijken. Om over innovatie van mobiliteit te kunnen spreken in een taalspel dat niet slechts begrippen als 'gasgeven' en 'afremmen' bevat, is het kortom nodig te onderzoeken hoe de spatiotemporele orde van passages in concrete praktijken van verplaatsing gemaakt en onderhouden wordt en welke effecten zij heeft. In de volgende drie hoofdstukken komt telkens een ander aspect van dit maken van passages an de orde. 
 \\ Met de auto naar het park}

De foto dateert uit 1902 toen auto's nog cen zeldzaamheid waren in de Verenigde Staten. We zien een automobilist die met zijn voertuig - een Toledo-naar de Grand Canyon is gereden. Er is geen weg te zien, of enge andere verwijzing naar menselijke beschaving. Hoe de man met zijn auto op deze plek is gekomen is onduidelijk, maar zijn aanwezigheid heeft iets vanzelfsprekends. Hij is er gewoon naar toe gereden, tot aan de rand, en vanuit zijn auto kijkt hij uit over de canyon. Het beeld herinnert aan de romantische schilderijen van Caspar David Friedrich, maar anders dan bij Friedrich raakt de automobilist niet verloren in de overweldigende mystiek van de natuur. De verhevenheid van zijn blik, op een plek waar ook de indianen uit de streek graag stonden, op de rand van de canyon, drukt eerder beheersing, macht en individualiteit wit.

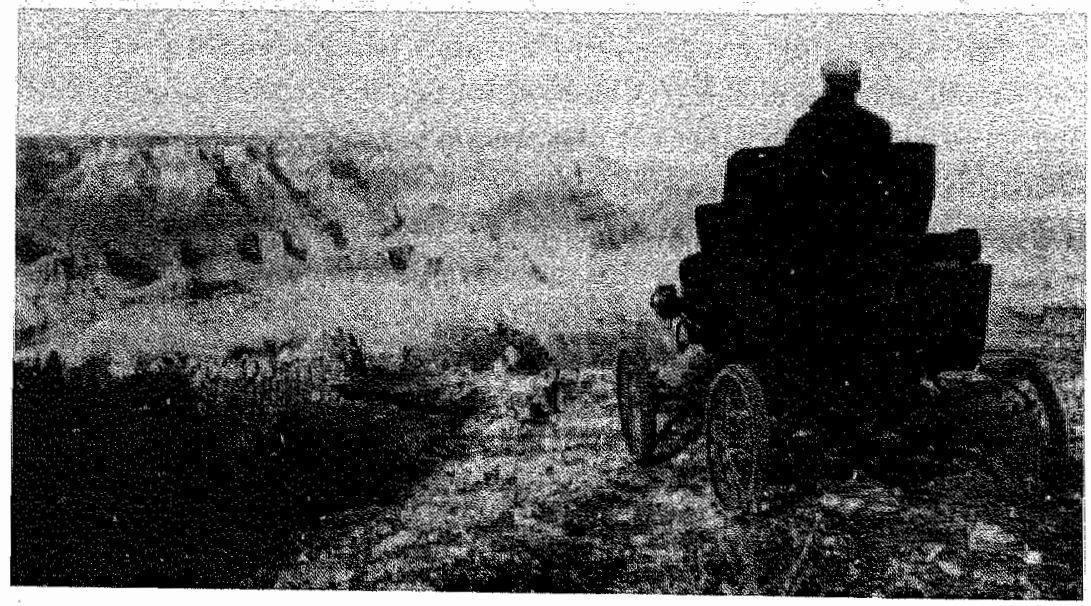

Figuui 4.1: Automobilist in een Toledo auto bij de Grand Canyon, Arizona, 1902, (Bron: Belasco, 1979) 
Talloze Amerikanen in de eerste decennia van de vorige eeuw moeten hebben gedacht wat deze foto toont: een auto geeft de vrijheid om zelf te gaan en staan waar en wanneer je wilt. De grote aantrekkingskracht van de auto school in het feit dat mensen nu op plaatsen konden komen waar de spoorwegen hen niet konden brengen, dat men zelf een reisroute kon vaststellen of veranderen zoals het uitkwam, dat men een eigen reistempo kon bepalen. De betrouwbaarheid en de snelheid van de trein, ooit toegejuicht als vooruitgang, werden nu eerder ervaren als beperkend dan als bevrijdend. De eerste automobilisten beschouwden het langzame tempo van hun auto als een woordeel omdat het hen in staat stelde in alle rust en van dichtbij te genieten van het landschap in plaats wan dit achter een raam in sneltreinvaart voorbij te zien flitsen. Edith Wharton schreef in 1907 dat de auto de 'romantiek van het reizen' had teruggebracht, "door ons te bevrijden van de verplichtingen en contacten van de spoorweg, de gebondenheid aan vaste uren en de gebaande wegen, de nadering van elke stad door een gebied van lelïkheid en verlatenheid dat door de spoorweg zelf werd gecreëerd:

De transitie van trein naar auto speelde zich in de Verenigde Staten af in de eerste decennia van de twintigste eeuw. "In rg ro vervoerden de Amerikaanse spoorwegmaatschappijen nog bijna een miljard mensen per jaar." Twintig jaar later bezat elke tweede Amerikaan een auto en was het aandeel van de spoorwegen in het totale aantal afgelegde kilometers gemarginaliseerd. Zowel in als tussen steden werd de auto de dominante wijze van verplaatsen, ten koste van openbaar vervoer als de trein, maar ook de elektrische tram en de metropolitan.4 Terugkijkend wordt de korte periode waarin zich deze transitie voltrok doorgaans verklaard uit precies die kenmerken van de auto waarover de eerste automobilisten zo enthousiast waren: vrijheid en ongebondenheid, zowel in geografische als in temporele zin. Vanuit het actorperspectief van de innovator kan de vraag gesteld worden of het wel ging om een overgang van het ene naar het andere vervoermiddel. Eerder is het zo dat, naar analogie van wat ik in het vorige hoofdstuk heb ik betoogd, de vrijheid en flexibiliteit die de auto bracht niet gexien moeten worden als verklaring voor de veranderende reispraktijk in de Verenigde Staten, maar als uitkomst van het bouwen van andere passages. 


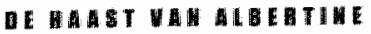

\section{Amerikaanse passages}

Waar ik in het vorige hoofdstuk het perspectief kon reconstrueren wan Thomas Cook die als vernieuwer van het reizen passages maakte voour zijn klanten, ontbreekt in dit geval éen centrale "heterogene ingeniewr" Daarom introduceer ik het actorperspectief hier op een andere manier: Bezie, bij wijze van gedachte-experiment, het maken van nieuwe passages als een grote denkbeeldige ontwerpopdracht. Om de door automobilisten zo gewaardeerde onmiddellijke beschikbarheid van de bestemming mogelijk te maken, moest er van alles veranderen.

\section{Fordisme}

Om in een auto te kunnen rijden moesten mensen erover kuminen beschikken. In populaire versies van de geschiedenis van het automobilisme in de vs is het vooral de verdienste wan Henry Ford dat de auto binnen bereik van de massa kwam. "Tot aan de introductie van de lopende band in de Ford Highland Park fabriek in Detroit in de jaren 19 I $_{3}-19 \mathrm{I} 4$ werd een auto aan beide zijden van de Atlantische oceaan ongeveer op dezelfde manier gemaakt. Hooggeschoolde mecaniciens stelden een auto samen uit een reeks onderdelen, er werd lang aan een auto gewerkt en de verkoopprijs was relatief hoog. De Highland Park fabriek, geopend in $19 \mathrm{xo}$, vormde een schoolvoorbeeld van moderne industriële techniek, maar het gebouw was niet geschikt voor de lopende band omdat het bijvoorbeeld meerdere verdiepingen telde. ${ }^{6}$ Vanaf $r 913$ werden steeds meer onderdelen van de auto gebouwd op bewegende assemblagelijnen. Toen de aanvoer vanaf deze lijnen de eindlijn dreigde te overstelpen, werd een bewegende lijn gebouwd voor het chassis. Tussen oktober en clecember I9 3 werd de hoeveelheid tijd die het koste om een chassis in elkaar te zetten teruggebracht van twallfeneenhalf uur naar twee uur en weertig minuten. Het principe van de lopende band werd verder geintensiveerd in de River Rouge fabriek die in I9 6 zijn deuren opende.

De rationalisering en standaardisering van het productieproces van auto's leidde tor een flinke verlaging van de prijzen, waardoor een snel groeiende groep Amerikanen kon beschikken over een eigen auto. De 
verspreiding van de auto in de Verenigde Staten vond vooral plaats tussen 19 r 2 en 1923 , toen de helft van de Amerikaanse huishoudens over een auto beschikte. ${ }^{7}$ In datzelfde jaar, 1923 , rekende de National Geographic in een speciale editie gewijd aan de automobielindustrie voor dat als alle dertien miljoen auto's die er in de vs rondreden achter elkaar gezet zouden worden op de Lincoln Highway, die van de oevers van de Hudson naar de Golden Gate voerde en 3.305 mijl llang was, de auto's in vijf rijen naast elkaar gezet zouden moeten worden.

De Fordistische produktiewijze vormt een belangrijke verklaring voor het snelle succes van de auto in de Verenigde Staten, maar Ling (r990) wijst erop dat ook culturele en politieke opvattingen een rol speellen. ${ }^{9}$ Zo zetten veel Amerikanen zich af tegen de grote spoorwegmaatschappijen die in hun pogingen monopolies te vormen eerder hun eigen belang hadden nagestreefd dan dat van de reiziger: ${ }^{\text {to }}$ Autorijden werd in brede kringen gezien als een vorm van vrijheid die aansloot bij de "selfrelliance" (Emerson) die bij de negentiende-eeuwse Amerikaanse burger zo hoog in het vaandel stond. De invloedrijke Progressives (een groeiende middenklasse van jonge, hoog opgeleide mannen) zagen tussen 19 10 en 1920 de auto als een middel om de problemen van de steden op te lossen. De auto gaf stedelingen de mogelijkheid buiten de stad te gaan wonen, waardoor de hoge woondichtheden die hadden geleid tot armoede en sloppenwijken omilaag konden. Ook, en misschien wel juist, op het Amerikaanse platteland werd de auto een onmisbaar onderdeel van het leven, zoals Berger (1979) en Kline \& Pinch(r996) hebben beschreven. Voor de landelijke bevolking betekende het einde van haar ruimtelijke isolement ook het einde van veel vertrouwde waarden en sociale instituties. Lokale, organische gemeenschappen maakten plaats voor vrijere samenwerkingsverbanden. Nieuwe wegen vormden bovendien een krachtenveld rond de steden waardoor kleine dorpen werden aangezogen. Al in de jaren twintig werd de auto op het platteland eerder als een noodzakelijkheid beschouwd dan als een worm van luxe." Juist op het platteland bleek de auto veel meer te kunnen zijn dan een vervoermiddel. De auto werd door de boeren aangepast voor een veelheid aan taken op de boerderij. ${ }^{\text {I. }}$ 


\section{Open Road}

Een belangrijke remmende factor voor de verspreiding en het gebruik van de auto was de slechte staat van de wegen. Net als in veel Europese landen was de verantwoordelijkheid voor wegen in de vs toebedeeld aan lokale en in het beste geval regionale overheden. Wegonderhoud werd gezien als een vorm van corvee en doorgaande wegen bestonden dan ook nauwelijks. Wie grotere afstanden wilde overbruggen nam de trein. Het waren weliswaar fietsers die aan het eind van de negentiende eeuw de Good Roads Movement een impuls gaven ${ }^{33}$, maar de roep om betere wegen werd pas echt gehoord door politici toen meer en meer Amerikanen ontdekten dat ze met hun nieuwe Ford eigenlijk geen kant op konden zonder zich vast te rijden op de slechte wegen. Dat bleek vooral als de nieuwe autobezitter een langere tocht wilde maken. Rijden in een open auto, met nauwelijks enige vering en bekleding, over slechte wegen was een vermoeiende, stoterige en tochtige beproeving, schrijft Belasco (1979): 'Alle wroege verhalen beschrijven gedetailleerd de zachte modder, verraderlijke rostblokken en berghellingen, het eeuwige stof en de mechanische gebreken. Het waren in eerste aanzet vooral de autofabrikanten die, doordat ze regelmatig testritten organiseerden over grote afstanden, de slechte staat van de doorgaande wegen onder de aandacht van politici brachten. Daarnaast pleitten vooral grotere steden voor betere wegen. Het verbeteren van regionale autowegen met federaal geld was voor politici in sommige staten een beproefde manier om stemmen te winnen; zo wist Huey Long van Louisiana keer op keer overwinningen te behalen door nieuwe wegen te beloven en ze vervolgens ook te bouwen. ${ }^{\text {Is }}$

In I9 I 3 werd de eerste doorgande autoweg van kust naar kust geopend: de Lincoln Highway liep tussen New York en San Francisco. ${ }^{16}$ In $\mathrm{r} 9 \times 6 \mathrm{kw}$ am werd de Federal Aid Road Act aangenomen en al snel na de Eerste Wereldoorlog stelde de federale overheid geld beschikbaar aan de staten om regionale en interregionale wegen te verbeteren. In de vroege jaren twintig werd zeven procent van de wegen in landelijke gebieden aangewezen om deel wit te maken van een landelijk wegennet. In I9.3 was 169.000 mijl aangewezen, in 1940235.000 mijl. ${ }^{17}$ Met de groei van het wegennet nam ook de noodzaak van eenduidigheid toe. 
Besloten werd dat de noord-zuid routes oneven nummers kregen (te beginnen met U.s. Route I langs de Atlantische kust tot aan U.S. Route IoI langs de kust van de Pacific) en de oost-west verbindingen even nummers (U.s. Route 2 langs de Canadese kust tot U.S. Route 98 langs de Mexicaanse grens).

Vance ( 1986 ) onderscheidt vijf fasen in de ontwikkeling van het Amerikaanse wegennet, waarvan de laatste de periode van de bouw van het Interstate Highway System (IHS) beslaat, van 1954 toen Eisenhower de eerste plannen bekend makte, tot aan de voltooïng in I99 I. De geschiedenis van de bouw van de Interstates is een studie in standaardisatie over grote afstanden. Om te beginnen was de aanleg van het IHS voornamelijk een aangelegenheid van de federale overheid, die meer dan negentig procent van de constructiekosten voor haar rekening nam. Washington was verantwoordelijk voor het opstellen van de specificaties van de wegen en stelde als doel dat deze overal in het land gelijk waren. Kort nadat Eisenhower tot de aanleg van het IHs had besloten legde het Bureau of Public Roads de standaarden vast die samen met de American Association of State Highway Officials waren opgesteld. Het doel van de ontwerpstandaarden was om de Interstates veiliger te maken en een 'pleasing appearance' te geven: ${ }^{88}$

Meer dan een jaar werd overlegd over een standaardteken voor de autosnelwegen waarbij meer dan honderd vormen werden bestudeerd - cirkels, driehoeken, vierkanten en een omtrek wan de Verenigde Staten - voordat uiteindelijk werd besloten tot een driekleurig "federal shield'. 9 De nummering van de Interstates zou precies tegengesteld zijn aan de nummers die in 1926 waren vastgesteld voor de highways. De keuze voor het 'logo" en de nummering mocht dan relatief eenvoudig zijn, het bepalen van de kleur voor de grote borden boven en naast de snelwegen was minder eenvoudig, schrijft Lewis. Een commissie van de American Association of State Highway Officials had een universeel systeem van witte letters op een groene achtergrond aanbevolen, maar de nieuwe hoogste, ambtenaar Bertram Tallamy, had een voorkeur voor witte letters op een blauwe achtergrond. Om het conflict op te lossen werd een drie mijl lange testweg aangelegd waarower honderden automobilisten moesten rijden met een snelheid van honderd kilometer per 
uur. Onderweg passeerden ze drie borden met het opschrift Metropols Utopia EXIT 2 MLES. Vijfentachtig procent van de automobilisten koos voor de groene borden en Tallamy bond in. ${ }^{\text {20 }}$

Lewis benadrukt het gestandaardiseerde karakter van de nieuwe snelwegen; van Californie tot in Maine zagen snelwegen er precies het zelfde uit, tot in de details als bewegwijzering en de kleur van de stre pen op de weg. ${ }^{21}$ Het IHS zorgde voor een netwerk van snelwegen dat over grote afstanden volstrekt homogeen van opzet was. Iemand die de bewegwijzering op een plaats begreep, kon die overal begrijpen. In de ontwikkeling van de landweggetjes van het begin van de eeuw via de 'gewone highways', de interregionale tweebaans highways en parkways nar het ws is de geografische identiteit van de weg gandeweg verdwenen en heeft plaarsgemaakt voor een identiteit op basis van het net werk warvan de weg deel uitmaakt.

\section{Fill'rup}

Eenmaal onderweg moet een automobilist benzine tanken, iets eten en overnachten. Het benzinestation, het wegrestaurant en het motel zijn onlosmakelijk verbonden met de Amerikaanse autocultuur. Het benzinestation ("gas station") maakte al snel deel uit van de mystiek van de ongebreidelde persoonlijke viijheid die de auto bracht. ${ }^{22}$ Bij het benzinestation werd de auto volgegooid en doorgesmeerd om weer verder te kunnen rijden. Cohn constateerde in I944 in zijn geschiedenis van de auto in de vs in onvertaalbaar Amerikaans:

'Fill 'er up?' is a thoroughly American phrase. It suggests endless abundance and open-handedness. It is characteristic of a continental people whose life is geared to the car - a free-and-easy people to whom mobility is of the essence of living. "'Look for us next Sunday, Bill. We ought to get there by diner time. It ain't over two hundred miles.') It is a phrase that could have been invented by no other people $(. . .)^{23}$

Het benzinestation ontwikkelde zich snel tot een plats van gestandaardiseerde consumptie, vooral ondat de oliemaatschappijen als Esso, 


\section{CALIFORMIA}

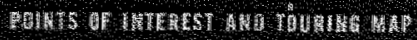

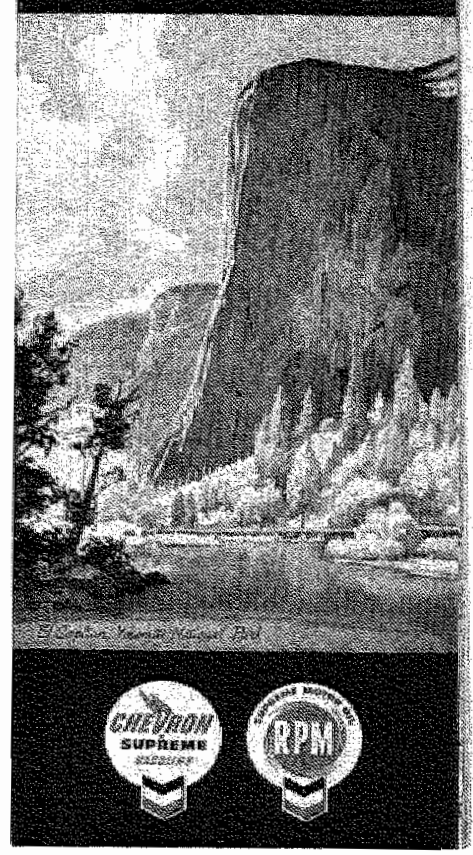

Figuur 4.2: Wegenhaart uit 1959, ustgegeven door Chevrom en Supmeme Motor Oil met een afbeelding Yosemitte National Park. [Bron: Yorke \& Margolies [1996)]
Gulf of Mobil als eersten het franchising-principe omarmden. Ze gaven architecten als Frank Lloyd Wright, Walter Dorwin Teague en Norman Bel Geddes de opdracht om benzinestations te ontwerpen die in grote aantallen gebouwd konden worden. Niet alleen de architectuur was gestandaardiseerd en daardoor vertrouwd, ook logo's keerden in het hele land terug - een oranje schijf, een vliegend paard of een dinosaurus. Van de kleurstelling van het station tot het uniform van de pompbediende streefde men naar standaardisatie en daarmee herkenbaarheid voor de automobilist die van ver kwam. ${ }^{24}$ In hun studie naar het Amerikaanse benzinestation onderzoeken Jakle en Sculle (r994) de manier waarop de Amerikaanse oliemaatschappijen tussen rg ro en 1920 de marketingstrategie van de "place-product-packaging" ontwikkelden. Place-productpackaging, stellen Jakle en Sculle, was een strategie die eerst door de oliemaatschappijen werd toegepast en daarna binnen de motelindustrie en door ketenrestaurants. Kern van. het idee was, clat de diensten werden gestandaardiseerd in tijd en ruimte, waarbij uiteenlopende symbolen werden gebruikt om de koppeling van de plaats en het product aan de reiziger duidelijk te maken. ${ }^{25}$

Waar logo's de standaardisering van het aanbod benadrukten en herkenbaarheid nastreefden, hadden oliemaatschappijen ook een andere strategie om automobilisten aan zich te binden: het uitgeven van wegenkaarten die juist de geografische verschillen benadrukten. Beginnend 
in het eerste decennium van de vorige eeuw gaven deze kaarten nier al leen praktische informatie die nodig was om de weg te vinden in een yreemde omgeving, ze moedigden automobilisten ook aan Amerika te ontdekken. Yorke \& Margolies (1996) betogen dat zich aan de veranderingen van de wegenkaarten de ontwikkelingen van het autoreizem in de VS laat reconstrueren. Vroege kaarten, uit de jaren twintig, toonden vaak een man en een vrouw, onderweg in een auto, genietend van de rit door het landschap onder een oranje zon - het logo van Gulf. Een kaart uit 1927 van Standard Oil vergeleek de automobilist met een pionier die in een huifkar nieuwe streken binnenreed. In de jaren dertig toonden. omslagen dynamische lijnen, als uitdrukking van gestroomlijnde snelheid en energie. Voor het eerst verschenen covers waarop alleen een vrouw achter het stuur zat; het benzinestation werd een afgebeeld als een veilige en vriendelijke haven voor de vrouwelijke automobilist. Vanaf de jaren vijftig verbeeldden de omslagen van de wegenkaarten vooral de natuurlijke schoonheid van het Amerikaanse landschap. Plaatjes van beroemde nationale parken, zoals Yosemite in Californië, combineerden een patriottistisch beeld van de natie met een a anmoediging voor automobilisten om weer op weg te gaan nadat de benzinerantsoenering in de oorlog voorbij was (zie figuur 4.2$)^{26}$

\section{Drive-ins}

Net als het benzinestation en de wegenkaart heeft ook het wegrestaurant in Amerika een proces van geleidelijke standaardisatie en ketenvorming ondergaan. Dat proces begon volgens Heimann ( 996 ) in $192 \mathrm{I}$ toen J.G. Kirkby, een zakenman uit Dallas, en R.W. Jackson, een dokter uit dezelfde plaats, de Pig Stands Company oprichtten. Het idee om een restaurant te bouwen dat zich tot doel stelde maaltijden aan automobilisten te serveren in hun auto was een idee van $\mathbb{K}$ irkby, die vaststelde dat 'people in cars are so lazy that they don't want to come out of them to eat'. ${ }^{27}$ De eerste Pig Stand had voorlopers in de vele 'roadside stands'. Bij deze kraampjes langs de weg konden automobilisten stoppen om iets te drinken of te eten, maar om dat te doen moesten ze hun auto uit, wat oponthoud betekende. Andere ondernemers volgden het voorbeeld van Pig Stand en nieuwe manieren werden bedacht om het 
woedsel van de keuken bij de klant in de auto te krijgen. Omdat autow mobilisten in hun (open) auto konden blijven zitten, waren The Pig Stands en concurrenten vooral populair in de zonniger delen van Amerika, Californie en Texas voorop.

Al de eerste keten van autorestaurants experimenteerde met verschillende ontwerpen voor de stands, zoals een zeshoekige vorm die de voorloper zou zijn van de cirkelvormige architectuur van de latere drive-ins. Om de aandacht van automobilisten te trekken werden grote borden langs de weg geplaatst die meer en meer de functie kregen van herkenbare logo's zoals automobilisten ze ook kenden van de benzinepompen. Maar niet alleen in het uiterlijk van het restaurant werd eenheid nagestreefd, ook de menu's in de verschillende restaurants werden zorgvuldig op elkaar afgestemd. De reden daarvoor was niet alleen de voorspelbaarheid voor de automobilist, maar ook de hoeveelheid tijd die nodig was om het voedsel te bereiden. Pig Stand werd groot met de combinatie van Coca-Cola, geroosterd varkensvlees en sandwiches met ham. Andere populaire gerechten waren de hamburger, hot dogs, belegd geroosterd brood, taart, ijs en regionale specialiteiten als chill, taco's en pizza's. ${ }^{28}$

Het drive-in restaurant werd vanaf de jaren twintig een baken voor de automobilist die zich geen tijd gunde om uit z'n auto te komen en zijn maaltijd dus door een cat hop (jonge vrouwen gekleed in een uniform) gepresenteerd kreeg op een speciaal daarvoor ontworpen dienblad dat aan het portier kon worden geklemd. Door hun kleding ontwikkelden de car hops zich tot een soort trademarks; aan de hop herkende men het restaurant. Het was precies het elimineren van deze menselijke schakel - de car hop - waarmee de gebroeders McDonald, die in r937 hun eerste restaurant openden in Californie, in 1948 afweken van hun vakgenoten. Daarbij speelde niet alleen een rol dat de car hops niet altijd even betrouwbaar waren, maar ook dat het bereidingsproces efficiènter georganiseerd kon worden als de automobilisten uit hun auto kwamen om zelf hun hamburgers te halen. 'De maaltijd werd in een snelle twintig seconden ingepakt":29

In 1952 hadden de broers het eerste miljoen hamburgers verkocht. Twee jaar later werd Ray Kroc aangesteld om McDonald's om te vor- 
men tor een keten en in I 96 I slaagde hij erin de broers uit te kopen. $Z 0$ snel vond het nieuwe concept van Kroc navolging dat in de jaren zestig. de laatste drive-ins verdwenen waren. Ze schakelden over op fast-food, self-service of take-home. De bediening in de auto zou pas weer terugkomen toen in de jaren zeventig het drive-thru concept werd ontwikkeld waarbij de automobilist zijn bestelling doet aan de ingang en die al rijdend ophaalt bij een loket. ${ }^{30}$

\section{Van autokamp naar motel}

Belasco (1979) beschrijft de opkomst van zogenaamde Auto Camps aan het begin van de eeuw en het ontstaan van een nieuwe bedrijfstak rond 'motels', een evolutie die plaatshad in een periode van ongeveer vijfendertig jaar ( 19 ro-1945). In de eerste fase, tussen r9 ro en 1920 , trokken honderdduizenden gezinnen uit de middenklasse met hun auto door het land, kampeerden langs de kant van de weg, elke nacht ergens anders, kookten boven een houtvuur en sliepen in hun auto of een tent. Het was een vorm van reizen die door tijdgenoten als 'gypsying' werd omschreven, een romantisch gekleurde herontdekking van het ware reizen na een tijd warin de trein op allerlei manieren de verplaatsing had gestandaardiseerd door strakke tijdschema's en vaste routes. De autokampeerders vergeleken hun auto graag met de oude postkoets en keerden zich af van wat Belasco het 'monopolistic rail-hotel complex' noemt. ${ }^{3 r}$

Het groeiende aantal autokampeerders leidde tot problemen voor de dorpen en streken die ze aandeden. De toeristen vervuilden de wegen, ruzieden met de lokale bevolking en werden ziek omdat ze vervuild water moesten drinken. On deze problemen te kanaliseren en te reguleren, gingen gemeenten er rond 1920 toe over om het autokamperen te beperken tot speciale gratis 'autocamps'. Veel autokampeerders verwelkomden het gemak van de officiële kampeerplaatsen; zij beschouwen het kamperen in het wild als te oncomfortabel en tijdrovend. In een onderlinge concurrentieslag gingen de gemeentelijke autokampeerplaatsen aanvullende faciliteiten leveren, zoals elektrisch licht, warme douches en centrale keukens. De overgang naar commercieel geëxploiteerde autokampeerterreinen kwam toen de extra voorzieningen te duat 
werden geacht en de gratis terreinen bovendien ongewenste bezoekers aantrokken. Vanaf 1925 werden overnachtingsgelden geheven, wat de weg vrijmaakte voor commerciële exploitanten van terreinen, die voorheen niet hadden kunnen concurreren met de gratis gemeentelijke terreinen. Deze commerciele exploitanten boden al snel betere service; vanaf 1925 verschenen de eerste hutten ('cabins') voor toeristen die meer comfort wilden. De motelindustrie was geboren schrijft Belasco (1979). Aan het eind van de jaren twintig, toen steeds meer toeristen geen zin meer hadden om hun eigen uitrusting mee te nemen, begonnen exploitanten van hutten goede bedden ter beschikking, bedlinnen, kachels en zelfs waterleiding aan te bieden. In de jaren dertig wendden voormalige hoteleigenaars zich tot deze goedkope 'cottage camps' en verbeterden de voorzieningen nog verder om zo tegemoet te komen aan de eisen van de autoreizigers. ${ }^{32}$ Deze ontwikkeling kan opgevat worden als een eerste vorm van standaardisering van de overnachtingen van autokampeerders.

Jakle, Sculle en Rogers ( 996 ) beschrijven hoe de motelindustrie in de loop der jaren verder standaardiseerde. "Daar is om te beginnen de anduiding "motel", die voor het eerst werd gebruikt in 1926 door Arthur Heineman, uitbater van het Milestone Mo-tel in San Luis Obispo in Californië. In die tijd waren er een kleine dertig aanduidingen voor het verschijnsel in omloop, variërend van Motor court en Cottages tot Tour-o-tel, Trav-o-tel en Plaza court - waarvan in de jaren vijftig nog slechts de neutrale aanduiding motel als soortnaam was overgebleven. De architectuur en ruimtelijke lay-out van het motel evolueerde van de anarchistische 'auto camps' met hun kris kras geplaatste cabins naar enkele dominante vormen, zoals de U-vorm, de L-vorm (beiden met de mogelijkheid om de auto voor de deur van de kamer te parkeren) of de hoogbouwvariant. ${ }^{34}$

In de jaren na de Tweede Wereldoorlog kreeg de basislogica van het motel op steeds meer plaatsen de overhand. ${ }^{35}$ In 1952 werd het eerste Holiday Inn Hotel Courts geopend in Memphis, Tenessee. Kemmons Wilson ontdekte tijdens een vakantiereis een jaar eerder dat comfortabele en betaalbare accommodatie op veel plaatsen ontbrak. Samen met Wallace E. Johnson, fabrikant van geprefabriceerde huizen, startte hij 
een motelketen die gebaseerd was op het principe van franchising. Ondernemers die zich bij de keten aansloten konden gebruik maken wan het Holiday Inn-logo en profiteren van nationale advertentiecampagnes. ${ }^{36}$ De architectuur van de Holiday Inn motels was aan strenge specificaties gebonden. Dat gold voor de basisvorm (de eerder genoend $\mathrm{L}$ - of U-vorm), het aantal etages (twee), de plaats van het zwembad en het kantoor en zelfs woor de dikte van de muur tussen kamers om geluidsoverlast te voorkomen. Holiday Inn standaardiseerde ook de 'room-geography', waardoor de reiziger zeker wist dat elke kamer er min of meer hetzelfde uit zou zien. De plaatsing van het bagagerek, de kasten, de diepte van de kasten, de indeling van de motelkamer en badkamer lagen vast. ${ }^{37}$ Net zo belangrijk als het ontwerp wan het motel zelf was de plaats van het gebouw aan de weg en de vraag langs welke weg dat moest zijn. Ook voor de plaats van een nieuw motel werden gestandaardiseerde criteria opgestell, waarin regionalle forenzenpatronen, verkeerstellingen en de afstand tot belangrijke bestemmingen ('draws') werd vastgelegd. De herkenbarheid van het motel vroeg om duidelijke borden die vanaf de weg gezien konden worden. Ondernemers hadden er veel voor over om de tracés van de nieuwe snelwegen te weten te komen, zodat snel met aankoop van grond in de buurt van open afritten kon worden begonnen.

Franchising, ketenvorming en de bouw van geprefabriceerde motels waren de mechanismen achter de standaardisering wan de motelindustrie. Deze standaardisering had voor de autoreiziger het effect dat de onzekerheid die reizen over grotere afstanden met zich meebrengt werd gereduceerd. Bekende logo's en handelsmerken, een moeiteloze bereikbaarheid en een voorspelbaar indeling en inrichting van de kamers wezen de automobilist de weg naar een "home away from home" (Margolies, 1995). Ze gaven de autoreiziger de mogelijkheid thuis te zijn op een vreemde plaats.

\section{Making miles}

Voor de eerste Amerika anse automobilisten was het reizen met de auto over langere afstanden een avontuur; ze hadden vaak geen idee wat ze onderweg zouden tegenkomen. Wie met de auto op reis ging, moest zelf 
over weel kennis en vardigheden beschikken. De eerste auto's waren technisch gebrekkjg en gingen vaak kapot. Wegen waren slecht en op oude foto's zijn T-Fords te zien die tot hun assen in de modder zijn weggezakt. Wegwijzers ontbraken of waren gericht op lokale bestemmingen. Voorzieningen om te tanken, te eten en te slapen waren aanwankelijk nog zeldzaam en automobilisten moesten omrijden om ze te bereiken. De eerste automobilisten moesten veel werk verzetten om wooruit te komen; ze zagen zichzelf graag als ontdekkingsreiziger en voelden zich verwant aan de pioniers die decennia eerder naar het westen van de Verenigde Staten waren getrokken. De zelfredzaamheid die werd gevraagd van automobilisten sloot aan bij de idealen van 'selfreliance' en individualiteit die teruggingen op het negentiende-eeuwse Transcendentalisme van Emerson en Thoreau. Niet zonder reden karakteriseerde een tijdgenoot het autoreizen als 'Thoreau at 29 cents a gallon'. ${ }^{38}$ Automobillisten reisden anders dan treinpassagiers. Dat ze waak niet meer dan twintig mijl per uur aflegden, zagen ze als een voordeel. Ze hadden de tijd om op de details in het landschap te letten.

Vanaf de jaren twintig, toen het aantal auto's sterk toenam en het netwerk wan highways werd witgebouwd, veranderde echter het karakter wan het autoreizen, constateert Belasco (r979). Automobilisten raakten geobsedeerd door de wens zoveel mogelijk kilometers af te leggen: "making miles". Het autorijden creëerde een eigen momentum en schiep zo een haast die doet denken aan die van Albertine. 'Er lijkt een onweerstaanbare drang te zijn om door te rijden", citeert Belasco een autokampeerder uit de jaren twintig, "Wij hebben geprobeerd deze behoefte te onderdrukken. Want waarom zou iemand kilometers reizen on de Niagara watervallen te zien om er vervolgens maar een wur te blifven zonder het wonder van de natuur op zijn waarde te schatten. Toch hebben we er ons allemaal aan schuldig gemaakt." 39 De onvoorspelbaarheid die gebrekkige auto's en slechte wegen veroorzaakten werden meer en meer als een last in plaats van als een avontuur ervaren. De automobilist moest voort. Nieuwe voorzieningen als benzinestations langs de wegen, drive-in restaurants met een overzichtelijke menu's en kampeerplaatsen en motels maakten het mogelijk langer 'on the road' te zijn.

Thomas Cook kon als een heterogene ingenieur snelle en voorspel- 


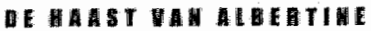

bare passages aanbieden doordat hij 'onderhandelde' tussen de elementen die de tijd-ruimtelijke orde van de verplaatsing vormden. De Amerikaanse automobilist had Cook niet langer nodig. Waar Cook aansluitingen synchroniseerde, hotels selecteerde, travelers cheques aanbood en employees aanstelde die ter plaatse het onverwachte het hoofd konden bieden, werd in de Verenigde Staten in een collectieve beweging de onvoorspel baarheid van de autoreis gereduceerd door gelijkwormigheid van en afstemming tussen alle elementen in de passage. In plaats van the Man from Cooks die de weg wees en vragen beantwoordde, konden de automobilisten terugvallen op de herkenbaarheid en logica van de gestandaardiseerde netwerken waaruit hun passage was opgebouwd. Er hoefden geen treinkaartjes te worden besteld, want men had zelf een auto; geen hotels te worden gereserveerd, want men koos zelf een motel langs de weg. Er waren geen restaurants waar men, eenmaal gearriveerd, alle tijd had om in avondkleding te dineren, maar drive ins, waar het eten snel werd bereid en opgegeten, het liefst in de auto. Zo kon de automobilist het zonder Cook stellen en toch een snelle en voorspelbare reis maken. Het standaardiseren van de elementen van de passage maakte het automobilisten mogelijk te anticiperen op wat zij onderweg tegen zouden komen; zij konden als het ware "vooruit reizen in de tijd'. In die zin is het creëren van een passage als de Amerikaanse op te vatten als het creëren van een collectieve verwachting.

Standaardisatie in deze passagebouw heeft hier twee betekenissen: aan elkaar gelijk maken en op elkaar afstemmen. In de bewegwijzering van de Highways en Interstates, de logo's van benzinemaatschappijen, de smaak van hamburgers en de indeling van hotelkamers waren verschillen niet gewenst. Maar standaardisering betekent niet alleen dat zaken aan elkaar gelijk werden gemaakt, maar ook dat ze op elkaar waren afgestemd. Zo waren de hotels rond r 9 Io niet ingericht op de eisen van de eerste automobilisten. Ze lagen in de centra van de steden, goed bereikbaar voor treinreizigers, maar niet voor automobilisten. Er golden ongeschreven kledingcodes waaraan automobilisten die de hele dag over stoffige wegen hadden gereden niet konden voldoen. De stadshotels sloten niet aan op de passages van autoreizigers. Omgekeerd hadden treinreizigers weinig aan een motel dat langs de invalswegen van 
een stad was neergezer. Gestandaardiseerde netwerken hebben als effect dat de wrijving van de modderige wegen is opgeheven. De Amerikaanse automobilist ervoer de gelijkvormigheid en afstemming tussen de elementen in de passage als "flow" (Castells).40

Standaardisatie van de passage had om te beginnen niet alleen een ruimtelijke en materiële, maar ook een temporele component. Met het aan elkaar gelijkmaken en afstemmen van auto's, wegen, benzinestations, restaurants en motels werd de tijdsspanne die automobilisten er doorbrachten gestandaardiseerd. Waar hotels aan het begin van de twintigste eeuw nog waren ingericht op een verblijf van soms weken, gold woor de meeste motels dat de reiziger er slechts een nacht verbleef. Betere en beter bewegwijzerde wegen maakten zoeken overbodig en standaardiseerden de reistijd tussen bestemmingen. In de wegrestaurants van McDonald's was, naar analogie van Fords lopende band, de bereidingstijd van hamburgers gestandaardiseerd en daarmee ook de wachttijd voor reizigers. Al deze afzonderlijke temporele ordes beinwloedden elkaar. De Amerikaanse passage riep een nieuwe omgang met tijd in het leven die miet uitsluitend te typeren valt in termen van eenvoudig snellere verplaatsingen of in termen de 'making miles'-ervaring. De nieuwe temporele ordes die ontstonden als gevolg van de koppelingen en afstemmingen tussen de innovaties in de nieuwe passage schiep ook een nieuw collectief tujdsbesef. 'On the road' leek tijd even gelijkvormig als de weg waarover men reed: voor de man (vooral voor hém) achter het stuur vervagen de verschillen tussen gisteren, vandaag en morgen, tussen de weekdagen en de seizoenen, tussen dag en nacht, en kent zijn haast geen natuurlijk grenzen meer. Voor het gedwongen tempo van de treinreis kwam zo een nieuw soort gedwongen tempo van de autoreis in de plaats. ${ }^{41}$

Standaardisatie leidde tot de mogelijkheid te anticiperen op de problemen die een autoreiziger onderweg moest oplossen en daarmee tot "flow", maar riep ook nieuwe spanningen op. Het verdwijnen van het toeval en de wrijving die de eerste autokampeerders zo hadden gewaardeerd betekende ook het verdwijnen van de verrassing en het avontuur. Automobilisten wisten wat ze konden verwachten bij een benzimestation van Standard Oil, een drive-in van McDonald's of een motel 
van Howard Johnson. ${ }^{42}$ Hoe kon de mythe van de 'open road' toch bliven bestaan? Naar analogie van begrip "plaatsmythe" (Shields) dat in het vorige hoofdstuk al aan de orde kwam als een element in de passages die Cook maakte, ontstonden in de Amerika nieuwe 'reismythes'. ${ }^{43} \mathrm{De}$ gestandaardiseerde emblemen, logo's, iconen en gratis wegenkaarten. van de Amerikaanse passage hadden niet alleen de functie automobilisten probleemloos naar hun bestemming te gidsen, maar vormden tegelijk de representatie van de waarden van zelfredzaamheid en indiwdualiteit die de eerste automobilisten koppelden aan het autorijden. De borden waarmee in 1926 de highways werden genummerd, werden krachtige culturele iconen zoals het voorbeeld van Route 66 aantoont. ${ }^{4}$ In de film The Grapes of Wrath van John Ford, naar het boek van Steinbeck, is het bord te zien als symbool voor de hoop op een beter leven die de bewoners van het droge Oklahoma naar Californië deed trekken. De drive-in en het motel gelden als krachtige emblemen van een mobiele levensstijl die vooral Amerikaans is. Edward Hopper schilderde de eenzaamheid van een benzinestation in het licht van de vroege avond. Dat de reis langs gestandaardiseerde motels en benzinestations niet slechts een gezichtsloze beweging inhield, bewijzen de talloze "road movies" waarin het thema van de reis zonder doel vaak op een romantische manier word verbeeldt: ${ }^{45}$ Ook in de literatuur en later de popmuziek zijn vele voorbeelden te vinden waarin het thema van de "blue highways", de wegen die naar de 'achterkant' van Amerika leiden, is nitgewerkt. 46

Deze spanning tussen 'flow' en 'mythe' typeert niet alleen de Amerikaanse passage, maar ook de bestemming die door die passage bereilkbaar werden. Nu onderweg zijn nauwelijks nog een a wontuur was en alleen het bereiken van de bestemming telde; werd het des te belangrijker dat die bestemming wél bleef verrassen. Immers, mensen moesten cen reden hebben om überhaupt op reis te gaan en die reden lag in een bestemming die a vontuut bood en juist niet leek op thuis. De standaardisering van benzinestations, wegrestaurants en motels tot herkenbare en voorspelbare knooppunten in een netwerk van passages had geleid tot wat Kunstier (r994) een 'geography of nowhere' heeft genoend. ${ }^{7}$ Voor de archetypische bestemmingen in de Verenigde Staten - de Nationale Parken - gold dat ze hun bestaan juist dankten aan hun status van unie- 
ke plaatsen. Maar hoe moesten de parken zodanig worden ingericht dat ze, als avontuurlijke en 'andere' bestemming, toch aansloten dan wel onderdeel gingen vormen van de passage die ze gemakkelijk bereikbaar maakte? Voor dit ontwerpprobleem stond vanaf 19 1.6 de National Park Service (NPS).

\section{Wildernis langs die snelwey}

Wat de Europese bezoeker van de Nationale Parken in het westen van de Verenigde Staten het meest opvalt, is de tegenstelling tussen de grootse verlatenheid van plaatsen als Grand Canyon, Zion en Bryce en de gemakkelijke, haast terloopse manier waarop deze landschappen toegankelijk zijn. Goed onderhouden en comfortabele wegen brengen de bezoeker naar de ingang van het park waar een vriendelijke parkranger klaarstaat om een kaart te overhandigen met daarop de wegen in het park, de wandelroutes en belangrijkste bezienswaardigheden. Elk park heeft een eigen bezoekerscentrum waar alle faciliteiten te vinden zijn die men kan wensen. Bereikbaarheid, zo wordt snel duidelijk, is niet alleen zaak van het fysiek transporteren van de bezoeker naar de belangrijkste locaties, maar ook het aanbieden van manieren om het landschap te leren kennen en te visualiseren. In Zion National Park is een speciaal punt gemarkeerd waar de bezoeker voor een beroemde rotsformatie, die White Throne heet, kan lezen waar hij of zij moet staan om een kopie te maken van een beroemde foto. Nadat de auto is achtergelaten op een van de parkeerplaatsen wordt men door duidelijke wegwijzers naar de beginpunten van gemarkeerde wandelingen gebracht die de bezoeker verder te voet het achterland van het park inleiden. De natuur lijkt hier zorgvuldig geënsceneerd om een bezoeker de ervaring van ongerepte wildernis te geven..$^{8}$

\section{De nationale parken als bestemming}

De Amerikaanse natuurparken zijn plaatsen die bij uitstek kunnen worden opgevat als het resultaat van de manier waarop ze toegankelijk zijn gemaakt. Vanaf het moment dat Yellowstone Park door het Ameri- 
kaanse Congres in 1872 werd bestempelid als het eerste "nationale park" in de wereld zijn de inrichting, het gebruik en het beheer van de Amerikaanse nationale parken in hoge mate verweven geweest met de passages die deze vaak afgelegen gebieden bereikbaar maakten. De folklore wil dat het idee om van Yellowstone een park te maken ontstond tijdens een discussie tussen woudlopers die in r 870 rond een kampvuar zaten. In plaats van het gebied te gebruiken voor particulier gewin, zou het landschap behouden moeten blijven door er een publiek park van te maken. Maar zoals Runte ( 1990 ) betoogt, was het feit dat hun voorstel snel werd overgenomen door politici en tot wet gemaakt nauwelijks ingegeven door altruistische motieven. Rond die tijd maakten de Northern Pacific Railroad en haar financier Jay Cooke plannen om de spoorlijn in het westen van Dakota door te trekken naar Montana. Het spoorwegbedrijf nam aan dat het voltooien van deze lijn Yellowstone "speedily accessible" zou maken warna zij een monopolie zou hebben op het vervoer van de toeristen die naar Yellowstone zouden komen. ${ }^{49}$

De 'pragmatische alliantie' (Runte) tussen de natuurbeschermers uit de hogere klassen en de spoorwegmaatschappijen in het westen van de Vs, die probeerden het reizigersverkeer te laten groeien door het aanbieden van bestemmingen, legde de fundamenten voor bijna alle parken die in de eerste decennia van de twintigste eeuw werden gesticht. De spoorwegen waren niet alleen van doorslaggevend belang om steun in het Congress te krijgen voor nieuwe parken als Glacier, ze namen ook het initiatief voor de bouw van toeristische faciliteiten zoals grote hotels. Eind negentiende en begin twintigste eeuw koste het veel tijd on de parken te bereiken en de wegen in de parken, als ze er al lagen, waren moeilijk begaanbaar. De bezoekers bleven er dus doorgaans lang. Om die reden werden de voorzieningen voor de toeristen meestal binnen de grenzen van de parken aangelegd.

Rond 1900 moest het idee om land te gebruken als nationaal park gerechtvaardigd worden ten opzichte van andere vormen van exploitatie, vooral de winning van grondstoffen en hout. ${ }^{5 \circ}$ Deze rechtva ardiging werd vaak gegeven in economische termen: de parken zouden gedurende lange tijd kunnen dienen als 'magneten voor toeristendollars'. De 'See American First'-campagne in het begin van de twintigste eeuw 
spoorde rijke Amerikaanse toeristen aan hun geld in de Verenigde Staten uit te geven en niet in Europa. Een andere reden om de parken toegankelijk te nuken was dat de bezoekers als kiezers zorgden voor de politieke macht om de natuur in de gebieden intact te laten. In angustus I 9 I 6 werd de National Park Service opgericht om de nationale parken en monumenten te beheren volgens de richtlijn 'to conserve the scenery and the natural and historic objects and the wildlife therein and to provide for the enjoyment of the same in such manner and by such means as will leave them unimpaired for future generations'. In deze opdracht ligt het dilemma besloten dat op vrijwel ell moment in de geschiedenis van de NPS terugkeerde, de keuze tussen behoud en bereilkbatheid.

\section{Parks are for people-in-automobiles}

Voor Stephen Mather, die in 1917 de eerste directeur werd van de NPS, was het duidelijk dat treinen zouden worden verdrongen door auto's als belangrijkste vervoermiddelen naar en in de parken. Hij smeedde een tweede 'pragmatische alliantie' (Flink, I.993) tussen de NPs en de belangen rond de auto in het hele land. Samen met andere vooraanstaande natuurbeschermers verwelkomde Mather de auto in de parken. Hij onderkende de politieke macht van de autoindustrie, de automobilistenverenigingen en het groeiende aantal autotoeristen. Hij achtte brede publieke steun noodzakelijk om belastinggelden beschikbaar te stellen voor het oprichten en onderhouden van de parken, maar ook om tegenwicht te bieden aan de toenemende druk van bedrijven en overheden om de grondstoffen in de parken commercieel te exploiteren. ${ }^{g x}$ Flink citeert de natuurbeschermer $\mathbb{E d w a r d ~ A b b e y , ~ d i e ~ s t e l t ~ d a t ~ i n ~ d i e ~ d a - ~}$ gen de slogan 'Parks are for people" de betekenis kreeg van "Parks are for people-in-automobiles". 52

Nieuwe wegen brachten telkens nieuwe bezoekers naar de nationale parken. De Federal Highway Act van r.92x en de instelling van een algemeen geldende accijns op benzine waarmee de aanleg en verbetering van autowegen werd bekostigd, resulteerden in 1929 in een netwerk van autowegen dat zelfs de meest afgelegen parken in het westen van de VS bereikbaar makkte voor Amerikanen die aan de oostkust 
woonden. Ook was op aandringen van de National Parks Highways Association, die in 19.5 was gevormd, een route uitgestippeld en bewegwijzerd die alle nationale parken met elkaar verbond. Deze "interpark route" was niet helemaal geplaveid. Niettemin fungeerde de route als een "psychological as well as a physical link among the national parks and encouraged people to travel them". ${ }^{3}$ NPS-directeur Stephen Mather zag deze Park-to-Park Highway, een cirkel wan zesduizend mijl wan staats- en lokale wegen, als een belangrijk middel om de parken in het westen tot een samenhangend systeem om te vormen. In de woorden van Carr ( 1998 ): 'connecting the parks, as well as managing them all according to consistent policies, were essential steps in transforming the federal scenic reservations into a modern park system?. 4

Auto's en wegen brachten mensen naar de parken en maakten ze tot populaire bestemmingen voor vakantiegangers. Maar ze hadden ook grote invloed op de ontwerpstandaarden van de landschapsarchitecten van de National Park Service. Het feit dát de NPs landschapsarchitecten in dienst had om te adviseren over de inrichting van het landschap onderstreept de samenhang tussen stedelijke parken zoals Central Park in New York (ontworpen in 1870 door Frederic Law Olmstedt) en de nationale parken. Zowel de stedelijke parken als de natuurparken werden gezien als zorgvuldig ontworpen plaatsen waar mensen konden herstellen van de stress die het moderne leven met zich meebracht. Waar de in de negentiende eeuw aangelegde stadsparken de natuur binnen bereik brachten van de valak lopende stedeling, gaf de auto hen de mogelijkheid om de natuur daar op te zoeken waar ze feitelijk was, maar beide soorten parken werden gezien als ontworpen plaatsen.

Het inpassen van parkdorpen, gebouwen, wegen en wandelroutes in het omringende landschap vormde voor Stephen Mather het belangrijkste probleem in het landschapsontwerp. Het uitdunnen van de begroeing bij uitkijkpunten, het aanleggen van wegen en wandelroutes, het ondergronds wegwerken van elektriciteitsdraden en het verbeteren van kampeerterreinen behoorden tot het vaste takenpakket van de landschapsontwerpers. ${ }^{5}$ In de jaren twintig en dertig kwam de zogenaamde 'rustieke stijl' in zwang. Deze stijl trachte de visuele invloed van gebouwde objecten in de parken te minimaliseren door bouwmaterialen 
uit de directe omgeving te gebruiken en vangrails, uitkijkpunten, bruggen en andere bouwsels te laten harmoniëren mer de omgeving. ${ }^{56}$

$\mathbb{B i j}$ het ontwerp van parkwegen werden de landschapsarchitecten en -ingenieurs geconfronteerd met specifieke problemen. Aan de ene kant zagen ze het als hun taak om gevaarlijke bochten, scherpe draaien en steille afdalingen, karakteristiek voor bergwegen, te verwijderen. Automobilisten wilden veilig en comfortabel kunnen rijden, ook in de parken. Aan de andere kant moesten de wegen zo worden aangelegd dat de verstonende werking op de wildernis die ze doorsneden minimaal was. Wegen moesten rustige bochten maken 'that flowed with and lay lightly on the land'57 zoals een destijds befaamde frase het uitdrukte. ${ }^{58}$ Het is interessant te zien dat de principes van de wegenbouw in de parken in de jaren twintig nog steeds werden beïnvloed door ideeën over parkontwerp zoals de negentiende-eeuwse tuinontwerper Andrew Jackson Downing ze formuleerde. Het idee van de ringwegen, dat terugging op Downing, werd op verschillende plaatsen toegepast, variërend van de Grand Loop in Yellowstone tot wegen op kampeerterreinen. Het laten rondrijden van voertuigen sloot zo goed aan bij de bedoeling van parkontwerpers om in de parken een 'flow' te creëren, dat ringvormige wegen en paden op alle schaalniveaus opdoken om verkeersstromen te sturen en te vergemakkelijken, schrijft Flint McClelland. ${ }^{59}$

Tussen r933 en 1940 ontving de National Park Service 220 miljoen dollar van verschillende New Deal instellingen. Deze fondsen werden vooral gebruikt om parkwegen te herbouwen en opnieuw te bestraten en om een aantal nieuwe en indrukwekkende "scenic roads" aan te leggen zoals de Zion-Mount Carmel Road en Tunnel, the Wawona Tunnel and Road in Yosemite en de Going-To-The-Sun Highway in Glacier National Park. Met de wegen kwamen de uitkijkpunten (afgeleid van de terrassen die negentiende-eeuwse parkontwerpers aanlegden), verkeersborden, wegwijzers, afgeronde bochten, parkeerterreinen en nieuwe aanplant waardoor de weg voor het oog werd ingebed in het omringende landschap. Dit waren 'intermediary landscapes' (Carr, ir98), zorgvaldig ontworpen als 'middle ground between the American automotive tourist and the vast reservoir of natural resources and national imagination that are our state and national parks. ${ }^{60}$ Deze 'bemidde- 


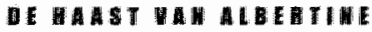

lende landschappen' waren het produkt van een cultuur die veel waarde hechtte aan de auto als manier om overal te kunnen komen. Land. schappen als Grand Canyon and Yosemite Valley konden in de ruimte die ze boden aan de auto ook worden gezien als iconen van een krachtige nationale identiteit die vrijheid en individualiteit onderstreepte. Vanaf de oprichting van Yellowstone in 1872 waren de Amerikaanse parken niet alleen plaatsen, maar eerst en vooral bestemmingen; bereikbaarheid en bestaan waren niet los van elkaar te zien. ${ }^{6 \mathrm{~B}}$

\section{Mission 66}

De onmiddellijke beschikbaarheid van de parken als bestemming, mogelijk door het creëren van nieuwe passages, bleef niet zonder effecten. In de jaren na de Tweede Wereldoorlog begon de bereikbaarheid het bestaan van de parken te bedreigen. ${ }^{62}$ Tussen 1947 en 1957 steeg het aantal auto's in de Verenigde Staten snel van 37 miljoen in 1947 tot 67 miljoen in $1957 .{ }^{63}$ Deze enorme groei van het autobezit weerspiegelde de voorspoed van de Amerikaanse middenklasse. De combinatie van gestegen inkomens, een hogere levenstandaard, meer vrije tijd en een toegenomen mobiliteit leidde tot voortdurend toenemende bezoekersaantallen in de nationale parken, die in die tijd vooral werden gezien als populaire vakantiebestemmingen ${ }^{64}$ In 1955 bezochten 55 miljoen mensen de parken. In dezelfde periode namen de bestedingen door de federale overheid aan de parken gerekend per bezoeker af. In reactie op de groeiende bezorgdheid over de verwaarlozing van het systeem van nationale parken, schreef de journalist-historicus Bernard De Voto, een uitgesproken natuurbeschermer, in 1953 in Harper"s Magazine dat sommige parken dan maar gesloten moesten worden. ${ }^{65}$ In 1954 en 1955 verschenen meer kritische artikelen. ${ }^{66}$ Sommige auteurs stelden voor meer geld te besteden aan 'our crumbling parks', anderen onderstreepten het belang van het werbeteren van de faciliteiten in "the country's shrines". Conrad Wirth, die in $195 \mathrm{x}$ directeur werd van de NPS, zei dat het publiek de parken 'doodknuffelde'. ${ }^{67}$ Wirth zag zich voor de opdracht geplaatst de passages die de parken bereikbaar maakten te onderhouden en waar nodig te repareren.

In zijn autobiografie herinnert Wirth zich hoe hij op een zaterdag- 
awond in februari 1955 het plan $\mathrm{kreeg}$ om de problemen in de overbevolkte parken aan te pakken. In plaats van jaarlijkse aanpassingsplannen waarop gemakkelijk bezuinigd kon worden, moest de Nps een tienjarenplan ontwikkelen dat in zijn geheel door het Huis van Afgevaardigden kon worden aangenomen. ${ }^{68}$ Op maandagochtend stelde Wirth twee commissies in on plannen te maken voor wat hij Mission 66 had genoemd, een nam die zowel het gevoel van een missie uitdrukte als verwees naar het jaar 1966 waarin de NPS haar 50 -jarig bestaan zou vieren. De commissies vroegen aan alle parken om de problemen te inventariseren en een schatting te maken van de extra kosten die ze zouden moeten maken om die problemen op te lossen. Na een jaar van voorbereidende onderzoeken en plannen, werd Mission 66 gepresenteerd aan president Eisenhower.

Nadat Eisenhower positief had gereageerd had op het voorstel werd Mission 66 officieel gepresenteerd tijdens het tweede jaarlijkse "Pioneer Diner' op 8 februari 1956 in Washington D.C. ${ }^{69}$ Meer danzevenhonderd gasten woonden het diner bij, onder wie leden van de Senaat, het Huis van Afgevaardigden, regeringsleden, leiders van natuurbeschermingsorganisaties, de hoofden van nationale en staatsparken en vertegenwoordigers van toeristische organisaties. Het diner, met op het menu geroosterd buffelvlees uit de staat Dakota, werd aangeboden door de minister van Binnenlandse Zaken Douglas McKay, politiek verantwoordelijk voor de NPS, en de American Automobile Association (AAA). De omslag van het dinerprogramma toont drie foto's van "motoring pioneers" in Yosemite in 1900 , een herinnering aan de belangrijke rol die de auto had gespeeld in de vorming van de parken. Edwin $S$. Moore van de California State Automobile Association zei in zijn tafelrede: 'Onze belangen in de nationale parken gaan terug tot het begin van het parksysteem toen we erin slaagden de parkgebieden te openen voor het gemotoriseerde publiek. Hoe kunnen we deze gebieden tegelijk behouden én ze open stellen voor gebruik? Dit lijkt op het eerste gezicht een tegenstelling, maar ik denk dat het kan en vindt dat her moet kunnen." 70

De brochure Our Heritage, die werd gepresenteerd tijdens het Pioneer Diner, benadrukte de NIs het belang van het parkensysteem als een 
"national resource" die cen grote bijdrage levert aan de Amerikaansele vensstandaard en de nationale economie. ${ }^{71}$ Het probleem was simpel, legde de NPS uit: 'de nationale parken zijn noch voldoende toegerust noch beschikken ze over voldoende personeel om hun onvervarngbare eigenschappen te beschermen, of zorg te dragen voor de opwang wande miljoenen bezoekers. ${ }^{72}$ Tot aan 1966 verwachtte men een groei van het aantal bezoekers van viftig naar tachtig miljoen. Mission 66 beoogde de uitvoering van een plan wan acht punten waa ronder het uitbreiden van de staf in de parken, het verbeteren van voorzieningen voor de staf, landaankoop voor het consolideren van bestaande en de vorming wan nieuwe parken, het aanpassen en verbreden van wegen en wandelroutes en de bouw van zogenaamde visitor centres. In retrospectief lijkt de opgave van Mission 66 samengevat te kunnen worden als: hoe zorgen we ervoor dat de groei van het aantall bezoekers, die allemaal met de auto komen, wordt opgevangen zonder dat de natuur in de parken beschadigd wordt. Een afbeelding in Our Heritage vat die opdracht bondig samen (zie figuur $4 \cdot 3$ ):

De spanning tussen bereikbaarheid en wildernis was niet nieuw. Thomas Vint, de belangrijkste architect van de Nps vanaf de jaren dertig tot in de jaren vijftig, gebruikte het begrip 'wilderness' daar waar hij de aanleg van wegen wilde voorkomen. Masterplannen moesten ertoe leiden dat in de parken verschillende zones kwamen, elk met een functie "willerness", "research', "sacred" and 'developped'. De aan- of afwezigheid van de auto vormde daarbij het onderscheidende criterium." Mission 66 stond in deze traditie. Om de parken in stand te kunnen houden, moesten er goede voorzieningen zijn woor de bezoekers, een uitgangspunt dat Lon Garrison, een van de Mission 66-ambtenaren, 'the paradox of protection by development' noemde. Centraal in het Mission 66-programma stond de gedachte dat door bepaalde gebieden in het park goed bereikbaar te maken door wegen, paden en andere faciliteiten, de invloed van de grote aantallen bezoekers in de rest van het park beperkt bleef. Goede voorzieningen zouden de natuur in de parken niet schaden maar juist beschermen. ${ }^{74}$ Voor Wirth en Garrison verschilden 'roadside wildernis' en 'true wildernis' hooguit gradueel. In een brochure die tijdens de Mission 66-periode werd uitgegeven door de NPS 


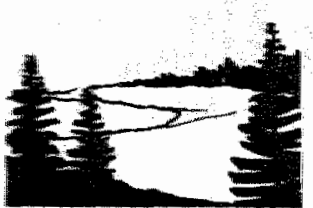

COUNTN PAIKK5

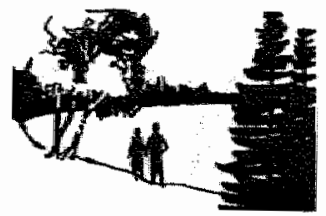

STATE PARKS

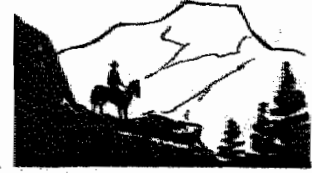

NATIONAL PARKS
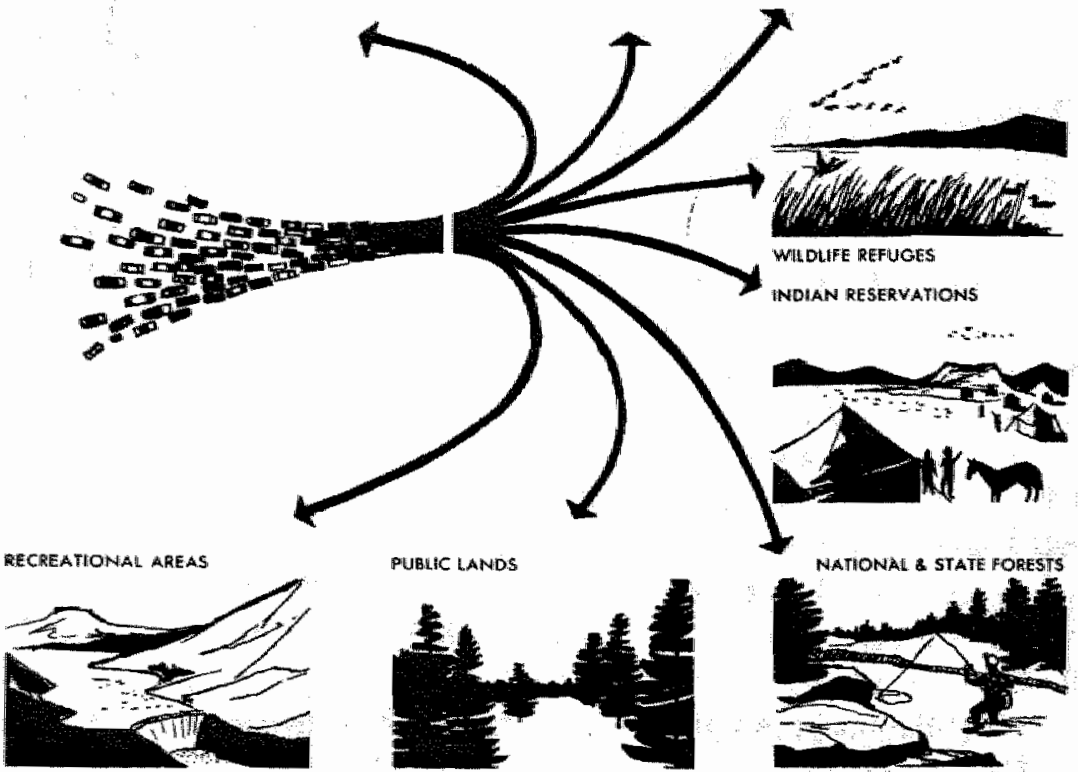

Figudir 4.3: Met de auto naar het park. [Bron: Our Heritage (1955). National Park Service History Collection in Harpers Ferry, Mirginia.]

komen we de uitdrukking "accesible wilderness" tegen, wildernis die bereikbaar was na een wandeling van tien minuten vanaf een van de parkwegen.75

Met Mission 66 deed ook het modernisme haar intrede in de parken. De rustieke stijl die tot dan toe de ontwerpcriteria van de NPs kenmerkte, maakte plaats voor een moderne architectuur ${ }^{76}$ Rusticke gebouwen, bruggen en uitkijkpunten waren aangelegd met het oogmerk ze te laten harmonieren met het omringende landschap. Die doelstelling werd minder belangrijk in de modernistische aanpak. Een goed voor- 
beeld wan een modernistische innovatie uit de periode van Mission 66 is het "visitor centre", dat het oude park "museum" moest vervangen. Het idee wan het bezoekerscentrum was om mensen de gelegenheid te bieden in een keer alle informatie te krijgen over het park die ze nodig hadden, vandalar dat de centra ook wel 'one stop service units' werden genoemd. ${ }^{77}$ De bezoekerscentra pasten in een strategie waarin men probeerde bezoekersstromen efficiënt door de parken te leiden. Anders dan de rustieke parkmusea, die vaak vlak bij de belangrijkste bezienswaardigheden lagen, waren de bezoekerscentra gesitueerd op plekken die goed toegankelijk waren, bijwoorbeeld bij de ingang van het park of op de kruising wan belangrijke parkwegen. Het centraliseren van activiteiten moest leiden tot een efficiënter gebruikspatroon wan de parken. De achterliggende planningstheorie sloot aan bij gangbare opvatingen over de inrichting en vormgeving van winkelcentra, bedrijvenparken en industrieterreinen (Allaback, 2000).$^{78}$ In de bezoekerscentra moesten mensen snel een overzicht kunnen krijgen vam de routes in het park, de belangrijkste bezienswaardigheden, de plats van de voorzieningen, de tentoonstellingen en -zeer belangrijk-de audiovisuele presentatie, die vanaf de jaren vijftig populair werd. Het waren allemaal manieren om het bezoek van grote groepen mensen aan de parken te vergemakkelijken en te bespoedigen.

Het Mission 66-programma zou uiteindelijk de tien jaar bijna volmaken en geldt als een van de meest succesvolle overheidsprogramma's in de Amerikaanse geschiedenis (Sellars, 1998). Talloze vernieuwingen en aanpassingen werden uitgevoerd en veel daarvan bepalen tot de dag van vandaag de aamblik van de parken. Dat neemt niet weg dat het programma geleidelijk meer kritiek kreeg. Aanvankelijk betrof die kritiek vooral de modernistische vormgeving van de nieuwe visitor centres en uitkijkpunten, vanaf het begin van de jaren zestig ook de natuurbeschermingsuitgangspunten. ${ }^{79}$ Volgens critici werden de parken onderworpen aan een proces van verstedelijking. Een artikel in National Parks Magazine stelde "that engineering has become more important than preservation, creating wide, modern roads similar to those found in state highway systems and visitor centres that looked like medium-sized airport terminals". ${ }^{\circ 0}$ Exemplarisch was de in 1959 gebouwde Clingman's 


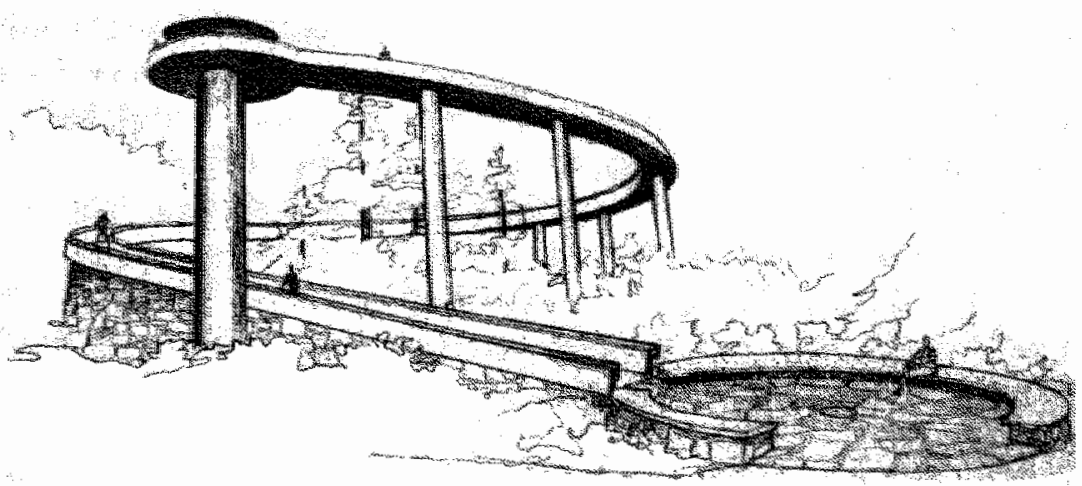

Figuur 4.4: De Clingman's Dome Tower wormde een radicale breuk met de naturalistische, rustieke stifl wararin uitkigkpunten en -torens werden gemaakt uit steen en hout. De toren bestaat uit een betonmen baan van twee meter breed en meer dian honderd meter lang die naar het uithikplateau zo"n vifftien meter boven de boomtoppen leidt. (Bron: Flint McCelland, 1997: 471)

Dome Tower, een uitkijktoren in Smokey Mountain National Park. De toren was een affront, volgens sommigen: een betonnen structuur die op geen enkele manier harmonieerde in het landschap en deed denken aan de oprit van en snelweg. De bewegende blik van de bezoeker die naar boven wandelde, imiteerde de visuele ervaring van het rijden op de parkweg, waarbij de bezoeker de schoonheid van de natuur zich zag ontwikkelen van het ene naar het andere uitkijkpunt (zie figuur 4.4$)^{8 .}$

\section{Circulatie en representatie}

Thomas Cook cultiveerde plaats-mythen over bijvoorbeeld de Schotse hooglanden. Immers, wie de romans van Sir Walter Scott had gelezen, wilde de ruige bergen in het noorden wel eens met eigen ogen zien en Cook maakte van dit verlangen gebruik door reisfolders en een blad als The Excursionist uit te geven. Maar verhalen vormen niet alleen de bouwstenen van de passage, ze worden er ook gevormd. Autokampeerders die elkaar onderweg tegenkwamen, wisselden verhalen uit over de toestand van de weg, de reparaties die ze hadden moeten witvoeren 
en de beste plaatsen om te overnachten. Naarmate het reizen per auto sneller, comfortabeler en vooral voorspelbaarder werd, viel er steeds minder over te vertellen. Het Interstate Highway System werd het domein van de verveling en die verveling riep weer het verlangen op de bestemming snel te bereiken; elke passage creëert zijn eigen verwachting. Die bestermming moest "anders" zijn dan de eenvormigheid die men onderweg zag, maar desalniettemin toch ded uitmaken van de flow' die de gestandaardiseerde passage creeerde. Om aan die dubbele eis te kumnen voldoen, moest in de parken een gestileerd verschil tot stand gebracht worden tussen snelweg en wildernis, of in bredere zin tussent cultuur en natuur. Het hybride landschap in de parken ging functioneren als de 'middle landscapes' die Leo Marx beschrijf: het zijn landschappen die een brug slaan tussen tussen technologie en het pastorale ideaal. $^{8 x}$

Niet alleen raakte het fysieke landschap steeds meer gestileerd, ook de representatie van 'de wildernis" werd meer een kwestie van "design". Zoals Nye ( 1997 ) terecht opmerkt, is in het creëren van bestemmingen als de nationale parken altijd een samengaan van technieken wam transport en representatie verondersteld. "The tourist arrives with preconceptions. There is no innocent eye. ${ }^{* 83}$ De opvattingen over de infichting en vormgeving van de parken waren van oudsher sterk beinvloed door de negentiende-eeuwse Engelse landschapsarchitectuur, waarin het esthetische, picturale aspect van de natuur op de voorgrond stond. Natuur moest vooral mooi zijn om naar te kijken. In de jaren twintig en dertig werd de inrichting van de parken, maar ook de anleg van bijvoorbeeld parkways beheerst door de visuele retoriek van bet uitkijkpunt, van het 'vista point'. De auto bracht de bezoekers niet alleen naar de uitkijkpunten toe, maar als je in de auto bleef zitten, werd het negentiende-eeuwse landschapsschilderij ook in beweging gezet. ${ }^{8}{ }^{4}$ De blik werd dynamisch, het landschap werd als een film geprojecteerd op de voorruit wan de auto. In de aanleg van de wegen in de parken, maar vooral ook van de Parkways - een soort langgerekte nationale parken - werd die film tot in de kleinste details geregisseerd. De ontwerpsnelheid van de parkwegen werd bewust laag gehouden; wie snel op wilde schieten had immers in de parken of op de Parkways niets te zoeken. Als 
een "wandelaar op wielen' ${ }^{98}$ moest de bezoeker de tijd hebben om te genieten van de mooie natuur.

Het is geen toeval dat in de periode van de Mission 66 de representatie van de wildernis meer aandacht kreeg. De parken dreigden overstroomd te worden door bezoekers en dat probleem werd opgelost door de woorwaarden te scheppen voor een snellere doorstroming. Dat deed men door de tijd-ruimtelijke orde van de parken op twee manieren aan te passen. Op het materiële niveau bouwde men modemistisch vormgegeven bezoekerscentra, uitkijkpunten en parkeerplaatsen die niet langer werden 'ingebed' in het landschap. De filosofie van de 'democratische toegankelijkheid' eiste snelle doorstroming op die plaatsen waar de meeste bezoekers kwamen. Maar aanpassing van de materiële vormgeving was niet voldoende om de bezoekersstromen te beheersen. De ervaring van de aanwezigheid in de parken moest worden gestileerd; in andere woorden, datgene wat het unieke karakter bepaalde van de parken moest worden 'samengevat' in gestileerde representaties of beelden. Hoe duidelijker de bezoekers van bijvoorbeeld Yosemite wisten wat de mooiste plaatsen in het park waren, hoe sneller ze het park weer zouden verlaten. De foto's van Ansel Adams van Half Dome en de anderhalve kilometer hoge rotsformatie El Capitan wormden de magneten die mensen naar die plaatsen trokken waar ze deze foto's 'in het echt' konden zien. ${ }^{86}$

Patin ( 1999 ) verdedigt de stelling dat de nationale parken beschouwd moeten worden als musea, niet alleen omdat ze de natuur en de wildernis in stand houden en bewaren voor latere generaties, maar ook omdat ze dezelfde technieken gebruiken alls musea om de blik van de bezoeker te reguleren en te organiseren. De natuur van de parken kan niet in musea tentoongesteld worden, maar de parkontwerpers konden wel teruggrijpen op de logica van het nuseum: 'het ontwerp van de ingangen, de presentatie van informatie, de sturing en richting van verkeersstromen en de regulering van de positie van de bezoekers." ${ }^{\text {\$7 }}$

Tijdens de Mission 66-periode werd de weg zelf een steeds belangrijker techniek, niet alleen om de blik wan de toeschouwer te organiseren, maar ook de volgorde en het tempo waarin de bezienswardigheden elkaar opvolgen. De 'loop-roads' ordenden het landschap in 
duidelijke tijd-ruimtelijke sequenties, op zodanige manier dat de bezoekers eerder langs dan door de wildernis werden geleid. Patin citeert uit het Handbook of Standards for National Parks and Parkway Roads uit 1958 , waarin NPS-directeur Wirth opmerkt dat '[roads] become principal facilities for presenting and interpreting the inspirational values of a park. "Net als de snelwegen, wegresta urants en motels van de Amerikaanse passage, creëerde de Nationals Park Service in de manier waarop zij de parken ontwierp niet alleen ruimtelijke en dus materiële orde, maar ook een temporele orde. Hier valt een analogie op met het in 1956 geopende Disneyland in Los Angeles - misschien niet toevallig het jaar waarin Mission 66 van start ging. Het ontwerp van dit attractiepark was erop gericht de beweging van de bezoekers door het park te controleren en te standaardiseren, merkt Bryman (1995) op. De ruimtelijke opzet, met het sprookjeskasteel wan Sneeuwwitje als "aandachtmagneet' halverwege het park, leidde de mensen van de ingang verder het park in. Bij de verschillende attracties werden de bezoekers in wagentjes rondgeleid. 'Dit houdt in dat iedere bezoeker slechts enkele momenten kan kijken naar de scenes en objecten die de "Imagineers" hebben gecreëerd. Disney kan zo de hoeveelheid tijd controleren die iedere bezoeker bij een attractie doorbrengt, waardoor grote aantallen mensen toegang hebben tot deze attracties. Dat het hierbij om "ritten" gaat, zorgt erwoor dat bezoekers de attractie allemaal op dezelfde manier zullen ervaren. Elke individuele bezoeker ziet precies hetzelfde alls alle andere bezoekers en zo wordt de ervaring van het attractiepark gestuurd en gestandaardiseerd. ${ }^{* 99}$

De parkontwerpers van Mission 66 beseften dat het alleen mogelijk was om groeiende aantallen bezoekers door de parken te laten stromen én de natuur te behouden door de verblijfstijd van de bezoekers te bekorten. Sindsdien is een dagenlange wandeling door het park, bijwoorbeeld naar de bodem van de Grand Canyon, in veel parken maar voor minder dan een procent van de bezoekers weggelegd. De rest verblijft steeds korter in de parken; een recent onderzoek concludeerde dat gemiddelde tijd die toeristen doorbrengen in de parken is afgenomen van enkele dagen honderd jaar geleden tot minder dan twaalf uur in 1990 , aan de zuidrand van de Grand Canyon zelfs tot vier uur: 


\section{Conclusie}

De wegen in de parken en de parkwegen maakten de wildernis bereikbaar op twee manieren. Ze vervoerden mensen naar en door de parken en brachten hen naar zorgvuldig uitgekozen plekken, waar parkeerplaatsen en uitkijkpunten waren aangelegd (zie figuur 4.4). Ze maakten de wildernis bereikbaar in de vorm van gestileerde representaties. Deze stilering had een gelaagd karakter. Om te beginnen werd het verschil tussen 'wildernis en 'snelweg' gestileerd. In de tweede plaats werden werschillen tussen soorten natuur gestileerd in het onderscheid tussen nationall parks, state parks, national monuments, wildlife refuges, indian reservations en dergelijke. Het karakter van de bestemming werd zo "voorgesorteerd". Tenslotte werden de verschillen tussen de parken gestileerd; wie Half Dome in Yosemite had gezien, was nog niet bij de geijsers van Yellowstone geweest. Het publiek werd in deze stileringen opgevoed doordat ze teruggrepen op duidelijke en herkenbare verhalen, beelden en emblemen.

In de 'intermediary landscapes' (Carr), op de grens tussen de Amerikaanse passage en de wildernis, werd de belofte die gecreëerd was door talloze afbeeldingen en andere representaties van de wildernis snel en efficiënt ingelost. Door deze stileringen leerde de bezoeker wat te verwachten en hoefde daarom niet langer te blijven dan wenselijk was vanuir het perspectief van de parkplanners en natuurbeschermers. Tijdens de Mission 66-periode werd een nieuw type passage gebouwd, een die mensen niet alleen snel en efficiënt naar 'de wildernis' bracht, maar hen ook weer snel en efficiënt huiswaarts liet keren. Dit gebeurde door, met de weg ernaar toe, ook de bestemming (het nationale park) én het collecrieve beeld van die bestemming sterk te stileren en te standaardiseren. Deze innovatie bleek (voor enige tijd) de sleutel tot het oplossen van het ontwerpdilemma dat het gevolg was van de groei van het aantal park bezoekers.

We kunnen de foto aan het begin van dit hoofdstuk nu met andere ogen bekijken. Voor hij met zijn Toledo aan de rand van de Grand Canyon stond, heeft deze automobilist waarschijnlijk veel werk moeten verzetten om de wrijving van gebrekkige autotechniek, slechte wegen 


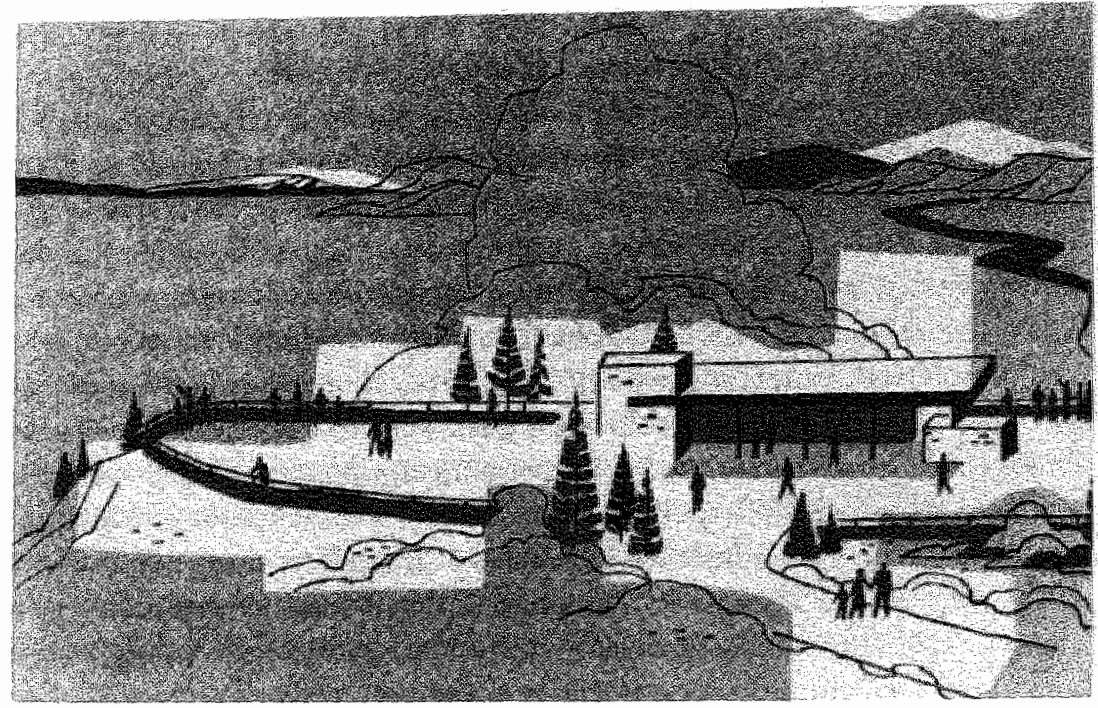

Figun 4.4: Gesticerde afbeelding van een bezoekerscentrum met uitkijkpunt die verscheen op het omslag wan de brochure Mission 66 in Action wit 1959. [Bron: Allaback, 2000: 31]

en ontbrekende voorzieningen op te heffen. Dat werk werd in de loop van de twintigste eeuw in toenemende mate 'uitbesteed' aan gestandaardiseerde netwerken. Niet alleen de produktie van auto's werd gestandaardiseerd op Tayloristische en Fordistische leest, ook de wegen, benzinestations, wegrestaurants en motels kenmerkten zich meer en meer door eenvormigheid en de noodzaak op elkaar aan te kunnen sluiten. Standaardisering vormde zo de voorwaarde voor de 'flow' waardoor automobilisten overal op elk moment konden komen. Er ontstond een gestandaardiseerde spatio-temporele orde, een wereld warin alle verschillen konden worden benoemd in termen van 'miles' per (autorijdend) uur.

De enorm stimulerende werking die dit netwerk thad op de (auto) mo* biliteit vormde echter een probleem als het ging om het ontwerp van de archety pische Amerikaanse bestemming, de nationale parken. De parken moesten enerzijds kunnen 'aansluiten' op de gestandaardiseerde 'space of flows' om überhaupt bereikbaar te kunnen zijn. En bereik- 
baarheid vormde vanaf de instelling van het eerste nationale park in 1872 , Yellowstone, het bestaansrecht voor deze natuurgebieden. Anderzijds mocht deze aansluiting er niet toe leiden dat de parken als bestemming hun unieke karakter verloren. Bij de uitvoering van deze ontwerpopdracht laveerde de National Park Service tussen de eisen van 'democratische bereikbaarheid' en de waarde van de wildernis die de dienst geacht werd ongeschonden door de geven aan komende generaties, een waarde die immers evenzeer het bestaansrecht van de parken bepaalde als hun bereikbaarheid.

Het voorbeeld van Mission 66 maakt ook duidelijk dat de vormgeving van de natuurparken nooit immanent stabiel is, dat het op allerlei momenten in de geschiedenis nodig is om de afstemming tussen bereikbaarheid en bestemming opnieuw te bepalen. Passages hebben effecten die woor een deel contingent zijn; de spatio-temporele orde is nooit "af", maar moet voortdurend worden gerepareerd. De parkplanners deden dat door de inrichting van de parken aan te passen, door bezoekerscentra te bouwen die bezoekers snel de weg wezen naar de belangrijkste voorzieningen en uitkijkpunten. Doorstroming was een eerste eis om te voorkomen dat de massa's bezoekers die door de auto werden gebracht het park zouden verstoppen. Die doorstroming werd niet alleen bereikt door aanpassingen in het materiële ontwerp van de parken, maar ook door de representatie van de wildernis te stileren. Zo werden de parken plaatsen waar mensen snel konden komen, maar er daarom ook maar kort konden blijven.

Voor de eerste automobilisten in de Verenigde Staten was de grote aantrekkingskracht van de auto dat ze zich konden ontworstelen aan het corridor-achtige karakter van de passages zoals ze die tot dan toe kenden: de vaste tijdstippen en routes, de tunnel door ruimte en tijd die de trein creëerde. Maar samen met de wrijving van moddlerige wegen werdween in de twintigste eeuw het avontuur van de reis, om plaats te maken voor de verveling en monotonie van de gestandaardiseerde verplaatsing. Het ideaal van ongebondenheid en flexibiliteit werd gedelegeerd aan de representatie van het autoreizen. Reismythes als van de 'open road', de 'frontier' en de transcendentalistische 'selfreliance" hielden het idee van een onvoorspelbare, avontuurlijke reis in stand. Dat 
het hier niet gaat orn een scherpe tegenstelling, maar dat het materiele en het immateriële deel uitmaken van dezelfde orde bleek in het voorbeeld van de nationale parken. Waar de "flow' van de gestandaardiseerde netwerken alanzet tot haast en de wil zo snel mogelink de bestemming te bereiken, cultiveerden de parken het gestileerde beeld van rust en tijdloosheid van de wildernis. Het uitkijkpunt van het bezoekerscentrum symboliseert deze typisch Amerikaanse kortsluiting tussen circulatie en representatie. De automobilist staat er met zijn rug naar het voertuig dat beloofde hem snel en comfortabel naar de wildernis te brengen, maar de enige manier om die wildernis te bereiken is door ernaar te kijken.

De Amerikaanse passage heeft niet alleen de activiteit van het autoreizen in de Verenigde Staten veranderd, maar ook het verkeerslandschap en de bestemmingen die erdoor bereikbaar worden. De reiziger kan er mu 'wooruit kijken' in de tijd en weet wat te verwachten, onderweg ên op de plaats van bestemming. Toch moet het idee van avontuur blijven bestaan, dat is immers een belangrijke aanzet tot reizen. Deze spanning tussen het voorspelbare en het onvoorspelbare keert voortdurend terug in de talloze ontwerpopgaven die voortvloeien uit de noodzaak de heterogene elementen in de passage te laten aansluiten.

Er is daarnaast sprake van een ander type spanning: ook al weet de reiziger wat te verwachten en is de reis van A tot Z gepland, op het moment zelf kunnen er onderweg dingen gebeuren waardoor de reis stokt en de reiziger oplossingen moet zien te vinden voor problemen die tot vertraging kunnen leiden. Het bijregelen van de spatio-temporele orde van de passage in real time is een vaardigheid die aan bod komt in het volgende hoofdstuk. 


\section{5 \\ On tijd in de lucht}

Op een vliegveld draait alles om tijd. Het is de overal aanwezige Universal Time Coordinated (UTC), de wereldstandaardtijd. Het is de zittende en slenterende tijd van de passagier die wacht tot het instappen begint. Het is de vertrektijd voor een captain van een Boeing 747-400 naar New York die via de 'slottijd' gerelateerd is aan de drukte in het luchtrum boven de Atlantische Oceaan. Het is de tijd die grondwerktuigkundigen nodig hebben om een mankement aan een vliegtuigmotor te repareren, de tijd die staat voor het tanken van de negentigduizend liter kerosine die op een middellange intercontinentale vlucht wordt verstookt. Tijd structureert de talloze logistieke processen op en rond de luchthaven, "synchroniseert de handelingen van mensen die zich over de hele wereld bevinden en geldt in de vorm van punctualiteit als het belangrijkste produkt van een vliegtuigmaatschappij, want nergens is het adagium 'tijd is geld' geldiger dan in de luchtvaart.

Al deze verschillende tijden komen samen in het moment waarop een vliegtuig snelheid maakt op de startbaan en zich op het oog trager dan mogelijk van de grond verheft. Het begin van een vliegreis, bijvoorbeeld een transatlantische vlucht van Amsterdam naar Boston, is te onderzoeken zoals een archeoloog een vindplaats onderzoekt. Net als het landschap blijkt ook het moment gelaagd te zijn. ${ }^{2}$ Om vanuit Amsterdam na zeven uur op het geplande tijdstip in Boston te arriveren moet een heterogene orde worden gecreëerd. Vliegtuig, passagiers, bemanning, brandstof, het eten voor onderweg moeten op het juiste moment op de juiste plek zijn en dit kan slechts door een nauwkeurige afstemming van complexe ketens van gebeurtenissen. Deze afstemming vind deels van tevoren plaats, bijvoorbeeld in de dienstregeling van een luchtvaartmaatschappii, de onderhoudsschema's van de vliegtuigen of 
de boekingen van reisbureaus. Of deze vooraf bepaalde orde ook de fietelijke orde van de gebeurtenissen is, blijkt pas als het liegtuig aan zijn reis begint. Door talloze oorzaken kan de orde verstoord worden: ingecheckte passagiers verschijnen te laat bij de gate waardoor het vertrek moet worden uitgesteld, mistbanken beperken het zicht waardoor vliegtuigen niet op het geplande tijdstip kunnen vertrekken, drukte in luchtruim noodzaakt tot langere viegroutes, bagage kon niet op tijd geladen worden. Verstoring van de geplande orde betekent meestal vertraging; de 'reparatie' van de passage resulteert in een later tijdstip van vertrek of aankomst.

Gleick ( 1.999 ) heeft gewezen op, wat hij noemt, de 'paradox van de efficiëntie” in de moderne luchtvaart. Als een complex weefsel van tijd en beweging zijn talloze processen nauwgezet op elkaar afgestemd met het oogmerk zo efficiënt mogelijk gebruik te maken van middelen die een maatschappij als de KuM ter beschikking staan. Alleen zo is het immers mogelijk om elk jaar winstgevend meer passagiers en bagage te vervoeren. Matr hoe complexer de orde, stelt Gleick, hoe groter de kwetsbaarheid voor kleine verstoringen en hoe langer vertragingen doorwerken. ${ }^{3}$ Hoe voorkomt een maatschappij als de kLM dat het netwerk door deze efficiëntieparadox vastloopt? Het beantwoorden van die vraag veronderstelt, net als in de voorgaande hoofdstukken, een actorperspectief dat ik in dit geval creëer door 'in' de passage te kijken, door te bestuderen hoe verstoringen worden gerepareerd op het moment dat ze zich voordoen. Dat kan alleen door als onderzoeker ter plekke aanwezig te zijn en de actoren te volgen zoals dat in de etnografische traditie van het veldonderzoek gebeurt. ${ }^{4}$

Een luchthaven kent vele locaties waar onder tijdsdruk gewerkt. wordt aan het uitvoeren en repareren van de dienstregeling, waarbij voortdurend afstemming plaatsvindt tussen de werkvloer en de vluchtleiding. Exemplarisch voor deze locaties zijn de vertrekhal en het Operations Control Center. In dit hoofdstuk zal worden onderzocht hoe op beide plaatsen de passage van de vliegreis iedere dag weer opnieuw vorm krijgt. Dat doe ik door me met name te richten op de wijze waarop KLM-personeel reageert op dreigende en zich daadwerkelijk voordoende verstoringen van de tempo-ruimtelijke orde van de vliegpassage. 


\section{In de vertrekhal}

Wie een indruk wil krijgen van de complexiteit van de reizen die luchtvaartmaatschappijen hun klanten verkopen, kan letterlijk de passage binnengaan door een passagier te volgen op zijn of haar weg door de wertrekhal naar de vliegtuigstoel. Op Schiphol parkeren automobilisten hun auto op het parkeerterrein $\mathrm{P}_{3}$ voor langparkeren, gaan met een onbemand voertuigie naar de bushalte vanwaar ze per bus naar de vertrekhal rijden. Treinreizigers komen vanaf de perrons in het boven het station gebouwde Schiphol Plaza, een overdekte plein waar het licht gedempt is en de aangrenzende doorgang naar de vertrekhal juist verlicht omdat mensen nu eenmaal de neiging hebben naar het licht te lopen. Monitoren geven informatie over de vertrek- en aankomsttijden van de wliegtuigen. Gele, groene en blauwe borden, in I990 ontworpen door Bureau Mijksenaar, leiden de reiziger naar de vertrekhal, die net als op de meeste grote vliegvelden boven de aankomsthal ligt om de vertrekkende van de aankomende passagiers te scheiden.

Vertrekhal 2 op Schiphol is ingericht voor de KL.M. De passagiers worden hier opgevangen door medewerkers van KLM Passenger Services. ${ }^{5}$ Het bedrijfsonderdeel, dat deel uitmaakt van Ground Services, is opgedeeld naar de drie 'kanten' van een vliegreis: Departure (de 'landzijde', alles voordat de passagier door de paspoortcontrole gaat, hoofdzakelijk de check-in van passagier en bagage), Air-side (het gebied na de paspoortcontrole, bijvoorbeeld transferpassagiers en activiteiten bij de gates) en Arrival (aankomende passagiers, bagagebanden). In de vertrekhal werken de afdelingen Special Services, Passenger Handling en Ticketoffice. Special Services (SPL/PX) ${ }^{6}$ houdt zich bezig met speciale diensten aan passagiers dan wel met diensten aan speciale passagiers van de KLM, zoals het regelen van een minicar voor vervoer naar de gate van mensen die slecht ter been zijn of het begeleiden van vip's of leden van het koninklijk huis. Daarnaast is de afdeling verantwoordelijk voor de wachtlounges voor business class passagiers, houders van frequent fyer kaarten als de Silver Wing en de Royal Wing Card en voor passagiers die van de KLM een speciale behandeling krijgen. Ook de vip-room en de speciale suite voor leden van het koninklijk huis vallen onder deze 
afdeling. Passenger Handling (SPL/Pu) houdt zich bezig met het begeleiden wan de 'gewone' passagier. Hoofdtaak is het inchecken wan passagiers en bagage. Bij Ticketoffice (SPL/PO) kunnen passagiers tickets kopen en reserveringen omboeken. Het is een afdeling die op verschillende plaatsen op de luchthaven posities heeft, maar de grootste is gesitueerd achter in de KLM-vertrekhal.

\section{Dag x: De gouternewr van South Dakota (Special Services)}

Zoals elke luchthaven staat Schiphol in het teken van eenrichtingswerkeer. Een vertrekkende reiziger meldt zich bij de incheckbalie, checkt zichzelf en eventueel zijn of haar bagage in, krijgt een instapkaart, passeert de paspoortcontrole, brengt wat tijd door in het douanegebied en bij de gate, geeft daar de instapkaart af en loopt door de aviobrug het vliegtuig in naar de op het ticket aangegeven stoel. In dit traject worden voortdurend 'sluizen' gepasseerd. De passagier wordt geidentificeerd, gecontroleerd en uiteindelijk bij de gate afgescheiden van de buitenwereld. Dat de passagier bij het binnengaan van het vliegtuig wordt verwelkomd door personeel van de luchtvaartmaatschappij is niet alleen vriendelijkheid maar ook voorzichtigheid: iemand die het vliegtuig weer uitloopt, vormt een veiligheidsrisico. Alleen in uitzonderlijke gevallen wordt de richting van de het traject dat een passagier op de luchthaven aflegt omgedraaid.

De gouverneur van South Dakota en zijn gevolg van ongeveer tien mensen zijn op doorreis van de Verenigde Staten naar Wenen en moeten enkele uren op Schiphol doorbrengen. De groep verblijft in de Royal Wing lounge. ${ }^{7}$ De groep ambtenaren die met de gouverneur meereist, heeft aangegeven dat men in de paar uur die men in Amsterdam is graag de binnenstad zou bezoeken. De gouverneur zelf blijft in de lounge om er te rusten; hij lijdt aan een nieraandoening waarvoor hij speciale medische apparaturur bij zich heeft die hem minder mobiel maakt. Het probleem is, dat de groep in transfer is en dus eerst helemaal zou moeten uitchecken (inclusief bagage) om vervolgens weer in te checken voor de vlucht naar Wenen. Er zou dan geen tijd overblijven voor een bezoek aan de stad. Omdat de gouverneur en zijn gevolg vallen onder de categorie bijzondere passagiers, stelt Special Services/Protocol een plan op om de standaardvoorschriften te omzeilen. 
Medewerkster Rietje ter Haar belt met de douane en marechaussee en geeft door op welk moment ze waar met de groep zal passeren op weg naar de uitgang. Achrer haar aan lopen de Amerikanen langs een route die alleen voor ingewijden bekend is, passeren de douane in omgekeerde richting en lopen langs een beveiligingsbeambte die de speciale Schiphol-passen controleert. Ze kennen Ter Haar en weten door haar tellefoontje al wat ze komt doen zodat verdere uitleg overbodig is. Bij de uitgang wacht een gids die de groep verder zal begeleiden naar het centrum van Amsterdam, daar zal rondleiden en op het afgesproken tijdstip weer zal afleveren bij de ingang war Ter Haar hen zal opwachten om hen opnieuw langs de dowane te loodsen.

Terug op haar kantoor vindt 'Ter Haar een fax uit South Dakota. De gouverneur reist met speciale medische apparatuur, maar wil liever niet dat daaraan bij de gate teveel aandacht wordt geschonken door de beweiligingsbeambten. Het verzoek aan KLM om een en ander discreet te behandelen is diplomatiek geformuleerd: 'The governor will be traveling with personal medical equipment which "could" (but should not) cause a problem when he checks in.' Ze belt de beveiligingsbeambte die ze toevallig kent, geeft de naam van de gouverneur door en de gate waar deze zal instappen. Net als de leden van het gevolg van de gouverneur zal ook zijn apparatuur zonder problemen de controle kunnen passeren.

\section{Dag 2: Pelgrims met een nummer (Passenger Handling)}

KLM-vlucht KL 734 vliegt naar Jeddah. Het vliegtuig verwoert bijna uitsluitend Nederlandse pelgrims op weg naar de jaarlijkse Haji in Mekka. Voor het KLM-grondpersoneel is een Haj-vlucht een speciale gelegenheid, ook al ondat de pelgrims worden weggebracht door hun familie en zich soms emotionele afscheidstaferelen afspelen; sommige oudere pelgrims komen immers niet weer terug van hun reis, bijwoorbeeld omdat ze bezwiijken in de mensenmassa rond de Kaába. Voor de kLM als maatschappij is deze vlucht bijzonder omdat de pelgrims over een Hajvisum moeten beschikken. De Saoedische autoriteiten zien er streng op toe dat de miljoenen pelgrims het land ook weer verlaten; ze worden met behulp van het speciale visum bij aankomst meteen gescheiden van de "gewone' reizigers. Omdat de luchtvaartmaatschappij door de Saoe- 
dische autoriteiten verantwoordelijk wordt gehouden voor de geldigheid van het visum van een passagier - op straffe wan een hoge boete per passagier - besteedt de KLM veel tijd en aandacht aan de controle van de Haj-visa. Elke pelgrim wordt apart ingecheckt. Na het feitelijke inchecken controleert een Arabisch sprekende KLM-employee van elke pelgrim de tekst op het visum opnieuw.

Voor het inchecken maakt het grondpersoneel normaal gesproken gebruik van het Axis-systeem, een grafisch invoersysteem waarbij met een kleine muis in het certrum van het toetsenbord wordt genavigeerd tussen de invulschermen. Ook biedt AxIs de mogelijkheid de adresgegevens uit het paspoort elektronisch in te lezen, wat tijd scheelt. Deze ochtend wordt axis omzeild omdat elke ingecheckte pelgrim een speciale code, een nummer, in het systeem meekrijgt, zodat hun uitzonderingsstatus wereldwijd bekend is. Deze code kan alleen worden ingevoerd in het oude en tragere, commandogestuurde inchecksysteem. Dat brengt echter een groter risico op fouten met zich mee en de grondstewardessen zijn zich zeer bewust van de gevolgen. Als de samenstelling van de code niet klopt, kost dat de KLM veel geld vertelt een van hen:

'Het systeem vraagt om een nationaliteit. Normal is de aanduiding 'NL', maar die voldoet in dic geval niet omdat de Saoedisch willen dat er 'Dutch' wordt ingevuld. Dat moet je weten, anders gaat het fout. De vorige mevrouw had geen woornaam, maar het systeem. moet een voornaam weten anders geeft het geen instapkaart af. Ik hoor anderen haar aanspreken als 'Uki' dus zet ik Uki in het systeem." (Interview)

Van de incheckballie lopen de pelgrims naar gate fo5 waar de vlucht naar Jeddah wordt afgehandeld. Hier blijkt een systeem wan "free seating' te gelden. De instapkaarten worden weliswaar door de automatische lezer gehaald om het feitelijke 'boarden' van cen passagier te bevestigen, maar de op de kaart aangegeven stoelnummers gelden niet. De pelgrims mogen zelf bepalen waar ze gaan zitten: de vrouwen achterin het wliegtuig, de mannen voorin, zodat zij tijdens het gebed niet door elkaar heen hoeven te zitten. 
Dag 3: De kleine lettertjes op bet ticket (Ticket Office)

Achterin de vertrekhall, tegenover balierij 16 , bevindt zich een grote halfronde balie, de Ticketoffice. Hier kan de gehaaste passagier op het laatste moment een kaartje kopen voor een willekeurige KLM-vlucht. Daar geldt dan wel een ander tarief dan het reisbureau op de hoek rekent voor een vroege beslisser. Ook de passagier wiens vlucht is geannuleerd wanwege het slechte weer of die om een andere reden het ticket wil of moet veranderen kam hier terecht. Tegenwoordig werken de medewerkers van Ticket Office met wereldwijde reserveringssystemen waarin de boekingsgegevens van uiteenlopende maatschappijen worden bijgehouden.

'In 1969 gingen we voor het eerst werken met een automatisch reserveringssysteem. Voor die tijd belde een reisbureau met de vraag of er nog plaats was op een bepaalde vlucht. Dan keek je op de lijst voor die vlucht. Zo ja, dan pakte je een kaartje, waarvan een deel naar de telexkamer ging en het andere deel in een kaartenbak. Per telex werd de reservering naar alle KLM kantoren verzonden en daar verwerkt. Dat ging met houten bakjes met vakjes. Als iets in aanvraag stond zat er een rood tabje op. Nu is er geen luchtvaartmaatschappij meer die handmatig reserveert en zijn alle netwerken onderling gekoppeld zodat je voor iedere passagier kan zien hoe zijn of haar reis eruit ziet, de bestemming, de tijden, de speciale voorwaarden, of ze een vegetarische maaltijd hebben besteld.' (Interview)

Tickets verschillen al naar gelang de condities waaronder ze gewijzigd kunnen worden. Hoe goedkoper het ticket, hoe kleiner de mogelijkheden af te wijken. Een werknemer van Volvo met een businessklas ticket wil een andere vlucht, maar de voorwaarden staan dat niet toe. Baliemedewerkster Joke Smalhout van To weet uit ervaring dat KLM met Volvo heeft afgesproken dat op dit type tickets eenmaal mag worden omgeboekt. Een jongen en een meisje willen eerder terug naar Mexico, maar de 'fairbase', de kleine lettertjes op hun ticket, geeft aan dat het alleen tegen betaling van honderd us dollars kan worden gewijzigd. Dat heeft het stel er niet voor over. 


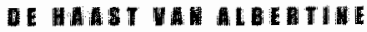

Een vrouw wil een hond meenemen op een vlucht naar Vancouver, Smalhout zoekt op haar scherm de voorwaarden voor een AVIH, een 'animal in hold', de vrachtruimte die net als het passagiersgedeelte tijdens de vlucht onder druk staat. Ze leest de kosten in het systeem: 240 Canadese dollars. Een man wil een eerdere vlucht naar Memphis. Deze vlucht is vol en zelfs overboekt. Net als andere maatschappijen worden steeds meer KLM-vluchten 'overboekt', dat wil zeggen dat er meer tickets worden verkocht dan er plaats is aan boord. Dit wordt gedaan omdat de ervaring leert dat een aantal passagiers niet komt opdagen. Het risico van lege stoelen weegt zwaarder dan ontevreden klanten, die ondanks het feit dat ze een ticket hebben worden omgeboekt naar een andere vlucht. In dit geval voorziet Smalhout dat er ondanks de overboeking plaats zal zijn, en boekt de passagier door.

\section{Observaties bij Passenger Services}

In de vertrekhal begint voor de passagier het traject van de incheckbalie naar de vliegtuigstoel. Dat traject kenmerkt zich door disciplinering: de reiziger wordt in een aantal stappen (bij de balie, bij het passeren van de douane, bij de gate, bij het instappen) omgevormd tot een entiteit die 'past' binnen de geplande passage. Vanuit het perspectief van de passagier is die disciplinering soms weinig inzichtelijk. Waarom moet men zich twee uur voor het vertrek van het toestel melden om vervolgens, na het inchecken, weer te moeten wachten in het douanegebied of bij de gate? Waarom is het zo duur om een ticket om te boeken? W/aarom mag men alleen handbagage meenemen in de cabine?

De ambiguïteit van de status van passagiers wordt versterkt doordat zij twee rollen hebben: ze moeten zorgen op tijd bij de gate te zijn, maar ze moeten als klant ook tijd doorbrengen in de talloze winkels en restaurants achter het douanegebied, die voor de luchthaven steeds belangrijker worden om de kosten van de uitbreiding van voorzieningen te bekostigen. Een luchthaven als Schiphol is aan de ene kant een instrument om passagiers zo snel als mogelijk af te handelen, terwijl het aan de andere kant steeds belangrijker wordt voor vliegmaatschappijen en luchthavens dat passagiers voldoende tijd hebben om hun geld uit te geven (Kloos en De Maar, 1996). Het contrast tussen de zakelijke 
functionaliteit van de check-in balies en de tientallen shops op de vijf commerciële 'eilanden' in het douanegebied is groot. De commerciële invulling van de wachttijd veroorzaakt soms problemen voor de passagiersafhandeling; passagiers vergeten de tijd of realiseren zich te laat dat ze eigenlijk al bij de gate hadden moeten zijn. Om zo snel mogelijk van de ene naar de andere wachtperiode te kunnen geraken, moet de passagier goed de weg kunnen vinden op de steeds uitgestrektere luchthaven. Lopen vanaf de check-in balie in de vertrekhal naar de verste gate op de G-pier neemt tussen de vijftien en twintig minuten, iets waar niet elke passagier op rekent. Vandaar dat bij de check-in tegenwoordig een folder wordt uitgereikt met daarop een kaartje van de luchthaven en de loopafstanden in minuten.

Waar passagiers hun stapsgewijze disciplinering wellicht ervaren als onvrijheid, zien de medewerkers van Passenger Service hen juist als de minst voorspelbare factor in de complexe ketens van gebeurtenissen die vooraf gaan aan het vertrek van een vliegtuig. Passagiers verdwalen en zijn te laat bij de gate, nemen te veel of te grote handbagage mee die vervolgens bij de gate moet worden ingenomen, beschikken niet over de juiste documenten, zijn kortom voor de KLM het lastigst te controleren. Wachttijden voor de passagiers zijn voor de vliegmaatschappij een manier om de passagierstijd en de dienstregeling in de pas te laten lopen. Vooral de passagier die wel bagage heeft ingecheckt, maar niet bij de gate verschijnt, in het jargon een-LMC ('min' Last Minute Change, ofwel een passagier minder op het laatste moment), bezorgt de KLM hoofdbrekens. Omdat bagage en passagier uit veiligheidsoverwegingen altijd samen moeten reizen, moet de bagage weer van boord gehaald worden, wat lange vertragingen oplevert. Deze soort vertraging krijgt bij de KLM de code $0_{3}$. Een speciaal mobiel roulerend team (MRT) moet ervoor zorgen dat deze code minder vaak toegekend wordt. ${ }^{8}$

Vertragingscode $0_{3}$ is een van de 99 internationale raTA-codes die staan afgedrukt op een geplastificeerd kaartje dat alle KLM-medewerkers bij de hand hebben. Het inzamelen van teveel handbagage bij de gate krijgt code ro, een defect aan het vliegtuig code $4 \mathrm{I}$, een tekort aan bemanning code 64 . De KLM-medewerkers in de vertrekhal hebben met slechts een deel van de codes te maken. Of een vliegtuig vertraging heeft, 
op welke gate het aankomt, of het wel of niet overboekt is ontrekt zich aan hun invloed. Hun handelingsruimte is beperkt; in de gegevensstromen die op hun schermen zichtbaar zijn kunnen zij alleen veranderingen aanbrengen voor zover ze op hun terrein liggen. Om de complexiteit van de gehele passage te kunnen overzien en te weten hoe verstoringen worden gerepareerd, volstaat het niet de enkele passagier, op reis van de ene naar de andere bestemming, te volgen. Een maatschappij als de KIM onderhoudt met een grote vloot wliegtuigen een wereldwijd netwerk van verbindingen. De regie van dat netwerk vindt plaats in het Operations Control Center:

\section{In het Operations Gontrol Center}

Elke passage kent een zekere voorspelbaarheid, maar is tegelijk het resultaat van toevalligheden. In de zeventiende en achttiende eeuw woeren de trekschuiten in Nederland volgens dienstregelingen die tamelijk nauwgezet werden uitgevoerd, wat onder meer mogelijk was ondat men op het water minder last had van slecht weer dan op de wegen die bijvoorbeeld in natte periodes onbegaanbaar waren. ${ }^{9}$ Ook stoomtreinen en stoomschepen zijn niet zo gevoelig voor de toevalligheid van bijvoorbeeld weersomstandigheden waardoor de regelmatigheid en voorspelbaarheid van passages kon worden vergroot, maar complexere dienstregelingen leidden tot nieuwe contingenties en dus tot nieuwe sturingsproblemen.

\section{De kunst van het sturen}

Beniger beschrijft in zijn boek The Control Revolution ( 1986 ) hoe industriële en technologische ontwikkelingen in de negentiende eeuw talrijke nieuwe 'technologies of control' veronderstelden, variërend van de penduleregelaar die het toerental van een stoommachine kon bijsturen tot de telegraaf waarmee ingewikkelde treindienstregelingen zonder ongelukken uitgevoerd konden worden. De grote transcontinentale spoorlijnen in de Verenigde Staten waren bijvoorbeeld enkelsporig, wat tot frontale botsingen leidde, zoals de Great Western Collision in $18_{4} \mathrm{r}^{\text {*a }}{ }^{\mathrm{a}}$ 
Behalwe veiligheid vroeg het snel uitdijende spoorwegennet in de Verenigde Staten en Europa om tal van afstemmingen en controles: dienstregelingen, de beschikbaarheid van rollend materieel op de juiste tijd en plaats, het vrijhouden van baanvakken en kruisingen met wegen, het plannen van de vervoerscapaciteit (aantallen reizigers en hoeveelheden wracht). Deze behoefte aan sturing en coördinatie leidde weer tot het instellen van een 'master of transportation' die binnen en bepaald gebied aan het hoofd stond van een 'chain of command' waarin de regels zeer precies waren geformuleerd. Op de trein zelf had de conducteur het heft in handen. In het geval van vertragingen, technische mankementen en andere verstoringen handelde de conducteur volgens gestandaardiseerde woorschriften. ${ }^{\text {" }}$ De conducteurs van de Western line, schrijft Beniger, kunnen worden beschouwd als de eerste mensen in de geschiedenis die ingezet werden als 'programmable, distributed decision makers in the control of fast-moving flows through a system whose scale and speeds precluded control by more centralized structures". ${ }^{12}$

Het aanpassen en herorganiseren van bestaande bureaucratische structuren van controle en toezicht was niet voldoende om de controleproblemen op te lossen die het uitdijende en versnellende transportsysteem met zich meebracht. Niet alleen de fysieke onderdelen van het systeem bewogen sneller, ook de communicatie over deze onderdelen moest sneller kunnen plaatsvinden; anders gezegd, de informatie over het bewegende voertuig moest sneller van A naar B overgebracht kunnen worden dan het voertuig zelf. Carey ( 1992 ) merkt op dat dit mogelijk werd door de telegraaf: 'The simplest and most important point about the telegraph is that it marked the decisive separation of "transportation" and "communication"." Bij de eerste spoorlijnen hielden baanwachters bij of baanvakken wrij waren of niet door met een rode of witte vlag naar de machinist te zwaaien. Dankzil de telegraaf kon men een spoorlijn in baanvakken verdelen, waarbij baanwachters van de ene aan de andere post telegrafisch konden doorgeven dat een trein in aankomst was. ${ }^{14}$ Deze co-evolutie van fysieke en elektrische netwerken is een central thema bij Beniger, mar wordt ook door andere auteurs beschreven. ${ }^{15}$

Niet alleen betekende de telegraaf dat voortaan twee snelheden mo- 
gelijk waren binnen een passage, wat de regeling van het treinverkeer vergemakkelijkte, men kon nu spoornetwerken en dienstregelingen beter integreren en coördineren. De telegraaf maakte het mogelik overzicht te creëren over talrijke gebeurtenissen die zich op werschillende plaatsen en tijdstippen afspeelden. Als voorbeeld van deze ontwikkeling beschrijft Beniger de innovatie van Daniel McCallum van de Erie Railroad in 1853. Om de besturing van dit netwerk te regelen, legde McCallum de nadruk op het verzamelen van informatie over de toestand op de sporen en hechtte hij belang aan hiërarchische communicatie, terugkoppeling van de informatie naar het proces en het opsporen van verstoringen en fouten in het proces. ${ }^{16}$ De trots van McCallum was een grote kaart in het kantoor van de General Superintendant waarop de informatie werd bijgehouden. Om dat te kunnen doen, moesten er vanuit de organisatie rapporten naar het kantoor worden gezonden, elk uur, elke dag en elke maand. De aanpak van McCallum was succesvol door de integratie van een aantal onderdelen: de telegraaf voor snelle communicatie, het rapportagesysteem en het organisatorische plan dat de verantwoordelijkheden van alle werknemers bij de spoorwegmaatschappij vastlegde. Hierdoor wist de Superintendent op elk uur van de dag de precieze locatie van elke wagon, elk rijtuig en elke locomotief en de taak die ze vervulden in de uitvoering van dienstregeling. Beniger beschrijft het systeem van de Erie Railroad in cybernetische termen als de terugkoppeling van versitoringen, fouten en afwijkingen in de dagelijkse realiteit naar de geplande realiteit zoals vastgelegd in de dienstregeling. In het mogelijk maken van die terugkoppeling, de kern van McCallums innovatie, was de telegraaf onmisbaar.

De controlekamer van McCallum leidde tenslotte tot een machtsverschwiving. Niet langer was de functionaris ter plaatse het best op de hoogre van de situatie en dus het best in staat om beslissingen te nemen. Nu had men juist in de controlekamer het overzicht over andere gebeurtenissen op andere plaatsen en tijdstippen, zodat men de consequenties van een beslissing beter kon beoordelen. De beslissings bevoegdheid verschoof van de plaats van handeling naar de controlekamer. Beniger benadrukt hier de historische continuïteit. Net zoals de conducteurs van de Western line de besturing van de trein over- 
namen van de machinst en de stoker en de controlekamer het weer overnam wan de conducteurs, zo zijn hedendaagse pilloten vooral "flight managers' die nauwelijks meer zelf her vliegtuig besturen als wel een oogje in het zeil houden terwijl computers en informatiesystemen het werk doen. ${ }^{\mathrm{T}}$

De genoemde drie aspecten van de kunst van het sturen binnen passages - een passage in twee snelheden, het creëren van overzicht en het herverdelen van beslissingsbevoegdheden - keren terug in het Frontoffice van het Operations Control Center.

\section{Het Frontoffice}

Het Frontoffice van het Operations Control Center (occ) van KLM is een moderne variant van de controlekamer van $\mathrm{McCallum} .{ }^{18} \mathrm{Het}$ is een ruime hal waarin het licht gefilterd door computergestuurde zonneschermen naar binnen valt en het klimaat elektronisch wordt geregeld. Voor in de hal staat een videowall die de halve breedte beslaat, maar niet in gebruik is. Het was de bedoeling dat op dit scherm alle vliegbewegingen van KLM wereldwijd in een oogopslag te volgen zouden zijn, maar door bezuinigingen werd de ingebruikname uitgesteld. Onder de videowall is een rij digitale klokken te zien die in groen de tijd aangeven. in een aantal wereldsteden. De middelste klok toont in rood de UTC (Uliniversal Time Coordinated), opvolger van de Greenwich Mean Time of GMT). ${ }^{19}$ In het midden van de zaal staan twee rijen desks met elk twee of drie beeldschermen, communicatieapparatuur en papieren. Aan weerszijden van de middelste rijen staan nog meer desks. Lang niet alle werkplekken zijn bezet. Mensen lopen heen en weer, praten of telefoneren. Op twee plaatsen voorin de zaal hangen frames met elk twee beeldschermen, een voor CNN, een voor Teletekst. Het Frontoffice is vierentwintig uur per dag actief. Er wordt gewerkt in drie ploegen. 's Ochtends om acht uur vindt in de grote Briefing Room het "ochtendgebed" plats, een korte bijeenkomst waar de vorige dag wordt geëvalueerd en de nieuwe dag voorbeproken.

In het Frontoffice zijn alle belangrijke bedrijfsonderdelen binnen KLM vertegenwoordigd. Alle besturingsregels, besluitwormingsproces sen, communicatielijnen en overlegstructuren die relevant zijn voor de 
witvoering van de KLM-vluchren op een dag zijn er fysiek onder een dak gebracht. Voor september I 999 zaten deze medewerkers op verschillende locaties, maar de KLM verwacht van de directere interactie tussen de medewerkers in het Frontoffice een adequatere reactie op verstoríngen, zodat de investering zichzelf terugverdient. De centrale functies in het Frontoffice zijn de Duty Manager Operations (DMO) en de (Senior) Operations Controllers ( $(s)$ oc). De DMO staat aan het hoofd van de hierarchische lijn, maar is niet direct betrokken bij dagelijkse beslissingen. Die worden genomen door de (Senior) Operations Controller die ervoor zorgt dat de dienstregeling op de dag van uitvoering zoveel mogelijk wolgens planning verloopt. $\mathrm{Hij}_{\mathrm{j}}$ is de spin in het web. Op netwerkniveau het niveau van de dienstregeling, dat wil zeggen alle vluchten die op een dag gepland staan - neemt de Operations Controller uiteindelijk de beslissingen, tegen de achtergrond van het operationele beleid dat door de DMO is vastgesteld. Er zijn op een dag van uitvoering steeds drie Operations Controllers aanwezig, een voor de vluchten van KLM Cityhopper (de F 50 en F70 vloot), een voor de vluchten in Europa (de 737 vloot) en een (de senior) voor de zogenaamde ICA- of intercontinentale vluchten (de wide body vloot). De controllers, die eindverantwoordelijk zijn voor alle aanpassingen op de dag van uitvoering op netwerkniveau, worden ondersteund door vertegenwoordigers van de belangrijkste bedrijfsonderdelen die bij de uitwoering betrokken zijn.

In een besturingsprotocol is vastgelegd hoe het occ 'de operatie bestuurt'. Het protocol beschrijft communicatielijnen, de besluitvormingsprocessen, de besturingsregels en de cultuur. Het is bedoeld om de besturing samenhang te verlenen en de werkwijze van het occ duidielijk te maken aan alle betrokkenen. Als doel van de besturing wordt in het protocol genoemd 'het verschil tussen de gewenste en geleverde kwaliteit met betrekking tot de realisatie van de dienstregeling zo klein mogelijk te laten zijn'. De besturing door het occ beslaat het hele proces - van de acceptatic van het plan en de daaraan gekoppelde gewenste kwaliteit, het inspelen op de omgevingsfactoren en het zoveel mogelijk pro-actief nemen en communiceren van de juiste matregelen tot aan het evalueren van de geleverde kwaliteit en de kwantiteit van de beshitrorming. 
13e besturing heeft als doel om het verschil tussen de Sewenste en geleverde kwaliteit zo klein mogelljk te laten ziln

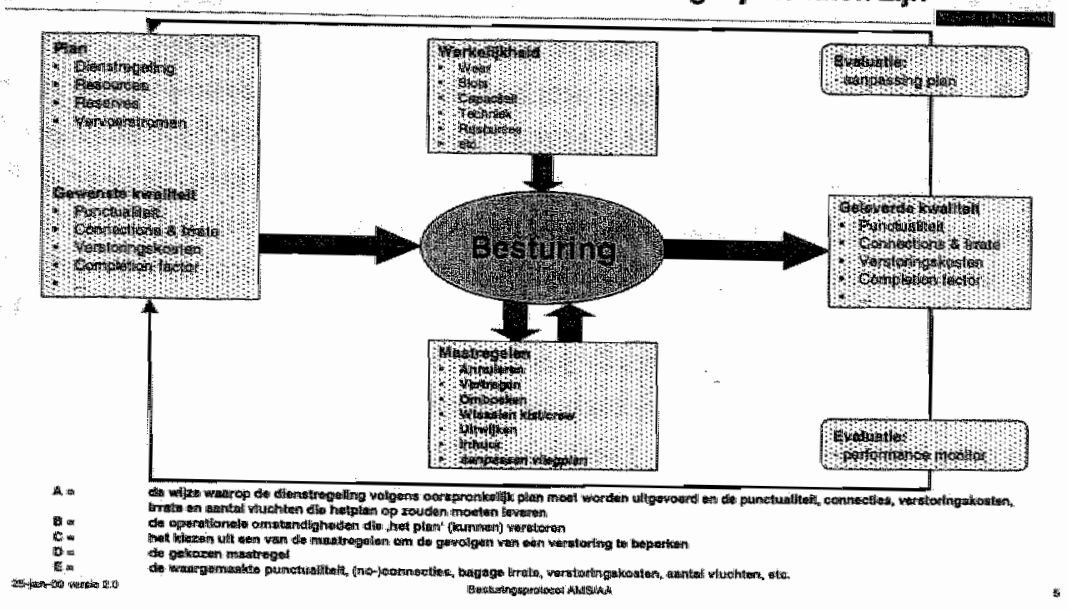

Figuur 5.1: Diagram uit een interne 0CC-map die bij elke medewerker in het Frontoffice op het bureau ligt. De besturing heeft als doel om het werschil tussen de gewenste en geleverde kwaliteit zo klein mogelijk te laten zijn.'

Het diagram in figuur 5.I toont hoe het occ zelf haar sturingsstrategie samenvat. Uitgangspunt is het plan waarvan behalve de dienstregeling ook de keuze van routes, inzet van vliegtuigen, reservestellingen en het verwachte aantal passagiers deel uitmaken. Van tevoren worden tevens kwaliteitseisen opgesteld waarbij in de eerste plaats wordt gekeken naar welke afwijkingen van de dienstregeling nog acceptabel worden geacht. Bij de vaststelling van het gewenste en gerealiseerde kwaliteitsniveau spelen punctualiteit, verstoringskosten, annuleringen en gemiste aansluitingen de rol wan indicatoren. Bij het realiseren van het plan zijn er allerlei factoren die, zoals het occ-document het formuleert, 'roet in het eten kunnen gooien': het weer, slottijden, technische mankementen, capaciteitsbeperkingen van start-en landingsbanen en een tekort aan per- 


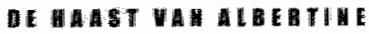

soneel. Als de gewenste $\mathrm{kwaliteit}$ verstoord dreigt te worden, moeten er zo pro-actief mogelijk maatregelen worden genomen om dat te vermiden of in elk geval gevolgschade te vermijden, stelt het occ. Er kan van vliegtuig ("kist') of bemanning ("crew") gewisseld worden, er kan uitgeweken worden naar een andere luchthaven, er kan extra capaciteit ingehuurd worden, de configuratie van het vliegtuig kan worden aan gepast, een vhcht kan worden vertraagd of versneld, of geannuleerd. Beslissingen over deze maatregelen worden op drie besturingsniveaus genomen. In de eerste plaats is er het vluchtniveau (niveau 3) waar beslissingen worden genomen die alleen gevolgen hebben voor een enkele wlucht. Deze besluiten worden genomen door de betrokken afdelingen en medewerkers. Het occ wordt pas betrokken in de besluitworming als een verstoring gevolgen heeft woor het niveau yan het netwerk als geheel (niveau 2), zoals vertraging, tussenlanding, annulering van een vlucht, aanpassingen van de capaciteit, een langere bloktijd ${ }^{20}$, als er extra kosten zijn, als er van de besturingsregels afgeweken moet worden, als een verstoring zeer complex is, bij een machinewisseling of in het algemeen bij twijfel of een verstoring op proces/vluchtniveau opgelost mag worden. Ten slotte is er het escalatieniveau (niveau r) van de "veiligheidsissues er/of non-standard operation zoalls calamiteiten, ongevallen of kapingen*. Dan is het de Duty Manager Operations die toezicht houdt over de hele besturing. Hij is zowel tijdens dag-en avonddiensten aanwezig voor het geval er op het hoogste niveau beslissingen moeten worden genomen. Tijdens dagelijkse evaluaties komen vragen aan de orde als: is de potentiele verstoring zo vroeg mogelijk gesignaleerd? Was alle noodzakelijke informatie tijdig beschikbare? Waren alle mogelijke scemario"s bij alle betrokkenen bekend? Is de gekozen oplossing duidelijk en gemotiveerd aan alle betrokkenen meegedeeld? Is het genomen besluit uitgevoerd zoals was afgesproken? Had het genomen besluit de verwachte en gewenste resultaten? Een goede besturing, zo concludeert het interne document, vergt betrokkenheid van iedereen. Iedereen die informatie binnenkrijgt, dient te beoordelen of die misschien van belang kan zijn voor andere processen. "We werken in een cultuur van respect, samenwerking, vertrouwen, professionaliteit en eigen verantwoordelijkheid.' Tot zover de papieren werkelijkheid. 
Dag r. Een gat in de romp in Barcelona (OC Europa)

De eerste ochtend dat ik meeloop in de Frontoffice van het occ is er weinig wind en veel mist. Daardoor heeft de verkeerstoren op Schiphol Beperkt Zicht Operaties (BZO) aangekondigd. De capaciteit van de luch thaven gaat terug van 68 aankomende vluchten per uur naar I 8 . De reden is, dat de mensen in de verkeerstoren de zogenaamde touch down area moeten kunnen zien. Zo niet, dan vergroten ze de afstand tussen de binnenkomende vliegtuigen, de zogenaamde 'separatie'. De verlaagde capaciteit heeft grote gevolgen voor de dienstregeling van de KLM. Van alle vluchten in Europa zijn er minder dan tien procent binnen vijf minuten van de geplande vertrektijd vertrokken. Bob Rotteveel, Duty Manager Operations van dienst deze ochtend, maakt zich er bijzonder druk over. Hij is het niet eens met het beleid van de Luchthaven Schiphol.

'Op Schiphol roepen ze help en Brussel acteert. ${ }^{2 x}$ Zo'n maatregel afkondigen is gemakkelijk, maar terugdraaien gaat langzaam. Een vertrekkend vliegtuig op Schiphol kent twaalf processen, van catering en schoonmaak tot tanken en bagageafhandeling. Als we een vliegtuig vertragen, moet er bij iedereen iets veranderen en dar vraagt om fouten. Iedereen catert op dat mooie plaatje 'dienstregeling', maar in de praktijk zit het soms tegen.' (Interview)

Volgens Rotteveel had de gondel van de verkeerstoren nooit als een vaste structuur ontworpen moeten worden. Dat had veel Bzo's kunnen woorkomen.

"Als het wolkendek op 400 voet hangt, dan steekt die toren in de wolken uit. Op de grond hebben we dan prima zicht, maar in de toren niet. Waarom hebben we niet een flexibele toren gebouwd, een watarvan de gondel omhoog en omlaag kan schuiven. Dan konden we op elk niveau blijven kijken. In de praktijk worden we vaak beperkt door kleine, maar hinderlijk rigide omstandigheden. We kunnen alles, maar vervolgens stop je voor een grasspriet." (Interview) 
Door de weersomstandigheden deze ochtend besluit men voor wat betreft de wluchten in Europa niet langer te sturen 'op punctualiteit' maar 'op vervoer'. In overleg met het Hub Control Centre (HCC) op Schiphol wordt besloten vertragingen te nemen op Europese wluchten. Rotteweel legt uit waarom.

'Sturen op vervoer heeft de kickback dat andere vluchten te laat komen. Figenlijk besluit je de hele dag te sneeuwballen, vertragingen te nemen op je feeders, je kleine vloot. Vertragingen op de continentale vloot probeer je zoveel mogelijk te beperken. Wij zeggen: we maken het huis schoon van de dag zelf en proberen de volgende dag zo weinig mogelijk vertragingen te hebben. Voor Europa betekent dat soms dat we massaal annuleren om de volgende dag met een schone lei te kunnen beginnen. Als we niet annuleren duwen we alles naar achteren, niet alleen de vliegtuigen, maar ook de bemanningen en die bemanningen hebben we de volgende dag weer nodig. Dus tillen we Europa niet over de nacht heen, want je orgel is vals. Je intercontinentale diensten krijgen hun passagiers niet, dus dat gat fout." (Interview)

De vertragingen in de ochtend werken de hele dag door, zegt Jan van Rees, Operations Controler belast met de eindverantwoordelijkheid voor de Europese wluchten. Het computerscherm op zijn desk toont alle vluchten die voor vandaag gepland staan als een balkje tegen een raster verticale lijnen die de 24 uren van de dag weergeven. Een rode stippellijn schuift langzaam over het scherm en geeft de actuele UTC aan; alles links daarvan is verleden tijd, rechts moet nog komen. De vluchten zijn weergegeven als balkjes, gele balkjes voor aankomende vliegtuigen, groen voor vertrekkende. Door op het balkje te klikken krijgt Van Rees alle informatie over de vlucht: het gate-nummer op Schiphol, de registratie, de namen van de bemanningsleden, de recente onderhoudsgeschiedenis van het vliegtuig, enzovoort. Van Rees kan een balkje verschuiven naar links en rechts (vervroegen dan wel vertragen) of van. boven naar beneden (het verwisselen van een vliegtuig). 
Met een paar klikken van de muis kan ik hier de dienstregeling aanpassen. Maar dat heeft daar (op Schiphol-Centrum - pp) grote gevolgen. Een gatewijziging moet aan de passagiers worden doorgegeven, de bagage moet naar een andere plek, de catering, de brandstof, alles moet aangepast. Daar zijn ze dan vaak ook niet blij mee. Maar het is miet anders. Wij hebben hier het overzicht, zij zien alleen hun eigen processen. Op een dag als vandaag als alle processen vertraagd zijn, sturen we op vervoer en niet meer op punctualiteit. Dat wil zeggen dat we al blij zijn als we de passagiers überhaupt op hun bestemming krijgen, beter laat dan niet.' (Interview)

De telefoon gaat en Van Rees schakelt de speaker in. De gezagvoerder wan een 737 die op het vliegveld in Barcelona staat meldt dat er een gat in de romp van zijn machine zit. Een bagagekar heeft een bocht te krap genomen. Van Rees organiseert een telefonische conferentie over het probleem. Met een paar drukken op een display voor zich kan hij de gezagvoerder, de Service Manager in Barcelona, verantwoordelijk op het buitenstation, de mensen van de Technische Dienst die achter hem zitten en de grondwerktuigkundige in Barcelona met elkaar laten overleggen:

We bebben de Bravo Delta Tango bier staan en daar zit een hele diepe kras met een gat in. We wilden daar graag maintenance bij bebben. OK. Duidelijk, ik denk dat we de gezagvoeder op een andere lijn hebben. Ik zet $u$ even in de wacht en komen dan bij u. Blijf aan de lijn. Bravo Delta Tango - staat op vertrek uit Barcelona. Nu belt de GWK (grondwerktuigkundige) en de gezagvoerder hangt op een andere lijn. Op $x$ zit nu de gezagvoerder. Met Jan van Rees. Dag. Ik schakel zo even de GwK bij, die heb ik op een andere lijn. Blijf aan de lijn. Met Ben. Rob. Ik ga even schakelen: Bravo Delta Tango in Barcelona met een scheur en een gat. Iedereen nu bijgeschakeld, GW $\mathrm{K}$ en maintenance. Er zit een zware kras in wan ongeveer 30 centimeter lang en in het midden van die kras zit een gat door de romp heen. De kras zit in het midden van de rompspanten en de langsverstijuers. Wat dat betreft, zijn die niet geraakt. Technische Dienst? We kunnen 
scheuren afplakken met high speed tape en leeg unpressurized terugvliegen naar Amsterdam als ... "(Bandopname)

De machine in Barcelona zal voorlopig niet vliegen. Jan van Rees moet nu een aantal problemen oplossen. Als het toestel al gerepareerd kan worden, zal het leeg terug moeten vliegen naar Amsterdam. Dat betekent dat de passagiers in Barcelona met andere wluchten naar Amsterdam moeten komen en dus omgeboekt moeten worden. Het toestel had na de landing in Amsterdam door moeten vliegen naar Hamburg en voor die vlucht moet wervanging gezocht worden. De cockpitbemanning stond gepland voor weer een andere vlucht evenals het cabinepersoneel. Ook zij zullen naar het zich laat aanzien vervangen moeten worden omdat de kans groot is dat ze door de vertraging de wetteljk vastgestelde maximum werktijd gaan overschrijden. Van Rees zoekt op zijn scherm maar een vliegtuig dat de vlucht naar Hamburg dan overnemen. Er is een 737 beschikbaar, maar die staat ook voor onderhoud gepland. Eerst moet dus duidelijk worden of dat onderhoud kan worden uitgesteld. Na overleg met de verantwoordelijke Duty Maintenance Manager blijkt dat het geval. Dan is het nog de vraag of deze $737 \mathrm{vol}$ doende stoel- en vrachtcapaciteit heeft om de vlucht naar Hamburg uit te voeren. Van Rees kijkt naar de verdeling tussen business- en touristclass. Hij belt naar de afdeling Reserveringen om een 'gordijntje', jargon voor een verplaatsing van het schot tussen de twee klassen.

Ondertussen overleggen de mensen van de technische dienist met de boordwerktuigkundige in Barcelona over de voorgenomen reparatie. Het plan om met de eerstvalgende vlucht naar Barcelona, die over een half uut vertrekt, twee engineers mee te sturen, wordt verworpen. Van Rees had dit toestel vastgehouden en belt nu met de Duty Area Manager (DAM) op Schiphol om te melden dat het vliegtuig zonder de engineers kan vertrekken. Ze galan's avonds, voeren's nachts de reparatie uit en komen met het gerepareerde toestel terug naar Amsterdam. Van Rees schuift op zijn scherm met gele balkjes. Het probleem wordt opgelost, de aanpassingen worden op de telex gezet en verzonden naar alle betrokken afdelingen. Alle elektronische systemen, van de computers in de reisbureaus tot de schermen op Schiphol, gevem met onmiddellijke 
ingang de nieuwe werkelijkheid weer. De dienstregeling is gewijzigd. Van Rees noemt het "een worm van schaken".

"We improviseren volgens vaststaande regels. Het zijn terugkerende scenario's. We staan hier als een dirigent voor een orkest. We beginnen elke dag met hetzelfde deuntje, in de maat. Er mag soms wel eens even een ander melodietje gespeeld worden, maar als we de bladzijde omslaan staat er voor alle zestig musici weer hetzelfde op papier." (Interview)

Door de schade in Barcelona heeft Van Rees zijn 'wisselgeld' in de vorm van vrije viegtuigen, bemanning en personeel voor die dag uitgegeven. Een volgende verstoring zal zich minder gemakkelijk laten oplossen.

\section{Dag 2: Soldaten op promotietoer (SOC ICA)}

De Senior Operations Controller is eindverantwoordelijk voor de intercontinentale vluchten. Ook hier een scherm met gele en groene balkjes, maar de balkjes zijn langer (de vluchten duren langer) en het onderscheid tussen dag en nacht, dat op de Europese schermen duidelijk zichtbaar is, ontbreekt hier. Joop de Mol werkt sinds r 97 1 bij de KLM.

"Wat ik nu voor me op het scherm zie, deden we vroeger met gele en groene magnetische strippen op twee metalen borden. Die bestreken elk 2.4 uur. Je zag de dag van uit voering en de dag van morgen. De lengte van de strippen gaf de vluchttijd off blocks weer. Dat verwijst naar de blokken die voor de wielen van een vliegtuig geplaatst worden. De vlucht begint als de blokken worden verwijderd, dan volgt de push-back, de taxiperiode, de start, de vlucht, delandingen weer een taxiperiode: 's Avonds om tien uur werd het bord van vandaag afgebroken en opnieuw opgebouwd als dag van morgen. Dat ging zo tot een paar jaar geleden. We zijn ermee opgehouden omdat er fouten werden gemaakt. Sommige veranderingen op de borden werden niet doorgegeven in de systemen.' (Interview)

Na het "ochtendgebed' om acht uur, waar ondermeer de vertragingen 
van gisteren worden geẽvalueerd en het voorval in Barcelona besproken, krijgt De Mol een telefoontje van de Duty Area Manager (DAM) van Area 5. Schiphol-Centrum is verdeeld in een aantal zones die elk geleid worden door een DAM. De DAM is gepikeerd omdat hij te laat op de hoogte is gesteld van een gate-wisseling, waardoor er problemen dreigen te ontstan met de afhandeling van twee vliegtuigen. De Mol schuift het balletje terug. De DAM is wel degelijk op tijd op de hoogte gesteld.

'Hij klaagt terecht over verstoring van allerlei processen, maar dan heeft hij straks niet goed geluisterd, want we hebben aangekondigd dat de kans op een wisseling aanwezig was. Dan had hij kunnen zeggen: sleepdienst, ik bel je zo terug om acht uur, de kans is groot dat we moeten gaan slepen. Het was natuurlijk nog fijner geweest als we het voor de landing hadden omgezet. Dan hadden we deze niet op D6 laten aankomen, maar meteen op F6. Dat realiseer ik me ook wel, maar op dit moment is dat mijn probleerm niet. Als er prioriteiten worden gesteld, dan doen wij dat." (Interview)

Het verschil met Europa is, volgens De Mol, dat de vluchten langer duren waardoor er meer tijd is om een verstoring op te lossen. Anderzijds heeft een verstoring ook al snel meer gevolgen. Zo is het gevaar dat de bemanning 'uit de uren loopt' (te lang dreigt te werken) groter. Precies. dit fenomeen doet zich voor. Een collega meldt aan De Mol dat de bemanning van een retourvlucht uit Abidjan (Ivoorkust) nog in het hotel zit. Op straat rijden rebellen wan het leger rond en er wordt geschoten. De vlucht wordt voor onbepaalde tijd vertraagd. CNN heeft nog geen bericht, de veiligheidsdienst van de KLM is druk bezig meer informatie te verzamelen, de bemanning zit in het hotel en wacht op nadere orders. De Mol is laconiek. 'Soldaten op promotietoer voor extra soldij. Het richt zich niet tegen buitenlanders, dus als ze in hun hotel blijven en niet met geld zwaaien komt alles in orde."

De afdelingen Cabin Crew en Cockpit Crew komen in actie. Zij kunnen op schermen de gegevens oproepen van elk bemanningslid, met daarbij de wensen omtrent indeling en vrije dagen. Daarmee wordt 20 goed mogelijk rekening gehouden bij het oproepen van de vervanging 
voor de bemanning uit Abidjan. Voor zowel Europese als ICA-vluchten zitten reservebemanningen thuis te wachten op een telefoontje. Indien nodig moeten zij in een uur op Schiphol kunnen zijn. In Abidjan blijft de situatie nog dagen onduidelijk, maar uiteindelijk keert de bemanning zonder problemen terug uit Afrika.

\section{Dag 3: Een sluimerende vulkaan in Ecuador (ATM)}

Bij de afdeling Air Traffic Management ligt een grote kaart van Europa op een kaartentafel. Er stalan honderden 'airways' op, vastgestelde routes door het luchtruim. Een vliegtuig dient zich exact te houden aan een vooraf opgesteld vliegplan. Dit vliegplan geeft aan van welke airways het wliegtuig gebruik moet maken. Als de afwijking van de airway meer dan dertig meter aan weerszijden bedraagt, moet de gezagvoerder dat kunnen uitleggen. Op sommige plaatsen bevinden zich knooppunten van airways, op andere een soort in- en uitvoegstroken in de lucht, punten die el $k$ vliegtuig moet passeren alvorens een bepaalde reeks airways te vollgen. Anders dan autosnelwegen zijn de snelwegen in de lucht gelaagd. Op elke airway kan op verschillende hoogte gevlogen worden, waarbij vooraf bepaalde verticale separaties gelden.

Behalve in airways is het luchtruim verdeeld in sectoren die bestuurd worden door de Air Traffic Control (ATC) van het bijbehorende gebied. Elke keer als een vlieger een nieuwe sector binnenvliegt wordt dit gemeld aan de ATC. Soms is het in een sector zo druk dat de bijbehorende ATC een zogenaamd slot uitgeeft. Dat betekent dat een vliegtuig die sector op een bepaald tijdstip moet binnenvliegen. Dit tijdstip wordt "slot" genoemd en het bepaalt in de praktijk de vertrektijd van een luchthaven. Jan de Roode van Flow Control vraagt slots aan voor vliegtuigen. Soms leidt een slot tot grote vertraging, die alleen kan worden voorkomen door de route - en dus het vliegplan - aan passen. Vandaag is het, net als op alle dagen, druk in de lucht. De airways boven Europa zitten bijna allemaal vol, afgezien van de routes naar Scandinaviè. Dat betekent dat veel vertrekkende vhchten een slottijd hebben. De Roode ziet ze woor zich op zijn scherm.

"Veel invloed op de slottijden hebben we niet; ze worden bepaald 
door de Verkeersleiding op Schiphol, die ze weer betrekt uit Brussel. Soms kan ik proberen een eerdere slottijd te krijgen, maar meestal is thet gewoon wachten. Het is belangrijk om je aan de slottijd te houden. Als je te laat vertrekt - dat noemen we "uit je slot schieten" loop je de kans dat Brussel je weer helemaal achteraan in de rij zet en dat kost uren. Vluchten met een slottijd zijn daardoor extra tijdkritisch. Er mag niets misgaan. (lnterview)

Behalve het aanvragen en controleren van slottijden zijn de mensen van ATM bezig met het maken van vliegplannen. Kees Derksen is bezig een vliegplan te maken voor een vlucht naar Quito, een dagelijkse bestemming in Ecuador. Het probleem is dat de drie aanvliegroutes naar het internationale vliegveld allemaal in de invloedssfeer liggen van de Guagua Pichincha, een actieve vulkaan. ${ }^{22}$ Asdeeltjes uit een vulkaan kunnen de motoren van een vliegtuig zodanig beschadigen dat het neerstort, dus noet er zorgvuldig gehandeld worden. Derksen controleert regelmatig een speciale website van de American Geological Society die de activiteit van de vulkaan voortdurend registreert.

'Cruciaal voor de keuze van de aanvliegroutes is de windrichting. Als ik mijn keuze voor een bepaalde route heb bepaald ga ik rekenen. Elk vliegtuig moet op elk moment gedurende een vlucht binnen 180 minuten uur op een luchthaven kunnen zijn. Dat is de zogenaamde ETOPS-regel, bedoeld om te voorkomen dat een vliegtuig in het geval van motoruitval niet te ver van een vliegveld verwijderd is. ${ }^{23}$ De ETOPS-regell legt beperkingen op aan de keuze van je traject. Verder moet ik rekening houden met de brandstof. Op een langere route moet ik extra tonnen tanken. Meer tonnen brandstof betekent minder passagiers en vracht, wat weer van belang is voor de stoelreserveringen. Zo grijpt alles in elkaar.'(Interview)

Als Derksen klaar is met zijn vliegplan stuurt hij het elektronisch door naar het Bemanningencentrum op Schiphol-Centrum. Daar zal de gezagwoerder het bekijken en, als hij ermee akkoord gaat, invoeren in de boordcomputer van zijn toestel. Van de route die Derksen heeft opge- 
steld zal alleen in uitzonderlijke gevallen worden afgeweken. Maar die doen zich vandaag niet voor: Vlucht KL 753 naar Quito vliegt volgens dienstregeling.

\section{Obsenvaties in bet Fromtoffice}

Het occ beschrijft in het besturingsprotocol haar eigen werk in cybernetische termen. Er is een plan (zie figuur 5. $x$ ) dat is uitgewerkt in een dienstregeling en er zijn doelstellingen omtrent de kwaliteit die de KLM will leveren. De dienstregeling is op te vatten als het programma dat de maatschappij heeft opgesteld on de doelstellingen te bereiken door het toewijzen van capaciteit en kennis. De uitwoering van de dienstregeling vormt het proces, waarbij de dagelijkse "werkelijkheid" voortdurend wordt getoetst aan de dienstregeling. Bij verstoringen van de dienstregeling worden maatregelen genomen. De effecten van die maatregelen worden teruggekoppeld naar zowel het niveau van de dienstregeling als de gewenste kwaliteit. Om de maatregelen die genomen worden om de verstoringen in het proces te repareren is het occ in het leven geroepen. De verschillende bedrijfsonderdelen van KLM leveren voortdurend informatie aan over de gang wan zaken in het proces. Verantwoordelijkheden zijn gecentraliseerd en bevoegdheden duidelijk aangegeven: het occ neemt de beslissing over de te nemen matregelen als verstoringen op netwerkniveau optreden. Veel aandacht wordt gegeven aan het leereffect; elke dag wordt de gang van zaken in het proces geèvalueerd.

Het reduceren van ongeplande, ongestuurde actie in complexe processen als het uitvoeren van de dienstregeling van een luchtvaartmatschappij is een belangrijke drijfveer voor het opstellen van geformaliseerde structuren en protocollen. In de praktijk is er evenwel ruimte om van de regels af te wijken als de omstandigheden dat vragen. Voor DMO Bob Rotteveel 'dienen de regels als leidraad, maar waarbij we tegelijkertijd zeggen, met verstandige mannen, wij wijken daar vanaf indien noodzakelijk, maar dan hebben we een verhaal.' (Interview) Operations Manager Wim de Boer benadrukt dat de besturingsregels in veel gevallen ruimte laten voor interpretatie en afwijking: 'We nemen geen vertraging voor vracht als de passagiers aan boord zijn. Maar wat doen we als die vracht bestaat uit de paarden van Anky van Grunsven? Die paar- 
den worden begeleid door mensen met een business class-ticket en thebben voor de KLM een zekere uitstraling. Dan nemen we wel vertraging. De besturingsregels geven de ruimte om per situatie af te wijken." (Interview)

In de cybernetische benadering gaat de geplande orde wooraf aan de feitelijke orde. Maar hoe wordt die feitelijke orde van een passage gerepareerd als zij afwijkt van de geplande? Welke concrete middelen staan een medewerker van Passenger Services of van het occ ter beschikking? Wie bepaalt of er ruimte is om van de regels af te wijken en hoe groot die ruimte is? Welke rol speelt het feit dat KLM-medewerkers vaak onder grote tijdsdruk beslissingen moeten nemen die vergaande consequenties kunnen hebben? Deze vragen zijn niet uitsluitend in cybernetische termen te beantwoorden, maar vragen om andere theoretische invalshoeken.

\section{Gesitueerd handelen en improviseren}

\section{Gesitueerd handelen}

Cybernetische stroomdiagrammen zoals het besturingsprotocol van het occ geven voorbeelden van mogelijke situaties waarin moet worden ingegrepen (weer, slots, capaciteit, techniek etc.), maar een volledige beschrijving van zo'n situatie vooraf is onmogelijk. Het plan loopt op de handeling vooruit. Die vooronderstelling is onder meer door Lucy Suchman (I987) in haar boek Plans and Situated Actions gekritiseerd. Zij onderzocht de manier waarop mensen omgaan met machines als een kopieerapparaat en stelde vast dat in concrete situaties, bijvoorbeeld als een kopieerapparaat het begeeft, plan en handeling verweven zijn. Ze illustreert dit door een vergelijking te maken tussen twee manieren om een boot te besturen, die van een inwoner van Truk, een eilandengroep in de Stille Oceaan, en die van een Europese kapitein. De laatste begint met het uitzetten van een koers volgens de algemene principes van de navigatie en vergelijkt tijdens de reis voortdurend de actuele situatie met de uitgestippelde koers om bij afwijking daarvan bij te kunnen sturen. De Trukese kapitein begint met het vaststellen van de bestemming. Hij 
vertrekt en reageert ad-hoc op de omstandigheden zoals ze zich voordoen. Hij gebruikt de informatie die de wind, het getij en de stroming, de fauna en de sterren, de wolken en de geluiden van het water tegen de boeg geven en stuurt daarop. ${ }^{24}$

Volgens Suchman is in elke handeling iets van de aanpak van de Europese ên de Trukese kapitein terug te vinden. Elke handeling, hoezeer die ook is gepland, is onderworpen aan de toevalligheden van het moment en is in die zin gesitweerd:

'Met gesitueerd handelen bedoel ik gewoon het handelen in de context van concrete omstandigheden. Zo opgevat zou men kunnen argumenteren dat we allemal handelen als de Trukese kapitein, hoezeer sommigen van ons ook spreken als Europeanen. We moeten wel handelen zoals de Trukesen, omdat we de omstandigheden van ons handellen nooit volledig kunnen voorzien en omdat die omstandigheden voortdurend veranderen. Als gevolg daarvan zijn onze handelingen nooit gepland in de sterke betekenis die de cognitieve wetenschap daaraan geeft. Eerder is het zo, dat plannen op z'n best gezien kunnen worden als een zwakke ondersteuning voor wat primair een ad boc activiteit is. Pas als we gedwongen worden de rationalliteit van ons handelen te verantwoorden, vallen we gegeven de vooringenomenheid van onze Europese cultuur terug op het feit dat we ons lieten leiden door een plan. Plannen kunnen alleen maar vaag zijn omdat ze vooraf opgesteld worden en rekening moeten houden met de onvoorziene toevalligheden van bepaalde situaties. Als ze terugkijkend worden gereconstrueerd, wissen ze systematisch bijzondere details uit die het handelen in een situatie karakteriseren, ten gunste van die aspecten van het handelen die in overeensternming zijn met het plan. ${ }^{25}$

Met haar onderzoek naar 'gesitueerd handelen' maakt Suchman aannemelijk dat het plan in de praktijk niet volledig aan de handeling vooraf gaat. De relatie tussen sturingsregels en -procedures en actuele situatie en sturingshandelingen is niet een determinerende, maar één waarin voortdurend afwegingen en beoordelingen worden gemaakt in het licht 
van zich voortdurend vernieuwende omstandigheden. Mensen kunnen in een situatie over plannen beschikken zoals ze ook gebruik maken van ervaring, vaardigheden, instrumenten, apparaten en dergelijke. Haar analyse van gesitueerd handelen wijst op een vorm van patroonherkenning, als een vorm van tweede-orde cybernetica. Er blijft een terugkoppeling bestaan zoals blijkt uit het voorbeeld van iemand die met een defect kopieerapparaat wordt geconfronteerd. ${ }^{26}$ Aan de cognitieve kant zien we hier aannames, interpretaties en bewijs, aan de temporele kant het feit dat het handelen zich van moment tot moment afspeelt.

In de termen van Suchman sturen de medewerkers van Passenger Services en de mensen in het Frontoffice als twee kapiteins op een schip: ze kunnen terugvallen op protocollen en procedures, maar omdat elke verstoring is op te vatten als een complex van toevalligheden zullen ze altijd cen zekere 'regelruimte' nodig hebben om te kunnen handelen. De beslissingen die ze nemen zijn niet te beschouwen als de exacte uitvoering van een vooraf opgesteld protocol, maar wijken in meer of mindere mate af van het ideaal. De stroondiagrammen van het besturingsprotocol vormen eerder onderdeel van de situatie dan dat ze van buitenaf (als een programma) de dagelijkse realiteit (het proces) zouden sturen. Het besturingsprotocol geeft een aantal maatregelen dat genomen kan worden in het geval van een verstoring op netwerkniveau (er kan worden uitgeweken naar een andere luchthaven; er kan extra capaciteit worden ingehuurd; de configuratie van een vliegtuig kan worden angepast; een vlucht kan worden wertraagd of versneld; een vlucht kan worden geannuleerd). Welke van deze maatregelen wordt genomen, hangt van de beoordeling van de situatie af.

\section{Improvisatie}

Het onderhouden en bijregelen van vliegpassages vergt veel 'gesitueerd handelen”. Maar waarom is dat eigenlijk het geval? Het heeft te maken met een belangrijk kenmerk van situaties waarmee medewerkers in de vertrekhal én in de Frontoffice te maken krijgen: hun handelen staat altijd onder tijdsdruk. Het opsporen van een passagier die niet aan de gate verschijnt kan niet wachten tot morgen, evenmin als het aanpassen van een slottijd voor een vertrekkend wliegtuig. Zoals een musicus niet even 
kan pauzeren om te kijken wat er nu precies in de partituur statat nadat eenconcertuitvoering is begonnen, zo kan de operatie op de dag van utwoering niet worden stilgezet om een probleem op te lossen. $\mathrm{Om}$ deze temporele dimensie van het handelen van KLM-medewerkers te analyseren heeft een begrip als "improvisatie' betere papieren dan 'gesitueerd handelen ' om dat het deze dimensie van de tijd expliciteert. ${ }^{27}$

De eerste associatie bij het begrip improvisatie is doorgans een artistieke: musici en acteurs improviseren. Van improvisatie is sprake als het moment van schepping en uitvoering samenvallen. Het vaak aangehaalde voorbeeld van de jazz laat zien dat de meeste musici improviseren op de rand van het bekende en het onbekende. Barrett (1998) citeert de jazz-saxofonist Steve Lacy:

'Er is een frisheid, een zekere kwaliteit die je alleen kunt bereiken door te improviseren, jets wat je onmogelijk krijgt met uitgeschreven muziek. Het heeft te maken met de 'rand'. Altijd op de grens van het onbekende en voorbereid zijn te springen. En als je je daarin begeeft, kun je terugvallen op een jarenlange ervaring en voorbereiding en op je muzikaliteit en dat wat je hebt voorbereid, maar het is een sprong in het duister., 2.8

Maar improvisatie beperkt zich niet tot de uitvoerende kunsten. Moorman en Miner ( 1998 ) onderscheiden well tweë̈nveertig verschillende definities binmen domeinen als organisaties, de muziekpraktijk, het theater, therapeutische en didactische praktijken en andere perspectieven: ${ }^{29}$ Al deze definities delen twee betekenissen.

De eerste betekenis heeft betrekking op het temporele karakter van het improviseren, waarin als gezegd plan en uitvoering samenvallen. Ciborra ( 990 ) schrijft bijvoorbeeld dat improvisatie zich kenmerkt door "immediacy; situatedness; idiosyncrasy; local knowledge; access to and deployment of resources at hand." $\mathrm{Om}$ het temporele karakter van improviserend handelen te analyseren makt hij onderscheid tussen objectieve en subjectieve tijd. Objectieve tijd is de gedeelde en meetbare kloktijd van Tayloriaanse bewegingsstudies, routinehandelingen, besturingsprotocollen en wat dies meer zij. Subjectieve tijd is de geleefde 
tijd van Bergson en de temporaliteit van Heideggers "in de wereld zijn. Aan Heidegger ontleent Ciborro ook thet samengaan van beide soorten temporaliteit in de 'kairos', het moment waarop ons zijn zich bewust is van de wereld en de mogelijkheden die daarin aanwezig zijn in plaats van afgeleid te zijn door alledaagse zorgen en belangen. ${ }^{3 x}$

Een tweede betekenis van improvisatie geldt het creatieve karakter van dit handelen. Het nieuwe ontstaat als elementen in de situatie, opgevat als een reeds aanwezige orde, een andere functie of betekenis wordt gegeven. Ciborra (I.998) spreekt hier van een ecology of improvisation' waarin bijvoorbeeld de instrumenten en artefacten in een situatie worden 'geannoteerd om niet te zeggen opnieuw worden uitgevonden'. ${ }^{32} \mathrm{Om}$ opnieuw een woorbeeld uit de muziek aan te halen: improviserend musiceren veronderstelt een grondige kennis vam harmonieleer, het vermogen te moduleren tussen toonsoorten, technische beheersing van een instrument en vertrouwdheid met uiteenlopende muzikale idiomen. Het nieuwe onstaat derhalve in de bewuste, gewilde afwijking of omvorming van het bekende. Hoe meer een musicus de bestaande orde beheerst, hoe inventiever die orde getransformeerd kan worden tot iets nieuws. Vertaald naar de situatie in de vertrekhal en in het Front Office: hier is van improvisatie sprake als een medewerker in het moment kan overzien hoe de orde kan worden gerepareerd door elementen te gebruiken die daarvoor niet bedoeld waren.

\section{Twee bezwaren}

Met behulp van begrippen als 'gesitueerd handelen' en "improvisatie" is het mogelijk beter te analyseren hoe KLM-medewerkers de verstoorde passage repareren dan met de cybernetische stroomdiagrammen: ze benadrukken het samengaan van plan en handeling waarbij ze bovendien het temporele en creatieve karakter van dit repareren onderstrepen. Toch zijn beide begrippen problematisch in twee opzichten.

Het eerste bezwaar richt zich op de impliciete tijdsopvatting die in elk wan de begrippen besloten ligt. In het geval van 'gesitueerd handelen' blijft sprake van de objectieve, sequentiele tijd van protocollen en routines, ook al worden die naar bevind van zaken en op basis van ervaring aangepast. Deze benadering bedient zich van een lineair tijdsbe- 
grip in de B-serie, warin tijd wordt opgevat als een reeks opeenvolgende momenten. Dat in de dagelijkse praktijk bij de kLM sprake is van een handelingsdruk die een eigen dynamiek oplegt aan de medewerkers wordt mede daardoor onvoldoende verdisconteerd. Improviserend handelen doet dit wel doordat de 'flow' van de gebeurtenissen uitgangspunt vormt, maar hier is het bezwaar dat tijd wordt gesubjectiveerd (het juiste moment of 'kairos. voor een handeling is persoonlijk); dit tijdsbegrip past in de A-serie van de ervaren tijd.

Het tweede bezwaan heeft betrekking op impliciete annames over de wisselwerking tussen het handelen en de situatie warrin wordt gehandeld. Het begrip 'gesitueerd handelen' erkent het contingente karakter van situaties en de noodzaak de situatie voortdurend opnieuw te beoordelen op grond van plannen die zelf worden aangepast in de loop van de tijd. Maar dit leidt tot een conceptuele versmalling van dat handelen tot cognitieve vaardigheden van patroonherkenning, ervaring en "tacit knowledge". Onduidelijk blijft hoe het handelen zich vernieuwt. Het begrip 'improvisatie" maakt het mogelijk dit aspect wel te analyseren. Hier ontstaat het nieuwe doordat aan elementen in de orde een nieuwe betekenis of functie wordt gegeven, iets dat duidelijk wordt in het exemplarische voorbeeld van de creatieve kunstenaar. Dit leidt echter tot het bezwaar dat het begrip aldus een zekere autonomie veronderstelt; immers, om te kunnen improviseren moet men wel in de orde mogen ingrijpen. De vraag wie wel en wie niet mag improviseren wordt niet beantwoord.

Het veldonderzoek toont dat het temporele karakter van de situaties waarin KLM-medewerkers handelen niet alleen in termen van kloktijd tegenover kairos kan worden begrepen, maar zich juist kenmerkt door een veelheid aan gebeurtenissen die al dan miet in de tijd op elkaar aansluiten en elkaar beinvloeden. Beide genoemde bezwaren tegen concepten als 'gresitueerd handelen' en 'improviseren' zijn te ondervangen door uit te gaan van het tijdsbegrip in de C-serie van de 'passagetijd', waarmee de vraag gesteld kan worden boe in de handelingspraktijk in de Vertrekhal en het occ meerdere tijdsordes worden geproduceerd en op elkaar afgestemd, en welke gevolgen dit heeft voor de verdeling van handelingscompetentie. Een analogie uit de praktijk van het musiceren 
kan dit punt verduidelijken. Voor een strijkorkest dat een fuga speelt is de praktische vragg aan de orde hoe men de verschillende muzikale gebeurtenissen (de verschillende stemmen waaruit de fuga bestaat) 'onder elkaar houdt" en gezamenlijk de eindstreep bereikt. ${ }^{3 .}$ Maar daarnaast is er een kwaliteitscriterium; gezamenlijk de eindstreep halen is niet hetzelfde als het geven van een goede uitvoering. Hoe zou men dit aan kunnen pakken? Een B-tijd benadering vertrekt vanuit de genoteerde temporele verhoudingen tussen de noten en stelt voor een metronoom te gebruiken die in het door de componist aangegeven tempo tikt. De metronoom coördineert de handelingen van de afzonderlijke musici en makt het hen mogelijk afwijkingen wan het tempo te corrigeren op het moment dat ze zich voordoen. Dit bijsturen doet denken aan Suchmans 'gesitueerd handelen'. De musici halen weliswaar gezamenlijk de eindstreep, maar het is de vraag of zij muziek hebben gemaakt; dat veronderstelt immers een levendiger musiceren dan het gedwongen tempo van de metronoom mogelijk maakt. In een A-tijd benadering spelen de musici in hun eigen subjectieve tempo dat herinnert aan Ciborra's kairos. Omdat een gedeelde temporele referentie ontbreekt, zullen zij elk afzonderlijk weliswaar goed en muzikaal spellen, maar het lukt hen niet de verschillende stemmen van de fuga te synchroniseren en gezamenlijk te eindstreep te halen. Het effect is hier dus omgekeerd: de musici hebben de vrijheid individueel hun tempo te kiezen en 'mooi' te spelen, maar de partituur komt niet tot klinken eenvoudig omdat de verschillende partijen niet "onder elkaar komen".

In de muzikale uitwoeringspraktijk wordt de oplossing voor dit probleem gezocht in het zo combineren van gemeten en ervaren tijd dat er een eigen collectieve tijdsorde ontstaat, waaraan muziekkenners vaak een dirigent of een orkest herkennen. Bij kamermuziek (kleinere gezelschappen) stemmen de musici het vooraf overeengekomen tempo op elkaar af door naar elkaar te luisteren, op elkaar te reageren en voortdurend bij te sturen. Versmellingen en vertragingen zijn relationeel, want hebben betekenis ten opzichte van elkaar en niet slechts ten opzichte van het metronoomtempo of het subjectieve tempo van de individuele musici. Bij grotere ensembles is al snel een dirigent nodig, niet in de rol, van metronoom, maar als tegelijk luusterend en sturend lid van het ensemble. 
Bij symfonie-orkesten wordt van de dirigent verwacht dat hij of zij het owerzicht heeft over zowel de partituur als ower de klinkende realiteit in het orkest én in staat is beide bij elkaar te brengen zodat een goede uitvoering klinkt. Het probleem van 'het onder elkaar blijven' van witeen lopende stemmen en het spelen van een goede uitwoering (dat wil zeggen een creatieve uitvoering) wordt hier opgelost door te centraliseren.

Niet zonder reden vergeleek een van de Senior Operations Controllers in het occ zijn werk met dat van een dirigent woor een orkest: "We beginnen elke dag met hetzelfde deuntje, in de maat. Er mag soms wel eens even een ander melodietje gespeeld worden, maar als we de bladzijde omslaan staat er voor alle zestig musici weer hetzelfde op papier.' Soms zitten de omstandigheden zo tegen dat de $k$ waliteit van de uitvoering noodgedwongen afneemt. Dan stuurt men niet meer op punctualiteit maar op vervoer en is op tijd vertrekken ondergeschikt aan überhaupt kunnen vertrekken. Het uityoeren en repareren van een complexe dienstregeling als die van de KLM is te vergelijken met het spelen van een symfonie; kwesties van tempo, creativiteit, overzicht, autoriteit en kwaliteit zijn voortdurend aan de orde. Er is voor de vluchtleider een belangrijk verschil: de musici zitten niet op het podium, mar bevinden zich over de hele wereld.

\section{Wisselgeid}

Het scherm dat Jan van Rees als wluchtleider Europa voor zich zag op 3 juli 2000 's middags om drie minuten voor zes heeft iets weg van de partituur van een compositie op het moment dat die wordt uitgevoerd (zie figuur 5.2).

In de kolom links staan de toestellen van de Europa-vloot. De horizontale lijnen verbeelden de bloktijden (de totale grond-en vliegtijd tussen vertrek een aankomst) van de geplande vluchten. Vertrekkende wuchten, aangegeven door gele balkjes, hebben een oneven vhuchatnummer, arakomende vluchten - de groene balkjes - cen even nummer. Onder de balkjes staan de bloktijden; als een vlucht vertraagd is wordt een deel van het balkje rood. Boven de balkjes staan de vertrek- of aan- 


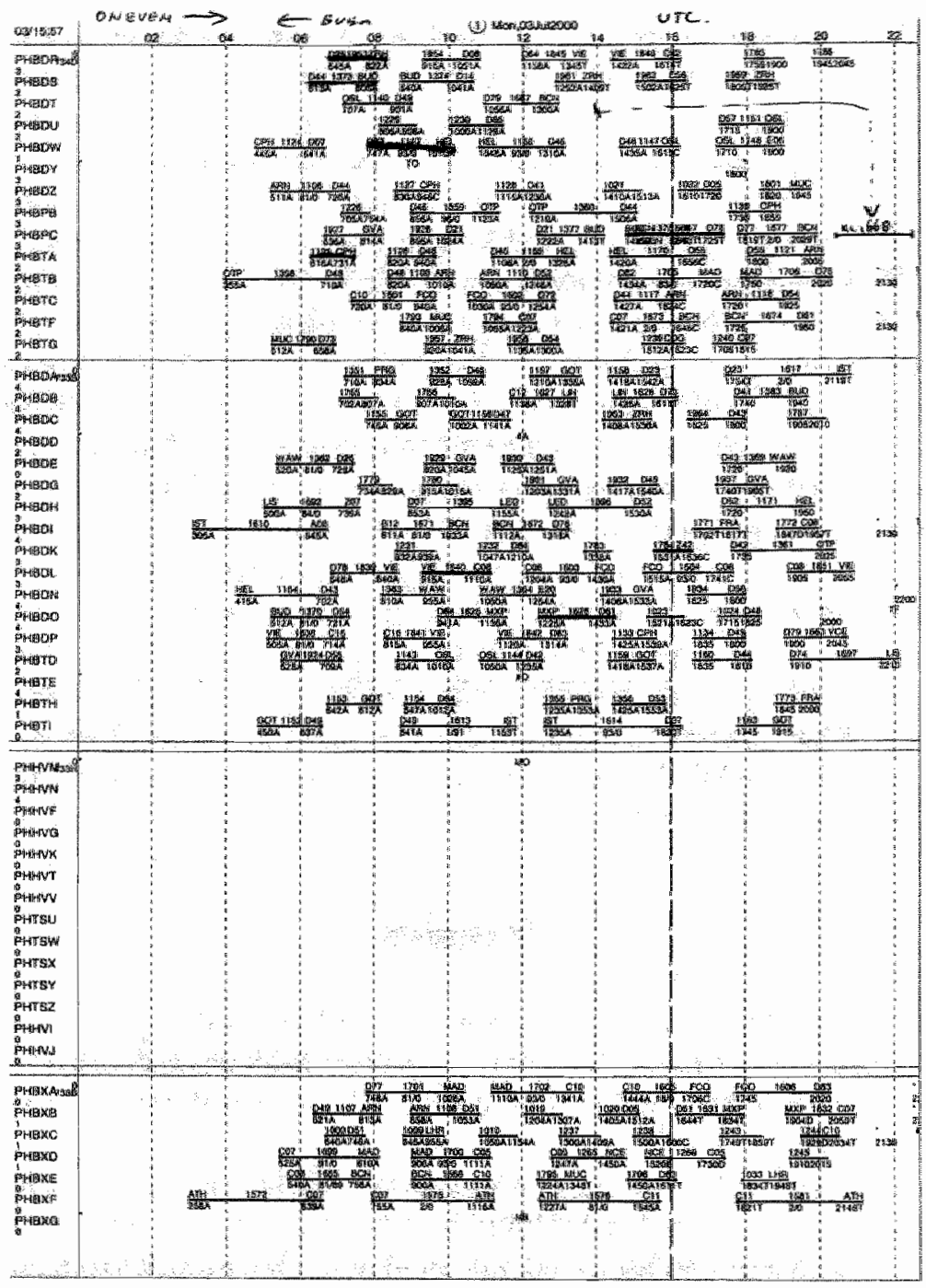

Figur 5.2: Schermbeeld wan de Operations Cantroller Europa op 3 juli 2000 om utc 15.57 (17.57 plaatselijke tijo). Het whiegtuig dat in Barcelona beschadigd raaht, de PHBOT ('Bravo Delta Hango') staat als derde vam boven genoteerd. 
komstgate en de bestemming in de drieletterige codes van de internationale luchtwart. De verticale stippellip markeert de urc-tijd, in her jargon "Zulu" genoemd. De platselipke (zomer)tijd in Amsterdam is twee uur later.

Van Rees kan wliegtuigen vertragen door balkjes naar rechts te schuiven of van vliegtuig wisselen door balkjes omhoog of omlag te schuiven. Door met zijn computermuis op de balkjes te klikken kriigt hij een overzicht van alle gegevens van een whucht: het vliegplan, de samenstelling van de crew, slottijden en de bezettingsgraad. Op dit moment is Van Rees bezig met het oplossen van de problemen rond het kapotte toestel in Barcelona. Om het probleem in Barcelona op re lossen makt hij gebruik van een vliegtuig dat in onderhoud gepland stond. Door in owerleg met de Technische Dienst het onderhoud wit te stellen, krijgt hij de beschikking over een extra vliegtuig.

'Dat luistert nauw. Je kunt niet zonaar een vliegtuig dat in onderhoud staat gebruiken. Want het uitstellen van het onderhoud levert over een paar dagen een probleem op; dat onderhoud moet toch gebeuren. Maar in dit geval kon ik zodanig schuiven in de onderhoudsplanning dat we verderop in de week geen problemen hebben. Dit vliegtuig was mijn wisselgeld woor vandaag. Dat is nu op. Als er nu nog een viliegtuig kapot gaat heb ik een probleem.' (Interview)

De term 'wisselgeld' is gelukkig gekozen. Door het onderhoud uit te stellen zorgde Van Rees ervoor dat het vliegtuig onderdeel ging uitmaken van de geplande passage op het moment dat zich het probleem in Barcelona voordeed. Hij repareert de temporele orde van vlucht KLI 668 door de temporele orde elders (het onderhoud) te wijzigen. Een dag eerder of later was het toestel wellicht niet beschikbaar geweest ondat het uitstellen van het onderhoud niet langer was toegestaan.

In de uitvoering van hun werk worden de KLM-medewerkers geleid door een enorme hoeveelheid regels, protocollen, codes, wetten en gebruiken die hun handelen sturen. Behalve de interne KLM-protocollen (die weer afgeleid zijn uit het beleid van de maatschappii), zijn er de internationale protocollen, luchtvaartregels en -wetten, maar ook een sca- 
la aan culturele gebruiken en codes waarmee rekening moet worden gehouden.. Om aan die structuren te voldoen en tegelijkertijd onder tijdsdruk problemen op te lossen, staat de KLM-medewerker een zeker kapitaal aan wisselgeld ter beschikking. Wisselgeld is nodig om in real tume (dat will zeggen op het moment zelf) de temporele orde van geplande processen te veranderen. De omvang wan dat ka pitaal bepaalt de ruimte die er is om oplossingen te vinden woor problemen. Het veldonderzoek levert een aantal woorbeelden op situaties warin KLM-medewerkers wisselgeld inzetten om problemen op te lossen.

We kunnen het begrip om te beginnen letterlijk nemen: geld is een voorbeeld van wisselgeld. Wim de Boer gaf in een interview aan dat de KLM gewend is de passagier hoe dan ook op zijn of haar bestemming te krijgen. Echter, als gevolg van de felle concurrentie in de internationale luchtvaart, bijvoorbeeld door de opkomst van bedrijven als EasyJet die goedkope vluchten aanbieden, zijn de marges kleiner geworden en is het belang van 'commercieel denken' toegenomen. Het oplossen van vertragingen en verstoringen in de dienstregeling kan veel geld kosten. Als een vliegtuig bijwoorbeeld niet van een buitenstation kan vertrekken omdat de bemanning 'uit de uren is gelopen' en de passagiers niet kunnen worden omgeboekt omdat de luchthaven gesloten is, moeten ze worden ondergebracht in hotels, een operatie waarvan de kosten hoog kunnen oplopen. Maar er zijn situaties waarin het laten owernachten van passagiers grotere verstoringen in de dienstregeling (en dus kosten) kan voorkomen. In het algemeen neemt het belang van wisselgeld in de letterlijke betekenis af. Meer en meer worden KIM-medewerkers gewezen op de noodzaak commerciële afwegingen te maken, ook al gaan die in eerste instantie ten koste van de passagier. Via concurrentie en marktoverwegingen beperkt de 'buitenwereld' zo de speelruimte die KLMmedewerkers hebben om verstoringen op te lossen; het bedrijf opereert niet in een luchtledig. Ook voor de passagier is geld een vorm van wisselgeld; hoe duurder het ticket, hoe meer er op het laatste moment nog te wijzigen valt.

Capaciteit in allerlei vormen (stoelen, bemanningen, vliegtuigen, slots, landingstijden) is een belangrijke vorm van wisselgeld. Zo zijn elke dag reservebemanningen beschikbaar die in een uur op Schiphol kun- 
nen zijn. Maar als deze bemanningen 'gebruikt' zijn voor een verstoring moet cockpit-en cabinepersoneel worden opgeroepen dat daar niet op rekent. Daarvoor moeten ze worden gecompenseerd, wat tot nieuwe verstoringen later in de dienstregeling kan leiden. De manier waarop capaciteit, in dit geval baancapaciteit, een vorm van wisselgeld is, blijkt ook uit de zogenaamde "noise-ban', de tijdstippen warop een luchtvaartmaatschappij flink moet betalen om te starten of te landen. Voor Schiphol geldt een zogenaamde "noise-ban" tussen elf uur "s avonds en zes uur 's ochtends. Baancapaciteit is dan extra schaars, maar niet elk tijdstip is gelijk. In de praktijk, weet Operations Manager Wim de Boer, is het kostbaarder om tien voor zes 's ochtends te landen dan om tien over elf 's avonds. Om die reden worden wliegtuigen die's ochtends eerder aankomen 'in hold' gehouden boven de luchthaven; ze cirkelen rond totdat om zes uur alle wachtende vliegtuigen tegelijk landen.

(Voor)kennis, ervaring en informatie zijn wisselgeld in de vorm van immateriële capaciteit. Veel medewerkers benadrukken het belang van zogenaamd pro-actief handelen. Hiermee bedoelen ze dat het anticiperen op verstoringen handelingsruimte kan opleveren. De voorbeelden van de sluimerende vulkaan in Ecuador en de rebellen in Abidjan maken duidelijk hoe belangrijk het voor het occ is om te weten wat de situatie is op een bepaalde bestemming. Voorkennis is sterk gekoppeld aan ervaring. Joke Smalhout van de Ticketoffice kan inschatten hoe druk het aan haar balie wordt door naar buiten te kijken. Aan het weer kan ze zien hoe lang de rijen worden en wat voor soort problemen de passagiers hebben. Bij mist zijn er veel omboekingen. Marijke van Dorp van de afdeling Passenger Handling geeft het voorbeeld van de zogenaamde 'bank-lines" voor de check-in balies. ${ }^{34}$ Aan de lengte van de rij wachtenden kan ze zien hoe lang het duurt voordat de laarste passagiers in de rij zijn ingecheckt en of de kans bestaat dat zij te laat bij de gate komen. In dat geval wordt bijvoorbeeld een extra balierij geopend om passagiers sneller te kunnen inchecken zodat ze op tijd zijn voor hun vlucht:

Of de KLM-medewerkers kunnen beschikken over de informatie die ze nodig hebben om in een situatie bestuiten te nemen, is mede afhankelijk van informatie-en communicatietechnologie. Operations Con- 
trollers in het occ kunnen beschikken over conferentietelefonie, internet, satelliettelefonie (eventueel met de cockpit), maar ook over 'ouderwetse" middelen als portofoonverbindingen en telex. Door het gebruik van communicatiemiddelen wordt 'de situatie' als het ware groter gemaakt; waardoor ook de "ecology of improvisation" groter wordt." Een voorbeeld. Een Boeing 747 stond met een kapotte motor in São Paulo. Een steen op de ladingsbaan was door de "reverserdeur" ${ }^{3.6}$ van een van de motoren gegaan. De gezagvoerder en de grondwerktuigkundige ter plaatse zagen het somber in en hadden reeds geconcludeerd dat reparatie dagen zou kosten. De machine zou niet inzetbaar zijn voor de retourvlucht, een forse verstoring op netwerkniveau. De technisch specialisten oordeelden anders. Via een scala aan communicatiemiddelen. zijn ze in staat om op afstand 'in de motor te kijken'. Door de uit Brazilië opgestuunde informatie te vergelijken met de reparatieaanwijzingen in het Maintenance Manual van Boeing verzonnen ze een reparatiestrategie waardoor de retourvlucht uitgevoerd kon worden en de verstoring op netwerkniveau beperkt bleef.

Tijdens de interviews woor het veldonderzoek werd mij keer op keer duidelik gemaakt dat risico (of in luchtvaarttermen "flight safety") niet als wisselgeld wordt beschouwd. Problemen worden in beginsel niet opgelost door tisico's te nemen. De veiligheid van passagiers en bemanning is volgens de KLM-mederwerkers geen onderwerp van onderhandeling; in het imago van luchtvaartmaatschappijen is het vertrouwen van passagiers immers cruciaal. Dat neemt niet weg dat binnen deze strenge marges in de praktijk voortdurend risico-afwegingen worden gemaakt. In het geval van het beschadigde vliegtuig in São Paulo maakte de gezagvoerder ter plaatse een andere risico-afweging (niet vliegen) dan de technici in het occ (wel vliegen).

Een laatste voorbeeld van wisselgeld is autoriteit. Of een medewerker of bedrijfsonderdeel een verstoring kan oplossen is afhankelijk van de beslissingsbevoegdheid die hij of $\mathrm{zij}$ in een situatie heeft. In de vertrekhal kunnen medewerkers van Ticket Office passagiers omboeken als zij aan de voorwaarden voldoen; het staat hen niet vrij op eigen gezag uitzonderingen te maken. Autoriteit creeert niet alleen bij KLMmedewerkers wisselgeld, maar ook bij passagiers, zoals bleek in het 
geval van het gevolg van de gouverneur van South Dakota, dat door de Ku belangrijk genoeg werd geacht om de richting wan de route door de vertrekhal om te draaien. Keerzijde van autoriteit als wisselgeld is begrip. Senior Operations Controller Joop de Mol sprak over "emmers vol begrip' die door de mensen van occ werden opgebracht voor de werknemers op de werkwloer. Bij het occ is men zich bewust van het feit dat bijsturingen daar meer werk betekenen. De manier waarop een verzoek wordt gericht, de toon die daarbij wordt aangeslagen is belangrijk, zei men. De Mol: 'Achteraf nog eens bellen om door te geven dat het goed gegaan zorgt ervoor dat men op Schiphol ook bij een volgende verstoring bereid is cen stap extra te zetten. Je moet de mensen aan je binden.' (Interview)

Samenvattend maakt het veldonderzoek duidelijk dat de dagelijkse uitvoering wan de dienstregeling van een luchtwaartmaatschappij als de KLM het noodzakelijk maakt voortdurend te anticiperen en te reageren op een veranderende werkelijkheid. Om te begrijpen hoe de $\mathbb{k}$ LM-medewerkers problemen oplossen voldoen noch tijdsbegrippen in de B-serie (de sequentiele benadering van de cybernetica en patroonherkenning) noch tijdsbegrippen in de A-serie (de geimproviseerde temporele orde). Eerder is sprake van een voortdurende produktie en reparatie van een complex van tijdsordeningen - de gestandaardiseerde kloktijd van de UTC, de diensttijden van de bemanning, de onderhoudstijden van de vliegtuigen, de wachttijden van de passagiers bij de gate-die onderling gerelateerd zijn zoals de stemmen in een fuga. Om die ordeningen te veranderen, anders gezegd om tijd te maken', moet werk verzet worden en daarwoor is wisselgeld nodig.

\section{Conclusie}

Elke reis of verplaatsing veronderstelt het creëren van een passage, een heterogene orde van materiële en immateriële elementen. Uit het voorbeeld van het KLM-netwerk werd duidelijk dat een passage niet alleen vooraf wordt gecreeerd, maar ook in het moment gerepareerd. De spanning tussen plan en werkelijkheid, voorspelbaarheid en contingentie 
maakt het noodzakelik de onderdelen van de passage voortdurend opnieuw op elkaar af te stemmen. Beniger (1986) betoogt dat de industriële en technologische ontwikkelingen in de negentiende eeuw om nieuwe vormen van sturing wroegen. Voor zover deze sturing bijvoorbeeld spoorwegnetwerken betrof, waren innovaties als die van McCalI um gericht op het mogelijk maken van een passage met twee snelheden, het creèren van overzicht in de actuele situatie en het herverdelen van beslissingsbevoegdheden. Ook nu nog maakt de informatie- en communicatietechnologie, gesymboliseerd door de talloze schermen die op een luchthaven te vinden zijn, het mogelijk op de actuele passage vooruit te lopen, daardoor meer situaties te kunnen voorzien (zowel in ruimte als in tijd) en op afstand te kunnen handelen, waardoor het niet langer nodig is ter plekke aanwezig te zijn.

Wat veranderde er sinds de dagen van McCallum? Nier de principes waarop zijn sturingsfilosofie was gegrondvest, wel de betekenis van informatie- en communicatietechnologie om de complexiteit van de netwerken in de luchtvaart te beheersen. Hogere snelheden en groeiende reizigersaantallen maken het nodig te innoveren. Voorbeelden zijn het vergroten van de capaciteit van een luchthawen (bijwoorbeeld door het aanleggen van nieuwe start-en landingsbanen) of van een luchtvaartmaatschappij (door de aanschaf van nieuwe toestellen), het investeren van meer geld of het aantrekken van ervaren personeel. Zulke innovaties impliceren altijd een herziening van de spatio-temporele orde van de vliegpassage. Het repareren van deze spatio-temporele ordes, anders gezegd het tot stand brengen van koppelingen tussen processen in de ruimte én in de tijd (synchronisering), wordt mogelijk door het inzetten van wisselgeld. Twee vormen van wisselgeld blijken bepalend voor het succes van een luchtvaartmaatschappij als de KLM, samengevat: overzicht en macht, anders gezegd, het centraliseren van het overzicht in de actuele situatie terwijl tegelijkertijd de mogelijkheid in die situatie in te grijpen wordt vergroot.

Van Rees heeft op zijn scherm overzicht over de situatie van het hele Europa-netwerk: waar zich vliegtwigen bevinden, wie de crew is, welke vliegtuigen in onderhoud staan en welke vliegtuigen "korte draaien" hebben (korte grondtijd voor het volgend vertrek). Hij zal proberen zo- 
weel mogelijk situaties te woorzien, omdat de mate warin een situatie is voorzien bepalend is voor zijn handelingsruimte. Onvoorziene situaties leiden gemakkelijk tot verstoringen en vragen dus om wisselgeld. Dat een vliegruig langer in onderhoud staat gepland hoeft niet te leiden tot onvoorziene situaties als dit bekend is bij de Operations Controllers, wandaar ook dat onderhoudsplanners deel uitmaken van het Frontoffice. Omgekeerd kan een onvoorziene situatie leiden tot een kleinere handelingsruimte. Als de gouverneur uit South Dakota en zijn gezelschap zich niet vooraf hadden gemeld, was hun verzoek de 'clean area' van de Royal Wing lounge te verlaten waarschijnlijk geweigerd. Dat de pelgrims onderweg naar Mekka gescheiden mogen zitten komt doordat de KLM deze situatie heeft voorzien.

Samen met de Operations Controllers voor de Cityhopper en de intercontinentale vluchten is Van Rees de enige bij de KLM die mag schuiven met gele en groene balkjes en daarmee in real time veranderingen. mag aanbrengen in de dienstregeling. Ook hier gaat het om een verdeling van wisselgeld: de captain die met een kapot toestel in São Paulo staat, kan zelf niet beoordelen of het toestel door kan vliegen. Dat gebeurt vanuit het occ, van waar technici 'in de motor' kunnen kijken. Het occ handelt vanuit het overzicht dat men heeft over de actuele en potentiele situatie van het netwerk en andere bedrijfsonderdelen zijn, althans op de dag van uitvoering en voorzover het netwerkzaken betreft, functioneel aan hen ondergeschikt. De wrijheid wisselgeld te munten om verstoringen op te lossen is niet gelijk verdeeld, of anders gezegd: niet elke KLM-medewerkers staat hetzelfde soort wisselgeld ter beschikking. Het vergroten van overzicht over de situatie gaat niet zonder reden samen met een centralisering van de autoriteit om in die situatie in te grijpen.

Informatie- en communicatietechnologie maken het mogelijk steeds meer processen vanuit één punt én op één moment te overzien. Bovendien is men in het controlecentrum op steeds meer plaatsen 'ter plekke': men weet hoe druk het is op JFK Airport in New York, hoe het weer daar is, wat de mankementen zijn in de straalmotor van een van de KLMvliegtuigen en, wellicht in de nabije toekomst, wat de fysieke en mentale toestand is van de gezagvoerder. Passages repareren impliceert bij de 
KLM uiteindelijk een verschuiving van de macht van de mensen ter plekke naar de controlekamer.

In dit hoofdstuk ging de aandacht uit naar één passage. Niet alleen binnen passages duiken echter machtsvragen op, ook tussen passages is dat het geval. De sturingsvragen die dan aan de orde komen, hebben een ander karakter dan in de overzichtelijke wereld van Schiphol. 


\section{6 \\ Het recht van de snelste}

In de dorpskom van Schiermonnikoog heerst de fietser: Omdat bezoekers hun auto op het vaste land moeten achterlaten wordt het straatbeeld gedomineerd door huurfietsen. Vergeleken met een willekeurig dorp op de wal zijn er meer verschillen. De voorrangsborden, parkeervakken, middenstrepen, fietsstroken, verkeersdrempels, stoplichten, haaientanden en andere wegmarkeringen, rotondes, vluchtheuvels, opstelvakken en zebrapaden die elders de aanblik wan het verkeerslandschap bepalen, ontbreken in het waddendorp. Zelfs trottoirs zijn er een zeldzaamheid. Fietsers, streekbussen, taxibusjes, voetgangers en een enkele auto delen de straten; het verkeer regelt zichzelf. Een beetje oplet ${ }^{-}$ ten is voldoende.

Afgaande op de verdeling van snelheid tussen verkeersdeelnemers staat Schiermonnikoog model voor een egalitaire samenleving. Op de vaste wal is dat anders, daar zijn de verschillen tussen langzaam en snel verkeer veel groter. Hier domineren de auto's die in steeds grotere aantallen het pad kruisen van andere weggebruikers, zoals fietsers en voetgangers. Dit leidde tot problemen waarvan onveiligheid op straat het meest in het oog springt. Tot 1973 nam het aantal doden in het verkeer toe tot 3300 per jaar en het leeuwendeel van deze slachtoffers viel binnen de bebouwde kom. Daarnaast hadden auto's steeds meer ruimte nodig, zowel om geparkeerd te worden als om snel door te kunnen rijden. Ruimte werd schaars en er ontstonden problemen met de doorstroming van het autoverkeer in stads- en dorpskernen, gebouwd in andere tijden en voor andere vormen van verkeer. Hoe werden deze problemen opgelost? Tal van innovaties, voor het grootste deel in de infrastructuur, moesten het stadsverkeer un goede banen leiden. Daarbij speelde de politieke conjunctuur een rol. Zo kwamen er in de jaren zestig grootscha- 
lige stadsstraten watar de langzamere verkeersdeelnemers ondergeschikt werden aan of gescheiden van het gemotoriseerde verkeer. ${ }^{1}$ Ook met technieken om het verkeer te reguleren zoals woetgangers- en fietsstoplichren, wuchtheuvels, zebrapaden en andere oversteekplaatsen werd de verkeersruimte opnieuw verdeeld. ${ }^{2}$ Vanaf de jaren zeventig werd de hegemonie van de auto ter discussie gesteld en kregen langzame verkeersdeelnemers meer aandacht. Woonerven, verkeerscirculatieplannen, betaald parkeren en fysieke obstakels als het Amsterdammertje beperkten de rumte voor de auto.

Door het toenemende autoverkeer werden straten betwiste ruimtes waarbij de strijd ging tussen verkeersdeelnemers onderling en tussen verkeeren bewoners. Over de technieken die strijdige ruimteclaims en andere belangen tegen ellkaar moeten afwegen, wordt vaak gesproken als neutrale middelen die een noodzakelijk gevolg zijn van de groei van het autoverkeer. Verkeersingenieurs werken doorgaans vanuit her imperatief dat het autoverkeer moet kunnen 'doorstromen', politici zoeken. graag naar efficiénte, liefst 'slimme' technische oplossingen om belangen van verkeersdeelnemers te verzoenen. Het verschil met het Operations Control Center van de KLM, waar men beslissingen neemt tegen de achtergrond van een zo efficiënt en punctueel mogelijke uitvoering van de dienstregeling, is dat een dergelijk wogelperspectief op straat ontbreekt. De vraag hoe de talloze verkeersdeelnemers in een grote stad als Amsterdam op tijd op hun bestemming komen wordt niet beantwoord in een controlecentrum, maar vormt de inzet van onderhandelingen, zowel op straat als in het gemeentehuis. ${ }^{3}$ Waar verkeersdeelnemers elkals weg kruisen, wordt voorrang genomen en gewacht, snelheid gemaakt en afgeremd. De vraag waarom de ene verkeersdeelnemer zou moeten wachten om de andere sneller te laten doorrijden kan niet alleen in termen van efficiëntie en doorstroming beantwoord worden, maar impliceert ook de mogelijkheid claims te rechtvaardigen en belangen af te wegen. Hoe kunnen we het politiek-normatieve karakter van het verkeer ter discussie te stellen? In dit hoofdstuk wordt dit gedaan door te onderzoeken boe passages, die verschillende snellheden mogelijk maken zoals een auto- en een fietspassage, elkaar kruisen. Het maken van dergelijke kruisingen gebeurt in uiteenlopende ontwerpstijlen, waarin naast 
het vormgeven van wegvakken en kruispunten ook het legitimeren van regels en het bedrijven van politiek aan de orde is.

\section{Denken over het kruispunt}

Regels voor het gebruik van de straat als ruimte om zich voort te bewegen zijn al oud. De Romeinen kenden eenrichtingsverkeer, voetgangersoversteekplaatsen (aangegeven door stapstenen), parkeerregels en rotondes. In het zeventiende-eeuwse Londen golden regels die voetgangers geboden dat zij op het trottoir moesten lopen. ${ }^{4}$ Paarden en koetsen veroorzaakten in steden en dorpen regelmatig dodelijke ongelukken en in Engeland werd al in r 865, nog voor de komst van de auto, een wer aangenomen die de maximum snelheid in de bebouwde kom op twee mijl per uur vaststelde. ${ }^{5}$ Verkeersveiligheid zoals wij het begrip nu kennen werd een politiek thema met de komst van de auto. ${ }^{6}$ Het eerste slachtoffer van een auto-ongeluk in de Verenigde Staten viel in 1899 toen een man niets vermoedend uit een tram de straat opstapte en werd overreden door een elektrische taxi die met een snelheid van vijftig kilometer per uur de tram passeerde. ${ }^{7}$ Vanaf ongeveer $\mathrm{I} 900$ werden overal in de Verenigde Staten en Europa maatregelen genomen om de verkeersveiligheid te verbeteren, zoals rijopleidingen om een verplicht rijbewijs te halen, invoering van kentekenplaten en de instelling van snelheidslimieten.

Veel van de innovaties in op het terrein van de verkeersveiligheid en verkeersregullering zijn bedacht door William Phelps Eno, die in $x$ 8 58 in New York werd geboren. In het in 1900 gepubliceerde traktaat met de titel Reform in Our Street Traffic Urgently Needed beklemtoonde hij de 'noodzaak van rationeel management en toezicht op de verkeersregels'. Zijn Rules of the Road, gepubliceerd in 1903 , werd zes jaar later tot wet verheven in New York City. ${ }^{8}$ Eno was verantwoordelijk voor tal van innovaties op het terrein van verkeersveiligheid en -regulering zoals stopborden, het gebod dat langzaam zoveel mogelijk rechts moet houden, het toepassen van eenrichtingsverkeer opdat het verkeer beter circuleert, taxi-standplaatsen, wluchtheuvels voor voetgangers en rotondes. ${ }^{9}$ 
Met de komst van de auto veranderde de publieke ruimte. De film Berlin. Die Sinfonie der Großstadt ( 1927 ) waarin Walther Ruttmann een dag uit het leven van de metropool Berlijn heeft vastgelegd, toont voetgangers, fietsers, trams, bussen en auto's die kris kras door elkaar heen lopen en rijden, een beeld dat wij niet meer kennen. Dat komt deels omdat er veel meer werd gelopen en gefietst dan tegenwoordig. Vooral 's ochtends vroeg als de arbeiders naar de fabriek liepen, was de straat het domein van de voetgangers. In de eerste decennia van de twintigste eeuw was de straat vooral ook het toneel van een 'oorlog' tussen auto's en voetgangers, zoals Belasco (1986) opmerkt. In 1925 werden in de Verenigde Staten vijfentwintigdduizend mensen gedood na een ongeluk waarbij auto's betrokken waren; bijna zeventig procent van hen was voetganger en van hen was een derde jonger dan vijftien jaar. De verantwoordelijkheid werd doorgaans niet bij de automobilist en zijn vervoermiddel gelegd: 'Het was gemakkelijker om op te roepen tot strenger ouderlijk toezicht dan om veiliger auto's te maken, en gemakkelijker om stadskinderen van de buurtstraten te verbannen dan om het autoverkeer aan banden te leggen." ${ }^{\text {10 }}$

Het is verleidelijk de veranderingen die zich op straat voltrokken eenzijdig toe te schrijven aan de verspreiding van de auto. Van een veelzijdige ruimte die plaats bood aan tal van functies zoals spelen, verkopen, recreëren en verplaatsen werd de straat meer en meer een monofunctionele ruimte waar de transportfunctie domineerde: Met de verschuiving van verblijfsruimte naar doorgangsruimte ontstonden als gevolg van snelheidsverschillen spanningen die opgelost moesten worden door innovaties zoals Eno ze introduceerde. Aan deze lezing kleeft echter het bezwaar van technisch determinisme, betoogt Baldwin (r999) in zijn boek over de domesticering van de straat in Hartford, Connecticut. De ontwikkeling van het verkeerssysteem was onderdeel van een bredere trend naar functiescheiding in de stedelijke ruimte. Aan het eind van negentiende eeuw bestond in Hartford, net als in andere plaatsen aan de Amerikaanse oostkust, een sterke sociale hervormingsbeweging die pleitte voor schonere en veiligere straten. Argumenten van hygiënistische en morele aard speelden daarin een belangrijke rol. De segregatie van functies in de publieke ruimte ging volgens Baldwin voor- 
af aan de verspreiding van de auto. Dat de functiescheiding die de moralisten unit de Progressive Movement creëerden dankbaar werd benut door automobilisten blijkt wel uit het feit dat automobilistenorganisaties zich graag bedienden van progressieve argumenten. ${ }^{x}$

Zoals het voorbeeld van Hartford duidelik maakt, was het toegenomen autogebruik aan het begin van de twintigste eeuw niet de enige oorzaak van veranderingen in de publieke ruimte. Ook andere sociale en culturele ontwikkelingen maakten de strat tot betwiste ruimte. De regulering van het verkeer in steden en dorpen - het probleem van het samengaan van meerdere snelheden - is nooit een zuiver technische aangelegenheid geweest; de ruimte die aan de auto werd toebedeeld is ook altijd gelegitmmeerd met politieke, culturele en soms ethische argumenten. Deze argumenten keerden terug in de wijze waarop men over de regulering van het verkeer sprak en over het karakter en het ontwerp van de openbare rumte. Historisch gezien zijn in het denken over de oplossing van het probleem van verschillende snelheden die elkaar kruisen twee dimensies te onderscheiden, respectievelijk de vomgeving van het verkeerslandschap en de regelgeving die betrekking heeft op de vraag hoe te handelen in dat verkeerslandschap.

\section{Vormgewing}

In de vormgeving van het verkeerslandschap gaat het om het creeren van de materiele voorwaarden voor het kruisen van meerdere snelheden in het geheel van elementen dat een verkeerssituatie bepaalt, zoals infrastructuur, stedenbouw en geografie. Bij het ontwerpen van verkeersituaties werken ontwerpers op een continuüm van stijlen waarvan de uitersten worden gevormd door twee ideaaltypen: een moderne en een organische ontwerpstijl.

\section{Modern}

In de moderne stijl wordt het probleem van het kruisen van meerdere snelheden opgelost door dit kruisen zoveel als mogelijk te voorkomen. Door verkeersdeelnemers met verschillende snelheden een 'eigen straat' te geven is het probleem van tegengestelde ruimteclaims op het eerste gezicht opgelost. Deze stijl kan gelden als modern omdat zij teruggrijpt 
op het denken van modernistische architecten als Le Corbusier en Frank Lloyd Wright. Met de andere architecten van de Congres intemationatex d'architecture moderne (CIAM) zochten zij oplossingen voor wat zij zagen als de nieuwe sociale en economische realiteit van de urbanisatie, de verstedelijking. Centraal daarin stond de idee van het zoneren, dat wil zeggen het scheiden van stedelijke functies zoals wonen, werken, recreeren en verplaatsen. Zo tekende Le Corbusier in zijn in 1925 verschenen boek Urbanisme een stadswijk waar drie 'circulatiesystemen' zin gebouwd op drie verschillende niveaus met als doel een terugkeer naar de menselijke maat. ${ }^{12}$ Frank Lloyd Wright koos bij het ontwerp van zijn Broadacre City als antwoord op de urbanisatie juist het transport als leidend principe. De moderne stad zou 'overal en mergens" zijn, meende Wright, en dat idee bracht hij tot uitdrukking in systemen van gescheiden autowegen. ${ }^{\text {in }}$

De idee van gescheiden verkeersstromen komt het duidelijkst naar woren in de autosnelwegen die woor het eerst in Duitsland en later ook in de Verenigde Staten en andere Europese landen werden aangelegd. In de vs ontstonden ze uit de zogenaamde parkways; zoals de Mount Vernon Memorial Highway in Washinton DC. 4 De gedachte achter de "limited access highway" was dat zij alleen voor gemotoriseerd verkeer toegankelijk was, uit twee rijbanen voor elke richting bestond zodat het verkeer gemakkelijk zou kunnen inhalen en dat erg geen gelijkwloerse kruispunten zouden zijn. "Hoewel de idee van een autosnelweg in de stad dus al oud is, duurde het zowel in de vs als in Europa tot ongeveer I960 voordat steden op grote schaal ontsloten worden voor het autoverkeer met stedelijke snelwegen.

In de Nederlandse stedenbouw kwam de moderne ontwerpstijl naar voren in het werk van de stedenbouwkundige Van Eesteren. In de jaren zestig introduceerde hij zowel in het ontwerp van de Bijlmer in Amsterdam als in Lelystad het principe wan de gescheiden verkeerslagen. Het autoverkeer wordt hier afgewikkeld op brede, verhoogde stadsstraten terwijl op de begane grond voetgangers- en fietspaden zijn aangelegd in een groene omgeving. ${ }^{16}$ Dat niet alleen het autoverkeer uitgangspunt hoeft te zijn bij het scheiden wan verkeerssoorten in het ontwerp van steden bewijst het voorbeeld van Houten. Bij de planning 
van de uitbreiding van het bestaande dorpje bij Utrecht in de jaren zeventig werd gekozen voor een ruimtelijke opzet waarin fietsers in het yoordeel zouden zipn boven automobilisten als het gaat on de directheid van de verbindingen tussen de belangrijkste bestemmingen in het dorp. In Honten vormt de fietsinfrastructuur het ramwerk voor de ligging van belangrijke voorzieningen als scholen, sportfaciliteiten en de gemeentelijke bibliotheek. In de aanlegr van infrastructuur is bewust geen voorrang gegeven aan auto's, wat tot uitdrukking komt in kruisingsvrije fietspaden, voorrang voor fietsers als zij van rechrs komen en de andeg van fietspaden langs prettig beplante assen. ${ }^{17}$

Het achterliggende principe van de moderne stijl is een combinatie van 'flow' en zonering. Niet alleen wordt het verkeer zoveel mogelijk gescheiden van andere maatschappelijke functies, ook de verschillende verkeerssoorten worden bij voorkeur apart gehouden. Door het verkeer op deze twee manieren te scheiden dient men twee doelen. In de eerste plaats kan het autoverkeer (of als men daarwoor kiest het fietsverkeer) gemakkelijker doorstromen en in de tweede plaats wordt 'de menselijke maat" (Le Corbusier) hersteld doordat langzame verkeersdeelnemers niet voortdurend kruisen met het snellere verkeer. In culturele zin is deze stijl verbonden met de opvatting van een makbare samenleving: architecten, stedenbouwers en verkeerskundigen geven een antwoord op de problemen van de verstedelijking door de goede steden en wegen te bouwen.

\section{Organisch}

Waar de moderne ontwerpstijl. het probleem tracht op te lossen door te voorkomen dat verschillende snelheden elkaar kruisen, richt de organische ontwerpstijl zich juist op het mengen van verkeersdeelnemers. Om dat te kunnen doen moet de verkeersruimte zo ontworpen worden dat snelheidsverschillen minimal worden. In de praktijk betekent dit meestal dat snelle verkeersdeelnemers zich moeten aanpassen an langzamere. Deze ontwerpstill, die in veel opzichten een bereflecteerde terugkeer inhoudt naar het soort verkeerslandschap dat bestond voor de grootschalige verspreiding van de auto en andere snelle vervoermiddelen, is in Nederland sinds een aantal jaren in opkomst. 
Van den Boomen (2001) beschrijft de nieuwe inzichten in het ontwerp van infrastructuur binnen de bebouwde kom van steden en dorpen. ${ }^{*}$ Voor borden, stoplichten en zebrapaden is niet langer plaats, evenmin als voor de ongelikvloerse kruisingen of vrijliggende fietspaden die het modernisme typeren. Het velligste kruispunt is een leeg plein, vinden sommige verkeerskundigen. Op dat plein wordt de automobilist in verwarring gebracht, remt af en zoekt oogcontact met andere weggebrukers. Van den Boomen beschrijt hoe de Nederlandse verkeersruimte in de afgelopen dertig jaar het toneel werd van verkeersdrempels (de eerste werd in 1970 in Delft aangebracht), woonerven, $30 \mathrm{~km}$-zones en rotondes. Al deze ingrepen hadden als doel de scheiding tussen snelle en langzame verkeersdeelnemers te verminderen. Op de brink in het Friese Oosterwolde is deze 'leesbare straat', zoals Van den Boomen het noemt, geradicaliseerd. Tot 1998 lag hier een geasfalteerd kruispunt uit de vierde categorie wan de Richtlijn Ontwerp NietAutosnelwegen (RONA), met voorsorteervakken, zebrapaden en voorrangsborden.

'Nu is het een plein van rode klinkers, niets meer en niets minder. Geen borden, geen trottoirs, geen fietspaden, niks, zelfs geen bielzen. Pas in tweede instantie vallen ingrepen op die de blik sturen, zoals de groene balustrades.

Een oude man met een rollator sukkelt diagonal over het plein, een moeder parkeert haar auto, stapt uit en doet haar kind een korte broek aan, een vrachtwagen laat een groepje fietsers van links voorgaan."xg

Ondanks de vele verkeersovertredingen en de ogenschijnlijke chaos is er sinds de herinrichting van de brink in Oosterwolde nog geen letselongeluk gebeurd terwijl er toch dagelijks 4.500 auto's passeren, schrijft Van den Boomen. Voor de herinrichting waren er drie ongelukken per jaar. De ontwerpers bereikten dat het plein veiliger en rustiger werd en dat de verkeersafwikkeling verbeterde wardoor de bereikbaarheid van het dorp werd vergroot. Dat deze ontwerpstijl niet is voorbehouden aan dorpen bewijst het voorbeeld van de Dam in Amsterdam, die in 2000 
opnieuw is ingericht volgens organische ontwerpuitgangspunten. Waar de verschillende verkeersdeelnemers - auto's, fetsers, trams, bussen en voetgangers - voorheen een duidelijke plaats was toegewezen, is nu een geraffineerde illusie gecreeerd van een groot plein waar alles en iedereen door elkaar heen rijdt en loopt. ${ }^{20}$

Het achterliggende principe van de organisch vormgegeven kruisingen is dat van de zelforganisatie. ${ }^{21}$ Kruisingen worden zodanig aangelegd dat het verkeer niet wordt gescheiden maar elkaar juist tegenkomt. De vormgeving wil hier niet duidelijke patronen vastleggen tussen verkeersdeelnemers, maar creëert een arena waarin die patronen als vanzelf ontstaan. In cultureel opzicht past deze ontwerpfilosofie in een discours warin zowel dwingende, door de overheid opgelegde regels als maakbaarheidsidealen op hun retour zijn ten gunste van de 'zelfreinigende' werking van de markt. ${ }^{22}$

\section{Regelgeving}

Het probleem van kruisende snelheden is niet alleen op te lossen door worm te geven aan het werkeerslandschap. Onlosmakelijk hiermee verbonden is de vraag hoe te handelen in dat verkeerslandschap en de beantwoording van die vraag veronderstelt de aanwezigheid van regels. Die regels kunnen verschillend van aard zijn, juridisch als ze betrekking hebben op kwesties van verantwoordelijkheid en aansprakelijkheid, en sociaal als ze dienen om het handelen van andere verkeersdeelnemers te kunnen interpreteren. ${ }^{23}$ Ook deze tweede dimensie van de regelgeving vormt een continuüm tussen twee ideaaltypische stijlen van legitimatie van het handelen: in dit geval een regulatieve stijl en een deliberatieve stijl.

\section{Regulerend}

In deze stijl wordt aangenomen dat om het verkeer in goede banen te leiden duidelijke afspraken nodig zijn, regels en richtlijnen die bepalen hoe weggebruikers zich in bepaalde situaties moeten gedragen en wat de beperkingen zijn voor hun verkeersgedrag. Verkeersregels zijn in deze opvatting overal geliik geldend en bindend, dat wil zeggen dat bij overtreding een waarschuwing, geldboete of zwaardere straf volgt. Regels hebben een juridische functie, namelijk het vaststellen van civielrechte- 
lijke aansprakelikheid voor het berokkenen van schade aan anderen en het kunnen toedelen van schuld als de wet in strafrechtelijke zin wordt overtreden. ${ }^{24}$ Daarbij gaat de wetgever uit van het principe dat verkeersdeelnemers verantwoordelijk zijn voor hun verkeersgedrag. In de woorden van mr. J. Spee, hoofd van het Bureau Verkeershandhaving Openbaar Ministerie: 'Als ik meedoe aan een spelletje ganzenborden moet ik mij gewoon aan de regels houden. Doe ik dat niet dan speel ik vals. Bevallen die regels mij niet dan moet ik dus niet meespelen. Op de weg is het niet anders. Een rijbewijs is een vergunning en aan die vergunning zijn voorwaarden verbonden, namelijk je houden aan de verkeersvoorschriften. Heb je daar geen zin in dan "wegwezen." :25

Wie in Nederland de straat op gaat, dient zich te houden aan verkeersregels die in Nederland zijn vastgelegd in het Reglement Verkeersregels en Verkeerstekens (RvV) (1994). Verkeersregels zijn in Nederland afgeleid uit de algemene gevaarsbepaling die in de Wegenverkeerswet van 1994 zo is geformuleerd: "Het is een ieder verboden is zich zodanig te gedragen dat gewaar op de weg wordt of kan worden veroorzakt of dat het verkeer op de weg wordt of kan worden gehinderd'. ${ }^{26}$ Voor de verschillende soorten verkeersdeelnemers als automobilisten, (brom)fietsers (in de wet aangeduid als bestuurders) en voetgangers gelden aangepaste regels. Zo worden eisen gesteld aan de maximale breedte van een fiets $(75 \mathrm{~cm})$ en de verlichting van een fiets ("een helder rood stralend duidelijk zichtbaar achterlicht, met goedkeuringsmerk'). Fietsers moeten hun hand uitsteken als ze naar links of rechts afslaan, mogen met $z$ 'n tweeẻn naast elkaar fietsen en mogen rechtsaf door rood of oranje als door een onderbord bij een verkeerslicht de tekst staat 'Rechtsaf vrij voor fietsers'. Fietsers moesten tot voor kort voorrang verlenen aan gemotoriseerd verkeer van links en rechts, maar deze door de Duitsers in de Tweede Wereldoorlog ingevoende regel is aangepast. Vanaf I mei $200 \mathrm{I}$ hebben alle bestuurders van rechts, dus ook fietsers, voorrang.

Een regulatieve stijl wan regelgeving gaat vaak samen met een moderne ontwerpopvatting. Om in een bepaalde situatie duidelijk te maken welke verkeersregels gelden, moet immers een breed scala a an materiële voorzieningen getroffen worden. Witte strepen op de weg scheiden verkeersdeelnemers. Borden maken duidelijk wellke maximum 
smelheid geldt. Stoplichten regelen kruisend verkeer door het te scheiden in de tijd als het niet mogelijk is het in de ruimte te scheiden. $\mathrm{Om}$ zich in het verkeer te kunnen bewegen moeten verkeersdeelnemers in staat zijn deze codes te herleiden tot gedragsregels. Deelnemen aan het verkeer vereist dus niet alleen dat iemand kan fietsen of een voertuig besturen, maar ook dat hij of zij het verkeerslandschap kan 'lezen', anders gezegd, de actuele situatie kan interpreteren tegen de achtergrond wan de geldende regels. ${ }^{27}$ Het probleem van kruisende snelheden wordt in de regulatieve stijl, die we bijvoorbeeld terugvinden in het denken van William Phelps Eno, opgelost door het vooraf verdelen van rechten en plichten in het verkeer. Snel verkeer heeft voorrang op langzam verkeer, rechts gaat voor en op het inrijden van de straat met eenrichtingsverkeer staat een boete, als er ten minste een agent in de buurt is. De regulatieve stijl steunt immers op de achterliggende principes van de naleving en sancties.

\section{Deliberatief}

Verkeersregells schrijwen voor hoe te handelen in een bepaalde verkeerssituatie, maar de wetgever heeft onderkend dat het onmogelijk is om elke situatie te reguleren. Sterker, in sommige gevallen kan het nodig zijn een verkeersregel te overtreden om te kunnen voldoen aan de algemene gevaarsbepaling, het niet in gevaar brengen of hinderen van het verkeer. Waar aan het ene uiterste van het continuüm het accent ligt op het formuleren van regels die zo precies mogelijk vastleggen hoe in een bepaalde situatie zaken als voorrang zijn verdeeld, treffen we aan het andere einde een benadering aan die uitgaat van het idee dat verkeersdeelnemers ook onderling tot een beoordeling van de situatie moeten kunnen komen. Verkeersregels spelen daarbij een andere rol dan in de regulerende benadering.

De deliberatieve benadering laat zich goed illustreren aan de Amerikaanse 4-way stop. Dit is een kruispunt waar verkeersdeelnemers hun woertuig volledig tot stilstand moeten laten komen. Deze regel - op het overtreden waarvan een strenge straf staat - is een tweede orde- of metaregel omdat zij tot doel heeft een situatie te creëren waarin de verkeersdeelnemers door oogcontact onderling kunnen uitmaken hoe de 
eerste orde verkeersregel, namelijk 'wie het eerst is gearriveerd op de kruising mag deze als eerste oversteken", "in de situatie past." Het achterliggende principe is daatom te omschrijven als "Verständigung" (Habermas), waarbij het feit dat de deelnemers onderling kunnen delibereren mogelijk wordt doordat er geen snelheidsverschillen zijn; de discussie heeft een machtsvrij karakter. Waar het strikt naleven van verkeerstegels leidt tot een, althams op papier, heldere verdeling van verantwoordelijkheden en aansprakelijkheid vooraf, impliceert de deliberatieve benadering een nadruk op een algemene verantwoordelijkheid die alleen in concrete situaties wastgesteld kan worden.

\section{Veranderingen in beleid}

Net als de opvattingen over de vormgeving van het verkeerslandschap veranderen de ideeèn over verkeersregels. Zo laat de eerder genoemde algemene gevaarsbepaling uit de Wegenverkeerswet van 1994 meer ruimte voor een eigen afweging in de situatie dan eerdere formuleringen. ${ }^{28}$ In de toelichting op her Reglement Verkeersregels en Verkeerstekens (RVV) uit 1990 wordt bovendien gewezen op het sociale karakter van verkeersgedrag: 'Verkeersveilig - maar bovenal sociaal - verkeersgedrag vraagt om verstandig inspelen op verkeerssituaties die eenvoudig niet in regels te vatten zijn. ${ }^{39}$ Het handelen van mensen wordt in deze visie gelegitimeerd op grond van een zelfstandige beoordeling van de situatie. Sterker, in veel situaties is het beter de beoordeling aan creatieve en verantwoordelijke verkeersdeelnemers over te laten dan het handelen als wetgever te willen preciseren. Dit leidt alleen maar tot het overtreden van regels en daarmee erodeert het hele stelsel, vreest men. ${ }^{30}$

Verkeersdeelnemers kunnen niet (alleen) vertrouwen op de 'officië-

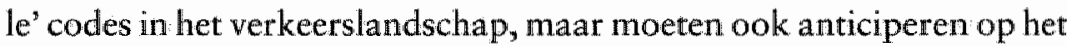
handelen van anderen. In het dagelijks verkeer ontstaan voortdurend situaties warin mensen regels overtreden en onderling een 'conflict' oplossen. Dat ongeschreven codes een rol spelen, is bijvoorbeeld te zien op het zebrapad. Volgens het Rvv moet een automobilist een voetganger hier voorrang verlenen, maar de praktijk in Nederland is anders. Als de automobilist al stopt, is dat een gunst die vergezeld gaat van een gul handgebaar, waarna de voetganger vlug oversteekt, bang om de auto- 
mobilist langer op te houden dan nodig is." Het voorbeeld van het zebrapad maakt duidelijk dat in de praktijk niet alleen de verkeersregels het handelen in een situatie bepalen, maar ook sociale en culturele regels en gewoontes. Nieuwe verkeersdeelnemers zijn niet klaar als zij de regels kennen, zoals Spee lijkt te suggereren; zij zullen in de praktijk moeten leren waar en hoe de regels wan toepassing zijn. In die zin is het verkeer een regelgeleide praktijk. ${ }^{32}$

\section{Ensembles van passages}

Op de vraag hoe verschillende functies in de publieke ruimte van de straat gecombineerd kunnen worden, of toegespitst op het verkeer, hoe meerdere snelheden kunnen kruisen, zijn antwoorden gegeven binnen de dimensies van de vormgeving en de regelgeving. Afhankelijk van de positie op het continuüm tussen respectievelijk modern-organisch en regulatief-deliberatief zijn verschillende vormen van innovatie te onderscheiden. De autosnelwegen in Los Angeles met hun fly-overs (ongelijkvloerse kruisingen) zijn een moderne oplossing waarin het autoverkeer een eigen snelheid $\mathrm{k}$ an handhaven omdat het geen verkeersdeelnemers met andere snelheden tegenkomt. De Dam in Ansterdam toont een organische oplossing waar het a-priori onderscheid tussen snelheden juist wordt vermeden. William Phelps Eno formuleerde in zijn Rules of the Road uit r 903 van bovenaf verkeersregels. Zijn ideeen zijn gemeengoed geworden in de hele wereld, maar worden de laatste jaren weer ter discussie gesteld om plaats te maken voor benaderingen waarin regels vooral dienen om verkeersdeelnemers hun eigen oordeel over een situatie te laten vellen.

Tot nu toe heb ik het probleem wan kruisende snelheden besproken in de standaardtermen warin snelheid wordt opgevat als een inherente eigenschap van een vervoermiddel of een verkeersdeelnemer. Het lijkt zo bezien nodig het verkeerslandschap vorm te geven en regels op te stellen voor het handelen in dat landschap omdat er verschillen in snellheid bestan. Otte (1993) formuleert dit perspectief zo: 'Het verkeersvraagstuk lijkt te zujn ontstaan in 1885 en r 886 toen Benz en Daimler drieen vierwielige voertuigen met gasmotoraandrijving op de weg brachten." Een auto verschijnt hier als vanzelf in het verkeerslandschap als 
een verkeersdeelnemer met een maximumsnelheid die tien maal hoger ligt dan van een langzame verkeersdeelnemer als de voetganger en vijt maal hoger dan die van de fiets. In de voorgaande hoofdstukken heb ik beargumenteerd dat snelheid geen inherente eigenschap wan vervoermiddelen is, maar de uitkomst van het vermogen snelle passages te bouwen. Opgevat als effect van passages is de snelheid van auto's en voetgangers een spatio-temporele orde waaraan zowel materiële (vormgeving) als immaterielle (regelgeving, normen i elementen te onderscheiden zijn. Anders gezegd, om in een stad snel in een auto te kunnen rijden movet een passage worden gemaakt. Dat geld ook woor het snel rijden op een fiets, alleen vergt dit een andere passage.

Wie snelheid beschouwt als een inherente eigenschap van de auto, neemt meestal een toeschouwersperspectief in. Redeneren in termen van passages stelt ons in staat ook hier een actorperspectief in te nemen. De innovaties die in deze paragraaf zijn besproken, zowel in de vormgeving als in de regelgeving, zijn gezien vanuit dat actorperspectief dan geen reactie op een reeds bestaande verdeling van snelheden, maar juist constitutief voor het optreden van die verschillen. Deze draaing van het perspectief vraagt wel om een verdere uitwerking van het passagebegrip, waarbij ik de aandacht niet richt op een enkele passage zoals in hoofdstuk 3 en ook niet op een passagenetwerk zoals in de hoofdstukken 4 en 5, maar op het 'samenleven' van meerdere snelheden in ensembles van passages. De eerste stap in deze verdere uitwerking van het passagebegrip is het vinden van een manier om snelheidsverschillen tussen verkeersdeelnemers anders te beschrijven dan als verschillen in $k i-$ lometers per uur.

\section{Tijd, ruimte en risico}

Snelheid als vaardigheid en ontwerp

Een automobilist die snel door een stad rijdt, heeft weinig tijd om te reageren op onverwachte situaties als het oversteken van voetgangers of het passeren van fietsers. Vandaar dat het een zekere vaardigheid en ervaring vraagt om een auto te kunnen besturen. Niet voor niets moeten 
mensen laten zien dat ze over die vaardigheden beschikken door het behalen wan een rijbewijs. Als een botsing dreigt kan een automobilist (of een ferser) afremmen, snellheid verminderen. Daarbij zal hij of zij een zekere remweg nodig hebben om tot stilstand te komen en die remweg is gerelateerd aan de snelheid; hoe sneller, hoe meer meters weg er nodig zijn om tot stilstand te komen. Een auto die dertig kilometer per uur rijdt heeft een remweg van tien meter, een auto die vijftig killometer per uur rijdt een remweg van dertig meter. Deze remweg is de optelsom van de tijd die nodig is om te reageren (reactietijd) en de tijd die nodig is om het voertuig tot stilstand te brengen gegeven een bepaalde snelheid. Dat betekent dat een rijdende auto altijd niet alleen 'beslag' legt op de weg vlak voor en achter de auto. Hoe sneller de auto rijdt, hoe langer het weggedeelte dat vrijgehouden moet worden om botsingen te voorkomen. Het adequat kunnen inschatten van de verhoudingen tussen snelheid, reactietijd en remweg is een van de belangrijkste vaardigheden waarover een automobilist moet kunnen beschikken.

Hoe vaardig ook, boven een bepaalde snelheid zou de bestuurder de macht over het stuur verliezen of botsingen veroorzaken als niet voorzieningen waren getroffen om het fysieke onvermogen om snel genoeg te reageren te compenseren. Alleen als de weg op een bepaalde manier is vormgegeven en als de regelgeving conflictsituaties bij voorbat in het voordeel van één soort verkeersdeelnemers beslist, kan bijvoorbeeld een automobilist met een zekere snelheid rijden zonder voortdurend te hoeven afremmen. Elke weg heeft een ontwerpsnelheid, zoals verkeerskundigen het noemen. Kuipers ( 1998 ) bijwoorbeeld, definieert in zijn handleiding voor kruispuntontwerp dit begrip als 'de snelheid die maatgevend is voor de vormgeving van de weg en de ontwerpelementen, zodat bestuurders van afzonderlijke voertuigen, niet gehinderd door overige verkeer, bij die snellheid veilig kunnen rijden. ${ }^{34}$ Het begrip ontwerpsnelheid makkt duidelijk waarom een autosnelweg waar $\mathbf{r} 20$ kilometer per uur gereden moet kumnen worden veel breder is dan een tweebaansweg waar men slechts tachtig mag rijden. Bij hogere snelheden is meer ruimte-zowel naast als voor de auto-nodig om te kunnen reageren op onverwachte situaties. Behalve de breedte van de weg wordt de ontwerpsnelheid ook bepaald door de boogstralen in de weg. Hoe 
ruimer een bocht, hoe minder een automobilist hoeft af te remmen zonder uit te bocht te viegen.

Net als de Operations Controler in het Front Office van de KLM moet een bestuurder van een auto vooruit kunnen kijken om tijdig op situaties te kunnen reageren. Aan die eis wordt voldaan door rekening te houden met wat verkeerskundigen 'stopzicht' en 'oprijzicht' noemen. Alleen als een automobilist voldoende ver van tevoren kan zien of een kruising vrij is (en dus of hij of zij voldoende ruimte heeft om eventueel tot stilstand te komen) is een hoge snelheid mogelijk. Als iemand in een snel rijdende auto voldoende overzicht wil thebben om te kunnen anticiperen moet daarmee bij de aanleg van wegen en kruispunten rekening worden gehouden. ${ }^{35}$ Snelheid is niet alleen een eigenschap van een voertuig, maar veronderstelt altijd een combinatie van vaardigheden van de bestuurder, technische eigenschappen van het voertuig en een complexe ordening van het verkeerslandschap in termen van vormgeving en regellgeving. ${ }^{36}$

\section{Snelheid als werdeling van tijd, ruimte en risico}

Om snel in een auto te kunnen rijden moeten mensen de tijd en de ruimte hebben om te kunnen reageren op onvoorziene situaties. In situaties waarbij verkeersdeelnemers elkaar tegenkomen vindt een uitwisseling van tijd, ruimte en risico plaats, zoals duidelijk wordt in het voorbeeld van een overstekende voetganger. De voetganger heeft, rustig wandelend, een zekere tijd nodig om de straat over te steken. In die tijd komt de auto dichterbij met een bepaallde snellheid. De voetganger weet doorgaans uit ervaring of de snelheid van de auto en de benodigde remweg voldoende tijd laten om de overkant te halen. De ruimte van de straat wordt hier betwist door twee verkeersdeelnemers; de straat maakt zowel deel uit van de passage van de voetganger als van de automobilist. In de beweging var de voctganger en de automobilist vindt een voortdurende uitwisseling plaats. De voetganger moet rumte laten aan de automobilist (door ofwel stil te staan of sneller te lopen) of de automobilist moet plaats maken voor de voetganger (door af te remmen). In het algemeen zal altijd een uitwisseling van ruimte plaatsvinden als verkeersdeelnemers elkaars weg kruisen. Daarbij geldt dat hoe hoger de 
snelheid van de auto is, hoe meer ruimte nodig is om "vooruit te kunnen kijken', dat wil zeggen om tijdig te kunnen reageren op onverwachte situaties. Omgekeerd heeft een voetganger nauwelijks een remweg, maar neemt het wel een bepaalde tijd om over te steken. De ruimte is hier relationeel, dat wil zeggen, ze maakt deel uit van de beweging van zowel de automobilist als de voetganger. Dat blijkt ook uit het ontwerp van straten: een ruime boogstraal maakt het een automobilist mogelijk snel een bocht te nemen, maar de voetganger is dubbel zo lang bezig om over te steken.

Snelheid impliceert niet alleen een andere inrichting en daarmee een andere verdeling van de ruimte, maar ook van de tijd. Een hoge rijsnelheid van een auto vereist niet alleen rumte, maar wijzigt ook de temporele orde tussen verkeersdeelnemers. Een voorbeeld is de verdeling van reactietijd. Voetgangers hebben onderling zeeën van reactietijd; zij kunnen gemakkelijk reageren op onverwachte situaties. Voor fietsers is deze tijd al korter en iemand die in een auto vijftig kilometer per uur rijdt, heeft deze reactietijd nog verder verkort. Behalve van zichzelf "vraagt" een automobilist een kortere reactietijd van andere verkeersdeelnemers. $\mathrm{Zij}$ moeten immers sneller reageren op het veranderen van de verkeerssituatie. Deze verkorting van de reactietijd op strat heeft, net als bij de herverdeling van de ruimte, vooral gevolgen voor de kwetsbaardere verkeersdeelnemers: kinderen, ouderen en gehandicapten. De langere reactietijd die zij nodig hebben wordt hen vaak niet gegund. Whitelegg (1997) geeft het voorbeeld van de afstelling van voetgangerslichten. Op sommige plaatsen kunnen de voetgangers alleen rennend de overkant bereiken binnen de groen-periode "De snelheid binnen de ene passage (de auto) noodzaakt ook hier tot snelheid in de andere (het lopen). ${ }^{37}$

Een laatste verdeling betreft risico, dat wil zeggen de kans op een botsing. Een verkeersdeelnemer die zelf meer risica's neemt, bijvoorbeeld door sneller te rijden dan is toegestaan, vergroot ook voor andere verkeersdeelnemers de kans op een ongeluk. Tussen gemotoriseerde en langzame vormen van voortbeweging bestaat een voorspelbare asymmetrie als het gaat om de kans op een dodelijk ongeval. Hillman, Adams en Whitelegg (1990) deden onderzoek naar het verdwijnen van 
zelfstandige mobiliteit onder kinderen en jongeren. De titell van hun boek One false move... verwijst naar een Engelse verkeersveiligheidscampagne. De campagneposter toont een kind dat op het punt staat de van de stoeprand de straat op te stappen en heeft als slagzin: "One false move and you're dead'. In Groot-Brittannie is (net als in Nederland) het aantal in het verkeer omgekomen kinderen sinds het begin van de jaren zeventig sterk gedaald. De stelling dat het verkeer veiliger is geworden kan worden gekritiseerd. In $197 \mathrm{x}$ mocht nog tachtig procent van de kinderen van zeven of acht jaar zonder begeleiding naar school, in 1990 was dit percentage gedaald tot negen procent. Het aantal jeugdige slachtoffers is niet gedaald ondat het verkeer veiliger is geworden, stellen Hillman [et.al.], maar omdat kinderen niet meer aan de gevaren op de weg worden blootgesteld. Uit studies in Groot-Brittannië en Duitsland blijkt dat ouders uit angst voor ongelukken hun kinderen steeds minder toestaan zich onafhankelijk te bewegen in hun directe woonomgeving. Bovendien besteden ouders meer tijd aan het begeleiden van kinderen in het verkeer. ${ }^{38}$

\section{Ruinte, tijd en risico als wisselgeld}

De passages van verschillende verkeersdeelnemers die elkaar kruisen staan niet los van elkaar maar zijn aan elkaar gerelateerd, anders gezegd, ze hebben een relationeel karakter. ${ }^{39}$ De auto-en de fietspassage beïnloeden elkaar, of beter geformuleerd, maken deel uit van elkaars passage. De spatio-temporele orde van de passage wordt deels vastgelegd in het de vormgeving van het verkeerslandschap, bijvoorbeeld door fietsers en auto's te scheiden, waardoor grote verschillen in snelheid kumnen optreden, of door ze juist te mengen, waardoor snelle en langzame verkeersdeelnemers zich aan elkaar moeten aanpassen. Maar deze orde komt ook tot uitdrukking in de regelgeving. Door vooraf verkeersregels vast te stellen, zoals voorrangsnegels, word een spatio-temporele orde vastgellegd; door het laten gelden van metaregels ontstaat de mogelijkheid om deze orde in de situatie in een onderhandeling tus sen mensen vast te stellen. Passages hebben snelheid als uitkomst en voor die uitkomst zjin andere snetheden bepalend. Hieruit volgt dat wegen of kruispunten in een stad of dorp geen intrinsieke eigenschappen 
hebben, als een tijd-ruimte die er is, maar dat ook de eigenschappen van het wegvak en het kruispunt relationeel zijn. Breedtes en boogstralen liggen vast, maar wat ze doen is afhankelijk van welke passage ze deel uitmaken. ${ }^{40}$ Ean automobilist passeert een andere kruismg dan een fietser. Datzelfde geldt voor voertuigen: een auto is niet op voorhand een sneller voertuig dan de fiets, maar slechts in een onderlinge relatie die niet alleen wordt bepaald door de eigenschappen van het voertuig.

Een passage is niet alleen relationeel in spatio-temporele zin, maar ook in de verdeling van de middelen om de orde te veranderen. In het vorige hoofdstuk werd duidelijk dat een passage zowel wooraf gemaakt wordt als in bet moment. Net als de vluchtleiders in het occ moeten automobilisten, fietsers en voetgangers een situatie kunnen overzien om te kunnen handelen. Om verstoringen in de passage als gevolg van onwoorziene situaties te kunnen repareren moeten zij kunnen beschikken over 'wisselgeld'. Voorbeelden van wisselgeld zijn voldoende ruimte om te kunnen manoeuvreren en uit te wijken, tijd om te kumnen reageren op onverwachte situaties en de vaardigheid om een situatie voldoende snel te kunnen beoordelen. Het wisselgeld ligt deels vooraf vast, bijvoorbeeld in de breedte van een fietspad of de platsing wan opstelvakken voor een kruispunt (vormgeving), maar ook in voorrangsregels of juist de vrijheid om ervan af te wijken en naar bevind van zaken te handelen. Het relationele karakter van de passage impliceert daarnaast dat wisselgeld ook wordt uitgewisseld in het moment zelf, dat wil zeggen in de beweging. Een automobilist die met hoge snelheid een fietser inhaalt, beperkt de manoeuvreerruimte voor de fietser en daarmee de mogelijkheden om op een onverwachte situatie te reageren. Omgekeerd zal een auto die achter een fietser rijdt in een smalle straat tijd inleveren omdat de fietser wisselgeld in de vorm van manoeuvreerruimte nodig heeft. Het kruisen van passages produceert én verdeelt snelheid.

Het relationele karakter van passages komt tot uitdrukking in de dimensies van de wormgeving en de regelgeving, respectievelijk in het spatio-temporele orde zoals die vooraf is yastgelegd en zoals die in het moment ontstaat. Met het relationele karakter van snelheid als uitkomst van passages is het nu mogelijk het probleem van kruisende snelheden te beschrijven vanuit het actorperspectief van de ontwerper. Die ont- 
werpt geen kruispunt voor passages, maar ensembles van passages: Immers, de verschillende ontwerpstijlen die in de vorige paragraaf besproken zin impliceren verschillende strategieën om passages te laten 'samenleven' en om het wisselgeld te verdelen tussen passages. Maar precies het feit dat de snelheden van verschillende verkeersdeelnemers aan elkaar gerelateerd zijn, maakt duidelijk dat nog één dimensie in het actorperspectief ontbreekt. Wie of wat bepaalt of en waarom de ene snelheid belangrijker is dan de andere? Waarom zou een auto moeten wachten op een fietser of andersom? Het maken van snelle passages veronderstelt een derde, politieke dimensie. Een manier om deze politieke dimensie zichtbaar te maken üs te onderzoeken hoe verkeerskundigen en stedenbowwers hebben geprobeerd om in Nederlandse steden en dorpen thogere reissnelheden voor de fiets te ontwerpen. Moeten fietsers eigen fietspaden hebben of is mengen met het andere verkeer de oplossing? Zijn speciale "fietsregels" nodig (zoals voorrang voor de fietsers van rechts) of is een fietser juist gebaat bij de vrijheid zijn of haar eigen regels te stellen?

\section{Ontwerpen voor die fiets}

Nooit is er meer gefietst in Nederland dan in $1960 .^{41}$ Fietsen had zich ontwikkeld van een bezigheid voor de sportieve elite aan het eind van de negentiende eeuw tot de gangbare verplaatsingspraktijk van de massa. Nog in de jaren vijftig rinkelde het in grote steden als Amsterdam op straat van de fietsbellen als de mensen naar hun werk of naar huis gingen. Vanaf het begin van het jaren zestig verloor de fiets terrein, eerst aan de brommer en wat later aan de auto. Het aandeel van de fiets in de totale vervoersprestatie nam scherp af om na een stabilisatie pas halverwege de jaren zeventig weer iets toe te nemen. ${ }^{42}$ Een belangrijke factor achter de groei van het aantal gemotoriseerde vervoermiddelen vormde de toegenomen welvaart. ${ }^{43}$ Het verkeersbeleid en de overheidsaandacht waren in de jaren zestig voornamelijk gericht op het 'faciliteren' van het groeiende autoverkeer en zowel het wegennet buiten de bebouwde kom als de wegen in de steden werden in hoog tempo aan- 
gepast aan de eisen van de moderne (lees: gemotoriseerde) samenleving. ${ }^{4}$ Tussen het langzame en het snelle verkeer ontstond een harde strijd om verkeersruimte en voorrang, waarin de fiets het aanvankelijk aflegde tegen de auto. Met de toename van het aantal auto's, een ontwikkeling waarmee de aanleg van aangepaste infrastructuur geen gelijke tred hield, steeg het aantal verkeersslachtoffers onder langzame werkeersdeelnemers onrustbarend. Het fietsen had, zou je kunnen zeggen, zijn onschuld verloren. De oplossing voor het probleem van de onveiligheid van het fietsen werd door de overheid gezocht in het aanleggen van fietspaden en het veiliger maken van kruispunten.

Na $1970 \mathrm{kreeg}$ de politiek meer aandacht voor luchtvervuiling door uitlaatgassen, stijgend brandstofverbruik en verspilling van grondstoffen. De fiets - gezond, schoon, stil, energiezuinig en flexibel, zo betoogde de in 1975 opgerichte Enige Echte Nederlandse Fietsersbond $(\text { ENfis })^{45}$ - werd herontdekt als een oplossing voor de problemen die thet gemotoriseerde verkeer opleverde. Naast een oplossing voor de kwestie van de verkeersveiligheid van fietsers was er nu volgens de beleidsmakers een tweede reden om fietsinfrastructuur aan te leggen, namelijk het bevorderen van de overstap van, zoals men het omschreef, het 'gaspedaal naar het fietspedaal'. In steden als Den Haag en Tilburg werden speciale fietsroutes aangelegd. Maar in $198 \mathrm{I}$, zes jaar nadat de fietsnetwerken waren aangelegd, bleek dat hoewel mensen er positief over oordeelden ze miet hadden geleid tot een toename van het aantal fietskilometers. Het aanleggen van fietspaden alleen bleek niet voldoende om meer mensen er op de kortere afstanden toe te brengen de auto in te ruilen woor de fiets. ${ }^{46}$

Nodig was, zo concludeerden onderzoekers en beleidsmakers, niet alleen de aanleg van enkele goede fietspaden over lange afstanden, maar een netwerk van fietspaden die nooit meer dan vijfhonderd meter van elkaar lagen. Zo'n netwerk zou rechtstreeks moeten zijn, ononderbroken en vrij van obstakels. Het zou het bestaande wegenpatroon moeten volgen, toegang moeten geven tot de belangrijke voorzieningen in een stad, zoals werk, recreatie, winkelcentra, overheidsgebouwen en dergelijke. Deze doelen werden nagestreefd bij de constructie van het Fietsnetwerk in Delft dat tussen 1982 en 1987 werd aangelegd. Aanvanke- 
lijk leidde de nieuwe fietsinfrastructuur in Delft tot een toename van het fiersgebruik, maar de toename zette niet door. De tweede belleidsdoelstelling, het verbeteren van de verkeersveiligheid, werd wel gehaald. Het aantal verkeersongelukken in Delft waarbij fietsers betrokken waren nam af en bleef op het lagere niveau. ${ }^{47}$

In het Tweede Structuurschema Verkeer en Vervoer (SVV II) uit I 990 werd de fiets nadrukkelijk gepresenteerd als een manier om de problemen van het groeiende autogebruik tegen te gaan. Men zette opnieuw zwaar in op wat in het beleidsjargon wodal shift werd genoemd, de overstap van de auto naar openbaar vervoer voor de langere en de fiets voor de kortere afstanden. ${ }^{48}$ Uitgaande van die doelstelling zag de rijksoverheid het als haar taak om het fietsen te bevorderen. De leidende rol van de centrale overheid kwam tot uitdrukking in het Masterplan Fiets (MPF) uit 199 I. Het doel wan het plan was tweeledig: meer en veiliger fietsen. Tussen $x 986$ (het ijkjaar in het Svv 11 j en 20 ro zou het aantal fietskilometers met dertig procent moeten toenemen ten koste van autokilometers. Een groei van het aantal kilometers in het openbaar vervoer moest komen van een verbeterde afstemming tussen fiets en openbaar vervoer. Ook voor clodelijke slachtoffers en gewonden onder fietsers werden streefcijfers genoemd, respectievelijk een vermindering van vijftig en veertig procent ten opzichte van 1986 . Het aantal fietsdiefstallen zou scherp moeten dalen. Vanaf 1995 zouden acties om het gebruik van de fiets te stimuleren onderdeel uit moeten maken van alle verkeersplannen, van de rijksoverheid, provincie en gemeente. ${ }^{49}$ Als ooit een gecoördineerde politieke en beleidsmatige inspanning werd verticht on het fietsen voorrang te geven dan was het nu. Hoe pakte men het aan?

\section{Fietsuriendelijke infrastructuur}

De algemene doelstelling in thet Masterplan Fiets luidde: "Een toename van het gebruik van de fiets als alternatief voor autogebruik, onder de voorwaarde dat de kans op ongevallen voor fietsers (en bromfietsers) drastisch vermindert." Als een van de mogelijkheden om deze doelstellingen te realiseren werd, net als in eerdere jaren, gedacht a an het verbeteren van de fietsinfrastructuur, omschreven 'als alle technische voorzieningen die bestemd zijn voor fietsers'. Zo hoopte men de fiets op de 
korte afstanden te kunnen laten concurreren met andere vormen van vervoer im termen van reistijd, comfort en veiligheid. Een goed functionerende fietsinfrastructuur werd bovendien gezien als de sleutel tot een duurzaam veilig wegverkeersysteem. ${ }^{50}$ Hoe deze infrastructuur eruit zou moeten zien is beschreven in een van de belangrijkste documenten die tijdens de MPF-periode verschenen, Tekenen voor de fiets. Ontwerpwizer woor een fietsuriendelike infrastructuur. Dit boekwerk, ook wel de 'ontwerpbijbel' voor fietsinfrastructuur genoemd, verscheen in 1993 en wordt inmiddels door de meeste gemeenten in Nederland gezien als cen ijkpunt om de kwaliteit van fietsvoorzieningen te beoordelen. Het handboek werd samengesteld door een werkgroep waarin een aantal belangengroepen samenwerkten, waaronder de Fietsersbond. ${ }^{5}$

De Ontwerpwijzer stelt eerst de vraag wat fietsen eigenlijk is. 'De ontwerper van een fietsvriendelijke infrastructuur moet vertrouwd zijn met de technische mogelijkheden en beperkingen van de fietser en fiets. De fietser is bestuurder, evenwichtskunstenaar en motor tegelijk. ${ }^{52}$ In tegenstelling tot traditionele technische handboeken, die vaak uitsluitend voorbeelden en stereotypen geven en bij voorbaat uitgaan van het integreren van de behoeften van de fietser met die van andere, snellere weggebruikers waardoor men snel in compromissen vervalt, wil het ontwerphandboek zich vooral richten op de behoeften van de fietser als gebruiker van het ontwerp:

'Omdat de fiets door spierkracht wordt aangedreven, moet het wegontwerp zodanig zijn dat energieverliezen zo klein mogelijk zijn. (...) Gesteund door twee wielen is de fietser voortdurend bezig niet om te vallen. Zijwind, zuiging door vrachtauto's, oneffenheden in het wegdek en gedwongen lage snelheden bepalen de stabiliteit en daarmee de benodigde manoeuvreerruimte. (...) De kwetsbaarheid van de fietser blijkt overduidelijk uit de ongevallencijfers. De wegbeheerder kan hierop echter grote invloed uitoefenen. Zo kan hij de fietser een 'ruimtelijke kreukelzone' geven die als ruimte voor noodmanoeuvres dienst kan doen. Weliswaar kan een fietser balanceren over een strook van $0,20 \mathrm{~cm}$ breed, maar acrobatick mag uiteraard niet het ontwerpuitgangspunt zijn. Bij een openslaand portier kan 


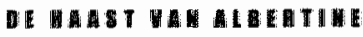

de extra ruimte op de fietsstrook levensreddend zijn. De kwetsbaarheid betekent ook dat fietsers niet gemengd kunnen worden met snelrijdende auto's en intensief vrachtwerkeer." 53

Een fiets heeft nauwelijks vering, gaat de Ontwerpwijzer verder, en "een vlak wegdek is dan ook een minimum woorwaarde om tegemoet te komen aan de eis van fietsvriendelijkheid". Dat een fietser in de open lucht fietst heeft woor- en nadelen. Beschutting tegen regen en wind nemen sommige wan de nadelen weg, maar de voordelen zoals een aantrekkelijke omgeving moeten in het ontwerp gehandhaafd blijen. Omdat fietsers sociale wezens zijn, moeten ze naast elkaar kunnen fietsen. Op die manier kunnen ouders bijvoorbeeld hun kinderen begeleiden. En ten slotte is de mens en dus de fietser geen machine, stelt de Ontwerpwijzer. Het aantal taken dat een fietser kan uitvoeren en de complexiteit ervan is gebonden aan grenzen die de ontwerper moet respecteren, daarbij tekening houdend met minder ervaren en minder valide weggebruikers. ${ }^{54}$

Uit de behoeften van de fietser als gebruiker wordt in de Ontwerpwijzer een programma van vijf eisen opgesteld waaraan de fietsvriendelijkheid van infrastructuur afgemeten kan worden: ${ }^{55}$

- samenhang;

- directheid;

- aantrekkelijkheid;

- veiligheid;

- comfort.

Uit de opzet van de Ontwerpwijzer spreekt een bepaalde opvatting van het ontwerpproces. Daarin gaat het volgens de auteurs om het afstemmen van vorm, functie en gebruik. Infrastructuur heeft een vorm, bijvoorbeeld kruispunten, wegvalkken of stallingen. De gewenste functie wan deze vormen van infrastructuur volgt uit het programma van eisen, bijwoorbeeld de voorwaarde dat het aantal fietsslachtoffers zal dalen of dat het aantal ontmoetingen met andere verkeersdeelnemers wordt geminimaliseerd. Op basis van berekening of waarneming stelt men vervolgens het verwachte gebruik vast. Bij het ontwerp zoekt men vervol- 


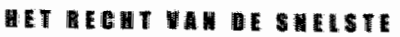

\begin{tabular}{|c|c|c|}
\hline worm & beongde functie & (venwachte) gebruik \\
\hline $\begin{array}{l}\text { ratwerk } \\
\text { - schalkels } \\
\text { - Whopen }\end{array}$ & $\begin{array}{l}\text { directe en weilige verplatsingen } \\
\text { per fiets mogeligh maken in een } \\
\text { samenhangend systeem }\end{array}$ & $\begin{array}{l}\text { matrix wan herkomstten en } \\
\text { matrix wan herkomsten en } \\
\text { of doorberekend) }\end{array}$ \\
\hline $\begin{array}{l}\text { werbinding } \\
\text { - interinka: } \\
\text { - lokaal } \\
\text { - buutriweau }\end{array}$ & $\begin{array}{l}\text { met de kwaliteit die volght uit het } \\
\text { niveau vain de verbinding in het netwerk } \\
\text { - vertinden } \\
\text { - verdelen } \\
\text { - ontsiluiten }\end{array}$ & $\begin{array}{l}\text { intensiteit } \\
\text { (waargenomen of doortherekend) }\end{array}$ \\
\hline $\begin{array}{l}\text { Worriening } \\
\text { - kruispunt } \\
\text { - wegwak } \\
\text { - overgang } \\
\text { - stalling }\end{array}$ & $\begin{array}{l}\text { met de kwaliteit die voligt uit het } \\
\text { niveau wan de werbinding } \\
\text { - ontmoetingen afwikkelen } \\
\text { - verkeer afwikkelen } \\
\text { - voorzieningen aansluiten } \\
\text { - stallingsplaats bieden }\end{array}$ & $\begin{array}{l}\text { gedrag en manoeuwres } \\
\text { werkeersdeelnemers (waargenoment } \\
\text { of berekend) }\end{array}$ \\
\hline
\end{tabular}

Fignur 6. 1: Verband tussen vorm, functie en gebruik. (Bmon: Ploeger let.all. $]_{\text {, }}$ 1993: 35 ).

gens naar een evenwicht tussen vorm, functie en gebruik door het draaien aan de 'stelschroefjes' van het ontwerp. ${ }^{56}$ Niet altijd is het ideale ontwerp mogelijk, bijvoorbeeld omdat fietsbelangen moeten concurreren met andere, zoals ruimtebeslag, voorrangsiegelingen voor ander verkeer of prioriteit bij de verkeerslichtafstelling. Vorm, functie en gebruik vinden we op drie niveaus: het netwerk (schakels en knopen), de verbinding (interlokaal, lokaal en buurtniveau) en de voorziening (kruispunt, wegvak, overgang en stalling) (zie figuur 6.x).

De Ontwerpwizer verwoord een actorperspectief: door het aanpassen van infrastructuur beoogt men snellere passages te maken voor de fiets. Een van de problemen die dan opgelost moeten worden is het 'samenleven' met andere snelheden, net name die van de auto. Het ontwerp van wegvakken (met als functie het afwikkelen van het verkeer) en kruispunten (die als functie hebben het afwikkelen van ontmoetin- 
gen) illustreert hoe dit probleem in de visie van de ontwerpers moet worden opgelost.

\section{Scheiden of mengen?}

De belangrijkste vraag bij het ontwerp van wegwakken, stelt de Ontwerpwijzer, is of het gemotoriseerde verkeer gescheiden moet worden van het fietsverkeer. Scheiden (fysiek en wisueel) of mengen heeft voor- en nadelen, betoogt men. Fysieke scheiding is volgens de Ontwerpwijzer aan de orde bij hoge autosnelheden en hoge intensiteiten van het autoverkeer. Voordelen zijn dat fietsers beter beschermd zijn dan bij visuele scheiding of gemengde profielen, de rijtaak voor de fietser comfortabeller is en automobilisten fietsers gemakkelijker kunnen passeren. Nadelen zijn dat de bewegingsruimte voor de fietser afneemt, de rijsmelheden van het autoverkeer hoger liggen, het attentieniveau van automobilisten afneemt en het ruimtebeslag toeneemt. Godefrooij ( 1997 ) wijst er bovendien op dat scheiding in de praktijk vaak wordt toegepast om de vrije doorstroming ("flow") van het autoverkeer te garanderen. 'Fietsers worden naar de zijkant van de weg verbannen en in sommige Europese landen zelfs naar het trottoir.' $\$ 7$ Visuele scheiding, bijvoorbeeld door het aanbrengen van een rode strook asfalt, biedt de fietser neer bewegingsvrijheid en zorgt ervoor dat auto's gemakkelijker kunnen inhalen, maar kost meer ruimte, leidt ertoe dat auto's sneller rijden en automobilisten minder aandacht hebben voor fietsers, automobilisten de fietsstrook gebruiken als parkeerruimte waardoor fietsers gevaarlijke manoeuvres moeten uitvoeren en vrachtverkeer de strook als manoeuvreerruimte zal gebruiken. In een gemengd profiel ten slotte, worden alle verkeerssoorten in dezelfde ruimte afgewikkeld en heeft als voordelen voor fietsers dat ze bewegingsvrijheid houden en dat geen extra ruimte nodig is. ${ }^{58}$ Nadelen zijn volgens de Ontwerpwijzer dat gemengde wegvakken onveiliger zijn, dat als er veel geparkeerd wordt finetsers vaak gevaarlijke manoeuvres moeten uitvoeren, dat fietsers vooral bij zogenaamde krappe profielen het gevoel kunnen hebben te dienen als 'remmend vlees'.

De vraag of het probleem van verschillende snelheden in clezelfde ruimte opgelost moet worden volgens een moderne dan wel een orga- 


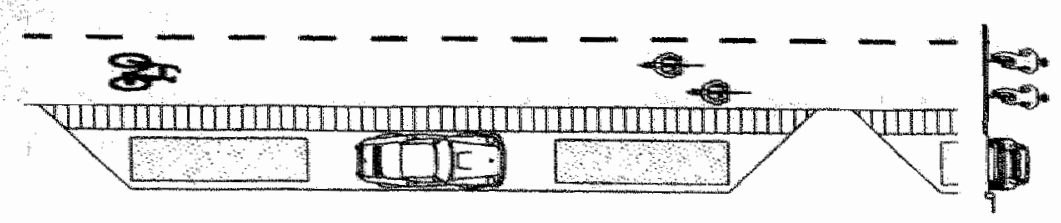

Figular 6.2: Een "Schrihstrook" tussen parkeervakken en fietsstrook geeft de fietser ruimte onn te manoetwreron... (Bron: Plogerer [et.at.], 1993: 76).

nische ontwerpstrategie is volgens de Ontwerpwijzer afhankelijk van snelheid en intensiteit van het gemotoriseerde verkeer. Hoe sneller en drukker het autoverkeer, hoe groter de noodzaak het fietsverkeer te scheiden. Scheiding in de rumte is dan nodig on weggebruikers het "wisselgeld' te bieden om te reageren op onverwachte situaties: oogcontact, stopzicht, anticipatie- en reactietijd en ruimte voor ontmoetings-, inhaal-, passeer-en uitwijkmanoeuvres. Omgekeerd, hoe langzamer en minder druk het autoverkeer, hoe minder ruimte nodig is om veilig te kunnen fietsen (zie figuur 6.2).

Niet alleen op wegvakken komen fietsers ander verkeer tegen, maar ook op kruispunten. Kruispunten leveren volgens de Ontwerpwijer de meeste problemen als het gaat om veiligheid en comfort yoor fietsers en de helft van alle verkeersslachtoffers onder fietsers valt op kruisingen. Op kruispunten komen wegen met verschillende functies bij elkaar. Meer nog dan bij het ontwerp van wegvakken vormt het integreren van de belangen van verschillende groepen verkeersdeelnemers een groot probleem. "In het algemeen wordt met de belangen van het autoverkeer steeds ruim voldoende rekening gehouden. In het verband met het beïnvloeden van de vervoerwijzekeuze is het echter zeer aanbevelenswaardig ook de belangen van het fietsverkeer voldoende zwaar te laten wegen. En het zijn juist de kruispunten waar het fietsverkeer veel aan reistijd kan winnen (of beter gezegd: verliezen)., $\$ 9$

De Ontwerpwijzer onderscheidt kruispunten met en zonder voorrangsregeling, kruispunten met verkeerslichten, rotondes en verkeerspleinen en ongelijkvloerse kruispunten. Bij de ontwerpen voor wegvakken kwam de positie wan een ontwerp in de dimensie van de 
vormgeving (modern-organisch) aan de orde, het ontwerp van kruisingen maakt duidelijk dat ook de dimensie van de regelgeving (regulatiefdeliberatief) bepalend is voor de snelheid van fietsers. Een voorbeeld van een regulatieve oplossing voor het probleem van kruisende snelheden is regeling wan het verkeer met verkeerslichten (een 'modern' ontwerp omdat het verkeer wordt gescheiden, niet in de ruimte maar in de tijd). Verkeerslichten zijn een soort "elektronische viaducten': 'Zoals altijd bij de verdeling van schaarse goederen, is ook de verdeling van schaarse groentijd op de eerste plaats en politieke en geen technische beslissing. Aan elke moderne verkeersregelinstallatie, hoe technisch en flexibel ook, liggen subjectieve beginselen ten grondslag. Deze beginselen worden vastgelegd in een regelstrategie en zijn discutabel. ${ }^{60}$ De Ontwetpwijzer geeft gedetailleerde beschrijvingen van maatregelen die genomen kunnen worden om de afstelling van verkeerslichten fietsvriendelijker te maken. Deze aanpassingen vergroten de kans dat men kan doorrijden en verkorten de wachtrijd. Voorbeelden zijn een stand-by regulering voor fietsers, de uitbreiding van de groenfase woor fietsers door die samen te laten vallen met parallel autoverkeer, rechtsafslaande fietsers door rood, meer dan een keer groen voor fietsers tijdens een cyclus en de detectie op afstand van fietsers door strips in het asfalt wan het fietspad. In de praktijk blijkt een fiets-en woetgangersvriendelijke afstelling van verkeerstichten overigens een zeldzaamheid omdat de congestie voor het gemotoriseerd die dit oplevert politiek niet wordt geaccepteerd. ${ }^{6 \mathrm{r}}$

Waar kruisingen met verkeerslichten aan het regulerende uiteinde van het regelgevingspectrum gedacht kumnen worden, bevindt de gemengde rotonde zich aan het andere uiteinde. De Ontwerpwijzer maakt onderscheid tussen rotondes met gemengde afwikkeling, met fietsstrook of suggestiestrook, en met vrijliggend fietspad in en uit de voorrang: een combinatie van vormgevings-en regelgevingselementen. Op de gemengde voor rangsrotonde geldt alleen de regel dat verkeer op de rotonde voorrang heeft. De snelheid van fietsers en gemotoriseerd verkeer is hier in principe gelijk. Op grotere rotondes kan men de fietser "uit de voorrang te halen'; regelgeving wordt dan aangepast om snel en langzaam verkeer te scheiden. 
Succes en falen tan bet Masterplan Fiers

In 1998 werd het Masterplan Fiets geèvalueerd tegen de achtergrond van de doelen die in 1991 geformuleerd waren. Aan een groot aantal studies en proefprojecten was ongeveer dertig miljoen gulden uitgegeven. De resultaten waren niet eenduidig. Ten opzichte van het ijkjaar I 986 was het aantal gefietste kilometers gestegen met vijf procent in 1996, maar in de jaren daarna was eerder sprake van stabilisatie. Ook het aantal diefstallen van fietsen lag jaarlijks nog tussen de zeshonderd-en zevenhonderdduizend. Wel waren resultaten geboekt op het vlak van de veiligheid; het aantal dodelijke slachtoffers onder fietsers nam in 1995 met veertien procent af ten opzichte van 1986 , slechts een procent minder dan het doel voor dat jaar dat in het MPF was vast ${ }^{\circ}$ gelegd. ${ }^{62}$ Ondanks het feit dat op tal van plaatsen in Nederland de infrastructuur 'fietsvriendelijk' is gemaakt, wordt er niet substantieel meer gefietst. Fietsen is wel veiliger geworden, maar blijkbar niet aantrekkelijker voor wie zich doorgaans in een auto verplaatst. Met de Ontwerpwijzer in de hand is dit falen niet goed te verklaren. Door het niet te hebben over het ontwerpen van 'infrastructuur voor de fiets' maar over het ontwerpen van ensembles van passages is dat wel mogelijk.

In de Ontwerpwizer' is een grafiek opgenomen waaruit 'globaal is af te leiden welke scheidingsworm bij verschillende snelheid-intensiteit combinaties gewenst is". Een verklaring voor het falen van de fietsvriendelijke infrastructuur begint bij deze grafiek (figuur 6.3). Op de verticale as is de "intensiteit" van het autoverkeer uitgezer (uitgedrukt in personenantoequivalenten of pae's per etmaal) en op de horizontale as de gemiddelde snelheid die door 85 procent van de auto's wordt aangehouden. In gebied $x$ is het niet te druk, rijden de meeste auto's niet harder dan dertig en 'is een gemengd profiel aan te raden'. In gebied 3 (gebied 2, veel langzaam rijdende auto's komt niet voor) rijden de meeste auto's langzamer dan zestig en is een weg zonder fietsstroken of fietspaden 'aanvaardbaar', oordeelt de wijzer. In gebied 4 is het drukker, maar ligt de snelheid van het autoverkeer nog zo laag dat fietsstroken en fietspaden "wenselijk" maar niet noodzakelijk worden geacht. In gebied 5 geldt het omgekeerde: de auto's rijden hier weliswaar hard, maar omdat het er zo weinig zijn, zijn fietsstroken en fietspaden niet noodza- 


\section{Volume of motorvehicles (1000 pcu/24 hours)}

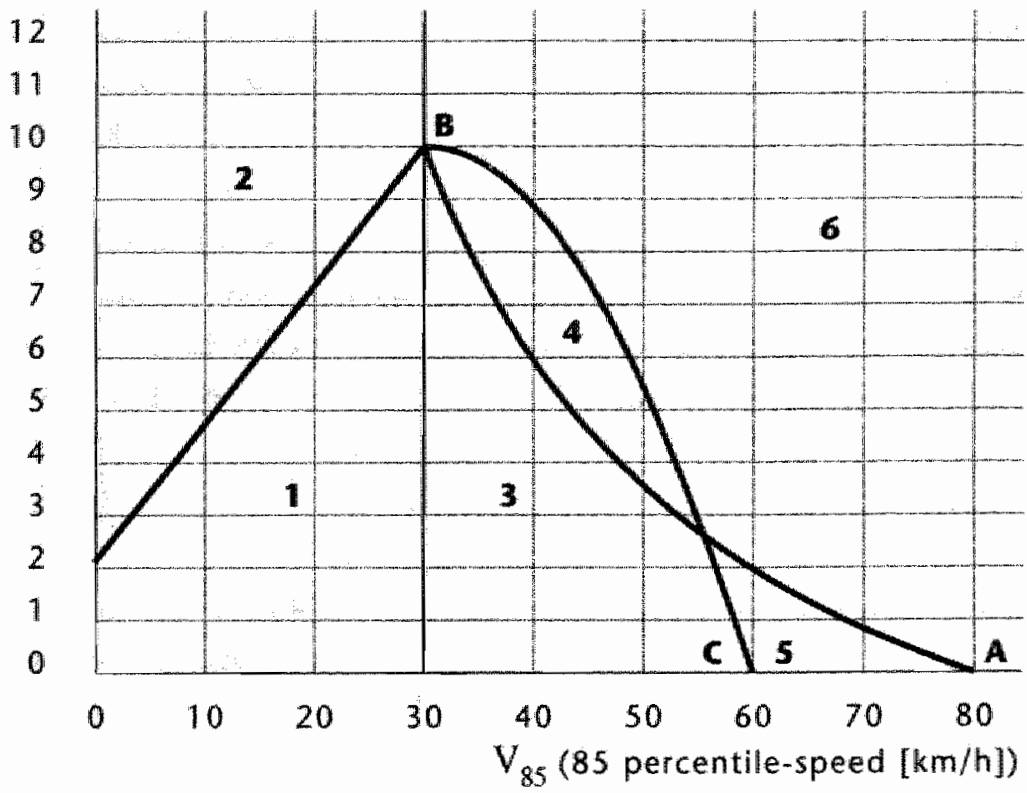

Figuur 6.3: "Snetheid en intensiteit zijn de belangrijkste factoren bil de keuze voor de mate van scheiding." (Bron: Ploeger [et. all] 1993:0ntwerpwijzer, p. 79 en 80).

kelijk: Dat geldt wel voor het grote gebied 6, waar veel auto's snel rijden. Fietspaden zijn hier altijd noodzakelijk, stellen de ontwerpers.

Het falen van de aanpak in de Ontwerpwijzer, althans waar het de overstap van auto naar fiets betreft, wordt verklaard door het feit dat het politieke karakter van dit plaatje onvoldoende wordt onderkend of beter, onvoldoende wordt verdisconteerd in de ontwerpstrategie. ${ }^{63}$ Door te stellen dat de 'snelheid en intensiteit van het gemotoriseerde verkeer de belangrijkste factoren [zijn] bij de keuze voor de mate van scheiding, worden die snelheid en intensiteit als een gegeven beschouwd. Maar niets gaat vanzelf zo snel als het gaat; daarvoor moet werk verzet worden en dat werk heeft in dit geval een politiek karakter. Immers, snelheid is relationeel en om snel te kunnen rijden moeten voortdurend ruimte, tijd en risico worden uitgewisseld. Dat wordt duidelijk door de 
grafick in figuur 3 met andere ogen te bekijken. Stel, op de horizontale as zou niet de snelleid van auto's uitgezet zijn maar van fietsen. Dan zou de maximum snelheid dertig killometer per uur geweest zijn en zou het hele gebied rechts van de verticale lijn, en daarmee de vraag 'scheiden of mengen', niet aan de orde zijn geweest. Dat de auteurs van de Omtwerpwijer moeite hebben zich een wereld voor te stellen waarin de maximumsnelheid van auto's wordt afgeleid van die wan fietsen getuigt natuurlijk van realisme, maar daarmee nemen ze feitelijk het recht van de snelste als uitgangspunt in het ontwerp van de fietsinfrastructuur. In dit ontwerp is daardoor onmogelijk geworden de legitinatie van dit recht als politiek probleem te beschouwen en dus als keuze te thematiseren. Het hoeft vervolgens niet te verbazen dat mensen in meerderheid blijven kiezen voor de auto.

In het technocratisch vocabulaire van de Ontwerpwijzer zijn schaarste en snelheid gegeven en bestaat de ontwerpopdracht erin binnen deze grenzen te draaien aan de 'stelschroeven' van vorm, functie en gebruik om zo een 'optimaal' resultaat te bereiken. Dat resulteert in een weelheid van mogelijke keuzes. Beter zou het zijn als het expliciteren van deze keuzes deel uit zou maken van de ontwerpstrategie. Passages krijgen daardoor een politiek karakter.

\section{De politiek van passages}

Om iets te kunnen zeggen over de politielk van passages is het nodig de betekenis van het begrip "politiek" nader af te bakenen. Ik wil dat doen door een tweetal gangbare definities te gebruiken om die verwolgens aan te vullen met een derde, eigen definitie. In de eerste betekenis wordt politiek opgevat als betrekking hebbend op verdelingsvraagstukken. Het maken van passages is dan politiek omdat passages verdelingen genereren van ruimte, tijd en risico. In de tweede betekenis is van politiek sprake als een bepalde kwestie onderwerp is van overheidsbemoeienis of -beleid en daarmee erkend is als onderdeel uirmakend van het publieke domein. In deze redenering is het maken van passages politiek omdat de overheid erbij is betrokken. ${ }^{64}$ 


\section{EE HAST HAV AIBEATIUE}

\section{De politiek van passages als verdeling}

Passages zijn relationeel en leiden tot verdelingen van ruimte, tijd en risico. Maar een benadering die de pollitiek van passages opvat als een verdelingskwestie moet niet alleen vaststellen wat er verdeeld wordt, maar ook tussen wie. Toe nu toe heb ik gesproken over passages als relationele ruimte-tijd ordeningen waarin verdelingen van wisselgeld worden gerealiseerd tussen fietsers, automobilisten, gemotoriseerd verkeer en voetgangers. Voor de ontwerper van fietsvriendelijke infrastructuur zijn dit eenduidige categorieën, maar in de praktijk zijn er grote verschillen. Kinderen, gehandicapten en ouderen hebben op de fiets meer reactietijd, stopzicht en manoeuvreerruimte nodig dan volwassenen tussen de twintig en vijftig. Waar de ene fietser genoeg heeft aan een smalle strook tussen rijbaan en geparkeerde auto's, kan voor de ander de 'schrikstrook' niet breed genoeg zijn. Asmussen (1996) betoogt in zijn studie De nieuwe normmens: 'Vaak wordt gesteld dat bij het ontwerpen van verkeers- en vervoervoorzieningen de mens alls maat der dingen wordt genomen, dat wil zeggen als belangrijkste criterium wordt gezien. Dit suggereert dat er een 'gemiddelde mens" bestaat die als norm fungeert voor het ontwerp. In de praktijk blijkt dat het ontwerp meestal is gebaseerd op een mens van circa 20-55 jaar in goede gezondheid (bijwoorbeeld voor wat betreft de voor het gebruik van het ontwerp vereiste loopsnelheden, reactietijden en waarnemingsafstanden. 'Omdat de verkeerspopulatie in werkelijkheid zeer heterogeen van samenstelling, bepleit Asmussen een ontwerpstrategie waarbij een 'nieuwe normmens' als uitgangspunt wordt genomen. ${ }^{6.5}$

Baeten, Spithoven en Albrechts (1997) definiëren het politieke karakter van mobiliteit in termen van insluiting en uitsluiting:

'Mensen hebben, al naar gelang de groep waartoe ze behoren (man/vrouw, werkgever/werknemer, volwassene/niet-volwassene, rijk/arm, enzovoort), ongelijke toegang tot de mobiliteit. Bepaalde groepen in de samenleving beschikken over de macht om het mobiliteitssysteem zodanig in te richten dat het hun mobiliteitsbehoeften, hun problemen en hun oplossingen beter behartigt. Andere groepen beschikken niet over die macht en zien lijdzaam toe hoe een aantal 
van hun mobiliteitsbehoeften, probleemdefinities en oplossingen daardoor niet of onvoldoende aan bod komen in het dominante discours. ${ }^{\text {*66 }}$

De mechanismen achter de in-en uitsluiting van mensen, plaatsen en activiteiten zijn goed te begrijpen in termen wan de eerder beschreven ontwerpstijlen. Zowel een modernistische ontwerpstraregie als een trgulerende opvatting van regelgeving impliceren een duidelijk onderscheid tussen verkeerssoorten, dat wil zeggen stoelen op duidelijk onderscheiden 'verkeersidentiteiten'. Zo is op een autosnelweg geen plaats voor voetgangers of fietsers. Om de "flow" van het autoverkeer mogelijk te maken, moeten langzame verkeersdeelnemers worden uitgesloten. Uitsluiting werkt hier als bevoordeling van een specifieke groep, namelijk automobilisten. Ook een met verkeerslichten gereguleerde kruispunt benadrukt de verschillen tussen verkeersdeelnemers - dat blijkt uit het verschil tussen "autolichten", fietslichten en voetgangerslichten. Omdat verkeersidentiteiten geen neutrale constructies zijn maar in meer of mindere mate samenvallen met andere, bijvoorbeeld sociale, verschillen, hebben moderne en/of regulerende strategieën een impliciet politiek effect. Behalve tussen verkeersidentiteiten en daarmee tussen mensen vindt uitsluiting plaats tussen plekken en activiteiten. Zo creèren de ongelijkvloerse autowegen in Bijlmer een niveau lager weliswaar een voetgangersgebied, maar omdat niet iedere voetganger gelijk is klagen vrouwen over sociale onveiligheid. Ten slotte worden activiteiten al dan niet uitgesloten in een moderne en regulerende ontwerpstrategie. Waar auto's voorrang krijgen is doorgaans geen ruimte om te spelen, op straffe van een aanrijding.

Bij ontwerpstrategieën die zich bevinden aan de organische en deliberatieve pool van respectievelijk het vormgevings- en regelgevingsspectrum, is het juist zaak het a priori onderscheid tussen verkeersidentiteiten te verkleinen. Op de Brink in Oosterwolde en de Dam in Amsterdam rujden, fietsen en lopen verschillende verkeersdeelnemers, maar deze verschillen zijn niet als uitgangspunt genomen in het ontwerp. Insluiting is hier een noodzakelijke voorwaarde voor een situatie waarin verkeersdeelnemers elkaar tegenkomen en in een "onderhande- 
ling' ter plaatse waststellen wie woorgaat.. In een dorp zonder borden wordt niemand aangesproken op grond van de wijze van voortbeweging. Het woonerf, een Nederlandse vinding uit de jaren zeventig, is een goed voorbeeld van een ontwerpopvatting waarbij men ervan uit gaat dat ongelijksoortige activiteiten tegelijkertijd kunnen plaatsvinden. Tegenover de monofunctionele verkeersader projecteerde men een ruimte die meerdere functies kon vervullen, namelijk van doorgangsrumte én verblijfsruimte tegelijk.

\section{Passages als overheidspolitiek}

De tweede betekenis van politiek ziet het maken van passages als iets waarbij de overheid betrokken is. In het gevall van het MPF waren er beleidsdoelstellingen - het verhogen van de verkeersveiligheid en het bewerkstelligen wan een modal shift van auto naar fiets - die zorgden woor een legitimatie voor de aanleg van fietsvriendelijke infrastructuur die op een breed draagvlak in de Tweede Kamer kon rekenen. Omgekeerd betekent dit dat wie snellere passages wil maken moet zorgen dat de keuzes die dit op straat veronderstelt, bijvoorbeeld in de verdeling van de verkeersruimte of de regeling van voorrang, door de politiek gelegitimeerd zijn.

Van belang is hier dat de overheid op meerdere niveaus opereert (rijk, provincie en gemeente om het meest gangbare onderscheid aan te houden) en dat de belangen op die niveaus kunnen botsen. Dat wordt duidelijk in het voorbeeld van de matregel 'Fietsers voorrang van rechts" die alle verkeersdeelnemers vanaf I mei zoor voorrang geeft als zij van rechts komen. Verkeerskundigen en beleidsmakers verwachtten dat de nieuwe regel de veiligheid van fietsers zou vergroten omdat de regelgeving duidelijker zou worden (alle verkeer van rechts heeft voorrang) en er voor zou zorgen dat fietsers sneller door zouden kunnen rijden. Bowendien zou de matregel een remmende werking hebben op het autoverkeer omdat automobilisten op gelijkwaardige kruispunten beter zouden moeten opletten. Waar deze innovatie op de dimensie van de regelgeving beweegt naar de regulerende pool, zou op de dimensie van de vormgeving wan kruisingen juist een beweging naar een meer organisch ontwerp van kruisingen de maatregel versterken. Immers, hoe 
meer gelijkwaardige kruisingen, hoe vaker de fietser, althans in theorie, voorrang heeft. In praktijk gingen veel wegbeheerders er juist toe over om het aantal voorrangskruispunten uit te breiden met als argument dat de nieuwe voorrangsregel tot onveilige situaties zou leiden. Deze modernistische aanpak (scheiden en bevoordelen van autoverkeer) werkte tegen de bedoelingen van de beleidsmakers en politici in Den Haag in; vooral in drukke situaties waren fietsers hun voorrang nu juist kwijt.

Politiek als keuze tussen ensembles vam passages

Kenmerkend voor veel problemen rond mobiliteit is dat de "micropolitiek' van de straat (waar verdelingen van ruimte, tijd en risico aan de orde zijn) en de "macropolitiek" van de overheid in een gespannen verhouding tot elkaar staan. Ondanks Kamerbrede steun voor het fietsen bijvoorbeeld, geldt in concrete situaties doorgaans het recht van de sne.. ste. Deze spanning is op te heffen door de politiek van passages niet slechts te definiëren in termen van verdelingsproblemen of als onderwerp van overheidsbeleid, maar als een ontwerpopdracht waarin ensembles van passages worden ontworpen. De kern van deze radicalisering van de ontwerpopdracht is dat het bij het ontwerpen van infrastructuur niet zozeer gaat om een keuze tussen 'de auto' en 'de fiets', of tussen groepen verkeersdeelnemers, of tussen discretionaire bevoegdheden in verschillende lagen in thet overheidsapparaat. De notie van ensembles van passages veronderstelt dat een ontwerp vastlegt boe snelheden 'samenleven'. Snelheden zijn relationeel en daarom betekent het ontwerpen van een passage voor de fiets altijd ook het ontwerpen van passages voor de auto; deze vormen een ensemble. Hoe moeten we ons die ensembles van passages voorstellen?

Winner ( 986 ) beschrijft hoe een voetganger en een automobilist elkaar regenkomen in een straat. Ze hebben allebei een zekere bewegingsvrijheid. De voetganger kan stilstaan wanneer hij wil, bijvoorbeeld om een etalage te bekijken of om een pratje met een voorbijganger te maken; de automobilist kan snel doorrijden, maar is weer beperkt doordat hij in de kleine ruimte van de auto zit, door de fysieke afmetingen wan de weg en door de verkeersregels. Stel, schrijft Winner, dat beide mannen elkaar tegen komen. De automobilist remt af, drukt op de 
claxon, steekt zijn hoofd uit het raampje en schreeuwt naar de overkant van de straat. Zoals ellke voetganger schrikt ook zilin vriend van het geluid van de claxon, kijkt geïrriteerd naar de afremmende auto en zier niet wie erin zit door de spiegeling van de ramen. 'Kun je morgen komen eten?' roept de automobilist. 'Wat?', roept de voetganger. Op dat moment beginnen achterop komende auto's te toeteren en rijdt de automobilist snel door. Hier is sprake van een botsing tussen een automobilist en een voetganger, ook al raakt niemand gewond, stelt Winner. 'Het is een botsing tussen de wereld van de bestuurder en die van de voetganger. De poging om een begroeting en een uitnodiging uit te wisselen, een tamelijk gangbaar gebaar, wordt hier gecompliceerd door de aanwezigheid van een technologisch apparaat en de condities waaronder het moet functioneren. De communicatie tussen de twee mannen wordt bepaald door de incompatibiliteit van de vorm van voortbeweging die bekend staat als lopen en een veel nieuwere, namelijk autorijden. ${ }^{67}$

Zoals het ontwerpen van een passage neerkomt op het maken van een wereld betekent het ontwerpen van ensembles van passage het maken van de manier warop die verschillende werelden aan elkaar gerelateerd zijn. Het Friese dorp Makkinga biedt een mooi voorbeeld van de manier waarop het kruisen van meerdere snelheden opgevat zou kunnen worden als het ontwerp van ensembles van passages. In Makkinga verdwenen de verkeersborden en voorrangsmarkeringen. Doorgaande straten werden door de aanleg van ondiepe goten visueel versmald. Het rode asfalt wan fietsstroken werd verwijderd. In het tijdschrift Noorderbreedte legt verkeerskundige Hans Monderman, verkeersveiligheidsconsulent in Friesland, uit waarom:

"Het verkeersvak is begonnen met de aanleg van wegen, door de sintels uit de schoolkachels te verspreiden over de zandwegen en dat was de taak van gemeentewerken. Die onderhield de wegen met teer, steenslag, klinkers, beton en asfalt. Een puur technische cultuur met duidelijke richtlijnen over beheer en onderhoud. Het vak beperkte zich tot getallen en maten, de technocratische organisatie van verkeersstromen. En daarbij is de mens steeds meer op de achtergrond 
geraakt. Hoe meer je je met ongevallenanalyses bezighoudt, des te meer word je op de basis teruggeworpen: waarom doen mensen wat ze doen? Dan zie je tot je schrik dat al onze richtlijnen, al onze normen alleen maar op auto's gebaseerd zijn: op remvertragingen, op breedtes, lengtes, boogstralen.

Deze technocratische aanpak heeft van dorpen als Makkinga een doorgangsruimte gemaakt, betoogt Monderman. Om straten weer meer te kunnen laten doen dan ruimte bieden aan de auto moest men ophouden het dorp alleen als een verkeerswereld te coderen waar slechts de regels van het verkeer gelden:

'Als je die verkeerswereld laat schieten en het dorp weer dorp maakt, gedraagt men zich anders. In Makkinga hebben we dat gedaan en je ziet een drastische verlaging van de snelheid. Dat is gebeurd door de culturele identiteit van het dorp een rol te laten spelen in de vormgeving en intichting. We moeten afleren dat een dorp begint bij een blauw bord met witte letters en omdat dat nog niet genoeg helpt bij een bord met de tekst: 'denk aan onze kinderen'. Alsof je daar niet op hoeft te letten als dat bord er niet staat. Met elkaar leven we in dat land van Bordje, een ongebreidelde ordeningsdrift waar de burger een schijnzekerheid aan ontleent: liever ongelukken met duidelijkheid dan veiligheid met onzekerheid. ${ }^{, 68}$

Werkt deze oplossing die van het dorp weer een dorp will maken in plaats van een doorgangsruimte? Ten dele. De meeste bewoners zijn tevreden omdlat bij het ontwerp niet bij voorbaat is uitgegaan van 'infrastructuur' of van 'voorrang voor het langzame verkeer', maar omdat in het ontwerp is nagedacht over het samengaan van meerdere werelden in de betekenis die Winner daaraan geeft. Maar er is ook kritiek. Ouders voelen zich door de verkeersdrukte in het dorp nog steeds genoodzaakt hun kinderen te helpen bij het oversteken en missen de zebrapaden, ook al zal de verkeerskundige ze kunnen uitleggen dat die niet langer nodig zijn.

Waarom is het ontwerp van Makkinga dan toch beter dan het was? 
In zijn overzicht van utopische motieven in het westerse denken heef Isiah Berlin ( I 990) gewezen op een centraal kenmerk in westerse toekomstvisies, namelijk de gedachte dat er uiteindelijk maar éen oplossing kan zijn voor problemen, waarmee meteen ook de tegenstellingen tussen mensen verdwenen zijn. De kern van de utopische traditie is het idee dat een ooit verloren eenheid te herwinnen valt. Dit idee heeft volgens Berlin grote invloed uitgeoefend, onder meer op het westerse denken over politiek. Dat denken stoelt op drie veronderstellingen: op alle echte wragen bestaat slechts één correct antwoord, er is een methode om dat antwoord te vinden en correcte antwoorden zijn onderling met elkaar te rijmen. ${ }^{69}$ Het ontwerp van Makkinga is beter dan her was omdat het duidelijk maakt dat er, anders dan in de utopische traditie wordt verondersteld, niet slechts éen antwoord is op de vraag hoe meerdere snelheden moeten samenleven. In het ontwerp zelf is immers gethematiseerd dat in het maken van ensembles van passages altijd politieke keuzes zijn geimpliceerd.

\section{Conclusie}

Om snel te kunnen autorijden of fietsen moeten passages worden gemaakt, spatio-temporele ordes die met wisselgeld worden onderhouden. In steden en corpen kruisen passages elkaar. Bij dit kruisen worden ruimte, tijd en risico uitgewisseld en dit maakt dat passages, opgevat als orde, een relationeel karakter hebben. Als een auto en een fiets elkaars weg kruisen, maakt de autopassage deel uit van de fietspassage. Dit relationele karakter heeft consequenties voor het ontwerp van passages: wie passages ontwerpt, bedrijft politiek. Traditionele opvattingen van politiek benadrukken het in- en uitsluitende karakter van mensen, plaatsen en activiteiten of de soms tegenstrijdige rol van de overheid in de legitimatie van wenselijkheid van de verschillen die op straat bestaan. Deze opvattingen van politiek kunnen niet goed verklaren waarom juist bij mobiliteitsproblemen een spanning blijft bestaan tussen de micropolitiek op straat en de macropolitiek van beleidsdoelstellingen van verschillende overheden. Aan de hand van het voorbeeld van de 
Ontwerpwijet heb ik beargumenteerd dat deze spanning ontstaat doordat impliciet het recht van de snelste als ontwerpkader wordt gehanteerd: Het politieke karakter van het ontwerp blijft daardoor onderbelicht.

Hoe dan te spreken van een politiek van passages? Door politiek te beschouwen als de beargumenteerde keuze tussen ontwerpen voor ensembles van passages. Niet tussen eindeloos veel mogelijkhedien, zoals het 'draaien aan de stelschroefjes' in de Ontwerpwijer suggereert, maar tussen twee of drie ontwerpen die onderling vergeleken kunnen worden in de dimensies van vorm-en regelgeving. Dit maakt het mogelijk te kiezen in de context. Die contexten kunnen zich aandienen op verschillende schaalniveaus. Het 'samenleven' van meerdere snelheden kan aan de orde zijn op het macro-niveau van het woon-werkverkeer in een grote stedelijke agglomeratie (bijvoorbeeld de Randstad) en dan betrekking hebben op de mate waarin het overstappen van de autowereld en de fietswereld (het 'linken' van snelheden) is georganiseerd. Ook op het meso-niveau van een stad als Groningen of Delft kan men verschillende soorten ensembles ontwerpen, zoals blijkt uit de voorbeelden van Delft en Houten. Wat werkt in Houten hoeft echter niet te werken in Amsterdam. In de context van de nieuwe wijk in Houten heeft men gekozen voor een modernistische ontwerpstijl (gescheiden fietspaden) in combinatie met deliberatieve regelgeving. In Amsterdam is, althans op de Dam, voor een organisch ontwerp gekozen. Ten slotte is er het micro-niveau van de kruising of het wegvak. Ook dit zijn ensembles van passages in de zin dat een kruispunt of een wegvak altijd deel uitmaakt. van meerdere passages en dus van de manier waarop die passages (en de snelheden die ze als effect hebben) 'samenleven'.

Een goed ontwerp thematiseert dit samenleven als een politiek probleem, een probleem dat keuzes veronderstelt. Het maakt duidelijk dat die keuzes niet gemakt zouden moeten worden door verkeerskundigen, maar door burgers zelf. Pas als we het kruisen van meerdere snelheden $i$ bet ontwerp zelf beschowwen als rakklakken van meerdere werelden, ontstat er voor burgers ruimte voor een politieke beoordeling van ontwerpen en innovaties in de context. Dat de fiets op Schiermonnikoog alomtegenwoordig is, kunnen we niet alleen begrijpen door 
te wijzen op het ontbreken wan haaientanden en stoplichten, maar vooral ook uit het feit dat het een Nationaal Park is, een eiland op drie kwartier varen van de vaste wal waar mensen juist komen om de wereld wan de auto achter zich te laten en, al is het maar even, in de wereld van de fiets te leven. 


\section{1 \\ De kunst van het reizen}

De vraag waarom mensen niet graag in langzame auto's rijden, waarmee dit boek begon, is tegelijk een goede en een slechte vraag. Het is een goede vraag omdat een vanzelfsprekendheid - namelijk dat snelle auto's de voorkeur hebben boven langzame auto's - wordt geproblematiseerd. In het eerste hoofdstuk heb ik uiteengezet dat die vanzelfsprekendheid begrepen kan worden binmen drie verschillende vertogen: een economistisch, een technisch-deterministisch en een cultureel-utopisch vertoog. De maatschappelijke dominantie van deze vertogen makt aannemelijk waarom het niet eenwoudig is anders over de vernieuwing van het reizen na te denken dan in termen van snelheid en traagheid. Precies daarom is het ook een slechte vraag. Spreken in termen van snel en langzaam creëert een vergelijkend perspectief tussen het oude en het nieuwe waarin wordt geabstraheerd van de activiteit van het reizen. Hoe iemand van de ene naar de andere plaats reist, is ondergeschikt aan de hoeveelheid tijd die dit kost.

Deze letterlijk 'vanzelf sprekende' wenselijkheid van snelheid bepaalt ook het debat rond de publieke problemen die voortvloeien uit groeiende mobiliteit. Dit debat heeft al decennia lang een tweeslachtig karakter. Enerzijds richtte het beleid zich op het mogelijk maken van sneller reizen, anderzijds stond de overheid voor de taak de problemen die dat snellere reizen met zich meebracht op te lossen zonder daarbij terug te vallen op traagheid als alternatief. In de jaren zeventig ontstond een beleidsparadigma warin de schaarste aan ruimte, schone lucht en veiligheid die het gevolg was wan de groei van de (auto)mobiliteit werd beschouwd als centraal publiek probleem. Het reduceren van die groei dan wel het verminderen van de negatieve effecten ervan gold als voornaamste oplossingsrichting. Opeenvolgende kabinetten ontwikkelden 
een rijke verzameling matregelen die als doel hadden dat mensen zo niet minder, dan toch anders zouden gaan reizen. Veel van die maatre gelen $k$ wamen niet verder dan de status van beleidsvoornemen. Ondanks vooruitgang op het terrein van de verkeersveiligheid en vermundering van de uitstoot van sommige schadelijke gassen lukt het niet de mobiliteitsdilemma's blijvend op te lossen.

Nederlandse mobiliteitspolitiek bleek opgevat te kunnen worden als. 'trjdwinstpolitiek' die stoelt op twee vooronderstellingen: door sneller te reizen walt tijd te winnen en de produktie van die snelheid leidt niet tot verliezen elders. Verkeerskundigen en vervoersplanologen kunnen beredeneren dat deze vooronderstellingen niet kloppen; sneller reizen leidt op de lange duur niet tot tijdwinst, als wel tot groei van het aantal afgelegde kilometers. Maar omdat zij in hun redeneringen uitgaan van een decontextualiserend tijdsbegrip in de B-serie kunnen zij het alternatief voor sneller reizen moeilijk anders formuleren dan als langzamer reizen. $\mathrm{O}_{\mathrm{p}}$ het niveau van het debat blijft het denken over vernieuwing daardoor gevangen in een vergelijkend perspectief waarin kloktijd de rol van noemer vervult (een auto is meestal sneller dan de trein) én warin innovatie één noodzakelijke richting heeft (we kunnen slechts kiezen tussen 'gasgeven' of 'afremmen').

De centrale these in dit boek is dat het debat over mobiliteitsproblemen en het spreken over innovatie van mobiliteit gebaat zijn bij cen vergelijkend perspectief dat zich niet uitsluitend bedient van begrippen als snel en langzaam en het decontextualiserende tijdsbegrip dat daaraan ten grondslag ligt. Om dit andere perspectief te kunnen ontwikkelen heb ik, naast tijdsbegrippen in McTaggarts A- en B-serie een tijdsbegrip witgewerkt in wat ik de C-serie heb genoemd. Tijdsbegrippen in de C-serie zijn ontwikkeld in sociaal-wetenschappelijke studies naar de wijze warap binnen praktijken uiteenlopende temporele ordes worden geproduceerd. Reizen is een voorbeeld van een praktijk die niet los te zien is van de wijze waarop spatio-temporele ordes worden gemaakt. Het maken van deze ruimte-tijd ordes heb ik beschreven als het creëren van passages. Bij het verder uitwerken van het begrip 'passage' heb ik het pragmatische uitgangspunt gehanteerd dat het maken van passages altijd betekent dat grotere en kleinere (ontwerp)problemen moeten wor- 
den opgelost. Een reiziger hoeft niet elke keer de hele reis opnieuw uit te vinden. Integendeel, de geschiedenis van het reizen laat zich juist schrijven als een reeks innovaties die niet alleen een snelle, maar vooral ook een probleemloze en voorspelbare reis tot doel hadden. Reizen is een activiteit waarbij mensen nauwelijks meer stilstaan juist omdat zicla geen problemen voordoen. Het werk dat verzet moet worden om reizigers 'wrijvingsloos' van de ene naar de andere plaats te brengen - het creëren, repareren en legitimeren van de passage - is in de coulisse verdwenen. Het landschap van snelwegen en fietspaden, wegwijzers en wegenkaarten, stations en vliegvelden valt niemand meer op.

Maar ook bij routinematige verplaatsingen, van huis naar het werk bijvoorbeeld, zitten onderweg dingen tegen, bijwoorbeeld vanwege een onverwachte file of omdat er geen parkeerplaats te vinden is. Het alledaagse, het vertrouwde aspect van de passage vormt dan niet langer een voldoende kader orm de problemen op te lossen. Zoals Gabriëls (200x) het formuleert in zijn omschrijving van het pragmatisme: "(...) als de vaste patanen niet meer werken, zich problemen voordoen, zet men de automatische piloot af." Een reiziger die vastloopt, kan alleen verder komen door praktische oplossingen te zoeken. ${ }^{2}$ Zo beschouwd is reizen, ook al gebeurt dat binnen een passage, een creatieve bezigheid die doet denken aan het werk van de vluchtleiders in het Operations Control Center. In de woorgaande hoofdstukken heb ik betoogd dat dit spanningsveld tussen standaardisering en identiteit, voorspelbaarheid en contingentie, insluiting en uitsluiting kenmerkend is voor de veranderingen en vernieuwingen van het reizen in de technologische cultuur.

Is thet met behulp van het begrip "passage" zoals dat in de voorgaande hoofdstukken is ontwikkeld, mogelijk anders te debatteren over mobiliteitsproblemen en een nieuwe taal te vinden om over vernieuwing van het reizen te spreken? Die centrale vraag wil ik in dit laatste hoofdstuk om te beginnen beantwoorden door het conceptuele werk in de voorgaande hoofdstukken samen te vatten in een theorie van passages. ${ }^{3}$ Vervolgens zal ik nagaan hoe deze theorie van passages het mogelijk maket het mobiliteitsdebat in andere termen te voeren en het spreken over innovatie van mobiliteit zelf te vernieuwen. Ten slotte geef ik aan 
hoe een theorie wan passages een aanzet kan vormen tot reflectie op het reizen in de technologische cultuur.

\section{Haar een theorie van passages}

Om snel te kunnen reizen moet werk worden verzet. Dat werk blijf in beschouwingen over moderne mobiliteit meestal buiten beeld. Zoals Gontsjarov keek naar de stoomboot die schijnbaar moeiteloos door de golven kliefde, zo wordt de versnelling van het verkeer en vervoer doorgaans opgevat als verklaring voor tal van maatschappelijke veranderingen, bijvoorbeeld in de economie en de ruimtelijke orde. Vanuit het 'terugkijkende' perspectief van Gontsjarov (en met hem moderniseringstheoretici als Giddens en Harvey) kunnen de stoomboot en de stoomtrein gelden als verklaring voor die veranderingen. $\mathrm{Zij}$ zien her resultaat van zorgvuldig afgestemde temporele ordes en noemen dat resultaat snelheid, een gedecontextualiseerde verhouding tussen rumte en tijd. Door "met de tijd mee te kijken" wordt zichtbaar hoe die temporele orde tot stand wordt gebracht. Om zijn klanten snel te kunnen laten reizen moest Thomas Cook eerst de problemen oplossen die zij onderweg tegen konden komen. Toen Cook een reis rond de wereld wilde verkopen, maakte hij die eerst zelf. Aan het einde van die reis kon hij vaststellen dat hij de "moeilijkheden van de route" had opgelost en dat hij nu de adviezen kon geven die wereldreizigers nodig hadden. $\mathrm{Zij}$ hoefden zelf niet langer de problemen op te lossen die bijvoorbeeld Phileas Fogg in zijn reis rond de wereld tegenkwam. De frictie van het onverwachte was geminimaliseerd en precies dát is wat snelheid mogelijk maakte.

Door de vraag te stellen hoe de spatio-temporele orde van een reis tot stand komt, ontstaat een actorperspectief dat het mogelijk maakt te onderzoeken welk werk verzet moet worden om passages te creëren, tê repareren en te legitimeren. Dit actorperspectief kan wisselen, maar wat Thomas Cook, de ambtenaren van de National Park Service, de KLMmedewerkers in de vertrekhal en het controlecentrum, en de ontwerpers van fietsvriendelijke infrastructuur gemeen hebben, is dat zij zich ge- 
plaatst zien voor problemen die opgelost kunnen worden door ze als ontwerpopgaven te zien. De conclusie van hoofdstuk 3 luidt dat een theorie van passages zich kenmerkt door een methodologisch uitgangspunt: om snel en wrijvingsloos te kunnen reizen moet een spatiotemporele orde gecreëerd worden en dit gebeurt weer door de problemen die de reiziger onderweg tegenkomt zoveel mogelijk op te lossen. Zijn deze problemen (goeddeels) opgelost, dan is een passage ontstaan. De passage kan worden onderzocht door een actorperspectief te (re)construeren.

\section{Het creèren van een beterogene orde}

Wat is een passage? Cook maakte passages door heterogene elementen op elkaar af te stemmen; materiële zoals spoorwegen, stoomboten, hotelcoupons en reisgidsen, maar ook immateriele zoals plaatsmythen. Kenmerkend voor een passage is dat niet alleen artefacten, ideeën en symbolen op elkaar afgestemd moeten worden, maar ook ruimte en tijd. Dat werd in hoofdstuk 4 onderbouwd door de vraag te stellen hoe de tijd-ruimtelijke flexibiliteit van de auto - het feit dat zo goed als elke plaats op elk gewenst moment bereikbaar is - in de Verenigde Staten mogelijk werd gemaakt. Om met de auto snel grote afstanden te kunnen overbruggen waren tal van innowaties nodig die allemaal op elkaar aan moesten sluiten. Dankzij de lopende band van Ford konden steeds meer Amerikanen over een eigen auto beschikken, maar om daarin te kunnen rijden waren wegen, wegenkaarten, een uitgebreid netwerk van benzinestations, motels en drive-in restaurants nodig. Waar deze ellementen meer en meer op elkaar waren afgestemd, werd de reis voorspelbaarder. Anders dan aan het begin van de twintigste eeuw, leverde het reizen per auto geen verhalen meer op, maar de mythes rond het autoreizen bleven: autoreizigers moesten leren wat autoreizen was en dat gebeurde door aan te sluiten bij Amerikaanse culturele oerbeelden als vrijheid, individualiteit en transcendentalistische 'selfreliance" (Emerson).

Aan de ene kant geldt dat hoe meer een passage is gestandaardiseerd en hoe meer de onderdelen ervan op elkaar aansluiten, hoe lastiger het is om die passage te veranderen. Aan de andere kant is geen enkele passage immanent stabiel; er ontstaan telkens nieuwe problemen door de 
effecten die passages hebben. De orde moet telkens worden aangepast en heeft daardoor een dynamisch karakter. In het voorbeeld vande archetypische bestemming in de Verenigde Staten, de Nationale Parken: de parken moesten als bestemming aanslwiten op de (gestandaardiseerde) passages die ze bereikbaar maakten, mar zonder hun unieke karakter als plaats te yerliezen. De 'flow' van de Amerikaanse passage maakte het voor steeds meer mensen mogelijk de parken bezoeken, wat leidde tot spanningen tussen 'use' en 'preservation". Beide principes wormden vanaf de jaren dertig, maar zeker in de jaren vijftig, een ontwerpdilemma woor parkbeheerders. Het Mission 66-programma trachtte dit dilemma op te lossen door de parken zo te ontwerpen dat de automobilist ze niet bezoekt maar passeert. Daarbij maakten de parkontwerpers niet alleen gebruik van materiële ontwerpelementen als parkwegen en uitkijkpunten, zij deelden ook de natuur in overzichtelifke categorieèn in. Snelle herkenning van bezienswaardige plaatsen zorgde dat parkbezoekers weinig tijd door hoefden te brengen in de parken. De gemakkelijke bereikbaarheid van de parken kon alleen gerealiseerd worden door de verblijfsduur van de bezoekers te bekorten. Omdat parken als bestemming moesten aansluiten op de passages die ze bereikbaar maakt, zijn ze niet alleen als plaats te begrijpen, maar ook als tijdspanne. Noch onderweg noch op de bestemming zijn tijd en ruimte te scheiden. Wie met de auto naar het park gaat, bereikt een andere bestemming dan wie dat lopend, per koets of per trein doet. Wie het reizen innoveert en de tijd-ruimte orde van de verplaatsing verandert, ontkomt er niet aan ook de tijd-ruimte orde van de bestemming te veranderen.

Het voorbeeld van de nationale parken toonde dat de ontwerpopgave waarvorr de National Park Service zich gesteld zag een dilemmakarakter heeft. De spanning russen standaardisering en identiteit kreeg in de parken de vorm van de keuze tussen "use" and "preservation". Voor het oplossen van dit dillemma was er niet én optimale oplossing. Eerder toont de historie van het parkontwerp dat dit ontwerpdilemma in verschillende periodes verschillend werd benaderd. Het rustieke ontwerp van de jaren dertig, warin natuur en cultuur zoveel mogelijk werden gemengd, bijvoorbeeld door gebouwen en andere infrastructuur op 
te laten gaan in het omringende landschap, maakte tijdens Mission 66 plaats voor een moderne aanpak waarin juist het onderscheid tussen natuur en cultuur werd benadrukt. Samengevat heeft een theorie van passages, naast het methodologische uitgangspunt van her actorperspectief een ontologisch uitgangspunt. Het object van onderzoek is de orde die in de passage wordt gecreèerd. Deze orde is heterogeen in die zin dat altijd sprake is van afstemming van materiële en immateriële elementen (artefacten en ideeèn), maar ook in de zin dat ruimte en tijd op elkaar worden afgestemd. Doordat een passage effecten heeft, is de orde nooit ummanent stabiel, maar heeft zij een dynamisch karakter.

\section{Het repareren van een temporele orde}

Elke reis heeft een tijdsverloop dat zo nodig aangepast kan worden. Het beschrijven van de ontwerpproblemen die hiermee samenhangen vraagt om een uitbreiding van het conceptueel instrumentarium. Elke vlucht van de KLM is te beschrijven als een orde van gebeurtenissen die grotendeels voorzien en gepland is - aan het moment van vertrek gaat een complexe reeks handelingen vooraf die in de tijd en de ruimte op elkaar moeten aansluiten -, maar die soms ook contingent en onvoorzien is. In de vertrekhal op Schiphol en in het controlecentrum van de KLM worden verstoringen in de dienstregeling gerepareerd.

Om de KLM-dienstregeling te kunnen uitwoeren is het nodig passages in twee snellheden te maken; door de inzet van informatie- en communicatietechnologie reist de informatie over een vliegtuig (bijvoorbeeld wanneer het zich waar bevindt) sneller dan het vliegtuig zell. Bijsturen van passages in real time gebeurt door het verschil tussen de geplande orde en de gerealiseerde orde te verkleinen. Om dit te kunnen doen hebben de werknemers van KLM, zoals zij het zelf noemen, de beschikking over 'wisselgeld' (geld, capaciteit, (woor)kennis en ervaring). Het veldonderzoek in hoofdstuk 5 bracht aan het licht waar dat wisselgeld in de dagelijkse prakti $k$ wordt ingezet. Hoe dichter een potentiële passage het moment van actualisering nadert, hoe minder de KLMmedewerkers terug kunnen vallen op de vooraf geplande orde. Anders gezegd, hoe minder tijd zij hebben om verstoringen op te lossen, hoe groter het belang van wisselgeld om alsnog te zorgen dat uiteenlopen- 
de processen en gebeurtenissen op elkaar aansluiten in de tijd. Als de geplande en de gerealiseerde orde niet samenvallen, is het belangripk het overzicht in de actuele situatie te vergroten. Dit overzicht is om twee redenen belangrijk. In de eerste platats geldt dat hoe beter een situatie is voorzien, hoe meer wisselgeld men in voorraad kan hebben om eventuelle verstoringen te repareren. Maar door het overzicht in een situatie te vergroten, komt ook meer wisselgeld beschikbaar doordat men bijvoorbeeld weet waar zich een reserveonderdeel bevindt dat nodig is om een gestrand vliegtuig te repareren. De vrijheid om wisselgeld in te zetten is niet gelijk verdeeld; niet alle KLM-medewerkers hebben dezelfcle bevoegdheden. Dit punt vloeit voort uit het vorige: het vergroten wan het overzicht van de situatie gaat samen met het verkleinen van het aantal actoren dat in die situatie kan handelen. Uiteindelijk heeft alleen de vluchtleider de discretionaire ruimte om te beslissen over het inzetten van wisselgeld, bijwoorbeeld door een vlucht te schrappen of een reservevliegtuig in te zetten.

Het veldonderzoek bij KLM identificeerde een nieuwe ontwerpopgave, namelijk het laten aansluiten in de tijd (op het geplande tijdstip van vertrek) van gebeurtenissen die plaatsvinden op heel verschillende locaties. In het oplossen van deze ontwerpopgave is een spanning zichtbaar tussen planning en improvisatie. Geen van beide biedt op zichzelf de mogelijkheid om het KLM-netwerk te laten functioneren. In de praktijk is er daarom altijd sprake van een zekere speling of tolerantie, matar hoe die vorm krijgt, bijvoorbeeld in de machtsverdeling tussen de verschillende bedrijfsonderdelen, ligt niet vast. Samengevat benadrukt een theorie van passages, naast het genoemde methodologische en ontologische uitgangspunt, het belang van een temporeel perspectief dat zichtbaar makt hoe de onderdelen van een passage niet alleen vooraf; maar ook in het moment op elkaar worden afgestemd.

\section{Het legitimeren van een politiek-normatieve orde}

De passages van fietsen en auto's zijn relationeel; ze maken deel uit van elkaar. Waar de fiets moet afremmen, kan de auto doorrijden of andersom. Bij het ontwerp van kruispunten en wegvakken heeft dat consequenties, bleek in hoofdstuk 6. Kruispunten of wegvakken, stoplich- 
tem en rotondes zijn geen neutrale elementen in het ontwerp van passages, naar ensembles van passages. Deze ensembles doen meer dan het genereren van verdelingen van tijd, ruimte en risico of het uitvoeren van politieke besluiten. Het zijn manieren om de werelden die het effect zijn van passages te laten samenleven. Dit leidt tot een dubbele conclusie: wie passages ontwerpt, bedrijft politiek en om de politiek van passages tot onderwerp te kunnen maken van het gangbare politieke debat is het nodig meerdere ensembles van passages te ontwerpen zodat burgers kunnen kiezen. Niet de keuzes van de verkeerskundigen, strevend naar een op papier althans optimale oplossing waarbij in de praktijk het recht van de snelste tot uitgangspunt wordt verheven, zouden de vormgeving van het verkeerslandschap moeten bepalen, maar de keuze van betrokken burgers. Alleen op die manier kan het probleem van de legitimatie van macht (die hier de vorm krijgt van het recht van de snelste) worden opgelost.

Passages komen nooit alleen, maar kruisen elkaar en de verstoringen die dit oplevert kunnen niet vanuit het centrale perspectief wan een controlecentrum worden opgelost. Er is niet een beste manier om de problemen die op kruisingen ontstaan, zoals verkeersveiligheid en schaarste, op te lossen. Historisch zijn meerdere stijlen te onderscheiden in de vormgeving van het verkeerslandschap (modem dan wel organisch) of op het terrein van de regelgeving van het handelen in dat verkeerslandschap (regulerend dan wel deliberatief). Uit het feit dat meerdere oplossingsstijlen mogelijk zijn, volgt het laatste uitgangspunt van de theorie van passages namelijk dat het bouwen van passages altijd aanleiding geeft tot politiek-nomatieve reflectie.

\section{Koppelingsstrategieën}

In de voorgaande hoofdstukken heb ik in een theorie van passages een aantal begrippen ontwikkeld om over vernieuwing van het reizen te spreken, namelijk als het maken, repareren en legitimeren van passages. De gevalsstudies suggereren dat de ontwerpopgaves die aanleiding geven tot innovatie zich altijd daar bevinden waar koppelingen tot stand gebracht moeten worden en ze benoemen bovendien uiteenlopende koppelingsstrategieèn. Veel innovaties van Cook zijn daarwan voor- 
beelden, denk aan de treinkaartjes van verschillende spoorwegmaatschappijen in Europa die een reiziger nodig had om een bestemming te bereiken en die door Cook - letterlijk - aan elkaar vastgemaakt werden om als coupon verkocht te kunnen worden. In de Amerikaanse $\mathbb{N a t i o -}$ nale Parken moest een koppeling gemaakt worden tussen de passage van de auto en de natuur van de parken. Dat gebeurde door de aanleg van parkwegen, wandelpaden, uitkijkpunten, parkeerplaatsen en bezoekerscentra. Deze 'intermediary landscapes' werden vormgegeven volgens bepaalde stijlen (bijvoorbeeld rustiek en modern). In de jaren vijftig, tijdens de Mission 66-periode werden ze zo ingericht dat de bezoekers niet lang in de parken hoefden te verblijven om toch de indruk te hebben gehad de natuur in de parken te hebben bezocht. De KLM staat dagelijks voor de opgave koppelingen in de tijd tot stand te brengen tussen uiteenlopende processen en gebeurtenissen die nodig zijn voor de uitvoering van de dienstregeling. Koppeling krijgt hier de vorm van synchroniteit. Planning is een manier om vertragingen te voorkomen doordat wooraf afstemming tussen processen en gebeurtenissen plaatsvindr, maar doordat op de dag van uitvoering altijd verstoringen optreden moet de planning ook in het moment aangepast kunnen worden. Innovatie is aan de orde waar men onder tijdsdruk gebeurtenissen en processen opnieuw moet koppelen in real time door de inzet van "wisselgeld'. De ontwerpers van fietsvriendelijke infrastructuur ten slotte, moeten kruisende passages in verschillende snelheden koppelen, bijvoorbeeld door te mengen en te scheiden. Het politiek-normatieve karakter van deze innowaties komt tot uitdrukking in 'ensembles'.

De kernbegrippen van de theorie van passages zijn als volgt samen te vatten (figuur $7 . \mathrm{I}$ ):

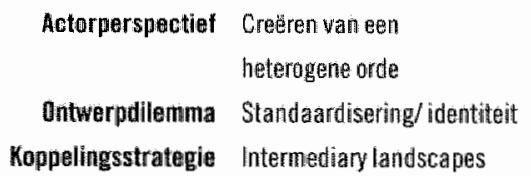

Figuur 7. 1: Kembegrippen in de theorie van passages
Repareren van een

temporelle orde

Planning/mprovisatie

Wisselgelld
Legitimeren van een politiek-normatieve onde Scheiden/mengen

Enisembies 


\section{Een wiljkende horizon}

Dat de mobiliteit van mensen toeneemt en zal blijven toenemen vormt tegenwoordig nauwelijks nog onderwerp van publiek debat. Dat debat betreft eerder oplossingen woor de problemen die het gevolg zijn wan de groei van het aantal afgelegde kilometers. Dat in dit probleemcomplex tijd centraal staat, blijkt uit de ongewilde traagheid van de file. Wie de vraag stelt waarom we de fille eigenlijk als een probleem zouden moeten zien, ontmoet in de regel onbegrip. De file is een anathema omdat mensen de auto zien als een machine die hen juist tijd moet besparen. Maar wie tracht 'tijd te sparen' door sneller te reizen ziet zich geplaatst voor een paradox die we in hoofdstuk $x$ hebben leren kennen als de haast van Albertine. Weliswaar kan zij dankzij de auto sneller reizen, maar ze is niet eerder thuis en bezoekt vrienden in twee dorpen in plaats van een.

Verkeerskundigen als Hupkes lossen de paradox van de haast van Albertine op door uit te gaan van de hypothese van de constante reistijd." Hoe het gestileerde feit van deze constante kan worden verklaard blijft vooralsnog onduidelijk; Hupkes spreekt van 'biopsychische wariabelen', maar de zwarte doos blijft ongeopend. De ironie van Hupkes" werk is dat zijn BREVER-wet het debat over de problemen die groeiende mobiliteit veroorzaakt niet verder helpt, maar juist beëindigt. Anders gezegd, als we het debat over mobiliteit voeren in termen van snelheid, dan is het afgelopen voor het goed en wel begonnen is. ${ }^{5}$ Sneller reizen zal leiden tot de vraag naar meer snelheid en de enige uitweg die dan rest is traagheid, maar zoals de irritatie over de file duidelijk maakt is traagheid taboe.

De theorie van passages reikt andere termen aan om het debat over mobiliteitsproblemen te kunnen voeren. Door niet slechts uit te gaan van een tijdsbegrip dat het mogelijk maakt tijd 'constant te houden' (kloktijd), maar tijd ook te beschouwen als temporele orde die het produkt is van 'passages' wordt het mogelijk andere vragen stellen. Albertine stapt van de koets in de auto en op grond van het onderzoek in voorgaande hoofdstukken is aannemelijk geworden dat zij daarmee niet alleen sneller reist, maar ook anders. Haar horizon wijkt - door in de auto te reizen in plaats van de koets is de ruimte-tijdorde wan haar pas- 
sage een andere geworden. Juist omdat tijd, anders dan bij Hupkes, niet constant gehouden kan worden, lost de paradox op: wie sneller reist bespaart geen tijd, maar maakt andere tijd. Drie voorbeelden uit de hoofdstukken 4,5 en 6 maken dit duidelijk.

In de Amerikaanse Nationale Parken stond de NPS voor de opgave om het groeiende autoverkeer door de parken te leiden zonder de naruur in de parken te beschadigen. Aanpassingen in de ruimtelijke orde zoals verbreding van de parkwegen, aanpassing van uitkijkpunten en de bouw van bezoekerscentra waren ook altijd aanpassingen wan de temporele orde. Het effect van die nieuwe spatio-temporele orde was dat bezoekers steeds korter in de parken hoefden te verblijven en toch het idee konden hebben dat ze in de wildernis waren geweest. Door nieuwe vormen van circulatie en representatie werden de parken beter bereikbaar en kwamen er meer mensen, maar ze veranderden er ook door. Iemand die rond 1960 naar Zion National Park kwam, bezocht een ander park dan een automobilist in 1930 . Door de spatio-temporele orde van de parken aan te laten sluiten bij de Amerikaanse passage en voortdurend aan te passen, raken de parken nooit 'vol'.

Om het werk van KLM-medewerkers op Schiphol te kunnen beschrijven hebben we niet genoeg aan de $\mathrm{UTC}_{3}$ de rode tijdlijn op het scherm van de Operations Controller. Kloktijd is niet slechts de onverbiddelijke metronoom die het tempo van tallozen dicteert. Voortdurend wordt in meer of mindere mate afgeweken van de vooraf opgestelde tijdsplanning en worden geld, risico, capaciteit, technologie, kennis en ervaring en autoriteit tegen elkaar uitgewisseld om de temporele orde te repareren, anders gezegd, om tijd te maken. De toenemende complexiteit van de passages die nodig zijn om een groeiend aantal luchtreizigers te kunnen bedienen, leidt tot nieuwe contingenties en daarmee tot de behoefte aan nieuwe vormen van wisselgeld om de orde te kunnen repareren. In passages is tijd nooit een absoluut gegeven; een complexere passage betekent dat zich nieuwe contingenties zullen voordoen. Elke passage, hoe rationeel die ook wordt bestuurd, blijkt onvolmaakt.

De groei van het autoverkeer in steden en dorpen is alleen mogelijk gebleken doordat bij het ontwerp van het verkeerslandschap uitgegaan wordt van de wenselijkheid van hoge snelheden voor een bepaalde groep 
reizigers. Omdat passages relationeel zijn, gaat deze snelheid ten koste van andere verkeersdeelnemers. Snelheid en groei leiden tot nieuwe verdelingsproblemen die niet éen optimale oplossing kentien. Eerder is voortdurend de kwestie van de 'distributie van de politiek' aan de orde. Wie moet wellke problemen voor welke reizigers oplossen en hoe worden deze oplossingen gellegitimeerd? De vraag is bijvoorbeeld niet boe de overheid de file moet oplossen, mar op welke manier concrete ontwerpoplossingen die daartoe worden ontwikkeld de verdeling van tijd, ruimte en risico veranderen en hoe deze verandering gelegitimeerd wordt.

De paradox van de haast van Albertine kan op nog andere manieren opgellost worden dan door een beroep te doen op de 'zwarte doos' van biopsychische variabelen. Meer mensen sneller laten reizen kan alleen door ontwerpproblemen op te lossen, maar zodra die problemen opgelost zijn is ook de spatio-temporele orde van de passage veranderd en zijn nieuwe verwachtingen gewekt. Een theorie van passages maakt het mogelijk mobiliteitsproblemen te herformuleren en daarmee werschuiven kwesties op de agenda van het publieke debat. Eenmaal los van het idee van "absolute reistijd" dat, zoals politici én kiezers graag zien, in meetbare toekomstbeelden wordt vastgelegd, kan het debat zich richten op de voor- en nadelen van de passages die sneller reizen mogelijk moeten maken. Het accent komt daarmee te liggen op ontwerpproblemen én op de verschillende manieren waarop deze opgelost kunnen worden. Rigide opvattingen van kloktijd als het onveranderlijk baken waarop we kunnen sturen maken plaats voor het uitwisselen van uiteenlopende soorten "wisselgeld" om temporele ordes te repareren. Verdelingen van snelheden tussen verkeersdeelnemers zijn eerder inzet van een debat over de verdeling van de schaarste dan uitgangspunt voor de aanleg van nieuwe infrastructuur.

In een theorie van passages verschijnen mobiliteitsproblemen als ontwerpproblemen. Daarmee wordt niet het bellang ontkend van andere benaderingen van deze problematiek, waarbij bijvoorbeeld de macht en invloed van actoren als de ANWB of de auto-industrie worden geanalyseerd. De keuze voor deze vorm van probleemdefinitie wloeit voort uit het oogmerk van dit boek: het politieke debat over mobiliteit en de vormgeving van ruimte en tijd die daarmee samenhangt te voorzien van 
een nieuw perspectief dat zich ontrukt aan het determinisme dat in de haast van Albertine besloten ligt. Het is niet gezegd dat we dan ook betere antwoorden krijgen op de vragen die in het debat aan de orde zijn. Ook hier wijkt de horizon. Het inwisselen van het ene voor het andere begrip betekent niet op voorhand dat we daarmee dichter bij een oplossing zijn. Debatteren in termen wan passages leidt niet automatisch tot betere inzichten, maar wel tot een betere agenda. Niet langer kan het debat slechts gaan over de vraag hoe we sneller kunnen reizen én hoe we de negatieve gevolgen van die snelheid kunnen oplossen. Centraal in de discussie staan nu de passages die bepaalde tijdsordes mogelijk moeten maken en daarmee de immovaties die nodig zijn om concrete ontwerpproblemen op te lossen.

\section{Passages en innovatie}

Hoe kan de theorie van passages opgevat worden als innovatietheorie? Daartoe moet aan drie criteria zijn voldaan. In de eerste plaats moet zij een nieuw wocabulaire bieden waarin over innovatie gesproken kan worden. In de tweede plaats moet zo'n innovatietheorie in staat zijn nieuwe verklaringen te bieden voor het succes en falen van innovaties. Ten slotte moet een innovatietheorie waarin passages centraal staan nieuwe inzichten verschaffen in de praktijk van het innoveren. In deze paragraaf komen deze drie eisen aan bod, waarbij zal blijken dat het gehanteerde tijdsbegrip het beslissende verschil vormt met concurrerende benaderingen.

\section{Twee vocabulaires}

In hoofdstuk 2 is een decontextualiserend vocabulaire beschreven waarin vergelijkingen worden gemaakt door tijd, ruimte, geld en "comfort" in onderlinge verhoudingen te beschouwen als variabelen en constanten. Ik noem dit voor de helderheid van het argument vocabulaire $x$. Het begrippenkader dat ontleend kan worden an de theorie van passages noem ik vocabulaire 2 . Wat zijn de belangrijkste verschillen tussen beide vocabulaires? 
In vocabulaire x staat B-tijd centraal (zie figuur 7.2 ). Tijd wordt beschouwd als een denkbeeldige lijn; gebeurtenissen winden eerder of later plaats. Met behulp van de klok wordt tijd verdeeld in gelijke eenheden die als matstaf kunnen dienen voor de duur van gebeurtenissen. Op deze manier kan tijd worden gekwantificeerd. Een gevolg van deze kwantificering van tijd in kloktijd is dat het mogelijk wordt tijd te decontextualiseren. In het geval van reizen houdt dit in dat geabstraheerd kan worden van concrete manieren van reizen. Cruciaal voor het denken over innovatie is dat nu een vergelijkend perspectief mogelijk wordt waarbij manieren van reizen vergeleken kunnen worden op een neutrale noemer, namelijk kloktijd. Dit vergelijkend perspectief keert terug in maatschappelijk dominante vertogen over stimulering van de economie, rechniekontwikkeling en moderne cultuur. Vergelijken is een manier om kennis te verkrijgen, bijvoorbeeld over de keuzes die mensen maken tussen verschillende manieren van reizen. In de economische wetenschap wordt het keuzegedrag van mensen onderzocht door modellen op te stellen. In modellen die gebruikt worden om het verplaatsingsgedrag van mensen te verklaren en te voorspellen wordt een gekwantificeerde tijd gecombineerd met hypothesen over het handelen van mensen, bijvoorbeeld de aanname dat mensen doorgaans maximalisering nastreven van het nut dat zij ontlenen aan activiteiten. Met deze modellen kunnen economen verklaren waarom mensen bijna aitijd snellere reismiddelen zullen prefereren boven langzamere. Voor het spreken over innovatie betekent dit dat vernieuwing gelijkgesteld wordt aan versnelling of dat het ontbreken van versnelling (of zelfs vertraging) als voomaamste hinderpaal wordt beschouwd. In beide gevallen vormt meetbare kloktijd het bepalende kader om succes en falen van innovaties te kunnen verklaren. Als versnelling negatieve maatschappelijke effecten oplevert, is het zaak deze tegen te gaan door ze als kosten te beschouwen en te internaliseren, dat wil zeggen proberen te woorkomen dat ze worden afgewenteld op de gemeenschap. In het beleid, zo bleek in hoofdstuk 2 , keert deze redenering terug in het streven naar zogenaamde "shifts", verschuivingen in het reisgedrag van mensen, het vestigingsgedrag van bedrijven, van tijdstippen in het woon-werkverkeer en dergelijke. Resultaten van het beleid zijn doorgaans geformuleerd als (gekwantificeerde) gewenste eind- 
toestand, bijvoorbeeld een verlaging van de groei van de (auto) mobiliteit, een bepaald percentage bedrijven dat bij openbaar vervoerlocatie is gevestigd of een daling van het aantal verkeersslachtoffers.

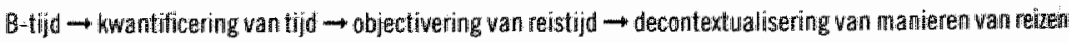
$\rightarrow$ vergellikhend perspectief door tijd (af ruimte) constant te houden $\rightarrow$ innoverem $=$ versneiling + dowreh nen van exteme kosten $\rightarrow$ resultaat $=$ 'shifts' en hwantitatieve streefbeelden

Figuur 7.2: Intowatie in vacabullaire :

In vocabulaire 2 staat $C$-tijd centraal (zie figuur 7.3 ). In de traditie van sociologische theorieen als die van Elias wordt tijd beschouwd als het produkt van een sociale orde of praktijk. Begrippen als haast en verwachting, snelheid en traagheid zijn contextgebonden. In tegenstelling tot de objectiverende, decontextualiserende stijl van redeneren in vocabulaire $\mathrm{I}$ is het hier dus juist noodzakelijk om te contextualiseren om iets over reistijd te kunnen zeggen. De vraag dient beantwoord te worden boe de temporele orde van de reis wordt gemaakt. Snelheid is in dit vocabulaire niet een gedecontextualiseerde verhouding tussen rumte en tijd, maar ontstaat door in passages problemen op te lossen die reizigers onderweg tegenkomen. Deze passages moeten voortdurend gecreëerd, gerepareerd en gelegitimeerd worden. Daarbij doen zich uiteenlopende ontwerpopgaven voor. Vergelijken tussen manieren van reizen gebeurt door de vraag te stellen boe problemen worden opgelosit in passages. Zo kunnen we vergelijken tussen zeventiende-eeuwse trekschuitpassages en de vliegpassages van het eenentwintigste-eeuwse door te bestuderen welk wisselgeld in beide netwerken beschikbaar was om afwijkingen van de geplande orde - de dienstregeling - repareren. Deze vergelijking levert een ander soort kennis op dan een vergelijking in termen van kilometers per uur. Een andere manier van vergelijken levert ook een andere manier van kiezen op. Het oplossen van problemen voor de reiziger (bijvoorbeeld door de aanleg van snelwegen) leidt tot nieuwe problemen; passages zijn immers niet immanent stabiel zoals we zagen. Voortdurend zijn dan ook ontwerpdilemma's aan de orde. Deze hebben niet éen beste oplossing en dat onderstreept het politieke ka- 
rakter van kiezen tussen passages. Innovatie van passages ten slotte, kumuen we definiëren als het ontwikkelen van koppelingsstrategieën, methoden en oplossingen voor concrete ontwerpdilemma's. Het resultaat van innovatie kunnen we niet als een eindtoestand beschrijven. Immers, nieuwe passages zullen nieuwe problemen opleveren en dus voortdurend vernieuwd moeten worden. Innovatie van passages heeft daarom het karakter van een leerproces.

C-tijd $\rightarrow$ tijd is uitkomst van socialle orde $\rightarrow$ reizen: het oplossen van problemen creéert meerdere temporele ordes $\rightarrow$ contextualisering van manieren van reizen $\rightarrow$ wergelijkend perspectief: hoeworden ontwerpopgawent opgelost in passages $\rightarrow$ innoveren $=$ ontwikkelen van koppelingsstrategieën + kiezen tussen ontwerpen $\rightarrow$ resultaat $=$ leerprocessen

Figut 7.3 : Innovatie in vocabulaire 2

Vocabulaire 2 maakt het mogelijk andere vragen te stellen en publieke problemen op een andere manier te definiëren dan vocabulaire $x$. Daardoor kunnen problemen verschuiven van positie op de agenda van het mobiliteitsdebat. Sommige komen hoger op de agenda te staan, andere zullen wellicht dalen of zelfs geheel verdwijnen. Gusfield ( $198 \mathrm{I}$ ) heeft dit een "ironisch perspectief' genoemd. Vanuit dit perspectief is dat wat doorgaans als vanzelfsprekend wordt gezien (bijvoorbeeld: een snelle auto is te verkiezen boven een langzame) niet langer onproblematisch. Naar analogie van Gusfields sociologische ironie richt vocabulaire 2 de aandacht op het 'culturele raamwerk' waarbinnen mobiliteitsproblemen als publieke problemen worden geconstrueerd. 'Zoals de kunstenaar, creëert de socioloog de mogelijkheid van alternatieve werelden. Door de institutionele en/of culturele kaders te tonen waarbinnen handelingen betekenis krijgen, stelt hij zich woor dat de dingen anders zouden kunnen zujn"?

\section{Innoveren is bet maken van een wereld}

Het tweede criterium waaraan voldaan moet zijn om een theorie van passages als innovatietheorie te kunnen zien is dat zij nieuwe verklaringen moet kunnen geven voor het succes en falen van innovaties. In 
de hoofdstukken $r$ en 2 bleek dat het succes van vernieuwingen van het reizen in vocabulaire $\mathrm{I}$ voor alles word werklaard uit de tijdwinst die ze opleveren. Dat de trein van de trekschuit heeft. 'gewonnen' kan worden begrepen uit het feit dat de treinreiziger voor minder geld eerder op zijn of haar bestemming is dan de trekschuitreiziger. Deze verklaringsstrategie decontextualiseert de feitelijke manier van reizen en vergelijkt in termen van gek wantificeerde reistijd (al dan niet in combinatie met geld en 'comfort').

Uitgaande van de theorie van passages kenmerkt een succesvolle innovatie zich doordat nieuwe passages ontstaan en daarmee andere praktijken van reizen. Deze veranderingen zijn nooit te herleiden tot één. enkele oorzaak; verklaringen in vocabulaire 2 hebben daarmee een complex karakter. Dat de auto zo succesvol is geworden in de Verenigde Staten is niet slechts te herleiden tot het feit dat automobilisten sneller en flexibeler konden reizen; om die transformatie te kunnen begrijpen is het nodig te onderzoeken hoe de heterogene elementen waaruit de Amerikaanse passage werd opgebouwd op elkaar aansloten, anders gezegd, door een context te schetsen waarin een keten van innovaties is verondersteld: niet alleen de lopende band, benzinestations, wegrestaurants en motels, maar ook nieuwe reismythen als die rond Route 66 en idealen over de bevrijdende werking van autorijden. Een ander element in de verklaring is dat het de NPS-parkontwerpers lukte om het probleem dat door de standaardisering ontstond - het verdwijnen van het avontuur van de reis zelf - op te lossen door bestemmingen te creëren die én aansloten op de passage door er onderdeel wan uit te maken én het karakter behielden van een unieke bestemming. Op een vergelijkbare manier volgt het succes van luchtvaartmaatschappijen als de KLM uit het vermogen om verstoringen var de dienstregeling te repareren door passages in twee snelheden te construeren en overzicht in de actuele situatie van het KLM-netwerk te combineren met een centralisering van de macht om in die situatie in te kunnen grijpen. En dat de aanleg van nieuwe fetsvriendelijke infrastructuur nauwelijks heeft geleid tot de beoogde 'modal shift' van auto naar fiets is te verklaren doordat de ontwerpers onvoldoende inzagen dat impliciete politieke keuzes in een ontwerp zelf gethematiseerd moeten worden. 
Een contextualiserende innovatietheorie die uitgat van passages vermijdt een reeks valkuilen die De Wilde (2000) heeft beschreven. ${ }^{8} \mathrm{LO}$ gische fouten als het pars pro toto ('de introductie van de T-Ford maakte Amerika tot een mobiele samenleving") en de impliciete implicatie ('mensen rijden auto omdat de auto sneller is dan de trein') worden zo voorkomen. Het beschrijven van een passage als wereld maakt gevoelig voor de bistoriciteit van vernieuwingen en voorkomt dat beschrijvingen een finalistisch of presentistisch karakter hebben. De effecten van vernieuwingen zijn immers nooit eenduidig maar hangen af van de relaties tot andere vernieuwingen en die zijn meer of minder toevallig. Het maken van passages veronderstelt altijd het bedrijven van politiek. Door innovaties te beschrijven als passages kunnen de nomatieve implicaties van deze vernieuwingen niet worden genegeerd. Waar de een sneller gaat, gaat een ander langzamer. Vernieuwingen betekenen niet voor ledereen en overal verbetering (of versnelling). Het passagebegrip maakt gevoelig voor de winst- en verliesrekening van innovaties. ${ }^{9}$ Een contextualistische theorie van passages omzeilt ook twee andere fouten - de culturele valkuil en de sociologische valkuil. Dat een auto sneller rijdt dan een trein is niet slechts een eigenschap van het voertuig en daarmee een vanzelfsprekend gegeven, maar is tevens het effect van een cultuur, de Amerikaanse, waarin de snelheid van de auto hoger wordt gewaardeerd dan van de trein omdat ze beter aansluit bij de waarden en oerbeelden van die cultuur.

\section{Innoveren als leerproces}

Een derde criterium betreft de mate waarin de theorie van passages consequenties heeft woor de praktijk van het innoveren van mobiliteit. De ontwerpfilosofie die besloten ligt in het passage-begrip concurreert met ontwerpopvattingen die uitgaan van vocabulaire $x$. De centrale ontwerpopdracht wordt daarin doorgaans geformuleerd als het bevorderen van de doorstroming van het verkeer en tegelijkertijd het verminderen van de schadelijke effecten die deze doorstroming heeft (bijvoorbeeld geluidsoverlast of toegenomen uitstoot van schadelijke gassen). De wenselijkheid van reissnelheid en tijdwinst vormt het vertrekpunt bij het identificeren van ontwerpopgaven. ${ }^{\text {ro }}$ 
Een ontwerpfilosofie die uitgaat van de theorie van passages kan op een andere manier aanwijzen waar innovatie van het reizen zich afspeelt. Op grond van het historisch en empirisch onderzoek in de voorgaande hoofdstukken is het mogelijk gebleken een methode te ontwikkelen om die ontwerpproblemen te benoemen, namelijk door het actorperspectief van de C-tijd in te nemen en te zien hoe de spatiotemporele orde van de passage wordt gecreëend, gerepareerd en gelegitimeerd. Innovatie is nodig daar waar de orde wordt verstoord en er problemen ontstaan. Vernieuwing is nodig walr de heterogene onderdelen in een orde aan elkaar gelijk gemaakt moeten worden maar zonder daardoor alle verschillen op te heffen, daar waar contingente gebeurtenissen in real time afgestemd moeten worden op de geplande spatio-temporele orde van de dienstregeling en daar waar verschillende passages elkaar kruisen en de verdelingen van tijd, ruimte en risico die dit oplevert gelegitimeerd moeten worden. De ontwerpopgaven die op deze punten ontstaan zijn niet eenduidig, maar hebben een dilemmakarakter. Volledige standaardisering (en maximale 'flow') binnen passages is onmogelijk te verenigen met het behoud van identiteit van bestemmingen. Exacte uitvoering van de dienstregeling van het KLMnetwerk is onmogelijk omdat altijd verstoringen optreden, het uitsluitend improviserend repareren van die verstoringen is ondoenlijk omdat het bijsturen wan een netwerk van vliegroutes centraal overzicht vraagt. Het volledig scheiden van passages ten slotte, is onmogelijk omdat er altijd kruisingen zijn, volledig mengen is onmogelijk omdat het verkeer zou vastlopen. Er zijn dus geen eenduidige oplossingen voor deze ontwerpdilemma's; eerder is sprake van verschillende ontwerpstijlen. Zo is in hoofdstuk 4 de rustieke stijl in het parkontwerp van de jaren dertig, waarin identiteit voorop stond, geconstrasteerd met de moderne stijl van de Mission-66 periode die standaardisering van ontwerpelementen in de parken nastreefde. Op grond van het onderzoek in hoofdstuk 5 is het mogelijk te onderscheiden tussen een centraliserende en een decentralliserende stijl als het gat om de inzet van wisselgeld. In hoofdstuk 6 ten slotte, heb ik in het ontwerp van wegvakken en kruispunten naast een modern/regulerende stijl een organisch/deliberatieve stijl onderscheiden. Koppelingen (zoals intermediary landscapes, wisselgeld en 
ensembles) als oplossing voor ontwerpdilemma's kunnen in verschillende stijlen worden ontworpen, anders gezegd, ontwerpdilemma's hebben meerdere oplossingen.

Beschikken we met een theorie wan passages over een receptenboek voor vernieuwing? Nee, want de relationaliteit van het passagebegrip impliceert nu juist dat innovaties altijd onvoorziene gevolgen zullen hebben. De theorie kan wel aangeven hoe met de onzekerheid die eigen is aan elk innovatietraject moet worden omgegaan. Zoals op Schiphol "wisselgeld' nodig is om de ordening van de gebeurtenissen op het moment zelf te repareren, zo moet een innovator kumnen beschikken over wisselgeld. Dit wordt gemunt in voortdurend veranderende situaties. Niet het ballistische imnovatietraject dat de uitkomst kan berekenen als de baan van een kogel vormt hier het ideale model, maar een "innovatie-passage' die zodanig is ingericht dat op het onverwachte kan worden ingespeeld doordat bekende wegen steeds opnieuw ter discussie kunnen staan: een passage die het nieuwe niet wil buitensluiten, maat juist het vermogen tot reparatic en improvisatie aanscherpt. ${ }^{\mathrm{I}}$

Op dit punt sluit ik aan bij een andere benadering van mobiliteitsinnovatie als leerproces, namelijk het 'Strategic Niche Management" (SNM) dat is uitgewerkt door Hoogma, Schot, Kemp en Truffer (2002)." Strategic Niche Management biedt een beleidsperspectief waarin middels een reeks experimenten niches worden gecreëerd voor veelbelovende nieuwe duurzame mobiliteitstechnologieèn. Hoe binnen deze niches geleerd kan worden over gebruikersvoorkeuren, maatschappelijke kosten en baten en regulering van de nieuwe technologie beschrijven de auteurs aan de hand van acht experimenten, waaronder autodelen en openbare fietsen die elektronisch gereserveerd kunnen worden. Een belangrijk verschil is, dat mijn benadering niet uitgaat van begrippen als 'mobiliteit" en "mobiliteitstechnologieën', maar reizen centraal stelt als een activiteit die zich afspeelt in passages. Als gezegd speelt vernieuwing zich daar af war de spatio-temporele orde wordt verstoord en er problemen ontstaan. Bepalend voor het succes van innovaties als autodelen of de elektrische auto is of zij deel gaan uitmaken van nieuwe of bestaande passages. Of dat lukt hangt af van het succes van de koppelingstrategieën die daartoe worden ontwikkeld. 


\section{Waarom mislukte de kilometerheffing?}

In drie opzichten blijken we de theorie van passages te kunnen beschouwen als een innovatietheorie. Maar wat houdt deze bevinding nu in toegepast op één concrete casus? Als voorbeeld kies ik de vooralsnog mislukte poging in Nederland automobiliteit te reguleren via de kilometerheffing.

Sinds het midden van de jaren tachtig hebben beprijzingsinstrumenten als rekeningrijden en vanaf 2000 de kilometerheffing op de beleidsagenda gestaan als innovaties om de maatschappelijke kosten van het autogebruik te internaliseren en de schaarste aan wegcapaciteit op te heffen door het verkeersaanbod te spreiden in tijd en plaats. Tijdens de formatiebesprekingen voor het eerste kabinet-Balkenende besloten de drie deelnemende partijen CDA, VVD en LPF om gedurende de kabinetsperiode de kilometerheffing niet in te voeren. Eerder al, was het door minister Netelenbos in het tweede Paarse kabinet ontwikkelde NVvr (zie hoofdstuk 2) als ondeugdelijk aan de kant geschoven. Beide besluiten markeren een voorlopig einde van een even veelbesproken als omstreden mobiliteitsinnovatie. Wat ging er mis bij het invoeren van de kilometerheffing?

Een eerste groep verklaringen heeft een 'extern' karakter. Zo hebben sommige commentatoren gewezen op het feit dat het minister Netelenbos op het beslissende moment, namelijk in de zomer van 1999 toen er groor maatschappelijk verzet tegen de plannen ontstond, aan politieke moed heeft ontbroken. Niet de innovatie zelf faalde (de kilometerheffing), maar externe omstandigheden stonden het succes in de weg. Dit type verklaring heeft een tautologisch karakter: de kilometerheffing mislukte vanwege het gebrek aan politieke moed - dat het Netelenbos aan politieke moed ontbrak blijkt uit het feit dat ze de kilometerheffing niet invoerde. Andere verklaringen hebben een 'intern' karakter; de oorzaak voor het falen wordt gezocht in de innovatie zelf. In de high-techvariant die Pieper op verzoek van het ministerie van Verkeer en Waterstaat in maart 2000 uitwerkte, 'past' het instrument van de beprijzing keurig in vocabulaire $\mathrm{x}$. Het probleem wordt gedefinieerd als tijdverlies als gevolg van files en trage doorstroming op de hoofdwegen. Door de kosten van het autorijden op bepaalde tijdstippen en plaatsen te verho- 
gen, zullen mensen hun manier wan reizen aampassen, hetzij door op andere momenten te reizen (shift in de tijd), hetzij door een ander vervoermiddel te kiezen zoals de trein of de bus (modal shift). Theoretisch geldt deze benadering al enige decennia als veelbelovend, hoewel er op economische gronden ook kritiek is geuit op de vooronderstellingen (Van Mierlo, 200 I). Strikt genomen is het lastig om het falen van de kilometerheffing te verklaren binnen dit vocabulaire, immers, zowel de onderliggende economische vooronderstellingen als de techniek die werd voorgesteld om deze te implementeren voorspellen succes. Dat de heffing toch faalde moet dus liggen aan de gebrekkige vertaling wan de theoretische vooronderstellingen naar de praktijk, bijvoorbeeld omdat experts er niet in slaagden politici, beleidsmakers en burgers te overtuigen van de geldigheid van hun wetenschappelijke inzichten.

Redenerend binnen wocabulaire 2 is het ook mogelijk een 'interne' verklaring te geven, maar dan een die het probleem "terugplaatst" in het bredere kader van het reizen in de technologische cultuur en uitgaat van de complexiteit van passages. Dit heeft om te beginnen consequenties voor de probleemdefinitie, namelijk niet als tijdverlies of tijdschaarste die gegeven zijn los van de manier waarop mensen reizen, maar als een verstoring van een passage, de heterogene orde die automobilisten in staat stelt zich snel te verplaatsen in hun auto. Door een drietal actorperspectneven in te nemen - creëren, repareren en legitimeren - worden ontwerpdilemma's zichtbaar die in vocabulaire $\mathrm{I}$ buiten beeld blijven.

Inzet van de kilometerheffing was het veranderen van de spatio-temporele orde van het wegverkeer in de randstad, niet door meer wegen aan te leggen en daarmee de capaciteit te vergroten, maar door het verkeersaambod te spreiden in de tijd. Vocabulaire 2 suggereert een actorperspectief op de vraag hoe zo'n nieuwe passage gecreëerd moet worden. De gewenste "flow" op de autowegen van de randstad veronderstelt een keten van innovaties die op elkaar afgestend moeten worden: materiële als de ontwikkeling van tolpoorten en later de elektronische kaart van Pieper of de electronica waarmee elke auto in Nederland uitgerust moet worden, maar ook immateriële zoals nieuwe wetgeving en bescherming tegen aantasting van de privacy van atutomobilisten. Het onvoldoende iclentificeren van de complexe ontwerpopgaven die voort- 
vloeien uit het op ellkaar aan laten sluiten wan de heterogene elementen in de nieuwe passage vormt een eerste reden voor het mislukken van de heffing.

Het systeem dat Pieper voorstelde, veronderstelde een "controlekamer" van waruit kon worden vastgesteld wat de prijs van bepaalde wegvakken op bepaalde tijdstippen moest zijn. Dit impliceerde een verschuiving van de macht om wisselgeld in te zetten, en wel van de automobilist (die voorheen zelf kon bepalen wanneer hij of zij van huis ging) naar de overheid fdie plaatsen en tijdstippen duurder kon maken en. daarmee de keuzevrijheid van de automobilist inperkt). Voor veel automobilisten, gewend om zelf te bepalen waar en wanneer ze kunnen reizen, is die machtsverschuiving onacceptabel. Automobilisten zoudem meer gaan betalen zonder zelf ander wisselgeld ter beschikking te krijgen. De tweede reden voor de mislukking van de kilometerheffing is dus dat de beleidsmaker's geen rekening hielden met gevolgen van nieuwe verdelingen van wisselgeld tussen de 'werkvloer' (de automobilist) en 'de controlekamer'(de overheid).

Het falen van de kilometerheffing heeft nog een derde reden. In de marktbenadering van de overheid worden automobilisten vooral aangesproken als mobiliteitsconsumenten; om door te kunnen rijden moest men betalen. Maar veell automobilisten, a an wie een stem werd gegeven door De Telegraaf en de ANwB, wierpen tegen dat kilometerheffing de files wellicht zou bekorten maar niet zou opheffen zodat men 'betaald in de file zou staan'. Kilometerheffing als keuzearrangement in de economische betekenis faalde ondat de overheid verzuimde ook een andere vorm van kiezen aan de orde stellen, namelijk het sociaal dilemma rond mobiliteit. Immers, kilometerheffing is behalwe een congestieinstrument ook een manier om de maatschappelijke kosten van mobiliteit te beperkem; door de schaarste anders te verdelen zijn minder nieuwe wegen nodig. In het plan van Pieper verdween deze tweede vorm van kiezen uit het zicht en, wellicht, daamee het draagvlak voor de maatregel. "De overheid slaagde er niet in de politiek-normatieve orde die in de vernieuwing van de passage was verondersteld te legitimeren.

Kilometerheffing had, althans op papier, de charme van de eenvoud. Het sociale dilemma zou worden opgelost door de inzet van 'slimme' 
technologie en meer marktwerking. Uitgaande van een theorie van passages wordt aannemelijk dat deze benadering van innovatie het zich, ondanks de vele jaren van studie en overleg tussen maatschappelijke actoren, te gemakkelijk maakte. ${ }^{14}$ Anders dan in wocabulaire $I$ is het in vocabulaire 2 mogelijk de invoering wan de kilometerheffing te analyseren als een complexe innovatie die tal van ontwerpopgaven met zich meebrengt. De theorie van passages maakt duidelijk dat deze ontwerpopgaven altijd een dilemmakarakter hebben: er is niet én beste manier om de elementen in de heterogene orde van de passage op elkaar aan te laten sluiten, om wisselgeld in te zetten of om worm te geven aan ensembles. Innovatie veronderstelt ontwerpen in een bepalde stijl en precies dit inzicht verdwijnt in vocabulaire $r$ uit het zicht. Waar het instrument juist bedoeld was om het keuzegedrag van automobilisten te beinvloeden en hen zo een snellere reis te kunnen garanderen, was het heersende gevoel dat er niets te kiezen viel.

De theorie van passages legt de nadruk op het feit dat in het debat over de publieke problemen rond mobiliteit de keuze voor of tegen de file uiteindelijk niet aan de orde is. Wie probleemloos wil kunnen reizen zal zich altijd gesteld zien voor ontwerpdilemma's en altijd nieuwe oplossingen moeten zoeken. Precies dit inzicht maakt het mogelijk innovatie niet te definiëren als de keuze tussen snel en langzaam, maar als de keuze tussen ontwerpen die getypeerd kunnen worden binnen een ontwerpstijl. Hoe moeten we ons dat kiezen voorstellen? Een gedachtenexperiment kan dit verhelderen. Bij de bouw van belangrijke nieuwe gebouwen of stadsvernieuwingen is het gebruikelijk dat architecten worden uitgenodigd om ontwerpen te maken. Deze ontwerpen zijn in de vorm van maquettes en tekeningen onderwerp van debat en uiteindelijk wordt, nadat alle betrokkenen zich hebben kunnen uitspreken, een ontwerp gekozen en gebouwd. Bij het ontwerpen of herinrichten wan het verkeerslandschap treffen we deze manier van innoveren natwelijks aan. De inzet van een theorie van passages opgevat als innovatietheorie is dat zij ons gevoelig maakt woor de vragen die eigenlik aan de onde zijn als het om zoiets ogenschijnlijk technocratisch gaat als het voornemen om de doorstroming van het autoverkeer in de Randstad te vergroten. De theorie stelt niet alleen dat we daarmee ook een (nieuwe) 
wereld scheppen, maar geeft aan op welke dimensies dat gebeurt en welke ontwerpstillen daarbij onderscheiden kunnen worden. Naar analogie van de architectuurwedstrijd zou men zich het volgende kunnen voorstellen: aan het publiek worden meerdere woorstellen voor vernieuwingen van passages voorgelegd waarvan de verschillen telkens beschreven worden met behulp van de in figuur 7. . genoemde begrippen. Met behulp van deze begrippen kunnen innovatieve ontwerpen worden onderuraagd: Hoe wordt vanuit het actorperspectief een ruimte-tijd orde geschapen? Welke ontwerpdilemma's kunnen vanuit dit perspectief onderscheiden worden en met welke koppelingsstrategieën denkt men die op te kunnen lossen? Welke 'bemiddelende landschappen' worden gemaakt, welke nieuwe vormen wan wisselgeld zijn aan de orde en hoe worden nieuwe verdelingen van ruimte, tijd en risico gelegitimeerd? Zo schept de theorie van passages politieke orde in het debat over de toekomst. ${ }^{\text {'s }} \mathrm{Na}$ een publick debat wordt het als 'beste' beoordeelde plan uitgevoerd. Ook in de evaluatie daarvan kunnen en moeten andere aspecten een rol spelen dan de vraag wie hoe her snelst thuis is. Het vergelijkend perspectief dat de theorie van passages opent, heeft hier consequenties voor de wijze waarop we oordelen: niet slechts tussen snel of langzaam, maar tussen alternatieve werelden in de betekenis die Gusfield daaraan gaf.

\section{Reizen in de technologische cultuur}

In hoofdstuk 2 werd duidelijk dat verkeerskundigen als Hupkes voor de geldigheid wan hun redeneringen een prijs betalen. Omdat het vergelijkend perspectief dat zij creëren gebaseerd is op een tijdsbegrip uit de B-serie en daarmee abstraheert van concrete praktijken van reizen, verlaten zij het politieke vertoog, of anders geformuleerd, de politieke consequenties van de keuze tussen scenario"s kunnen niet langer benoemd worden. Hun scenario's verschillen nog maar op een punt, namelijk sneller of langzamer. Spreken over reizen in termen van passages en de vernieuwing daarvan sluit daarentegen dit politieke debat juist in ondat beslissingen over mobiliteit niet langer gerechtvaardigd kunnen 
worden in de vanzelfsprekende wenselijkheid van snelheid, een wenselijkheid die zelf niet ter discussie staat. Als innovatie van passages altijd het kiezen tussen ontwerpoplossingen in een bepaalde stijl inhoudt, gaat het debat over de kwaliteiten van die stijlen. Men debatteert dan over reizen zoals men debatteert over stijlen in de kunst of in de wetenschap. Ontwerpstijlen veronderstellen dat het mogelijk is meerdere antwoorden te geven op de wragg: hoe te reizen? ${ }^{16}$ Dit boek wil daarom ook gelezen worden als een pleidooi voor een andere reflectie op de transformatie van het reizen in de technologische cultuur.

Wie op die veranderingen will reflecteren, stuit al snel op een cultuurhistorisch vertoog dat wordt gekenmerkt doot een dualisme. Aan de ene kant vinden we het ware reizen dat zijn betekenis ontleent aan de subjectieve ervaring, het reizen dat zich vastzet in de herinnering. De vraag 'hoe te reizen' wordt beantwoord in de these dat de reis zelf belangriiker is dan het bereiken van de bestemming. Reizen geldt als een "rite de passage", een actieve gebeurtenis waarbij de reiziger zich niet alleen verplaatst, maar ook verandert. ${ }^{.7}$ In de moderne culturr heeft de reis meer en meer plaatsgemaakt voor de serplaatsing, de wrijvingsloze reis, die bij een aantal auteurs zijn voltooiing vindt in het virtuele reizen, het "reizen" achter het computerscherm, waarbij de reiziger in een slechts een paar klikken over de aardbol zwermt. Hier neemt het antwoord op de vraag 'hoe te reizen' de vorm aan van het steeds verder bekorten van de tijdspanne die de reis beslaat. Wat telt is niet de reis, maar het bereiken van de bestemming. ${ }^{x}$

De dualiteit tussen reizen en verplaatsen blijkt zich telkens te vernieuwen in beschouwingen over de transformatie van het reizen. Er was ooit een tijd dat mensen nog echt konden reizen, maar met de komst van snellere vervoermiddelen verdween die "kunst van het reizen", de ars apodemica die tussen 1500 en 1800 terug te vinden was in talloze reisbeschrijvingen. ${ }^{19}$ Een voorbeeld. In zijn boek The Image. A Guide to Psendo-Events in America, dat oorspronkelijk in 1962 verscheen, beschrijft Daniel Boorstin het moderne reizen als 'een verdwenen kunst'. Hiil dateert het begin van het verval halverwege de negentiende eeuw, toen het karakter van het reizen, onder meer door de groeiende populariteit van Thomas Cook \& Son begon te veranderen. 'Deze verande- 
ring heeft zijn hoogtepunt bereikt in onze tijd. Vroeger noopte reizen tot langdurige planning, grote uitgaven en flinke investeringen in tijd. Men liep risico's voor zin gezondheid of zelfs zijn leven. De reiziger was actief. Nu is hij passief geworden. In plaats van een atletische oefening is reizen een toeschouwerssport geworden. ${ }^{\text {"2o }}$ Reizen is tegenwoordig geen kunst meer, en dat kan zelfs een reden zijn het maar helemaal achterwege te laten. Bij Reịnders (200x) lezen we over het virtuele reizen, het 'reizen in het hoofd' als alternatief voor het verspillende fysieke reizen: 'Daarmee maakt de geschiedenis een opmerkelijke draai. Vroege reizigers in het hoofd, zoals Homerus en Mandeville, deden dat omdat reizen te moeilijk was, in onze dagen komt men er veeleer toe omdat echt reizen te gemakkelijk is."

De theorie van passages maakt het mogelijk te ontstijgen aan dit dualisme. We kunnen preciezer onderzoeken boe en waar het reizen is veranderd. Dat betekent dat we ook in historisch en cultureel opzicht kunnen vergelijken zonder terug te hoeven vallen in dualismen als sneller of langzamer, reizen of verplaatsen. Elke reis brengt onzekerheden mee en veronderstelt manieren om die onzekerheid tegen te gaan. Dat gold voor de vaart met Nederlandse trekschuiten in de zestiende en de zeventiende eeuw evengoed als voor de vliegreizen die de KLM verkoopt. Wat veranderd is zijn de middelen om die onregelmatigheid te verkleinen, om nieuwe passages te bouwen en over grotere afstanden op elkaar af te stemmen, om nieuwe passages in politiek-normatieve zin te legitimeren en in stand te houden. Begrippen als actorperspectief, ontwerpdillemma's en koppelingsstrategieën verschaffen een kader waarmee we kunnen vergelijken boe mensen reizen, hoe zij problemen oplossen.

Door reizen weer te beschouwen als een kunst ontstaat nieuwe conceptuele ruimte voor reflectie. Praktijken van reizen veranderen niet alleen door innovaties; vernieuwingen zijn evenzeer het effect van beschouwingen over hoe anders te reizen. Die zijn in de huidige debatten over mobiliteit, waarin de utopie van het 'steeds sneller' vergezeld gaat van het dystopische 'einde van de reis', ver te zoeken. Anders dan de retoriek van Boorstin en zoveel anderen suggereert, is er sinds de dagen van de ars apodemica minder veranderd dan we denken: door te reizen scheppen we een wereld. Het mobiliteitsprobleem mag dan opgelost zijn 
op de tekentafel, of de auto die we daarop geschetst zien het predikaat snel of langzaam krijgt, hangt niet alleen af van wat we op de tekentafell kunnen zien. Niet toevallig gaat het Engellse woord 'travel' terug op het woord 'travail' dat werken betekent. Dat werk, dat al te wak buiten beeld blijft in veelbelovende schetsen van nieuwe wegen naar de toekomst, will een theorie van passages weer zichtbaar maken. 


\section{Noten}

\section{Steeds sneller}

I Als mensen zouden accepteren dat een anto langzamer rijdt dan tegenwoordig - 60 kilometer per uur in plaats wan r $20-k u n$ je een heel ander voertuig construeren. Een ander rype mom nor, zonnecellen op het dak - daar kun jegigantische slagen mee maken. Mar je betaalt wel een prijs: snetheid. En snelheid is een bepalend alement gewotden in onze cultunr. We zullen dus ook die cull rurele waarden moeten weranderen, om tot een optimale inzet van duurzame technologie te kunnen komen. (Interview Leo Jansen d.d. zo november 199 11. Over de wag welke relatie bestat tussen milieubelasting en de (rii)snelheid van uiteenlopende vervoermiddelen, zie bijwoorbeeld: Baaijens [et.al.] (1997). Over de relatie russen snelheid en verkeersveiligheid, zie bijvoorbeeld: Oei ( 990 ), Rotteved (1.992) en Peeters [et.al.] (1995). Woor een beschouwing over de maatschappellijke kosten van de 'snelheids" en mobiliteitscultuur", zire ook: Davis $(1994)$.

2 Rivetreld (2000) en Nijkamp (2001) creären een vergelijkbaar vertekpunt in het belang van toenemende reissnelheden om de transtormarie van het reizen in de afgelopen twee ed uwen te beschrinven.

3 Naar en mogelijke herintroductie van het luchtschip is de afgelopen jaren veel onderzoek gedaan. Zie bijvoorbeeld Peeters, P. M. [et.aL ] (1996).

4 Mobiliteitsproblemen hebben ütemard betrekking op zowel het reizen van mensen als het vervoer van goederen. In dit boek ligt het accent op personenmobiliteit.

5 Baeren, Spirhoven en Albrechts (2000) beschrijven het sterke verband tussen mobiliteitsproduktie en vrije markteconomie. De grondslagen van de vrije markteconomie leggen volgens hen 'op een dwingende manier de contouren vast waarbinnen mobiliteit wordt geproducuerd'.

6. Van het verband tussen vergelijken en begrijpen - een gemeenplaats in het werenschapsonderzoek - geeft Maas (2003) een mooi woorbeeld. Maas beschrijft de bijdrage vam William Stanley Jevons ( $1835^{-1} 882$ ) aan de moderne economie als een nieuwe still van redeneren, "mechanical reasoning", warin de menselijke geest, mensielijk wedrag of economische systemen worden vergeloken met mechanische instrumenten als de weegschaal. Deze nieuwe stijl van redeneren, warin mechanische objecten als middelen van verklaring werden opgevat, maakte het voor aconomen mogelijk nieuwe weagen te stellen en nieuwe theorieen te formuleren.

7 Vertogen zün talig, maar spelen zich af 
binnen materiële kaders en worden gestut door maatschappelijke belangen (Foucalt). Ik vat het begrip vertoog hier op als "a specific ensemble of ideas, concepts, and categorizations that are produced, reproduced, and transformed in a particular set of practices and through which meaning is given to physical and social realities'. (Hajer, 1995: 44). In hoofdstuk 2 kom ik terug op Hajers wertoogbegrip om de Nederlandse mobiliteitspolitiek te analyseren.

8 "During the half millemium since the onset of the Transportation Revolu. tion, the creation and relief of stress has been continuous - so much that we have come to expect an ever-expanding transportation and a continuous effort to improve facilities and technology.' (Vance, 1986: 13).

9 "The Era of Technological Advance so emphasized speed that we may begin to distinguish between various forms of transit on this basis. Finally, travelers had a choice.' (Vance, 1986: 27).

ro Zie woor een beschrijving van de veranderende organisatie van postkoetsdiensten in de achttiende eeuw Brune (r.99 I). Voor de geschiedenis van het familiebedrijf Thurn und Taxis, zie Behringer (r99o).

rx Vance, $1986: 163$ en 163 .

12. Filarski, 1997: r.6.

r3 Filarski, r997: r.29.

r 4 Smith \& Marx, 1994: 2. Zie ook Bimber (r990)en Mackenzie en Wacjman (r999) woor gelijkluidende definities wan de technisch-determinustische visie op techniekontwikkeling.

is Smith \& Marx, rg94: Ir.

16 Filarski, 1997: r.28.

17 Voor deze (al te) beknopte weergave van het economisch vergelijkend perspectief heb ik gebruikt gemaakt van Sharp ( $988 \mathrm{r}$ ), in het bijzonder van hoofdstuk 5, 'Time and Transport'. De grondlegger van de modeme tijdallocatietheorie is de Amerikaanse Nobelprijswinnaar Becker (1965). Een andere klassieke tekst over tijd en economie is Shackle $\left(1_{9} 8_{3}\right)$. Zie ook Kirsch, $\mathrm{Ni}_{\mathrm{i}}$ kamp \& Zimmermann ( 988 ) voor de thematiek van 'tijdpreferenties'. Voor een economische benadering van reistijd, zie Bexelius ( 1976 ) en Bruzelius (1979).

18 'The most important benefit resulting from the majority of new investments in transport projects is a saving in transport time that can be transferred to some alternative and preferred activiry." (Sharp, 198I:85)

I9 "Prijsverhoging van thet gebruik wan de weg leidt alleen dan tot substantieel minder gebruik van die weg en tot substitutie naar andere gebruikstijden of andere vervoersmogelijkheden, als de prijs van de vraag ernaar voldoende elastisch is." (Van Mierlo, zooo: r9). En verder: 'Al met al kan hieruit geen enkele andere conclusie worden getrokken, dan dat de vraag zeer prijsinelastisch is. Met een gemiddelde schatting van $-0,25$ kunnen wij er zeker niet ver naast zitten. Met andere woorden: de vraagcurve loopt bijna evenwijdig aan de prijsas en de vraag reageert nauwelijks op prijswerande. ringen. Als dat klopt, en daar lijkt het toch wel verdacht veel op, $k$ an her op timisme over de effectiviteir van BOR Leen pakket beleidsmaatregelen waaronder beprijzing door rekeningrijden dat in 2000 door minister Netelenbos werd geintroduceerd. Zie ook hoofdstuk 2- PP] dat door het kabinet tentoon wordt gespreid geenszins worden gedeeld." (Van Mierlo, 200r: 2r).

20 Nowotny (1989).

21 'The New York's World Fair will predict, may even dictate, the shape of things to come.' (Geciteerd in: Gellern" ter, 1995:343). Zie ook: Cohen (I989). 
2 Voor een historisch overzicht van de "streamlined decade', zie: Bush ( 1975$)$ en Lichtenstein \& Engler (r992).

23 De beschrijving van de Chrysler-tentoonstelling is ontlleend aan Nye, 1994:2 r 7 ev.

24 Couperus (1901)gebruikt deze nitdrukking in een iets andere vorm om het fietsen wam een wan de hoofdpersonen in De boeken der kleine zielen, Wan der Welcke, te beschrijven: "trappelend om snelheid en verte". Mark wan den Heuvel kwam op her idee deze uitdrukking om te vormen tot de tirel van Van den Heuvel 8 Peters (1998).

25. Voor verkeersutopieen, zie Dienel 8 Trischler (Red.) (I997).

26 "Rumte moest van tijd worden gescheiden, voor het mogelijk was om $\mathrm{ki}$ lometers-per-uur te anvarien: afstand gedeeld door tijd als een fractie, in plaats van een intrinsieke verhouding van proportionalitell. Snelheid is iets dat mensen vandaag de dag vanzelfsprekend voor lief nemen. (...) [Het] is een van die termen waarmee we onszelf gevangen zetren un een wereld zonder uitgang. Mensen spreken over hoge en lage snelheid, over snel en langzaam, over duurzame en destructieve snetheid. Sommigen fantaseren zelfs dat het goede leven bereikt kan worden door "slow-bies" te worden, door te onthaasten. De mogelijkhejd om de valkuil vari snelheid te omzeilen komt in het geheel niet bij ze op." IVan Illich tijdens het "Speed"-congres Doors of Perception in de Stadsschouwburg te Ansterdam op 8 november 1996.$)$ Zie ook: Millar \& Schwarz (Red). (1998).

27 Hofland, I964:23.

28 "Alles geht jetzt schmeller als früher; wir sparen Zeit beim Transport von Menschen, Gütern und Informationen, wir sparen Zeit beim Einkauten und bel der Hausarbeit, sogar beim Es- sen (Fast Food). Wh gewihnen Unmengen an Zeit, haben aber weniger als je zuvor: Die am Vomitrag gewonnene Zeit geht an Nachmittag werloren. Je mehr Zeit wir sparen; desto weniger Zeit haben win: (Zoll, r988: (O-IX).

29) Proust, 199 1 : 403-404. Dit fragment wordt ook geciteerd in Sachs (1992: r66) en dient daar als illustratie van wat Sachs het conflict tussen de "onbegrensde beguerte' en de "begrensde tijd" noemt. Omdat het aantal uren in een dag niet toeneemt, is de enige nitweg uit dit conflict of wel te hasten of wel beter te plannen, meent Sachs "The more opportunities there were for new experiences, the more the offerings competing for the limited number of hours enticed, the more waluable time became: an expensive commodity that had to be saved, exploited, and carefully planned.' (Sachs, I992: r67).

30 Ibid., p. 404.

3 T Toen Albertine hatar toque en sluier goed aan de Verdurins had laten zien, wierp zij mijeen blik toe om mij eraan te herinneren dat ons niet al te veel tijd restte voor wat wij wensten te doen." (Proust, 1991: 409).

32. Sachs, r999: 193 .

33. Ook Lewis Mumford wijst in zijn Technics and Civilization (x934) op deze efficiency-paradox en grijpt op zijn beurt terug op Veblem en Russell: 'In The linstinct of Workmanship Veblen has indeed wondered whether the typewriter, the telephone, and the automobile, though creditable techroilogical achievements "have not wasted more effort and substance than they have saved," whether they are not to be credited with an appreciable conomic loss, because they have increased the pace and volume of corresponden ce and communication and travel out of all proportion to the real need. And 
Mr. Bertrand Russell has noted that each improvement in locomotion has increased the area over which people are compelled to move: so that a person who would have to spend half an hour to walk to work a century ago must still spend half an hour to reach his destination, because the contrivance that would have enabled him to save time had he remained in his original situation now - by driving him to a more distant residential area - effectually cancels out the gain." (Mumford, $1963: 2721$.

34 "Countless bridges, tunnels, highways, cables and antennae are the heredity of that belief. Instead, the suspicion grows that progress could perhaps also imply deliberately leaving the resistance of time and space unchanged, or even increasing it.' (Sachs, r.999: 195).

35 Whitelegg (1993).

36 Tromp \& Bosch (1996).

37 Ibid., p. 4 .

38 Rifkin, 1987:65.

39 Een vergeliikbare strategie wordt voorgesteld door de onderzoekers van het in 199x opgezetre Tutzing Time Ecology Project waarin onder meer onderzoek werd gedaan naar de samenhang tussen de moderne omgang met tijd, gericht op controle en economische groei, en wat men omschrijtt als de "current sociomenvirommental crisis". Zie Adam \et.al.] (r997). Behalve door Rifkin ( 1987 ) wordt een terugkeer naar de ritmes en tijdschalen van de natuur ook bepleit door Held \&c Geissler (Red.) (1995).

40 Höming, Gerliard \& Michailow (r995). Voor cen economische studie naar het reisgedrag van "tijdpioniers", zie Baaijens \& Nijkamp (1997). In Nederland leidde de oproep tot 'onthassting' die minister Margreeth de Boer (Vrom) deed in thaar nieuwjaarstoespraak in januari 1997 tor een matschappelijk debat over dit nieuwe begrip. Over het "onthastingsdebat", zie: Van Workum [et.al.] (1.998).

4 I In Nederland heeft Terreehorst ( 1997 ) bijwoorbeeld gepleit voor een manier van leven waarin traagheid als positief element is opgenomen. In haar 'Sllow City" ligt het accent op tempoverschillen in plaats van de monocultuar wan de snelheid.

42 Virilio formuleerde zijn "dromologie" (leer van de snelheid) woor het eerst in 1977 (Virilio, 1977) en werkte deze daarna uit in opeenvolgende boeken waarin hij varieert op het thema van de 'razende stilstand'. Voor een inleiding in het denken van Virilio, zie: Der Derian (Red.), (1998) en Armitage (Red.), (2000).

43 'Deswegen meint der Begriff Fortschritt nicht eine simple $I$ ageveränderung, in der ein Agent von A nach B fortrückt. Fortschrittlich ist seinem Wesen nach mur derjenige "Schritt", der zur Steigerung der "Schritrfähigkeit" fuhrt. Dies gibt uns die Formel der Modernisierungsprozesse an die Hand: Fortschritt ist Bewegung zur Bewegung, Bewegung zur Mehrbewegung, Bewegung zur gesteigerten Bewegungsfähigkeit. Nur weil dies gilt, kann in der Moderne aus der Kinetik unmirtelbar die Ethik hervorgehen. Es gibt keine ethischen Imperative modernen Typs mehr, die nicht zugleich kinetische Impulse wären. Der kategorische Impuls der Moderne lautet: Um uns arihaltend als Fortschrittswesen zu betätigen, sollen wur alle Zustände überwinden, in denen der Mensch ein bewegungsgehemmtes, ein in sich angehaltenes, ein erbarmungswiir digr festgestelltes Wesen ist.' (Sloterdijk, r $989: 3,6$ en 37 ).

$44 \mathrm{Vgl}$ als het regent, dan zijn de straten nat ergo als het niet regent zijn de stra ten niet nat. Deze redenering is niet lo- 
gisch slaitend. Het kan met regenen arwijl de straten toch nat zijn, bijwoorbeeld omdat er net een sproeiwagen is gepasseerd. Zie De Wilde (r997) naar aanleiding wan Peters (I997a).

45 Hawthome, r996:269.

46 Ubid., P. $27 x$.

47 Ibid., p. 274 .

48 Ibid., p. 280 .

49 "Holland zonder haast" is de titel van eent reeks fotoboeken met werk van uiteenlopende fotografen, gemaakt in de jaren vijfug. Zie: Holland zonder baast. (1998). Amsterdan: Voemoot. Draaisma (2001) beschript een vergelijkbaar verschijnsel in zijn boek over het autobiografische geheugen.

5o Bergson argumenteert bijwoorbeeld dar tijd duurt; hoe lang een tijdspanne duturt, hangt af van de ervaring van iemand en is onafhankeligk van een objectieve rijdmeting. 'Temps' (als kloktijdy is een reductie van de 'duree', de veel rijkere geleefde rijd. Voor mensen als levende, existerende wezens is de geleefde tijd primair.

5 I Het arrikel van McTaggart werd oorspronkelijk gepubliceerd in het tijdschrift Mind in 1908 en is herdrukt in Poidevin \& MacBeath (Red.). (I g9,3). "Positions in time, as time appears to us prima facie, are distinguished in two ways. Each position is Earlier than some and Later than some of the other positions. (...) In the second place, each position is elther Past, Present, or Future. The distinctions of the former class are permanent, while those of the latter are not. If $M$ is ever earlier than $N$, it is always earlier. But an event which is now present, was future, and will be past. $(\ldots .$.$) For the sake of brevity$ I shall give the name of the A series to that series of positions which runs from the far past through the near past to the present , and then from the present through the near future to the far future, or conversely. The series of positions which runs from earlier to later, or conwersely, I shall call the B series." (Poudevin \& MacBeath, $1993: 24$ ) Ondat de A serie tegelijk essentieel is on tijd te kunnen begrijpen en tot logische inconsistenties leidr, concludeert McTagn gart dat rijd niet bestaat. Zie ook Adam (r990), Gell (r992) en Urry (zooo) voor een kritische analyse van het argument van McTaggart en het onderscheid tussen tijdsbegrippen in respectieveligk de A-serie en de B-serie.

s2 Fenomenologische beschouwinger over tijd behoren meestal tot de A-serie. Dat gelde bijvoorbeeld voor de 'fenomenologie wat het interne tijdbewustzijn' wan Husserl, maar ook woor het werk van Heidegger, Sartre, Merleau-Ponty, James, Schiitz en Bourdieu. Al deze denkers benadrukken het dynamische, subjectiewe, stream-of-consciousness-achtige karakter van tijd.

53 Goudsblom, r997: 2r.

54 Van tijd is bij Elias sprake als er meerdere gebeurtenissen (Elias spreekt van 'Geschehensabläufe') met elkaar in verband worden gebracht, en dat ver onderstelt teen verknoping van tenminste drie contimua: 'tussen mensen, die verknopen, en twee of meer veranderingscontiana, warvan er, in een bepaalde groep mensen, attijd een de functie van standaardcontinutim heeft ${ }^{2}$. (Elias, 1988 : 1 $z$ ). Over de tijdsociologie van Elias zie verder Tabboni $(200 \mathrm{I})$.

55 In een denkbeeldige dialoog met Kant argumenteert Durkheim dat mensen zich tijd slechts kunnen woorstellen als periodes. Omdat de periodisering van tijd-dagen, weken, malanden - de ritmes van collectieve activiteiten als feesten en andere publieke aangelegentheden aangeeft, is de categorie tijd (maar ook de andere kantiaanse categorieèn) social van aard, sitelt Durkheim. Zie 
Gell (r992) woor cen inleiding in de tijsociologie van Durkheim. Voor overzichtsstudies wan de sociale theorie over tijd, zie: Adam (r990) en $(7995)$.

\$6 De literatumr over de geschiedenis van de tujdbepaling is omvangrijk. Als bronnen voor mijn eigen onderzoek zijn heb ik gebruik kunnen maken wan: Aveni (1989), Banetr (1998), Borst (r990), Howse (1980), Landes (1983), Dohrn-Van Rossum (xg96) en Wendorff (r980). Het standaardwerk over" de rol wan tijd in de historiografie is Kosseleck (1979).

57 Voorbeelden van antropologisch onderzoek naar tijdrekening: Fabian. (1983), Gell (1992), Levine (r998) en Ostơr ( $(993)$.

58 Voor een inleiding in de 'sociologie van de tijd", alsook een bundeling vant klassieke teksten, zie Hassard (1990). Andere voorbeelden van sociologische theorievorming over tijd zijn: Lash \& Urry (1994), Nowotny (1989). Schmied (1985), Uny (2000), Young (1988), Young \& Schuller (r988) en Zerubavel (1981).

59 Zie Thompson (1967) voor een klassilek geworden voorbeeld van deze opvatring.

60 Lewis Mumford (1934) stelt dat de "mechanical elements" warmee we ons ominingen (ook) gebruikt worden om gebeurtenissen opnieuw te ordenen in rumte en tijd: "The refrigeration of eggs, for example, is an effort to space their distribution more uniformIy than the hen herself is capable of doing: the pasteurization of milk is an attempt to counteract the effect of the rime consumed in completing the chain between the cow and the remote consumer. The accompanying pieces of mechanical apparatus do nothing to improwe the product itselfi: refrigerawon merely halts the process of de- composition, while pasteurization acwally robs the milk of some of its va lue as nutriment. Where is possiblla ro distribute the population closer to rural centers where milk and butter and green vegetables are grown, the elaborate mechamical apparatus for counteracting time and space distances may to a large degree be diminished." (Mumford, 1934:27x.)

61 Thrift, 1996: 169-212. Een ander voorbeeld is het onderzock wan Horning letal.) (1997 en 1999) naar de manier warop nieuwe communicatictechnologieen leiden tot nieuwe "tijhlpraktijken'.

62 lk heb deze A-serie benadering van reistijd onderzocht aan het woorbeeld wan het wandelen in de vroege negentiende eeuw: Zie Peters ( $1998 \mathrm{c}$ ).

63 De historische informatie woor dit voorbeeld is ontleend aan Vance, 1986: 448. Clark \& Staunton (1989: 87 ev.) merken op dat stoomschepen weliswaar sneller en regelmatiger voeren dan zeilschepen, maar dat het vier decennia duurde (wan 1850 tot 189 ) voordat het zeilschip althans voor vrachtvervoer) in alle situaties was vervangen door stoomschepen thet "salling-ship effect').

64 Zie Braudel (1979) en (in 992).

65 In mijn definitie van publieke probla men sluit ik aan bij Gusfield (I98 1 \%. Gusfield onderscheidt publieke prom blemen van sociale problemen Van publieke problemen is volgens hem pas sprake als zij het onderwerp zijn van conflict of controwerse in de arena's van her publieke handelen en debar. In deze arena's is de macht, invloed en autoriteit om het probleem te definieren ongelijk verdeeld tussen verschillende sociale groepen. Het vermogen om de publieke definitie wan een problem te beinvloecen omschriff Gusfield als het "probleemeigenaarschap". In hoofd- 
stuk 2 ga $1 \mathrm{k}$ dieper in op her publieke 4 karakter van mobiliteitsproblemen.

66 Een untzondering in Nederland vormt het werk wan de filosoof Hans Achterhurs. Zie bijvoorbeld zijn analyse van de relatie tussen mobiliteit en moderniteit in Achterhuis ( 1995 ), de relatic tussen mobiliteit en schaarste in Achterhuis (1997) en ( $1998 \mathrm{~b}$ ), allsook zijn beschouwing over de wijze warop mobiliteitsteclmnologieen als verkeersdrempels en snelheidsbegrenzer voorbeelden zijn wan wat hij de "moralisering win apparaten" heeft genoemd. (Achterhuis, rgga).

\section{Gasgeuen of alremmen}

I Bron: interview met Ary Koot, voorlichter van het Traffic Information Centre, dd. 2 oktober zoor. De analyse wan het Nederlandse mobiliteitsdebat in dit hoofdstuk is behalve op de in de literatuarlijst genoende beleidsdocumenten gebaseerd op krante-artikelen en interviews met ambtenaren en politici. Delen van het onderzoek dat an dit hoofdstuk ten grondslag ligt verschenen eerder in Peters (r998ia) en Peters [et.al.] (200x).

2 'Het spitsvignet is bedoeld om de automobiliteit te spreiden, niet om die terug te dringen. En spreiding interesseent mij niet. Ilc heb liever dat mensen in die file staan, dan kiezen ze tenminste voor het openbaar verwoer. (Van der Malen 8 Pama, I994). Deze wisie werd drie dagen later in het hoofdsartikel van NRC Handelsblad afgedaan als 'een bedenkelifike opvatting, want hier wordt de Verelendung tot beleid verheven." NRCHandelsblad, 25 oktober 1994). 'Wegen natar de toekomst' is de titel van een op (technologische) innovatie gericht onderzoelsprogramma van het Ministerie van Verkeer en Waterstaat.
De impressie van het Congres Kiezen yoor vernieuwing' op 2.2 mei zoor in Rotterdam is gebaseerd op de Nieuwsbrief National Verkeers-en Vervoersplan, nummer ro, 8 juni zoor, een uitgave van het Projectrean Nvv wan het Ministerie van Verkeer en Waterstaat. 5 Meadows (1972). Zie woor een beschrijuing en analyse van de Nederlandse receptie van het Rappont an de Club van Rome Hajer (1995) en Peters (1997).

6 Het Structumschema Hoofduegennet I 966 , dat voonut keek nar het jaar 2000 , voorag de aanleg wall $\$ 300$ nieuwe killometers weg tot an 2000 , warrbij men witging van een groei van het autoverkeer tot die rijd met een factor drie. Het Rijkswegenplan uit 1968 bevestigde nog eens de noodzaak wan een grofmazig net wan autosnelwegen. Voor de naoorlogse ontwikkeling van de mobiliteit in Nederland, zie ook Ligtermoet (1990), Provoost (1996: 6ri ev.) en Schot [et.al.] (2002).

7 Zie voor een mooie studie naar dit verkeersplein Buiter \& Volkers (1996).

8 Voor een overzicht van de effecten van de Nederlandse mobiliteitspolitiek in steden als Amsterdam, Rotterdam en Utrecht in de maoorlogse jaren, zie hoofdstuk 6 ('Stad Nederland') in Schuyt \& Taverne (2000) en Provoost (1996).

9 Zie: Ministerie van Verkeer en Waterstaat $(\operatorname{rg} 7 \mathrm{r})$.

ro Het aantal auto's in Nederland was gegroeid van 522.000 in 1960 tot 2.5 miljoen un $\times 970$. In 2000 waten dat er 6.5 miljoen, een millioen minder dan voorspeld in de TP $2000-8$ sudie var het Ministerie van Verkesr en Waterstaat (Bron: Centralal Bureau voor de Staristiell).

I. Ligtermot (1990:57).

I. McKinswey \& Company, \& Ministerie van Verkeer en Waterstat ( 986 ). 
3. Tweede Structururshema Verkeer en Verwoer Deel D, p. 8.

I4 In de beleidspraknik werd 'marktwerking' aanvankelijk wooral vertaald naar marktwerking in het openbaar werver en werzelfstandiging wan vervoersbedrijven als MS en de streekvervoerbedrijwen.

x 5 Hendriks \& Tops (zoor).

16 In juni $200 x$ bestoot ook Utrecht mee te doen met her zogenaamde Bereikbaatheidsoffensief Randstad (BoR), marar pas nadat dudelijk was geworden dat de tolpoorten er niet zouden komen.

17 Zier vrom-raad (1.999). Overigens valt wel lets af te dingen op deze conclusic; weel van de in het svv u voorgestelde beleidsmatregelen, zoals biyroorbeeld het rekeningrijden, waren immers nowit uitgevoerd. De effectiviteit van deze matregelen kon daarom strikt genomen niet beoordeeld worden. Feitelijk stond in her wow Raad rapport niet de effectiviteit yan her beleid ter discussie, maar de fon)mogelijkheid van een beleid te voeren dat gericht is op het terugdringen van de automobiliteit.

I 8 Voor een kritiek op het gebruik van het predikaat "slim" als het gaat om informarietechnologie, zie: De Wilde (2000).

19 Automatische voertuiggeleiding (AvG) is een verzamehaam voor technolog:sche middelen die de taak van de bestaurder ondersteumen en op termijn gedeeltelijke kunnen overnemen. A.VG kan een bredere toepassing hebben dan alleen op de snelweg. Een paginan grote advertentie van autofabrikant DaimlerChrysler die in het voorjanr van 2002 in Nederlandse kranten verscheen, toonde een afbeelding van een toekomstig kruispunt in een toekomstige grote stad. Err rijden auto's en er lopen mensen. Op het asfalt ziin zo ver het oog reikt zebrapaden op de weg ge- schilderd. Stoplichren en werkeersborden ontbreken. Onder een witu scheidingsstreep stat de kop: Vellig oversteken moet overal kummer. De advertentietekst luidt: 'Bi Dainter. Chrysler bekijken we de straten alsot ze een lange oversteekplaats zijn. Monenteel ontwikkelen we een intelligent recogrition systew dat onze auto's in de toekomst in stat stelt eventwel obstakels zelf te herkennen. En warnee de bestunder gewarschuwd wordt, om sneller te kunnen reageren. Goed nieuws dus woor atutomobilisten. En voor iedereen die hun pad kruisir." Op de met een computer verwaardigde afbeelding gaan utopisme en absurdisme hand in hand.

20 Het Nvwp Deel A: Kabinetsstandpunt, dat op 2r mei $200 \%$ door de ministers vata Verkeer en Waterstaat en van Volkshuiswesting, Rumtelijke Orde en Millieubeheer naar de Tweede Kanner werd gezonden, somt een reeks 'sleuteltechnologieën' $\mathrm{op}$, waaronder 'een on board-computersysteem voor onz der meer communicatie tussen wctetuig en wegkant, en voor elektronische voertuigidentificatie; keteninformatie en chipkaartbetaling voor verwoersdiensten; auromatische voertuiggeleiding, zoals automatische cruise control en intelligente snelheidsaanpassing en nieuwe aandriffechnieken, zoals brandstofcel, hybride systemen en dergeliike.' (Nvvp Deel A: Kabinetsstandpunt, $200 \mathrm{r}, \mathrm{p}, \mathrm{x} 2 \pm \mathrm{ev}$ )

$2 x$ Voor een owerzicht wan de literaturar over de effecten van xCT op personernen goederennobiliteit zie met name hoofdstuk 4 van Peters, Peeters, De Wilde \& Clement (200I).

22 Het is overigens opvallend dat het woord "rekeningrijden" niet langer woorkwam in het NVup. Op het moment dat het instrument nog werd bediscussieerd in her parlement was her 
al verdwenen uit het beleidswocabulaire.

23 Mogelijk heeft ook een rol gespeeld dat de milieubeweging, die zich zij het schoorwoetend altijd achter rekeningrijden had opgesteld als middel om behalve de congestie ook de milieubelasting wan het verkeer iers te verminderen, na de woorkeur gaf an een geavanceerder systeem van kilometerheffing. In 2000 liet de Stichting Natur en Milieu een onderzoek uitvoeren dar concludeerde dat zo'n kilometerheffing technisch en financieel op relatief korte termijn haalbaar zou kunnen zijn en bovendien een groot ef fect op de milieubelasting door het werkeer zou kunnen hebben. (Peeters, Rietveld \& Ubbels, 2000). Na publicatie van het rapport in november 2000 ontstond rond de killometerheffing in enkele maanden cen brede nieuwe vertoogcoalitie tussen de ANW B en de milieubeweging die de minister een elegante uitweg bood uit het vastgelopen tolpoortendossier. Van de politieke partifien nam D66 her voortouw in her pleidooi voor de kilometerheffing.

24. Voor de plaatsbepaling zou de automobilist gebruik kunnen maken van het nieuw op te richten Network Location Services (NLS), maar bijwoorbeeld ook van bestaande GSM-netwerken of een Gess-systeem, dat ook voor een routezoeksysteem gebruikt kan worden. In de visie van Pieper controleert de overheid op gezette tijden de juiste werking van die 'trusted wallet' en de plaatsbepaling om fraude te woorkomen.

2.5 Achter de schermen werd wel degelijk hard gewerkt aan de introductie, waarvoor op het ministerie van Verkeer en Waterstat een projectgroep wan vele tientallen ambtenaren was wrijgemaakt.
26 De Boer \& Hoedeman (2002).

$27 \mathrm{scp}^{2}\left(\mathrm{r}_{976}\right)$.

28 Zo is het jaarlijks aantal dodelijke verkeersslachtoffers sinds het begin van de jaren zeventig met tweederde gedaald. Ook de nitstoot wan lood, koolmonoxide, stifstofoxiden en koolwaterstoffen is gedaald, maar niet genoeg oun de problemen die deze stoffen veroorzaken - zoalls verzuring en gezondheidsschade - helemaal te doen werdwijnen.

29 Zie bijvoorbeeld Tertoolen (1994), Van der Vught ( 1996$)$, Enckevort \& De Kruijk (x996) en Steg \& Sievers (r996).

30 Vrijsen (2001).

$3 x$ Gusfield $(198 x)$.

32 Hajer sluit aan bij het begrip "vertooganalyse' zoalls dat in de sociale wetenschappen is ontstaan en waarin wordt onderzocht hoe en waarom een bepaalde probleemdefinitie dominant wordt en autoriteit krijgt en andere probleemdefinities niet. Daarnaast vat hij een vertoog op als "a specific ensemble of ideas, concepts and categorizations that are produced, reprodinced and transformed in a particular set of practices and through which meaning is given to physical and social realities.' (Hajer, I995: 44).

33 Complexe problemen zoals zure regen of de mobiliteitsproblemen die in dit hoofdstuk worden besproken omvatten volgens Hajer altijd meerdere wertogen. "Consequently a policy document on acid rain may easily involve discursive elements from disciplines as various as physics, tree physiology, ter rrestrial ecology, mathematical modelling, economics, accounting, engineering, and philosophy.' Hajer, 1995: 45). Her 'communicatieve wonder' van de milieupolitiek is, betoogt Hajer, dat ondanks al deze variaties in manieren van spreken de deelnemers aan 
het debat elkaar lijken te begrijpen. Een problecm als zure regen wordt daarmee een interdiscursief thema en de wratag wordt dan relevant hoe de verschillende actoren in het debat manieren vinden om elkaar te begrijpen en hoe de vele kennisgebieden samenkomen in gezaghebbende verhalen over zure regen. (bid.: 46 ).

34 Grote beleidsnota's als het svv rn en het NVWP werschijnen in een aantal stappen. Eerst stuwrt de regering het kabinetsvoornemen ('deel $A$ ', in het geval van het swv If in 1988 ) naar de Tweede Kamer. Verwolgens verschijnen de overzichten wan de inspraakrondes ('deel B') en aanvullende documenten ("deel $\left.C^{\prime}\right)$. Vervolgens neemt de regering een beslissing ("Deel D). Als de nota door de Tweede Kamer is besproken, geammendeerd en aangenomen verschijnt deze als Planologische Kernbeslissing (PKiB) ('deell $\mathrm{E}$ ' in het geval van het sw If in $199 \mathrm{x}$ ). Het sw a werd na 199 I wrijwel jaarlijks op onderdelen door regering en Tweede Kamer aangepast aan actuele ontwrikkelingen. Een voorbeeld is het door minister Jorritsma in 1996 uitgebrachte Samen Werken Aan Bereikbaarheid (swaB).

35 Interview met drs. H. Schartman (Ministerie van Verkeer en Waterstaat, $\mathrm{Di}$ rectoraat-generaal Personenverwoer, directeur Afdeling Innovatie en Ongeving), Den Haag, 25 januari $200 \mathrm{r}$.

36 De Wilde (2000).

37 Nationatal Verkeers en Vervoersplan $200 x-2020$, Tweedle Kamer, vergaderjaar $2000-200 \mathrm{x}, 27455$, nes. $2-3$, p. 6 .

38 De voorkeur woor een overlegmodel is niet nieuw in de Nederlandse polinek. Geul (r9g8) beschrijft de 'Oud-Hollandsche methode' van schikken en plooien, een traditie die volgens hem teruggaat tot de zeventiende eeuw.

39 Bron: Milieubalans 200 r van het Mimisterie van WROM.
40 Zie bïwoorbeeld Van Goeverden $8 x$ Van den Heuvel ( 1993 ).

4 II Zie voor het begrip "actieruimte' Dijst (r995) en Dijst \& Vidakovic (r995).

$4 \approx$ Voor een overzicht wan de uitgebreide theoretische literatuur over 'reistijd. waardering", zie bijvoorbeeld: Gonzalez (1997).

43 Voor een voorbeeld wan Nederlands onderzoek, zie: MuConsult (x995).

44 Ministerie van Verkee en Waterstaat, 1973: 7 .

45 Ibid., p. I3.

46 Hupkes, 1977 [eerste band]: 19.

47 Hupkes, 1977 [eerste band]: 37.

48 Her vermoeden wan een constante in de reistijd is al minstens een ceuw oud. In r goz schreet H.G. Wells in een beschouwing over het verband tussen toenemende reissnetheid en de uitdijende structutur wan steden dat mensen dagelijks maximaal twee uren reizen. Zie Wells, $1999: 25$. Het eerste onderzoek naar tijdbesteding dat aandacht besteedr aan reistijd is Time-budgets of Htwman Behaviour van Sorokin (r939). Deze Amerikaanse sociologische studie maakt onderscheid tussen 'transportation' (ergens arriveren met een vervoermiddel) en lopen (naar en rond thuis, wandelen voor plezier etc.). Voor 'transportation' werd een gemiddelde van 81,6 minuten per dag per deelnemer gevonden, voor lopen een gemiddeldle van 55,5 minuten per dag per deeinemer. Ook Sorokin constateert een toename van de afgelegde afstanden als gevolg van verbeteringen an het vervoersysteem. (Sorokin \& Berger (1939)).

49 Hupkes, 1977 [band $\mathrm{T}$ ]: $26 \mathrm{x}$.

so Hupkes, 1977 [band $\mathrm{r}$ ]: 256.

5 I Hupkes noemt Doxiades. Clark, Lee en Ogden; Buckminster Fuller; Hägerstrand.

52 Szalai \& Converse ( 9972 ).

53. Hupkes, r977 [band 1 ]: 260 . 
54 De hyporhese van de constante reistijd verwijst niet ongeproblematiseerd naar een stand van zaken in de werkelijkheid. Integendeel, de BREVER-wet stoelt op weronderstellingen over de aard wan verplaatsingsgedrag, veronderstellingen over de aard en omvang van de onderzoekspopulatie, (impliciete) definities van begrippen als "verplaatsingen', 'reistijd" en 'wet', de betrouwbarheid wan data verkregen middels uiteenlopende dataverzamelingstechnieken (dagboeken, enquêtes, interwiews) en verwachtingen over de extrapoleerbaarheid en generaliseerbaarheid van bevindingen uit verschillende onderzoeken. De BREver-wet is wat we een 'gestileerd feit' zouden kunnen noemen, een feit waarin tal wan andere standen van zaken zijn voorondersteld. Zie voor een kritiek op het gebruik door Hupkes van het begrip 'wet': De Wit (1980) en Van Wee $(x 999)$.

55 Hupkes, $x 977$ [band $x$ ]: 259 .

56 Hojer en Mattsson (2000) ordenen die aanzetten naar discipline: biologische, economische en sociale verkla ringen. Onderzoekers die opteren voor een biologische verklaring leggen een verband tussen het bestaan van de constante en, wat zij noemen, het menselijk verplaatsingsgedrag. De gemiddelde reistijd is constant omdat mensen over biologische of psychologische eigenschappen en mechanismen beschikken (bijvoorbeeld hormonale homeostase of een genetisch bepaald gediragspatroon) die erwoor zorgen dat de tijd besteed aan verplaatsingen zich tussen een minimum en een maximum beweegt. Hupkes ( 1979 ) zelf verwijst naar dit type verklaring in zijn veronderstelling dat mensen behoefte hebben aan "het stabiliseren van bepaalde biopsychologische variabelen", waarvan reistijd er een zou kunnen zijn.
Hoe zo'n biopsychologische variabele onderzocht zou moeten worden blifft vooralsnog onduideliik. Szalai ( 1972 : I I) heeft het over "a fundamental substrate of human imperatives where the use of time is concerned". Schater $(\mathrm{x} 998: 459)$ stelt dat de "ultimate reason" voor het constante tijdsbudget voor verplaatsingen onduidelijk is en wellicht is terug te voeren op een 'basic human instinct'. Hij verwijst daarbii naar cen artikel van Marchetri (r994) waarin de "anthropological in" variants in travel behavior" worden verklaard uir het feit dat de mens tegelijk een 'territoriumdier' en een 'holbewoner' is.

Andere verklaringen wan de Breverconstante passen de economische nutstheorie toe op verplaatsingsgedrag. Hupkes zell $(1977,1979)$ kiest voor dit type verklaring. $\mathrm{Hij}$ stelt dat het totale nut warn een verplaatsing is afgeleid uit een combinatie van intrinsiek nut en afgeleid nut. Dit levert een optimum op rond 75 minuten. (Hupkes, 1979 : 368.) Hamerslag ( 1998 ) vult aan dat de keuze om een verplaatsing te maken met een bepaalde verwoerwijze, afstand en tijdsduur wordt bepaald door nut en offer van de werplaatsing, en de tijd- en geldbudgetten. Het nut wordt doorgaans werondersteld gelijk te zijn aan de meerwaarde van een verblijf elders boven dat wan een langer verblijf op het wertrekpunt. Offers zijn onder meer te spenderen tijd en geld. Van Goeverden (1999) wijst er verder op dat het verplaatsingsgedrag van persomen niet alleen wordt bepaald door nutsmaximalisatie, maar ook samenhangt met de ruimtelijke ordening en de kwalliteit van vervoersystemen. Een bekend vorbeeld is het verdwijnen van voorzieningen uit kleine kernen als gevolg van de opkomst van de auto. De versnelling van het vervoersysteem, 
met als direct effect dalende reistijden, heeft wo geleid tot een wergroting van de noodzakelijk af te leggen afstanden voor bezoek aan acriviteiten. Afnemernde en toenemende reistijden heffen elkaar op.

Sociale verklaringen van de constante reistijd en cen constant aantal verplaatsingen zijn er nauwelijks. Höjer 8. Mattsson (2000) wijzen op de chronogeografie van Hägerstrand zie hoofdsruk 3). Het dagelijks leven bestaat voor een belangrijk deel uit routines en gewoonten. Het is nier vreend te veronderstellen dat het verplaatsingsgedrag ook onderworpen is aan gewoonten. Hägerstrand stelt dat een (werk) dag een bepaalde verdeling kent in termen van tijdsbesteding per activitét (slapen, werken, persoonlijke verzorging, eten, reizen). De hoeveelheid tijd die besteed kan worden a an reizen is, gemiddeld genomen, dus beperkt. Dit is overigens de enige verklaring die niet het constante karakter van de tijdsbesteding aan reizen verklaart, maar ook de absolute waarde van de constante, namelijk tachtig minuten, menen Höjer en Martsson.

De drie genoemde typen verklaringen voor de hyporhese wan de constante reistijd komen aan de orde in Peters, Peeters, De Wilde \& Clement (zoon).

57 Hacking ( 2985 ).

58 'Time is seen as the stable framework within which these predetermined events occur in inexorable order, static, objective and unchanging." (Gell, r992: 180).

59 Sorokin \& Berger (1939).

60 Deze laatste variant wordt verdedigd door Van Goeverden (r999).

Gx Zie bijwoorbeeld het onderzoek van Schafer en Vicror (1997) en Schafer ( 1998 ). Zij stellen dat constante tijden geld budgetten voor reizen opgaan voor elf verschillende regio's in de wereld en bovendien dat de constante opgaat voor een reeks wan vervoersystemen. Schafer gebruikt de constante tijd en geldbudgetten om, onder de condities van een toenemende economische welvaart en voortgaande versnelling van vervoersystemen, een sterke toename van het wereldwijd afgellegde aantal kilometers te voorspellen voor 2050.

62 Hupkes, 1977 [band $x$ ]: 26.3-264.

63 Ibid., p. 284 .

64 Goudsblom, 1997:37.

\section{De passages van Themas Goolk}

I Deze gegevens zijn ontleend aan het 'Woord vooraf' door Yolanda Bloemen en Marja Wiebes bij de Nederlandse uitgave van Gontsjarovis 'Reis om de de wereld'. (Gontsjarov (1987)). Ibid. p. 20 en $2 \mathrm{I}$.

3 'One can associate the beginning of the modern era with various facets of changing Jxuman practices, but the emancipation of time from space, its subordination to human inventiveness and technical capacity, and so setting it against the space as a tool of the space conquest and land appropriation is no worse a moment to start reckoning from any other departure. $\mathrm{Mo-}$ dernity was born under the stars of acceleration and land conquest, and these stars form a constellation which contains all the information about its character, conduct and fate. It needs but a trained sociologist, not an imaginative astrologer, to read it out.' (Bau$\operatorname{man}_{2}$ 2000: $x$. I.2)

4 O'Dea (1994) heeft onderzocht of en hoe reismotief en de aard van de activiteit op de bestemming voor indiwiduen de allocatie van reilstijd beinnwloeden. 
6. Mayerstrand heeft het over drie typen constraintsi" capability, coupling en authority. 'Capability constraints' verwizzen nar de beperkingen van menselijke beweging gegeven fysieke of biologische factoren. Een persoon kan bijwoorbeeld niet op twee plaatsen tegelijk zipn. "Coupling constraints" duiden a an dat het nodig is gedurende een bepaalde tijd op één plaats te zijn om te werken of in interactie te treden met andere mensen. 'Authority constraints' tensilotte, duiden aan dat er plaatsen en tijdstippen kunnen zijn die geen deel kunnen uitmaken van het ruinte-rijd pad van een individu, bijvoorbeeld een militaire basis (plaats) of een winkel na sluitingstijd.

7 Deze conclusie bedoelt niet te suggereren dat Hägerstrand zich uirsluitend bedient van een gekwantificeerd tijdsbegrip. In Hägerstrand (1988) makt hij bijvoorbeeld onderscheid russen 'symbolic" en "embedded time'. '(...) embedded twe in the visible and tan. gible rextity and symbolic time, an abstract and 'freestanding' ertury, invented to summarise a large number of experiences and observations. This distinction means that symbolic time is wholly a cultural phenomenon whereas embedded time is only partly so." (...) "[Symbolic time] is something for the unbound mind to play around with and a "measuring rod" to use in the laboratory. In reality matter, space and rime always go together in the weaving of biognaphies. One cannot fully nuderstand the one without taking the others into account." (Hägerstrand, 1.988 .35 en 39 ).

8 Janelie ( $\mathrm{x} 968)$. Voor een uitgebreide bespreking van Janelle's concept "timespace convergence", zie: Parkes \& Thrift ( 980 ). Fer begrip 'time-space convergence" ligt ten grondslag aan zo- genaamde "tempografische" karten die niet de rumtelijke afstanclen tonen tussen steden, mar de afrtanden in (klokke)tid. Uiteraard rerandert het aanzien van een kaart al naar gelang: het verwoersysteen dat als uitgangspunt wordt genomen. "The elements of a time-space map are organised in such a way that the distances between then are not proportional ro the physical distance as in topographical naps, but proportinal to the trawel times between them. Short travel times berween two points resitil in their presentation close together on the map; points separated by long travel times appear ilistant on the map." (Spiekermann 8 Wegener, $1994: 654)$.

9 'Convergence is a direct result of the inpur of new rechnologies - more direct roads, taster velhicles, routes bypassing intervening places, and so forth. The histories of mail delivery, international air travel, and telephone comections provide examples of how various space-adjusting technologies have led to the convergence of places.' (Janelle, r99 I: 53):

no Parkes \& Thrift, x 8 \&: 296.

I I

$\mathrm{I} 2$

13

Geciteerd in Swinglethurst, 1974: 1 .

"Welche Veränderungen müssen jetzt eintreten in unster Anschauungsweise und in unseren Vorstellungen: Sogar die Elementarbegriffe von Zeit und Raum sind schwankend geworden. Durch die Eisenbahnen wird der Raum getötet, und as bleibt uns nur noch die Zeit ubrag ... In vierthalb Stunden reist tnan jetet nad Orléans, in ebensoviel Stunden nach Rouen. Was wird dan erst geben, wenn die L $\mathrm{i}$ nien mach Belgien und Deutschland ausgefihut und mit den dortigen Bathnen werbunden sein werden Mir ist, als kamen die Berge und Wolder alles: Länder auf Paris angeruickt. Ich rieche 
schon den Duft der deurschen Linden; wor meiner Tür brandet die Nordsee." (Geciteerd in Schivelbusch, 1977:38$39 \%$.

$\mathrm{r}_{4}$ Schivelbusch (1977) merkt op dat de topos van de wernietiging wan de ruimte door de tijd wooral betrekking had op de overgeleverde ervaring van een ruimte-tijd-continuäm, een ervaring die voortkwam uit het feit dat verkeerstechnieken organisch met de natruir verweven waren. Juist ondat oude rerkeerstechnieken in een mimetische verliouding stonden tor de doorkruisde ruimte werd de weg van de ene natar de andere platats als een, om met Bergson te spreken, duree ervaren. 'Das Raum-Zeit-Verhältnis, das die Eisenbahn schafft, erscheint gegenüber dem eotechnischen als abstrakt und desorientierend, weil die Eisenbahn in ilurer Realisierung der newtonischen Mechanils all das genau negiert, was den eotechnischen Verkeht charakterisierter sie erscheint nicht mehr wie die Kutsche und die Straße eingebunden in den Landschaftsraum, sondern durch diesen geschlagen.' (Schivelbusch, 1977: 38$)$.

15. "Je mehr die Produktion auf dem Tausclawert, daher auf dem Austausch beruht, clesto wichtiger werden für sie die physischen Bedingungen des Austauschs - Kommunikations- und Transportmittel. Das Kapitall treibt seiner Natur nach über jede räumliche Schranke himaus. Die Schöpfung der physischen Bedingungen des Austauschs - von Kommunikations- und Transportmitteln - wird also für es in ganz andrem Maße zur Norwendigkeit - die Vernichtung des Raums dureh die Zeit." (Marx, r974: 423).

I6 "Moreover, "clock time" should not be accepted simply as an unquestioned dimension of the construction of topographical models, but must be regar- ded as itself a socially conditioned influence upon the nature of the timespace paths traced out by actors in modern socieries." (Giddens, I984: 32 ).

I7 Giddens, 1990: 7 ev.

18 Ibid., p. 16.

r9 "The dymamism of modernity derives from the seperation of time and space and their recombination in forms which permit the precise time-space "zoning" of social life; the disembed" ding of social systems (a phenomenon which connects closely with the factors involved in time-space separation); and the reflexive ordering and reordering of social relations in the light of continual inputs of knowledge affecting the actions of individuals and groups." (Giddens, 1990: 17 )

so Giddens sluit in zijn nadruk op het belang van het onderscheid tussen 'aanwezigheid' en "afwezigheid" aan bij het werk van Heidegger. Zie ook Gregory (r989) en Lash \&. Urry (1994: 23x evi).

21 Giddens, $1990: 17$.

22 De World Standard Time (W/ST) werd ingesteld in oktober 1884 . Op uitnodiging van de president van de Verenigde Sitaten kwamen toen $4 \mathrm{r}$ gedelegeerden uit 25 landen bijeen in Washington D.C. tijdens de International Meridian Conference. Zie ook: Kern ( 983 ), Blaise (2000) en de opmerkingen bij noot 57 .

23 Giddens, $198 \mathrm{r}$ : $x 3 \mathrm{x}$.

24 Giddens, I990: 20. "Time-space distanciation" veronderstelt mechanismen om het handelen dat uit de concrete face-to-face situatie is geheven opnieuw te structureren. Dit gebeurt middels zogenaamde 'disembedding mechanisms' die deel uitmaken van moderne sociale instituties. Giddens bespreekt symbolic tokens (geld) en expert systems. Beide mechanismen züjn gebaseerd op nieuwe vormen van trust. 
25 In The Condition of Postmodernity ( 1989 ) betoogr Harvey dat deze versnelling bepalend is voor wat hij 'tijdruimte compressie' noemt, de ervaring dat de ruinte ineen gekrompen is tot een "global village" en de tijdshorizon zich heeft "verkort' tot een punt waarin alleen nog het heden lijkr te bestaan. Harvey illustreert dit proces van tijdruimte compressie net een afbeelding van een krimpende wereldbol (zie figuur 3.4) (Harwey, 1990: $240 \mathrm{ev}$ ).

26 'The general effect, then, is for capitalist modernization to be very much about speed-up and acceleration in the pace of economic processes and, hence, in social life." (Harvey, 1989: 230).

27 Harvey, $1989: 264$.

28 "The time ir takes to traverse space and the way we commonly represent that fact to ourselves are useful indicators of the kind of phenomena I have in mind". (Harvey, r989: 240).

29 "More emphatically, capitalism became embroiled in an incredible phase of. massive long-term investment in the conquest of space. The expansion of the railway network, accompanied by the advent of the telegraph, the growth of steam shipping, and the building of the Suez Canal, the beginnings of radio communication and bicycle and automobile travel at the end of the century, all changed the sense of time and space in radical ways:" (Harvey, r989: 264).

30 Harvey, $1989: 266$ en 267. Op een vergelijkbare mamier analyseert Harvey postmoderne films als Blade Runner (Ridley Scot) en Himmel über Berlin (Wim Wenders) als uitdrukking van een nieuwe ronde van tijd-ruimte compressie alls gevolg wan de flexibele accumulatue van de jaren zeventig en tachtig van de vorige eeuw.

3x "The turnpikes and canals, the railways, steamships and telegraph, the radio and the automobile, containeri- zation, jet cargo transport, television and telecommunicationis, have altered space and time rellations and forced new material practices as well as new modes of representation of space. The capaciry to measure and divide time has been revolutionized, first through the production and diffusion of increasingly accurate time pieces and subsequently through close atrention to the speed and coordinating mechanisms of production (automation, ro botization) and the speed of mowement of goods, people, information, messa. ges, and the like." (Harvey, r996: 240$24 \mathrm{r}$.

32. Voor vergelijkbare bezwaren tegen het technisch determinisme dat besloten lligt in de metaforiek van de "krimpende wereld' en de 'vernietiging van de ruinte door de tijd besloten ligt', zie Kirsch (1995) en Stein (200r). Ook May en Thrift (200I) gaan uitgebreid in ap het economisch en technisch determinisme wartoe met name Harvey's begrip 'time-space compression' kan leiden. Zowel Giddens als Harvey vatten de scheiding van tijd en ruimte op alls aen historisch proces dat kenmerkend is voor de moderniteit. Voor Thrift (r996) is dit een doodlopende weg. Juist het gebruik van de term moderniteit versterkt het finalistische en technisch-deterministische karakter van beschouwingen over tijd, ruimte en versnelling. Volgens Thrift watten weel sociologen de moderniteit op als 'a period of acceleration, which marks a decisive break with a slower, more stable past, a period of remorselessly constant renewal in which the experience of the ephemeral, the fugitive, the contingent' (Baudelaire) becomes increasingly and jarringly apparent.' (Thrift, 1996: 164). De kritiek wan Thrift op dit moderniteitsbegrip richt zich op de woorstelling van de geschiedenis als een 
proces van voortschrijdende temporele coördinatie, standaardisatie en regelmaat, een proces dat zich bovendien concentreerr in éćn enkel deel van de wereld, namelijk het westen. Temporele precisie, on ten voorbeeld te geven, is volgens hem niet een historisch proces dat een richting heeft isteeds preciezer), maar is sllechits te begrijpen binnen de praktijken waarin die precisie blijkbaar noodzakelijk is.

33 Gontsjarov, $1985: 20 \mathrm{en} 2 \pi$.

34 "Technollogy does not spring, ab initio, from some disinterested fount of innovation. Rather, it is born of the social, the economic, and the rechnical relations that are already in place. A product of the existing structure of opportunities and constraints, it extends, shapes, reworks, or reproduces that structure in ways that are more or less unpredictable. And, in doing so, it distributes, or redistributes, opportunities and constraints equally or unequally, fairly or unfairly.' (Bijker \& Law, r992: $x$ I).

De vooronderstelling dat technologie nooit haar eigen verklaring $k a n$ vormen ligt ten grondslag aan het wetenschaps-en techniekonderzoek in de afgelopen kwart eeuw: Technologieën evolueren niet onder invloed van een noodzakelijke of innerlijke logica, betogen bijvoorbeeld Bijker \& Law, en de vraag is dan waarom ze feitelijk de vorm kregen die ze kregen. "This is a question that can be broken down into a range of further questions. Why did the engineers think in this way rather than that? What assumprions did the engineers, or the business people, or the politicians, make about the kinds of roles that people - or indeed machines - might play in the brave new worlds they sought to design and assemble? What constraints did they think about - or indeed run into - as they built and deployed their technologies? What are the uses - or abuses to which the technologies were put by their users once they were deployed? How, in orher words, did users and their technologies shape and influence furure social, economic, and technical decisions?" (Bijker \& LaW, I992: 3-4). Vragen als deze zijn in het wetenschaps-en techniekonderzoek in uitlopende empirische domeinen onderzocht vanuit drie theoretische invalshoeken, de systeembenadering die door Hughes ( 1983 ) en anderen is ontwikkeld, de actor-netwerktheorie die voor thet eerst werd geformuleerd door Callon ( 1980 ) en later vooral is uitgewerkt door Callon, Latowr, Law en Akrich, en ten slotte de Social. Construction of Technology-benadering Pinch \& Bijker (1987) (zie ook Biijker (1995). Hoewel ik niet expliciet gebruik maak wan het theoretische wocabulaire dat in elk van deze ctrie tradities is ontwikkeld, is mijn boek in weel opzichten schatplichtig aan het conceptuele werk dat hier is verzet.

35 Vance, $1986: 198$.

36 lbidi, p. 198.

37 Swinglehurst, $1974: 8$.

38 - 'my mind's eye has often reverted to the spot - a thought flashed through my brain - what a glorious thing it would be if the newly developed powers of railways and locomotion could be made subservient to the cause of temperance'.' (Geciteerd in Brendon, I99 I: 5). Mijn beschrijving wan de innowaties van Cook is deels ontleend aan Lash \& Urry (I994: $260 \mathrm{ev}$ ) en Urry (1995), die zelf weer gebruik maken van Brendon ( $199 \mathrm{r}$ ), de belangrijkste secundaire bron over leven en werk van Thomas Cook en zijn zoon John Mason Cook. Verder geven Pudney (r953) en Withey (1997) veel informarie over zowel de levenstoop van 
Thomas Cook als de geschiedenis wan zijn firma. Smith ( 2998$)$ biedr een vierdelige reeks reprints wan originule boeken en brochures die door de firma Thomas Cook \& Son werden uitgegeven in de negentiende eeuw. Alting (r998) schreef een geschiedenis van de firma Thomas Cook in Nederland, die begon met de opening wan het eerste kantoor in Amsterdam in 1898 . Tussen $193 x$ en 1989 werkte het bureau in ons land onder de naam WagonsLits/Cook.

39 Het jaar $184 x$ was in meerdere opzichten een milparal in de geschiedenis van het moderne reizen en volgens Lash en Urry zelfs te beschouwen als her begin van de moderniteit als een sociaal-geografisch werschijnsel (Lash and Urry, 1994: 26 I). In Groot-Brittannie verscheen woor het eerst een national spoorboekje, Bradshaw geheten. In York werd het eerste Europese hotel geopend dat deel uitmaakte van het treinstation. Cunard begon een eerste transatlantische lijndienst met stoomschepen. En in Amerika werd The Wells Fargo Company opgericht, die later zou opgaan in American Express (Brendon, $199 \mathrm{x}$ : 12 ).

40 Brendon, $991: 8$.

4x Lash \& Urry, I994: 262.

42 "During the late eighteenth and nineteenth centuries numerous other placemyths developed: They became attached to particular kinds op social space, spaces that could only exist. with large numbers of wisitors (...). The characters of such spaces were premised upon the tourist gaze, that they were to be gazed upon with curiosity by many outsiders who have often travelled long distances to gain a view." (Lash and Urry, 1994: 266).

43 Geciteerd in Brendon, 1991: 54.

44 Brendon, r99 I: 60 en 61 .

45 Brendon, r99 : 80 .
46 Dat aantal koffers was aanzienlij $\mathrm{k}_{\text {, }} \mathrm{ze}$ ker bij langere reizen. Kleedigewoonten van de gegoede burgerij in de negentiende eeuw schreven bijvoorbeeld voor dat men $z i c h$, als eenmaal de bestemming was bereikt, meerdere malen per dag moest kunnen werkleden. (Gregory (r993).

47 Jules Verne's Reis om de wereld in tachtig dagen zou gebaseerd zijn op de excursie van Cook. De dochter en biografe van de Franse schrijver herinnerde zich in haar memoires hoe haar vader langs een van de Parijse boulevards cen folder voor de wereldexcursie zag liggen, achtergelaten door een van de vele toeristen die met Cook $\&$. Son naar Parijs waren gekomen. De folder maakte duidelijk dat dankzij de verbeterde aansluitingen van internationale trein- en scheepvaarterbindingen een res om de wereld nu geworden was tot een uitgebreide vakantie, die niet meer dan drie maanden in beslag hoefde re nemen. Op het moment dar Verne's roman verscheen in feulletonvorm, in het najaar van 1872, was Cook net begonnen aan zijn wereldreis. De herinnering van Verine"s dochter lijkt dan ook onbetrouwbat.

48 Tijdens de tocht over de prairies zag Cook "pratirie fires on all sides, antelo" pes, wolves, and Indians (...)'. De laatsten waren, hoewel tot de tanden gewapend, vriendelijk, schrijft Cook en "gave evidence of friendship by cheers and actions, waving of caps and other signs of mirth'. The Rocky Mountains vielen Cook regen, maar de Sierra $\mathrm{Ne}$ vadia was 'rio mistake'. (Smith, 1998 : 22)

49 'In a week or ten days more we expect to reach the $x 8$ ath degree of longitude, when London will be under our feet, and a day will mysteriously drop from: the callender. But this going round the world is a very easy and almost imper- 
ceptible business; there is no difficulty abour it (...)." Smith, 1998 [band 3]: 23). Ook de eerdere aanhalingen tit de briewen wan Cook zijn ontleend aan Smith (r.998).

50 "It is this way. On reaching the $x$ 8oth dlegree of longitude we are at the antipodes of Greenwich, and London time is 12 hours in adwance. We then take a leap of 24 hours, leaving Greenwich r2 hours in our rear; but crossing the meridian line we put back our time an hour for every $x 5$ degrees, and by the time we weach London the clocks and tume will have righted themselves.' (Smith, 1998 [band 3]: 26).

5i. "I feel that I have mastered the anticipated difficulties of the route; I shall know how to advise inquirers as to time; expense and accomodation of all kinds; and the full details I shall give to the public for the guidance of those who follow as $]$ do not contemplate a second tour round the world. After 32 years of almost incessant travelling, with the view of making travelling easy, cheap and safe for others, I ought to "rest and be thankful" that no evil has befallen me. "(Smith, $1998: 47$ ).

52 Lash en Ury (1994) noemen Thomas Cook and Son "waarschijnlijk de meest indrukwekkende economische organisatie die in het negentiende-eeuwse Groot-Brittannië ontstond' en het georganiseerde kapitalisme van de twintiggste eeuw zou wat hen betreft beter als 'Cookism' dan als 'Fordism' beschreven kunnen worden. (Lash \& Urry, 1994: 26x) Urry heeft geweren op een lange reeks innowaties die Cook aanbracht in, wat hij noemt, de 'sociale organisatie van het reizen". Zie naast lash and Urry, 1994: 261 ook Urry, 1995: 4 4 ev.

53 Het begrip 'passage' is gebruikt door anderen om de gelaagdheid van een transitie of translatie aan te geven. Zo gebruikt Hendriks (2000) het in de betekenis van een 'nieuwe plaats van handeling (...) waar autisten en nietautisten kunnen oversteken". Hendriks verwijst op zijn beurt naar Michel Serres' 'doorgang van het Noord-Westen' die hier een metafoor wordt woor de het overbruggen van de kloof tussen natuurwetenschappen en humanoria. (Serres ( 1980$)$ ).

54 Voor het begrip 'heterogeneous engineer', zie Law ( 1987 ). Law beschrijft de zeereizen van de Portugezen in de vijftiende als het resultat van 'onderhandelingen' tussen de ongelijksoortige elementen in het heterogene netwerk dat hun verplaatsing mogelijk maakte. Van dat netwerk maakten bijvoorbeeld zeilschepen, kennis wan navigatie, maar ook de wind, zeestromingen en de opvattingen wan de koning van Portugal deel uit. "I suggested that "heterogeneous engineers" seek to associate entities that range from people, through skills, to artifacts and natural phenomena. This is succesful if the consequent heterogeneous networks are able to maintain some degree of stability in the face of the attempts of other entities or systems to dissociate them into their component parts. It follows from this that the structure of the networks (or systems) in question reflects not only a concern to achieve a workable sollution but also the relationship between forces that they can muster and those deployed by other forces." (Law, $x 987$ : 129).

55 In die zin vormt het begrip "passage" ook een impliciete kritiek op de "scheiding van ruimte en tijd' bij Giddens. Ruimte en tijd zijn nooit gescheiden geweest.

56 Van der Woud, x987: x6. Mijn keuze voor de definitie van 'orde' door Van der Woud is tot op zekere hoogte arbir- 
rair. In de sociale wetenschappen nemen het begrip "orde" en de wraag naar de sociale orde een centrale plaats in. Zo is theoretisch en empirisch onderzoek gediann naar de produktie van sociale ordeningen (bijvoorbeeld als "figuratie" (Elias) of "structuratie" (Giddens), stijlen van ordenen (bijwoorbeeld Law, r994) en ordes als resultalt wan praktijken (bijwoorbeeld Schatzki, x996; Knorr-Cetina \& Von Savigny (200 I)). Over de samenhang tussen de noodzaak van een nawwkeurige afstemming van tijd en plaats in de bedrijfsvoering van de spoorwegen enerzijds en de opkomst van standaardtijd en een toenemend tijdsbewustzijn in de Verenigde Staten, zie: Landes $(1983)$, Bartky (1989), Stephens (1989) en Blaise $(2000)$. De invloed van de spoorwegen op een uniforme tijdrekening in Nederland is beschreven in Knippenberg \& Nauta (1989).

58 Zie bijvoorbeeld Draaisma, 1993: 8I.

59 Brendon, $199 \mathrm{x}$ : I $5 \mathrm{r}$.

60 Zie bijvoorbeeld Grewall (1996) en Je damski ( 5994 ).

61 "Most travellers hopped from one outpost of the Britsh Empire to the next, with the American dominated Japanese ports (and, for the more adventurous, French Indochina) thrown in." (Withey, $1997: 272$ ).

62 Als de wereldreizigers al landen als Japan en China aandeden, dan zagen ze weinig meer dan de havensteden, waar ze, in het kieizog van Cook, verbleven in luxe westerse hotels, hun aandacht richten op overbekende sights en het contact met de onaangename lokale werkelijkhieid liefst vermeden.

\section{Het de auto naar het park}

I Geciteerd in Withey, $x 997: 335$.

2 Voor historische details over de transi- tie van trein naar auro, zie bijwoorbeeld: Goddard (1994) en Belasco (2982).

Zie: Bellasco (r979). Ook Belasco benadrukt hoezeer de ongebondenheid van de auto als woordeel boven de trein werd gezien. In motoring there were no r A.M. departures, no rushed me:als at some seedy depot lunch counter, and no rude awakenings by an anxious porter at 5:30 A.M. In a "highway Pullman," the driver was his own station master, engineer, and porter, with no one's time to make except his own." (Belasca, 1979: 22).

Wachs ( 1998 ) wijst op het verschijnsel dat de worm van Amerikaanse steden in hoge mate wordt bepaald door de grootte die ze hadden op het moment dat de auto aan invloed won. Oudere steden als Boston en New York hadden al een behoorlijke grootre en beschikten bovendien over goed ontwikkeld stedelijk openbaar vervoer. Anders dan in deze oudere steden is in nieuwere steden als Los Angeles en Phoenix (om slechts twee voorbeelden te noemen) de yorm volledig bepaald door de beschilkbaarheid van autovervoer. Daardoor kenmerken deze steden zich door een veel lagere ruimtelijke dichtheid. Zie ook hoofdstuk 7 ("Transportation: From Animal to Automobile') in Monkkonen (r.888). Voor een overzicht van de bouw en ontwikkeling van de Subway in New York, zie Hood ( 1993 ).

Henry Ford heeft zelf niet het minst biggedragen aan deze opvatting. Zie bijwoorbeeld zijn autobiografie $M_{y}$ Life and Works uit 1922, waarin hi] witeenzet hoe hij zijn ideaall - de motorisering van de Amerikaanse natie planmatig dichterbij bracht. Zie ook Flink (r993) over de historische bete. kenis van Ford woor de Amerikaanse autoindustrie. 
6 Flink, 1993:48.

7 Vance (1986:499) onderscheidt drie periodes warin het autobezit snel groeide: "The first - numerically the least; though relatively the greatest period was from 1908 to $19 \times 3$. Numbers changed rapidly again in the rg 20 's going from 7.5 million in 19.9 to 26.7 millon in 1929. Again in the late 1940 and the late $x 950$ s the figures ballooned rapidly from 37 million in 19.47 to 67 milliom in 1957. "Ling (1990: 125 ) schrijft: 'Registrations in eartier year equalled only 4.2 per cent OC US households but by 1923 registrations had soared to 50.3 per cent of households. Although tialf of the American hougeholds did not possess autonobiles in 1923 according to these figures, President Warren Harding declared that the "noton car has becone an indispensable instrument in our political, social, and industrial life."

8 Schllesinger \& Isracl, I 999: 2.

9 Zie Ling (1990).

1o Goddard (1994) beschrijft bijvoorbeeld hoe spoorwegmatschappijen kunstmatig de prijzen van goederentransport troog hielden voor korte afstanden, wardoor kleine boeren voor het verwoer wan hun produkten naar lokale markten veel geld $\mathrm{k}$ wiijt waren. De auto bood hen en alternatiel verwoermiddel en darmee onafhankelijkheid wan de spoorwegmaatschappijen.

Ir Berger, x979: 1 I 5 .

I2 Kline \& Pinch (1996), Zie ook: Kline (2000).

I) Vance, $1986: 497$.

I.4 Touring in an open car, with meager springs and little padding, on rough roads was an arduous, bumpy, drafty ordeal. All early accounts detail the trial of solt mud, tortuous mountain rocks and grades, perpetual dust, lost directions, and mechanical break- downs. Mud was especially troublesome in the Midwesit just after the spring thaw and in the dry plains after a summer storm." (Belasco, r979: 30).

If 5 Patron (1986).

16 Hokanson ( 1999 ).

17 Vance, 9986508 .

$x 8$ "This semingly simple step brouglut about much-needed amiformity. Some states had no design standards for superhighways; indeed, some lacked even a basic highway design nanual. Standardisation would giwe the Interstates "all known" safety features as Well as "pleasing appearance" " $\left[e^{-}\right.$ wis, $1997: 136)$.

r9 Lewis, $1997: 136$.

20 Lewis, 1997: 137.

2. "The only thing to rival the sameness of the commercial enterprises along the edge of the Interstates was the sameness of the highways themselves. As the states received ninety percent of the money to build these highways from the federal gowernment, they had to conform to federal standards in much the same way chat a restaurant or motel franchise must meet the standards of its parent company. This simple fact in effect makes the Interstate Highway System the largest franchise in Amerim ca. McDonald's and Holiday Inn might be big, but the Interstates are bigger." (Lewis, r997: 285 ).

22 Aan het begin van de rwintigste eeww was geenszins duidelijk dat de elektrische auto het uiteindelijk zou verliezen ran de bezineauto. Voor onderzork naar de strijd tussen de benzine- en eloktrische auto in de Verenugde Staten aan het begin yan de twintigste eeuw, zie: Mom \& Kirsch (2oor).

23 Cohn, $1944: 263$.

24 'Recognition From the road became paramount, and this led to the spread of the franchise business and use of standardized images and eventually 
logos in advertising, both on and offsite." (Willson, 1992: 33 ).

25 "(...) With the rise of corporate America has come a pervasive standardisation of roadsides, a kind of "commonplaceness, "what some commentators have gone so far as to call "placelessness." Roadsides have become so alike across the country that many critics fear that insufficient character exists distinguishing localities from one another: Uakle \& Sculle, r994: ro en $20)$.

26. 'Like jazz music, the auromobile road map is an American innovation and is just as much a part of American culture. Road maps brought much needed order to the national road system. Through both illustration and cartography, they manifest the changes in the American landscape resulting from the twentieth century"s "auto-mobillty. "Their covers promoted a romance of the road that sold gats, oil, batteries, tires, and other products. Most significantly, road maps created a core of American values based on the freedom of the open road.' (Yorke \& Margolies, 1996: 5 )

27 Heimann, I996: 14 . Zie ook: Jakle \& Sculle (x999).

28 'Menus un the early days were simple and limited to food that was quick to prepare and serve. The Pig Stand built its business on barbecued pork and ham sandwiches washed down with Coca-Cola.' (Heimann, r996:22.)

29 'So the McDonald's decided to drop car service and concentrate on a specific menu of ten items that a customer would have to get ont of his car to buy. A production line preparing the reasonalble priced ten-cent burgers, fifteen cent French fries and twenty-cents malts was installed, with paper replacing dishes and fingers replacing silverware. The meal was bagged in a speedy twenty seconds." (Heimann, 1996: ( 4 4). Andere veranderingen waren een niewwe inrichting wan de keuken met stalen meubilair dat snel schoon te maken was, het vooraf bereiden van het eten in afwachting van de klanten en een nieuwe arbeidsverdeling die gebaseerd was op nauwkeurig gesynchroniseerd teamwerk. (Clark \& Staunton, 1989: 96 e.ฬ.).

3o Fastfoodketens als Burger King en Kentucky Fried Chicken streefden in navolging van McDonald's rationalisering en standaardisering na. Ritzer (1996) heeft betoogd dat de vier criteria die volgens hem het succes wan deze ketens bepalen - 'efficiency", 'calculability', 'predictability" en "control" - op tal van terreinen in de economic en thet sociale lewen aan invloed winnen. Dit proces noemt hij de "McDonaldisering van de samenleving". Zie: Ritzer (r996).

3 I Belasco: "Slow, arduous, and close to nature, autocamping revived what tourists imagined to be a more leisurely pace, personal independence, simplicity, and family solidarity of preindustrial times.' (Belasco, 1979: 45) Lackey (1997) wijst erop dat de eerste automobilisten zich met name in her westen van de Verenigde Staten verbonden konden voelen met de pioniers die zich er decennia eerder hadden gevestigd. Alleen in hur auto, overgeleverd aan de weer en wind, konden zij de populaire mythologie rond de 'Fontier' herbeleven, iets wat voor de treinreiziger, gebondien aan ongewild gezelschap, snelheid en vaste routes, niet was weggelegd. (Lackey, $997: 4$ ).

32 "Thus the motel industry was bom. In the late 1920 , as more tourists tired of carrying equipment, cabin operators addled good beds, linen, stoves, and indoor plumbing. During the depression, when many former hotel patrons turned to these low-cost "cottage camps," 
proprietors further upgraded facilities to suit the tastes of these fastidious tra. vellers. By 1945, the "motor court" was sufficiently well established to interest large-seale developers.' (Belasco, 1979:4).

33 Jakle, Sculle, \& Rogers (1996).

34 Jakle, Sculle, \& Rogers, $1996: 36$.

35 Jakle; Sculle, \&ogers (1996) merken op dat in de motelindustrie ketenvorming en franchising relatief latat op gang kwamen, pas vanaf de jaren zestig, dus beginnend met de bouw van het rus. Tot die tijd was het motelbedrijf rooraleen 'mom-and-pop' aangelegenheid. Uitzondering wormden ketens als Alamo Plaza, dat al in de jaren veertig een keten van motels exploiteerde (waarvan er nog een aantal bestaat in $z^{7}$ oorspronkelijke vorm), en vanaf de jaren wijftig later Holiday Inn.

36 Flink, r993: 304.

37 "Although the design had its flaws - the oversized windows leaked energy and noise, the bathrooms were minuscule, the flat roofs allowed snow and rainwater to accumulate - it brought a new level of sophistication and modernity to the motel industry." (Jakle, Sculle, \& Rogers, 1996: 270 )

38 Geciteerd in Belasco, 1979: 8. "Everything is good on the highway, schreef Emerson in zijn essay Experience ( 1844 ). Voor een analyse van de omgang van de Transcendentalisten met de symboliek wan de weg, zie met het hoofdstuk "Transcendental Motoring" in Lackey ( 9997 ).

39. We have vowed to curb this impulse. Just why a person should travel miles to see Niagarn Falls only to remain about one hour and fail to get a full ap. preciation of this wonder of nature, is more than I can understand. Yet we have all been guilty of this wery thing." (Belasco, I 979: 87.)

40 Gastells (r996) spreekt van een 'space of flows', een nieuwe ruimte die de topologie heefr wam cen netwerk. In deze netwerken verdwijnen plaatsen niet, maar ze ontlenen hum identiteit aan hun plaats in het netwerk. "By flows I understand purposeful, repetitive, programmable sequences of exchange between physically disjointed positions held by social actors in the economic, political, and symbolic structures of society." (Castells, I996: 4r2).

$4 \mathrm{I}$ De uitdrukking "gedwongen tempo" ontleen ik aan. Vermij (200I) die haar gebruikt een studie naar de introductie van de lopende band in Nederland.

42 "Central are messages communicated through standardization: sameness of promised product and service playing out in the sameness of building form and styling as sign system. Each place in a network must be easily anticipated by the knowing consumer. Surprise enters only through the drift of carefully calculated change intended as difference in sameness.' Jakle \& Sculle, 1994: $19-20)$.

43 Shields (r99r): "As 'guiding metaphors' these were argued to provide at set of rules of conduct and procedurefor practices and regimes of thought.' (Shields, r99 $1: 256)$.

44 Wallis (1993). Zie ook: Yorke \& Margolies (1996).

45 Over de cultuurhistorische achter grouiden van de 'road movie', zie: Eyerman \& Löfgren (1995) en Cohan \& Hark (r997).

46 Zie bijwoorbeeld Lackey (r997). Over de 'blue highways', zie Least Heat Moon (1984).

47 Kunstler (1994).

48 Over de wormgeving van de Anerikaarse nationale parken, zie: Carr (1998), Flint Mcclelland (1997) en Sellars (r997).

49 Runte, $1990: 17$.

50 Voor de geschiedenis van de spanning 
russen natururbehoud en toerisme, zie: Mash (1982) en Hays (r987).

5 "Along with orher prominent preservationists, Mather welcomed the automobile in the parks: he recognized the potential polinical power of the automobile industry, automobile clubs, and the growing number of automobile rourists. A broad base of popular support was deemed essential to the parks both to obtain adequate congressional funding for development and maintenance, and to thwart the mounting pressure for the exploitation of park resources from commercial in rerests and other governmental agencies." (Flink, $\times 993: \times 72)$.

52 Plink, 1993: 173 .

53 Flink, I990: 173.

54 Ciar, r998: 4.47 .

55 Flint McClelland, $1997: 162$.

56 Flint McClelland maakt aamemelijk dat deze ontwerpethiek teruggat tot de teksten van de negentiende-euwse tuinontwerper Andrew Jacksion Downing, wiens ideeen de fllosofische basis vormden voor "for preserving Ameri" $c$ a's natural areas and translated the idea of "wilderness", as evocative of the sublime and picturesque, into design tems:" (Flint MeClelland, 1997 : xo).

57 Flint McClelland, $1997 \times 175$.

${ }_{5} 8$ 'Lying Lightly on the Land' is ook de titel van een tentoonstelling over de aanleg wan parkways en parkwegen, georganiseerd door de swes en de Historic American Buildings Survey/Historic American Engineering Record. De expositie kan ook on-line bexocht worden: hrtp//www.n.nps.gow/habshaet $/ 11 /$

59 Flint McClelland, $1997: 178$.

60 Carr, $1998: 92$.

6in "The public was as vitul to the succes of mational parks as was the scenery; without people there were no parks, only wild regions of public domain, which, as snch, were easily subject to other forms of ownership and exploitation. The picturesque alchemy that slufted lands into valued landscapes - still the principal mechanism of scenic preservation in the early $20^{\text {th }}$ century-occured through shared public experiences of landscape beaury. The expansion of this phenomenon on an national scalle depended on large numbers of people being able ro reach national parks affordably. (Cari, $9998: 86)$.

62 Dit deel van min onderzoek is behal. ve op eerder genoemde secundaire literatuur gebaseerd op primaire bronnen uit de National Park Service History Collection in Harpers Ferry, Virginia. Daarnaast gebrük ik inteniews met Ethan Carr (Park Historic Structures and Cultural Landscapes Program, NPS), Tim Davis (Historic American Buildings Sutvey/Historic American Engineering Record) en Dawid Nathanson (NPS History Collection, Harpers Ferry Center, Harpers Ferry, Virginial.

63. Vance, 1986: 499.

64 "National Parks are very democratic vacation spots. They are not wery expensive. It's probably the least expensive option for most Americans for vacation: In the East it's not necessanily that way because you would have to Ay west, but in the West and much so in California, really the cheapest way to go on vacation was to pile the kids in the station car and driwe to the $\mathrm{Na}$ rional Park. Gasoline is cheap, there"s no tolls on the road. There are entrance fees, but they are modest. And you camp, which is nexpensive. This begins in the 1920 , when parks become tremendously populat, because they are affordable. Before the atutomobile, they were very expensive. people had to take trains, stay in hotels. It was an 
experience reserved for people with money. [Iriterview Ethan Carr, 2000]

6.5 De Voto schreef: "The national park system must be temporarily reduced to a size that Congress is willing to pay. Let us, as a beginning, close Yellowstone, Yosemite, Rocky Mountain, and Grand Canyon National Parks close ans seal them, assign the Army to patrol them, and so hold them secure till they can be reopened. "De Voto, B. (r953). 'Let's close the National parks'. Harpers's Magazime. October $\times 953$, p. $49^{-52}$.

66 Om enkele te noemen: Holly, H. "National Parks Need \$\$ and Sense". Woman's Home Companion. May 1955. p. I3-x5; Netboy, A. "Crisis in Our Parks'. American Forests. May 1955 , p. 24-27; Stevenson, C. "The Shocking Truth About Our National Parks". Reader's Digest. January, 5955, P. 45so.

67. Wirth: 'The public is loving the parks to death'. Zie Sellars, 1997: I $8 \mathrm{r}$.

68 "If reasoned that orher bureaus, such as the Bureau of Public Roads, the Bureau of Reclamation, and the Army Corps of Engineers got money year after year. They had big projects, such as dams and long highways, to construct that couldn't possibly be completed under a single annual appropriation or even in two or three years. That was it. Our projects were relatively small ones that could be cut out of the budget because they were not sufficiently appealing to the committees that reviewed our request. But if we included one all-inclusive, long rerm program for the entire park system, it would mean a complete review and some major policy changes by Congress.' (Wirth, I980: 239).

69 Eisenhower vroeg zelfs warom het voorstel niet al veel eerder was gedaan, namelijk bij zijn aantreden in 195,3 . [Bron: Verslag van de Cabiner Meeting op 27 januari 1956 . National Park Service History Collection RG 23, Preliminary Inventory, Folders: Series IHigher Echelon.]

70 'Our interest in the national parks goes back to the beginning of the park system when we were succesful in having the park areas opened to the motoring public. How do we preserve these areas and at the same time provide adequately for their use and enjoyment? This would seem somewhat of a contradiction. Nevertheless we think it can be done, and we think it must be done." 'Pioneer Dinner Launches Mission $66^{\circ}$. National Parks Magazine, April- June $x 956$, p. 59-60.

$7 I$ Wirth was zelf nauw betrokken bij de kleinste details wan de zorgvuldig opgezette promotiecampagne voor Mission 66. Hij ontwierp persoonlijk de omslag van de brochure over het programma met de titel Our Heritage. We zien cen all American family - vader, moeder, zoon, dochter - over een foto van de Liberty Bell.

72 'The National Parks are neither equipped nor staffed to protect their irrepllaceable features, nor take care of the increasing millions of visitors,' Bron: Our Heritage, (1956) p. 5. (National Park Service History Collection in Harpers Ferry, Virginia).

73 "The primary impetus for the national park general development plan, as expressed by Albright in 1925, was to assure that the vast majority of every park would be free of automobiles and the intenswe uses implied by such accessability. The master plan of a national park therefore implied zoning the entire park for different levels of use, fron the most intensively developed areas (the road corridors) to entirely inaccessible portions of the back country where even trails were prohibited." (Carr, r998: 197). 
74 "This idea became the fundamental principle of Wirth's Mission 66 program: in effect, if visitors were going to use certain areas, prepare for this by improving roads, trails, and park facilities that would limit the impact to specified areas. Public use would be contained, leaving alone the undeveloped areas of the parks. As Wirth stated in his annual report of 1956 , park development was "based upon the assumption" that "when facilities are adequate in number, and properly designated and located, large numbers of visitors can be handled readily and without damage to the areas. Good development saves the landscape from ruin, protecting it for its intended recreational and inspirational walues." (Sellars, 1998 : 18 r).

75 Een kleurige brochure uit $x 957$, The National Park Wilderness, anderscheidde verschillende soorten wilder" nis, waaronder wat werd genoemd 'accessible wilderness, available within a ten-minute walk from many park roads, or where visitors could "see, sen$\mathrm{se}$, and react to wilderness, often without leaving the roadside.". (Sellars, 1998: 187 ).

76 'As. Mission 66 planners prepared for a decade of development in the parks, skyscrapers and high-density housing replaced historic buildings and familiar neighborhoods. For the majority of the population in positions of political power, downtown highrises and business centers anticipated a better, more efficient lifestyle for all Americans. The forces at work - capitalism and a sociery obsessed with progress were prevalent throughout the count$r y$; it was only a matter of time before they would enter the national parks.' (Allaback, 2000: ro).

77 Allaback, 2000: 21.

78 "Like the shopping center, the visitor center made it possible for people to park their cars at a central point, and from there have access to a range of services or attractions. Earlier "park willage" planning had typically been more decentralized, with different functions (museum, administrations building, comfort station) spread out in an arrangement of individual, rustic buildings. The Mission 66 visitor center brought these activities together in a single, larger building intended to serve as a control point for what planners called "visitor flow," as well as a more efficient means of serving far larger numbers of visitors and cars in a more concentrated area." (Allaback, 2000: 24).

79 'Wirths program was confronted by the rising power of the conservation movement, whose leaders could take their case directly to the public and to highlly placed politicians, widely broadcasting disapproval of national park management.' (Sellars, 1998: 185 ).

80 Sellars, $1998: x 86$

8 II 'An artical in National Parks Magazine declared that inappropriate Mission 66 development made the parks seem "urbanized." It claimed that "engineering has become more important than preservation," creating wide, modern roads similar to those found in state highway systems and visitor centres that looked like medium-sized airport rerminals. (...) The modernism of Mission 66 seemed particularly jarring when compared to the log-and-stone rustic architecture of earlier park structures designed to harmonize with surrounding landscapes. In many ways the rustic structures recalled the frontier and the days of "leddy Roosevelt as if to suggest a primirive America that the parks represented, rather than the urban America symbolized by the standardized designs of Mission 66." 
(Sellars, 1998: 86 en $\times 87$ ) Zie ook: Fint MeCleiland, $1997: 47 x$ en 472 .

82 De notie wan "intermediary landscape" sluriran bij een weetal andere begrippen die het hybride en geconstrueerde karakter van deze landschappen willen aanduider. De eerste is "middle lands. cape vari Leo Marx ( 1964$)$, en landschap 'tussen' het negentiende-ceuwse pastorale ideal en de stedelijke, technologische wereld die werd gesymboliseerd door de trein. 'Middle land" scapes' hebben zowell een narratieve als een materièle component. Shields (199 r) gebruikt het begrip "liminality" om an te geven dat deze platsen en landschappen zich in meerdere opzichten bevinden op de drempel. In het voorbeell van de Engelse badplats Brighton is dat bujwoorbeeld de drempel tussen land en zee, tussen werk en vitie tijd, maar ook wissen werschillenda sociale en morele gebruken en codes. 'Intermediary landscapes'zouden ten slotte opgevat kunnen worden als wat Star \& Griesemer (1989) boundary objects" hebben genoemd.

83 Nye (1997) wijst er terecht op dat "natuurlijke" toeristische bestemmingen als de Nationale Parken altind het produkt zujn geweest wan het samengaan wan technologieèn van tramsport en representatie. "The visual conventhons we use to understand the lands. cape] emerged from painting and photography and were made universal by advertising and film. The towist arrives with preconceptions. There is no innocent eye. Even if a site be regarded primarily as an unspoiled natural view, it is always seen through the lens of a powerful visual culture." (Nye, 1997:5).

84 [Landscape designers] designed curves that restricted speeds to thiry-five or forty miles an hour and placed those curves in way that organized the long looks. Since the road follows mountain crests for most of its length, distant wews tend to be wiews down over deep walleys and countless ranges. receding into the blue distance. Motorists feel like they are at the top of the world, and they share this new uniwerse with the car. "The designers have organized this national public landscape around the private car and the private comsumption of nature." (Wilson, 1992: 36 ).

85 Deze uitdrukking dank ik aan Rein de Wide.

86 Urry (r990) heeft dit verschijnsel, Waarbij toeristen zoeken naar de originelen van overbekende afbeeldingen, beschreven als de "toeristische blik".

87 'This llogicl includes the design of entrances, the display of information, the control and direction of traffic patterns, and the regulation of the positions of visitors - in general, modes of organizing wision through the presentation of objects and spaces for what we can call the "museological" gaze" (Patin, 1999:48). Voor een vergelikbare benadering van de vistualiseringstechnieken in de parken, zie: Grusin (1995).

88 Patin, r999:55-56.

89 "This means that each person will only spend a few moments gazing at the scenes and objects that the Imagineers have created. As a result, Disney can control the amount of time that each person expends on the atraction so that large numbers of people can be allowed to access it. The fact that these are rides also means that visitors experience such attractions in the same way. Each person will see the same as everyone else so that the experience of many heme pank atractions is controlled and thereby standardized"." (Bryman, 1995: 100 ):

90 Nye, 1997: 2:. Nye merki verder op 
dat visuele technieken als het IMAXtheater bij de Grand Canyon het voor bezoekers mogelijk maken om in korte tijd een natuurervaring op te doen die anders het maken van lange wan. delingen zou vergen. Het gevolg is, schrijft Nye, dat weel wan hen de Grand Canyon beschouwen zo niet als een door mensen gemaakte attractie. 'Their characteristic questions, recorded by park staff, assume that human beings either dug out the Canyon or that they ought to improve it, so that it might be viewed more quickly and easily. There are repeated queries for directions to the (non-existent) road, elevator, funicular, train, bus, or trolley donw to the bottom.' (lbid.)

\section{Op tifid in de lucht}

I Bij de KLM startte in 1999 een project 'On Time' om de werknemers in alle geledingen extra attent te maken op het belang van het tijdig vertrek van vluchten. Gert Mooin, projectleider van het On Time projeet bij KLM: 'In ons team, dat bestaat uit specialisten wan Ground Services, Cabin Crew, Flight Operations, Engineering \& Maintenance en Operations Control hebben we gekeken naar de hele keten van vluchtuitwoering. Bovendien zijn we we nagegaan in hoeverre het samenspel tuissen de verschillende onderdelen daarim op detailniveau een rol speelt. Er is nauwkeurig opgeschreven wat er nu precies gebeurt in de tijd dat een vliegtugg aan de grond staat en hoeveel tijd elke activiteit in beslag neent. Dus; hoe lang duurt het voordat de passagiers zijn uitgestapt, hoe werken de schoonmakers, wanneer komt de catering aan boord? Uit die inventarisatie bleek dat het om een gigantische hoeveelheid activiteiten gaat.
Kritische en minder kritische, want een aancal is afhankelik wan elkaar en heeft kop'staart verhoudingen. Zo kan bijwoorbeeld de schoonmaak ploeg pas aan boord als alle passagiers zijn nitgestapt." (occ Nieuws, september r $999, \mathrm{p}, 2)$

2 Hoofdstuk I van Mom [et.al.] (xg99) geeft een gederailleerde moose beschrijwing van de processen en gebeurtenissen die vooraf gaan aan het vertrek van een vliegtuig.

"The paradox of efficiency means that as the wreb tightens it grows more vulnerable to small disturbances - disruptions and delays that cascade through the system for days. (...) In the most extreme case, everything depends on everything else. Vibrations anywhere can be felt everywhere.' (Gleick, I999: 223-224).

4 Met de witdrukking 'follow the acrors' maken wetenschaps- en techniekonderzoekers zoals Collins en Latour duidelijk dat de etnografische onderzoeksmethode niet uitgaat van vooraf vastgestelde verklarende begrippen en categorieën op grond waarvan empirische bevindingen worden geinterpreteerd, maar dat omigekeerd de actor wordt beschouwd als de expert en de onderzoeker probeert het perspectief van de actoren te beschrijwen en te begrijpen. Zie voor een klassiek geworden voorbeeld Latour \& Woolgar (1979).

5 Deze paragraaf is gebaseerd op veldonderzoek bij de KLM in april 2000 in de vertrekhal 2 waarbij ik medewerkers wan de affeling Departure van Passenger Services heb gevolgd. De namen van alle genoemde personen zijn pseudoniemen, Gesproken citaten, 20 wel de op zichzelf staande fragmenten als opmerkingen in de lopende tekst, zinn transscripties wan bandopnames wan interwiews en gebeurtenissen. 
6 De k1M gebruikt codes om bedrijfsonderdelen aan te duiden. De letter 5PL staan voor Schiphol, dan volgt een aanwulling dic her bedrijfsonderdeel nader bepaalt, in dit geval ' $\mathrm{Fx}$ '.

7 Ku.M beschikt op Schiphol over Europese lounges en de Intercontinentale lounges, beide in twee kwaliteitsklassen, Royal Wing (meeste voorzieningen) en Business Class. De lounges bieden een verscheidenheid aan voorzieningen woor de wachtende of overstappende passagner: gratis hapjes en drankjes, kranten en tijdschriften, ligbanken (Royal Wing), werkplekken, douches (Royal Wing) etc. In de Royal Wing lounge is bovendien een post van de Ticket Office aanwezig waar passagiers hun tickets kunnen wijzigen.

8. Hoe eerder duidelijk is of en welke passagiers ontbreken, hoe sneller men kan reageren. Om die reden wervroegde de Ki.M de tijd dat een passagier zich bij de gate moet melden met tien minuten (early boarding). Meer tijd geeft meer ruimte on te handelen en toch binnen de dienstregeling te blijven. Het voortdurend inbouwen van 'buffertijd' in processen heeft ertoe geleid dat een wlucht tussen Amsterdam en Londen nu een uur en twintig minuten duart, even lang als toen in r 947 een propellerwliegtuig de dienst onderhield.

'Indeed, dependabilitity, regularity, and something approaching yeat-round service were unique fearures of the new innovation. The ordinances under which the trekschuiten operated stipulated the exacr time of their departure and the maximum duration of their trips. Bells rung were rung to announce the departure time, and foreign observers frequently marvelled at the fact that the barges actually obserwed their published schedules.' (De Vries, r98r: 24). Voor historische details over het systeem van trekschuiten in de lage landen, zie ook: Vance $(1986)$.

Io Beniger (1986).

Ir 'Control of each train became centralized in its conductor, who had standardized detailed programs for responding to delays, breakdowns, and other contingencies, who carried a watch synchronized with all others on the line, and who moved his train according to precise timetables. The conductor controlled all operations between origin and destination, including those of the engineman and the brakeman on each car, from his platform outside the first car of the train." (Beniger, r986: 225).

$x_{2}$ Ibid.

I3 Carey, 1992:2 33 .

II 4 Pope (200r) geeft een uitgebreide beschrijwing van dit controlesysteem aan de hand van wat bekend werd als "The Clayton Tunnel disaster" in $r 86 r$, waarbij twee treinen op elkaar botsten in een tunnel om dat de communicatie, per telegraaf, tussen twee baanwachters faalde. Deze ramp vormde voor Charles Dickens de anleiding voor thet schrijven van "The Signalman'.

I.5 'By $1868,21,75$ I milles of line had been set up in Great Brittain transmitting over 6 million messages a year, from $338 \mathrm{r}$ points open to public, often at railway stations. The service had proved its worth in all manner of situations, as an aid to police work, as a means to get news rapidly in print and, most especially, as an essential adjunct to tailway operation." (Thrift, $x 990$ : $469)$.

I6 "Although organizational control demanded that responsibility be formally divided and power distributed, McCallum believed, the general superinterdant retained responsibility for system-wide control, which he saw as dependent on four informationall ca- 
Pabilities: $(1)$ "The means of knowing wherher such responsibulities are fathWally executed"; $(2)$ "great promptness in the report of all derelictions of duty, that evils may at once be corrected"; (3) "such information, to be obtained through system of danly reworts and checks that will not enbarris principal officers, nor lessen them influence with their subordinates"; and $(4)$ "the adoption of a system, as a whole, which will not only enable her General Superintendant to detect erross immediateby, but will also point out the delinquent" (Beniger, 1986:229).

r7 Beniger, $1986: 237$.

I8 Hoe zorgen we ervoor dat de dienstregeling van de KLN zo stipt mogeligk wordt uitgevoerd en hoe vangen we eventuele werstoringen van de dienstregeling zo goed mogelijk op? Die vaag staat central bij het Operations Control Center (acc). Het gebouw warin het $\mathrm{occ}$ is gevestigd werd in september 1999 geopend. De bouw en inrichring kostten r2o miljoen gulden. Het ligt op Schphol-Oost, het gebied langs de Haarlemmer trekvaart wat de luchthaven ooit is ontstan en dat nu plats bied aan tal wan luchtvartgerelateerde bedrijven. Het occ heef naast de zogenaande Backoffice een Frontoffice waar men die zich bezighoudt net de processen op het miveau van het totale WM-netwerk op de dag van uityoering. Min beschrijwing van het werk wan her $0 \mathrm{CC}$ is gebaseend op een veldonderzoek in juni 2002 , waarbij ik behalve van mijn eigen observaties gebrimk heb gemaakt wan interne KaMpublicaties. Hier ook hier geldt dat de namen van alle genoemde personen pseudoniemen zjin. Gesproken citaten, zownl de op zichzelf staande fragmenten als opmerkingen in de lopende tekst, zijn transiscripties van bandop names van interviews en geburtenissen.

19. In de luchwart wordt gebruk gemakt van de Coordwated Uhwersal Time (uTch de internationale standaardmid. Deze term wordt tegunwoordig gebruikr woor wat vroeger bekend was als de Greenwich Meridian The (GMT) en wordt doorgaans aangeduid als "Zuhu". Standaardtijd is gebaseerd op de 2 -utursklok, dus vier unir 's middags wordt geschreven als: 16:00 wur UTC. Wanmeer een precisie wan minder dan een seconde nodig is, wordt ondersheid gemankt ussen UTC en UTI, die gebaseerd is op de rom tatie wan de arde zoals dit astronomisch wordt vastyesteld. UTr, gebruikt voor astronomische warnemingen en voor mavigatedoeleinden, wordt beinwhed door kleine variaties in de rotatie van de arde. Linternationale afspraken is vastgelegd dat de a fwijking tussert UTC en UT niet groter mag $z i j n$ dan 0,9 seconden. Eens per jaat of an. derhalf jaar word darom een "schrikkelseconde" toegevoegd anu urc.

"Bloktijd" wil zeggen de tijdsperiode thisen het moment dat het vliegruig vertuekt van de gate, ell op weg gat naar de sturtbaan (of blocks) en het moment dat het vliegtuig stilstaal op de gate van de bestemming (on blocks).

$2 x$ In Brussel bevind zich de Gentra: Flow Management Unit, een centraal organ dat het lwchrwerkeer in heel Luropa coördineert. Hier worder de vertrektiden voor alle vertrekkende wiegtuigen op alle luchthavens met die computer berekent en afgegeven. Deze zogenaande "slots' zijn binderud.

22. De wulkaan Guagua Pichincha makt deel uit wan het Andesgebergte en is gersitueerd op tien zeemiflen westelijk van de intemationale luchthaven van Quito.

23 Erops staat noor "Extended-Range 
Twin-Engine Operations:. Elke vliegmaatschappij heeft cen ETops-status die wordt uitgegeven door de internationale luchwartautoriteiten. De ETOPS-stanus is gerelateerd aan Flight Planning, training van de bemanning, training van het technisch personeel, wiegtuigoperatie, cerrificatie, wetgeving ete. Een hoge ETons-status is gewild omdat dan in de regel kortere routes gewlogen kunnen worden.

24 Suchman ( 1987$)$.

25 "By situated actions I mean simply actions taken in the context of particular, concrete circumstances. In this sense one could argue that we all act like the Trukese, however some of us may talk like Europeans. We must act like the Trukese because the circumstances of our actions are newer fully anticipated and are continuously changing around us. As a consequence our actions, while systematic, are never planned in the strong sense that cognitive science would have it: Rather, plans are best viewed as a weak resource for what is primarily ad hoc activity. It is only when we are pressed to account for the rationality of our actions, given the biases of European culture, that we invoke the guidance of a plan. Stated in advance, plans are necessarily vague, insofar as they must acconodate the unforseeable contingencies of particular situations, Reconstructed in retrospect, plans sysrematically filter out the particularity of detail that characterizes situated actions, in favor of those aspects of the actions that can be seen to accord with the plan." (Suchman, 1987: ix).

26 'The situation of the user comprises preconceptions about the nature of the machine and the operations required to use it, combined with the moment by moment interpretations of evidence found in and through the actual course of its use.' (Suchman, r987)
27 Her inprowiseren door kunstenaars is door een aancal onderzoekers gebruikt als cen manier om nieuwe strategieêtn te ontwikkelen voor het sturem en veranderen van organisaties. In plaats wan improviserend handelen door werknemers zoveel mogelijk re beperken door het aanreiken van strategische planning, besturingsprotocollen en vasthiggende regels, zou het vermogen tot inproviseren juist gezien moeten wordden als een belangrijke bron van wernienwing De manier waarop dat wordt woorgesteld hangt af van welke definitie van improvisatie wordt gegeven en in welke context het begrip wordt gebruikt. Zie Crossan, Lane, White \& Klus (r.996) en Crossan (r.998).

28 "There is a freshness, a certain quality, which can only be obtained by improvisation, something you cannot possibly get from writing. It is something to do with the "edge". Always being on the brink of the unknown and being prepared for the leap. And when you go out there you have all your years of preparation and all your sensibilities and your prepared means but it is a leap into the unkmown.' (Barretr, I998: 606).

29 Moorman \& Miner ( 1998 ).

30 Ciborra, 1999: 84. Zie ook: Ciborra, C. (2000). Moods, situated action and tirne. A new study of improvisation. Paper presented at the $24^{\text {bis }}$ Information Systems Research Seminar in Scandinavia.

31. Ciborra, 1999:92.

32 "For example tools and artefacts which populate the task environment, such ats workstations, pencils, deskiks etc. are always annotated, if not "re-invented" (De Certeau, 198,4 ) with personalized adaptions, such as "hacks", "macros" and a plethora of "add-ons". (...) More subtly, Scribner ( 1984$)$ suggests that practical thinking and improwisation 
take place through sophisticated processess by which the rask environment and its affordances (people, artefacts, information) (Gibson, r997) are internalized into problem setting and sol. wing. To the point that even written, formal instructions are interpreted by experienced workers not as a (preplanned way to solve a problem or execute an action, but as an "input to an, as yet; unspecified problem" to be adressed." (Ciborra, 1999: 84). Dit be grip heeft een verwantschap met het door andere auteurs gebruikte begrip 'bricolage' dat ontleend is aan LéviStrauss die in zijn boek Pensée saturage $\left(x 6_{2}\right)$ het beeld van westerse wretenschap (rationeel, planmatig) contras. teert met nilet-westerse kennisverwerwing die uitgat wan wat toevallig voorhanden is.

33 Een fuga is een polyfone muzikale vorm waarbij een aantal zelfstandige stemmen in een onderlinge wisselwerking wordt gevarieerd.

34 Bij een bank-line wordt niet voor elke balie een rii gevormd, maar een enkele rij voor alle beschikbare balies in een balierij. De passagier die aan de beurt is wordt geholpen door een balie die op dat moment vrij is. Dir heeft als voordeel dat men niet meer in de werkeerde rij kan staan'. Her systeem is overzichtelijker en rechtwaardiger dan wanneer elke balie een eigen wacherij heeft.

35 Suchman beschrijft deze spatio-temporele ambiguïteit van controlecentra alswolgt: "Centres of coordination are designed to maintain two contraclictory states of affairs. On the one hand, to function as centres requires that they accupy a stable site to which participarts distributed in space can orientate, and which at any given moment they now how to find. At the same time, to coordinate a system of widely distributed activities, personnel within the site must somehow have access to the situation of others distant in space and time. A job of technologies in such sertings is to resolve this contradiction through the reconfiguration of relevant spatial and temporal relations. (Suchman, 1993: $\times 15$ ). Suchman ontleent het begrip "centre of coordination' op haar beurt weer aan Garfinkel $(1967)$.

36 Een "reverserdeur" is ten onderdeel in de motor dat de straalstroom aan de achterzijde van de uitlaat schuin naan voren afbuigt, hetgeen een remmend effect op her whiegning heeft.

\section{Het recht van ute snelste}

1 Nog in 1960 werden in ons land evenveel kilometers op de fiets afgelegd als in de auto, maar vanaf dat moment is het antal autokilometers vertienwoudigd en liep her aantal fietskilometers. wat terug. (Bron: CBs). De invloed van de auro op de ruimtelijke planning in steden is onderwerp geweest van talloze planologische en geografische studies. Provonst (x996) beschrijft de debatten rond stedelijke (auto)mobiliteit in. Nederland en het gebied rond Rotterdam. Een klassieke Amerikaanse studie is Jacobs (196x). Voor recente Amerikaanse voorbeelden, zie Holtz Kay (r997) en Safdie \& Kohn ( 1998 ). 2. De eerste verkeerslichten in Amster dam stonden op het Leidseplein en werden op 17 oktober 1932 in gebruik genomen. Deze verkeerslichten werden centraal angestuurd vanuit thet Bureau Verkeerswezen op de Overtoom. (Niewold, \& Paarlberg, 1997: 9).

3 Grote stedien als Amsterdam, Rotterdam en Den Haga beschikken wel over een verkeerscommandokamer van 
waartit alle stoplichten in de stad aangestuturd kunnen worden en waar het verkeer op drukke punten in de gaten wordt gehouden met camera"s. (Niewold \& Paarlberg (1997)).

4 Sernett (1994).

5. Deze Locomotive Act, ook wel Red Flag Act genoemd, schreef voor dat zelfuoorbewegende ("locomotive") voertuigen door tenminste drie persomen bediend moesten worden, van wie een met een rode wlag vijftig meter voor het voertuig uit moest lopen om het tegemoetkomende verkeer te waarschuwen en te helpen om geschrokken paarden weer in bedwang te krijgen. De twee anderen hielden zich respectievelijk bezig met stoken en sturen. De wet werd in 1878 geammendeerd (de rode wag was niet langer verplicht, maar er moest nog wel. iemand voor op lopen) en in 1896 weer ingetrokken.

6 Uiteraard vielen ook daarvoor doden en gewonden in het verkeer. Berman (1983) geeft aan dat de onmacht van de voetganger in het drukke stadsverkeer al door Baudelaire werd beschreven: " I was crossing the boulevard, in a great hurry, in the midst of a moving chaos with death galopping at me from every side." "The archetypal mo" dern man, as we see him here, is a pedestrian thrown into the maelstrom of modern city traffic, a man alone contending against an agglomeration of mass and energy that is heavy, fast and lethal.'(Berman, r.983: I 59).

'The accident illustrated all the problems of introducing autos into crowded city streets. Drivers like Smith resented hawing to drive at less than top speed and thought of the streets as arteries for travel. (...) The debarking trolley passenger, Bliss, thought of the street as a walkway Not surprisingly, it never occured to him to look. (McShane, 1994: 773 ).
8 Zie McShane, 1994: 185 e.v. Eno bllikt zelf terug op zijn innowaties in Eno (1939).

9 De strijd tegen het lawaai van autoclaxons in grote Amerikaanse en Eu ropese steden vormt hier een belangrijke context. Door verkeersstromen ordelijk te laten verlopen middels (stille) visuele tekens en materiêle obstatkels was het voor automobilisten miet langer nodig het gevaar wan een aaryrijding af te wenden door te toeteren, zo luidde de achterliggende redenering. Zie: Bijsterveld ( $200 \mathrm{r}$ ).

ro "It was easier to call for stronger parental authority than to build safer cars, and easier to ban city children from neighborhood streets than to restrice traffic.' (Belasco, 1986 : 116 ).

II Baldwin (1999), met dank aan Frank Geels die me op dit boek attendeerde. Over de Progressive Movement en de auto, zie ook Ling (1990).

If Le Corbusier, r 994: 220 ev. Berman ( 1983 ) schrijft dat de ideeën van lue Corbusier voortk wamen uit een persoonlijke ervaring in de zomer van 1924 toen hil tijdens een avondwandelingetje van de straat werd gereden door het autoverkeer. Geschokt vergeleek hij de straten (en de stad) wan zijm middelbare leeftijd met dic uit zijm jeugd, "the road belonged to ws then." (Berman, $1983: 165)$. Een aantal weken later maakit Le Corbusuer een gewaagde gedachtesprong. In plats van de alomtegenwoordigheid van de auto af te wijzen omdat zij de ruimte wan voetganger bedreigt, moet die voet ganger zelf in een auto gaan rijden. "The man in the street will incorporate himself into the new power by becoming the man in the car." (Ibid.: 167 ). Deze 'nieuwe mens' heeft een 'nieuw soort straat" nodig die een "verkeersmachine' zal zijn. "In this street, as in the modern factory, the best equipped 
model is the most thoroughly automated: no people, except for people operating machines; no unarmored and unmechanized pedestrians to slow the flow. "Cafes and places of recreation will no longer be the fungus that eats up the pavements of Paris." In the city of the future, the macadam will belong to the traffic alone." (Ibid.: $\times 67$ ).

I3 Broadacre Ciry was Frank Lloyd Wright's wisioen wan het ideale suburbia, meerkernig, met een lage dichtheid en wolledig gericht op de anto. De architect introduceerde zijn oplossing woor het probleem van de verstopte steden in 1932 in het boek "The Disappearing City" en werkte er aan tot aan zijn dood in 1959 . Een houten schaal model dat hij maakte, toont een netwerk van autosnelwegen die aansloten op een raster van ontsluitingswegen. Op de belangrijkste knooppunten situeerde Lloyd Wright grote 'markets' (woorlopers van de Amerikaanse mallis), maar ook andere centra wan religieus en cultureel leven. Zie: Wright (1958) en De Long ( 1998 ).

4 Voor de Verenigde Staten, zie Davis (1997) en Carr (1987). Voor Duitsland, zie Stommer \& Philipp ( 1982 ). Voor Nederland, zie Provoost (1996).

I5 In de wakliteratuur wordt onderscheid gemaakt tussen de termen "kruispunt" en 'kruising". In het eerste geval gat het on een ontmoetingspunt van wegen waar her verkeer wel van weg kan wisselen, in lhet tweede geval om een ontmoetingspunt waar men niet kan of mag wisselen (bijvoorbeeld de kraising van een spoorweg en een autowegy. Een owergang voor (brom)fietsers is een kruising (soms een kruispunt) van een fietspad met een rijweg watr (nagenoeg) alle (brom)fietsers de rijbaan oversteken en niet wan richting mogen veranderen. Zie bijwoorbeeld Kuipers, I998: I.I. $x 6$ Voor de verkeersopwattingen van Van Eesteren in het ontwerp van de Bijlmer; zie ook hoofdstuk 4 van Honmels (200r).

r) Over de rol van fietsinfrastructuur in de ruimtelijke inrichtng inrichting van Houten, zie Lammers ( 1995 ). De voetgangersgebieden die in de jaren zeventig in veel binnen-en buitenlandse steden werden aangelegd, zijn een ander voorbeeld wan modernistische scheiding van verkeerssoorten.

I 8 Van den Boomen (200r).

19 lbid.

20 De meningen over het succes van deze operatie zijn verdeeld. Er is geen duidelijke keuze gemaakt of de Dam een verkeersplein of een verblijfsplein moest worden, stelde de verkeersveiligheidsorganisatie $3 \mathrm{VO}$ in augustus $200 x$ in Het Parool. Tegenstanders van de herinrichting zagen hun gelijk bevestigd na een dodelijk ongeval op de Dam in augustus zoor waarbij een 27 " jarige vrouw on het leven $k$ wam toen zil met haar fiets midden op de Dam werd overrreden. (Bron: Het Parool, 9 augustus $200 \mathrm{x}$ ). Het verkeerskundig bureau Witteveen+Bos concludeerde ma onderzoek in opdracht van de gemeente Amsterdan dat op de Dam, 'alhoewel daar de verschillende verkeersdeelnemers mengen, geen extreem onweillige verkeerssituatie is gecreëerd". Wel adviseerde het bureau enkele kleine verkeerskundige wijzingen zoals het plaatsen van enkele borden. (Persbericht Gemeente Amsterdam, $2 x$ januari $2002 \%$.

2. Voor een populaire beschouwing over biologische metaforen alls zelforganiserende systemen in het denken over techniek, samenleving en economie, zie Kelly ( 1995 ).

22 Niet voor niers gebruikte Pieter Winsemius in zijn notitie 'De maatschap Nederland' de metafoor van de roton- 
de om het nieuwe rol van de overtheid als maatschappelijke procesbegeleider te typeren. Zie Winsernius (200I) en Brouwer (2001)

23 Juridische regels steunen weer op achterliggende beginselen die als kader dienen voor die regelgeving. Otte (1993) onderscheidt er drie: 'Het werkeer eist veel van degenen die daaraan deelnemen. De verkeersdeelnemers worden geacht in permanent wisselende omstandigheden en bij een veelwoud an keuzemomenten, waarbij veelal in een seconde moet worden beslist en gehandeld, het gewenste verkeersgedrag re kunnen onrwikkelen. Het bepalen van dat wenselijke verkeersgedrag is dan ook onderhevig aan een voortdurende spanning. In dat spanningsweld worden in thet algemeen drie ijkpunten aanwezig geacht die het verkeersrecht en het gedrag van de verkeersdeelnemers behoren te beheersen: veiligheid, wlotheid (of doorstroming) en vertrouwen.' Otte, x $993: 43$.

24 Voor een overzicht wan het Nederlandse verkeersrecht, zie Otte (r993).

25 Mr. J. Spee in ANWB ( 999 . Zie ook Spee ( $1999 \mathrm{I})$.

26 De algemene gevaarsbepaling heeft in de loop van twintigste eeuw een transformatic ondergaan. In de Motor-en Rijwielwet van 1905 luidde zij: "Het is den bestuurder van een motorrijtuig of een rijwiel verboden daarmede over de weg (of een rijwielpad) te rijden op zodanige wijze of met een zodanige snel. heid, dat de vrijheid of de veiligheid van het verkeer (op dien weg) wordt belemmerd of in gevarar gebracht." De formulering in de Wegenverkeerswet wan 1935 luidde: 'Het is verboden zich op een weg zodanig te gedragen, dat de wrijheid wan het verkeer zonder noodzack wordt belemmerd of de veiligheid op de weg in gevaar wordt gebracht of redelijkerwijze is aan te nemen, dat de veiligheid op de weg in gevaar kas worden gebracht.

27 Deze materiële witdrukkingen van verkeersregels hebben een geschiedenis. McStane beschrijt hoe het snel complexer wordende verkeer in New York City aan regels werd gebonden. Daarin speelde William Phelps Eno een belangrijke rol, Zijn idecèn over de meest efficiènte manier on langzaam en snel werkeer te scheiden stond aan de basis wan de eerste reeks verkeersregels die in 1903 in de Verenigde Staten werd ingevoend. Tot het pakket regels behoorde de verplichting voor langzamere verkeersdeelnemers om rechts te houden. Artefiacten die voor ons een vanzelfsprekende betekenis hebben, zoals een stoplicht, werden door Eno bedacht. Dat had aanvankelijk een blauw licht boven en een geel licht onder. De keuze voor de kleuren rood en groen was arbitrair. (MeShane ( $(994))$.

28 Artikel 5 van de Wegenverkeerswet uit r.994.

29 Toelichting RvV (I g9o) (B. p.I5).

30 Otte (r993) merkt op dar het niet nauwkeurig in regels vastleggen van verkeerssituaties in het verleden vaak werd gezien als een onvermogen wan de wetgever, maar dat de opvattingen datarover zijn veranderd. "Anno I 990 is de wetgever daarentegen van oordeel dat het streven natr zo precies mogelijke regeligeving tot ongewenste regelverdichting leidt: "Te ver afdalen in verfiningen door voor ledere situatie een regel te willen voorschrijwen is een onderschatting van de complexiteit van her hedendaagse verkeer en een miskenning van de creatiwiteit en verantwoordelijkheid die iedere weg. gebruiker moet bezitten en als regel ook bezit. Die creativiteit en werant. woordellikheid vormen tegelijkertijd de andere kant wan de medialle. Her 
handelen naar eigen inzicht en werantwoordelijkheid draagt ertoe bij, zo is de laatste jaren wel gebleken, dat daar war de regelgeving te ver is doorgeschoten zil massaal wordt genegeerd. De geloofwaardigheid wan voorschrifteen, ook die welke voor de verkeers" veiligheid van her grootste belang zijn, weemt daardoor sterk af." (Otte, I993: 30).

3r Op dit punt bestaan opvallende verschillen tussen landen. In Noorwegen bijwoorbeeld remmen auto's al af als ze een voetganger in de buurt van een zebrapad zien, in Parijs stoppen automobilisten hoogst zelden voor een overstekende voetganger.

32. Jonasson ( 2000 ) verbindt aan dit onderscheid een interessante conclusie: 'Discourses [on traffic] seem to be filled with stories about conflicts, accidents, struggles, and powerlessness, while non-werbal action seems to be almost all about smoothness, cooperation and negotiation, except for a small number of actual collisions. Applied traffic safety and management deals with discusive projections of what is thought to be real and rational problems in different traffic worlds.' (Jonasson, 2000: i).

33 Otte, r993: 7 .

34 Kuipers ( 1998 ).

35 Het ontwerp is hier deels cultureel bepaald. Op autosnelwegen in Nederland worden kruisingen doorgaans twaalfhonderd meter van tevoren aangegeven zodat de bestuurder ruim de tijal theeft te bepalen welke richting hij of zilj zal nemen, maar in Belgie is dic afstand vaak veel minder, wat voor een Nederlandse bestuurder tot paniekachtige reacties kan leiden.

36. Michael (1998) stelt voor het belang van de interactie tussen mens en ma chine in het geval van autorijden tot uitdrukking te brengen door het niet niet langer te hebben over 'persons' maar over 'car-sons'. Hij gaat in zijn bespreking van her hybride katrakter wan de 'car-son' ecliter ner ver genoeg omdat hij de invloed van het verkeerslandschap buiten beschouwing laat.

37 "All traffic engineering and infrastructure planning embodies the theft of time in some shape or form and its redistribution to wealthier groups." (Whitelegg, r 997: 133 ). Dat een snel rijdende auto in de stad rijd neemt van anderen blijkt ook uit een ander voorbeeld. In drukke straren moeten de ouders, meestall de moeders, toezicht houden op hun buiten spelende kinderen, een vorm van 'tijddiefstal' die door Whitelegg 'timelock' is genoemd. (Whitelegg, 1993).

38 Ook in Nederland, zo stelt de stichting Kinderen Voorrang!, is het aantal verkeersslachtoffers onder kinderen weliswaar gedaald, maar is de bewegings. wrijheid van kinderen afgenomen. Ouders laten hun kinderen minder vaak zelfstandig over straat gaan omdat ze het verkeer te gevaarlijk vinden. De stichting wijst erop dat kinderen die niet buiten spelen sociale, emotionele en licharnelijke achterstanden kumnen oplopen. In 1999 bracht de stichting een startnotitie uit onder her motto 'Kinden praten mee over het verkeer" waarin gepleit wordt voor deelname van kinderen aan projecten die als doet hebben de openbare ruimte aan te passen (kinderparticipatie). In relationele opvattingen van tijd en ruirnte wordt betoogd dat zij niet onafhankeijijk wan gebeurtenissen bestaan, zoalls bijwoorbeeld Newton stelde, maar slecht als relaties tussen sitanden wan zaken. Zo stelt Leibniz dat ruimte en tijd niet meer zijn dan 'een structuur wan relaties van een be. paalde soort'. Meer bijzonder: "space is the order of coexistence - that is, the 
order among mutually contemporaneous states of things; while time is the order of succession - that is, the order among the warious different murually coexisting states of things which because they are (mutually) coexisting must, of course, have some "spatial" structure." (Rescher (r979), geciteerd in Harvey, $1996: 252$ ) Voor beschouwingen over relationele tijd-ruinte, zie: Earman ( 1989 ), Latour (r997), Poidevin \& MacBeath (1993) en Harvey (1996).

Latour (1993) wat materiele objecten in het verkeerslandschap op als actoren. In een onder wetensichaps- en techniekonderzoekers inmiddels klassiek voorbeeld analyseert hij de verkeersdrempel. De drempel verschijnt als een object warmee een bepaald doel (de drempel) wordt bereikt. Op cen weggedeelte waar automobilisten te snel rijden zou je een agent neer kunnen zerten die een handgebaar maakt naar de automobilisten. Agenten zijn duur, dus heeft men deze handeling (her maken van een handgebaar) gedelegeerd aan een verkeersbord. Dat heeft echter niet altijd het gewenste effect; automobilisten houden de vrijheid de verkeersregel te overtreden. Met een verkeersdrempel lukt dat niet meer. Het programma - 'matig uw snellheid" - is volgens Latour gedelegeerd van de agent, via het verkeersbord naar de verkeersdrempel. Auto's, wegen, werkeersborden en vluch theuvels zijn zo op te vatmen als een reservoir van gedelegeerde handelingen. Volgens Latour is sociale orde niet slechts een zaak van maatschappelijke arrangementen, maar wordt ons (morelle) handelen voor een belangrijk deel bepaald door de niet-menselijke actoren waarmee mensen zijn omgeven.

$4 \mathrm{x}$ Dankzij de gegevens van de fietsbelasting die de overheid in 18.98 invoerde, is bekend dat er in 1899 in Nederland 9.4.370 fietsen waren en dat $x$ op de 53 Nederlanders een fiets had. (Adri de la Bruhèze \& Veraat, 1999: 17/. Het aanal fietsen in Nederland nam snel toe, van $3,24.000$ in 1906 naar 1,8 miljoen in $\times 924$ tot vier miljoen in 1940 . In dat jaar beschikte de helft wan de Nederlandse bevollking over een fiets. Deze toename ging gelijk op met veranderingen in het gebruik van het rijwiel. Van een sportmiddel voor de gegoede burgerij weranderde de fiets in een transportmiddel van de middenstand (de bak-en transportfiets) en een dagelijks vervoermididel van de arbeiders. (Bruhèze \& Veraart, I997: I9.) Veraart ( 1995 ) stelt vast dat de fiets in de jaren twintig en dertig het belangrijkste verwoermiddel in het dagelijkse woon-werk verkeer was, maar ook in de jaren vijftig was het fietsgebruik en - verkeer nog vergelijkbaar met de decennia voor de oorlog.

42 Zie bijvoorbeeld Adri de la Bruhèze \& Veraart, 1997: I. I en het Eindrapport Masterplan Fiets (1998). Den Haag: Ministerie van Verkeer en Waterstaat, P. 4 r. Nederland heeft overigens nog altijd per hoofd wan de bevolking meer fietsen dan enig ander land in de wereld. De fietsdichtheid in Nederland was in 1998 her hoogst in de wereld, namelijk $r, 0$ fietsen per inwoner (1996). Denemarken en Duitsland wolgen met respectievelijk I, I en $x, 3$. Het aantal bruikbare fietsen in Nederland bedroeg in 200 r 17,8 miljoen. (Bron: Bovag/Rail). Na de auto en de trein worden in Nederland de meeste kilometers op de fiets afgelegd. Sinds het begin van de jaren negentig is het andeel van de fiets in de rotale verwoersprestatie in Nederland min of meer stabiel, zo"n I 3 miljard kilometer per jaar. Omdat het total aantal afgelegde killometers toeneemt (wan 167,7 
miljard in 1990 naar $\pi 87,6$ miljard in $200 x)$, daalt de relatieve bijdrage van de fiets an de totale vervoersprestatie. Daar staat tegenover dat het aantal fietsen in Nederland blijft toenemen. (Bron: cBs/Onderzoek Verplaatsings Gedrag (ovgl).

43 Zie Van den Heuvel \& Peters (r998).

44 Zie woor een beschrijving van de ideologie achter dit proces van modernisering als wersnelling van thet verkeer, Provoost (19.96).

45 De naam van de fietsersbond veranderce een aantal malen in haar geschiedenis. De Eerste Enige Echte $\mathrm{Ne}$ derlandse Wielrijdersbond (ENw werd in 1975 opgericht. Als gevolg van een door de ANWB aangespannen proces in 1979 werd de naam weranderd in de Echte Nederlandse Fietsersbond (En $\mathrm{F}$ ). De huidige naam is Fietsersbond. De Fietsersbond is de groorste belangenvereniging voor fietsers in Nederland met 33.000 leden. Ze geeft het bondsblad 'Vogelvrije Fietser" uit, verricht ondersteunende werkzaamheden, organiseert activiteiten en doet lobbywerk bij de landelijke en plaatselijke politick.

46 Lammers, 1995:7.

47 De effecten van het fietsroutenetwerk in Delft zijn uitvoerig onderzocht. Voor een overzicht zie Hartman (1997).

48 Van alle autoritten is veertig procent korter dan vijf kilometer en dus te fietsen, zo werd in het svv ar vastgesteld. Cijfers uit Evaluatierapport Masterplam Fiets (1997). Den Haag: Ministerie van Verkeer en Waterstaat.

so Fietswriendelijke infrastructuur vormt sinds een drietal decennia onderwerp wan onderzoek. Over de relatie tussen stedebouw en fietsen, zie bijvoorbeeld Zandvoort Ordening en Advies (1995) en Mobilopolis: De actieve fietsstad. (Eindrapport) (1997). Nijmegen: KU
Nijmegen, Vakgroep Planologie/Haskoning, Nijmegen/Goudappel Cofeng. Deventer; over de geschiedenis van het fietsbeleid in een aantal Nederlandse en Europese steden, zie de eerder genoende studie van Adri de la Bruhèze \&. Veraart (r999). Voorbeelden van buitenlands onderzoek naar her fietsen in steden zijn Dekoster, Schollaert, Bochu, \& Lepelletier (1999), McClintock (r992) en Tolley (r997).

5 I Zie noot 44.

52 "Deze combinatie van taken brengt een aantal min of meer tegenstrijdige kenmerken mee, die de fietser zijn bijzon. dere positie in het verkeer geven. Zo fungeert spierkracht als natururlijke snelheidsbegrenzer rerwil tegelijkertijd een zekere snellheid onmisbaar is om het voertuig stabiliteit the geven. Ook is de fietser enerzijds $k$ wetsbaar, en anderzijds wendbaar en zeer flexibel in her verkeer. En volgens de Wegenverkeerswet behoort de fiets tot het langzaam verkeer, maar in de stad biedt de fiets een van de snelste vervoerwijzen." (Ploeger, Botma, Michels \& Stichting crow, 1993: I. 3 e.v.) Zie voor een samenvatting van de idecën achter de Ontwerpwijzer wok: Ploeger (1997).

Ploeger [et.al.], r993: I4 en Ir 5.

Ibid.

Deze eisen worden als volgt geoperationaliseerd. Om de samenhang van een netwerk van fietsroutes te bepalen kijkt men bijwoorbeeld naar de vindbaarheid van bestemmingen, consistentic en kwalliteit, de routekeuzevrija heid en compleetheid thet anntal aangesloten plaatsen van herkomst en bestemming). Directheid wan de fietsroute wordt afgemeten aan de afwikkelingssnelheid en doorstroming op een route (de ontwerpsnelheid mag volgens de Ontwerpurjzer nooit minder zijn dan tien $\mathrm{km} /$ uur en aanbevolen 
wordt 25 tot $30 \mathrm{~km} / \mathrm{u}$ ), oponthoud en de omrigafstand. De adutrekkelikbeid wordt bepaald door te kijken naar het aantal klachten over een route en de afname daarvany zichebartheid (bijvoorbeeld de sterkte van de openbare verlichting, , het overzicht, de kans op verblinding, de sociale wigheid en de ruimtelike beleving. Daamaast moet een fietsroute veilig zijn, wat kan wor" den wastgesteld op grond van het aan. tal verkeersslachtoffers (doden en gewonden, de kans op ontmotring met autowerkeer, de complexiteit wan de rijtaak en, wat men noemt, her "klachtenpatroon subjectieve veiligheid". Het comfort ten slotte, wordt bepaald door de vlakkeid van het wegdek, de heuvelachtigheid, verkeershinder (uitgedrukt als "de kans dat een ontmoeting met een andere werkeersdeelnemer de nit voor de fietser in enigermate verstoort'), stopkans (het aantal keren dat men gemiddeld per kilometer moet stoppen) en weershinder bijvoorbeeld wind en sneeuw.

56 "Het zal duidelijk zijn dat dit evenwicht wak alleen door middel van een iteratief proces kan worden gevonden. Er moet herhaaldelijk aan de drite 'stelschroefjes' worden gedraaid woordat het ontwerp 'waterpas' staat. Soms zal het hiervoor nodig zijn doelstellingen bij te stellen. In de praktijk betekent dit dat de vootziening mer een lager kwaliteitsniveau wordt uitgewoerd dan op grond wan het programma van eisen wenselijk is. Er wordt dus water in de wijn gedann tert anzien vam da fietsvriendelijkheid van de voorziening" (Ploeger let.al. 1, 1993: 34).

Godefrooij (r997). In Noorwegen is het gebruikelijk dat fietsers altijd op het troittoir fietsen. Niet altijd worden fietsers naar de zijkant van de weg "verbannen." In een recent herontwerp van het centrum van Stratsburg is juist in de middenberm plaats ingeruind worr fressers.

Integration underlines the equality of all road whers, as all have the same fruedom of movement.' (Godefrooil, I997: $23 \mathrm{I}$ ).

59 Ploeger [et.all], $1993: 149$.

60 Plorger [et.al.], r993: 20 . Oyer de effecten van van de afstelling van afstelling van verkeersregelinstallaties (WR's) voor fietsers en andere langza " me weggebruikers, zie ook Studiecentrum Verkeerstechniek (svT) (x98 r), Werkgroep Evaluatie Verkeerslichtenregelingen (1986), Van den Hout 8 Werkgroep Evaluatie Verkeerslichtenregelingen (r990) en Smeets (r999).

$6 \mathrm{x}$ Wilson \& Middelham (2000): Opeen met verkeerslichten ger geld kruispunt kan de wachttigd voor het langzam verkeer anzienlijk worden gereduceerd als in eern cyclus rwee of meer groenfasen voor dat langzaan verker worden gegeven. Uit de enquêteresultaten blijkt, dat wegbeheenders dat over de bele linie slechis zelden doen. De voorgaande resultaten zijn niet verwonderlijk, omdat zowel coördinaties als meervoudige reallisaties voor het langzaam verkeer een grote aanslag doen op de capaciteit van een kruispunt. Dit betekent dat een keuze voor fets w woetgangersvriendelike regelingen dan ook valak congestie voor het gemotoriseerde verkeer tot gevolg heeft, wat door de politiek meestal niet wordt geaccepteerd.' (Wilson \& Mid. dellham, 2000: is 5 Zie voor een krantemartikel op basis van dit onderzoek Vermeer (2002).

62 Deze cijfers zijn afkomstig wit het EvaInatierappont Mastemplan Fiets. (1997). Den Hag: Ministerie van Verkeer en Waterstaat.

63 De grafiek in figuur 6.3 vom eer mooi voorbeeld wan het decontextualiserende vergelijkende perspectivef 
dat in de hoofdstukken $\mathrm{I}$ en 2 aan de orde kwam. Om te kunnen wergelijken moeten auro en fiets 'aan elkaar geliik gemaakt worden". De verdwenen context heeft hier onder meer een politiek karakter.

64 $\operatorname{Er}$ zijn uiteraard talloze definities van her begrip 'pollitiek' te geven. De definities die ik in dit hoofdstuk gebruik, worden toegelicht in Woerdman (1999).

65 Asmussen (x996).

66 Baeten, Spithoven \& Albrechts, r997: $\mathrm{r} 44$.

67 Winner, 1986:8 en 9 . Winner grijpt in het gebruik van de term 'wereld' terug op Wittgenstein.

68 Van der Veen (200.1).

69 Zie Berlin, 1990: 23 en 24.

\section{De lumst wan het reizen}

$x$ Gabriells, $200 \mathrm{r}: 232$.

2 Reizen is niet alleen een activiteit die ons woor problemen stelt, maar ook een manier om die problemen op te lossen. Het idee dat mensen leren door te reizen is al oud, denk bijvoorbeeld aan de "Bildungsreise" die Duitse gezellen moesten maken voor ze zich ergens mochten vestigen om hun valk uit te offenen of de Grand Tour die Engelse aristocratische jongeren maakten naar Italiè en Griekenland on daar kennis te nemen van wat zij beschouwden als de bakermat van hun beschawing. Zie bijworbeeld Hlavin-Schulze (1998).

Een theorie van passages is geen theorie in de traditionele betekenis, dat wil zeggen een verzamelling hypothesen of algemene uitspraken waaruit toetshare voorspelingen zijn af te leiden. Eerder wat ik het begrip 'theorie' hier op als een reeks samenhangende begrippen waarmee de activiteit van het reizen beschreven kan worden en waar- mee transformaties in het reizen verklaard kunnen worden.

4 Een paradox is een schijnbare regenstrijdigheid die bij nadere beschouwing verdwijnt. Wan Dale geeft het voorbeeld "niets bebbende, alles bezittende' ( 2 Cot 6: ro). Deze paradox lost op als we inzien dat datgene wrartran men niets heeft (bijvoorbeeld materie le bezittingen) niet hetzelfde is als datgene waarvan men alles bezir (bijvoorbeeld geloof of innerlijke rust》.

Dat blijkr bijwoorbeeld uit de discussie rond substitutic van fysieke door "wirtuele' mobiliteit. Lange tijd werd bijvoorbeeld telewerken gezien als een beleidsinstrument om het woon-werkverkeer in de spits te ontlasten. Redenerend vanuit de constante reistijd levert telewerken hooguit een verschuiving van de mobiliteit op, maar geen afname. De totale reistijd van de thuiswerkers blijft constant en zij zallen de uren reistijd die ze hebben "witgespaard' door te telewerken op andere momenten besteden, bijwoorbeeld door in hun vrije tijd meer kilometers. af te leggen. (Zie voor deze kwestie bijvoorbeeld Peters, Peeters, Wilde \& Clement (200I).

6 Mesman (2002) gebruikt een vergelijkbare metafoor van een schuivende horizon om aan te geven dat de ontwikkeling van medische technologie niet alleen neuwe behandelingsmogelijkheden schept, 'maar ook nieuwe vragen, nieuwe dilenma"s ên nieuwe tragedies." (Mesman, 2002: I 59 ).

Gusfield, I98 r: 19.1.

8 Wilde, $R$. de. (200o). Innovating innovation. A contribution to the philosophy of the future. Paper read at Policy Agendas for Sustainable Technological Innovation, I-3 December 2000, at London.

9 De Wilde (200r) heeft dit beschreven als het 'Sachs-principe". 
ro Een recent voorbeeld van deze ontwerpfilosofie is de HogeSnetheids Weg (HSw) die door het bouwconcern Strukton is voorgesteld, een verhoogde weg boven de middenberm van de bestaande A 2 waarover automobilisten tegen betaling van acht eturo flewrij van Amsterdam naar Maastricht kun" nen rijden. De bouwonderneming licht hat ontwerp toe op: http://www. strukton.ni/projecten/hogesnelweg. hitml

IT Het zodanig inrichten van een innovatietraject dat tegenwerking juist wordt gezocht in plaats van vermeden vorms ook de kern van de PROTEE methode die in 1998 en 1999 werd ontwikkeld in het kader van het Vijfue Kaderprogramma van de EU door een internationaal consortium wan onderzocksinstituten, waaronder het Centre de la Sociologie de l'Innovation (CSI) in $\mathrm{Pa}$ rijs en de Faculteit der Cultuurweten * schappen van de Universiteit Maastricht. In dit onderzoeksprogramma is een reeks indicatoren opgesteld waarmee de kwaliteit van innovatietrajecten in thet multimodale goederenvervoer kan worden vastgesteld. Zie het PROTEE Final Repore dat te vinden is. op: http://europa.eu.int/comm/transport/extra/final_reports/strategic/PRO TEE.pdf

I2 Strategic Niche Management benadert innovatie vanutit de gedachte dat ontwerpers sociale visies en waarden hebben die, vaak impliciet, hun ontwerpen beinvloeden. Als technologieèn worden geintroduceerd in de maatschappi wordt het lot wan zo'n technologie bepaald door het gedrag van consumenten, producenten, politici en beleidsmakers. Zij bepalen of en hoe een technologie deel gaat uitmaken van het dagelijks leven. Deze "co-produktie fof co-evoleutie of co-constructie) wan het technische en het sociale" wordt on- woldoende onderkend in het debar over de toekomst van mobiliteit, stellen de auteurs. Zie: Hoogma, Kemp, Schot \& Truffer (2002).

I3 Deze thematiek is nader witgewerkr in Peters \& Hajer (200r).

I. 4 Met mijn vraagtekens bij deze aconomistische en technisch-deterministische opvatting wan innovatie sta ik in tein lange kritische traditie. Deze kritieken nemen uiteenlopende disciplinaire kaders als vertrekpunt, maar delen het inzicht dat techniekontwikkeling geen op autonoom proces is. De wisselwerking tussen de ontwikkeling van techniek en sociale processen is op uitecnlopende manieren geconceptualiseerd. Zo heefr Hughes ( 19.83 ) beargumenteerd dat de uitvinding, productie en diffusie wan de gloellamp geen "exogeen' (buiten de maatschappij) maar 'endogeen" proces was, dat wil zeggen tot stand kwam binnen de economische dynamiek van kennisintensiewe markten en ondernemingen. Ook kan techniekontwikkeling opgewat worden als een evolutionair proces waarbij tecthniek zich ontwikkelt in een economische dan wel matschappelijke ongeving die selecteert, wat kan leiden tot een stabilisatie van een bepaalde techniek. In de evolutionaire benadering is innovatie een complex en gelaagd proces, watarin vele actoren en factoren een rol spelen. De onderlinge afhankelijkheid en verwevenheid van technologische, economische en sociale trajecten worden als een "technologisch regime" beschreven. Een dergelijk socio-technisch systeem vertoont de neiging zichzelf te reproduceren /lock in"). In het sociaal-consteructivistisch techniekonderzoek van Pinch \& Bijker ( $r 987$ ) worden technologische ontwilkeling en innovatie geanalyscerd in termen van betekenissen die relevante sociale groepen aan nieuwe producten 
toekennen. Stabilisatie wan technologische artefacten komt tot stand doordat deze betekenissen stabiliseren (closure'). De actor-nerwerk theorie van Latour, Callon, Law en Akrich ten slotte, wijst een a priori onderscheid tussen een technisch en een sociaal domein af en verklaart het succes en falen van innovatie uit de kracht wan netwerken van menselijk en niet-menselijk actoren (Callon, 1987; Law, r987; Latour, r993; Akrich, r992)

Is Ook conceptuele innovaties kunnen op deze manier worden ondervtaagd. Zo stelt de directeur wan het Ruimtelijk Planbureau, een nieuw onathankelijk kennisinstituut op het gebied wan de ruimteliike ordening, voor om het in zijn ogen wersleten begrippenpaar stad \& land in te ruilen woor het 'netwerk'. 'Niet de steden zijn drager van ruimtelijke ontwikkelingen, maax "knooppunten" die op verschillende manieren met elkaar verbonden zijn. (...) Bewegingen zijn voor de ruimte veel bepalender dan plekken." (Schreuder, 2002).

16 Een voorbeeld: het organische ontwerp van het verkeerslandschap in dorpen als Makkinga staat voor een ontwerpstijl waarin de wereld wan de automobilist ondergeschikt is aan die van de wandelende en fietsende bewomers, op andere plaatsen is dat vaak andersom.

I7 Eric Leed ( 9991 ) beschrijft in zijn mooie boek The Mind of the Traveller de opeenvolging "wertrek - passage aankomst" als de basisstructuur van de reis. Van den Abbeele (1992) schrijft: "The economy of travel requires an o $i$ kos (the Greek for "home" from which is deriwed "econony") in rellation to which any wandering can be comprebended (enclosed as well as understood). In other words, a home(land) must be posited from which one leaves on the journey and to which one hopes to return.. (..) The oikos defnies or delimits the movement of travel according to that old Aristotelian prescription for a "well constructed" plot, namely, having a beginning, a middlle, and an end.' (Van den Abbeele, 1992 : xviii). De dualiteit van het ware reizen en de nurrige verplatatsing heeft romantische ondertonen. In de romantiek neemt het ware reizen de vorm van thet wandelen. Rousseau verwoordde deze voorkeur in zijn Confessions waar hij zich herinnert hoe hij in zijn jeugd te voet reisde, zonder de last van bagage, plichten en zaken. Tot zijn spiit was hil zich, toen hij ouder werd, nergens anders van bewust dan van de noodzaak zijn bestemming te bereiken. In $L$ Emile (1762) wijst hij zijn pupil er dan ook op dat we niet zouden moeten reizen alsof we koeriers zijn die alleen maar bezig zijn met het bereiken van hun bestemming. Als arriveren het enige is dat telt, reis dan per koets maar in andere gevallen moet je gaan lopen. (Geciteerd in Van den Abbeelle (r992)). Over de cultuurgeschiedenis van het wandelen, zie met name: Wallace (1993); Koenig (1996), Jarvis (1997), Meeuse (2000) en Solnit (2000).

r 8 In de afgelopen decennia is door uiteenlopende auteurs het einde wan de reis aangekondigd, allthans de reis met een structuur als door Leed (I99I) aangeduid. Het onderscheid tussen wertrek, passage en aankomst zou aan het vervagen zijn. In plaats wan een enkelvoudige beweging zou het leven van steeds meer mensen de vorm van een permanente passage aannemen. Dankzij snelle vervoermiddelen en draadloze informatie- en communicatietechnologie zijn mensen steeds minder aan plaatsen gebonden. Volgens Makimoto en Manners ( 1997 ) kunnen zij daardoor hun diepste natuur verwezenlij- 
ken, namelig de zucht tot nonadisme. Ook de Amerilkanse econoom en beurshandelaar Knoke (1997) beschreef in zin "essential road map to the twenty-first century "en toekomstige maatschappin waarin "plaats' er nier meer toe doet. In de "Age of Every. thing' hebben transport en communicatie de verschillen tussen dichthis en ver doen werdwingen.

19 Stagl (x995) beschrifte in winn boek over de 'theorie van het reizen' tussen $r 500$ en $r 800$ de kunst van het reizen als een worm wan prakrische kennisverwerving. De ars apodemica werd inderdaad opgevat als een kunst of kunde, en worm van kennisverwerving die verbonden was met de praktijk van het reizen, en niet als een wetenschap. Ze omvatte dan ook verschillende onderdelen. Om te beginnen waren er de praktische reisaanwijzingen, nutrige informatie over tollen, herbergen, steden en postkoetsdiensten voor de reiziger die in onbekend streken zijn weg moest zocken. De kunst wan het reizen schreel ook voor hoe een reiziger zilin ervaringen in den vreende kon boekstaven. Het nutrige, het gedenkwaardige, het opvallende, het bruikbare en het aangename waren de belangrijkstecategorieën waarin de reisbeschrifvingen moesten worden gecatalogiseerd. Een belangrijk element in de ars apodemica was de pedagogiek van het reizen, immers als reizen een kunst en een kunde was, dan moest die geleerd worden. Een ander onderdeel van de kunst van het reizen was de reflectie op de vraag "hoe te reizen?' Het jusste reuzen stond niet alleen in dienst van de ontwikkeling en de opvoeding, naar ook wan het ontwikkelen van humanistische idealen in de omgang met vreemden.

"This change has reached its climax in our day: Formerly travel required long planning, large expense, and great investments of time. If inwolwed risths to health or even Hife. The traveler was active. Now he became passwe. Instead of an athletic exercise, travel became a spectator sport." (Boorstin, 196:2:84). In Nederland winden we de these van de verdwenen kunst wan her reizen bij Ritter (ry2I). 'Nu de tanden een worden van uiterlijk, nu het herousne van het reizigersschap verdwing (...) Wat is voor het reizen noodzakelikker dan de aandoening van afstand?" Brilli (1997) verwijst in de titel van zin boek over de geschiedenis wan het reizen naar de verdwenen kunst wan het reizen: 'Als reisen eine Kunst war.' Uit Alain de Bottons recente bestseller (2002), waarin hii eigen reisimpressies beschrift en daarbij refereert aan de reiservaringen van "gidsen" als Flaubert, Ruskin, Humboldr en Van Gogh, valt af te leiden dat de kunst van het reizen niet zozeer verdwenen als wel vergeten is.

21 Reijnders, $2000: 266$. 


\section{Literatuur}

Abbeelle, G. Van den. (r 992). Trawel as metaphor: from Montaigne to Roussecu. Mineapolis: University of Minnesota Press.

Achterhuis, H.J. (1995). Op zoek naar ruimte en tijd. SMO-boek, 69 (r995), 65-72.

Achterhuis, H.J. (5997). Mobiliteit en schaarste. KOM: Tijdschrift woor empirische filosofie, $2 \pi(3), 240-253$.

Achterhuis, H.J. (r.998a). De erfenis van de utopie. Amsterdam: Ambo.

Achterhuis, H.J. \&c Elizen, B. (Red.). (1998b), Cultww en mobititeit. Den Haag: sDu. Adam, B. (1990). Time and Social Theory. Cambridge: Polity Press.

Adam, B. (I 995). Timewatch: the social analysis of time. Cambridge: Polity Press. Adam, B., Geißler, K., Held, M., Kümmerer, K., \& Schneider, M. (1997). Time for the Environment: the Tutzing Time Ecology Project. Time of Society, 6(x), 73-84.

Adri de la Bruhèze, A. A. \& Veraart, F. C. A. (1999). Fietsverkee in praktijk en beleid in de twintigste eeuw: overeenkomsten en verschillen in fietsgebruik in Amsterdawn, Eindhoven, Enschede, Zuidoost-Limburg, Antwerpen, Manchester, Kopenhagev, Harnover en Basel. Den Haag: Ministerie van Verkeer en Waterstaat, DirectoraatGeneraal Rijkswaterstaat, Hoofdkantoor wan de Waterstaat, Directie Kennis.

AGV. (1995). Voorkomen blift beter: mogelijkheden woor een verkeersveilige ruintelijke ordening. [Den Haag]: Ministerie van Verkeer en Waterstaat/Directoraat-Generaal Rijkswaterstaat/Adviesdienst Verkeer en Vervoer.

Akrich, M. (1992). The De-Scription of Technical Objects. In W. E. Bijker \& J. Law (Red.), Shaping Technology/Building Sochety. Cambridge/London; The Mir Press, $205-224$.

Allaback, S. (2000). Mission 66 visitor centers: the History of a Building Type. Washington D.C.: National Park Service.

Allen, J., \& Hamnet, C. (1995). A Shrinking World?: Global Unevenness and Inequality (Vol. 2). Miiton Keynes: Open University.

Alting, H., \& Kroef, R. van der (1998). Thomas Cook woo jaar in Nederland. Grom ningen [etc.] Histodata [etc.].

Armitage, J. (Red.). (2000). Paul Virilio: from modernism to bypermodernism and beyond. Thousand Oaks, CA [etc.]: Sage.

Asmussen, $\mathrm{E}$. (1996). De nieuwe notmmens: mens... maat der dingen: op weg nad integrale weiligheid en toegankelikheid voor iedereen. [Den. Haag]: pov Zuid-Hol. land.

Asselberghs, M.-A. (r959). Het ijzeren paard: versierd verslag van de lotgevallen van de stoomlocowotief. Amsterdam: De Bezige Bij.

Asseldonk, Y. van., Peeters, P. M., \& Sombroek, C. (1994). Trends op visite: een on- 


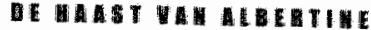

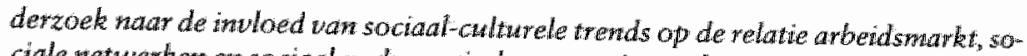
chat netwerken socizal verkeer: eindrappon. Amersfoort: Stichting Werkgroep "zduizend.

Auge, M. (r995). Non-places. Introduction to an antropology of supermodernity. London New York: Verso.

Ausubel, J. H. Marchetri, C. \& Meyer, P. \{1998). Toward green mobility: the evalution of ransport. European Rewew, $6(2), 1,7-156$.

Aveni, A. F. (1989). Empres of time: calendars, clocks, and cultwes. New York: Basic Books.

Baajuns, 5., Buinsma, F., Nijkamp, P. Peeters, P., Peters, P., Be Rietwedd, P. (1997). Slow mokion: Een andere kijk op snelheid. Delfr: Delfise Universitaire Pers.

Baaifens, $S, 8$ N Nijkan, P. (1997). Time pioneers and travel behawiour: an mestigathon mto whe viability of "slow motion". Amsterdam [etc.]: Tinbergen Institute.

Baart, T., Markerink, C., Merz, T. \& Zuyl-Moores, J. (1996). Stuelweg = Highways in the Netherlands. Amstendam: Architecutra \& Natura.

Baeten, G., Spithoven. A., B Albrechts, L. (r997). Mobiliteir Lawdschap wan macht en onmacht. Leuven: Acco.

Bagwwll, P. S. (1988). The Transport Revolution London: Routledge.

Baldwin, P. C. (1999). Domesticating the strete the reform of publit space in Hartford, 1850-1930. Columbus: Ohio State Unversity Press.

Barnett, J. E. (1998). Time's Penduhm: The Quest to Capture Thme, from Sw dials to Atowic Clocks. New York: Plenum Trade.

Barietr, F. I. (1998). Coda - Creativity and Improwisation in Jaz and Organizations: Implications for Organizational Learning. Organization science: a jowrnal of the Institute of Mantgement Sciences, 9 (1998)(5),605-622.

Bartiky, 1. R. (r.989). The Adoption of Standard Time. Technology and Culure, $30(\mathrm{x})$, $25=56$.

Batenburg, R. S., \& Knulst, W. P. (1993). Social-cultwele beweegredenem onderzoek naar de inuloed van veranderende leefortronen op de mobiliteitsgroei sinds de jarev zeventig. Rijswijk: Sociaal en Cultureel Planburean.

Bander, H. (r986). Een vertrouwde wereld: 100 jaar innovatie in Nederland. Amsterdam: Bert Bakkee.

Bauman, Z. (I998). Globalization: The Human Consequences. Cambridge: Polity Press.

Baman, Z, (2000). Liquid modernity. Cambridge [etc.]: Polity Press.

Bausinger, H., Beyrer, K., \& Korff, $\mathrm{C}$. (Red.). (r99x). Reisekultur: Von der Pilgerfahrt zwa modowen Tounswus. München. Verlag C.M. Beck.

Beck, U., Hajer, M. A., \& Kesselting, S. (Red.). (r999). Der anscharfe Ort der Polltik: Empinische fallswdien zar Theorie der reflexiven Modemisierumg, Opladen: Leske + Budrich.

Becker, G. S. (1965). A Theory of the Allocation of Time. The Ecomonic Journal, $75(299), 493 \cdot 5 x 7$.

Behringer, W. (1990). Thum und Taxis: die Geschichte ibrer Post wnd hor Unternehmen." München: Pipor."

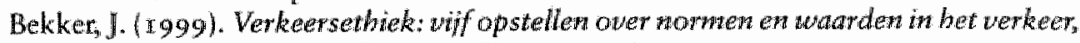
vier rencties of de opstellen. Den Haag: ANw $\mathrm{B}$. 


\section{OITEAHTUE}

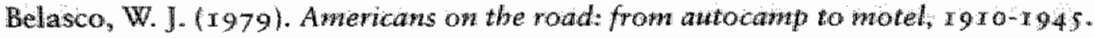
Cambridge, Mass: Mirt Press.

Melasco, W. I. (x982). Cars Versus Trans: 188 and r9ro. In G. H. Daniels \& M. H. Rose (Red.) Energy and Transpont: Historical Perspectites on Policy Issues. Beverly Fills/LondoniNew Delhis Sage Publications, $39-53$.

Deniger, J. (1986). The Control Rewolution: Tednolagical and Economic Origins of the Information Society. Cambridge, MA: Harvard University Press.

Berger, M. L. (r979). The Devill Wagon in God's Country. The Automobile and Social Change in Rural America, 1893-1929. Hamden: Archon Books.

Berlin, I. (1990). The Declinte of Utopian ldeas in the West, The crooked timber of bumanty: chapters in the bistory of deas. London: John Murra, 20-48.

Berman, M. (1983). All That Is Solid Melts Into Air. The Experience of Modernity. London: Verso.

Bertman, S. (1998). Hyperculture: The Human Cost of Speed. Westport, Connecticuthomdon: Praeger.

Bexelius, S. (x 976). A Time Budget Hypothesis As Explanation Of Traffic Demand. Colloquin Vervoersplanologisch Spetruerk, I 2 I I 27 .

Bhatotra, A. Pruilssers, A. F., Vos, C. J., Moscowiter, H., \& Lieshout, J. van. (r997). Overstappen: grand design for the swallex scale. Rotterdam. Kuiper Compagnons.

Bijler., W. E, \& Hughes, T. P. (Red.). (1987). The social comstruction of technological systems: wew directions in the sociology and bistory of techology. Cambridge, MA: MTri Presis:

Bijker, W' E., \& Law, J. (r992). 'General Introduction'. In: Shaping technology/buthling society : studies in sociotechnical change. Cambridge, MA: MrT Press, p. x- 6.

Bijker, W. E. (x995). Of Bicycles, Bakelites, and Bulbs: Tonards a Theory of Sociotechnical Cbange. Cambridge, Ma.fondon: The MrT Press.

Bijsterveld, K. (200r). The Diabolical Symphony of the Mechanical Age: Technology and Symbolism of Sound in European and North American Noise Abatement Cant paigns, 1900-40. Social Studies of Science, $3 \mathrm{I}(\mathrm{r}$ (February 2001) , 37-70.

Bimber, B. (r990). Karl Marx and the Three Faces of Technological Determinism. Social Studies of Sicience, $20(x 990), 333-35 \mathrm{r}$.

Blaise, C. (2000). Time Lord: Sir Sandford Fleming and the creation of standard time. London: Weidenfeld $\&$ Nicolson.

Bleijenberg, A. N., Berg, W. J. van den, \& Wit, G. de. (1994). Maatschappelijke kosten vat het verkeer. Literatuarotierzicht. Delf: CE:

Bode, 5., \& Millar, J. (1997). Airport. The most important new buildings of the twentieth century. London/Amsterdam: Photographers Gallery/Netherlands Design Instinute.

Boelens, L (1991). De planologie vathet hid-ruimte-wagstuk. Crisis van de cotrige rende tegenbeweging. Archis $(10-91), 40-45$.

Boerg. E. de. (196). Transport Sociology: Social Aspects of Transport Planwing. Oxford fetc..]: Perganom Press.

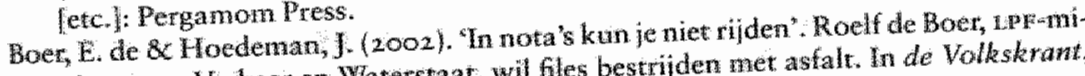
nister wan Verkeer en Waterstaat, wil fles bestrijden met asfalt. In de Volkskran. 2aterdang 4 september 2002 .

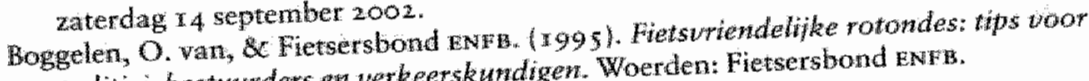

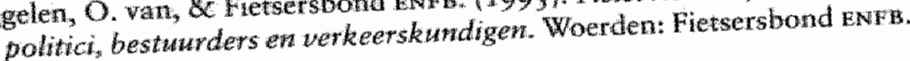




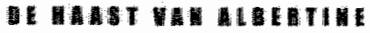

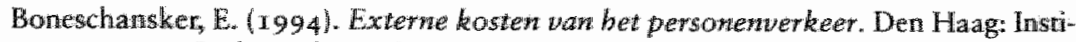
tuut voor Onderzoel wan Overheidsuitgaven.

Boneschansker, E. (Red.). (1995). Maatschappelike kosten en baten wan mobilitert Werkdocument $40 \mathrm{ed}$. Vol. Institut woor Onderzoek van Overheidsuitgaven ), Den Hag. Instituut voor Onderzoek wan Overheidsulitgaven.

Boomen, $T$. van den. (200r) Op natar de leesbare straat. In: NRC Handelsblad, 2 jumi $200 \mathrm{C}$.

Boorscin, D, (1962). From Traveler to Tourist: The Lost Art of Travel, The Image, ar, What Happened to the American Dream: New York: Atheneum.

Borst, A. (1990). Computus: Zeit und Zabl in der Geschichte Europas: Verlag Klaus Wagenbach.

Botton, A. D. (2002). De kwast van het reizen. Amsterdam [etc.): Atlas.

Wouwers, A. M. C. M., \& Dierikx, M.I. I. (1996). Op de drempel van de lucht. Tach. tig jaar Schiphol. Den Haag: sou Uitgevers.

Boyry, $\mathbb{P}_{\text {, }}$ \& Minderhout, M. (1996). Telematica en $\mathrm{I}$ in het verkeer: De stand wan za. ken wan telematica en informatietechnologie in het verkeer en vervoer. Io I: kwartadreeks over informatie en informatiebeleid, $14(2), 3 I-40$.

Brala, H. wan den. ( 1996$)$. Wèg wet de file: sociologie van bet antorijden. Amerstoort: Enzopress.

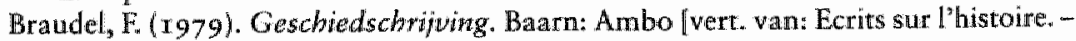
Parts : Flanmarion, 1969 .

Braudel, F. (1992). De Middellandse Zee. Het landschap en de mens (Vol. I). Amsterdam/Antwerpen: Uitgewerij Contact [oorspr. uitgave: 1949].

Brendon, P. (x99. I). Thomas Cook: 15 o years of popular towrism. London: Secker $8 x$ Warburg.

Brill, A. (1997). Als Reisen eine Kunst war. Vom Beginn des modermen Towrismus: Die Grond Tou Berlin: Verlag Klaus Wagenbach.

Brinckerhoff Jackson, J. (1984). Discovering the vernacular landscape. New Haven: Yale University Press.

Brinckerhoff Jackson, J. (r994). A Sense of Place, A Sense of Time. New Haven and London: Yale University Press.

Brouwer, A. (200x). De droom van de kennismaatschappij. Interwiew met Rein de Wilde. De Groene, d.d 7 juli 200 r.

Brune, T, "Von Nützlichkeit und Pünklichkeit der Ordinari-Post". In Bausinger, H., Beyrer, K., \& Korff, G. (Red.). (r99x). Reisekulut" Von der Pilgerfabrt zum modarmen Tourismus. München: Verlag C.H. Beck, $\times 23-130$.

Brum, S. D., 8c Leinbach, T. R. (Red.). (rg9r). Collapsing space and tme: geograp. bic aspects of comwnucations and information. London: HarperCollins Academic.

Bruno, L. C. (1993). On the move: a chronology of aduances in transportatiow. Detroit [etc.]: Gale Research.

Bruzelius, N. (1979). The Value of Travel Time: Theory and Measurenent London: Croom Helm.

Bryman, A. (1995). Disney and his worlds. London [etc.]. Routledge.

Buiter, $\mathrm{H}_{.,}$\& Volkers, K. (x996). Ondewanjigeschiedenis van een verkeersknooppunt. Unech: Matrijs.

Bullard, R. D., \& Johnson, G. S. ( 1997 ). Just Tronspontation: Dismantling Race and Class Barpiers to Mobility. Gabriola Lland: New Society Publishers. 


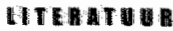

Bumce, M. F. (1994). The conmonside ideal: Angho-American images of landscape. London letc. ]: Rounledge

Bush, J. D. (1975). The Streamlined Decade. New York: George Brazillewte.

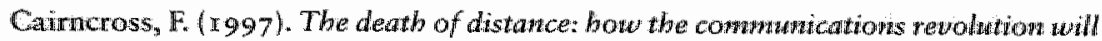
change our hves. Boston, MA: Harvard Business School Press.

[alfee, J, \& Winston, C. ( 1998$)$. The value of nutomobile travel time: implications for congestion policy. J. Public Economics, $69(\mathrm{x}), 83-\mathrm{ro2}$.

Gallon, M. (1986). Some Elements of a Sociology of Translation: Domestication of the Scallops and the Fishermen of Saint Brieuc Bay. In J. Law (Red.), Power, Acrion and Belief: a new Sociology of Knowledge? London: Routledge and Kegan Paul, r96233.

Carey, J. W. (r992). Communication as culture: essays on wedia and society. New York [etc. ]: Routladge.

Cartstein, T., Parkes, D., \& Thrif, N. (Red.). (1978). Timing Space and Spactug Time, Wol. 2: Human Activity and Time Geography. New York: John Wiley and Sons.

Car, E. (1987). The Parkway in New York City. Paper presented at the Second Bienmial Linear Parks Confetence, Boone, NC.

Carr, E. (1998). Wildemess by design: landscape apchitecture and the National Park Service. Lincoln and London: University of Nebraska Press.

Castells, M. (1996). The Rise of the Network Society. Oxford: Blackwell Publishers, Inc.

Cascells, M. (r997). The Power of Identity. Oxford: Blackwell Publishers, Inc.

Certean, M. de. (r993). Walking in the city. In S. During (Red.), The Cultral Studies Reader. London and New York: Routledge.

Ciborra, C. U. (r999). Notes on improvisation and time in organizations. In Accounting, Management and Information Technology; $9,77-94$.

Ciborra, C. U. (Ed.). (2000). From control to drift: whe dynanics of corporate informatron infrastructures. Oxford [etc..]: Oxford University Press.

Clark, P., \& Staunton, N. (1989). Innovation in techwology and organization. London [etc.] Routledge.

Claudon, $\mathrm{F}$ ( $(\mathrm{Tg} 88)$. De romantische reis. Utrecht: $\mathrm{K}$ wadraat.

Clifford, I. (1997). Routes: Travel and Translation in the Late Twentieth Century. Cam* bridge, Massachusetts/London: Harvard University Press.

Cohan, S., \&. Hark, I. R. (Red.). (r997). The Road Movie Book. London: Routledge."

Cohen, B. (x989). Trylon and perisphere: the 1939 New York World"s Fair. New York: Abrams.

Cohn, D. L. (1944). Combustion on Wheels. An Infomal History of the Autowobile Age. Boston: Houghton Mifflin Company.

Copeland, J. (1968). Roads and their traffic $1750-1850$. Newton Abbot: David $8 x$ Charles.

Couperus, L. (190 Y. De boekew der klewe zielen. loorspr. uingave] Amsterdinn Veen. Crang, M. (1998). Cultural geograpby. London [etc.]: Routledge.

Crang. M., \& Thrift, N. (Red.). (2000). Thinking space. London [etc.]: Rontledge.

Cross, $\mathrm{G}$ (1993). Thme and Maney: The Making of Conswner Culture. London and New York: Routledge. 


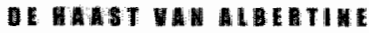

Crossan, M. M. (1998). Variations on a Theme-Improvisaton in Action. Organization science: a journal of the lnstitute of Management Sciences, 9 (1998)(5), 593599.

Crossan, M. M., Lane, H. W., White, R. E., \& Klus, L. (19,6). De improviserende organisatie. HRM-select: bet bestu wit de internationale valkpers, $4(1996), 72-89$.

CROW kemniscentrum voor verkeer vervoer en infrastructuur. Afdeling Communicitie Afdeling Communicatie (2000). Handboek ontuerpen voor kinderen: aanbe-

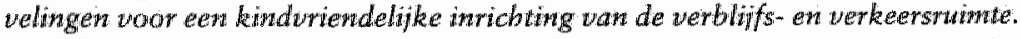
Eide: Grow:

Danly, S., \& Marx, L. (1988). The Railroad in American Ant Representations of Tech. nological Change. Cambridge, MalLondon: The MIT Press.

Dawis, A. (1994). The speed and Mobility Culture: The sacrifice of health and quality of life. Traffic Engineting + Control, 35(10), 568-576.

Davis, 1. ML (1997). Mownt Vewon Meworial Highway and the evolution of the Anerican parkway. Unpublished Ph.D., University of Texas, Austin..

Davison, G. (r992). Punctuality and Progress: The Foundations of Australian Standard Time: Australian Historical Situdies, 25(99), x69-199.

De Long, D.G. (Red.). (1998). Frank Lloyd Wright and the lining city. Weil am Rhein: Vitra Design Museum.

Dekoster, J., Schollaert, U., Bochu, C., \& Lepelletier, M. (1999). Cycing: The way ahead for towns and cities. Luxembourg; Office for Official Publications of the European Communities.

Der Derian, ]. (Ed.). (1998). The Viriho reader. Malden, MA.: Blackwell.

DHV Raadgevend ingenieurs bureau BV, 8 Ministerie van Verkeer en Waterstatat. Projectbureau Integrale verkeers- en vervoerstudies Projectbureau Integrale verkeersen vervoerstudies. (x980). Fietsbelewing en vervoenwizekeuze: een kwantitatiene benadering. ['s-Gravenhage],

Dienel, H. L., \& Trischler, H. (Red.). (r997). Geschichte der Zukumtt des VerkebrsVerkebrskonzepte won der Fräben Nenzent zum $2 x$. Jabrbundert. Frankfurt/New York: Camppus Verlag.

Dierikx, M. L. J. (1999). Blouw in de lucbt: Koninklijke Luchtvaart Maatschappuj r919-1999. Den Haag: Sdu Uitgevers.

Dierikx, M. L. J., Schot, J. W., \& Vlot, A. (2002). Van uithoek tor knooppunt: Schiphol, Tecbriek in Nederland in de twintigste eeww: transport en communicatie. Zutphen: Stichring Historie der Techniek/Walburg Pers, Vol. V, I I 7 -1 44 .

Dijst, M. (1995). Het ellptisch leven - Actieruinte als integrale mat woor bereik en wobilitew - wodelowtwikeling met als voorbeld tweeverdiewers mel kinderen in Howen en Utrebt. Utrecht/Delft" Koninklijk Nedertands Aardrijkskundig Genootschap/Faculteit Bouwkunde Technische Universiteit Delft.

Dijst, M., \& Vidakovic, V. (1995). Stabiele werhouding tussen reistijd en verbliffstijd. Verkeershude, $1995(4), 37-41$.

Dijst. M. J., \& Kapoen, L. L. (Red.). (1998). Op weg war steden van morgen: Perspectiever op werkeer, vervoer en inrichting van stedalike gebieden. Assen: Van Gorcum.

Dohrn-Van Rossum, G. (1996). History of the Howm: Clocks and Modern Temporal Onders. Whiversity of Chicago Press. 


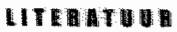

Dowmes, J. D., \& Emmerson, P. (1983). Do higher speeds increase nawel or save time? In Bovy (Red.), Colloquim Vervoersplanologisch 5 peurwerk, 7 1-187.

Dooman, M. (r997). Steeds mooier: Over woontgang in de kwnst. Anusterdam: Pro metheus.

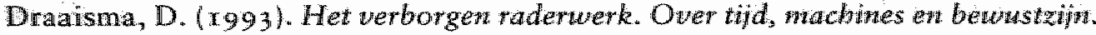
Baarn: Ambo.

Draalsma, D. (200 $)$. Waarom bet leven sneller gaat als je ouder wordt: over bet atutobiografische gebeugen. Gronimgen: Historische Uitgeverij.

Duncan, I., \& Gregory, D. (Red.). (r999). Writes of Passage: Travel Writing, Place and Ambiguty. London and New York: Routledge.

Earman, J. (1989). World enough and space-time: absolwte wersts relational theories of space and time. Cambridge, Mass. [etc.]: MrT Press.

Ellchardus, M. (1996). De genobiliserde samenleving: thssen de onde en en newwe ordening van de tifd. Brussel: Koning Boudewijnstichting."

Elias, N. (1988). Uber die Zeit. Frankfurt am Main: Suhrkamp.

Enckevort, I. van, \& Kruijk, M. de. (r996). Milientelevant gedrag en sochale dilemmas: Hat optreden van sociale dilemma's bijautomobiliteit. Den Haag; Raad voor het Milieubeheer.

Eno, W. P. (1939). The story of bighway traffic control, $1899-1939$. Saugatuck, Conn. Eijssen, J. (2002). Nederland in de file: Over mobihteitsproblemen en technologische oplossingen. Afstudeerscriptie Faculteit der Cultururwetenschappen, Uniwersiteit Maastricht.

Eyerman, $\mathrm{R}_{\text {, }}$ \& Löfgren, $\mathrm{O}$ ( 1995$)$. Romancing the road. Theory, Culture do Society, × $2(1), 53-79$.

Feifer, M. (r985). Going places: the ways of the tourist from imperial Rome to the present day. London [etc.]: Macmillan.

Fenn, D. (1999). Masters of Improvisation. Inc: the magazine for growing compantes, $2 \times(2), 83-88$

Filanski, R. (1995). Kanalen van de Koning-Koopman: goederentwoer, binnenscheepvaart en kanalenbonw in Nederland en Belgiè in de earste helft van de negentiende eeuw. Amsterdam: NEFA.

Filarski, R. (I997). Opkomst en verval van verwoersystement de ontwikkeling vanuit een historisch perspectief. Tidschrift voor werwoerswetenschap, $33(2), 107-132$.

Fischer, L. (r997). Induzierter Verkehr und die These des konstanten Zeitbudgets. Iritermationales Verkehrswesen, $49(\mathrm{x}), 55 \mathrm{x}-556$.

Flink, J. J. (1993). The Antomabile Age. Cambridge, Mallondon.

Ford, H. \& Crowther, S. (1922). My Lifeand Works. Ciarden City, New York: Garden City Publishing Co. Inc.

Forrester J. (1983). Bicycle transportation. Cambridge, MAn: Mrt Press.

Fraser, J. T. (1987). Twme, the familiar stranger. Redmond., WA: Tempus Books of Mi crosoft Press.

Freeman, M. (1999). Raihways and the Victorian intagination. New Haven, CI [ete.]: Yale University Press, cop.

Friedland, $\mathrm{R}_{\text {, }}$ \& Boden, D. (Red.). ( $\left.\mathrm{T} 994\right)$. NowHere. Space, Time and Modernity. Berkeiliey, Los Angeles, London: University of Califormia Press. 
Frieling, Euking, B., Tisma, Onderzoeksatelier Deltametropool. (2000). Tijd als in. strument tam ordening, Delft: Delfu Universiry Press.

Fuchs, J.M. (9981). Onderweg: en weww personen ew goederenterwoer in Nederland. Den Haag: Koninklike Nederlandse Vereniging wan Transport-Ondermemingen.

Fuchs, J. M., \& Simons, W. J. (1968). Woont, in "t zadel, kameraden: Een eewu fietsen in Nederland. Amsterdam: De Bussy.

Gabriels, R. (200 ). Intellectuelen in Nederland: publeke comtrowersen over kernenergie, armoede en Rushdie. Amsterdam: Boom.

Geels, F. W., Smit, W. A. (2000). Falled technology futures: pitfalls and lessons from a historical survey. Futures, $32,867-885$.

Grelernter, D. (1995). I939 The Lost World of the Faur. New York [etc.]: The Free Press.

Gell, A. (1992). The Anthropology of Thme: Cultural Constructions of Temporal Maps and Images. Oxford: Berg.

Geul, A. (1998). Beleidsconstructie, coproductie en communticate: zes beproefde methodieken van beleidsontwikkeling. Utrecht: Lemma.

Giddens, A. ( $98 \mathrm{x})$. A Contemporary Critique of Historical Materialism. London: Macmillan.

Giddens, A. (1984). The constitution of society: outine of the theory of structuration. Cambridge: Pollity Press.

Giddens, A. (1990). The Consequences of Modernity. Oxford: Polity Press.

Gieryn, T. F. (2000). A Space for Place in Sociology. Annual Rewiew of Sociology, 26. $463-496$.

Gleick, J. (1999). Faster, The Acceleration of Just About Everything. London: Little, Brown and Company.

Goddard, S. B. ( 9994$)$. Getting There: The Epic Struggle betweew Road and Rail in the American Centwry. New York: Basic Books [Harper Collins Publishers].

Godefrooij, T. (x 997). Segregation or integration for cyclists? The Durch approach. In $\mathrm{R}$. Tolley (Red.), The greening of urbon transport: planming for walking and cycling in Western citites. Chichester [etc.]: Wiley, $229-238$.

Godefrooij, T., \& Komitee "so is tevel". $(1982)$. Snelheid remmen: over wegintichting en aangeposte rijsnelheden. Woerden Amsterdam Den Haag: Enfa, Stop de kindiermoord, Vbv.

Goeverden, C. D. van, \& Heuvel, M. G. van den. (r993). De verplacatsingstijdfactor in relatie tot de vervoerwijekewze (Ivv rapport; vK 5304.30r ed.). Delft: Technische Universiteit Dellf, Faculteit der Civiele Techniek, Vakgroep Verkeer.

Goeverden. K. van. (1999). De betekenis van de wet vam BREVER, Colloqum Vervoersplanologisch Spentwerk I 999: Nederland is af Delif: Cvs, Vol. 2,627-645.

Contsjarow, 1. A. (x987). Reis on de wereld. Amsterdam: De Arbeiderspers.

Gonzalez, R. M. (r997). The value of time: a theoretical review. Transpow Rewiews, $x>(3), 245-266$.

Goudsblom, J (x997). Het regime vam de tijd. Amsterdam: Meullenhoff.

Gregory, A. (1993). De gouden tijd wan het reizen" $880^{-1939}$. Harlem: Schuyt.

Gregory, D. (r989). Presences and absences: time-space relations and structuration theory. In D. Held \& J. B. Thompson (Red.), Social theory of modem socite ties: Anthony Giddens and his critics. Cambridge: Cambridge University Press, $\times 85 \cdot 2 \times 4$. 


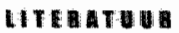

Gregory, D. (1994). Geographical Imagimations. Oxford: Blackwell.

Grewal, 1. (r.996). Howe and harew: nation, gender, empire, and the caltures of travel. London: Leicester Univ. Press.

Guronemeyer. M. ( 1993 ). Leben als letzte Gelegewhen: Sicherheitsbedurfwnse wnd Zeitknaphent Darmstadt: Wissenschaftiche Buchgesellschaft, cop.

Grossklaus, G. (1995). Medien-Zeit, Medien-Roww: zwm Wandel der pumzithichen Wabnehmurg in der Moderne. Frankfurt am Main: Suhrkamp.

Grusin, R. (r995). Representing Yellowstone: Photography, Loss, and Fidelity. Configutations, $(1995)(3), 4 \times 5-436$.

Gusfield, I. R. (1981). The culure of public problews: drinking dritwg and the symbolic order. Chicagollondon: The Uniwersity of Chicago Press.

Hacking, I. (1985). Styles of scientific reasoning. In J. Rajchman \& C. West (Red.), Postanalytic philosopby. New York: Columbia University Press, $145-165$.

Hagerstrand, T. (I970). What about people in regional science? Papers of the Regional Sciemce Association, 23,7-2 I. .

Hägerstrand, T. (I988). Time and Culture. In G. Kirsch \& P. Nijkamp \& K. Zimmermann (Eds.), The Formulation of Time Preferences an M Mulidisciplinary Perspec true: Their Consequences for Inditidual Bebaviour and Collective Decision-Making. Aldershot/Brookfield: Avebury, 3,3-42.

Hajer, M. A. (I995). The Politics of Environmental Discomrse: Ecological Modernitation and the Pollicy Process. Oxford: Clarendon Press.

Hajer, M. 8 Halsema, F. (Red.). (2997). Lard in zicht-Een cultumpolitieke visie op de ramtelijke invichting. Amsterdam: Uirgeverij Bert Bakker/Wiardi Beckman Stichting,

Hajer, M. A. (1999). Zero-Friction Society. Urban Design Quarterly, $7 \mathbf{x}, 29-34$.

Hajer, M.A. (2000) Politiek als wormgeting. Amsterdam: Vossiuspers.

Hajer, M. A., \& Reijndorp, A. (200r). Op zoek naar nienw publiek domem: analyse en strategie. Rotrendam: NAi Uingevers.

Ham, W. van. (1989). Tot gerief wan de reiziger: Vier eewwen Amsterdam Haarlem. s-Gravenhage: sDu Uitgeverij:

Hamerslag, $\mathbb{R}$. (I998). Verplaatsingstijdbesteding en mobiliteit: De beperkte bruikbaarheid van de Wet van Brever, Colloquim Vervoersplanologisch Speurwerk 1998 : Sturen met structuren. Delft: cvs. Vol. $4,1702-17 \times 7$.

Hamilton, A. (2000). The Art of Improvisation and the Aesthetics of Imperfection. The British poumal of atesthetics, $40(2000)(1), 165.185$

Hanson, S. (Redi). (I995). The Geograpby of Urban Transportation. New York/London: The Guilford Press.

Hartman, J. (1997). The Delft bicycle network revisived. In Tolley, R. (Red.). (r997). The Greening of Urban Transport: Plawning for walking and cycling in Westem at ties. Chichestrer [etc.]: Johri Wiley \& Sons.

Harvey, D. (1990). The Condition of Postmodernity: An Enguiry into the Origins of Cultural Change. Oxford: Blackwell.

Harvey, D. ( 1996$)$. Justice, nature and the geography of difference. Cambridge, MA [etc.]: Black well.

Hassand, J. (Red.) (1990). The Sociology of Time. London: The MacMillan Press, Ltd. Hawthome, N. (r996). Het buis wet de zeven zegels. Amsterdam: Meulenhoff. (OOor- 
spronkelijke uitgave $185 \mathrm{x}$; vertalitid en van een nawoord voorzien doon Anton Hakman...

Hays, S, P. (1987). Beaty Heath, and Permanence: Enmonmental Politics in the Unted States, 1955-1985. Cambridge [etc.]: Cambridge University Press.

Healey, P. (1997). Collaboratue plawning: shapug places in fragmented sacreties. Basingsitoke [etc.]. Macmillan.

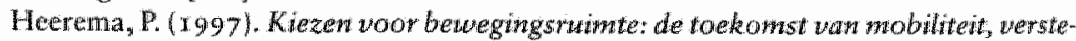

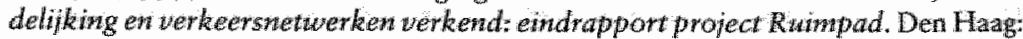
Ministerie Wrow/Riksplanologische Dienst.

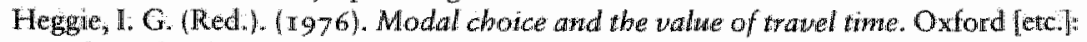
Clarendon Press.

Heimann, J. (1996). Car Hops and Curb Service. San Francisco: Chronicle Books.

Held, M. Q Geissler, K. A. (Red.). (1995). Von Rythmen und Eigenzeiten: Perspektwen einer Oekologie der Zent. Sruttgart: Hirzel.

Hellemans, $F$, (1998). Napoleon and Internet: $A$ historical and anthropological view on the culture of punctuality and instantaneity. Telematics and Imformatics, 15,227 134.

Hendriks, E, \& Tops, P. (2001). Politiek en interactief bestwnt: interacties en iwterpre. taties rond de ontwikkeling wan het Nationad Verkeers-en Veruousplan. "s-Gram venhage. Elsevier bedriphinformatie.

Hendriks, R. P. I. (2000). Autistisch gezelschap een empirisch flosofisch orderzoek nadx bet gezamewlik bestan wan awistische en riet-antistische personen. Lisise: Swets \& Zeitlinger.

Hetherington, K. (1997). The Badlands of Modernity. Heterotopia and social ordering. London and New York: Routledge.

Heuvel, M. van den., \& Peters, P.F. (x998). De roep on snelbeid en verte: Een studie naar de verswelling ton verwoer in bistorisch en mats shappelipk perspectief, 1339 1997. Tilburg: Katholieke Universiteit Brabant.

Hillman, M., Adams, J., \& Whitelegg, J. (1990). One false wove ... a study of children's independent mobility. London: PSI.

Millman, M. \& Whalley, A. (T979). Walking is transport. London: PS1.

Hlavin-Schulze, K. (1998). "Man reist ja nicht, un anzukommen": Retsevals kwltwrelle Praxis. Frankfurt/Main: Campus Forschung.

Hofland, H. J. A. (1964). Geen tid: op zoek natar oorzaken en geiolgen van bet moderne vijgebrek. Armsterdam: Scheltema \& Holkena. [Oorspr. uitgave 1955].

Hogenhuis, C.T., Panne, F, van der, 8 Hoekstra, T. (200 1 ). Een miewue ecomomie, een berrijde tijdz. de rolvan lcr in wersnalling ent onthasting. Kampen: Kok.

Hojer, M., \& Matson, L.G. (2000). Determinism and backeasting in future studies. Futures, $32(2000), 613-634$.

Hokanow, D. (1999). The Lincoln Hghtay. Main Street acposs America. lowa Ciry: Univerity of lowa Press.

Holtz Kay, J. (ngg7). Asphalt Natron: How the Antomobile Took Over America and How We Cav Get It Back Crown Publishers.

Hommets, A. M. (2oor). Unbwildiwg cities obduracy in wban sociotechnical change. Maastricht: Universitaire Pers Mastricht.

Hood, $\mathrm{C}_{\text {. }}(\mathrm{rg9}$ ). 722 Miles: The Building of the Swburys and How They Traws formed New York. New York: Simon \&C Schuster. 


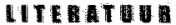

Hoogma, R., Kemp, R., Schot, J., \& Truffer, B. (2002). Expermentwg for Sustamuble Tramsport: The approdich of Strategic Niche Managentent. London/New York: Spon Press.

Horming, K. A., Ahrens, D., 8 Gerhard, A. (4997). Zentpraktiken: Expenmemterfelder der Spatmodeme. Frankfurt am Main: Suhrkanp.

Howning, K. H., Ahrens, D., \& Gerhard, A. (T 999). Do Technologies Have Time? New practices of time and the transformation of communication technologies. Time $O$ Societ $y, 8(2), 293-308$.

Hörning, K.H., Gerhard, A, \& Michailow, M. (1995). Twe Proneers. Flexible Working Time and New Lifestyles. London: Polity Press.

Hout, T. wan der. \& Werkgroep Evaluatie Verkeerstichtenregelingen. (1990). Verthes en winst bij werkeershobtenregelingen. Ede: Stichting C.R.O.W.

Howse, D. (1.980). Greenwich twe and the discovery of the longitude. Oxford: Oxford University Press.

Hoyle, B. S., \& Knowles, R. (Red.). (r998). Modern Transport Geography: John Wiley \& Sons.

Hughes, T. P. ( 1983$)$. Netuorks of Power: Electrification in Western Socien I 880 II 930 . BaltimorefLondon: The Johns Hopkins University Press.

Hughes, T. P. (m989). American genesis: a century of invention and technological entbusiasm $1870-1970$. New York: Viking Penguin.

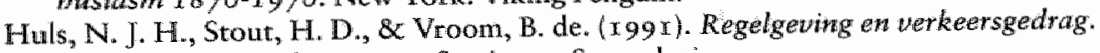
Leiden: Onderzoekscentrum Sturing en Samenlewing.

Hupkes; G. (1977). Gasgewen of afremmen. Toekomstscenario's moor ons werwoersys teem. Deventer: Kinwer.

Hupkes, G. (x979). Nieuwe ontwikkelingen rond de BREvEk-wet. Verkeerskunde, $30(8), 363,-369$.

Hutchins, E. ( 199 ). Organizing work by adaptation. Organizational Science, $2, x 4$ 29.

Hutchins, E. (x995). Cognition in the wild. Cambridge, MA, [etc.]: MrT Press.

Huth, H. (1990). Nature and the American: Three Centuries of Changing Attitudes. Lumcoln and London: University of Nebraska Press.

Illich, I. (1974). Energy and Equity. London and Boston: Marion Boyars.

Ingold, T. (1993). The Temporality of the Landscape. World Archaeology, $25(2), 152-$

174 .

Jacobs, J. (r96 $\mathrm{x})$. The Death and Life of Great Americaw Cities. New York: Vintage Books [A Division of Random House, Inc.].

Jakle, J. A. (1985). Tha tourist: travel iw twenteth-cewtwy North America. Lincoln [etc.]. University of Nebraskit Press.

fakle, J. A. (r990). Landiscapes redesigned for the atromobile. In M. P. Conzen (Red.), The making of the Aneriata landscape (pp. 293-3xo). Boston, MA. [etc.]: Unwin Hyman: Unwin Hyman.

Jakle, J. A., \& Sculle, K. A. (1994). The Gas Station in America. Baltimore and Boston: The Johns Hopkins University Press.

Jakle, J. A., Sculle, K. A., \& Rogers, J. S. (1996). The Motel in America. Baltimore and London: The Johns Hopkins University Press. 
Jakle, J. A., \& Sculle, K. A. (r999). Fust food: roadside restaurants in the watomobile age. Baltimore, MD [etc.]: Johns Hopkins Uniwersity Press.

Janelle, D.G. (1968). Central place development in a time-space framework. Professional Geographer, 20, $5-10$.

Janelle, D.G. (1991). Global Interdependence and Its Consequences. In Brunn, S. D. \& Leinbach, T. R. (Eds.). ( 999 ). Collapsing space and time: geographic aspects of communications and information. London: HarperCollins Academic.

Janssen, R. (I992). Arbeid, tijd en geld ontschaarsen. Een nieuwe kijk op armoede ent burgerschap. Utrecht: Commissie Oriënteringsdagen.

Jarvis, R. (1997). Romantic writing and pedestrian travel. Basingstoke: MacMillan.

Jasanoff, S. (Red.). (2995). Handbook of science and technology studies. Thousand Oaks, CA: Sage, cop.

Jedamski, D., Jehle, H., \& Siebert, U. ( 5994$).$ "Und tät das Reisen wählen!" : Frawenreisen, Reisefrawen: Dokwmentation des interdisziplinären Symposiums zur Frans. enreiseforschung, Bremen 2 $\mathrm{I}_{\mathrm{n}}-24$. Juni 1993 . Zürich [etc.]: $\mathrm{eFeF}$.

Joerges, B. (1994). How to Recombine Large Technical Systems: The Case of European Organ Transplantation. In J. Summerton (Red.), The Development of Large Technical Systems. Boulder/San Francisco/Oxford: Westriew Press, 25-5I.

Joerges, B. (x999). Do Politics Have Artefacts? Social Stadies of Science, 29(3), 4 I I-43X. Jonasson, M. (2000). The creation of places in traffic through performative action. Gothenburg. Department of Human and Economic Geography School of Economics and Commerciall Law University of Gothenburg.

Jorritsma, P. (1990). Over tijd, reizen en verblipven: Nederlanders gegroepeerd naar bun dagelijkse verplaatsingen.. Groningen: Geo Pers.

Kalfs, N.., \& Meurs, H. (1995). Ontwikkelingen en trends in het urijetijdsverkeer: stand van zaken notitie. Rotterdam: ministerie van Verkeer en Waterstaat, DirectoraatGeneraal Rijkswaterstaat, Adviesdienst Verkeer en Vervoer.

Kampen, L. T. B. van. (1992). De veiligheid van de fiets in bet wegverkeer, een literdtuurstudie als onderdeel A van bet project "Veilige fiets en letselpreventie" van het Masterplan Fiets. Leidschendam: Stichting Wetenschappelijk Onderzoek Verkeersveiligheid swov.

Kaplan, C. (1996). Questions of travel: postmodern discoutrses of displacentent . Durham: Duke University Press.

Kelly, K. (I995). Out of control: the new biology of machines, social systews and the economic world. Reading Ma.: Addison Wesley.

Kern, S. ( 1983$)$. The Culture of Time and Space I $880-19$ I 8 . Lonclon: Weidenfeld and Nicholson.

Kesselring, S. (200r). Mobile Politik. Ein sociologischer Blick auf Verkehrspolitik in München. Berlin: Edition Sigma.

Kirsch, S. (r995). The incredible shrinking world? Technology and the production of space. Envirowment and Plawning D: Society and Space, $53,529-555$.

Kirsch, G., Nijkamp, P., \& Zimmermann, K. (Red.). (1988). The Fonmulation of Time Preferences in a Multidisciplinary Perspective: Their Consequences for Individual Behaviour and Collective Decision-Making. Aldershot/Brookfield: Avebury.

Klant, J. J. (1954). De Fiets. 's-Gravenhage: Bert Bakker/D.A. Daamen's uitgeversmaatschappij in.v. 


\section{HTHATHE}

Kline, R., \& Pinch, T. (1996). Users as Agents of Technological Change: The Social Construction of the Automobile in the Rural United States. Tedmology and Culwate, $37,763-795$.

Kloos, M., \& Maar, B. de. (r996). Schiphol Architecurre. Innovative airport desigw. Amsterdam: ARCAM/Architectura \& Natura Press.

Kinippenberg, H., \& Nauta, B. (r989). Naar eenheid wan tijd in Nederland 1835 -1909. Tijdschrift voor Sociale Geschiedenis, $15(4), 325-344$.

Knippenberg, H., \& Pater, B. de. (r988). De eenwording van Nederland. Nijmegen: suN. Knippenberg-Den Brinker, C. W. F. (1987). Time in Travel. Rijksuniversiteit Groningen, Groningen.

Knoke, W. (1997). Platsloze niewwe wereld: wegwijzer wat de eenemtwintigste eeun. Schiedam: Scriptum.

Koenig, G. M. (1996). Eine Kullurgeschichte des Spazierganges: Spuren einer buergerlichen Praktik $1780-1850$. Wien [etc.]: Boehlau.

Kraan, M. E. ( 1996$)$. Time to travel?: A model for the allocation of time and money. Enschede: Universiteit Twente.

Kramarae, C. (Red.). (1988). Technology and women's voices: keeping im tonch. New York/London: Routledge \& Kegan Paul.

Kuipers, L. (r998). Kruispuntontwerp. Alkmaar: G.C.T.

Kunstler, J. H. ( 1994 ). The Geography of Nowbere: the Rise and Decline of America's Mant-Made Landscape. New York [etc.]: Simon \& Schuster.

La Porte, T. ( 1988 ). The United States air traffic system: Increasing reliability in the rnidst of growth. In R. Mayntz \&C T. P. Hughes (Red.). The Development of Large Technical Systems. Frankfurt am Main/Boulder $\mathrm{CO}$ : Campus Verlag/Westwiew Press, 2 I 5-244.

Lackey, K. ( 1997 ). RoadFrames: The American Highway Narrative. Lincoln and London: University of Nebraska Press.

Lammers, J. ( $(9995)$. Cities make room for cyclists: examples from towns in the Netherlands, Denmark, Germany and Switzerland. The Hague: Ministry of Transportation, Public Works and Water Management.

Landes, D. S. (1983). Rewoltution in Time. Clocks and the Making of the Modern World. Cambridge, MA.: Harvard University Press.

Langeveld, J. W. M., Tjallingii, S. P., \& Bus, L. (1997). Stromenland: netwerken wan verkeer en water als dragers voor rwimtelijke ontwikkeling. Wageningen: Instituut voor Bos-en Naturironderzoek (rBN-DLO).

Lash, S., \& Urry, I. ( 1994$)$. Economies of Signs and Space. London: Sage Publications. Latour, B. (r992). Aramis, ou l'amour des techniques. Paris: Editions la Decouverte. Latour, B. (1993). La elef de Berlin el autres leçons d"wn amateur de sciences. Paris: la

Découverte.

Latour, B. (r997). Trains of Thought: Piaget, Formalism, and we Fifth Dimension. Common Knowledge, 6 (No. 3 Winter 97), 170-191.

Law, J. (x987). Technology and Heterogeneous Engineering: The Case of Portuguese Expansion. In W. E. Bijker \& T. P. Hughes (Red.), The Social Construction of Technology: New Directions in the Sociology and History of Technology. Cambridge, MA.: MIT Press, IIT-II4.

Law, J. (1994). Organizing modernity. Oxford: Blackwell. 


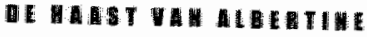

Lay. M. G. (1992). Ways of the World: A Hetory of the World's Rodds and of the We. bicles That Used Thew. New Brumswick NJ: Reutgers University Press.

Least Heat Moon, W (1984). Blue highways: a joumey into America London: Picador.

Le Corbusier (r994) Urbanisme. Paris: Flammarion.

Leed, E. I. (r99x). The Mind of the Traweller. From Gilgamesh to Global Towrism. BasicWooks/Harper Collins Publishers.

Lefebvre, H. (x99n). The Production of Space. OxtordCambridge MA: Blackwell.

Leigh Star, \$, \& Griesemer, J.R. (1989). Inutitutional Loology, "Tramslations' and Boundary Objects: Amateurs and Professionals in Berkeley's Museum of Vertebrate Zoology, $1907-39$. Social Situdies of Science, $19,387-420$.

Lemaire, T. (1970). Fulosofie wan hot landscbap. Baarn. Litgeverin Ambo.

Lewine, R. V. (1998). A Geography of Time: The Temporal Misadventures of a Socual Psychologist, or How Every Culture Kexps Tine J ust a Little Bit Differenty. New York [NY]: Basic Books.

Lewis, D. L. C Goldstein, L. (Red.). (1983). The Antomobite and American Culdure: Univesity of Michigan Press.

Lewis, T. (1997). Divided bightwas: building the interstate bighways, transforming American life. New York: Viking.

Lichtenstein, C., 8x Engler, F. (1992). Streamlined" a wetaphor for progress: the esthetics of mininnized drag. Baden: Lats Mueller.

ligtermoet, D. M. (1990). Beleid en planning in de wegenbown De relatie tussen be. leidsuoming en planning in de geschiedenis unn de admleg en verbetering van rijkswegen. Amsterdam: Onderzoekcentrum Beleid \& Planing Vrije Uniwersiteit, vakgroep Politicologie.

Ling, P. I. (1990). America and the antomobile technology peform and social change, 1893-1923. Manchester and New York: Manchester University Press.

Lippincott, K., Eco, U., \& Guylenborg, H. van. (Red.). (r999). Het werbaal van de tid. Hadrtem: Schnyt.

Lögren, $0 .(x, 99)$. On boliday: a bistory of vacationing. Berkeley [etc.]: University of Califomia Press.

Loos, A., \& Kopman, J. (r993). Reistijd cruciaal voor kenze verwoerwijze. Verkaerskutude, $44(5), 26-29$.

Lowe, J. C., \& Moryadas, S. (1975). The Geography of Movement. Boston: Houghton Mifflin Company.

Lowe, M. D. (1989). The bicycle: vehicle for a small planet. Washington DC: World watch Institute.

Maas, H. (2003). Mechanical Reasoming: Willam Stanley and the Making of Moderw Ecomomics. Fortheoming.

Mackenzie, D. \& Wajcman, J. (r999). The social shaping of technology. Buckingham [etc. ]: Open Universiry Press.

Macnaghten, P., \& Urry, J. (1998), Cowtested Natures. London Sage Publications.

Maczak, A. (1995). Travel inearly modern Europe (U. Phillips, Trans.). Cambridge: Polity Press.

Makimono, T, \& Manners, D. (r997). Digital nomad. Chichester [etc.]: Wiley.

Maten, K. van der \& Pama, G. (1994). Minister De Boef over de spanning tussen mi 


\section{UTHETUE}

Trea to conomie. 'Laat mensen in de fle staan, dan kiezen ze voor openbar verwoer". In NRC Handelsblad, 22 oktober r994.

Marchetr, C. (1994). Anthropological Invariants in Travel Behavior. Technological forecasting and soctal change: an memational jommal $47(x), 75-88(x, 4)$.

Margohes, J. (I995). Home Away from Fome: Motels in Amenca. New York: Bulfinch press.

Warx, K. (1974). Grundrisse der Kritik der Politiscbew Oekonomie [Robemumf. BerIinn Dietz Verlag.

Marx. (. (xg64). The Machine in the Gardent Technology and be Pastoral Teal in America London Oxford New York: Oxford University Press.

Mag, J., \& Thrift, N. (Red.). (200 I). Thmespace: Geographies of Temporality. London: Routledge.

Mayntz, R., \&ughes, T. P. (Red.). (1988). The Development of Large Technical Sys tems. Frankfurt an Main/Boulder, Col.: Campus Verlag/Westriew Press.

MeClelland, L. F. (1997). Building the National Parks: Historic Landscape Design and Construction. Baltimore \& London, Johns Hopkins University Press.

McClintock, H. (Red.). (r992). The Bicycle and City Traffic Principles and Practice. London: Belhaven Press.

McGrath, J.E. (1988). The Social Psychology of Tme. New Perspectives. London* Sage Publications.

Mckean, J. R., Johnson, D. M., \& Walsh, R. G. (1995). Valuing Time in Travel Cost Demand Analysis: An Empirical Investigacion. Land Economics, 7 (1), 96- 105.

Mckinsey \& Company, \& ministerie wan Verkeer en Waterstaat. (1986). Afrekenen met files: samenvatting, conclusies en aanbevelingen. [A msterdam]: McKinsey \& Company.

McQuite, $S_{m}$ (1998). Visions of Moderwity: Representation, Memory, Tune and Space in the Age of the Camera London [etc.]: Sage Publications.

McShane, C. (1994). Dowm the Asphalt Path: The Automobile and the American City. New York: Columbia Uniwersity Press.

Meadows, D. (1972). Rapport van de Club van Rome. De grenzen an ale groei. Utrecht/Antwerpen: Uitgeverij Het Spectrum.

Meeuse, P. (Red.).(zooo). Lopen. Amsterdam: De Bezige Bij.

Nesman, J. (2,002). Ervaren pioniers. Omgaan met twifel in de intensive care woor pasgeborenen. Armsterdam: Aksant.

Methorst, R., \& Pieters, J. (1994). De straat van de toekomst: een studie matar de baalbaarbeid wan bet stellen van functic-eisen aan wegen. Den Haag: Voetgangersvereniging vav.

Metz, J. ( 1987$)$. Veiliger fuetsen in Amsterdam ontwikkelingen van de laatste viftien jatr. Amsterdam: Dienst Rumateligke Ordening.

Michael, M. (1998). Cola)gency and the Car: Atributing Agency in the Case of the Road Rage". In B. Brenna \& J. Law \& I. Moser (Red.), Machines, Agency and Desire. Oslo: Centre for Technology and Culture, $125-x_{4} x^{2}$

Michels, T. (Red.). (r993). Cycling in the city pedalling in the polder Recert developments in policy and research for bicycle facilities in The Netherlands. Ede: cnow.

Michon, J. A. (x999). Globalization and the Use of Time. Paper presented at the Symposium of Time and Globalizarion, Parijs, 5 november 1999.

Mierlo, J. G. A. van. (2000). De wereld gaal an beleid tem ander...: ower belendsfalew 


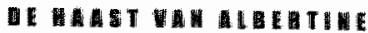

in de publieke sector w wat daw ann to doen. Maastriche: Universitare Pers Maasrricht.

Millar, J, Schwar, M. (Red.). (x998). Speed-Wisioms of an Accelerated Age. London [Etc.]: The Photographers' Gallery [Etc.].

Ministerie wan Verkeer en Waterstat. (197Y). TP 2000: op weg nat 2000, een toekonstprojectie van Verkeer en Waterstaat. Den Haag: ministerie van Verkeer en Waterstat/Staatsuitgeverij.

Ministerie van Verkeer en Waterstat. (1973). TP zooon eerste deel awwoordnota: me thodologiv: "s-Gravenhage: Staatsuitgeverij.

Minsterie van Verker en Waterstaat. (1975). TP zooo: iwede deel antwoondnota. "s-Gravenhage: Staatsuitgeveri.

Ministerie wan Verkeer en Waterstat Mimisterie van Volkshuisvesting en Rumrelijke Ordening (1977). Structumichema verkeer en vervoex. '\$-Gravenhage: Staatsaitgeverij. [a. Beleidswoornemen. $(1977$.$) b. Hoofdignen uit de inspraak. (x978.) \mathrm{c}$ Adviezen. (1978.) cr. Aanwullend advies. (r979.) d. Regeringsbeslissing. (1979.)

Ministerte van Verkeer en Waterstaat/Ministerie van Volkshuiswesting Ruimtelijke Ordening en Miltieubeheer (1988-1990). Tweede strukwwschewa verket en verwoer. "s-Gravenhage: Sdu. [DI. A: Beleidswoormemen. - DI. C: Adwiezen.-DI. D: Regeringsbeslising. - D1. E. Tweede structuurschema .... : tekst van de na parlementaire behandeling vastgestelde planologische kernbeslissing.

Ministerie van Verkeer en Vervoer, Directorat-Generall voor het Vervoer, Directie Individueel Personenvervoer. (1996). Samen werken an bereikbatrheid. "s-Gravenhage: Ministerie van Verkeer en Waterstaat, Directoraat-Generaal voor het Verwoer.

Ministerie van Verkeer en Waterstaat. (1997). Euduatierappont Masterplan Fiets. Dem Hag: Ministerie van Verkeer en Waterstaat

Ministerie van Verkeer en Waterstaat, Interprovinciaal Overleg (IPo), Vereniging van Nederlandse Gemeenten (WNG), \& Unie van Waterschappen. (1997). Dwarzalaw veilig verker: intentieverklaving van de Minister van Verkeer en Waterstaat, bet. Interprovincial Overleg, de Verenging van Nederlandse Germeenten, de Unie van Walerschappen aver bet startprogramma dumrzam veilig. Den Haag: [s.n.].

Ministerie van Verkeer en Waterstaat, Projectdirectie Nationaal Verkeers- en Vervoersplan. (200x). Van A matar Beter: Nationaal Verkeers en Verwoersplan 200x. 2020 : kabinetssiandpunt en resultaten insprat en advies. Den Haag: ministerie van Verkeer en Waterstaat. $[5 \mathrm{dl}$.].

Minnen, J. van. (1 995). Ronondes en voorrangsregelinger. Leidschendam: Stichting Wetenschappelijk Onderzoek Verkeersveiligheid swow.

Misa, T. J., Brey, P., \&. Feenberg, A. (2003). Modewity and Tecbnology. CambridgelLondon: The MiT Press.

Mol, A (x997). Wat is kiazen: Een empirisch-fnlosofiscbe verkenming. Enschede: Univiersitcit Twente.

Molin, E. J. E. \& Tinumermans, l.. (1998). De snelbeid begrensd: en onderzoek nam bet draguhak woor de intelligente smulheidsadapler voor personenawto's. Delf: Sectie Transportbeleid en Logistieke Organisatie (TU Delff).

Mom, G., \& Kirsch, D. A. (2001) Technologies in Tension Horses, Electric Trucks, and the Motorization of Anerican Cities, 1900-1925. Technology and culwwe the internutional quatterly of the Society for the History of Teathology $42(3), 489-518(430)$. 


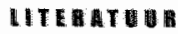

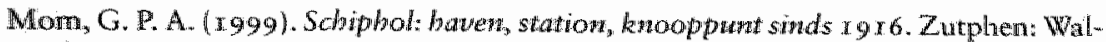
burg Pers.

Mom, G. P. A., Schor, J. W., \& Stat, P. E. (2002). Werken aan mobiliteitu de inburge-

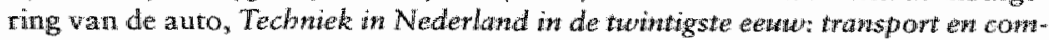
wwuncatie. Zutphen: Stichting Historie der Techniek/Walburg Pers, Vol. V, 45-74.

Mlonkkonen, E. H. (1988). America Becomes Urban: The Development of U.S. Towns r 780-x 90. Berkeley [etc.I: University of California Press.

Moorman, C., \& Miner, A. S. (1998). Organizational Improvisanion and Organizational Memory. The Academy of Management review, $23(1998)(4), 698-723$.

Moors, E. H. M. \& Geels, F. W. (200r). Dymamics of socrotechnical chunge in transport br mobility: opportunities for govemance. Bulthoven: National Institute of Public Health and the Environment.

Morris, M. (1988). At Henry Parkes Motel. Cultural Situdes, $2, x-47$.

MuConsult. (1995). Tijdsbestedingsonderzoek 2995 Ontwikkelingen in tidsbestedimgen in mobiliteit tussen 1975 en 1995 . Amersfoort MuConsult BV.

Mumford, L. (1963). Tecbnics and chilizatiom. San Diego [etc.]: Harcourt Brace Jovanovich.

Mumford, L. (1964). The Highway and the City. New York: New American Library.

Nash, R. $(1982)$. Wilderness and the American Mind. New Haven and London: Yale University Press.

Nelson, D. (rg80). Frederick W. Taylor and the wise of scientific managentent. Madison: Unversiry of Wisconsin Press.

Niewald, R., \& Paarlberb. B. (x997). Gebouraamt de signalen... 65 jaar verkeets lichten Amsterdaw. Amsterdam: Geneente Amsterdam Dienst Infrastructur Verkeer en Vervoer.

Nijkamp, P. (200 n). Modern nomadisme, bet milieu en de stad. Amsterdam: wu Boekhandeluntgeverij.

Nowotny, H. (1989). Eigenzeit: Entstehung wnd Strukturierung ermes Zeitgefibls. Frankfurt am Main: Suhikamp.

Nye, D.E. (I994). American Technological Sublime. Cambridge, MA Mondon: MrT Press.

Nye, D.E. (1997). Narratives and Spaces: Technology and the Constwaction of American Culture. Exeter: University of Exeter Press.

O'Dea, W. P. (1994). The Value of a Travel Time Sawing to an Individual. Internation. al Journal of Transpont Economics, 2 it (3), 255-268.

Oei H.L. (I990). Snetheid en verkeersonveiligheid op $80 \mathrm{~km} / \mathrm{mur}$-wegen: een literatunstudie. Leidschendam: Stichring Wetenschappelijk onderzoek Verkeersveiligheid sion

Ohler, N. (1986). Reisen tw Mittelater. Munchen: Artemis.

Omneren, C. van. (1990). Ran $2 x$ en de auto: verschillew in verphatsingstiden tussen

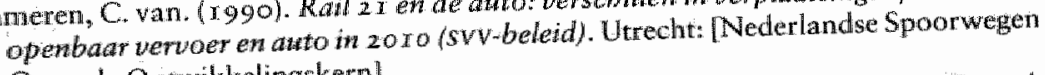
Centrale Ontwikkelingskerm].

Onthowski, W: J. (r996). Improvising Organizational Transformation Over Time: A Situated Change Perspective. Information systems research: a jourmal of the Institwe of Managenent Sciences, $7(1996)(x), 63-92$. 


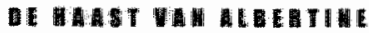

Osborme, P. (2000). Traveling Light: Photography. Travel and Visual Culture. Manchester: Manchester University Press.

Ostor, A. (1993). Vessels of Tho. An Essay on Temporal Change and Social Transformation. New Dielh: Oxford Uniwersiry Press.

Otre. M: (1993). Het stelsel van gedragsregels in bet ureguerkear. Arnhem. Gouda Quitut.

Otte, M. (1994). Verkeerstegels in revisie: pleidooi voor een witputtend RVV. Arnhem: Gounda Qunt.

Overeem, M. van \& Tuynman, D. S. (Red.). (n979). Awto weg of awtoweg: en stadkaan van meningen en een discussie erowet / door de politici D.S. Tuynwan n.. let al.); o.Lv. H.J. Noortman (smo-boek; I I ed.). Scheveningen: Stichting Maatschappij en Onderneming.

Pacey, A. (1983). The Culture of Technology. Oxford: Basil Blakwell.

Parkes, D., \& Thrift, N. (1980). Times, Spaces, and Places; A Chronogeographic Per spective. Chichester/New York/Brasbane/Toronto: John Willey \& Sons.

Pascoe, Di (200x). Airspaces. London: Reaktion.

Pater, B. C. d., \& Schmal, H. (I982). Reistijden, reiskosten en forensisme op Amsterdam in de periode $1855-1980$ : en lijdgeografiscbe studie. Amsterdam: Vrije Uni versiteit Amsterdam, Geografisch en Planologisch Instituut, Vakgroep Algemene Sociale en Historische Geografie.

Patin, T: (1999). Exhibitions and Empire: National Parks and the Performance of Ma-

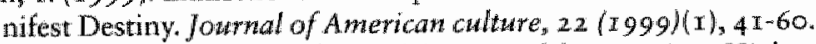

Patton, P. (1986). Open Road: A Celebration of the American Highway. New York: Simon and $S c h u s t e r$.

Peeters, P. M. (1988). Schoow op weg: naar eentrendbremk in bet personenuerkeer: rapport. Amstendam: Vereniging Milieudefensie.

Peeters, P. M., Asseldonk, Y. van, Binsbergen, A. J. wan, Goeverden, G. D. van, Vermijs, R. G. M. M., Rienstra, S. A., \& Rietreld, P. (1995). Mag bet letsje minder snels: boofdrapport: een onderzoek nat de matschappehike ecowomische kosten en baten waw verlaging van swelheden van personewawto's. Delft [etc.]: Technische Universiteit [etc.]

Peeters, P. M., Tensen, D. K., Sleurink, M., Be Timmeren, A. van. (I996). Revival waw bet luchtschip: Een verkenwing nat de mogelijkbeden van een berinvoering van bet luchtschip voo passagiers en vrachtvervoer in Nederland. Rotterdam: Adviesdienst Verkeer en Vervoer.

Peeters, P.M. Rietveld, P. 8c Ubbels, B. (2000). Effectiviteit en haalbaarbeid wan een kilometerheffing. Hoofdrapport. Amsterdam/Ede: Vrije Universiteit Peeters Advies.

Perers, P.F. (1990). Hoe bekeer je en automobilist? Intermediain( $\mathrm{x}-2)$, i 5 - 19 .

Peters, P.F. (1994). De verdwewen borizon: Over de anatomie wan de rets in 2050 . Den Haag: Rijksplanologische Dienst.

Peters, P.F. (1995a). De verdwenen horizon: over de anatomie van de reis in 2050 . Kaw. nis en Methode, XIX(1995- $\mathrm{x}), 64-80$.

Peters, P.F. (1995b). Leve de auto. In $\mathbb{K}$. Waagmeester (Red.), Ontstolen welvart, Kroniek van dutwzan Nederland. Utrecht: Platform voor Duurzame Ontwikkeling/Jan Mets, 36-59 


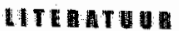

Deters, PE. (x997a). De hast van Abertime. Fysieke nobiliteit, snelheid en de herontdekking van het langzanye. In M. A. Hajer \& F. Halsema (Red.), Lawd in wicht: Een cultumpolitieke visie op de mintelike wrichting. Amsterdam: Bert Bakker/Wiardi Beckman Stichting, $29-43$.

Peters, P. (n997b). Reistij in de dagen wan Thomas Cook: De co-evolutie wan snelheid en temporele precisic in verplatsingspraktijken. Kenth en Methode, $X \times 1(1997-3), \times 78-119 \%$.

Peters, P.F. (1997\%). De roekomst volgens de Club van Rome. In K. Waagmeester (Ed.), Howdbore economie (pp. I 5-37). Kampen: Kok Agora/NcDo.

Peters, P.F, Henvel, M. van den \& Renssen, H. van. (n997d). Tidd in relatic tot dum zalan consumeren. Den Hag: ministerie wan Volkshuisvesting, Ruimtelike Ordening en Milieubeheer/Directie Industrie- en Consumentenbelieid.

Peters, P.F. (rg98a). De smalle marges wan de politiek. In H. Achrerhuis \& B. Elzen (Red.h, Cultum en mobiliteit. Den Haag: sou, $38-63$.

Peters, P.F ( 998 b). Verkeersethiek op straat. Filosofie 3 Praktipk, 19(3), 449 - 59 .

Peters, P.F. ( $998 \mathrm{c}$ ). Lopen in Schuberts Winterreise. Hollands Madndblad, $1998(6-7)$, $5 \cdot 13$.

Peters, P.F. (x999). In de praktijk: nat een andere conceptwalisering wan werplaatsingent. Delft Connekt.

Peters, P. F., \& Hajer, M. A. (200r). Paying in the Polder. Urban Road Pricing and Dutch Cultures of Deliberation. Amsterdam: The Amsterdam Research Centre for the Metropolitan Environment (AME).

Peters, P. F., Peeters, P. M., Wilde, R. de, \& Clement, B. (200r). Een constante in beWegtng? Reistifd, writwele mobiliteit en de BREVER-wet. Roterdam: Adviesdient Verkeer en Vervoer.

Pieters. J. ( 1994 ). De straat wan de toekonst: ontwerptips woor een doelmatige, dumzaaw veilige weginrictling. Den Haag: Voetgangerswereniging VBV.

Ploeger, J. (1997). Designing for cyding: the new Durch Design wanual. In R. Tolley (Red.), The Greening of Urban Transpont Planing for walking and oycling in Wes. tem cities. Chichester [etc.]: John Wiley \& Sons, 397.402.

Ploeger, J, Botma, H., Michels, T., \& Stichting CRow. (1993). Tekenen voor de fiezs: ontuerpwijzer voor fietsuriendelijke infrastructumt. Ede: Stichting CRow.

Poidevin, R. L., \& Macbeath, M. (Red.). (1993). The Pbilosopby of Tiwe. Oxford: Oxford University Press.

Pope, N. (200r). Dickens" "The Signalman" and Intornation Problems in the Railway Age. Tewhology and culture: the international quarterly of the Society for the History of Tecbnology, $42(3), 436-488$.

Pourter, T. M. (1994). Making Things Quantitative. Science in comtext, 7 (3), 389-408.

Porter, T. M. ( 1995 ). Trust in numbers: the pursuit of objectinity in science and public life. Princeton, NJ: Princeton University Press.

Pratt, M. L. (1992). Imperial eyes: travel writig and travisultwation. London: Routledge.

Projectueam National Verkeer-en Vervoerplan (NVvP. (1999). Perspectiewentota therkeer en wertoer. Den Haag: Projecteam Nationaal Verkeci- en Vervoerplan.

Proust, M. (1991). Sodom en Gomorra. Ansterdam: De Bezige Bij. (Vert. van: Sodom et Gomorrhe. - Paris : Gallimard, 1954.-1 (A la recherche du remps perda). Vert. [uit het Frans door] Thérèse Comips. 


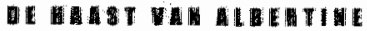

Provoost, M. (1996). Asfatt: AutoMobiliteit in de Rotterdamse stedebown. Rotterdan: Uitgeveril oro.

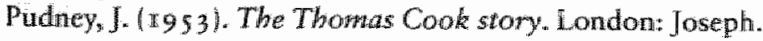

Rae, J. B. (1971). The rodd and the car in American life. London: Mrr Press.

Rtatz, K. (1998). American Roads, Roadside America. The geographical review Wol. 8. 8. Do. $3(1998), p \cdot 363-387$.

Reheis, $\mathbb{P}$ (1996). Die Kreativitä der Langsamkent: never Wohlstand durch Ent schlewngug. Darmstadt: Wissenschaftiche Buchgesellschaft.

Reichert, F. (Red.). (r998). Ferweisen in Mittelaler. Berlin: Akademie Verlag:

Reijnders, 1.: (2000). Reishst: op weg nat hat paradis en andere bestemmnngun. Antsterdam: Van Gennep.

Richards, J., \& Mackenzie, J. M. (r.88). The railway station a social bistory. Oxford [etc.]: Oxford University Press.

Richardson, $\mathrm{E}$ ( 1973 ). Daws, parks and politics: resoufce, development and preserwathom the Truman-Eisenbower era. [Lexington, KY] University Press of Kentucky.

Rienstra, S. A., Rietveld, P. (1995). Mag het ietsje minder snel: bet matschappelipa dragulak woor wizigingen in bet beleid ten aanzien wan de swelhet wan bet antomerkeet: een strvey. "s-Gravenhage: Projectbureau Integrale Verkeers- en Verwoerstudies.

Rietweld, P. (2000a). De latente vrag name mobiliteit. Rooiliph : mededelingew uan bet Planologisch en Dewografisch Institwut (5), 222-228 (227).

Rietweld, P. (2ooob). Swe heid bereikbaarbeid: snelbeidsuerlaging wssen fen en ficthe. Amsterdam: Vrije Universiteit.

Rifkin, J. (r987). Time Wars. The Primary Conflict in Human History. New York: Henry Holt and Company.

Ritter, P. H. (1927). De kunst wan bet rezen. Arnhem: Van Loghum Slaterus en Visser:

Ritzer, G. (1996). The McDonaldization of Society. An Investigation into the Clbangug Character of Contemporary Social Life. Thousand Oaks, Cad London/New Delhi: Pine Forge Press.

Ritzer, G. (r998). The McDonaldization Thesis: Explorations and Extensions. London/Thousand Oaks/New Delhi: Sage Publications Hed.

Rokach, A., 8x Millman, A. (1992). Focus om travel: photograpbing memorable pretures of jowmeys to new places. New York: Ablieville Press.

Rosen, P. (1999). Towards Sustainable Urban Transport: Constructivisw, Planning and Policy. Cambridge: Anglia Polytechnic University.

Rothman, H. K. (1998). Detil's Bargains: Tourism in the Twentieth-Century American West: Kansas University Press.

Rommans, J, Kemp, R, Asselt, M. van, Geels, F., Verbong, G., \&. Molendijk, K. (2000). Transities of tratsitiemanagement de casus van en amissieame energievoonzid wing: Mastricht: International Centre for Integrative Studies (1CIs).

Rotteveel, K. (Red.). (1992). Gnenzen an de snelbeid: verslag wan de studiadag ower effecticwe swelheidsbegrenzing. Amersfoort: Initiatiefgroep Wijs op Weg.

Runte, A. (1979). National parks: the American experience. Lincoln, NE; London: Uniwersity of Nebraska Press.

Runte, A. (1990). Thams of Discovery: Westem Railroads and the National Parks (Revised edition ed.). Niwot [Col.]. Roberts Rineharts. 
Sachs, (1992). For lowe of the antomobile: looking hack wo we bistory of ow desilins. Berkeley [etc. ]: University of Califorma Pressi

Sachs, W. (1999). Planet Dialectics: Explorations En Enomment and Development. London/New York: Zed Books.

Safdie, M. \& Kohn, W. (1997). The City After the Automobile: An Architects Wiston: New York: Harper Collins.

Salwerda, J. C., \& Bruin, R. A. de. (1991). Achtergmonden wa het fietsgebruik: "fretsstad" Zunolle persus "antostad" Breda. Veenendal/Den Haag: Traffic Test bw/PbIVNS.

Sax. J. L. (1980). Mountains without bandrails: reflections on the national parks. Ann Arbor: University of Michigan Press.

Schafer, A. (r998). The Global Demand for Motorized Mobility. Transpotation Re search, Part A: Policy and Practice, $32(6), 455$.

Schater, A., \& Victor, D. (1997). The Past and Future of Global Mobility Scientific American, $27,(4), 36-39$.

Schafer, A., \& Victor, D. (2000). The future mobility of the world population. Tramsportation research Part $A, 34(3)$, I $7 \mathrm{I}-206$.

Scharff, V. (r99). Taking the Wheel. Women and the Coming of the Motor Age. New York: Free Press.

Scharzki, T. R. (1996). Social practices: a Witgewsteinian approach to buman activity and the social. Cambridge [etc. I: Cambridge University Press.

Schatzki, T. R., Knorr-Cerina, K., \& Savigny, E. von. (200r). The pratice turn in contemporary theory. New York: Routledge:

Schivelbusch, W. (1977). Geschichte der Eisenbabnreise. Zur Industrialisterng ton Rawm und Zeit in 19. Jahrbundert. München: Carl Hanser Verlag.

Schllesinger, A. M. \& Israel, F. L. (Red.). (1999). Touring America Seventy-Fuve Years Ago: How the Antow obile and the Railroad Changed the Nation: Cbrowicles from National Geograplyic. [S.L.] Chelsea House Publishers.

Schmied, G. (1985). Soziale Zeit: Unfang" "Geschuwdigkent" und Evolution. Berlin: Duncker und Humblot.

Schot, J. W. (2002a). De mobiliteitsexplosie in de twintigste seuw, Techniek in Nederland in de twintigste euw: transpont en communicatie. Zutphen. Stichting Historue der Techniek/Walburg Pers, Vol. V, 13-18.

Schot, J. W. (2002b). Begrensde mobiliteit, Techwiek in Nederland in de twintigste eewa: transport en communicatie. Zutphen: Stichting Historie der Techniek/Walburg Pers, Vol. V, $145-149$.

Schot, J. W., Mom, G. P. A., Filarski, R., \& Staal, P. E. (2002). Concurrentie en afstemming: water, rails, weg en lucht, Techniek inederland in de twintigste eeut: tramsport en communicatie. Zutphens Stichting Historie der Techniek/Walburg Pers, Vol. $V, 19,44$

Schön, D. A. (1983). The reflective pracritioner: bou professionals think thaction. New York: Basic Books.

Schreuder, A. (2002). Wim Derksen, directeur van het nieuwe Rumrelijk Planbireau: "Nederland zal keuzes moeten maken". In NRC Handelsblad, 3 oktober 2002.

Schuyt, K., \& Taverne; E. (2000). 1950 : welwant in zwat-wit. Den Haag: Sdu Uitgewers. SCP. (1976). Autogebruksbeperking: mogelikbeden ena anvardbaarbeid. Rijswijk: Social en Cultured Planbureau. 


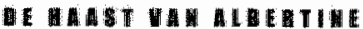

Segal, H. P. (1994). Future Mnperfect. The Mixed Blessngs of Technology in America. Amberst: The Unverstry of Massidhusers Press.

Sellats, R. W. (1997). Preserving Niature in the National Parks: A History. New Hawen and London: Yale University Press.

Semnet, R. (1994). Flesh and Stone: The Body and the City western Cintization. New York/London: W.W. Norton B Company.

Serres, M. (r980). Le passage du Nord-Onest. Paris: Editions de Miruit.

Shackle, G. L. S. ( 1983 ). Time in economics. Westport: Greenwood Press, Publishers. Sharp, C. (I981). The Economics of Twe. Oxford: Robertson.

Shaw $).(1994)$. Punctuality and the Everyday Ethics of Time: Some Evidence from the Mass Observation Archive. Time Society, 3, 79-97.

Shields, R. (1.99 I). Places on the Margin: Altemative geographies of modernity. London and New York: Routledge.

Simpson, I. C. (1995). Technology, Time and the Conversations of Modernity. New York and London: Routtedge.

Slebos, $C_{\text {, }}$ Schot; J van der, 8 Stichting Kinderen Voorrang. (r999). De toekomstrets: iderën woor duwzam verkeer 2030. [Utrecht]: Stichting Natuur en Milieu.

Sloterdijk, P. (x987). Kopernikanische Mobilwachung und ptolemaersche Abruestung: desthetischer Versuch. Frankfurt am Main: Suhrkamp.

Sloterdijk, D. (1989). Eurotaotsmws. Zur Kritik der politischen Kintetik. Frankfurt am Man: Suhrkamp.

Smeets, R. (r999). Groen licht voor de fietsers in Breda: een onderzoek naur de effecten van fietsuriendelijke verkeerslichten in Breda. Breda: Nationale Hogeschool voor Toerisme en Verkeer.

Sinelik, E. L.* W Witsen, M. van. (1964). Ethiek wan bet werkeer. Nijkerk: Callenbach.

Smith, M. R, \& Marx, L. (Red.). (1994). Does technalogy drive history? The Dilemma of Technological Determintism. Cambridge, MA [etc.]: Mrr Press.

Smith, P. (Red.). (x998). The History of Towism: Thomas Cook and the origins of leiswre travel. London: Routledge/Thoemines Press [Vier banden].

Sabel, D. ( 996 ). Lengtegraad. Baarn: Ambo.

Solnit; R. (2000). Wanderlust; a bistory of walking. New York [etc.]: Viking.

Sorokin, P. A., \& Berger, C. Q.(r939). Time-budgets of human behavior. Cambridge., MA: Harward University Press.

Spee, J. ( $999 \mathrm{I})$. Ik rij als een scheermes: gedrag en wangedrag in bet verkeer. Amsterdam: Balans.

Spence, M. D. (0999). Dispossessing the Wilderness: Indian Remowal and the Makmg of the National Parks. New York/Oxford: Oxford University Press.

Spiekermann, $K_{\text {., }} \&$ Wegener, $M$. (1994). The shrinking continent: new time-space maps for Europe. Enviromment and Plantwig B, 21, 653-673.

Stagl, J. (r.995). A bistory of crriosity: the theory of trawel $550-1800$. Chur: Harmood, cop.

Standage, T. (1998). The Victorian Internet: The Remarkable Story of the Tele graph and the Nowetenth Century's On-Line Pioneers. New York: Walker and Compary.

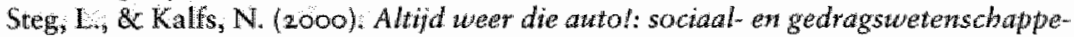
likk onderzoek en het verkeers-en vertoerbeleid. Den Hag: Social en Cultured Planbureau. 
Steg, L., \& Siewers, I. (1996). Moliewproblemen als sociale dilemonass: Factoren die wan imwloed zijn op bet ontstaan wan en mogelifke oplossingen woor grootschalige socalle dilemmat "s. Den Haag: Raad woor het Milieubeheer.

Stein, J. (200 I). Reflections on Time, Time-Space Compression and Technology in the Nineteenth Century. In May, J. \& Thrift, N. (Eds.). Timespace. Geographies of temporality. London/New York: Routledge, pp. ro6-1r.9.

Stephens, C. ( 1989$)$. The Most Reliable Tume: William Bond the New England Railroads and Time Awareness in Nineteenth-Century America. Technology and Culture, $30(x), 1-24$.

Stichting Centrum voor Regelgeving en Onderzoek in de Grond- Water- en Wegenbouw en de Verkeerstechniek. (1996). Regeltactieken voor verkeerstichtew" bet effect op bet milieu. Ede: Stichting crow.

Stommer, R., \& Philipp, C. G. (I982). Reichsawtobahn: Pyyamiden des Dritten Reichs: Analysen zur Aesthetik eines unbewaeltigten Mythos. Marburg: Jonas Verlag.

Studiecentrum Verkeerstechniek ( $5 v 7)$. ( 1981 ). Fietsers, bromfietsers en verkeerslichtery: enkele aspecten ten aanzien van fiets-en bromfietsvoorzieningen op wet verkeerslichten geregelde kruispunten. Driebergen-Rijsenburg: Svt.

Suchman, L. A. (1987). Plans and Situated Actions: The Problem of Human-Machine Communication. New York: Cambridge University Press.

Suchman, L. (r993). Technologies of accountability: Of lizards and airplanes. In G. Burton (Red.), Technology in warking order: studies of work, interaction, and technology. London [etc.]: Routledge, I I 3-1 26.

Summerton, J. (Red.). (1 994). Changing Large Technical Systems. Boulder [etc.]: Westview Press.

Sundquist, J. L. (I969). Politics and policy: the Eisenhower-Kennedy, and Johnson years ([2nd.pr] ed.). Washington: The Brookings Institution:

Susman, W. I. ( $(984)$. Culture as History: The Transformation of American Society in the Twentietb Century. New York: Pantheon Books.

Swinglehurst, E. (1974). The romantic joutney: the story of Thomas Cook and Victorian travel. London: Pica Editions.

Szalai, A. \& Converse, P. E. (1972). The use of time: daily activities of arban and subm urban populations in twelve countries. The Hague/Paris: Mouton.

Tabboni, S. (200r). The Idea of Social Time in Norbert Elias. Time o Society; xo( $x$ ), 5-27. Teenstra, A. (1942). De Fiets: Plezier ervan, pech ermee. Zwolle: La Rivière \& Voorboeve.

Tenner, E. (1996). Why Things Bite Back: Techwology and the Revenge of Unintended Consequences. London: Fourth Estate.

Terreehorst, $\mathrm{P}$ ( ( 9997$)$. Langzame stad, snelte mensen: Leven in een inforwatietidperk. Amsterdam: Van Gennep.

Tertoolen, $\mathrm{G}$. ( 1994 ). Uit eigen beweging...?! : een veldexperiment over beinwloedings pogingen van bet autogebruik en de daardoor opgeroepen psychologische weerstanden. Utrecht: Universiteit Utrecht, Faculteit Sociale Wetenschappen.

Thompson, E. P. (1967). Time, Work-discipline and Industrial Capiralism. Past and Present, 3 8(December 1967), 56-97.

Thoms, D., Holden, L., \& Claydon, T. (Red.). (1997). The motor car and popular culture in the zath century. Aldershot [etc.]: Ashgate. 
Thrift, N. J. (1990). Transport and Communications 1730 I9 I.4. In R. A. Dodgshon Q R. A. Butlin (Red.), Historical Geograpby of England and Wales. London: Academic Press, 453-486.

Thrift, N. (1996). Spatial Formations. London: Sage Publications.

Tolley, R. (r989). Calming traffic in residential areas. Llanddewi Brefi: Brefi.

Tolley, R. (Red.). (1997). The Greening of Urbaw Transport: Planning for walking and cycling in Western cities. Chichester [etc.]: John Wiley \& Sons.

Tromp, H., \& Bosch, J. van den. (1996). Langzaam rijden gaat sneller. Verkeerskunde, $\operatorname{Ig96(2).~}$

Untermann, R. K. (1984). Accommodating the Pedestrian: Adapting Towns and Neighborboods for Walking and Bicyling. New York [etc.]: Van Nostrand Reinhold Company.

Urry. (1990). The Tourist Gaze. Leisure and Travel in Contemporary Societies. London: Sage Publications.

Urry, J. (1995). Consuming Places. London and New York: Routledge.

Urry, J. \& Rojek, C. (Red.). (1997). Touring cultures: transformations of travel and theory. London: Routledge.

Urry, J. (2000). Sociology beyond societiest mobilities for the twenty-first century. London [etc.]: Routledge.

Vance, J. E. (1986). Capturing the Horizon. The Historical Geography of Transportation Since the Transportation Revolution of the Sixteenth Century. New York: Harper \& Row.

Veen, $C$. van der (200x). Liever veiligheid met onzekerheid dan ongelukkern met duidelijkheid. Noorderbreedte, 25, 4A (Augustus 2001), 4-9.

Vegesack, A. von, \& Kries, M. (1999). Automobility. Weil am Rein: Vitra Design Museum.

Veraart, F. C. A. (1995). Geschiedenis van de fiets in Nederland, $1870-1940$. Eindhoven: Technische Universiteit Eindhoven, Faculteit Technologie Management.

Vermeer, B. (2002, II maart 2002). Ordelijk wachten. NRC. Handelsblad, iO.

Vermeulen, J., Kampman, B., Janse, $P_{n}$, \& Centrum voor Energiebesparing en Schone Technologie. (2000). Fietsbeleid beloond. Delft: CE.

Vermeulen, W. ( 1998 ). Kinderern op weg naar school: zorgen voor morgen: enquêturapport basisscholen 1998 . Den Haag: De Voetgangerswereniging.

Vermij, R. (200r). Gedwongen tempo. De lopende band in Nederland tot de Tweede Wereldoorlog: NEHA-Jaarboek, 64(200I), 227-257.

Verstraete, G. (200n). Verstrooide burgers: Eutopese cultwu in een tijdperk van globalisering. Amsterdam: Vossiuspers UvA.

Vester, F. (1995). Crashtest Mobilität: die Zukunft des Verkebrs ; Fakten, Stategien, Löstungen. München: Heyne.

Vigat, G. (2002). The politics of mobility: transpont, the entiroutment and public poliay. London [etc.]: Spon Press.

Virilio, P. (1977). Vitesse et Politiqute. Paris: Editions Galilée.

Virilio, P. (1984). L'espace critique. Paris: Christian Bourgais Edireur.

Virilio, P. (I993a). Laut du moteav. Paris: Editions Galilếe.

Virilio, P. (1993 b). Revolutionen der Geschwindigbeit. Berlijn: Merve Verlag Berlin. 


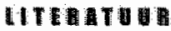

Wries. G.de. (ro99).Zeppelis: Over flosofie, techologie en oultum. Ansterdam: Vain Gennep.

Vries, G. de (zoor). Wetenschaps-en techniekonderzackers: was is de geest geblueven? Rrisis: Hidschrif woor empirische filosofie, $2(x), 62-78$.

Wries, J. de. (1981). Barges and capitalism: passenger transpontation in the Duth eco.

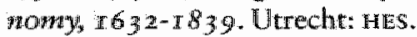

Vrijsen, $\mathrm{E},(200 x)$. Sluipmoord op de tol. Vier wrouwelipke ministers tegen de mamen in de spits. Reconstructie van vijftien jaar debat over rekeningrijen. In Elsevier, 18 augustus 2001, 10-14.

vkom-raad. (r999). Mobliteit met beleid (Advies on 7). Den Haga vaom-rad.

Vust, M. wan der. (1996). Social dilewmas and tramspontation decisions. Proefschrift Rijkstunversiteit Limburg.

Wachs, M. Crawtord, M., Q. Wirka, S. M. (1992). The car and the city: the awtowobile, we built enviromment and daly urban life. Ann Arbor: University of Michigan Press.

Wajcman, J. (1991). Feminism confroms technology. Cambridge: Polty Press:

Wallace, A. D. (x993). Walking, Literature, and Eaglish Culure: The Origins and Uses of Peripatetic in the Nineteenth Century. Oxford: Clarendon Press.

Wallis, M. (1993). Rowte 66: the mother road. New York: St. Martin's Pressin

Wee, B. Van. (1999). Hoe wetmatig is de BREver-wet. Verkeerskunde, $50(9)$, , 6-17.

Weick, K. E. (1993). The collapse of sensemaking in organizations: The Marn Gulch Disaster. Administrative Science Quarnerly, 38,628-652.

Weick, K. E. (r998). Introductory Essay - Improvisation as a Mindset for Organizational Analysis. Organization science: a journal of the Institwte of Managewnent Sciences, $9(x 998)(5), 543-555$.

Wellmann, A. (r99r). Der Spaziergang. Stationen eines poetischen Codes. Würburg: Königshausen \& Neumann.

Wellmann, A. \{ 1992$\}$. Der Spaziergang: ein literarisches Lesebuch. Hildesheim [etc.]: Georg Olms.

Wells, H. G. (r999). Anticipations of the Reaction of Mechanical and Scientific Progress Upon Human Life and Thought. Mineola [N.Y.]: Dover Publications, Inc. [Oorspr. uitg, 1902$]$

Wendorff, R. ( 1980 ). Zeit wnd Kultur. Geschiche des Zeitbew Btseins in Europa. Wicsbaden: Westieutscher Verlag.

Wendorff, R. (Red.). (1989). Im New der Zeit. Menschliches Zeiterleben interdisziplinaer. Stuttgart: S. Hirzel Wissenschaftiche Verlagsgesellschaft Stuttgart.

Werkgroep Evaluatie Verkeerslichtenregelingen. (1986). Evaluatie verkeershobtenregelingen. Driebergen-Rijsenburg: Studiecentrum Verkeerstechniek.

White, $\mathrm{R}$. (2000). Howe on the Road: The Motor Home in America. Washington and London: Smithsonian Institution Press.

whitelege, J. (1993). Time Pollution. The Ecologist: be jowrnal of the post industrial age, $23(4), 32-134$.

Whitelegs, $\mathrm{J}$ ( 1997$)$. Critical mass: transport, enuroment and sochery in the TuentyFirst Century. London, Chicago: Pluto Press, cop.

Whitelegg, J. (r998). The Rickshaw Irony. Ecologist, $28(3), 138-139$.

Wide, R. de. (1997). Op de klippen. $K$ or $M$ Tidschrift woor empirische filosofie, $X X I(\times 997-3), 254-26 x$. 
Wilde, R, de (2000). De voorspellers een kritiek op de toekomstindwstrie. Amsterdam: De Ballie.

Wilde, R. de, \& Peters, P.P. (2000). Vergtrikt in het ner. Review van Castells' The Information $A$ ge: Economy, Society and Culture. Krisis: tijdschrift woor empirische filosofie, $2(3), 57-67$.

Wilde, Ae. de. (2000). Imnowating innowation. A contribution to the philosopby of the futwre. Paper read at Policy Agendas for Sustainable Technological Imnovarion, $x$ 3 December 2000 , London:

Wilde, R. cle. (2001). De mythe wan de kenniswerker - Dam denken over kennis. Opleiding en ontwikketing: tijdschrift over opleiden in arbeidsorganisaties, 4 (12), $5-8$

Willkinson, B. (1997). Nonmotorixed Transportation: The Forgotten Modes. The Annals of the American Academy of Political and Social Science, r997/Transport at the Millennium), 87-93.

Williams, C. T. (Red.). (1998). Travel Culture: Essays on What Makes Us Go. New York: Pragger.

Williamson, A.n (1997). The Golden Age of Travel: Around the World with Thomas Cook.

Wilson. A. (1992). The Culture of Nature: North American Landscape from Disney to the Exxon Valdez. Cambridge MA \& Oxford UK: Blackwell.

Wilson, A., \& Middelham, F. (2000). Wordt Nederland goed geregeld? Verkeerskum

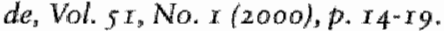

Winner, L. (1977). Autonomous Technology. Cambridge, Mass: MIT Press.

Winner, L. (1986). The whale and the reachor: a search for limits in an age of high technology. Chicago, Il. [etc.]: University of Chicago Press.

Wimner, L. (r999). Do artifacts have politics? In D. MacKenzie \& J. Wajcman (Red.), The social shaping of technology. Buckingham [etc.]: Open University Press, 28-40.

Winsemius, P. (2001). De maatschap Nederland. [S.L.: s.n.]

Wirth, C.L. ( 9 98). Parks, Politics, and the People: University of Oklahoma Press.

Wit., J. G. de. (1980). De wettelijke aanspraken van Brever. Verkeerskw de, 3\%, 354" $3578455-418$.

Withey, L. (1997). Grand Tow's and Cook's Towrs: A Hristory of Leisure Trowel, $x$ 750. 1915. New York: William Morrow.

Woerdman, E. (1999). Politiek en politicologie. Groningen: Wolters-Noordhoff.

Woolgar, S., \& Cooper, G. (I999). Do Artefacts Have Ambivalence? Mloses" Bridges, Winner Bridges and other Urban Legends in S\&'TS. Siocial Studies of Seience, 29/3), 433-449.

Workum, I. van, Beckers, T., Nationale Commissie voor internationale samenwerkug en duturame ontwikkeling, Nederlandse Vrouwen Raad; \& Stichting Nataur en Milieu. (1998). Alles, behalve tijd: butdel naar aanleiding van bet NCDO-podiun ower de gehaaste sanenleving. Baarn: Agora.

Wond, A. van der. (1987). Het lege land. De rumtelifle arde van Nederlakd 7798 1848 . Amsterdam: Meulenhoff.

Wright, F. L. (1958). The living city. New York: FHorizon Press.

Wupertall lnstitut. (Red.). ( 996$)$. Zukunftsfabiges Deutschland. Ein Beitrag zan eimey global nachbaltigen Entwicklung. Basel Boston Berlin: Birkhauser Verlag. 
Yorke, D. A., \& Margolies, J. (1996). Hitting the road: the ant of the American rodud map. San Francisco, CA: Chronicle Books.

Young, M. (1988). The Metronomic Society. London: Thames and Hudson.

Zahavi, Y. (1.979). Travel Behaviow in Transportation Systems. Paper presented at the Conference on Research Directives in Computer Control of Urban Traffic Systems, Pacific Grove, California.

Zandwoort Ordening en Advies. (1995). Stedelijk intichting en fietswerkeer. Utrecht: Zandvoort Ordening en Advies.

Zerubavel, E. (r98r). Hidden Rythms: Schedales and Calendars in Social Life. Chicago and London: University of Chicago Press.

Zimmerli, W. C., \& Sandborhe, M. (Red.). (1993). Klassiker der modernen Zeitphilosophie. Darmstadt: Wissenschaftliche Buchgesellschaft.

Zoll, R. (1988). Krise der Zeiterfahrung. In R. Zoll (Red.), Zerstörung atnd Wiederaneignung der Zeit. Frankfurt am Main: Suhrkamp.

Zuckermann, W. (1991). End of the Road. From World Car Crisis to Sustainable Transportation. Post Mills Vermont: Chelsea Green Publishing, Company. 


\section{Summary}

\section{Albertine in a hurry. Travel In technological culture: towards a theory of passages}

Albertine in a burry is concerned with the debates on public problems related to mobility and the innovations that are suggested to solve these problems. Since the r.970s, mobility problems have been described and analysed within a conceptual framework that indicates the inevitability of increased mobility on the one hand and the many problems resulting from this growth on the other. Arguing along these lines, I suggest, often leads to dead end streets. My thesis sets out to enrich and augment the dominant vocabulary in debates on mobility. Along with transportation economists, urban planners, social geographers and traffic engineers, it claims that both travel speed and travel time are crucial factors in understanding the character of modern travel. Within these disciplines, travel speed and travel time would normally be considered as quantitative, decontextualized variables in models that explain travel behaviour. By analysing four exemplars of modern traveling, I argue that travel speed and travel time can also be understood as the product of historical and contextualized transit practices. In order to travel either quickly or slowly, passages have to be designed, created, repaired and legitimized. Using this new concept, I am able to render a pragmatic understanding of the way people travel from one place to another. While reformulating mobility problems as design problems that are related to "passages" does not solve them, I do claim that the quality of our debates will improve. The conceptual framework I develop enables to question some of the mobility innovations that have been suggested in a new way: how can they be conceived of as passages? How are these passages created? Who controls the 'switchbord'? What are the politics of these new passages? The point is that travel 
speeds can never be a sufficient argument for mobility innovations; instead we should envision different passages and present them as argued choices, not between different speeds but between different 'worlds'.

To create a starting point for my analysis, in chapter I I reconstruct three discourses that explain the importance of increasing travel speed in the modern era: a technological-deterministic, an economic and a cultural-utopian discourse. Arguing within the technologicaldeterminist discourse, transportation technology (both vehicles and infrastructure) follows a logical sequence in which faster means of transportation replace slower ones. But why do people choose faster transport? Economists argue that people will allocate their time in such a way that they maximise their utility. Because travel time can be considered as a disutility, people will choose fast transportation. Another pull-factor it is the cultural-utopian image of a 'zero friction' society in which progress and mobillity go together. An examplar of this discourse is the 1939-1940 New York World"s Fair, where General Motors and Chrysller built exhibitions that portrayed fast travel as a precondition for a modern, individualist society.

The promise of saving time by traveling faster has been criticized by advocates of slowness as a fallacy: time 'saved' will be spent on other activities (Sachs). An example from the novel Remembrance of Things Past by Proust illustrates this paradox. One of the characters, Albertine, travels in a car for the first time. She does not believe that she can travel to two distant villages in one day. Although one would expect her to save a day by traveling by car, when she arrives at her friends house in the first village, she already wants to hurry on to the next village. This paradox - that speed doesn't save time - can be explained by indicating what the 'slowness'-discourses share with the 'speed'-discourses: fast transportation leads to haste, ergo sllow transportation brings us rest. To escape from this discursive gridlock, one has to examine the way time is used to create the comparative perspective implicated in the words 'fast' and 'slow'.

Many theories on time create dichotomies between subjective and 
objective time. An example is McTaggart's 1908 distinction between A-series time, when we use concepts like past, present and future and which assumes an observer, and B-series time, when we use concepts like earlier and later and no observer is assumed. A third concept of time can be taken from the work of Elias who considers time as a social construction and studies the ways people create temporal orders to coordinate social life. Braudel's work also makes clear that time scales should be seen as a construction. Speed and slowness are relational concepts that depend on a context. One can sit quietly in a fast moving train, as in a fragment from Hawthorne's 185 novel The House with the Seven Seals. This contextual ' $\mathrm{C}$-series time' will be a heuristic device in my analysis of travel time: it is never given, but has to be constructed as a temporal order within historical practices.

Chapter 2 takes the recent history of the Dutch debate on mobility politics as evidence for the claim that a B-series conceptual framework, in which time is quantified and decontextualized, can explain many phenomena related to mobility, but also has shortcomings. Starting in the early I970s, politicians have argued that increased mobility will lead to future problems, ranging from congestion in urban areas, unsafe roads, problems that are related to the quality of life (noise, pollution, health risks, urban sprawl etc.) and problems resulting from unequal access to car-centred transportation systems, leading to social exclusion. A variety of policy measures aimed at changing people's travel behaviour have been suggested, and some were implemented. However, in the long run the basic social dilemma remains: benefits for an individual traveler lead to societal costs. It seems impossible to find a way out of this dillemma and policy analysis can explain why. The basic dilemma is not solved but is continually reformulated in new discourse coalitions (Hajer) and by new problem owners (Gusfield) who dominate the debate. Consequently, problems and solutions rise and fall on the agenda of public debate.

Economists and transportation experts have tried to explain why mobility continues to increase and why it is so difficult to change people's travel behawiour. An exemplar of their style of reasoning can 
be found in the 'hypothesis of constant travel time' which states that within a population the mean daily time travelled is constant. In stronger variants of this hypothesis, the constant is taken to be 70 minutes over a long period of time, regardless of culture and country. In the Netherlands, such a hypothesis was formulated by Hupkes in the r.970s as the "BREver-law". Hupkes constructed two scenarios, using his law. The first was based on fast transportation systems like cars and airplanes, the second on the so-called "softer" and slower modes like public transport, walking and cycling. Political and public debate on mobility has been characterised by two claims: faster modes will save time and these time gains can be achieved without losses elsewhere. Hupkes uses his Brever-law to show that the arguments behind these clams are invalid: because travel time is constant, faster modes will lead to greater distances travelled and thus to increased mobility. Hupkes' concept of travel time relies on the quantified B-series and renders convincing arguments, but it does so at a price. Innovation boills down to the choice between two scenario's, the one characterized by "accelerating" and the other by 'breaking'. Because the quantified nature of travel time is not at stake in this style of reasoning, it becomes even more central to the argument. In order to formulate other choices than the one between 'accelerating and breaking', we have to challenge the B-series concept of time in his argument (time is a quantity and therefore we can use it to compare between modes, times and places). To do so, I have worked out a $\mathrm{C}$-series notion of contextualized and historicized travel time in the next four chapters.

The B-series concept of travel time that characterizes the style of reasoning of transportation economists like Hupkes has a history, as becomes clear in chapter 3 . It assumes that time and space can be seen as separate entities, and as Bauman points out, this is an essential feature of modern societies. Therefore, I start constructing a $\mathrm{C}$-series notion of travel time with the analyses of time and space in modernity as they have been given by sociologists and social geographers. Whereas Hupkes takes travel time as the time people allocate to 
rravelling, social geographers also look at the relation between time and distance. People move within so-called "prisms", the total spatial range they can cover within a certain amount of time, Hagerstrand argued, and the size of these prism's is determined by the means of transportation available. A walker moves in a smaller prism than a car traveler. Janelle also underlined the importance of means of transportation when he coined the concept of "time space convergence", the decrease of travel time between two places.

Using these concepts we can describe modernity as a historical process leading to a 'shrinking globe' on which people move within ever bigger prisms. This idea relates closely to the characteristic experience of modernity that has been summarized in the nineteenth century phrase 'the annihilation of space through time'. This metaphor, implicitly or explicitly, returns in the work of the sociologist Giddens and he social geographer Harvey as they historicize the separation of space and time, and try to explain why modernity is characterized by a process of constant speeding up. But in doing so, both end up in a position that situates the cause of historical change in a quasi autonomous technological development. For Giddens the invention and diffusion of the mechanical clock is decisive, and to this Harvey adds technologies of transportation and communication. As argued in chapter $\mathrm{I}$, developing a $\mathrm{C}$-series notion of travel time should be able to historicize and contextualize, and Giddens and Harvey went a long way towards doing so. But in presenting time and space as effects of autonomous technological developments, they have swapped one self-evident, autonomous cause for another. Now that time and space can no longer be taken as constants, the explanatory power has shifted to technology. However, technological developments can never be their own explanation. As scholars within the field of science $8 x$ technology studies have claimed, they are to be explained as the results of a complex and seamless web of social, technological, economic, cultural and political factors. In order to create a $\mathrm{C}$-time notion of travel time, I have to go one step further and describe the technologies that 'shrunk the world" from an actor"s perspective. 
In the remainder of this chapter, I create this perspective by describing the work that had to be done by Thomas Cook to make the world smaller for his customers. From $184 \mathrm{I}$ on, Thomas Cook organized excursions by train, first to destinations in England and Scotland, later to other European cities and eventually around the world. My claim is that in order to sell travel speed and shorter travel times, Cook had to build passages. As a unit of analysis, passages can be described and researched on three levels. First, as heterogeneous spatio-temporal orders that assume both materiall elements (in the Cook-case: trains, stations, hotel coupons, schedules) and immaterial elements (Cook's teetotalism ideals and colonialist presuppositions). Second, as planned but at the same time contingent orders, that have to be continuously 'repaired', for which Cook relied partly on his famous 'Man from Cook's', an local employee who hellped travelers to solve their problems. And third, as orders that both include and exclude people, places and times, which accounts for the fact that the passage of Cook's trip around the world was also shaped by the political topography of the Victorian empire. Travel time can now be analysed in a $\mathrm{C}$-series conceptual framework that not only contextualizes time and space, but also the tramsit practices that render spatio-temporal orders. In the next chapters, I study three different transit practices to further elaborate these three conceptual levels.

Chapter 4 focuses on creating the heterogeneous order of a passage. In the previous chapter, I argued that this order is built out of material and immaterial elements. To answer the question of how these elements are connected to render the effect of a swift journey from one place to another, I examine a historical case-study on how car travel in the United States affected the design of the National Parks. There are many explanations for the relatively short period of time in which the transition from train to car took place in North America. One underlines the fact that by car people could travel where and when they wanted. This ubiquity of car travel can be taken as an effect of passages. To analyse these passages, I create an actor's perspective by way of a thought experiment: what connections had to 
be made between diverse elements to make places accessible at any time? The "American Passage" was created not only out of cars, but also roads and highways, gas stations, fast food drive in restaurants, and motels. To connect these elements in such a way that "flow' was the main effect of a passage, they had to be standardized. As a result, car journeys became more predictable than in the days of the early motorists. Together with the contingency of travel, stories of hardship and adventure on the road disappeared, only to reappear on a narrative and iconographic level. Next to "place myths" (Shields), 'travel myths' told car travelers how driving America's 'blue highways' could again be experienced as an adventure.

American passages not only made new destinations accessible, they also changed them, as is shown in the example of one of the quintessential American destinations, the National Parks. The dilemma between use and preservation of the parks characterizes the history of National Park Service (NPS) park designs. In the 1930 , park roads, look out points and park museums were designed to blend into in the surrounding landscape. This rustic style was abandonned when in the 1950 s the number of visitors by car rose dramatically. Helping all these people to find their way through the parks quickly became the main objective of the new designs that the Mission 66 program introduced in 1956 . Visitor centres were located near major intersections, and provided visitors with information so they knew where to find the major sights. Preserving the wilderness while at the same time circulating increasing numbers of car through the parks not only asked for material innovations such as the visitor centres, but also for a constant restyling of the representations and iconography of park nature in "intermediary landscapes" (Carr). This first case study concludes that to understand the creation of passages, we have to study innovative connections between the material and immaterial elements in the heterogeneous order that enables swift transportation.

The American passage showed that the predictability of a journey is an important precondition for "flow". The car traveler knows what to 
expect and tries to reduce the contingencies that may cause delays. Chapter 5 asks how planned passages can be repaired when contingencies nonetheless occur. This second case study focuses on the work that has to be done by the Dutch airline carrier KLM to provide their customers with reliable and punctual flights. How to fly on time when the complexity of the operation increases?

Ethnographic research in the Departure Hall on Schiphol Amsterdam Airport and in KLM's Front Office of the Operations Control Center provides an answer. If we follow an air traveler checking in, we see them moving from the check-in counter, through customs, to the gate where he boards the airplane. During the first part of the journey, KLM employees in the departure hall are able to solve problems and air travelers are disciplined step by step. Why this is so becomes clear in the Front Office of the Operations Control Center. Here the processes making up the KLM network on the day of operation are continually monitored. If something goes wrong anywhere - be it in baggage handling, aircraft handling, passenger services or elsewhere - this may affect scheduled departure times. Repairing planned passages relies on three interrelated innovations that date back to the nineteenth century operation of train networks (Beniger). First, the information concerning a moving train had to be send faster than the train itself and the telegraph made this possible. Second, a real time overview of the situation in the network had to be created, which could be done in a control room. Third, in order to synchronize the elements in the network, the power to act in a situation had to be transferred from local employees to the control room.

Identifying these innovations provides a conceptual framework, but does not explain from an actor's perspective how KLM employees repair passages in real time. Therefore, three problematic situations in the Front Office are analysed using the concepts of 'situated action' (Suchman) and 'improvisation' (Ciborra). I argue that a third concept can be taken from the field-notes to conceptualize the interplay between many different temporal orders. When exchanging a broken down plane by a reserve plane, a occ-employee said: "This was my "exchange money" for this day. My next problem will be harder to 
solve." To solve a problem, one can not stop the operation for a moment. One has to rely on "exchange' that is part of a continually evolving situation. Interwiewing and observing the employees in the Front Office suggests different kinds of 'exchange', that can be used to repair passages and fly on time: money, risk, capacity, knowledge and experience, information- and communication technology and authority. Innowating "exchange" is necessary to connect and. synchronize the countless temporal orders that constitute a passage in real time, orders that may be compared to the voices in a fugue: if one is late, the others don't sound right.

A third actor's perspective is necessary to understand how passages are related to each other. This question is examined in chapter 6 , which focuses on Dutch urban transport and, more specifically, on how the Dutch government tried to design infrastructure aimed at an increased use of bicycles. Unlike in the case of airflight, no centralized decisions are taken when people travel through a city. Urban travelers are each others contingencies and urban space and time are constantly being contested. Innovative solutions for this problem of crossing passages date from the nineteenth century when the traffic landscape was redesigned in order to create both the material and immaterial conditions for the crossing of different passages. Different design styles can be distinguished over time, depending on the amount to which passages are separated or mixed. Regulating the crossing of passages also has immaterial aspects in the form of traffic rules. The crossing of passages requires, what I call, "ensembles'. Considered from an actor's perspective, they not merely distribute already existing speeds but are constitutive of differences in speed attained. Instead of the crossing of existing speeds, ensembles produce speed or slowness in the way space, time and risk are exchanged between travelers. Because the distribution of space, time and risk between travelers is unequal, the design of ensembles is a matter of politics.

Evidence for this claim comes from the third case study that reconstructs the politics of passages from the example of the Dutch governments Bicycle Masterplan. In the early 1990 , the Dutch 
government introduced this policy scheme as a means to increase the use of bicycles in Dutch cities. One of the most important publications during the Bicycle Masterplan period was the Design Manual for Bicycle Friendly Irfrastructure. I use it to understand an actor's perspective on the innovations needed to create new passages for the bicycle. Analysing the way the Manual treats one of the basic questions in the designing bicycle infrastructure - do bicycles have to be mixed or separated from motorized traffic? - I conclude that the designers' solutions are representative of a technocratic position. They take the differences in speed between motorized and nonmotorized traffic as a given and present a broad range of possible design solutions that aim at 'finetuning' form, function and use of infrastructure. In cloing so, they ignore the fact that in the design of crossings and road sections the politics of passages are always present, either in the way space, time and risk are distributed on the street level, or in the way the design is implicitly or explicitly the expression of democratic politics. The concept of "ensembles" makes it possible to formulate a new normative criterion for innovative design. Because there can be no single optimal solution, even after finetuning the details of a situation, a good design should present two or three possible solutions which can be explicitly compared in terms of the way they not only distribute space, time and risk but also create new 'worlds' (Winner).

Can the results of the three case studies be systematized be systematized in a conceptual framework? Would this framework help to enrich and augment the dominant vocabulary in current mobility debates? Would it be possible to use such a framework to assess critically mobility innovations? Questions such as these are taken up in the concluding chapter 7. As transportation economists, urban planners, social geographers and traffic engineers do, I hold that travel time and travel speed are important concepts to understand modern travel. Whereas the $B$-series approach enables the heuristic use of travel time as a quantified variable in descriptive and explanatory models, in this thesis transit practices have been studied 
in order to understand how time is created in the activity of traveling. This pragmatist approach entails a time concept in what I have called the $\mathrm{C}$-series and which is linked to a different style of reasoning. Working towards a theory of passages, I should be able not only to give alternative descriptions and explanations of traveling in the technological culture, but also to reformulate the questions in current: debates on the problems and politics of mobility, as well as critically assess innovative strategies in solving these problems.

First, the outlines of a theory of passages are sketched. Creating actor's perspectives makes it possible to study and conceptualize the work that is done within transit practices to create passages; heterogeneous spatio-temporal orders that have to continuously repaired and legitimized. This work is never finished, because new sollutions constantly have to be found for design dilemmas. Solving these dilemmas involves what could be called "connecting strategies", ways to connect the heterogeneous material and immaterial elements in the passage. Second, a new vocabulary can be created in which mobility problems are reformulated as design problems. This will improve the quality of the debate because on the agenda are not onlyr dichotomous choices between 'accelerating' or 'breaking', for or against new roads, flow or congestion, speed or slowness. Instead, treating mobility problems as design problems makes it possible to debate different design styles. Thus, a new sensitivity to the question as to what is actually at stake when we talk about something so seemingly technocratic as solving mobility problems. And thirdly, we can critically assess innovations. My conceptual framework indicates that there is always more than one solution. It suggests that innovative solutions can be questioned. Which 'intermediary landscapes" are made? Which forms of 'exchange money' are at stake? How are new distributions of space, time and risk created? Thus, a theory of passages can help to reorder the debate on the future of traveling in a technological culture. The comparative perspective that is opened by a theory of passages has consequences for the way we make our choices: not between speed or slowness, but as Gusfield and Winner put it, between different "worlds". 


\section{Curriculum vitae}

Peter Peters werd geboren op i 8 juli 1960 in Amsterdam. Na het behalen wan het Vwo-diploma studeerde hij sociologie aan de Rijksuniversiteit Groningen, waar hij in $1985 \mathrm{cum}$ laude afstudeerde. Na zijn studie was hij als redactiemedewerker werkzaam bij de afdeling Culturele Programma's van de Nos-televisie, waar hij ondermeer betrokken was bij het programma 'Nederland C'. Vanaf $\mathrm{r} .988$ werkte hij als freelance publicist voor onder meer Intermediair en was hij muziekmedewerker van NRC Handelsblad. Van 1990 tot 1996 was hij hoofdredacteur van het muziekrijdschrift Mens en Melodie. In 1994 schreef hij in opdracht van de Rijksplanologische Dienst het essay De verdwenen borizon. Over de anatomie van de reis in 2050 . Dit essay vormde de opmat voor twee vervolgonderzoeken in opdracht van de ministeries van vrom en Verkeer en W/aterstaat waarin zowel de haalbaarheid van trage vervoersystemen als de behoefte aan hogere reissnelheden werden belicht vanuit een cultuurwetenschappelijk perspectief. In april 1996 werd hij als assistent in opleiding aangesteld aan de Faculteit der Cultuurwetenschappen van de Universiteit Maastricht en nam hij deel aan de aio-opleiding van de onderzoeksschool wrMc (Wetenschap, Techniek en Moderne Cultuur). Het schrijven van zijn proefschrift combineerde hij met contractonderzoek waarin mobiliteitsk westies vanuit het perspectief van de technologische cultuur werden geanalyseerd. Ook was hij betrokken bij onderzoek in het Vijfde Kaderprogramma van de Eu naar innovaties in intermodaal goederenvervoer. Op dit moment is hij werkzaam als universitair docent bij de capaciteitsgroep Wijsbegeerte van de Faculteit der Cultuurwetenschappen van de Universiteit Maastricht, waar hij onder meer betrokken is bij de opleidingen Cultururwetenschappen en European Studies. 